\author{
UNIVERSIDADE DE SÃO PAULO \\ FACULDADE DE FILOSOFIA, LETRAS E CIÊNCIAS HUMANAS \\ DEPARTAMENTO DE HISTÓRIA \\ PROGRAMA DE PÓS-GRADUAÇÃO EM HISTÓRIA SOCIAL
}

AZUCENA CITLALLI JASO GALVÁN

Terrorismo de Estado e guerra suja: Discursos e práticas da Doutrina de Segurança Nacional e da Contrainsurgência no México (1964-1982)

Versão Corrigida

São Paulo

2016 


\title{
Terrorismo de Estado e guerra sucia: Discursos e práticas da Doutrina de Segurança Nacional e da Contrainsurgência no México (1964-1982)
}

\author{
Versão Corrigida
}

Dissertação apresentada ao Programa de PósGraduação em História Social do Departamento de História da Faculdade de Filosofia, Letras e Ciências Humanas da Universidade de São Paulo, para obtenção do título de Mestre em História.

Orientadora: Prof. Dra. Maria Aparecida de Aquino

De acordo:

Asinatura da orientadora: 
Autorizo a reprodução e divulgação total ou parcial deste trabalho, por qualquer meio convencional ou eletrônico, para fins de estudo ou pesquisa, desde que citada a fonte.

\section{Catalogação na Publicação \\ Serviço de Biblioteca e Documentação}

Faculdade de Filosofia, Letras e Ciências Humanas da Universidade de São Paulo

J39t

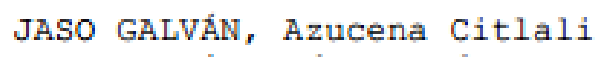

1. Doutrina de Segurança Nacional. 2 .

Contrainsurgência. 3. guerra suja no México. I.

Aquino, Maria Aparecida de, orient. II. Título. 
JASO GALVÁN, Azucena Citlalli. Terrorismo de Estado e guerra suja: Discursos e práticas da Doutrina de Segurança Nacional e da Contrainsurgência no México (1964-1982). Dissertação apresentada ao Programa de Pós-Graduação em História Social do Departamento de História da Faculdade de Filosofia, Letras e Ciências Humanas da Universidade de São Paulo, para obtenção do título de Mestre em História.

Aprovado em: 30 de agosto de 2016.

\section{Banca examinadora:}

Profa. Dra. Maria Aparecida de Aquino (Orientadora)

Julgamento: Aprovado

Prof. Dr. Fabio Luis Barbosa dos Santos

Julgamento: Aprovado

Prof. Dr. Robert Sean Purdy

Julgamento: Aprovado
Instituição: Universidade de São Paulo (USP)

Assinatura:

Instituição: Universidade Federal do Estado de São Paulo (UNIFESP)

Assinatura:

Instituição: Universidade de São Paulo (USP)

Assinatura: 
Para Felipe y Magdalena, con amor.

Para Alexandre. 


\section{AGRADECIMENTOS}

O presente trabalho foi realizado entre os anos de 2013 e 2016. Ao longo desses anos, foram muitas as pessoas que contribuíram para que tanto a pesquisa, como minha estância no país, fosse possível. Em primeiro lugar, agradeço a minha orientadora Maria Aparecida de Aquino, pela aposta neste projeto, pela disposição, pela paciência e a leitura atenta e sempre crítica. Aos professores Fábio Luis Barbosa e Sean Purdy, pela grande contribuição na banca de qualificação. Da mesma forma, agradeço a bolsa concedida pela CAPES, fundamental para a conclussão deste trabalho.

Ao doutor Aurélio de los Reyes, pelos ensinamentos para o desenvolvimento do trabalh de arquivo. Ao senhor Joel, arquivista no AGN porque, definitivamente sem sua inestimável colaboração, esta pesquisa não teria sido possível. Aos companheiros da UNAM, por me ensinar que a construção do conhecimento é um exercício necessariamente coletivo. Especialmente a Rubén Ortíz por compartilhar inquietudes, material, conhecimento e experiências.

Não posso deixar de agradecer aos velhos amigos de lá e aos novos de aqui, por ajudar a resistir no grande desafio que representou a distância. Aos colegas do mestrado, os queridos Emilio Colmán, Mariana Silveira, Aura Hurtado e Dimas Nuvolari, pelas conversas, pelos desabafos e angústias compartilhadas. Aos meninos da casa, Rafael Aragi, Pedro Serrer, Andreas Guimarães, Diógenes Miranda, Victor Mendes e Rafael Gorenstein, pois foram fundamentais para encarar o sufoco de uma cidade monstruosa como São Paulo. Obrigada pelas conversas, pelas jantas maravilhosas, pelo carinho. Obrigada.

Agradeço aos meus pais pelo apoio apesar da distância e da dor de não estar juntos nos momentos das perdas. Por ter me educado sempre na liberdade, por confiar em mim, por respeitar minhas decisões, e por sentir-se orgulhosos. Tudo o que faço é pensando em vocês. A minha irmã Anaid Segura pelas visitas, pelos anos de companheirismo, pois, sem dúvida, sem sua força, não teria as condições para enfrentar este desafio. Agradeço especialmente a Alexandre Varella pelo amor, pela parceria e pelos aprendizados. Por ter bancado, em todos os sentidos possíveis, esta pesquisa. Além do valiosíssimo e generoso apoio na tradução e correção de estilo da dissertação. 
Persigue quien arriba es. Encarcela. Secuestra. Desaparece. Asesina.

No sólo acaba con cuerpos, con vidas.

También destruye historias.

Sobre la desmemoria construye el de arriba su impunidad.

El olvido es el juez que no sólo lo absuelve, también lo premia.

Por eso, y más, nuestros dolores y rabias buscan la verdad y la justicia.

Tarde o temprano aprendemos que no se encuentran en ningún lado, que no hay libro, ni discurso, ni sistema jurídico, ni institución, ni promesa, ni tiempo, ni lugar para ellas. [...]

Porque llegará el tiempo en que paguen quienes nos deben todo.

Pagará quien persiguió, pagará quien encarceló, pagará quien golpeó y torturó. Pagará quien impuso la desesperación de la desaparición forzada. Pagará quien asesinó.

Porque el sistema que creó, alimentó, cobijó y protegió el crimen que se viste de mal gobierno, será destruido. No maquillado, no reformado, no modernizado. Demolido, destruido, acabado, sepultado será.

Por eso en este tiempo nuestro mensaje no es de consuelo ni de resignación para quienes se duelen por una o muchas ausencias.

De rabia es nuestro mensaje, de coraje.

Porque conocemos ese mismo dolor.

Porque tenemos en las entrañas la misma rabia.

Porque, siendo diferentes, así nos parecemos.

Por eso nuestra resistencia, por eso nuestra rebeldía.

Por el dolor y la rabia.

Por la verdad y la justicia.

Por eso:

No claudicar. No venderse. No rendirse.

Subcomandante Insurgente Moisés - Subcomandante Insurgente Galeano / septiembre de 2015. 
Abel García Hernández Abelardo Vázquez Peniten Adán Abrajan de la Cruz Alexander Mora Venancio Antonio Santana Maestro Benjamín Ascencio Bautista Bernardo Flores Alcaraz

Carlos Iván Ramírez Villarreal Carlos Lorenzo Hernández Muñoz César Manuel González Hernández Christian Alfonso Rodríguez Telumbre

Christian Tomas Colon Garnica

Cutberto Ortiz Ramos Dorian González Parral Emiliano Alen Gaspar de la Cruz. Everardo Rodríguez Bello Felipe Arnulfo Rosas Giovanni Galindes Guerrero Israel Caballero Sánchez Israel Jacinto Lugardo Jesús Jovany Rodríguez Tlatempa Jonas Trujillo González Jorge Álvarez Nava Jorge Aníbal Cruz Mendoza Jorge Antonio Tizapa Legideño Jorge Luis González Parral José Ángel Campos Cantor José Ángel Navarrete González José Eduardo Bartolo Tlatempa José Luis Luna Torres Jhosivani Guerrero de la Cruz

Julio César López Patolzin Leonel Castro Abarca

Luis Ángel Abarca Carrillo

Luis Ángel Francisco Arzola Magdaleno Rubén Lauro Villegas Marcial Pablo Baranda Marco Antonio Gómez Molina Martín Getsemany Sánchez García Mauricio Ortega Valerio Miguel Ángel Hernández Martínez Miguel Ángel Mendoza Zacarías Saúl Bruno García 


\section{RESUMO}

JASO GALVÁN, Azucena Citlalli. Terrorismo de Estado e guerra suja: Discursos e práticas da Doutrina de Segurança Nacional e da Contrainsurgência no México (1964-1982). 2016. 281 f. Dissertação (Mestrado) - Faculdade de Filosofia, Letras e Ciências Humanas da Universidade de São Paulo. São Paulo, 2016.

O presente trabalho visa abordar as características do sistema político mexicano que permitiram o passo silencioso de um Estado com traços autoritários para um contrainsurgente. O sistema político mexicano, derivado da Revolução popular iniciada em 1910 e da criação do Partido Revolucionario Institucional(PRI), propiciou uma cultura política que fortaleceu a figura presidencial. Esta extrapolava as atribuições constitucionais e se legitimava tanto na política interna como na externa através do "nacionalismo revolucionário". Os governos de Gustavo Díaz Ordaz, Luis Echeverría e José López Portillo (1964-1982) estão marcados pela crise hegemônica evidenciada na radicalização das organizações de esquerda. Entre outros motivos, pelo esgotamento do modelo econômico desenvolvimentista, pela crise de representatividade do partido e falta de espaços para a participação política, pela corrupção das instituições e a escalada de violência do Estado contra a oposição. Nesses dezoito anos localizamos uma transformação nas formas de violência institucional pela assimilação da Doutrina de Segurança Nacional e a Doutrina Contrainsurgente dos Estados Unidos da América, por exemplo, na consolidação de grupos paramilitares pagos pelo Estado e treinados em norte-américa. $\mathrm{O}$ nacionalismo revolucionário possibilitou então que a submissão à ideologia estadunidense não fosse explícita, gerando dinâmicas repressivas (qualitativamente) similares às vivenciadas nas ditaduras latino-americanas. Ainda que o México tenha sido considerado uma democracia exemplar alheia às guerras sujas e aos golpes de Estado que comoveram o continente na segunda metade do século XX. O objetivo deste trabalho é salientar os elementos contraditórios existentes entre o discurso público, analisado a partir dos informes presidenciais, e o discurso elaborado desde os órgãos de segurança, isto é, os relatórios da Dirección Federal de Seguridad. Nessas contradições podemos ir avaliando as formas de alinhamento às doutrinas de segurança estrangeiras.

Palavras-chave: Doutrina de Segurança Nacional; contrainsurgência; guerra suja no México. 


\begin{abstract}
JASO GALVÁN, Azucena Citlalli. State terrorism and dirty war : Discourses and practices of the National Security Doctrine and Counterinsurgency in Mexico (1964-1982).2016. $281 \mathrm{f}$. Dissertation (Master's degree) - Faculdade de Filosofia, Letras e Ciências Humanas da Universidade de São Paulo, 2016.
\end{abstract}

The main objective of this Master's project is to address the characteristics of the Mexican political system that allowed the silent step from a state with authoritarian traits to a counterinsurgent one. The Mexican political system, derived from the popular revolution that began in 1910 and from the creation of the Partido Revolucionario Institucional, maintained a political culture that strengthened the figure of president. This went beyond the powers permitted by the constitution and legitimized both internal and external policies through "revolutionary nationalism." The governments of Gustavo Díaz Ordaz, Luis Echeverría, and José López Portillo (1964-1982) are marked by a hegemonic crisis seen in the radicalization of leftist organizations. Other motives for this shift include: the depletion of the developmentalist economic model, the crisis of representation in the party and a lack of spaces for political participation, the corruption of institutions, and the escalation of state violence against the opposition. In these eighteen years, a transformation occurs in the form of institutional violence through the assimilation of the National Security Doctrine of the United States; for example, the consolidation of paramilitary groups paid by the state and trained by northern neighbors. Revolutionary nationalism then allowed the non-explicit submission to American ideology, generating results (qualitatively) similar to those experienced in the repressive dynamics of Latin American dictatorships. Still, Mexico has been considered an exemplary democracy, despite dirty wars and coups that shocked the continent in the second half of the twentieth century.The aim of this study is to highlight the contradictory elements between the public discourse, analyzed from the presidential reports, and the discourse developed from the security organs, in other words, the reports of the Dirección Federal de Seguridad. These contradictions we can to evaluated the alignment of forms to foreign security doctrines.

Keywords: National Security Doctrine; counterinsurgency; dirty war in Mexico. 


\section{LISTA DE SIGLAS}

Ação Cívica - AC

Agência para o Desenvolvimento Social e Econômico - USAID

Aliança para a Segurança e a Prosperidade da América do Norte - ASPAN

Aliança para o Progreso - ALPRO

Archivo General de la Nación - AGN

Asociación Nacional Cívica Revolucionaria - ACNR

Asociación Nacional Obrero Campesino Estudiantil - ANOCE

Brigada Blanca $-\mathbf{B B}$

Central Campesina Independiente - CCI

Central Independiente de Obreros Agrícolas y Campesinos - CIOAC

Central Nacional Campesina - CNC

Central de Trabajadores de México - CTM

Central Intelligence Agency - CIA

Centro Académico Memoria de Nuestra América - CAMeNA

Centro de Investigaciones y Estudios Superiores en Antropología Social - CIESAS

Centro de Investigaciones y Seguridad Nacional - CISEN

Comando das Organizações Revolucionárias Unidas - CORU

Comité de Lucha Revolucionaria - CLR

Comité para la Seguridad del Estado -KGB

Confederación de Cámaras Industriales de los Estados Unidos Mexicanos - CONCAMIN

Confederación Patronal de la República - COPARMEX

Consejo Nacional de Huelga - CNH

Consejo Nacional de Publicidad - CNP

Cuerpos de Defensa Rural - CDR

Departamento Autónomo de Prensa y Publicidad - DAPP

Dirección Federal de Seguridad - DFS

Dirección General de Investigaciones Políticas y Sociales - IPS

Dirección General de Policía y Tránsito - DGPyT

Doutrina da Contrainsurgência - CI

Doutrina de Segurança Nacional - DSN 
División de Investigaciones para la Prevención de la Delincuencia - DIPD

Ejercicios Regionales del Ejército - ETR

Ejército Guerrillero de los Pobres - EPG

Ejército Popular Revolucionario - EPR

Ejercito Zapatista de Liberación Nacional - EZLN

Equipo Argentino de Antropología Forense - EAAF

Escuela Nacional de Antropología e Historia - ENA

Estado Maior Presidencial - EMP

Federal Bureau of Investigation - FBI

Federación de Estudiantes Campesinos Socialistas de México - FECSM

Federación Nacional de Estudantes Técnicos - FNET

Fiscalía Especial para Movimientos Sociales y Políticos del Pasado - FEMOSPP

Frente Cívico Mexicano de Afirmación Revolucionaria - FCMAR

Frente Electoral del Pueblo - FEP

Frente Universitario Anticomunista - FUA

Fuerzas Armadas Rebeldes - FAR

Fuerzas Revolucionarias Armadas del Pueblo - FRAP

Grupo Anfibio de Fuerzas Especiales - GAFES

Grupo de Amigos Personales - GAP

Grupo Interdisciplinario de Expertos Independientes - GIEGI

Grupo Popular Guerrillero - GPG

Guardia Unificadora Iberoamericana - GUIA

Guerra de Baixa Intensidade - GBI

Guerreros Unidos - GU

Instituto Cubano de Amistad con los Pueblos - ICAP

Instituto Federal Electoral - IFE

Instituto Politécnico Nacional - IPN

Juventudes del Partido Comunista Mexicano - JCM

Liga Comunista 23 de Septiembre - LC23S

Liga Comunista Espartaco - LCE

Liga Leninista Espartaco - LLE

Liga Universitaria Nacionalista - LUN 
Movimiento de Acción Revolucionaria - MAR

Movimiento de Liberación Nacional - MLN

Movimiento Marxista Leninista de México - MM-LM

Movimiento de Izquierda Revolucionaria -MIR

Movimiento Revolucionario del Pueblo - MRP

Movimiento Universitario de Renovadora Orientación - MURO

Organização de Estados Americanos - OEA

Organização Latino-Americana de Solidariedade - OLAS

Organização de Solidariedade dos Povos de África, Ásia e América Latina - OSPAAAL

Partido Acción Nacional - PAN

Partido Comunista Mexicano - PCM

Partido de los Pobres-Brigada Campesina de Ajusticiamiento - PDLP-BCA

Partido Guatemalteco del Trabajo - PGT

Partido Popular - PP

Partido Popular Socialista - PPS

Partido Proletario Unido de América - PPUA

Partido Revolucionario del Proletariado Mexicano - PRPM

Partido Revolucionario Institucional - PRI

Plan de Defensa Nacional II - DN-II

Procuraduría General de la República - PGR

Productora e Importadora de Papel - PIPSA

Secretaria da Defesa - SEDENA

Secretaría de Gobernación - SEGOB

Tratado Interamericano de Assistência Recíproca - TIAR

Unidad Popular - UP

Unión General de Obreros y Campesinos de México - UGOCM

United States Army School of the Americas, ou Escola das Américas - SOA

Universidad Autónoma de la Ciudad de México - UACM

Universidad Autónoma del Estado de Guerrero - UAG

Universidad Autónoma de Nuevo León - UANL

Universidad Autónoma de Puebla - UAP

Universidad Nacional Autónoma de México - UNAM 


\section{SUMÁRIO}

\section{LISTA DE SIGLAS}

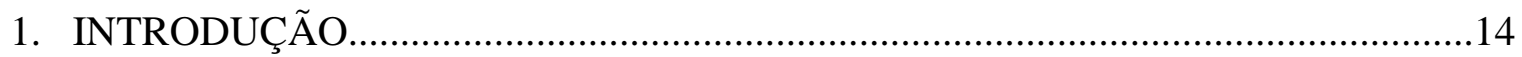

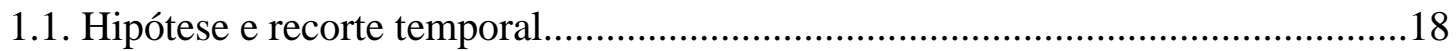

1.1.1. O movimento armado mexicano.................................................................

1.1.2. O movimento estudantil e as guerrilhas urbanas.........................................30

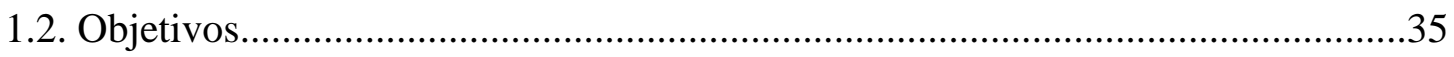

1.3. Fontes

1.3.1. Informes presidenciais..........................................................................

1.3.2. Documentos da Dirección Federal de Seguridad (DFS)y de la Dirección de Investigaciones Políticas y Sociales (IPS) localizados no AGN.....

2. GUERRA FRIA E CONSOLIDAÇÃO DO ANTICOMUNISMO................................49

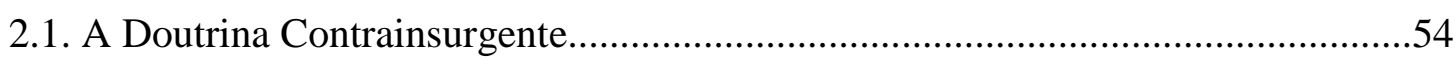

2.2. O Informe Rockefeller e a América-Latina.........................................................57

2.3. A Doutrina de Segurança Nacional..................................................................60

2.4. Segurança Nacional Mexicana...........................................................................63

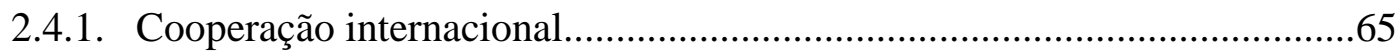

2.4.2. A Dirección Federal de Seguridad por dentro............................................73

2.5.As Forças Armadas: profissionalização e despolitização........................................79

2.5.1. O Exército mexicano no contexto latino-americano......................................85

2.5.2. Preparação da Guerra Total.......................................................................89

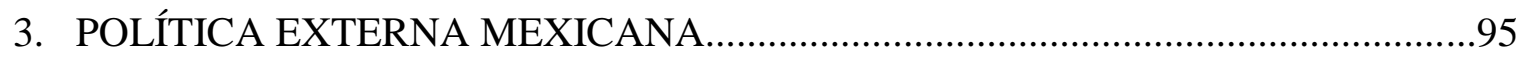

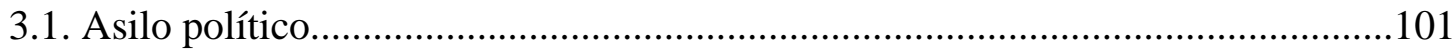

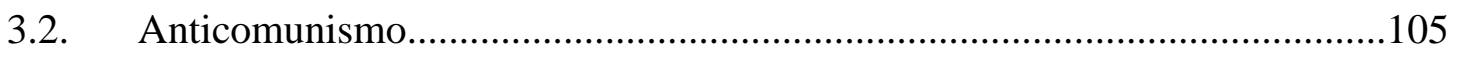

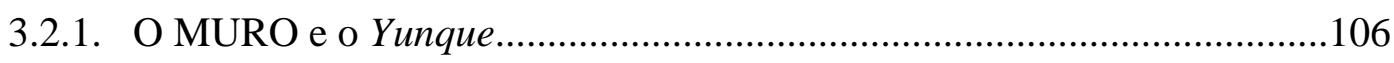

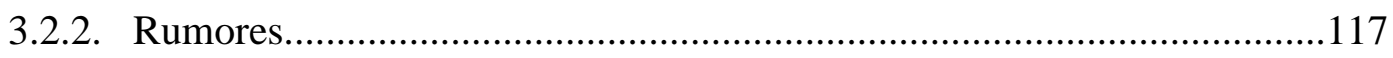

4. INSTITUCIONALIDADE E ORDEM INTERNA................................................130

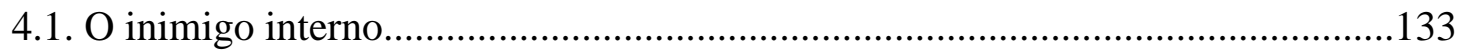




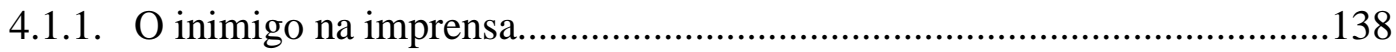

4.2. A conspiração comunista internacional...........................................................141

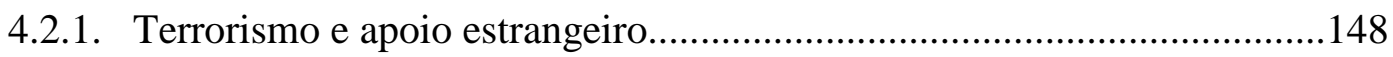

4.2.2. A Revolução Cubana e a "orfandade" da guerrilha mexicana..................150

4.2.3. Maoísmo e a guerra popular prolongada no México...............................157

4.2.3.1.O PRPM e o treinamento militar......................................................164

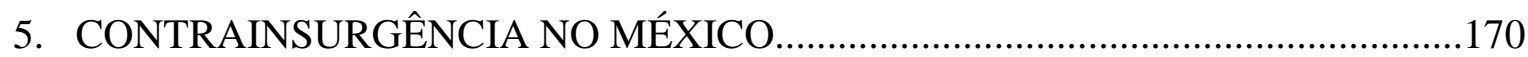

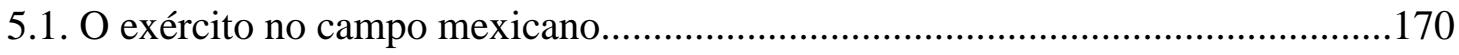

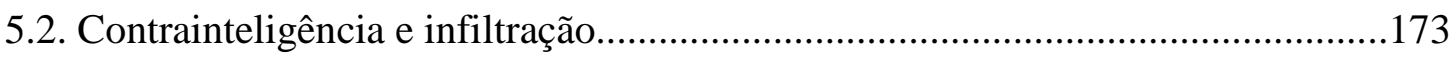

5.2.1. Movimento Revolucionario del Pueblo..............................177

5.3. Grupos paramilitares

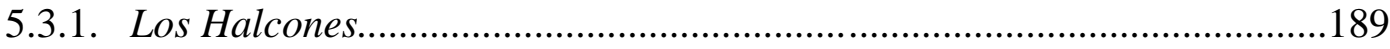

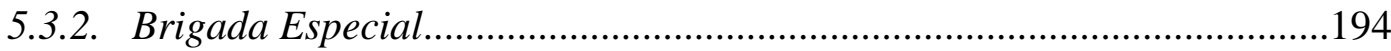

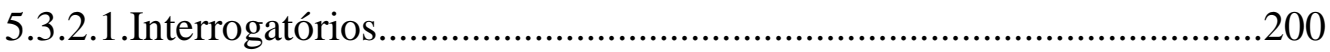

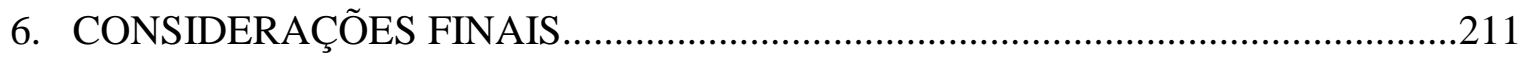

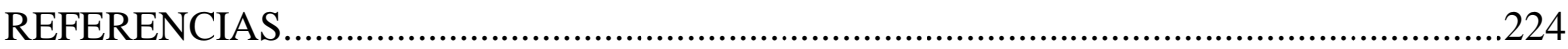

ANEXO 


\section{INTRODUÇÃO}

$\mathrm{O}$ ano dois mil significou, momentaneamente, a possibilidade de uma transformação no panorama político mexicano. Pela primeira vez em setenta e um anos, a disputa eleitoral foi ganha por um partido político de oposição ao Partido Revolucionario Intitucional (PRI). Assim, o Partido Acción Nacional (PAN), um dos partidos mais longevos da história política mexicana ${ }^{1}$ encabeçado pelo ex-gerente da Coca-Cola no México, Vicente Fox Quezada, simulou romper com as formas priístas de governar.

A nova classe dominante mostrou uma face ainda mais violenta. De acordo com o jornalista Carlos Fazio, atualmente "as flagrantes violações aos direitos humanos, com vexames e torturas aos detentos" aumentaram muito, convertendo-se no prelúdio de uma “perigosa involução autoritária dos aparatos do Estado" (FAZIO, 2011). Com uma estratégia conservadora, alguns setores políticos, junto aos monopólios de comunicação de massa, promovem e legitimam a ação violenta do Estado.

A mudança que a população mexicana almejava, de uma transição democrática, foi imperceptível, e a violência política entrou numa espiral incontrolável. Nesse processo apreciamos umas características forjadas na sólida experiência do exercício da repressão. Isto é, o partido da transição não desmontou o aparato repressivo criado pelo PRI, simplesmente o moderniza.

Em março de 2005, por exemplo, os mandatários dos EUA, Canadá e México assinaram a Aliança para a Segurança e a Prosperidade da América do Norte (ASPAN). Declaram que "num mundo que evolui rapidamente, devemos construir novos espaços de cooperação, para providenciar maior segurança a nossas sociedades abertas, fazer nossas empresas mais competitivas, e nossas economias mais sólidas" (OFICINA DE PROGRAMAS DE INFORMACIÓN INTERNACIONAL, 2005). O eixo estratégico nessa nova aliança estava - como nos velhos tempos da Doutrina de Segurança Nacional (DSN) no binômio segurança-prosperidade. Como um desdobramento do ASPAN criou-se a Iniciativa Mérida (2008). O Congresso dos EUA aprovou 465 milhões de dólares para apoiar

\footnotetext{
${ }^{1}$ Fundado por Manuel Gómez Morín (1897-1972), político e ex-reitor da UNAM (1939). Surgido como oposição ao regime do general Lázaro Cárdenas, os militantes consideravam que a Revolução Mexicana tinha se tornado "um pesado redemoinho de apetites desencadeados, de propaganda sinistra, de ideologias contraditórias, de mentira sistemáticas (sic), que impede a visão limpa da vida nacional" (PARTIDO ACCIÓN NACIONAL, 2016).

Advertência: As traduções da bibliografia e dos documentos ao português são nossas. Optou-se por uma tradução das fontes de época - desde o espanhol mexicano - conservando, a medida do possível, as palavras iguais ou parecidas no português, se apresentam semântica idêntica ou semelhante. Em anexo, há uma seleção das fontes transcritas para apreciação dos originais em espanhol.
} 
a luta contra as drogas no continente. Desse orçamento, México obteria 400 milhões de dólares que seriam utilizados para a modernização do sistema de comunicações, radares, treinamento de cachorros, helicópteros e aeronaves, além da assessoria e treinamento técnico policial e militar (GONZÁLEZ TORRES, 2012).

Com esse antecedente, Felipe Calderón Hinojosa, o segundo presidente do PAN (2006-2012), iniciou seu governo declarando a guerra contra o narcotráfico, o novo rosto do inimigo interno. Os militares são colocadosfora dos quartéis para patrulhar as ruas de diversas cidades do país nos chamados "operativos conjuntos",2. A partir desse momento a violência teria crescido em vários sentidos: das Forças Armadas contra o crime organizado; do crime organizado contra as Forças Armadas; e de ambos contra a população civil.

A militarização do território nacional e a guerra contra o narcotráfico superou todos os recordes mexicanos: aproximadamente 74 mil mortos tipificados como "baixas colaterais" e 15 mil desaparecidos, somente entre 2006 e $2012^{3}$. Em tempos de ruptura do tecido social propiciada pela guerra e enquanto os protestos eram reprimidos violentamente, Enrique Peña Nieto, um rosto jovem do PRI, assumiu a presidência. O velho partido com promessas de renovação voltaria valendo-se das velhas tácticas: a fraude eleitoral, a manipulação dos meios de comunicação, a prisão de opositores políticos e a violência contra o movimento social.

Em números, o saldo de três anos do governo priísta chegou aos 25 mil desaparecidos e 100 mil pessoas assassinadas violentamente (ARISTEGUI, 2012; GORDTS, 2014). Estes números vieram à tona como consequência de dois casos que comoveram o país, em 2014, trazendo para a opinião pública o histórico papel que protagonizaram as Forças Armadas na execução da repressão através de métodos de violação dos direitos humanos.

Em Tlatlaya, Estado do México, foram fuzilados 22 jovens suspeitos de pertencer a um cartel do narcotráfico. A versão oficial proporcionada tanto pelo Exército como pela Procuraduría General de la República (PGR), apontava que os militares dispararam em defesa própria. Em investigações jornalísticas, assim como em informes elaborados por organizações de defesa dos direitos humanos, apoiados nas declarações de uma sobrevivente, soube-se que o grupo de jovens se encontrava desarmado. Rodeados pelo Exército se entregaram sem resistência. Os jovens foram torturados e posteriormente fuzilados. Os corpos foram removidos, a cena do crime foi alterada, foram plantadas armas de fogo de uso exclusivo do Exército (FERRI, 2014).

\footnotetext{
${ }^{2}$ A estratégia de "operativos conjuntos" consiste, basicamente, na cooperação das forças federais (Exército e Marinha) com os corpos policiais de cada estado, a fim de militarizar a totalidade do território (EL UNIVERSAL, 2011).

${ }^{3}$ Cifras relativas ao período entre janeiro de 2006 e fevereiro de 2012.
} 
Sabemos que as Forças Armadas são uma corporação que atua através de uma cadeia de comando que, pela disciplina da corporação, não dá espaço para desacatos. Segundo o Centro de Derechos Humanos "Miguel Agustín Pro Juárez" (2015), a ordem que os militares receberam foi a de "abater delinquentes", sem presunção de inocência, sem respeito ao devido processo. Até agora não há nenhum militar processado.

O outro caso é o desaparecimento de 43 estudantes indígenas camponeses da Escuela Normal Rural "Raúl Isidro Burgos" de Ayotzinapa, Guerrero [fig.1]. Os jovens estavam na cidade de Iguala realizando uma atividade para angariar fundos no intuito de locomover-se à passeata comemorativa do massacre de estudantes de 1968, que todo ano, ocorre na capital do país. Durante os acontecimentos do 26 de setembro de 2014, além do desaparecimento dos 43 jovens, foram assassinadas seis pessoas, entre elas o normalista Julio César Mondragón, cujo corpo apareceu horas depois do ataque com a pele do rosto arrancada, sem olhos ${ }^{4}$.

As hipóteses dos acontecimentos são várias. Uma delas é que os autores foram os Guerreros Unidos (GU), organização criminosa que opera nessa região do estado, vinculados ao prefeito da cidade de Iguala, José Luis Abarca, e à esposa dele, María de los Ángeles Pineda Villa, irmã dos líderes do cartel. Aquela noiteAbarca mobilizaria, a polícia municipal para evitar os possíveis protestos dos estudantes no ato presidido por sua esposa. A polícia entregaria os jovens a um grupo de sicários dos GU, que procederiam a assassinar e queimar aos estudantes no aterro de uma comunidade próxima.

Outra hipótese, sustentada pelos sobreviventes do ataque e defendida pelos pais e familiares dos estudantes desaparecidos: depois de um ataque coordenado entre policiais e pistoleiros, reunidos num hospital onde esperavam que alguns dos feridos fossem atendidos, elementos do Exército apareceram para fotografar e torturar psicologicamente aos jovens. Posteriormente, quarenta e três deles seriam trasladados às instalações da $27^{\mathrm{a}}$ Zona Militar ${ }^{5}$. Diante da paralisia institucional, a busca independente dos quarenta e três normalistas conduziu a um sem-fim de fossas clandestinas com corpos que até agora não foram reconhecidos (GIEI, 2015).

\footnotetext{
${ }^{4}$ A versão oficial apresentada pela PGR argumenta que o rosto do jovem foi comido pelos animais selvagens da região. Atualmente, o corpo de Mondragón está sendo novamente examinado pelo Grupo Interdisciplinario de Expertos Independientes (GIEGI) e pelos membros do prestigioso Equipo Argentino de Antropología Forense (EAAF), pois, considerando os resultados da primeira necropsia, existe a possibilidade de que o rosto de Julio tenha sido arrancado quando o jovem ainda estava com vida (PIETRICH, 2015).

${ }^{5}$ Tanto o Ejército Popular Revolucionario (EPR) (grupo armado que apareceu publicamente em 1996 no estado de Guerrero) como Francisco Gallardo (ex-general preso entre 1997 e 2002 por sua posição sobre a necessidade de criar a figura de um ombudsman dentro das Forças Armadas), alertaram, sem repercussão na investigação oficial, que os relatos dos sobreviventes descreviam perfeitamente as características de um operativo militar. Sendo assim, provavelmente, os estudantes teriam sido incinerados nos crematórios militares (EPR, 2014; MARTÍNEZ, 2015).
} 
Entre 1967 e 1972, no estado de Guerrero operou a guerrilha liderada pelo professor Genaro Vázquez Rojas, a Asociación Nacional Cívica Revolucionaria (ACNR). Constituída pelos sobreviventes do massacre de aproximadamente oitenta copreros (trabalhadores que extraem o azeite de coco), organizados contra o governador do estado, Raymundo Abarca Alarcón o 20 de agosto de 1967. A guerrilha foi contra o aumento dos impostos ao azeite de coco, e contra a imposição de um presidente para a Unión Regional de Productores de Copra del Estado de Guerrero. No mesmo estado, em 1969, ao concluir uma concentração dentro de uma escola primaria na cidade de Atoyac, pais de família e professores foram massacrados pela Polícia Judicial, sob as ordens do mesmo governador. A partir de então, o professor Lucio Cabañas Barrientos teve de passar à clandestinidade, quando funda o Partido de los Pobres-Brigada Campesina de Ajusticiamiento (PDLP-BCA).

Chamamos a atenção ao fato de que o sobrenome ostentado pelo governador que massacrou nos anos sessenta é o mesmo do prefeito que ordenou o ataque dos normalistas em 2014. Este detalhe ajuda a ter uma ideia do continuísmo na política mexicana. Podemos referir-nos, pois este exemplo permite, à tradição consolidada do cacicazgo, forma de controle político nas regiões rurais ${ }^{6}$.

Como um processo paralelo à política continuísta e às formas de repressão, encontramos também a recorrência da guerrilha. Ambos líderes anteriormente mencionados, Genaro Vázquez e Lucio Cabañas, foram estudantes da Escuela Normal Rural de Ayotzinapa. Foram militantes da Federación de Estudiantes Campesinos Socialistas de México (FECSM), assim como das Juventudes del Partido Comunista Mexicano (JCM). Esses grupos armados, com sólidas bases de apoio, tornaram-se os referenciais mais fortes da luta armada rural entre a década de sessenta e setenta. Por estes motivos, o estado de Guerrero é considerado um dos estados mais afetados durante a guerra suja ${ }^{7}$.

O contexto violento presente na sociedade mexicana neste início do século XXI não

\footnotetext{
${ }^{6} \mathrm{Na}$ definição do antropólogo norte-americano Paul Friedrich, o cacique é uma liderança forte e autocrática relacionada aos processos políticos locais e regionais. Sua "dominação é pessoal, informal e geralmente arbitrária, e é exercida mediante um núcleo central de familiares, pistoleiros e dependentes; se caracteriza pela ameaça e o exercício efetivo da violência" (MEYER, 2000, p. 36). Estas figuras, recorrentes na política mexicana, geralmente, são personagens poderosos que dominam uma região a partir de vínculos como os laços sanguíneos, compadrios e alianças matrimoniais. É um elo entre a modernidade política e o mundo rural e provincial. A figura do cacique, então, consegue transmitir e aplicar leis provenientes do governo federal no âmbito local, utilizando canais tradicionais para impor, precisamente, medidas alheias à tradição. Ou, de maneira inversa, é a figura que leva as demandas locais para a esfera política central (CHEVALIER, 1993, p. 275). O cacique é, enfim, a articulação entre duas culturas políticas.

${ }^{7}$ A Universidad Autónoma del Estado de Guerrero (UAG), pela ação de vários acadêmicos e estudantes, conseguiu a instituição de uma Comissão da Verdade. A finalidade era registrar as pessoas que foram afetadas durante a guerra suja no estado, especificamente entre 1969 e 1979. Além do esclarecimento da verdade com relação à violação dos direitos humanos, a comissão enfocou a reparação econômica das vítimas e familiares.
} 
pode se entender fora do marco do complexo processo de institucionalização da repressão. Por um lado, temos práticas políticas arraigadas na estrutura política que são fundamentadas no exercício da violência. Por outro lado, desde 1964 encontramos a presença constante de um grande número de organizações armadas, urbanas e rurais, que respondem, claro, a diversas causas e demandas, segundo as peculiaridades do local em que se desenvolvem. Sobre isso, Carlos Montemayor afirma que desde a década de sessenta, o "México tem vivido em estado de guerra de maneira quase ininterrupta" $(1999, \text { p. } 27)^{8}$. Desde então, a resposta do Estado tem sido quase que exclusivamente militar, sob a premissa do aniquilamento da oposição. Não existe um esforço real por compreender e solucionar as causas que produzem essas manifestações da luta violenta. As necessidades econômicas e sociais, assim como as exigências de caráter político, continuam ignoradas (MONTEMAYOR, 1999, p. 21-26; SIERRA, 2008, p. 361).

Acreditamos que existe uma linha contínua nos processos políticos mexicanos desde a segunda metade da década de sessenta. Os massacres de camponeses, operários e estudantis, a tortura, a execução e o desaparecimento de militantes de oposição (ou suspeitos de sê-lo) nas mãos das forças de segurança do Estado (FAZIO, 2012; ORGANIZACIÓN DE LAS NACIONES UNIDAS, 2011).

\subsection{Hipótese e recorte temporal}

Ao ponderar-se o anterior e atendendo à necessidade de compreender o avanço do processo de destruição do tecido social mexicano, nesta pesquisa trabalhamos sob a hipótese de que entre 1964 e 1982 ocorre uma mudança qualitativa nos métodos de repressão às manifestações de oposição ao regime. O México passou de um Estado autoritário ${ }^{9}$ a um contrainsurgente, onde o desaparecimento, a tortura, a prisão política e a execução foram recursos utilizados para o extermínio da esquerda civil e armada. Ou melhor, o Estado utilizou táticas militares na luta

\footnotetext{
${ }^{8}$ Carlos Montemayor (1947-2010) poeta, tradutor, ensaísta e romancista. Dividiu suas tarefas intelectuais entre o estudo e promoção da poesia em língua indígena e a luta social. A partir da sua experiência na mediação entre as guerrilhas aparecidas na última década do século XX e o Estado, deixou uma série de reflexões sobre a maneira pela qual o Estado historicamente reage à luta armada. Por isso que os textos do autor, a partir da sua experiência e proximidade com os movimentos armados, signifiquem um grande referencial para este trabalho (MONTEMAYOR, 2010).

9 A definição de "autoritarismo" apresenta várias facetas, dependendo do contexto em que é utilizado o termo. Para o caso de nossa pesquisa, o conceito serve para caracterizar a estrutura de um sistema político que privilegia a autoridade governamental e diminui o consenso. Ou seja, o sistema onde o poder se concentra em uma pessoa ou em um órgão, deixando em segundo plano as instituições representativas (STOPPINO, 1998, p. 94-103).
} 
política gerando um período que bem pode ser denominado como "guerra suja".

Este conceito foi acunhado pelo jornalista francês Hubert Beuve-Méry para refletir sobre um novo tipo de guerra, a sale guerra indochinoise (a guerra suja indochinesa), num artigo publicado no 17 de janeiro de 1947 no jornal Le Monde. O conceito se referia fundamentalmente às execuções em massa, à tortura e desaparecimento e aos julgamentos irregulares como estratégia do Exército francês contra as organizações armadas anticoloniais (ROBIN, 2004, p. 76).

Sabemos que este termo é polêmico para pensar a história mexicana. Lembremos que o conceito de guerra suja foi retomado para caracterizar os conflitos cujo desenvolvimento violavam as Convenções de Genebra ${ }^{10}$. Em território latino-americano se utilizou a partir da década dos oitenta, durante os processos de abertura democrática dos regimes do Cone Sul. Apesar de que o termo foi introduzido informalmente para descrever a situação mexicana nessa mesma década, até o ano dois mil começa a circular amplamente nos meios de comunicação. Segundo a historiadora Adela Cedillo (2008) este descompasso provavelmente esteja relacionado ao fato de que o México não participou na Operação Condor, plano executado entre 1975 e 1983 e que consistia na coordenação dos serviços de inteligência do Brasil, Paraguai, Chile, Uruguai e Argentina (todos com governos militares) respaldados pelos EUA e cujo objetivo era erradicar o comunismo em escala continental (CALLONI, 2005). Ou seja, o conceito estaria entendido sempre na sua relação à repressão dos regimes militares sobre a oposição política e guerrilheira.

O recorte temporal que propomos nesta pesquisa corresponde a três períodos presidenciais, encabeçados por Gustavo Díaz Ordaz (1964-1970), Luis Echeverría Álvarez (1970-1976) e José López Portillo (1976-1982). Em conjunto, estes dezoito anos são considerados como o colapso dos elementos constitutivos da cultura política mexicana ${ }^{11}$.

A partir da década dos quarenta, o Estado mexicano adotou uma política protecionista para o fomento da industrialização. Os traços fundamentais desse projeto econômico modernizador foram os seguintes: o fomento da inversão através da baixa imposição físcal ao

\footnotetext{
${ }^{10}$ Assinados em 1949, os Convênios de Genebra significam uma tentativa de normatizar o direto internacional humanitário no que se refere ao tratamento de feridos, doentes, náufragos e prisioneiros de guerra, bem como para o estabelecimento de normas de proteção à população civil (COMITÉ INTERNACIONAL DE LA CRUZ ROJA, 2012).

${ }^{11}$ A socióloga María Aidé Hernández define cultura política como o conjunto de orientações políticas e crenças relativas ao sistema político compartilhadas por um determinado grupo social. Tais orientações podem ser de três tipos: 1) cognitivas (conhecimentos e crenças); 2) afetivas (sentimentos); 3) avaliativas (juízos e opiniões sobre o sistema e atores políticos). (HERNÁNDEZ, 2008, p. 261-303). Em termos mais simples, Arnaldo Córdova a define como uma "sedimentação histórica na consciência coletiva de percepções, conhecimento e prática da coisa pública; modo de ser dos homens e codificação, arbitrária e geralmente anárquica, de ideais e experiências do todo" (CÓRDOVA, 1989, p. 320).
} 
capital privado; baixos salários impostos pelo controle vertical da classe operária, que, ao mesmo tempo, se traduz na pauperização das massas camponesas; baixos preços e tarifas de produtos e serviços estatais para dinamizar o consumo (PUNTO CRÍTICO, 1973, p. 33-34). Estas medidas contribuíram para o crescimento do operariado, da burguesia e das classes médias, em detrimento das massas camponesas ${ }^{12}$.

As condições geradas pelo milagre mexicano permitiram um crescimento econômico relevante que fez que "as forças produtivas se desenvolvessem notavelmente provocando mudanças na estrutura e no peso específico das classes sociais" (WOLDENBERG; HUCUJA,1979, p. 29) através da execução de um modelo econômico desenvolvimentista. Fomenta-se a inversão privada nacional e estrangeira, assim como a criação de infraestrutura econômica junto a organismos e empresas paraestatais. Socialmente surgiu uma burguesia nacional protegida pelo Estado e se esboçou o que posteriormente seria a moderna classe média, entendida no sentido de "pequena burguesia", como uma classe ou camada social proprietária que está entre a burguesia e a classe operária (SMITH, 2001, p. 334). O processo de industrialização, então, modificou as características da população mexicana ${ }^{13}$.

Enquanto isso, os poderes econômicos e políticos ficavam cada vez mais centralizados na figura presidencial: "além disso, com o desenvolvimento econômico, começaram a ser tão amplos os recursos federais que todo projeto importante, estadual ou regional, dependia das decisões tomadas na Cidade do México para sua realização" (AGUILAR CAMÍN; MEYER, 2000, p. 216). Ou seja, temos que o crescimento econômico foi possível graças à aparente imobilidade do sistema político, que é estável e fortemente autoritário, inibindo a formação e fortalecimento de uma esquerda que representasse um verdadeiro perigo.

Já na metade da década de 1950, uma crise econômica internacional refletiu na economia mexicana e a espiral inflacionária começou a crescer. Os assessores da área de

\footnotetext{
${ }^{12}$ Segundo Armando Bartra, na década de 1960 havia mais de 400 mil camponeses sem terra: “a insuficiência das terras nas mãos dos camponeses não só se expressa nos 25 milhões que carecem de parcela, porque quase dois milhões dos que si estão em possessão dispõem de minifúndios temporais de infra-subsistência, de modo que devem somar-se aos que carecem de terra na busca de ingressos complementares" (BARTRA, 1985, p. 99). A proletarizada classe camponesa converteu-se num excedente de força de trabalho cujos traços principais consistiam "no deslocamento da força de trabalho e, com isso, a constituição de um exército de reserva cuja presença não é nova na qualidade, mas sim na quantidade, pelas dimensões que alcança o desemprego neste período". (RUBIO, 1987, p. 52). A manifestação social deste conflito econômico se traduz na subocupação rural, que se manifesta "no momento mesmo em que toda, ou parte da mão-de-obra agrícola tem trabalho temporário, vê-se obrigada a utilizar parcialmente seu tempo em atividades remuneradas nas quais o salário é ainda mais baixo, ou então, não recebe nenhum salário. Nos casos mais extremos, o fenômeno se manifesta no desemprego, ou no que alguns economistas e sociólogos chamam 'ócio rural'” (STAVENHAGEN et. al. 1985, p. 127).

${ }^{13}$ Em 1940 a agricultura representava o $10 \%$ da produção nacional (em 1977, o 5\%); a manufatura, o 19\% (em 1977, o 23\%). Em 1940 a população era de 19,6 milhões de pessoas; em 1977, era de 67 milhões; e em 1970, chega a 70 milhões. Por último, enfatizamos que em 1940, cerca de $20 \%$ da população morava nos centros urbanos; em 1977, já é 50\%.
} 
economia do presidente Adolfo Ruíz Cortines (1952-1958) avaliaram a pertinência de promover a substituição de importações de bens de capital, a fim de exigir o aumento nos investimentos e a busca de mercados maiores, aumentando o mercado interno e a exportação manufatureira. O Estado iria incrementar sua participação no processo de produção, aumentando também o setor paraestatal. Este processo é chamado "desenvolvimento estabilizador" (SEMO, 1989, p. 45). O país entrou numa crise sem precedentes: quinze por cento dos funcionários de instituições e empresas do Estado foram dispensados, a moeda foi desvalorizada e os créditos estatais foram concentrados nos latifúndios e na indústria manufatureira.

Observamos que a esquerda debilitada, e, de alguma maneira, esmagada pelo controle estatal, começa a se reconfigurar nesse período. Inicia-se, assim, um novo ciclo de mobilização operária e de radicalização das classes médias. Na mesma medida, incrementa-se o uso da repressão para contê-los.

Para explicarmos este contexto de crise política e econômica, retomamos a definição do filósofo e militante italiano Antônio Gramsci, propondo, assim, que em 1964 começa decididamente um processo de crise hegemônica. Na definição do autor, existe hegemonia quando:

A supremacia de um grupo social se manifesta de duas formas, como
"domínio" e como "direção intelectual e moral". Um grupo social é
dominante em relação a grupos adversários que tendem a "liquidar" ou a
submeter inclusive com a força armada, sendo dirigente dos grupos afins e
aliados. Um grupo social pode e inclusive deve ser dirigente, ainda antes de
conquistar o poder governamental (esta é uma das condições principais para
a própria conquista do poder); depois, quando exerce o poder e ainda que o
tenha fortemente em punho, torna-se dominante, mas deve seguir sendo
também "dirigente" (GRAMSCI, 1975, p. 387).

Entendemos hegemonia, então, não somente como a direção das decisões econômicas e políticas da sociedade, mas também, como a direção moral e intelectual dessa sociedade. Este último fator torna viável o domínio e ajuda na construção do consenso. A esse respeito, o historiador inglês E. P. Thompson assevera que a hegemonia não é uma imposição simples que implique a dominação total, não vai impor "uma visão total da vida: pelo contrário, impõe cabrestos que impedem a visão em certas direções enquanto a deixam livre em outras" (THOMPSON, 1995, p. 106). O fato de que as crises possibilitem a radicalização da resistência, não implica que anteriormente não existiram, mas como aponta Barrington Moore, "há uma tendência constante de que os detentores de autoridade invertam esse 
processo em seu próprio benefício e, portanto, apresenta-se uma tendência de parte dos súditos de resistir à autoridade, evadi-la, ou ainda, opor-se a ela" (MOORE, 1989, p. 38).Nesse sentido, a hegemonia utiliza tanto a coerção necessária para manter o poder, como o consenso que o faz culturalmente aceitável.

Agora, numa situação crítica, a classe dirigente definitivamente já não possui o controle absoluto das classes subalternas. O consenso é quebrado. A sacralização da figura presidencial foi deixada de lado. A classe política já não representa a totalidade da população e há um evidente distanciamento das massas. O partido caduca. O partido termina se tornando anacrônico e nos momentos de crise aguda, chega a se esvaziar inteiramente de seu conteúdo social, ficando como se estivesse construído no vazio (GRAMSCI, 1972, p. 105). A tolerância e a concessão, tão eficientes para a consolidação dos governos priístas, ficou afetada pelo aumento da repressão e a precarização da vida, resultados da crise do modelo econômico.

Atendendo a nosso recorte temporal, nos deteremos, portanto, nas características da posição mexicana dentro da Guerra Fria, em dois sentidos. Por um lado, observamos o fato de que o México radicalizou à esquerda a política exterior, se mostrando, além de independente, contra a linha estadunidense de forma agressiva. Criou-se uma imagem de governo progressista com o fim de preservar a legitimidade internacional baseado no histórico nacionalismo revolucionário. Lembremos que os governos pós-revolucionários se revelaram discursivamente anti-imperialistas, pois, durante o processo revolucionário de princípio do século $\mathrm{XX}$, os EUA mantiveram uma posição abertamente intervencionista (AGUILAR CAMÍN; MEYER, 2000). Além do mais, os estrangeiros sempre foram os patrões exploradores dos operários e camponeses, pelo que se compartilhavam certos elementos nacionalistas entre a burguesia e o povo em geral.

Aproveitando essa característica comum, os sucessivos governos puseram ênfase na construção do mexicano: a identidade nacional através da cultura e a educação pública. As bases ideológicas pós-revolucionárias permitiram assim:

uma grade comum de leitura dos acontecimentos que funda sua solidariedade de ação; permite exprimir, em termos de interesses gerais e escolha da sociedade, dando-lhes um alcance geral, decisões e atitudes cuja origem está muitas vezes na conjuntura mais imediata; constitui enfim, para além de toda finalidade puramente prática, um conjunto de crenças que permite integrar os membros do partido numa comunidade quase espiritual (BERSTEIN, 2003, p. 91).

A construção da identidade nacional é o fundamento da política externa, já que 
determina diretamente a política militar e a estratégia global. Paralelamente à radicalização externa, na política interna se viveu um progressivo abandono de tais preceitos revolucionários enquanto se impulsionavam políticas conservadoras ${ }^{14}$.

O interno e o externo são políticas indissolúveis. Nesse sentido, a ideologia joga um papel fundamental, pois é constitutiva do sistema e prevalece sobre qualquer outra consideração. Tomado o anterior ao pé-da-letra, poderíamos pensar que a ação internacional fosse pura e simples projeção externa dessa ideologia ${ }^{15}$. No entanto, "os objetivos de longo prazo apregoados pelo poder [...] justificam de saída todos os compromissos e todas as sinuosidades da Realpolitik e dão uma coerência às ações mais contraditórias" (MILZA, 2003, p. 378).

\footnotetext{
${ }^{14}$ Para a caracterização do "nacionalismo revolucionário", acolhemos a definição feita por Arnaldo Córdova, que expõe o conceito em dez pontos principais: 1) Estado como ponta da organização política e social, assim como do desenvolvimento material. Mas devido à precariedade econômica pós-revolucionária, a política adquiriu um papel mais relevante. 2) A propriedade privada é considerada o princípio básico da organização social, sujeita à política que o Estado impõe no desenvolvimento econômico. 3) Fundamenta-se na ideia do atraso material do país, como eixo das soluções políticas propostas para conseguir o desenvolvimento. 4) O conceito de ordem e de instituições sociais é definido como uma necessidade que a sociedade é incapaz de construir, por isso o Estado tem a missão de impô-los através de um governo forte, exercido por um governante árbitro dotado de faculdades extraordinárias. 5) Partindo da ideia de ordem social e institucional (habitual, pacífica e permanente), se cria um modelo de conciliação de classes sociais sob direção do governante árbitro, sendo que o Estado é o único espaço para a resolução de conflitos. 6) As massas são consideradas parte fundamental para a consolidação da política de desenvolvimento, pelo que são incluídas no bem-estar econômico através de reformas sociais, e mobilizadas pelo corporativismo das organizações de classe. 7) Neutralização da possibilidade de explosão revolucionária das massas em dois sentidos: desprestigiando, política e ideologicamente, a oposição não oficial sob o argumento do risco de perder as conquistas da Revolução, ou seja, as reformas sociais; e alimentando a ideia do poder sem limites do Estado, especificamente do governante. 8) Atraso econômico também como fundamento da política exterior, permitindo a penetração do capital internacional, em troca da aceitação do papel regente do Estado na economia nacional. Assim se corrobora a ideia do desenvolvimento independente. 9) Na defesa dessa soberania político-econômica, as medidas estatais vão da expropriação e nacionalização de empresas estrangeiras, até a diversificação e regulamentação das inversões estrangeiras, mas sem colocar a ruptura com a potência econômica em questão. 10) Como ideologia dominante, responde aos interesses da classe dominante, mas não é expressa pelos representantes desta, e sim pelos grupos políticos que exercem o poder, mediante a política estatal. (CÓRDOVA, 1980, p. 35-38).

${ }^{15}$ Pierre Milza (2003, p. 378) aponta que a ideologia é a peça-chave na conformação da cultura política. Seguindo a Almond e Verba (cientistas políticos dedicados ao estudo do conceito de cultura política na década de sessenta), María Aidé Hernández define cultura política como o conjunto de orientações políticas e crenças relativas ao sistema político, compartilhadas por um determinado grupo humano. As orientações são de três tipos: 1) cognitivas (conhecimentos e crenças); 2) afetivas (sentimentos); 3) avaliativas (juízos e opiniões sobre o sistema e atores políticos). (HERNÁNDEZ, 2008, p. 261-303). Focando-nos no terceiro tipo, fazemos uma distinção entre os conceitos de cultura política e ideologia, propondo, que a cultura política é o corpo de crenças da população a respeito do político, com uma pretensão geral e nacional. Enquanto que ideologia é uma formulação doutrinária elaborada por um grupo diferenciado (militantes ou seguidores) que a promove conscientemente, e que, quando una classe se converte em dominante tem o poder de impô-la (PESCHARD, 2001, p. 8-11). Atendendo a esta distinção, Marilena Chauí aponta que é impossível compreender a origem e a função da ideologia sem observar a luta de classes, pois "a ideologia é um dos instrumentos da dominação de classe e uma das formas da luta de classes. A ideologia é um dos meios usados pelos dominantes para exercer a dominação, fazendo com que esta não seja percebida como tal pelos dominados" (CHAUI, 2009, p. 33). Então, a principal função da ideologia é esconder a existência dessa luta. Além disso, a autora coloca que o crescimento do poder da ideologia está em relação a sua capacidade para ocultar a origem da divisão social e, portanto, da luta de classes.
} 


\subsubsection{O movimento armado socialista mexicano}

A diferença entre as formações guerrilheiras que ocorreram desde os primeiros anos da luta pela independência no século XIX, passando pela guerrilha na Revolução Mexicana, e o movimento aramado da segunda metade do século XX, sustenta-se principalmente em duas premissas: o marxismo-leninismo é colocado como o guia científico que permitiria uma leitura da realidade objetiva para projetar a transformação da sociedade; a via armada seria a única tática possível para implantar o socialismo (MORENO, 2012; RANGEL, 2013).

Entre 1964 e 1982, as organizações armadas proliferaram de maneira tal que temos o registro de que aproximadamente mil e setecentos mexicanos optaram por este método de luta, integrando em volta de 32 grupos guerrilheiros (SIERRA, 2008, p. 364) [fig. 2] ${ }^{16}$. Existe um consenso parcial na historiografia mexicana de que os grupos armados foram uma resposta à inaptidão das autoridades locais na violência para lidar com os reclamos populares, pois, facilmente podem ser localizados como fenômenos colaterais da pobreza, a injustiça e a violência, sobretudo no âmbito rural. Sobre isso, assinala o antropólogo peruano Ricardo Melgar Bao, as guerrilhas e movimentos armados que se sucedem durante a Guerra Fria são expressão das diversas conjunturas regionais e nacionais. Porém, não se devem menosprezar os debates e as experiências internacionais como influências:

Os espelhos entrecruzados da revolução russa, da guerra civil na Espanha, da luta de libertação nacional na Argélia e Vietnam, da revolução chinesa, da revolução mexicana e da revolução cubana, têm gravitado de diversas maneiras nos imaginários e lógicas da recepção guerrilheira latino-americana (MELGAR, 2008, p. 36-37).

Por outro lado, na sua análise das diversas formas de aquisição do poder, o sociólogo Barrington Moore propõe que os grupos que estão na luta pela tomada do comando geralmente criam doutrinas que permitem proporcionar uma explicação do que está errado nas condições atuais, assinalando, da mesma forma, os possíveis caminhos para a correção do estado de coisas. Essa doutrina é denominada pelo autor como "mito constitucional”. Pode-se apresentar de duas maneiras diferentes: como nativismo ou como xenofilia. O nativismo seria

\footnotetext{
${ }^{16}$ Em 1975, no relatório carcerário intitulado "Cárcere preventiva da Cidade e de Mulheres”, encontramos uma lista com os nomes das pessoas que visitaram "os membros dos grupos subversivos que se encontram sujeitos a processo penal ou já foram sentenciados por suas atividades de agitação". Para ter uma ideia da diversidade dos grupos e do número de prisioneiros, há um total de 162 supostos guerrilheiros somente na Cidade do México. (“Cárcel preventiva y de Mujeres”, México, 23-11-1975, Archivo General de la Nación (AGN), Investigaciones Políticas y Sociales (IPS), Caixa 1491 B, Expediente 14, folhas 1-19).
} 
“a reafirmação enérgica, e um tanto deturpada, do modo indígena de vida, reação amiúde produzida numa sociedade que se sente ameaçada por forças superiores à sua compreensão e ao seu controle". A xenofilia, pelo contrário, é definida como "o anseio de copiar os modos de outra cultura" (MOORE, 1972, p. 18-19).

Estas duas formas de construção doutrinária descritas por Moore podem ajudar para entender a distinção feita pela historiografia para caracterizar a guerrilha urbana e diferenciála da rura ${ }^{17}$. Destaca-se, assim, a legitimidade das lutas que têm motivos históricos para a subversão, e desqualificam-se as que supostamente têm motivações puramente ideológicas. Destacamos que essa leitura dicotômica está contida na perspectiva de análise das autoridades e da polícia política.

Os motivos da guerrilha rural, então, estariam localizados no passado, na tradição. As guerrilhas de estrato camponês-rural surgem como radicalização das circunstâncias sociais, agrárias ou políticas da região. Estas são geralmente regionais, de mobilização lenta, e recorrentes na história do México. Ou seja, se apresentam de maneira cíclica. Existem ciclos de confluência e polarização das circunstâncias de pobreza extrema, discriminação, isolamento, exploração, despojo e pouca ou nula ação da justiça, o que cria um ambiente propício para o surgimento da violência. Essas circunstâncias têm que ser lidas a partir de questões culturais que permeiam o meio rural mexicano, como os laços complexos de parentesco; laços linguísticos, culturais ou religiosos; produtivos e econômicos; assim como a relação do povo com as elites regionais que exercem a hegemonia econômica e política (MONTEMAYOR, 1999).

Segundo esta perspectiva, a guerrilha rural responderia, então, a um memorial de agressões de caráter histórico que justifica a via armada como legítima defesa. Dessa forma, as práticas e normas se reproduzem de geração em geração no âmbito do "costume"18. Acrescentamos a estes elementos o peso que têm os componentes da violência agrária: o fator econômico, que salienta a pobreza extrema e a usurpação de terras; e, por outro lado, a repressão exercida por corpos policiais, militares e paramilitares em defesa da propriedade de caciques e latifundiários:

\footnotetext{
${ }^{17}$ O historiador Alan Knight faz uma distinção parecida para a análise do zapatismo e do maderismo durante a Revolução Mexicana (1910-1917). Para o autor, é obvio que as razões da subversão das comunidades indígenas e camponesas encabeçadas por Emiliano Zapata eram legítimas, pois tinham um caráter histórico, remontando-se aos quase quinhentos anos de exploração e despojo. Enquanto que o movimento liderado por Francisco I. Madero respondia a razões políticas e econômicas que beneficiariam um pequeno grupo social (KNIGHT, 1985).

${ }^{18}$ Seguindo a proposta de E. P. Thompson, "é mais simples legitimar práticas (ou protestos) em termos do uso consuetudinário ou de emolumento ou direito prescritivo" (THOMPSON, 1989, p. 43).
} 
A pobreza nas zonas rurais mexicanas não parecia constituir por si só a única razão determinante da luta armada que se desatou no país. Também não os fatos de violência dos caciques, por mais cruéis que tenham sido. $\mathrm{O}$ fator decisivo costumava ser a certeza de que não havia nenhuma possibilidade legal de solucionar esses problemas, nem portas abertas no governo para discuti-los (SIERRA, 2003, p. 45).

Consideremos, também, que a partir da década dos quarenta, o campo mexicano foi totalmente abandonado em detrimento da industrialização. Não existiram projetos de desenvolvimento que implicassem uma mudança social profunda, nem a médio, nem a logo prazo. A aplicação de projetos de desenvolvimento regional - seja de infraestrutura econômica, agrária, florestal, de saúde, ou de comunicações - não foi efetiva para consolidar a reciprocidade entre governantes e governados. O motivo: esses programas nasceram como estratégia de guerra contrainsurgente (MONTEMAYOR, 1999, p. 22).

As guerrilhas rurais se desenvolveram principalmente entre 1965 e 1974, em várias regiões do país. Pelo valor simbólico e por conter as características esboçadas acima, mencionaremos a seguir o assalto ao quartel da cidade de Madera, Chihuahua, que, de fato, inaugura a experiência armada socialista mexicana no 23 de setembro de 1965. Após este primeiro levante houve reverberações de importância nos estados de Sonora, Sinaloa, Guerrero, Oaxaca e Chiapas.

Partindo da avaliação elaborada pelas autoridades, este núcleo armado surge

A partir da transformação do Partido Popular (PP) em Partido Popular Socialista (PPS $)^{19}$ desenvolveu-se em vários setores de jovens a inquietação por lutar, da maneira que for, pela revolução socialista, para o qual se produziram círculos de estudos em vários grupos que, independentemente das indicações, se é que as houve, de altos dirigentes de seu Partido, consideraram que o melhor caminho para lutar era o de organizar os camponeses nas zonas de maior influência no passado, pela presença de líderes guerrilheiros destacados, como foi a presença de Francisco Villa em Durango e Chihuahua [fig. 3$]^{20}$.

Neste caso, as autoridades avaliaram que no estado de Chihuahua existia um trabalho "totalmente unificado", entre o PPS, o PCM e a FECSM. O trabalho de base dos partidos e da

\footnotetext{
${ }^{19}$ Fundado em 1948, definia-se como lombardista, ou seja, seguidor das propostas do sindicalista marxista Vicente Lombardo Toledano. Nunca se apresentou como uma oposição real, pois entrava nas características de partido paraestatal. Isto é, um partido que na fachada se apresentava como oposição, mas que somente contribuía para legitimar uma democracia de partido único. Contudo, na década de sessenta, os militantes decidem mudar. Acrescentam o adjetivo "socialista". Isto é, definiam-se não como lombardistas, e sim, como marxistas-leninistas. Assim, iniciam um processo de radicalização e de oposição real, sobretudo no âmbito rural.

20 "Datos confidenciales", Chihuahua, 09-1965, AGN, IPS, Caixa 1448 B, Exp. 41, folhas 1-2.
} 
federação com organizações camponesas paulatinamente foi-se traduzindo numa sequência intensa de recuperação de terras que estavam concentradas nas mãos de latifundiários, ocupações de dependências federais dedicadas à resolução de conflitos agrários, assim como na politização dos camponeses da região, realizada por lideranças das escolas normais rurais da região. O nível da luta estava se elevando ${ }^{21}$.

A intransigência e a violência com a qual o governador general Práxedes Giner Durán vinha reagindo contra os camponeses contribuiu para que numa reunião clandestina entre estudantes e dirigentes camponeses, em 1963, chegou-se ao entendimento de que seriam utilizadas armas para intensificar a recuperação de terras. No entanto, o resolutivo da reunião enfatiza o contexto de autodefesa.

O aumento da repressão, assim como a prisão das lideranças principais, precipitaram a saída de um pequeno núcleo que decidiu reunir-se novamente, de maneira clandestina, no intuito de discutir o abandono da luta legal para avançar na construção da luta armada (1964) (GRUPO POPULAR GUERRILLERO, 1965). Nas resoluções deste segundo encontro clandestino decidiu-se, então, por assumir os lineamentos estratégicos do que nos manuais contrainsurgentes se conhece como castro-guevarismo ou foquismo (RANGEL, 2013, p. $74)^{22}$.

A inteligência mexicana registra entre 1964 e 1965 vários enfrentamentos entre militares e guerrilheiros. Num informe militar, por exemplo, se relata que durante uma ronda rotineira um contingente militar deteve três camponeses com atitudes suspeitas. Esse momento foi aproveitado por um grupo de doze elementos que atacaram os soldados, deixando, inclusive, três feridos. Informa-se, também, que os militares, ao tentarem fugir "deixaram em poder da gavilla uma equipe de rádio-transmissão" 23 . Finalmente o comandante responsável supervisionou a região do ataque pessoalmente, dando a ordem para deixar cento e setenta elementos militares para "una batida de los sediciosos" 24 . Ou seja, em vocabulário

\footnotetext{
${ }^{21}$ A concentração de terras em Chihuahua é historicamente das mais alarmantes. Em 1963, por exemplo, “dos 24,5 milhões de hectares com que contava a entidade, entre seis e oito milhões estavam no poder de 300 latifundiários, quer dizer, 20 mil para cada um; enquanto que cem mil ejidatarios mantinham em possessão 4,5 milhões de hectares, por um promédio de 45 por cabeça" (RANGEL, 2013, p. 69).

${ }^{22}$ Segundo o manual da Escola das Américas, "Guerra Revolucionaria e ideologia comunista", a estratégia do foquismo está caracterizada por ser uma organização limitada (em números), operando num ambiente favorável, se existe um movimento de massas que acoberta o foco, partindo da premissa de um governo debilitado. Esta estratégia, diz o manual, "é atraente desde o ponto de vista do tempo, porque não requer uma organização complicada. Esta estratégia é um modelo revolucionário mais rápido em comparação com as estratégias de tipo maoísta". (SOA, 1989c, p. 11).

23 "Gavilla" é o termo pejorativo que se utiliza para definir um grupo de pessoas vinculadas com o roubo de gado, o roubo de fazendas ou à violência sexual contra as mulheres.

24 "Incidente entre fuerzas militares y la gavilla de Arturo Gámiz en la región de Madera", Chihuahua, 29-051965, AGN, IPS, Caixa 449, Exp. 1, folha 1.
} 
militar, um ataque para matar.

Além das expropriações de armas, o pequeno grupo recebeu treinamento de quatro meses no estado de México, Zacatecas e na Cidade do México, sob a supervisão do capitão Lorenzo Cárdenas Barajas ${ }^{25}$. Os líderes principais estavam perfeitamente identificados. O médico Pablo Gómez, "cabeça intelectual no movimento de gavillas", ingressou à Confederación de Jóvenes Mexicanos em 1948. Um ano depois, une-se ao Movimiento de la Juventud Popular (organização juvenil pertencente ao PPS). Pelo seu passado como estudante normalista, Gómez mantinha uma forte influência no setor estudantil, onde conseguiu estabelecer um núcleo político. Por outro lado, Arturo Gámiz, regressando a Chihuahua após um tempo estudando na Cidade do México, incorpora-se ao núcleo de Gómez como estudante da escola normal de Chihuahua ${ }^{26}$.

Segundo os planos do então denominado Grupo Popular Guerrillero (GPG), o assalto ao quartel de Madera tinha a finalidade de abastecer-se de armas, equipamento e alimentos. $\mathrm{O}$ pequeno grupo rodeia o quartel na madrugada do dia 23 de setembro. Treze jovens decidem iniciar o ataque e esperavam o resto do contingente que apoiaria a ação com armas, contudo, não apareceram, perdendo-se no caminho. Como estava amanhecendo e perderiam o fator surpresa, resolveram agir assim mesmo. Os guerrilheiros resistiram ao contra-ataque dos militares durante uma hora e meia, porém, oito dos treze jovens foram massacrados: Pablo Gómez (médico), Miguel Quiñones Pedroza (diretor de uma escola rural), Rafael Martínez Valdivia (professor normalista), Óscar Sandoval Salinas (estudante normalista), Salomón Gaytán Aguirre e Antonio Escóbel (camponeses), Emilio (estudante normalista) e Arturo Gámiz (professor rural) (CASTELLANOS, 2008; LUGO, 2015) [fig. 4] ${ }^{27}$.

Após a fatídica tentativa de assalto, os sobreviventes e o núcleo que não havia chegado ao assalto, refundam a guerrilha sob o nome Grupo Popular Guerrillero “Arturo Gámiz”, liderados pelo jovem Óscar Eguiarte. Os resultados desastrosos devido à precária preparação dos guerrilheiros, assim como pelos excessivos operativos militares, podem ser acompanhados no diário de campanha do próprio Eguiarte (1968). Os poucos e debilitados sobreviventes novamente integrariam outros grupos em outras regiões do país, como seria o caso do Movimiento 23 de Septiembre ou o Movimiento de Acción Revolucionaria-23 de

\footnotetext{
${ }^{25}$ Em 1964 Cárdenas Barajas estava com 45 anos, garantindo estar aposentado da corporação castrense. O capitão "presumia haver treinado Fidel Castro durante sua estada no México. Por sua casa [...] passaram quase todos os grupos em formação guerrilheira da época, para receber apoio econômico, armas ou o compromisso de treinamento. Todos foram desarticulados (CASTELLANOS, 2008, p. 79-80).

26 "Datos confidenciales", Chihuahua, 09-1965, AGN, IPS, Caixa 1448 B, Exp. 41, folhas 1-2.

${ }^{27}$ Para conhecer mais detalhes sobre o assalto destacamos o romance escrito por Carlos Montemayor, Las Armas del Alba (2009).
} 
Septiembre, através dos quais se estabeleceram estreitos vínculos com o PDLP de Lucio Cabañas no sul do país.

Numa carta pessoal dirigida a seu filho, Rafael Quiñones Vargas - rico pecuarista de Chihuahua, militante do PRI e prefeito de Madera entre $1971-1974^{28}$, expressa o clima tenso que se respirava na região. Quiñones escreve:

Já reapareceram os guerrilheiros; no dia 7 do presente assaltaram o rancho do senhor Ramón Molina, ele foi crivado de balas e foram levadas todas as armas e apetrechos do rancho; um dos que estavam com o senhor Ramón quando os pegaram e que no final o soltaram, disse que ele reconheceu Salvador Gaytán, os demais não reconheceu ninguém; acredita que Arturo Gámiz por ali estava, mas não tem certeza porque não o conhece. Aparentam estar muito bem armados ${ }^{29}$.

A polícia política continuava reunindo notícias sobre a presença de guerrilheiros na serra de Chihuahua. Enrique Hernández Gómez, dono de uma serralheria num município próximo a Madera, informava sobre a presença entre dez ou doze homens armados com rifles em terrenos da propriedade dele. Da mesma forma, Gilberto González Múzquis, também madeireiro, "informa que a gavilla deteve vários caminhões para roubar o salário dos seus trabalhadores" 30 . O clima de paranoia percebesse nos documentos onde se afirmam rumores, sem apresentar nenhum tipo de investigação. Por exemplo, em 1967 afirmava-se que Rubén Castillo, militante da Central Campesina Independiente $(\mathrm{CCI})^{31}$ "recebeu um carregamento de armas procedente de Cuba e que já se encontra na serra, onde estão 17 grupos integrados por 17 homens cada um, 32 .

Por outro lado, as autoridades locais também informam que o governador Giner Durán, “toma enérgicas medidas para combater numerosas gavillas que criam confusão em diferentes partes do estado". Entre essas medidas, menciona-se que enviaram "um grupo de agentes da polícia do estado e elementos do exército [...] com instruções de capturar os integrantes das gavillas e proceder energicamente aplicando-lhes o que se conhece como a

\footnotetext{
28 "Precandidatos a presidentes municipales", Chihuahua, 04-05-1965, AGN, IPS, Caixa 449, Exp. 1, folhos 1-2.

${ }^{29}$ Chihuahua, 24-10-1966, AGN, IPS, Caixa 458, Exp. 1, folha 1.

30 "El gobierno local toma enérgicas medias para combatir a numerosas gavillas que cometen tropelias en diferentes partes del estado", Chihuahua, 24-10-1966, AGN, IPS, Caixa 458, Exp. 1, 24-10-66, folha 1.

${ }^{31}$ Organização criada a partir da reunião de aproximadamente 300 líderes camponeses em 1961 promovida como uma frente política de esquerda que confrontasse a política agraria do PRI. As principais demandas giravam em torno da liberdade sindical, autonomia ejidal, reparto agrário e a democratização do sistema político. A figura principal dentro da CCI, era o ex presidente Lázaro Cárdenas, junto a outros importantes líderes camponeses como o próprio professor Genaro Vázquez Rojas (que depois lideraria um grupo guerrilheiro em Guerrero) (GRAMMONT, 1989, p. 275)

32 "Memorándum: Central Campesina Independiente", Chihuahua, 07-08-01967, AGN, IPS, Caixa 1448 B, Exp. 41 , folha 1.
} 
'ley fuga',33.

Essa "dinâmica da hidra" seria uma das características mais marcantes do movimento armado socialista mexicano: "como uma cabeça de hidra, cada movimento destruído terminava convertido em dois" (SIERRA, 2008, p. 365) [fig. 5].

\subsubsection{O movimento estudantil e as guerrilhas urbanas}

Para alguns autores, o movimento estudantil de 1968 teria produzido três efeitos ideológicos importantes na esquerda: um consistia em "apontar e sublinhar os efeitos negativos do modelo de crescimento econômico que o setor público promovia de maneira entusiasmada". Outro era o "questionamento à fé tradicional no setor privado como peça central para alcançar o desenvolvimento do país". Finalmente, o terceiro efeito era que o movimento estudantil deixou claro para a dissidência de esquerda que "para conseguir algumas mudanças, não era suficiente reunir enormes manifestações e fazer apaixonados discursos" (BASAÑEZ, 1988, p. 11).

O movimento estudantil mexicano tem uma sólida tradição. Na capital mexicana, o movimento estudantil do Instituto Politécnico Nacional (IPN) ${ }^{34}$ chegou ao ápice durante a greve mantida durante abril de 1956. Paradoxalmente, a greve foi comandada pela Federación Nacional de Estudantes Técnicos (FNET), uma organização filiada à Confederación de Jóvenes Mexicanos, do próprio PRI (FEMOSPP, 2006). Diversas Escolas de educação superior, assim como várias normais rurais decidiram iniciar uma greve em demanda do aumento da verba para suas instituições. O número de estudantes mobilizados superou os cem mil. Em junho desse ano, como as autoridades educativas pactuaram com as lideranças do movimento e quase todas as reivindicações foram concedidas, a greve foi dissolvida. Mas os estudantes continuaram mobilizados. Durante um protesto menor pela forma autoritária de designação dos funcionários administrativos da moradia estudantil, houve uma reação sem precedentes e que seria prelúdio do que se avizinhava. As instalações do IPN são ocupadas

\footnotetext{
33 "El gobierno local toma enérgicas medias para combatir a numerosas gavillas que cometen tropelias en diferentes partes del estado", Chihuahua, 24-10-1966, AGN, IPS, Caixa 458, Exp. 1, 24-10-66, folha 1. A ley fuga foi uma prática consolidada durante a ditadura de Porfirio Díaz, na qual os presos, geralmente de status político, eram libertados para, posteriormente, serem assassinados de forma traiçoeira.

${ }^{34}$ Instituição criada durante o governo de Cárdenas com a intenção de formar profissionais técnicos para poder manter o projeto de industrialização que o país precisava. O projeto pedagógico tinha a vocação de matricular, sobretudo, estudantes provenientes de famílias rurais, favorecendo a capilaridade social.
} 
pelo exército, resultando no fechamento da moradia estudantil em 23 de setembro de $1956^{35}$.

Entre novembro de 1963 e junho de 1968 ocorreram, pelo menos, 53 mobilizações protagonizadas por estudantes em diversas localidades do país. Classificadas pelos seus objetivos:

23 foram motivadas por problemas da própria escola, 8 incorporavam assuntos da localidade, 6 se inspiravam em assuntos internacionais (apoio a Cuba e protestos pelas políticas estadunidenses em Vietnam e outros países), e 4 tinham demandas que diziam respeito diretamente ao sistema autoritário de controle político (AGUAYO, 2015) ${ }^{36}$.

O movimento de 1968 inicia em julho desse mesmo ano, provocado por um confronto entre estudantes de "preparatória" 37 da UNAM e de um colégio privado. Controlado o conflito com excesso de violência por parte do corpo de granaderos $^{38}$, o fato desatou uma onda de indignação especialmente no âmbito estudantil politicamente organizado. O conflito transcendeu rapidamente os espaços políticos tradicionais (PCM, federações e outros partidos), porém a repressão aumentou da mesma forma. Criou-se, por exemplo, o Consejo Nacional de Huelga (CNH), onde confluíam representantes de escolas e faculdades da UNAM, assim como representantes de outras instituições públicas, bem como instituições privadas. As demandas do movimento se sintetizaram em seis pontos:

1. Liberdade para os presos políticos ${ }^{39}$.

2. Revogação dos artigos 145 e 145 Bis do Código Penal Federal.Ambos os artigos constituíam o delito de "dissolução social", incluído no texto constitucional em 1941 no contexto da Segunda Guerra Mundial, a fim de reprimir os possíveis agentes

\footnotetext{
${ }^{35}$ Hoje só algumas escolas rurais mantêm o sistema de internato. $\mathrm{O}$ direito à moradia continua sendo uma pauta do movimento estudantil. Casualmente, como se fosse uma premonição, naquele 23 de setembro de 1956 esteve presente o jovem estudante Arturo Gámiz García, que em exatos nove anos perdera a vida no assalto ao quartel da cidade de Madera (MONTEMAYOR, 2010).

${ }^{36}$ Esta informação foi localizada pelo pesquisador Sergio Aguayo nos informes de espionagem que a embaixada norte-americana no México enviava sistematicamente ao Departamento de Estado em Washington.

37 A educação "Preparatória" vinculada à UNAM, e Vocacional do IPN, correspondem ao ensino médio, bem como aos cursos pré-vestibulares no sistema educacional brasileiro.

${ }^{38}$ Corpo especial antimotins da Cidade do México. Parte do aparato policial dependia diretamente das ordens da autoridade política do então chamado Departamento do Distrito Federal.

${ }^{39}$ Além de defender os estudantes presos, o movimento levantou a questão da libertação dos maquinistas de trem encarcerados desde 1959. Os maquinistas eram liderados por Valentín Campa (militante do Partido Comunista Mexicano) e Demetrio Vallejo. Pela primeira vez, um movimento social alcançou caráter nacional, mobilizando milhares de trabalhadores em torno de demandas pelos direitos trabalhistas, sobretudo pela democratização dos sindicatos. Perante a greve iniciada em 1959, o governo ordenou a ocupação militar de locais do sindicato e outras instalações dos maquinistas. Houve mortos e desaparecidos, além de um número indeterminado de grevistas processados. A luta pela liberdade de Vallejo e Campa, de Alberto Lumbreras, Miguel Aroche, Dionisio Encinas e outros presos políticos, foi acolhida por grande parte dos movimentos sociais e organizações políticas até o fim da prisão, dez anos depois.
} 
nazifascistas no país. Consistia na pena de prisão (de 2 a 12 anos) para quem "de forma falada ou escrita, ou por qualquer outro meio, realize propaganda política entre estrangeiros ou entre nacionais mexicanos, difundindo ideias, programas ou normas de ação de qualquer Governo estrangeiro que perturbe a ordem pública ou afete a soberania do Estado mexicano". Essa perturbação da ordem está definida na medida em que produz atos de rebelião, sedição ou motim. (SÁNCHEZ CÁRDENAS, 1970, p. 182). Importante mencionar que com esse dispositivo do general Miguel Ávila Camacho, o México permaneceu num Estado de Exceção até a revogação dos artigos, em 1970.

3. Desaparecimento do mencionado corpo de granaderos.

4. Destituição dos chefes policiais, o major Raúl Mendiolea Cerecero e o general Luis Cueto Ramírez, assinalados como responsáveis pela execução da violência contra os estudantes.

5. Indenização para os familiares de mortos e feridos desde o início do movimento ${ }^{40}$.

6. Responsabilização dos funcionários que participaram nos fatos repressivos.

O incremento do cerco militar sobre o movimento chega ao auge com a invasão militar da cidade universitária da UNAM e do IPN, que encontrou a resistência dos estudantes que zelavam pelas instalações ocupadas. O corolário do movimento foi, claro, o trágico massacre durante um ato realizado na Praza das Três Culturas de Tlatelolco na Cidade do México. O que ocorre a escassos dez dias das primeiras olimpíadas realizadas no continente americano (ESCAMILLA, 2014). Para executar o plano de dissolução do movimento, além da cooperação entre o Exército e os corpos policiais, introduziu-se pela primeira vez na história um corpo paramilitar: o Batallón Olimpia ${ }^{41}$.

A literatura sobre o movimento estudantil assenta que o massacre de 1968 é a origem da guerrilha contemporânea. Raúl Álvarez Garín (membro destacado do $\mathrm{CNH}$ ), por exemplo, aponta que "inspirados ou impulsionados diretamente por jovens do 68 se reativaram e alcançaram um alto nível as lutas sociais operárias, camponesas e populares”, colocando, assim, em primeiro plano os temas da mudança social e, sobretudo, a necessidade de mudança política. A partir desse ano e das formas nas que se traçou a saída do conflito, precipitou-se o surgimento das guerrilhas urbanas, além de que "adquiriram outra dimensão as ações

\footnotetext{
40 Ainda hoje não há um número exato sobre a quantidade de mortos, feridos e desaparecidos durante o movimento, nem como resultado do massacre do 2 de outubro.

${ }^{41}$ Grupo conformado por elementos pertencentes ao Estado Maior Presidencial e à DFS, sob o pretexto de resguardar as instalações esportivas onde se realizariam os jogos olímpicos de 1968. Participou junto ao exército na matança dos assistentes à manifestação de 2 de outubro na Plaza de las Tres Culturas de Tlatelolco.
} 
guerrilheiras rurais" (ÁLVAREZ GARÍN, 2003, p. 134) ${ }^{42}$.

Este argumento, acreditamos, sobrevaloriza o movimento, apesar de que, definitivamente, é um divisor de águas da história contemporânea. Seguindo a avaliação feita pelo ex-militante armado Antonio Rhi Sausi (à contramão de Álvarez Garín), os referenciais que foram absorvidos pelos estudantes radicalizados são as lutas guerrilheiras de Chihuahua e Guerrero: "o surgimento destas expressões guerrilheiras de um movimento de massas e sua identificação com a luta armada, como forma fundamental de luta, constituíam a 'verdadeira' alternativa" (RHI SAUSI, 1977, p. 70).

Uma parcela importante dos estudantes que se incorporaram à guerrilha provinham, na verdade, de dinâmicas diferentes ao movimento estudantil - de uma vasta gama de processos políticos e universitários de outros estados (Michoacán, Chiuahua, Jalisco, Nuevo León e Sinaloa), sem uma conexão orgânica com o movimento de 1968 (MONTEMAYOR, 2010, p. 13). Há indícios para garantir que, de fato, o Comando Armado Lacandones (incorporado em 1973 à Liga Comunista 23 de Septiembre) foi a única organização conformada estritamente por estudantes que tiveram antecedentes organizativos no movimento estudantil de $1968{ }^{43}$.

Não entanto, o ano de 1968 entraria profundamente na consciência democrática e se transforma rapidamente em consciência revolucionária socialista, "que impulsiona o desenvolvimento de todas as forças de esquerda, e engloba, dá tom e sentido ao movimento de massas no país". O movimento é o ponto de partida que legitima as posições de esquerda e de pensamento socialista: “o país não se politiza em abstrato, se politiza para a esquerda" (ÁLVAREZ GARÍN, 2003, p. 198). Na literatura especializada encontramos repetidamente que o principal legado do movimento estudantil foram as ações guerrilheiras "e as prisões do país cheias dos partidários do movimento" (BASAÑEZ, 1988, p. 185).

Agora, se consideramos que o "68" é o fundador simbólico da guerrilha, não devemos esquecer que a complexidade interna do movimento não pode ser reduzida a uma explicação causal da guerrilha posterior (MONTEMAYOR, 2010). O processo de politização e a experiência política dos jovens avançaram. Porém, é a repressão o que precipita a

\footnotetext{
${ }^{42} \mathrm{O}$ argumento é amplamente discutível, se considerarmos que não há nenhum tipo de documentação ou depoimento que comprove ter havido uma discussão em torno do significado ou repercussão do movimento estudantil. Conhecemos, unicamente, as saudações feitas por Genaro Vázquez ao movimento em comunicados que eram lidos nos atos e reproduzidos para distribuir nas passeatas, através de testemunhas. Porém, não temos como averiguar a veracidade do fato.

${ }^{43}$ Em abril de 1973, na cidade de Guadalajara, ocorre uma reunião para consolidar uma coordenação nacional de grupos armados que aglutinasse os sobreviventes dos grupos que estavam sendo sistematicamente exterminados pela violência de Estado. A partir de então, começariam a atuar de maneira conjunta e coordenada, com um alcance nacional. A chamada Liga Comunista 23 de Septiembre reivindicava com o seu nome o assalto ao quartel de Madera de 1965.
} 
radicalização dos quadros políticos urbanos. Primeiro foi o massacre de estudantes num comício realizado no 2 de outubro, mas o estopim, mesmo, foi outro massacre de estudantes, esta vez no 10 de junho de 1971, durante a primeira manifestação estudantil depois do trauma de Tlatelolco.

Entre 1968 e 1971 grande número de estudantes permaneceram presos, outros se exilaram, outros mais se distanciaram do exercício político por medo. Enquanto isso, na capital, os estudantes de um grande número de universidades estaduais começaram a radicalizar as reivindicações e as táticas de autodefesa ${ }^{44}$. E é justamente em torno à luta encabeçada pelos estudantes do norte do país, da Universidad Autónoma de Nuevo León (UANL), que se organiza uma importante manifestação na capital para se solidarizar contra a imposição de uma Lei Orgânica que beneficiava os círculos políticos estaduais e violentava a autonomia universitária.

Em 10 de junho de 1971, num clima pouco mais relaxado, gerado pela paulatina saída dos presos políticos de 1968, pelo retorno de um grupo de asilados, assim como pela promessa de uma reforma política, os estudantes decidem sair às ruas. Logo a passeata foi violentamente atacada por um grupo de jovens paramilitares ao grito de "Che, Che Guevara!", tentando confundir o centro gerador da violência, os jovens paramilitares gritavam palavras de ordem da esquerda (ESCAMILLA, 2014; CONDÉS, 2007b). Novamente o saldo real de mortos e desaparecidos é desconhecido.

Segundo depoimentos, o 10 de junho foi a prova irrestrita de que não existia espaço para a participação política, que não existia vontade governamental para uma reforma, e sobretudo, deu espaço para considerar que as armas eram a única opção para uma transformação ${ }^{45}$. A guerrilha urbana estaria fundamentada sobre experiências traumáticas e convicções sinceras e valentes (ÁLVAREZ GARÍN, 2003, p. 213). Nesse sentido, a grande contribuição do movimento estudantil foi a demonstração dos limites de tolerância do sistema político mexicano que, evidentemente, resultavam ser estreitos (SCHMITH, 1986, p. 44). Particularmente, o massacre em Tlatelolco significou a morte do projeto de continuidade da modernização do México, em termos geracionais. Representou, ainda, o choque entre a sensibilidade política e social "assentada nos moldes vazios da unidade nacional e na veneração aldeã aos símbolos pátrios". Os jovens que tiveram uma formação política entre 1968 e 1971 se tornaram "testemunhas frescas e irredutíveis de uma realidade

\footnotetext{
${ }^{44}$ Escamilla (2014) aponta que, durante esses anos, o centro nevrálgico da luta estudantil transferiu-se para Guadalajara, Sinaloa e Monterrey, locais importantes para a posterior guerrilha urbana.

${ }^{45}$ MORENO BORBOLLA, José Luis: depoimento [06-12-2004], México. Entrevista concedida a Fiona de la Rosa González.
} 
desnacionalizada e dependente em rápida transculturação neocolonial, extraordinariamente sensível às causas e aos símbolos que lhes eram contemporâneos" (AGUILAR CAMÍN; MEYER, 2000, p. 269-270).

Podemos observar, então, que existe uma correlação entre repressão e rebelião, na seguinte ordem: o fechamento dos caminhos democráticos; a intolerância; e o uso excessivo da força repressiva, que "levaram muitos jovens do protesto legal e aberto e da reivindicação de justiça ao rechaço das instituições e à insurgência armada" (CONDÉS, 2007a, p. 16). Segundo um ex-militante armado, na mente "super-ideologizada" dos estudantes guerrilheiros, utilizou-se o marxismo como perspectiva teórica, mas intuitivamente fazendo a mistura entre correntes revolucionárias e revisionistas. Seguindo esta consideração, o autor descreve uma operação com dois pontos centrais que, segundo ele, estavam presentes na maioria das leituras dos grupos armados urbanos:

$1^{\circ}$ ) o Estado e o capitalismo no México se encontram na sua crise definitiva, a repressão era a prova de sua debilidade; e $2^{\circ}$ ) o radicalismo das formas de luta de muitos setores de massas era um signo evidente de que a revolução estava "ao virar a esquina” (RHI SAUSI, 1978, p. 71).

Esta reflexão se generaliza após o massacre de Tlateloco nos círculos estudantis mais politizados. Depois de 1971, as agrupações guerrilheiras, que já estavam na clandestinidade, vêem confirmados os seus esquemas. Desta maneira, a esquerda armada urbana, igual que a rural, foi forjada ao calor da repressão. O levante armado, não pode se explicar, portanto, unicamente partindo das supostas motivações ideológicas. Deve ser levado em conta que existia um sentimento de ofensa: "os jovens que se levantaram em armas estavam cheios tanto de convicções como de injúrias, não tiveram, em geral, outro caminho; poucos foram os que, por motivações - digamos - 'puramente ideológicas', lançaram-se à rebelião" (CONDÉS, 2007a, p. 16).

\subsection{Objetivos}

Os elementos que constituem a memória são necessariamente sociais. Transitam em quadros espaciais e temporais tendo como instrumento a linguagem. Agora, o indivíduo recorda de algo somente quando está imerso na perspectiva de um grupo. A memória tem a função de construir ou, na maioria das vezes, conservar identidades. Dessa forma, entendemos 
"memória coletiva" como uma prática social e cultural de diferentes sociedades que "possibilita a abordagem e análise de acontecimentos que, por distintas formas e mecanismos, apesar da insistência das imposições do esquecimento, mantêm-se na lembrança das coletividades" (MENDOZA GARCÍA, 2007, p. 314). Nesse mesmo sentido, o "esquecimento social" é gerado a partir da implantação de uma série de práticas e processos que permitem o encobrimento de acontecimentos ou fatos de interesse para algum grupo ou coletividade, com a finalidade de que desapareçam como referências sociais.

Consideramos esses conceitos para tentar explicar que não existe um número significativo de pesquisas sobre a guerra suja mexicana, e que este processo não seja considerado como parte da história por uma parcela importante da população. Partindo da definição do conceito "esquecimento institucional" " elaborada pelo psicólogo social Jorge Mendoza García, podemos sugerir que, uma vez tomado o poder por um grupo, a necessidade de se manter e, sobretudo, de legitimar sua política, impõe conscientemente uma versão oficial da história. O grupo precisa, então, mostrar-se como o mais adequado, o mais qualificado para o exercício do poder.

Segundo Mendoza, o grupo no poder acessa a memória coletiva para, posteriormente, isolá-la ou esvaziá-la de significados através de instituições políticas, acadêmicas, educativas, militares, clericais e, recentemente, através dos meios de comunicação de massa. Desta maneira, tais instituições resultam ser "as únicas capacitadas para dizer o que se sucedeu e o que não aconteceu, o que há que lembrar e o que esquecer; [...] porque o deixar de comunicar o que em algum momento aconteceu e se soube que advém de uma forma de esquecimento" (MENDOZA GARCÍA, 2007, p. 322).

A imposição de limitações para o estudo histórico das atividades clandestinas do Estado poderia responder à possibilidade de que o sistema político mexicano construiu com sucesso uma série de instituições de alcance nacional. Por intermédio delas geraram-se os consensos necessários para o "ocultamento" da memória da guerra suja, e seu correlato, os próprios movimentos sociais e militares de oposição:

um dos efeitos que teve tal força conformadora da cultura dominante é o acobertamento [da memória e dos movimentos] com um discurso capaz de questionar sua existência e realidade; de imprimir um selo de legitimidade a respeito de seus fundamentos; ou até de ser ignoradas e omitidas da linguagem (OCEJA, 2013, p. 9).

\footnotetext{
${ }^{46}$ Segundo o autor, existem duas formas de consolidar o esquecimento social, além do provocado a partir das instituições: por meio da proibição (imposição de castigos como a prisão o a morte); e pela velocidade da informação nas sociedades contemporâneas (MENDOZA GARCÍA, 2007, p. 320).
} 
Atendendo a esta reflexão, a proposta desta pesquisa é apresentar a contradição existente entre o discurso oficial e as atividades clandestinas que, desde o Estado, operavam contra a oposição, ou seja, numa institucionalização da contrainsurgência ${ }^{47}$. Propomos problematizar a guerra suja mexicana desde as narrativas do próprio Estado, sublinhando as contradições entre o discurso público (emitido pelos presidentes) e o discurso privado do poder (relatórios dos agentes das agências de inteligência).

Os serviços de inteligência no México foram fundamentais para a estabilização do contexto mexicano depois de 1929. Nasceram com o Estado priísta. Nesse mesmo ano foi criado o Departamento Confidencial, com o objetivo de auxiliar o governo dando seguimento à investigação dos possíveis fatores desestabilizadores. A partir de 1938 coloca-se maior ênfase na discrição dos agentes, que começam a tecer redes de colaboração com organismos de caráter não oficial, como a Cruz Vermelha Mexicana ou as autoridades universitárias. Em 1946, por decreto do primeiro presidente civil (Miguel Alemán Valdés), o Departamento Confidencial troca de nome para Dirección Federal de Investigaciones Políticas y Sociales (IPS). Também se cria a Dirección Federal de Seguridad (DFS), organismo reformulado a partir do esquema da Federal Bureau of Investigation (FBI na sigla em inglês) dos EUA. A IPS até 1964 permanece com a mera função de observar eleições e elaborar biografias de candidatos. A DFS, por outro lado, tinha uma função operacional, além da execução da espionagem política (AGUAYO, 2014a, p. 73). Um ano depois (1947) cria-se o Estado Mayor Presidencial, com a finalidade de preservar a segurança do presidente e de sua família, para depois conformar um pequeno grupo de analistas políticos, constituídos como "organismo de inteligência para informar oportuna e verazmente ao presidente e ao secretário da SEGOB dos diferentes problemas, assim como da origem e causa dos mesmos, para que [...] se pudesse prever a evolução dos conflitos e evitar colapsos econômicos e sociais" (IBARROLA, 2003, p. 64).

São analisados, então, os informes elaborados pela polícia política mexicana, pois, a nosso ver, estes representam o coração das atividades clandestinas do Estado, no princípio de que ao tratar-se de assuntos que envolvem a segurança interna, guardavam uma vocação secreta. Mostrando as contradições com respeito ao discurso oficial, pretendemos, na medida em que as fontes o permitam, reconstruir alguns episódios da negada e silenciada guerra suja, sob a ótica repressiva.

\footnotetext{
${ }^{47}$ Entendemos, por instituição, não unicamente as entidades consagradas nos documentos legais, como também as "práticas informais, que inclusive podem ser ilegais, que efetivamente regem a conduta cidadã" (MEYER, 2013). Ou seja, as regras e valores que regulam uma disputa ou o exercício de poder e que integram e fortalecem um regime político.
} 
Em outras palavras, o objetivo não é fazer uma história do movimento armado mexicano desde a perspectiva construída pelo Estado. Pretendemos abordar os temas principais da Doutrina de Segurança Nacional e da Doutrina Contrainsurgente - localizadas nas narrativas oficiais - para salientar as contradições que possibilitaram o ocultamento da guerra suja.

\subsection{Fontes}

\subsubsection{Informes presidenciais}

No presidencialismo, a figura depositária do poder executivo é o centro e a chave de toda a estrutura política. Sua onipotência não conhecia nenhuma das limitações que formam o complicado sistema de freios e contrapesos ideado pelo federalismo, pelo parlamentarismo, pela divisão de poderes e pelo regime de partidos. O presidencialismo era, por tanto, "el resultado de la concentración política, jurídica y social de las decisiones” (MONSIVÁIS, 1993, p. 113-126). No sistema político mexicano, a figura presidencial foi promovidaconstitucionalmente com poderes extraordinários permanentes ${ }^{48}$. Além disso, o fato de ser reconhecido como árbitro supremo a cuja representatividade todos os grupos submetiam suas diferenças e por cujo conduto legitimava seus interesses.Estimulou-se nas massas o culto não só à personalidade do presidente, também ao poder presidencial (GONZÁLEZ CASANOVA, 1967; CARPIZO, 1987; COSÍO VILLEGAS, 1976).

Se a instituição presidencial se localiza na ponta da pirâmide do sistema político mexicano, consideramos que o discurso oficial possa ser esmiuçado a partir dos informes presidenciais. Uma vez por ano, pontualmente no primeiro de setembro, o presidente se

\footnotetext{
${ }^{48}$ Segundo o advogado Jorge Carpizo, as principais características do presidencialismo mexicano, que não estão contidas nos parâmetros constitucionais, podem se resumir da seguinte maneira: a) o presidente da república é ao mesmo tempo o chefe do partido hegemônico; b) o poder legislativo está completamente debilitado, porque a maioria dos legisladores são, também, membros do partido predominante; c) a suprema corte de justiça está integrada por elementos políticos que não se opõem aos assuntos de interesse presidencial; d) existe uma marcada influência na economia através de mecanismos como o banco central, organismos descentralizados e companhias de participação estadual; e) o exército também está institucionalizado e seus chefes dependem diretamente do presidente quem tem o postode "Chefe Supremo das Forças Armadas"; f) há uma forte influência na opinião pública através do controle dos meios de comunicação de massa; g) o poder executivo concentra e distribui os recursos econômicos; $h$ ) o presidente tem amplos poderes constitucionais e extra constitucionais (por exemplo, a faculdade de designar o sucessor e governadores, fazendo da eleição popular uma ficção); i) na figura presidencial concentram-se as decisões de todos os aspectos internacionais nos quais o país intervém, sem oposição do senado; j) o governo do distrito federal depende diretamente do executivo; e por último - como elemento psicológico - k) sempre se aceita o papel predominante do executivo sem que se lhe questione (CARPIZO, 1985, p. 25-26).
} 
apresenta ao Congreso de la Unión. Em termos formais, o informe presidencial é um balanço que o poder executivo realiza sobre sua gestão anual com o objetivo de informar à cidadania representada por deputados e senadores reunidos no Congresso - os avanços e resultados em diversas esferas da administração pública (economia, política interna e externa, bem-estar social).

Para situar a importância dos informes, acreditamos que é necessário entendê-los no seu contexto, pois representam uma peça-chave dentro do sistema político mexicano. A apresentação de informes escritos é uma obrigação contida no Artigo 69 da Constituição mexicana:

\begin{abstract}
À abertura de sessões do Congresso, sejam ordinárias ou extraordinárias, comparecerá o presidente da República e apresentará um informe por escrito; no primeiro caso, sobre o estado geral que guarde a administração pública do país, e no segundo, para expor ao Congresso ou à Câmara do que se trate, as razões ou causas que fizerem necessária sua convocação e o assunto ou assuntos meritórios de uma resolução peremptória (CONSTITUCIÓN POLÍTICA DE LOS ESTADOS UNIDOS MEXICANOS, 1917).
\end{abstract}

Apesar de que a exigência se limita à apresentação escrita do informe, sua leitura foi instituída como uma tradição, inclusive antes da promulgação da Constituição de 1917. Esta prática se fundamente na Constituição de Cádiz (1812), que exigia a presença do Rei na abertura das Cortes. Posteriormente, a tradição liberal enfatizou a necessidade do informe como uma forma de manter o equilíbrio entre poderes. Assim, qualquer elemento do Congresso podia questionar o Executivo, pedir informações extras ou manifestar desacordos. Porém, é durante a ditadura do general Porfirio Díaz, com a concentração excessiva do poder na figura presidencial, que se intensifica a ritualização no processo de leitura dos informes $\left(\right.$ MEYER, 2005) ${ }^{49}$.

\footnotetext{
${ }^{49}$ Aqui, o conceito de "ritual político" vem da perspectiva de Pierre Bourdieu. Para ele, os rituais são maneiras de atualizar os mitos políticos, tendo uma importância capital na consolidação de instituições, e, sobretudo, como reforço das divisões sociais. Os ritos de passagem não só estão relacionados com a transição de um estágio para outro ( $v$. $g r$. da infância para a idade adulta). Também traçam uma linha divisória entre os que podem chegar a ele e os que não podem. Essa linha divisória é reforçada pela ordem política. O autor acredita ser mais apropriado chamá-los de "ritos de instituição". O ato de instituir é entendido como sancionar um estado de coisas no âmbito jurídico-político, mas também como uma forma de conhecimento e reconhecimento das diferenças. Bourdieu sugere que a eficácia simbólica dos ritos de instituição reside no fato de que sua celebração se incide no real, e, ao mesmo tempo, sobre a representação do real. Nesses atos de instituição se produzem definições sociais, identidades e, sobretudo, limites que são reconhecidos por quem compartilha as crenças coletivas propostas pela instituição e materializadas em símbolos e signos: "As mostras de respeito que consistem, por exemplo, em nominar alguém por seus títulos (Senhor Presidente, Excelência, etc.) são outras tantas repetições do ato inaugural de instituição realizado por uma autoridade reconhecida universalmente e fundada, portanto, no consensus ómnium; têm o valor de um juramento de fidelidade. De mostra de
} 
É uma ação simbólica com uma série de regras estabelecidas acompanhadas de certos comportamentos tanto do presidente, como de legisladores e do conjunto da sociedade, conformando um protocolo que "tenta ser um meio de transmissão de crenças, emoções e percepções sobre a realidade política nacional e a gestão de governo" (LÓPEZ LARA, 2006, p. 46). Esse protocolo está constituído, então, como um ato de "renovação da versão oficial e mitificada da Revolução mexicana". Significa, paralelamente, um "ato público de renovação do mandato e da disciplina em torno do chefe do Executivo" (p. 43).

O protocolo é um mecanismo perfeitamente articulado como um ritual cívico, expressão do nacionalismo mexicano que ajudou na construção da identificação entre a pessoa do presidente e os símbolos nacionais. Embora Álvaro Obregón e Plutarco Elías Calles tenham consolidado o formato da cerimônia do informe, foi Lázaro Cárdenas quem começou a utilizar o rádio e os jornais para a difusão da cerimônia. Por sua parte, Miguel Alemán, a partir de seu quarto informe (1950), utiliza a televisão - sendo a primeira transmissão oficial da história mexicana (GONZÁLEZ REYES, 2011, p. 57-58).

O que poderia simplesmente significar uma tradição democrática sã, um efetivo acesso à informação de interesse público e uma mostra de transparência na gestão, apresenta uma progressiva complexidade quando se converte na "festa do presidencialismo mexicano" com uma projeção popular e social acompanhada de um cerimonial que demonstra, para quem conhece os códigos, a concentração excessiva do poder [fig. 6-8].

Com o transcorrer do tempo, a leitura do informe também se modificou, especificamente quanto a sua extensão. $\mathrm{O}$ que começou com oito páginas lidas pelo ditador Porfirio Díaz, em 1891, aumentou para vinte, durante a breve gestão de Francisco I. Madero. Posteriormente, Venustiano Carranza duplicou o volume para cinquenta e nove páginas (MEYER, 2005). Na segunda metade do século XX, as transmissões se fizeram ainda mais longas. À amplitude do informe se soma o fato de que o presidente era interrompido com ovações e batidas de palmas dos legisladores. A versão eletrônica utilizada neste trabalho, disponível na página oficial da Câmara dos Deputados, é uma versão estenográfica. Estas versões também permitem recriar a imagem do ambiente dentro do recinto, pois registram os momentos quando o presidente era ovacionado, enfatizando os temas de maior importância no momento.

Em 2003, o Departamento de Referencias de la Subdirección de la Biblioteca

reconhecimento com respeito à pessoa em particular a quem se dirigem. Porém, sobretudo com respeito à instituição que tenha instituído a si (é por isso que o respeito às formas e às formas de respeito que define a cortesia são tão profundamente políticos). A crença de todos, que é prévia ao ritual, é uma condição para que o ritual seja eficaz" (BOURDIEU, 1993, p. 111-123). 
Legislativa elaborou um CD-ROM intitulado Informes presidenciales; 1917-2000, baseados nos Diarios de los Debates de la Cámara de Diputados del Congreso de los Estados Unidos Mexicanos, publicação impressa que recolhia a reprodução estenográfica dos informes. Em 2008 foram disponibilizados através da página web da Câmara, em formato PDF e atualizados até o ano 2006. A coleção consta de dezenove documentos ordenados cronologicamente por período presidencial, incluindo a resposta do deputado correspondentes. Também há um anexo biográfico do presidente em questão e um anexo fotográfico.

\subsubsection{Documentos da Dirección Federal de Seguridad (DFS)y de la Dirección de Investigaciones Políticas y Sociales (IPS) localizados no Archivo General de la Nación (AGN)}

Como contrapartida à versão oficial, aqui se propõe a análise dos informes elaborados pelas agências de inteligência mexicana. Isto porque neles encontramos, de maneira fragmentária e pouco sistematizada, as atividades clandestinas do Estado. Como antecedente, mencionamos um fato importante que define os alcances e possibilidades que oferece este acervo documental. Sob a pressão de organismos de Direitos Humanos e, sobretudo, das organizações históricas de busca de desaparecidos, em 2002, o presidente Vicente Fox anuncia a criação da Fiscalía Especial para Movimientos Sociales y Políticos del Pasado (FEMOSPP).

Para consertar o "esquecimento" da guerra suja mexicana, a FEMOSPP teria dois objetivos fundamentais: tanto esclarecer os processos sociais e políticos desde 1968, como julgar os responsáveis pelos possíveis crimes cometidos. Em outras palavras, a investigação e os julgamentos do terror de Estado cometido pelo PRI. O fato de que esta iniciativa se constituísse como uma política de Estado animou os mais otimistas.

Desta maneira, o presidente Fox dispôs a transferência da documentação das históricas agências de inteligência. O Centro de Investigaciones y Seguridad Nacional (CISEN) ${ }^{50}$ enviou para o Archivo General de la Nación (AGN) os fundos documentais correspondentes às extintas Dirección Federal de Seguridad (DFS) e Dirección General de Investigaciones Políticas y Sociales (IPS). Somam um total de 4.223 caixas com 58.302 expedientes ${ }^{51}$, além

\footnotetext{
${ }^{50}$ Nome atual do serviço de inteligência mexicano.

51 Quando falamos de "expedientes", nos referimos as pastas que estão localizadas dentro das caixas e que conservam os documentos.
} 
de 7 milhões de fichas com informação sobre pessoas ou acontecimentos, cuja descrição não foi especificada na ata de entrega. A informação está dividida em dois espaços físicos: a Galeria 1, que resguarda os documentos da DFS, e a Galeria 2, da IPS. Esta medida pode ser considerada revolucionária, pois, até então, não existia nenhum tipo de fonte para o estudo da repressão no México.

O AGN resguarda a documentação gerada pela totalidade das instituições federais. Um dos objetivos estratégicos da instituição é garantir a conservação do patrimônio documental nacional, fomentar a pesquisa dos arquivos históricos e difundir de maneira adequada o acervo documental (AGN, 2014). Todas as secretarias de Estado estão obrigadas a enviar a documentação de carácter "histórico",52. Agora, o primeiro problema sobre o qual nos deparamos: especificamente os arquivos históricos pertencentes aos serviços de inteligência não foram assumidos como parte do AGN. Ou seja, continuam sob a guarda da Secretaría de Gobernación (SEGOB) ${ }^{53}$, a qual designou o próprio CISEN, que depende da SEGOB, para a proteção deste patrimônio. Neste sentido, os titulares de cada dependência são os encarregados de estabelecer tanto os critérios para determinar a "historicidade" dos documentos antes de serem enviados para o AGN, assim como a organização dos mesmos. O AGN, por sua parte, deve manter a organização proposta pelas dependências de procedência.

O possível desmonte da estrutura autoritária do Estado a partir da criação de instituições que deveriam descentralizar o poder da figura presidencial, como foi o caso do Instituto Federal Electoral (IFE), não foi considerado para o caso dos arquivos históricos. A situação destes fundos são uma mostra do peso autoritário que permeia o sistema político mexicano. Dito de maneira coloquial: "se puso la Iglesia en manos de Lutero".

Ironicamente, o prédio que abriga o AGN é a antiga prisão chamada Palácio de Lecumberri. Construída por ordem do ditador Porfirio Díaz, foi inaugurada em 1900. A arquitetura responde ao modelo panóptico, ou seja, trata-se de uma construção em forma de balão cujo centro é destinado ao corpo de vigilância, enquanto que o resto da construção está disposta de maneira radial, "mediante galerias de forma estrelada que convergem no espaço central, no qual se erigia uma torre de 35 metros de altura destinada para a vigilância de todo o presídio" (EXCELSIOR, 2013) [fig. 9].

Duas dessas galerias são as que abrigam os documentos de interesse à pesquisa. Por ter-se inaugurado uma década antes do início da Revolução Mexicana, momento de ebulição

\footnotetext{
${ }^{52}$ Em 1998 estabelece-se que as consultas podem ser feitas 30 anos após a data de elaboração do documento, sempre que não comprometa a segurança nacional ou a vida privada das pessoas envolvidas (SEGOB, 2008).

${ }^{53}$ Esta secretaria seria o equivalente ao Ministério da Casa Civil, no caso do Brasil.
} 
política e social, o presídio foi imediatamente apelidado como "Palácio Negro", pois, desde sua inauguração, ele foi destinado à tortura de presos políticos, assim como assassinatos com esse mesmo carácter. Até seu fechamento em 1976.

O acervo documental apresenta sérios problemas de consulta. Um deles é que na ata administrativa de entrega/recepção do acervo do CISEN, não se detalha o tipo de suporte do material (vídeo, áudio, fotografia). Simplesmente existe uma breve descrição dos documentos onde se assinala a procedência (SEGOB, 2001). O pesquisador enfrenta as "contradições em que ambas as dependências incorrem, pois, o CISEN manifesta ter remitido para o AGN todos os documentos e o AGN responde que não chegou informação em formatos de áudio e vídeo" (DOYLE, 2008).

Encontramos documentos, no interior da Galeria 1, que vão desde 1947 até 1985. No seu estado original, esses papéis unicamente podem ser revisados pelos indivíduos sobre os quais recaem as investigações, no caso de se encontrarem ainda vivos (ou então por membros da família). Os pesquisadores têm acesso unicamente às Versões Públicas (VP), que são maços que reúnem grande parte dos documentos elaborados sobre alguma pessoa específica. Vêm com a supressão (fitas negras) de dados pessoais que estejam relacionados com outras pessoas sobreviventes. As VP são acessíveis unicamente pela solicitação eletrônica.

Sempre que algum pesquisador tenha solicitado uma VP pela primeira vez, esta fica à disposição para consulta livre. Até aqui a norma está de acordo com a Ley Federal de Transparencia y Acceso a la Información Pública y Gubernamental (Artigo 30) (CÁMARA DE DIPUTADOS, 2014). A situação se complica quando o pesquisador requisita informação sobre algum grupo ou instituição, pois aí se depara com parágrafos inteiros suprimidos. Não existe nenhum critério para a mutilação dos documentos (se não comprometer a segurança interna do país). De fato, são os próprios funcionários do CISEN os que elaboram as versões. Não existe, portanto, uma equipe especial para este trabalho.

Um dos maiores obstáculos para a pesquisa desse acervo (durante nossa pesquisa) foi a presença sempre vigilante do responsável da Galeria 1, agora falecido: Vicente Capello y Rocha. Agente da DFS desde 1961, Capello, sem nenhum fundamento legal, permanecia na Galeria "oferecendo cooperação técnica em atividades de identificação e organização" (CAMACHO, 2007). Além disso, desempenhava o cargo de responsável pelo atendimento aos pesquisadores. A seleção dos documentos que o pesquisador tem acesso depende, literalmente, da boa vontade do ex-agente. Depois de uma avaliação intimatória sobre os interesses na informação resguardada, ele mesmo seleciona os documentos que podem ou não ser consultados, sem nenhum critério fora do "olho crítico", digamos assim, de um ex- 
policial. Tal experiência é compartilhada por vários pesquisadores que já trabalharam neste acervo. Um procedimento comum, entre outros, é a consulta de algum documento num determinado dia, e, no seguinte, sem nenhum tipo de explicação, ser informado da inexistência do mesmo. Assim, o estudante de Doutorado em História do Instituto Mora, Mario Santiago, numa entrevista concedida ao jornal El Universal, narra:

Não pude consultar nenhum documento original relacionado com as organizações de extrema direita. Me negaram a existência de documentos que depois apareceram. Quando pedi o expediente de Plata Moreno, me disseram que não existia. Voltei um ano depois e já havia uma versão pública. Então reclamei que um ano atrás me disseram que não existia. $\mathrm{O}$ encarregado riu e falou "assim são as coisas. As vezes aparecem e as vezes não” (MARTÍNEZ, 2015).

Agora, a Galeria 2 (IPS) mantém os documentos datados entre 1925 e 1985. Apesar de estar aberta e resguardada pelos funcionários do AGN, apresenta, também, uma série de inconvenientes que comprometem a pesquisa. Primeiro, não existem instrumentos de consulta que sejam verdadeiramente úteis. As pesquisas têm que ser realizadas no Centro de Referências do arquivo, espaço onde se mantém uma série de índices com os conteúdos de cada galeria. Infelizmente, a descrição do fundo IPS é o bastante genérica como para impossibilitar que se ache alguma coisa. Os documentos estão desordenados, ou seja, não estão agrupados cronologicamente, nem por pessoa investigada, nem por tema ou organização. Podemos encontrar, assim, dentro de uma mesma caixa, informes relativos ao movimento estudantil de 1956, documentos do setor de recursos humanos da instituição correspondentes ao ano de 1973, fichas de detenção de supostos guerrilheiros da década dos oitenta.

Dessa maneira, o informe da FEMOSPP complicou ainda mais a situação das consultas. Existem denúncias de que esse informe foi censurado e de que não teve um carácter oficial, pois, de fato, não foi publicado. A analista da ONG estadunidense The National Security Archive destacada para dar seguimento ao trabalho da FEMOSPP, Kate Doyle, denunciou em reiteradas ocasiões que a comissão integrada por 27 pesquisadores, historiadores e ativistas pelos direitos humanos foi francamente hostilizada pelo governo Fox. O trabalho da promotoria foi utilizado simplesmente para detectar o material "mais perigoso" dentro dos arquivos históricos, "não para promover a justiça, mas sim, para neutralizá-lo". O problema residiu, segundo Doyle, no fato de que se os pesquisadores solicitassem documentação, o material permanecia "sob guarda". Até agora, grande parte dos documentos 
utilizados para a construção do informe continuam barrados para a consulta de pesquisadores independentes (DOYLE, 2006).

Por outro lado, não houve nenhum responsável julgado pelos crimes de Estado dos anos da guerra suja ${ }^{54}$. Dessa forma, o direito à verdade de familiares de desaparecidos e executados durante o perído é novamente negado. E junto com isso o acesso à informação. $\mathrm{O}$ único "triunfo" obtido pelo trabalho da FEMOSPP foi a legislação do crime de “desaparecimento" em 2003. Aliás, o triunfo foi efêmero, pois:

Num giro kafkiano uma nova regulação federal publicada em maio passado proíbe a detenção prolongada dos acusados, a menos que se produza uma evidência [física] - digamos, um corpo - de seu crime. Como resultado, dois ex oficiais de polícia encarcerados pelo desaparecimento de Jesús Piedra Ibarra em 1975 foram liberados imediatamente (DOYLE, 2006) ${ }^{55}$.

Preocupados por esta situação, várias instituições defenderam projetos para fazer descrições mais úteis e funcionais. Um exemplo é o recurso eletrônico elaborado pela pesquisadora Daniela Spenser do Centro de Investigaciones y Estudios Superiores en Antropología Social (CIESAS). Num CD-ROM (SPENSER, 2003), junto a uma equipe de estudantes, a historiadora classificou documento por documento. Eles realizaram a descrição detalhada de cada um e descreveram a localização exata. Além disso, o recurso permitia ao pesquisador fazer buscas por nome, palavra ou data. Porém, inexplicavelmente, o valioso material não tem utilidade atualmente. Ou as referências não coincidem, ou os documentos não existem mais.

Outro projeto foi o encabeçado pelo historiador Aurelio de los Reyes, que organizou um seminário dentro do curso de História da Facultad de Filosofía y Letras da UNAM com o objetivo de catalogar o acervo visual da Galeria 2. Participamos desse seminário, como parte de um número considerável de estudantes. Assim, tivemos a oportunidade de revisar caixa por caixa com a intenção de localizar e descrever fotografias, mapas, cartazes, fanzines ou qualquer tipo de material gráfico. Após quatro anos de trabalho (2007-2011), de novo, as caixas foram inexplicavelmente revolvidas. Alguns documentos fotográficos desapareceram e

\footnotetext{
${ }^{54}$ Então fiscal especial, Ignacio Carrillo Prieto apresentou acusações contra o ex-presidente Luis Echeverría, assim como contra outros ex-funcionários, por cumplicidade nos massacres de estudantes de 1968 e 1971. Porém, a Suprema Corte de Justiça engavetou os casos, pois, no seu entendimento, estes crimes já teriam prescrito.

${ }_{55}$ Jesús Piedra Ibarra foi guerrilheiro da Liga Comunista 23 de Septiembre, seu desaparecimento é icônico, sobretudo, porque a mãe dele, Rosario Ibarra de Piedra, encabeço as denúncias de tortura e a busca de desaparecidos. Agora, os outros acusados, como executores ou colaboradores dos crimes de Estado, continuam evadindo a justiça usando um dispositivo legal que os protege.
} 
outros foram trocados de lugar. O trabalho do seminário que, além de ter localizado o material gráfico, ajudava a reforçar as precárias ferramentas de consulta, terminou não servindo para nada devido ao desordenamento do acervo.

Desde março de 2015 circulou a notícia de que a SEGOB restringiria, de maneira ainda mais drástica, a consulta dos acervos em questão. A aplicação do Artigo 27 da Ley Federal de Transparencia y Acceso a la Información, reformado em 2012 (CÁMARA DE DIPUTADOS, 2012), coloca o acervo num novo patamar. Como mencionado linhas acima, para que um arquivo adquira o carácter de "histórico" se estabeleceu que um documento poderia ser aberto para consulta trinta anos depois de sua elaboração. Com a última reforma, criou-se a categoria de "arquivo histórico confidencial". Considera-se, então, que a existência de dados pessoais (de vivos) são um fator suficientemente sensível para ampliar o critério de abertura para setenta anos. Ignora-se o fato de que a proteção de dados pessoais tem que ser repensada, como aponta a legislação anterior, quando esta informação seja necessária para a investigação de violações aos direitos humanos.

Atualmente, sem nenhuma explicação, somente podem ser consultadas as VP já elaboradas. Não serão elaboradas novas. A reforma definitivamente compromete a possibilidade de construir a memória histórica sobre os delitos cometidos pelo Estado mexicano no passado. $\mathrm{O}$ acervo está sistematicamente sendo censurado:

A proteção de dados não deve ser escusa para impedir que a sociedade mexicana tenha acesso a páginas muito dolorosas de seu passado e possa, afinal, liberar-se de seus efeitos lacerantes, mediante a busca da verdade contida em seus arquivos. A proteção de dados pessoais não deve servir para ocultar os cometidores ou invisibilizar vítimas de crimes de lesa humanidade (ROCHÍN, 2015).

Avaliamos, então, que os arquivos históricos de DFS e IPS são de interesse social, a prova da atividade do Estado. A informação privada, consequentemente, aporta elementos para a consolidação do direito à verdade, sobretudo, nos casos em que se investiguem violações aos direitos humanos. As restrições atuais, baseadas no mito da proteção da esfera privada, são uma mostra de que existe um esforço para proteger os funcionários que cometeram os delitos, afinal, são eles mesmos que classificam e censuram os documentos.

$$
* * *
$$

O relato sobre as condições em que se encontra o arquivo permite situar os limites desta 
pesquisa. Consultamos uma parte do fundo que está desorganizado e é relativo à DFS, detendo-nos nos assuntos relativos ao movimento social e armado dentro do período considerado. Buscamos, assim, sistematizar a informação para destacar exemplos que nos possibilitassem traçar um panorama geral da contrainsurgência mexicana. Quando permitem os documentos, elaboramos as narrativas mais completas sobre este e aquele grupo ou acontecimento específico. Alguns episódios apresentam mais informação que outros. Porém, procuramos fazer com que todas essas histórias, que não podem ser mais que fragmentárias, possam contribuir para acentuar um contexto mais amplo. Afinal, mostram as contradições entre este trabalho secreto e clandestino da contrainsurgência e o discurso oficial da figura mais importante do sistema político mexicano, o presidente.

Aprofundaremos, então, na análise das doutrinas de Segurança Nacional e da Contrainsurgência em que o anticomunismo e a leitura bipolar da realidade ganham um papel central. Detemo-nos na relação que estabelecem os EUA com a América Latina, sobretudo, como consequência do Informe Rockefeller. Vai em destaque, assim, o funcionamento da Dirección Federal de Seguridad e do Exército mexicano, a fim de apresentar o funcionamento das duas instituições encarregadas da segurança interna mexicana na sua relação com as novas doutrinas militares norte-americanas. Dessa forma, no contexto latinoamericano da Guerra Fria, salientamos as alterações que ambas instituições mexicanas apresentam no recorte temporal proposto.

No terceiro capítulo acentuamos o discurso presidencial em torno da política externa apresentando uma análise sobre a construção da imagem do país e reportando à experiência histórica revolucionária e à maturidade das instituições democráticas, bem como à posição do México no conflito mundial. A radicalidade demonstrada - marcando a independência a respeito das propostas estadunidenses - ganham força com a utilização política do asilo. $\mathrm{Na}$ linguajem presidencial o anticomunismo é um conceito que supostamente não tem cabida no contexto mexicano e é questionado a partir da relação entre o Estado e os grupos políticoeconômicos anticomunistas. Dessa maneira, apresentamos um pouco da estrutura das organizações com esse perfil, assim como suas estratégias.

No quarto capítulo, vemos as formas em que o Estado construiu a imagem do inimigo interno. A partir daí, propomos que o conflito interno, isto é, o movimento social cada vez mais radical, bem como a proliferação dos grupos armados, são tratados com um olhar desde a Doutrina de Segurança Nacional. Com os elementos da DSN, o Estado e seus órgãos de segurança interna erguem a versão contrainsurgente a partir da qual se combate a oposição. Especialmente, na ideia de que a guerrilha mexicana foi patrocinada por alguma força externa. 
Por fim, no capítulo cinco, buscamos características da contrainsurgência mexicana salientando o papel do exército no meio rural e o paramilitarismo no contexto urbano. Apresentamos, assim, a infiltração da DFS nos grupos guerrilheiros e alguns casos de interrogatórios aos guerrilheiros detidos, como dois elementos que caracterizam a contrainsurgência mexicana e que, também, a aproximam da história das guerras sujas latinoamericanas. 


\section{GUERRA FRIA E CONSOLIDAÇÃO DO ANTICOMUNISMO}

Definimos Guerra Fria como uma série de processos que se sucederam entre o fim da Segunda Guerra Mundial (1945) e a desintegração da URSS (1991). Grosso modo, está caracterizada pela nova distribuição global de forças a partir da derrota das potências consolidadas durante a primeira metade do século XX (Alemanha, Itália e Japão). A luta pela hegemonia mundial no pós-guerra precipitou o rompimento e o confronto entre as potências aliadas que outrora haviam derrotado o eixo nazifascista.

A partir de 1947 se concretiza uma leitura binária da realidade. Por um lado, estavam os EUA, com a vantajosa posição de quem não tinha sofrido os estragos da guerra no seu território. Possuidora de uma economia dinâmica, com um forte consenso em torno aos seus governantes, grande parte da sociedade civil estava mobilizada ao redor dos históricos pilares institucionais: "a igualdade e liberdade individuais, o respeito à propriedade privada, a livre concorrência e o convencimento de ser excepcionais" (AGUAYO, 2014b).

Esta percepção dicotômica foi elaborada durante a administração do democrata Harry S. Truman (1945-1953), com base no documento intitulado "The Sources of Soviet Conduct $^{\text {,56 }}$ publicado na revista Foreign Affairs de George F. Kennan. O autor tinha sido funcionário da embaixada dos EUA em Moscou durante os últimos anos da Segunda Guerra. Kennan projetava um antagonismo "natural" entre capitalismo e comunismo. Contradição que se aprofunda, segundo o autor, pela manipulação ideologicamente irresponsável das lideranças soviéticas, no interior, e a intransigência agressiva com relação ao mundo exterior. No artigo se alerta para o fato de que a política soviética não tem características “aventureiras". Pelo contrário, sua atividade política "é um curso fluído que se move de forma constante, onde quer que the seja permitido mover-se, em direção a uma finalidade predeterminada" (ZIMBRES, 2005). Neste caso, a derrota final do capitalismo.

A recomendação a partir desta observação é que a política estadunidense devia propiciar as condições para "conter" o comunismo. A estratégia foi planejada "a longo prazo", no refreamento "paciente, ainda que firme e vigilante, das tendências expansivas russas". Desta maneira, diz Kennan, não seria necessário o confronto direto. As pressões soviéticas sobre o "mundo livre" poderiam ser contidas e neutralizadas, construindo um sistema "de correlação de forças numa série de pontos geográfica e politicamente cambiantes, que correspondam às mudanças e manobras da política soviética” (GONZÁLEZ GÓMEZ, 2003,

\footnotetext{
${ }^{56}$ Aqui se utiliza a tradução ao português feita por Danilo Zimbres, publicada na revista Política Externa, junho de 2005, v. 14, n. 1 (ed. Paz e Terra).
} 
p. 28).

Nesse contexto, os EUA assumem a missão global de defender o "mundo livre". A leitura binária da realidade se sustenta, assim, na ideia de que o mundo se divide contundentemente entre sociedades "livres" e sociedades "oprimidas". Sob estes princípios a administração estadunidense superdimensiona a suposta "ameaça comunista". Nas palavras de Hobsbawm (2009, p. 232) elabora-se um "anticomunismo apocalíptico" que iria servir como pretexto para assumir uma postura hegemônica sustentada num novo desdobramento militarista perante a possibilidade (também superdimensionada) de que a URSS sovietizasse a Europa oriental.

Durante os primeiros anos da Guerra Fria, a URSS não tinha condições reais para disputar a hegemonia mundial (DEUTSCHER, 1969). Contudo, o comunismo internacional atravessava um momento de fortalecimento e credibilidade. A Segunda Guerra Mundial ajudou para que os Partidos Comunistas crescessem, se fortalecessem e, em vários casos, viessem sair da clandestinidade, convertendo-se, como no caso italiano ou francês, nos aliados para a derrota dos restos do nazifascismo.

Os EUA (a "decadência de Ocidente") e a URSS (a "tirania de Oriente"), com modelos econômicos e projetos políticos e sociais divergentes e incompatíveis, iniciaram uma escalada competitiva que se manifesta enquanto uma construção cultural em termos dicotômicos, como anteriormente mencionamos. Outra característica é a construção discursiva desenvolvendo uma linguajem própria desse tempo. Conceitos como "Guerra Fria", "Cortina de Ferro", "esfera soviética", "ameaça comunista", "terrorismo", entre outros, estão vinculados à espetacularização e popularização desenvolvida, acima de tudo, pela crescente força política outorgada aos meios de comunicação. O que foi devido, também, à massificação dos mesmos (VEIGA; DA CAL; DUARTE, 1998).

À paranoia anticomunista se acrescenta a ideia de que o avanço dos pequenos grupos violentos, armados pelo comunismo internacional, provocaria a queda de mais territórios. A situação ajudaria à expansão vermelha por toda a Europa e o Oriente Médio. Um a um, os países cairiam como peças de dominó. Como reação diante desta possibilidade, uma das medidas tomadas nos EUA foi a formação de uma Comissão de Atividades AntiNorteamericanas comandada pelo então senador republicano, Joseph McCarthy, desatando um clima de histeria coletiva, dando passo a uma "caça às bruxas" dentro e fora do território norte-americano.

Em 1950, o Secretário de Estado, Dean Acheson, elaborou um documento (de circulação interna) intitulado "National Security Council Papel No. 68 (NSC-68)". 
Odocumento representa um alerta sobre a ameaça global comunista. Considerando, então, que para o desenvolvimento do sistema político e econômico ocidental funcionar e desenvolver-se de maneira efetiva, necessariamente tem que estar respaldado pelo poderio militar ${ }^{57}$.

Já durante a administração Eisenhower (1953-1961) continua se privilegiando o poder nuclear, porém, considerado simplesmente como um elemento dissuasivo. Isto é, ao elevar-se a inversão na pesquisa nuclear e armamentista, alimentando discursivamente a ideia do desenlace fatal, se procurava reduzir as tentativas soviéticas de avanço sobre outras latitudes. Assim, não existiria o perigo real de uma guerra no sentido geral e mundial como constantemente se proclamava (HOBSBAWM, 2009).

Num tempo de confronto entre as grandes potências, as nações periféricas começaram a "esquentar-se". A década de sessenta viu uma série de conflitos de caráter anticolonial e nacionalista na África, Ásia e América Latina. Os dois polos hegemônicos tiveram participação direta nos conflitos. Utilizamos, por isso, a palavra "intervenção" para descrever a participação das potências - seja de forma consentida ou imposta - nos processos políticos, econômicos e militares de qualquer país, uma vez que isso se legitima através da estratégia total de Estado. A qual é definida como "a capacidade de utilizar, de forma permanente, a totalidade das forças efetivas e potenciais da nação - econômicas, militares, científicotécnicas, psicológicas - para alcançar objetivos primordiais" (GONZÁLEZ GÓMEZ, 2003, p. $10)$.

Dessa forma, as doutrinas referentes à política exterior são consideradas elementos centrais da estratégia total, pois são a expressão dos objetivos e interesses de um Estado no mundo $^{58}$. Isto é, a natureza de seu compromisso internacional e o papel que lhe toca desempenhar no seu poderio, particularmente, o militar.

Alertamos que a intervenção estadunidense nos processos sociais mundiais, e especificamente nos latino-americanos, não é uma característica apenas do século XX. Como sublinha o jornalista e pesquisador Gregorio Selser ${ }^{59}$, a prática intervencionista está presente

\footnotetext{
${ }^{57}$ Entre 1950 e 1953, período de guerra na Coréia, por exemplo, a verba militar aprovada pelo Congresso norteamericano foi de 13 bilhões para 50 bilhões de dólares. (GONZÁLEZ GÓMEZ, 2003, p. 32).

58 Sobre o termo "doutrina", Sergio Aguayo aponta que "há uma implicação espiritual na política exterior e por isso as iniciativas presidenciais são chamadas 'doutrinas', como se formassem parte do direito canônico da religião. A certeza de ser um povo excepcional [já] justificou atos de agressão contra países mais fracos" (AGUAYO, 2014b).

${ }^{59}$ Gregorio Selser (1922-1991) foi um historiador e jornalista argentino de militância socialista exilado no México desde 1976, após o golpe militar liderado pelo general Jorge Videla. No México, atuou como jornalista e professor especialista nos temas latino-americanos contemporâneos. Autor de 47 livros, o mais conhecido é Sandino, general de hombres libres (1955) e a monumental Cronología de las intervenciones extranjeras en América Latina (2010), descrição do dia a dia das lutas de emancipação do continente - guerras civis, conflitos de fronteira, tratados comerciais, acordos diplomáticos, golpes de Estados, assassinatos políticos, rebeliões
} 
desde a declaração deindependência dos Estados Unidos a respeito da metrópole inglesa. Desde 1776 começa a construção de uma argamassa ideológica que possibilitaria a hegemonia econômica e política do país norte-americano nos últimos tempos. O intervencionismo norteamericano, então, adquire diversas formas, dependendo das conjunturas. Assim, não se restringe unicamente à ação francamente militar e de caráter oficial (como aconteceu durante a guerra contra o México entre 1847 e 1848, que resultou na perda de grande parte do território mexicano). Podemos observar, também, intervenções de tipo encoberto, de caráter político, diplomático e econômico "em sua variada gama de expressões expansionistas, imperialistas, hegemonistas e neocoloniais" (SELSER, 2010, p. 27).

A política exterior norte-americana tem uma continuidade que expressa interesses e objetivos próprios de uma maneira definida e permanente, “que escassamente ou alguma vez tiveram em conta, tal como predica um pretendido altruísmo, os interesses e objetivos de nações e povos da região" (SELSER, 2010, p. 31). O processo de construção da política exterior vai sendo definida, primeiro, em termos da necessidade de expansão, depois, de dominação. Finalmente, em termos de hegemonia.

A política exterior estadunidense, na sua relação com a América Latina, pauta e dá tom à política internacional destes países, de maneira contundente durante a segunda metade do século XX. Porém, observamos que existe um movimento dialético entre a política exterior norte-americana e as conjunturas nacionais que oferecem chão às constantes reformulações doutrinais. Isto é, as relações interamericanas não são produto de vontades individuais, casualidades ou acidentes, "elas responderam à interação de interesses nacionais e regionais, como interpretado dentro do cambiante contexto internacional" (SMITH, 1996).

Seguindo esse raciocínio, abalizamos que para este período, os interesses fundamentais dos Estados-Nações podem dividir-se em dois grandes blocos. O primeiro são os interesses geopolíticos, onde a palavra-chave é segurança, considerando que os protagonistas seriam as burocracias especializadas na violência dentro do aparato de Estado. Por outro lado, encontramos os interesses econômicos, isto é, a busca da prosperidade através de grupos econômicos direta ou indiretamente representados no aparato estatal (SMITH, 1996).

Ambos os interesses não são excludentes, pelo contrário. Quanto maior for a segurança, maior será a estabilidade econômica. Agora, os interesses nacionais são

armadas, movimentos insurgentes, eleições polêmicas. Devido ao trabalho de coleta de matérias sobre o acontecer latino-americano desde 1974, criou-se a Fundación Latinoamericana Gregorio Selser, que desde 2005 integra o Archivo Gregorio y Marta Selser no Centro Académico Memoria de Nuestra América (CAMeNA), na Universidad Autónoma de la Ciudad de México (UACM). 
comumente expressos numa linguajem moral. Sendo assim, "o crescente anticomunismo dos Estados Unidos, que subiu de tom, permitiu às direitas mais intransigentes se colocar sem ajustes na moda norte-americana" (VEIGA; DA CAL; DUARTE, 1998, p. 165). No entanto, o medo da perda de influência estadunidense no continente aumentava. Há enfáticos discursos deste medo. O irmão do então presidente, Milton S. Eisenhower, em 1953, analisava que:

\begin{abstract}
A possível conquista, hoje, da nação latino-americana, até onde alguém pode prever, não seria por assalto direto. Ela viria, mais provável, por meio de processo insidioso de infiltração, conspiração, divulgação de mentiras e sendo minadas as instituições livres, uma após outra. Grupos de comunistas altamente disciplinados estão ocupados, noite e dia, de forma ilegal ou abertamente, nas repúblicas americanas, assim como estão em cada nação do mundo. Enquanto muitas pessoas podem agora pensar a América Latina como fora da linha de ataque na luta do mundo moderno, o sucesso dos comunistas nessas nações poderia rapidamente mudar todos os mapas que os estrategistas usam para calcular as probabilidades do futuro (SMITH, 1996).
\end{abstract}

Dessa maneira, as forças pró-estadunidenses no continente começam a unir-se com três objetivos: 1) eliminar os partidos comunistas do continente; 2) reafirmar o controle do Estado sobre os sindicatos e qualquer outro tipo de organização que dê espaço à inconformidade; 3) isolamento diplomático soviético no continente (SMITH, 1996) ${ }^{60}$. Entre os países alinhados, antes da metade do século XX, podemos citar os governos militares instaurados a partir de golpes militares no Peru e na Venezuela, em 1948. Fulgencio Batista (Cuba), Anastasio Somoza (Nicaragua) e Rafael Leónidas Trujillo (República Dominicana) já eram dirigentes de ditaduras consolidadas. Ainda, em 1949, ocorre o "bogotazo", que manteve fechado o congresso colombiano por dez anos. Os homens fortes ou ditadores militares contribuíram para a articulação de um sistema transnacional chamado "panamericanismo", no qual se logra a "estruturação de um sistema de dependência continental que fusiona os exércitos e empresas nacionais e transnacionais sob a liderança dos Estados Unidos e das corporações econômicas e financeiras" (GONZÁLEZ CASANOVA, 1988, p. 17).

Nesse contexto antidemocrático latino-americano, os EUA orquestram um golpe de Estado contra o governo progressista (toscamente qualificado de comunista) do general Jacobo Arbenz, na Guatemala (1954). Desde nossa perspectiva, esse fato inaugura a entrada

\footnotetext{
${ }^{60}$ Como mencionamos acima, a questão do apoio estadunidense aos regimes ditatoriais dessa época também implicou uma discussão interna, pois estes regimes eram impopulares, sobretudo, pelo uso excessivo da violência contra a oposição. Daí que, entre 1956 e 1959, por exemplo, não houvesse ataques diretos contra os revolucionários cubanos que lutavam contra o outrora amigo Fulgencio Batista.
} 
da América Latina na Guerra Fria, considerando, sobretudo, a forma de intervenção. Isto é, a organização e execução dos planos coordenados pela CIA para contribuir à desestabilização dos governos e abrir caminho para os golpes de Estado (SELSER, 1961; KATZ, 2004).

\subsection{A Doutrina Contrainsurgente}

A administração Kennedy (1961-1963) trouxe inovações à política exterior estadunidense, aprofundando ainda mais a dimensão militarista e de confrontação aberta. Maxwell Taylor (assessor militar e Chefe do Estado Maior Conjunto) e Robert McNamara (Secretário da Defesa) localizaram uma "nova fronteira" da ameaça comunista: o Terceiro Mundo em geral e a América-Latina em particular.

A teoria da conflagração comunista internacional, além do mais, viu-se afetada pelo rompimento sino-soviético ${ }^{61}$. O inimigo se diversifica, já não era unicamente a URSS, como também a China, e, principalmente, Cuba do triunfo da Revolução comandada pelo jovem Fidel Castro, em $1959^{62}$. Fato que significava uma fissura no escudo anticomunista hemisférico. $\mathrm{O}$ inimigo estava em casa.

Como mencionado anteriormente, a luta das duas grandes potências esteve focada na busca de apoio nas regiões que estavam em seus campos de influência. Ambas as potências se viram involucradas em atos de intervenção: como coadjuvantes nas conjunturas que criaram instabilidade política; colaborando na eliminação dos atores sociais e indivíduos considerados como fatores de instabilidade, apoiando regimes, destituindo outros. Mantinha-se, alimentavase uma tensão de confronto interno, e de maneiras diversas (pressões diplomáticas, intervenção direta, financiamento, treinamento militar e ideológico, venda e distribuição de armas).

Lembremos que, desde 1947, vários países latino-americanos assinaram o Tratado Interamericano de Assistência Recíproca (TIAR), onde se projetava a possibilidade de exercer uma “intervenção militar associada" (GONZÁLEZ CASANOVA, 1988, p. 13). Sob essa doutrina de solidariedade continental, os EUA impulsionavam a ideia da luta contra o

\footnotetext{
${ }^{61}$ No fundo da ruptura Moscou-Pequim estava o desejo de liderança do bloco socialista: os chineses iniciariam uma política externa agressiva, enquanto que os soviéticos continuavam na lógica da coexistência pacífica. Assim, Mao iniciaria uma campanha de agressões em que os soviéticos foram acusados de desvios, de revisionistas, e de trair os princípios leninistas (VEIGA; DA CAL; DUARTE, 1998; LEONHARD, 1971).

${ }^{62}$ Considerar Cuba como ameaça se radicaliza no contexto da saída deste país da OEA e do marcante pronunciamento conhecido como a Segunda Declaração de Havana, onde o comandante em chefe anuncia a virada socialista da Revolução (CASTRO, 1962).
} 
comunismo e em prol da "liberdade". Em 1951 se faz conhecer a Ata de Segurança Mútua dos Estados Americanos, em que se estabelecem uma série de acordos bilaterais entre os EUA e outras nações americanas. A ata foi concebida para cobrir quatro objetivos: 1) Garantir as fontes de recursos económicos; 2) estabelecer as vias para a concessão desses recursos para os países assinantes; 3) Manter as Forças Armadas norte-americanas preparadas para a defesa de territórios estratégicos; 4) Reduzir a atuação das Forças Armadas norte-americanas na defesa desses territórios (GRIFFITHS SPIELMAN, 2011, p. 104-105). Paralelamente, é criada a United States Army School of the Americas, ou Escola das Américas (SOA), em Fort Gulick, na zona do Canal do Panamá.

Entretanto, o desconhecimento das condições políticas, econômicas e sociais dos territórios em conflito provocou a formulação de um "enfoque abstrato da violência política terceiro-mundista que considerava as nações como fichas de um jogo Leste-Oeste e foi incapaz de localizar os movimentos revolucionários dentro de um contexto regional" (MAECHLING, 1990, p. 37).

Com estes antecedentes, a administração Kennedy desenvolve, então, a Doutrina da Contrainsurgência (CI). Fundamentalmente, consiste em fazer frente à nova ameaça utilizando recursos militares acompanhados de recursos político-econômicos. Definida pelo Pentágono, a CI está integrada por “aquelas medidas militares, paramilitares, políticas, econômicas, psicológicas e cívicas tomadas pelo governo para vencer a insurgência subversiva" (KLARE; STANE, 1976, p. 17). O foco está colocado nas medidas aparentemente não militares, como a construção de estradas, os programas de saúde e de educação. O objetivo é a legitimação popular dos regimes, apoiados no controle dos meios de comunicação e no trabalho especializado de campanhas propagandísticas. Desse jeito, fica estabelecido que "as tarefas principais das forças armadas latino-americanas eram a segurança interna e a ação cívica (a saber, os projetos de desenvolvimento social e econômico patrocinados pelos militares)" (KLARE; STANE, 1976, p. 27). Nas suas próprias palavras, "ganhar mentes e corações".

Os EUA, assim, iriam dispor de programas de ajuda econômica e assessoramento técnico para que os países que estavam "ameaçados pelas lutas comunistas” aplicassem reformas beneficiadoras de seus povos. É lançado o programa de ajuda hemisférica, conhecida como Aliança para o Progreso (ALPRO), em agosto de 1961. Há uma preocupação por encaminhar programas de "modernização" no Terceiro Mundo. Em 10 anos, destinou-se 20 mil milhões de dólares para que "os governos do subcontinente realizassem as indispensáveis reformas que permitiriam erradicar as causas internas que pudessem favorecer 
a extensão do exemplo da Cuba revolucionária a outros países" (GONZÁLEZ GÓMEZ, 2003, p. 72$)^{63}$.

Na teoria, a aplicação dos programas deveriam assegurar a criação, a longo prazo, das condições econômicas e sociais suficientes para a eliminação das causas de descontentamento social. Porém, o Departamento de Defesa inaugura, simultaneamente, os Grupos de Assessores em Assistência Militar, com a finalidade de oferecer treinamento para as forças militares contra subversivos, fomentando a formação de grupos paramilitares especializados. O objetivo pedagógico estava orientado à "profissionalização" dos exércitos através de cursos ministrados em instituições educativas do Exército dos EUA, "onde se alentava os oficiais a participar nos processos políticos de suas respectivas nações" (GONZÁLEZ GÓMEZ, 2003, p. 44). Desvia-se, dessa maneira, o interesse na defesa externa, orientando os esforços para a segurança interna.

Outro ponto fundamental na CI está relacionado ao melhoramento dos corpos policiais dos países "clientes". Os policiais tinham um papel fundamental para a detecção da subversão, destinando-se uma verba importante para a fundação da Academia Internacional de Polícia em Georgetown, para o melhoramento da administração policial, a modernização das operações de comunicação e inteligência, o ensino de métodos modernos de controle de motins, e o estabelecimento de instituições centralizadas de comando e controle.

Este mesmo esquema contrainsurgente foi aplicado pelo governo de Lyndon B. Johnson (1963-1969) privilegiando de forma mais aberta a questão militar em detrimento dos programas econômico-sociais. Com o objetivo de prever unilateralmente o avanço soviético, no período Johnson se inicia a guerra em Vietnam constituindo-se numa espécie de laboratório desta nova tática contrainsurgente.

Entre 1969 e 1974, o duo conformado por Richard Nixon e Henry Kissinger alavanca mais modificações à política exterior no contexto do desgaste e iminente derrota das tropas estadunidenses no Vietnam, bem como com o crescente avanço dos protestos antiimperialistas no continente americano em destaque a partir da invasão da Bahia dos Porcos (1961), em Cuba, e da República Dominicana, em 1965.

\footnotetext{
${ }^{63}$ Mais que para contribuir ao desenvolvimento econômico, como se pregava, era uma ajuda militar, tornandose, fundamentalmente, um apoio financeiro para a contrarrevolução e comumente utilizado.
} 


\subsection{O informe Rockefeller e a América Latina}

É pertinente sublinhar a importância do texto intitulado "Informe Rockefeller", pois é a base da reviravolta que os EUA deram a respeito das relações com o resto dos regimes do continente. O documento apresenta uma análise da situação latino-americana a partir de uma turbulenta viagem realizada pela Missão Presidencial dos EUA à América-Latina, encabeçada por Nelson A. Rockefeller ${ }^{64}$. No documento original de 136 páginas, Rockefeller é enfático ao declarar que:

A preocupação do homem é o homem. E o homem deve ser a preocupação não somente do seu próprio governo, como de todos os governos e todas as pessoas. Se não somos guardiões de nossos irmãos, somos pelo menos irmãos de nossos irmãos. Se fracassamos, em nossa consciência, deste essencial conceito ou em nosso compromisso com ele, teremos fracassado ante nós mesmos da maneiramais crítica (ROCKEFELLER, 1969, p. 342).

Segundo este documento, o momento era propício para deixar a atitude paternalista com as demais nações hemisféricas. Era o momento para aceitar que cada nação assumisse as responsabilidades pelo seu próprio desenvolvimento. Assim, assinala-se que um dos interesses nacionais dos EUA deveria ser a necessidade de restituir as relações com o resto dos países latino-americanos. Para realizar este objetivo plenamente fazia-se necessária uma análise da situação existente no continente.

Brevemente, Rockefeller destaca que há um alarmante crescimento populacional, sendo que, aproximadamente, sessenta por cento tinham menos de 24 anos. Ou seja, havia uma maioria jovem. O processo de industrialização, ainda que bastante atrasado, deveria continuar avançando. Estas duas condições somadas pelo fato de que a comunicação de massas permitia conhecer e tomar consciência da miséria social e dos privilégios das elites, criando, de alguma maneira, um meio propício para o avanço das ideias comunistas. As contradições da vida urbana latino-americana, então, propiciavam a radicalização dos protestos por educação, moradia, saúde e trabalho.

Por outro lado, os governos eram considerados profundamente nacionalistas. Existia

\footnotetext{
${ }^{64}$ Nascido em 1908, Nelson Aldrich Rockefeller, membro do chamado clão Rockefeller, cuja fortuna se finca no setor petrolifero e imobiliário. Entre 1940 e 1944 foi responsável pelo Escritório de Assuntos Interamericanos, pelo que encabeçou os programas para projetar a política norteamericana em latinoamérica, no contexto da Segunda Guerra Mundial e do combate ao nazi-fascismo. Desempenhou várias funções na administração pública, sobretudo na área da saúde, educação e programas de bem-estar social na década de cinquenta, além de prestar serviços de assistência pessoal nos assuntos externos para o presidente Eisenhower (1954-1955). Foi eleito governador do estado de Nova Iorque em três ocassiões (1962, 1966 e 1970); e participou, sem sucesso, como candidato à presidência pelo partido republicano em 1960, 1964 e 1968 (PUNTO FINAL, 1969, p. 1-16)
} 
uma luta pela identidade nacional e autoafirmação, especialmente em anteposição aos EUA. Por exemplo, avaliando-se que o desenvolvimento científico e tecnológico era extremamente precário na região, os ciúmes, o ressentimento e a frustração em relação aos países mais desenvolvidos eram sentimentos presentes nos discursos políticos. Portanto, os governos latino-americanos enfrentavam um dilema, pois tinham consciência de que a cooperação e participação dos EUA contribuiria para acelerar a concretização de suas metas de desenvolvimento, "mas seu sentido de legitimidade política pode muito bem depender do grau de independência que possam manter dos EUA" (ROCKEFELLER, 1969, p. 289).

Seguindo esta linha discursiva, Rockefeller considera que existem três forças de mudança social e política. Ele recomendava prestar especial atenção para a correta avaliação dos conflitos nacionais. Os jovens, reconhecidos como sujeitos políticos profundamente idealistas, resultavam ser um setor vulnerável "à penetração subversiva e a ser explorados como elementos revolucionários para a destruição da ordem existente" (ROCKEFELLER, 1969, p. 290). Os trabalhadores sindicalizados, por sua vez, tinham a crescente influência comunista dentro dos setores dirigentes. Por último, considerava-se o risco do avanço dos setores progressistas da Igreja católica, a opção pelos pobres e a teologia da libertação, pois estas tendências tinham uma grande recepção entre as populações mais miseráveis da região.

Uma parte que se destaca no documento é a análise positiva e, paralelamente, cautelosa, que se faz dos exércitos latino-americanos. Para Rockefeller, tanto na América Central como na América do Sul, os militares representam o grupo político mais poderoso. Símbolo de poder, autoridade e soberania nacional, em última instância, eles são os árbitros do bem-estar nacional. Reconhece que na história latino-americana existia a tendência para que os grupos militares intervenham no caso de que o governo em curso seja julgado como fracassado ou irresponsável. Desta maneira, "todos os governos militares no hemisfério chegaram ao poder para 'resgatar' o país de um governo incompetente ou de uma situação econômica ou política intolerável” (ROCKEFELLER, 1969, p. 291).

No entanto, Rockefeller alerta sobre a periculosidade das Forças Armadas, porquanto "se corre sempre o risco de que o estilo autoritário dê como resultado a repressão". Historicamente, grande parte dos regimes que foram dirigidos por militares tiveram atitudes fechadas e repressivas, no que concerne às liberdades civis e reformas sociais. Contudo, segundo o encarregado norte-americano, existe uma grande legitimidade e vinculação com o povo, pois, geralmente, veem os militares como filhos de pessoas sem-terra, pobres, e que atendem a um apetite de superação pessoal. Por isso, "o novo homem militar está preparado para adaptar sua tradição autoritária para os objetivos do progresso social e econômico" 
(ROCKEFELLER, 1969, p. 292).

Depois desta análise, Rockefeller propõe - como objetivo para a política norteamericana - a estreita cooperação com outras nações do continente, fortalecendo a segurança interna delas por meio de suas próprias corporações (militares e policiais). No informe são propostas quatro ações concretas:

1. Elaboração de programas de assistência e capacitação militar. No objetivo de profissionalizar as Forças Armadas, propõe o fortalecimento dos "programas de capacitação que trazem pessoal militar e policial das outras nações do hemisfério aos Estados Unidos e a centros de treinamento no Panamá" (ROCKEFELLER, 1969, p. 310).

2. Brindar apoio para preservar a segurança interna. Ou seja, assistir os corpos policiais, elemento chave para a segurança interna. Sobretudo no âmbito urbano, perante a crescente ameaça comunista, tornava-se indispensável ter uma polícia bem preparada e motivada. Em outras palavras, contribuir para a erradicação da tradicional corrupção policial latino-americana.

3. Vender o equipamento bélico que seja requerido. Neste ponto, adverte sobre o problema que resultaria vender o que os EUA estabelecem como necessário para cada país. Como avaliado anteriormente, por parte dos regimes existia um anseio por equipar-se militarmente, e, por outro lado, também havia um sentimento antipaternalista resultado da agressiva política estadunidense. Rockefeller alerta, então, sobre a necessidade de evitar que o material bélico seja comprado de outros vendedores (CORLAZZOLI, 1987, p. 32).

4. Por último, o informe considera pertinente dar continuidade à ALPRO. Mas também recomenda a criação de um Instituto de Assuntos do Hemisfério Ocidental que sirva para estudar e atender as questões militares. Enquanto que uma Agência para o Desenvolvimento Social e Econômico (USAID), dependente do Instituto, funcionaria como um braço econômico e social.

Desta maneira, inicia-se a época do "patrocínio" dos aliados regionais, impulsionando de forma sistemática a assistência militar, o que consolidaria um escudo hemisférico contra o comunismo. Acrescentava-se, assim, à tradição autoritária latino-americana, a perspectiva da segurança nacional, bem como a

"tecnocrática", as ideias "monetaristas" e o liberalismo monopólico, o racismo 'biossociológico' e o ódio aos pobres, aos “desviados” e aos 
intelectuais; o terrorismo de Estado e as técnicas psicológicas de amedrontamento; as táticas militares de genocídio e os assassinatos seletivos, tudo interpretado através das filosofias tradicionais do poder, com gestos de cinismo e hipocrisia, e legitimado por meio de valores que se dizem "religiosos", "liberais", "democráticos" e "científicos", que ajudam a exercer o poder real da maneira mais arbitrária, enquanto se justificam as decisões sobre a base de princípios, tradições ou conveniências, até fazer do irracionalismo "racional" ou "técnico" dos novos ditadores, a expressão oficial e laudatória de seu poder (GONZÁLEZ CASANOVA, 1988, p. 21).

\subsection{A Doutrina de Segurança Nacional}

Os EUA iniciaram um processo de treinamento de exércitos e corpos policiais com o objetivo de que funcionassem efetivamente como os guardiões da segurança continental, sem ter que deslocar soldados estadunidenses. As novas metodologias militares foram espalhadas especialmente para os exércitos latino-americanos, em grande parte pela United States Social Warfare Center and School (localizada em Fort Bragg, North Carolina) e pela United States Army School of the Americas (em Fort Gulick, Panamá). O objetivo fundamental continuava sendo a luta contra o comunismo. Isto é, a preparação para uma agressão que viria do exterior, utilizando os recursos internos. Foi elaborado um corpo doutrinário que sistematizava as questões de segurança e política externa elaboradas pelos assessores das sucessivas administrações norte-americanas (desde Truman). O conceito "segurança" foi elevado como valor central da organização social (CORLAZZOLI, 1987, p. 22).

Conhecidos como National Security Affairs nos EUA, na América Latina adquiriram o nome de Doutrina de Segurança Nacional (DSN). São reconhecidos como regimes de segurança nacional, especificamente, os desenvolvidos no Cone Sul: Brasil (1964-1985), Argentina (1976-1983), Chile (1973-1989), Uruguai (1973-1985), e Paraguai. Neste último caso, a ditadura é mais longeva, porém, considera-se que dá uma guinada para a DSN entre a década de setenta e oitenta (SERRA, 2005, p. 16).

Conceitualmente, "uma nação está segura quando seu governo tem o poder suficiente e a capacidade militar para impedir o ataque de outros estados contra seus legítimos interesses e, no caso de ser atacada, para defendê-los por meio da guerra" (ROCKWELL; MOSS, 1990, p. 44). Sob esta definição tradicional, o Estado mantém o papel de garantidor da segurança da coletividade, ou seja, da nação. Portanto, o conceito supõe que o propósito do Estado é a proteção dos interesses nacionais.

Mas o acolhimento e assimilação desta doutrina induzida a partir da política externa 
norte-americana por meio das assessorias militares adquiriram especificidades dependendo de cada país. Como afirma Joseph Comblin, embora as corporações militares tenham a bandeira do nacionalismo, procederam à deslegitimação dos fatores internos de oposição e descontentamento. Isto ao combaterem o comunismo, que foi considerado uma ideologia evidentemente exótica. Aparentando, assim, que "nesses regimes, a sociedade escapa ao controle do homem" (COMBLIN, 1978, p. 16). Consequentemente, a segurança continental (proclamada um tempo atrás como uma necessidade pelos EUA) foi traduzida como Segurança Nacional. O chamado "inimigo interno" na realidade circulava por uma região mais ampla. Por isso os programas de cooperação internacional para o combate à subversão, como a famosa Operação Condor, seriam considerados legítimos.

A geopolítica, também, é considerada como a guia científica do projeto nacional e como fundamento racional de um projeto político. É definida como a "relação entre a geografia e os Estados, sua história, seu destino, suas rivalidades, suas lutas" (COMBLIN, 1978, p. 24). Estes elementos são os que dão conteúdo empírico à construção dos interesses nacionais. A geopolítica, claro, é uma ciência anterior à Guerra Fria, existindo países que contavam com um vasto desenvolvimento no campo. Porém, a reviravolta da década de setenta permitiu que as geopolíticas dos países latino-americanos se integrassem num bloco anticomunista. Isto é, assumiu-se a leitura da realidade dicotômica como parte dos projetos nacionais.

Outro conceito chave para a DSN é a Guerra Total. Seguindo a lógica bipolar da Guerra Fria, os conflitos políticos internos tornaram-se assuntos internacionais, pois são alimentados desde o exterior. A guerra é considerada total, porque expressa um conflito "em que os recursos políticos, militares, econômicos e psicológicos estão plenamente comprometidos e onde a sobrevivência de um dos beligerantes está em perigo" (NINA, 1979, p. 34). O objetivo, então, é o aniquilamento do outro.

Agora, em questões da ordem interna, a Nação é definida como "única vontade, um único projeto", e se expressa através do Estado. O Estado, então, é a personificação da Nação. Tem a capacidade para se impor sobre outros projetos que disputam o poder, pois é o executor das aspirações nacionais (integridade territorial e nacional, democracia, progresso, paz social, soberania) (COMBLIN, 1978, p. 50). É interessante observar que entre o Estado e a Nação não existem fronteiras conceituais. O Estado é concebido fundamentalmente como o "centro e a soma do poder, não correspondendo, os esquemas de divisão do poder, mais que num sentido funcional" (CORLAZZOLI, 1987, p. 45).

Dentro desta comunidade nacional, rechaça-se a ideia de classe social, e, portanto, de 
luta de classes, pois as contradições geradas pelos interesses particulares chocam com a ideia de unidade nacional. O indivíduo perde sentido e unicamente vê realizadas suas aspirações sempre que se considere, e seja considerado, como membro da comunidade nacional (SERRA, 2005, p. 144). Os partidos políticos, por exemplo, são estimados como a aspiração de grupos particulares, e, portanto, sua existência é contrária à Nação. Daí que seja necessário combatê-los, uma vez que não pode ser tolerada qualquer expressão de oposição organizada. São mobilizados os recursos totais para alcançar os objetivos nacionais (aspirações gerais que contemplem a Nação na sua totalidade) considerando sempre a possibilidade de avanço do inimigo.

Para a salvaguarda dos objetivos nacionais, é necessária a construção de uma política de Segurança Nacional que esteja orientada ao estabelecimento de linhas de ação para a manutenção da ordem. Esta política se expressa, no âmbito interno, pela diligência no funcionamento das instituições; e no externo, pelas relações internacionais. Também contempla as atividades econômicas e financeiras, cujo foco é o desenvolvimento, este entendido como o crescimento continuo da capacidade do poder nacional. Para a consecução do desenvolvimento, a política de Segurança Nacional deve focar-se, também, nos fatores psicossociais, ou seja, nos fatores morais e psicológicos da população, assim como no controle da educação, do sistema de saúde, das relações laborais, da assistência e previdência social. Por último, comporta uma renovada política militar que recolhe tanto as inovações doutrinais, como o novo papel político de sujeito da mudança social (CORLAZZOLI, 1987).

Portanto, a elaboração de estratégias para a solução de contradições internas e externas está determinada por uma visão militarista dos aspectos econômicos, políticos e sociais. A DSN militariza a vida cotidiana (COMBLIN, 1978, p. 63). Pois, teoricamente, diante de uma guerra total, unicamente pode-se responder com a segurança total: "uma segurança que neutralize todas as vulnerabilidades a fim de enfrentar com êxito todas as ameaças provenientes de todo tipo de antagonismos reais ou potenciais do presente ou do futuro" (CORLAZZOLI, 1987, p. 41).

Assim, perante um governo supostamente manipulado pela ação comunista, a defesa dos objetivos nacionais, da democracia e das instituições livres, somente caberia à corporação militar (atendendo às características esboçadas pelo Informe Rockefeller). Ainda que os militares sejam considerados pela DSN como sujeitos de transformação democrática, seus guardiões por excelência, convêm sublinhar que, na teoria, os regimes de Segurança Nacional se caracterizam pela pretensão de ser transitórios. É preciso uma elite militar governando para restabelecer a normalidade democrática, consolidando instituições que seriam provisórias. 
Teriam de ser governos de exceção. Paradoxalmente, grande parte deles se estenderam por até vinte anos.

\subsection{Segurança Nacional mexicana}

O conceito Segurança Nacional foi pouco utilizado no âmbito mexicano. Entre 1946 e o fim da década de setenta, graças ao crescimento econômico e relativa paz social, não houve necessidade de uma sistematização do conceito de segurança. De fato, não existe literatura a respeito. O conceito foi simplesmente utilizado "como sinônimo de controle da dissidência por meio da força (uma interpretação que, todavia, se mantêm)" (AGUAYO, 1990, p. 115). Só em 1973 que o conceito aparece formalmente no Regulamento Interior da SEGOB, designando à DFS a função de analisar e informar os fatos relacionados com a segurança da nação. A instituição se fundou em 1947 por diligências do então presidente Miguel Alemán Valdés, que reuniu um corpo especializado com o objetivo de cuidar de sua segurança pessoal, assim como a de sua família. Fundada pelo coronel Carlos Serrano ${ }^{65}$, seu primeiro diretor foi o coronel Francisco Inurreta ${ }^{66}$.

A DFS foi fundada com polícias de diversas corporações - possivelmente num esforço da primeira gestão civil - para restar poder político à corporação militar. Porém, a Secretaria da Defesa (SEDENA) e o Estado Maior Presidencial (EMP), sentindo-se excluídos, pressionaram para incorporar dez oficiais graduados do Heroico Colégio Militar, em abril de 1947. Neste primeiro momento, a DFS respondia diretamente às ordens da presidência. Em 1952 é enviada à SEGOB (AGUAYO, 2014a). Os dirigentes da DFS historicamente foram quase todos militares ${ }^{67}$.

O Federal Bureau of Investigation (FBI) foi o modelo utilizado para modernizar o antigo Departamento Confidencial. Instituição norte-americana que, inclusive, ministrou os primeiros cursos “onde nos diziam como nos portarmos, vestir-nos, comportarmo-nos em festas às quais tínhamos que ir de smoking” (AGUAYO, 2014a). Além dos cursos, em 1949

\footnotetext{
${ }^{65}$ Essemilitar é mais conhecido por sua fama como traficante de ópio, por sua atuação como senador da República e como grande amigo do ex-presidente Alemán (MORALES OYARVIDE, 2010).

${ }^{66}$ Veterano da Revolução Mexicana, incorpora-se desde os anos vinte ao Departamento Confidencial.

67 Tenente Coronel Marcelino Inurreta de la Fuente (9 outubro 1947-1 dezembro 1952); Coronel Leandro Castillo Venegas (1 dezembro 1952-1 abril 1958); Lic. Gilberto Suárez Torres (1 abril 1958-1 fevereiro 1959); Coronel Manuel Rangel Escamilla (1 fevereiro 1959-1 dezembro 1964); Capitão Fernando Gutiérrez Barrios (1 janeiro 1965-30 novembro 1970); Capitão Luis de la Barreda Moreno (1 dezembro 1970-8 marzo1977); Lic. Javier García Paniagua (8 março 1977-15 agosto 1978); Tenente Coronel Miguel Nazar Haro (16 agosto 197813 janeiro 1982); Lic. José Antonio Zorrilla Pérez (1982-1985); Capitão Pablo González Ruelas (1985).
} 
houve uma assessoria in situ. O FBI aportou agentes para a perseguição que o presidente Alemán empreendeu contra o jornalista Rafael García Travesi, que foi agarrado em Los Angeles e posteriormente entregue à DFS.

A informação considerada importante para preservar a Segurança Nacional mexicana e continental era elaborada, estudada e centralizada pela DFS. Contudo, existiam equipes de inteligência em outras instituições, por exemplo, a Sección Segunda del Estado Mayor de la Secretaría de la Defensa (inteligência militar); a Dirección General de Investigaciones Poíticas y Sociales (IPS) que, como a DFS, dependia da SEGOB; a Jefatura de Policía da Cidade do México e a Policía Judicial Federal. No fundo documental consultado, encontramos vários exemplos que nos ajudam para estabelecer as redes de informação e inteligência que colaboravam estreitamente com a DFS. Entre outros documentos, localizamos um brevíssimo informe elaborado por elementos do EMP, desde a $5^{\text {a }}$ Zona Militar (correspondente ao estado de Chihuahua), na qual se assinala expressamente que se trata de um "extrato de novidades para o Senhor Secretário", Luis Echeverría. Com um carimbo que marcava sua confidencialidade, informa-se sobre um confronto entre elementos militares e elementos da Policía Municipal, resultando em um civil ferido. Menciona-se, também, que o prefeito municipal, de nome Guadalupe Bustillos, "é pessoa que vai em contra à política do governo" $"$.

Inclusive, existia um repasse de informação de elementos que não tinham vinculação orgânica com a DFS, nem com o governo. A cooperação na "salvaguarda da Nação" se dava, por exemplo, pelos membros da imprensa. Num telegrama dirigido também a Luis Echeverría, secretário da SEGOB, informa-se de maneira breve e concisa, que, tanto em prédios públicos como em escolasda cidade de Parral, Chihuahua, tinha sido espalhada uma propaganda assinada por supostos dirigentes e estudantes das escolas normais da região norte do país. Não apresenta nomes. A propaganda, na avaliação do informante, expressava, sem aportar maiores detalhes, a defesa dos guerrilheiros que operavam no estado de Chihuahua. $\mathrm{O}$ emissor da brevíssima informação foi o diretor do jornal El Correo de Parral, Rubén Rocha ${ }^{69}$.

O PRI, como partido de Estado, encarnação dos princípios revolucionários, também enviava informação diretamente para Luis Echeverría, o qual repassava à DFS para a devida

\footnotetext{
68 "Extracto de novedades para el Sr. Secretario", Chihuahua, 22-03-67, AGN, IPS, Caixa1467 B, Exp. 10, folha 1.

69 "El Director de 'El Correo de Parral' informa que edificios públicos y escolares amanecieron con propaganda de estudiantes normalistas defendiendo a los guerrilleros", Chihuahua, 08-10-65, AGN, IPS, Caixa 1448 B, Exp. 41, folha 1 .
} 
análise. O dirigente nacional do PRI entre 1968 e 1970, Alfonso Martínez Domínguez ${ }^{70}$, informa a Echeverría que, durante uma turnê pelo estado de Durango em 1969, tanto o governador do estado, Alejandro Páez Urquidi, como o comandante da Zona Militar da região, lhe confiaram informações sobre a detenção do ativista Álvaro Ríos. Ambosfuncionários coincidem, apresenta o informe, em que "seria conveniente liberar esta pessoa, [com] prévias gestões destes dois funcionários a fim de lograr que o dirigente Álvaro Ríos se sentisse moralmente comprometido" 71 .

\subsubsection{Cooperação internacional}

Os olhos do Estado não necessariamente recebiam salário da DFS, pelo contrário, respondiam a uma estrutura hierárquica em que o dever patriótico era prioridade. Ou seja, funcionários do PRI, jornalistas e militares, também eram fornecedores de informação de inteligência, como pudemos ver nos casos acima comentados. Por outro lado, o FBI, a CIA, o Departamento de Estado e a Embaixada dos EUA elaboravam informes sistemáticos sobre a situação mexicana, e que eram entregues diretamente à SEGOB ${ }^{72}$. Recentemente veio às claras o fato de que a cooperação entre os EUA e o México em matéria de segurança e inteligência estavam coordenadas por Winston Scott, chefe da estação da CIA na Cidade do México desde 1956 (MORLEY, 2011; AGEE, 1978).

A cooperação se estabeleceu como uma rede de espionagem: o Projeto Litempo. Pelas investigações realizadas por Jefferson Morley, biógrafo do Winston Scott, a partir de documentos recentemente abertos pelos EUA, sabemos o nome dos contatos dos importantes personagens da política mexicana que foram recrutados para Litempo. Scott utilizou a

\footnotetext{
${ }^{70}$ El Lic. Alfonso Martínez Domínguez (1922-2002), militante do PRI, foi três vezes deputado federal. Na sua última gestão (1964-1967) trabalhou próximo do presidente Gustavo Díaz Ordaz. Este último o nomeia como presidente do Partido em 1968. Entre 1970 e 1971, foi nomeado regente do Departamento do Distrito Federal (hoje Cidade do México). Por sua suposta participação no massacre de estudantes do 10 de junho de 1971, e as acusações do presidente Echeverria no que diz respeito à liderança do grupo paramilitar Los Halcones (com o que ganhou o apelido de "Halconso"), o presidente forçou sua saída do DDF. A amizade com o presidente López Portillo, Martínez Domínguez foi indicado para ocupar a governatura do estado de Nuevo León (19791985) (DÁVALOS; CARRIZALES, 2002).

${ }^{71}$ Distrito Federal, 19-03-69, AGN, IPS, Caixa 2938, Exp. 15, folha 1. Álvaro Ríos foi um conhecido militante do movimento camponês independente do norte do país, da Unión General de Obreros y Campesinos de México (UGOCM). Esta importante organização, criada em 1949, pretendia fazer correlação de forças com a governista Central de Trabajadores de México (CTM). Na década de sessenta, funcionando como braço camponês do PPS, utilizou a recuperação de terras açambarcadas por latifundiários como método principal na luta camponesa (WOLDEMBERG; HUACUJA, 1991, p. 161).

${ }^{72}$ Sergio Aguayo apresenta nas suas pesquisas os avanços mais significativos na análise dos documentos norteamericanos de inteligência sobre o México, acima de tudo, aos referentes ao movimento estudantil, o que inclui o massacre de 2 de outubro.
} 
amizade pessoal para a realização desse projeto. Na lista encontramos:

- LITEMPO-1: Emilio Bolaños, sobrinho de Gustavo Díaz Ordaz, militante do PRI.

- LITEMPO-2: Gustavo Díaz Ordaz, desde que foi secretário da SEGOB (1952-1964), e enquanto foi presidente (1964-1970). Amigo pessoal de Scott, inclusive foi padrinho no matrimônio do norte-americano ${ }^{73}$.

- LITEMPO-4: Fernando Gutiérrez Barrios, o diretor da DFS (1965-1970) ${ }^{74}$. Dele sabemos que requisitou apoio para o interrogatório de mexicanos que tiveram alguma relação com Lee Harvey Oswald após o assassinato do presidente Kennedy.

- LITEMPO-8: Luis Echeverría Álvarez, que, entre outras coisas, dedicava-se a atender "solicitações especiais do governo norte-americano para dar vistos para viajantes cubanos que buscavam escapar da revolução socialista de Fidel Castro" (MORLEY, $2006)^{75}$.

Nos documentos de inteligência norte-americanos recentemente abertos nos EUA existem indícios para considerar como parte dessa rede de colaboradores, Adolfo López Mateos, presidente do México entre 1952 e 1964; o delegado e posteriormente diretor da DFS (1978-1982), capitão Miguel Nazar Haro; assim como o general Luis Gutiérrez Oropeza, chefe do Estado Maior Presidencial (1964-1970). Porém, ainda não existem elementos suficientes para confirmar estas suposições (CARRASCO ARAIZAGA, 2008, p. 22).

No marco dessa rede de espionagem observamos as formas nas que a DFS mantinha um férreo controle de estrangeiros e refugiados políticos. Registravam-se minuciosamente suas atividades no território nacional, as suas relações no país, e as viagens realizadas a países socialistas. Portanto, incluíam-se neste controle os mexicanos que mantinham alguma relação com estrangeiros (CONDÉS, 2007a, p. 89-90).

A este respeito, encontramos exemplar o caso dos cidadãos guatemaltecos radicados no México. Nos informes elaborados sobre Moisés Evaristo Orozco Leal, cidadão

\footnotetext{
73، O mais extraordinário [no casamento de Scott em 1962] é que suas testemunhas foram o presidente da República, Adolfo López Mateos, e o secretário de Gobernación, Gustavo Díaz Ordaz”. Aliás, a relação entre Scott e Díaz Ordaz era tão estreita que "quando este chegou a Los Pinos, um diplomata estadunidense recorda: 'para Scott era mais fácil se comunicar ou ter uma reunião com o presidente mexicano que com o mesmo embaixador Fulton Freeman"” (DEARBORN, 1998 apud AGUAYO, 2014a).

${ }^{74}$ Fernando Gutiérrez Barrios, capitão de infantaria, chefe de controle político da DFS (1952-1958) e subdiretor da mesma agência entre 1958 e 1964. Foi nomeado diretor geral da DFS para o período de 1964-1970. Nos sexênios de Echeverría e López Portillo exerceu a função de subsecretário da SEGOB na área de segurança interna. A partir de 1982, diz o historiador Enrique Condés Lara, "começa sua conversão de policial para político". Dessa forma, foi Diretor Geral de Caminos y Puentes Federales; foi governador do estado de Veracruz (1986-1988); finalmente designado pelo presidente Carlos Salinas de Gortari como secretario da SEGOB na área de inteligência até 1993 (CONDÉS LARA, 2007a, p. 116).

${ }^{75}$ Os documentos da CIA sobre o Projeto Litempo estão digitalizados, disponíveis na página web The National Security Archive: http://nsarchive.gwu.edu/NSAEBB/NSAEBB204/index2.htm [Último acesso em: 29-05-16]
} 
guatemalteco refugiado no México desde 1944, são destacados vários motivos de seu asilo. Em primeiro lugar, explica-se que o pai dele foi Diretor Geral da Polícia Nacional durante a brevíssima presidência do general Federico Ponce Vaides. Estudou a educação básica no México e voltou para Guatemala em 1958, onde permanece até 1964. Simpatizante do governo do general Jacobo Arbenz, assim que este sofreu o golpe militar, em 1954, Orozco Leal decide se filiar ao Partido Guatemalteco del Trabajo (PGT) ${ }^{76}$. Durante sua permanência na Guatemala, em 1963, viaja a Cuba como convidado do Instituto Cubano de Amizade com os Povos, estabelecendo contato desde a embaixada cubana no México ${ }^{77}$.

Retornando a Guatemala, Orozco assume o cargo de Secretário Geral do Partido Unidad Revolucionaria, "de ideologia de esquerda moderada", motivo pelo qual, o regime militar guatemalteco começa a persegui-lo. Finalmente, decide pedir asilo na embaixada mexicana na cidade de Guatemala, em 1964. Estabelecido novamente no México, registra-se uma suposta viagem realizada por Orozco a Cuba, entre 1966 e 1967. Segundo sua declaração, a viagem devia-se ao fato de que no México permanecia desempregado e sem expectativas de encontrar trabalho ${ }^{78}$. Segundo a investigação elaborada pela DFS, depois de sua permanência de um ano na ilha, Orozco Leal pode ser considerado "uma pessoa perfeitamente bem treinada em comunismo e em teoria de guerrilhas e se lhe considera extremamente perigoso" ${ }^{, 79}$.

No depoimento do guatemalteco pode-se ler que o retorno para o México aconteceu pelo suposto vencimento de um contrato de trabalho na ilha. Menciona também que seu objetivo era voltar para Guatemala, aproveitando um processo de distensão em que o regime militar oferecia garantias aos exilados. O interrogado põe ênfase nas críticas públicas que realiza aos grupos armados (de esquerda e de direita), pois como assinala, o sítio que pertencia ao pai dele na Guatemala fora ocupado pela guerrilha, motivo pelo que não podia regressar. Ele garante, desta maneira, que não tem relações políticas com asilados guatemaltecos no México, e que o único motivo que tem para adquirir armas seria "para se proteger dos chamados 'Mano Blanca' da Guatemala, os quais publicaram estender até o

\footnotetext{
76 “Memorandum. Asunto: Moisés Evaristo Orozco Leal”, Distrito Federal, 01-08-67, AGN, IPS, Caixa 1467 A, Exp. 1, folhas 1-2. Neste documento, encontramos uma anotação manuscrita, do lado superior esquerdo: "De parte Sr. Scott”. Este é o único documento consultado em que se faz menção ao chefe da CIA [fig. 10].

77 "Declaración de Moisés Evaristo Orozco Leal", Distrito Federal, 02-08-67, AGN, IPS, Caixa 14767 A, Exp. 1, folhas $1-3$.

78 “Declaración de Moisés Evaristo Orozco Leal”, Distrito Federal, 02-08-67, AGN, IPS, Caixa 14767 A, Exp. 1, folhas 1-3.

79 "Memorandum. Asunto: Moisés Evaristo Orozco Leal", Distrito Federal, 01-08-67, AGN, IPS, Caixa 1467 A, Exp. 1, folhas 1-2.
} 
México seus assassinatos contra todos aqueles guatemaltecos de ideias liberais" $" 80$.

No entanto, no sentido contrário ao depoimento de Orozco Leal, os agentes que deram seguimento ao caso garantem que, assim que o guatemalteco voltou de Cuba, estabeleceu contatos com um grupo de asilados guatemaltecos de filiação comunista, servindo como enlace entre estes e guerrilheiros cubanos. Sublinha-se o fato de que, apesar de ser militante do PGT, tornou-se um estreito colaborador das Fuerzas Armadas Rebeldes (FAR) ${ }^{81}$. Sua função se concentrou no recrutamento de homens e de armas, organizando esquemas de compra-venda no México destinadas ao grupo armado no território guatemalteco.

Um memorando constata que, em maio de 1965, o sujeito em questão participou numa reunião de dirigentes comunistas guatemaltecos no México, na casa do próprio Marco Antonio Yon Sosa ${ }^{82}$. Não encontramos mais informação sobre este caso.

Outra forma de apoio secreto da inteligência mexicana à segurança nacional dos EUA apresentava-se na forma de proteção a colaboradores ou delatores que cooperavam com o governo norte-americano. Assim, silenciosamente, longe da opinião pública, "México se converteu discretamente em refúgio de ex revolucionários arrependidos, de criminais e delatores de seus antigos correligionários que souberam seguir os canais adequados" (CONDÉS, 2007a, p. 90).

Quanto a isso, encontramos dois casos documentados. Sam Giancana, um dos líderes do crime organizado e da máfia de Chicago, firmou residência na pitoresca cidade de Cuernavaca, em Morelos, entre 1966 e 1974. Detido por agentes da DFS e "posto num avião rumo aos Estados Unidos. Aí o esperavam uns clientes com quem tinha ficado mal em certo pequeno encargo que devia ter cumprido em Cuba" (BUENDÍA, 1984, p. 39). O assassinato dele ocorreu paralelemente ao de outros mafiosos implicados num plano para assassinar Fidel Castro em $1961^{83}$.

\footnotetext{
80 "Declaración de Moisés Evaristo Orozco Leal", Distrito Federal, 02-08-67, AGN, IPS, Caixa 1467 A, Exp. 1, folhas 1-3. A "Mano Blanca" foi um esquadrão da morte paramilitar ao serviço de fazendeiros, com a faculdade, também, de interrogar e prender suspeitos de ameaçar a segurança nacional guatemalteca. Estes esquadrões atuavam sob comando e supervisão das Forças Armadas guatemaltecas (COMISIÓN PARA EL ESCLARECIMIENTO HISTÓRICO, 1999, p. 144).

${ }^{81}$ Guerrilha guatemalteca surgida em 1962. Carlos Figueroa Ibarra avalia o período entre 1965 e 1966 como o momento de auge das FAR, quando conseguiu manter várias frentes em todo o país, realizando justiçamentos, sabotagens econômicas, emboscadas contra o exército, controle de povoados na região sudeste, propaganda armada, sequestros econômicos e políticos. As FAR resistiram várias ofensivas militares, contudo, após a morte do dirigente militar, o comandante Luis Augusto Turcios Lima, ocorrida em 1966, a guerrilha se dispersou (FIGUEROA, 2010).

${ }^{82}$ Líder político-militar do Movimiento Revolucionario 13 de Noviembre, grupo armado cujas origens estão em 1960. Yon Sosa foi capturado e assassinado em território mexicano, em 1970 (FIGUEROA, 2010).

${ }^{83}$ Giancana controlava casinos tanto em Las Vegas como em Havana, durante a ditadura de Batista. As teorias sobre as motivações que levaram ao assassinato de Giancana são enturvadas, quando, em 1977, Judith Campbell Esner expressa que por algum tempo foi amante, simultaneamente, do presidente Kennedy e do
} 
Cuernavaca foi a cidade que também albergou o recém-derrocadoxá iraniano Muhammad Reza Pahlavi, em janeiro de 1979, após o golpe da revolução islâmica que instauraria o aiatolá Khomeini no poder. No entanto, o asilo outorgado ao ex-mandatário iraniano gerou uma crise diplomática entre os EUA e o México. Em novembro do mesmo ano, Reza Pahlavi traslada-se para Nova Iorque com o objetivo de atender seu precário estado de saúde. Durante sua estância nos EUA, estudantes iranianos tomaram a embaixada dos EUA em Irã fazendo vários funcionários estadunidenses reféns. Exigiam o retorno do xá. Nesse contexto, "Washington acreditava que [o xá] fosse para o México o mais rápido possível, mas o governo de López Portillo informou que não seria admitido" (AGUAYO, 2014b) ${ }^{84}$. Nas suas memórias, o presidente Carter afirmou que esse fato o deixou "furioso [...] tinham-nos dado garantias de que o xá seria bem-vindo: [...] López Portillo é um homem sem palavra" (CARTER, 1983 apud AGUAYO, 2014b) ${ }^{85}$.

Outro aspecto no esquema de cooperação entre ambos os países estava em relação à vigilância de embaixadas, agências de informação e missões comerciais ou científicas provenientes dos países do bloco socialista instaladas no México. Dentro do grupo documental que analisamos há a estreita vigilância dos funcionários soviéticos que, aliás, “disfrutavam de um lugar privilegiado para realizar atividades de espionagem (tinha no México a missão de inteligência maior da América Latina: 35 pessoas)" (AGUAYO, 2014a).

Em suas atividades públicas, a embaixada soviética sempre foi respeitosa do governo mexicano. No relato elaborado em torno à conferência do segundo secretário da embaixada da URSS no México, V. Goncharenko sobre o tema "A política exterior da URSS", há a transcrição de alguns pontos considerados importantes pelo agente que elaborou o informe. Os eixos da palestra realizada no Instituto de Intercambio Cultural Mexicano-Ruso giravam em torno da posição soviética sobre a paz e os esforços do governo comunista para conseguir o desarmamento. Sobre isso, o agente sublinha que:

A União Soviética simpatiza com o México em todos seus aspectos, pois até a frase do Patrício Mexicano Benito Juárez, "O respeito ao direito alheio é a paz", a União Soviética a fez sua, e volto a repetir, lutou junto com México

próprio Giancana. Uma versão sobre o assassinato aponta que, efetivamente, o ménage a trois teria sido o motivo principal (BUENDÍA, 1984, p. 39).

${ }^{84}$ Cabe mencionar que uma situação similar ocorreu com o asilo do guatemalteco Jacobo Arbenz, em 1954. Após a condenação pública contra o golpe de Estado, o governo mexicano negou os pedidos de asilo do general Arbenz, atendendo, dessa vez, às pressões norte-americanas (PELLICER; MANCILLA, 1978, p. 102)

${ }_{85} \mathrm{O}$ autor aponta que a crise dos reféns foi um fator decisivo para a derrota de Carter, em 1980, para Reagan (única vez que as decisões mexicanas tiveram uma influência de impacto nos processos políticos norteamericanos). 
pela paz na ONU e em todos os congressos que tinham ocorrido ${ }^{86}$.

Apesar destas mostras públicas de simpatia, a DFS elaborava perfis com os antecedentes dos funcionários da embaixada. Localizamos dois. O de Nikolai Seerfevich Leonov destaca as supostas atividades desenvolvidas conjuntamente com elementos comunistas mexicanos, entre 1965 e 1966. Indica-se que mantém "contato com membros da esquerda mexicana especialmente do interior, para onde viaja continuamente". Também, que "se pode comprovar que Nikolai Leonov é o contato da embaixada da URSS para o subsídio de organismos de esquerda em Michoacán" ${ }^{\text {"87. }}$

Da mesma forma, ainda que mais detalhado, é traçado o perfil de Valentín Sergeyevich Loginov, Terceiro Secretário da Seção Consular da Embaixada Soviética. Vai em destaque que é membro do Comitê para a Segurança do Estado (KGB) desde 1958. Além da sua formação, sublinha-se sua presença constante na América Latina. Entre 1960 e 1963, permaneceu em Cuba como destacado, fazendo uma pausa em 1961, quando viajou para o Panamá e o Equador acompanhando um time soviético de futebol: "Nesta viajem levou uma forte soma de dinheiro para os Partidos Comunistas de ambos os países”. No México, desde 3 de agosto de 1965, Luginov:

Substitui Oleg M. Nechiporenko, outro membro da KGB, fazendo-se cargo de todas as atribuições e contatos dele. Em janeiro de 1966, tratou de atrair um chofer da embaixada norte-americana. Luginov é um membro do serviço de inteligência, bem ativo e capaz. Em virtude de que não tem que desempenhar outros trabalhos extras, $95 \%$ de seu tempo o dedica a atividades de espionagem ${ }^{88}$.

O informe também anexa uma lista intitulada "Agentes do Serviço de Inteligência destacados no México", incluindo nomes e cargos. É feita a distinção entre os agentes da KGB, cujo chefe é Sergei S. Konstantinov e o subchefe Aleksander V. Prirodko, que tem, debaixo de sua autoridade, vinte agentes, entre os quais se encontra Luginov. Na segunda parte da lista, citam-se onze agentes do GRU (Serviço Militar de Inteligência) sob o mando de

\footnotetext{
86 “Conferencia sustentada por el segundo secretario de la embajada de la URSS en México. - V. Goncharenko sobre el tema 'la política exterior de la URSS'", Distrito Federal, 04-08-66, AGN, IPS, Caixa 826, Exp. 8, folhas 1-2.

87 "Nikolai Serfevich Leonov. - Antecedentes", Distrito Federal, c. 1966, AGN, IPS Caixa 1467 B, Exp. 10, folha 1.

88 “Valentín Sergayevich Luginov", Distrito Federal, c. 1966, AGN, IPS, Caixa 1467 B, Exp. 10, folhas 1-2.
} 
Vladimir N. Sodilov e de Georgy A. Schuchkin ${ }^{89}$.

Por último, quanto aos seguimentos feitos pela DFS sobre a embaixada soviética, encontramos um informe contendo a análise de uma chamada telefônica entre um tal "Carlos Blanco" (de quem não temos referências) e Valentín Luguinov, no dia 6 de dezembro de 1966. O agente relata que "Blanco indicou a Luginov que 'o Comandante Carlos' (Carlos Casamadrid Miranda) queria ver a Pável A. Yatskov para um assunto urgente”. Casamadrid Miranda foi um oficial naval e piloto aviador formado em serviços de inteligência nos EUA, era membro da DFS. Por outro lado, Yastskov é lembrado por sua célebre reunião com Lee Harvey Oswald na embaixada soviética no México e sua negativa ao norte-americano de visto de entrada à URSS.

A partir dessa ligação, o agente que elabora o informe descreve uma janta "que pode estar relacionada com a chamada [telefônica]”. Realizada em 11 de outubro de 1965, o jantar foi entre Yatskov e um indivíduo mexicano não identificado, no restaurante "La Tablita". Terminado o evento, "o mexicano pôs um pequeno objeto sobre a mesa. Yatskov o cobriu com seu guardanapo e logo o deslizou em seu bolso. É obvio que dito objeto lhe foi passado clandestinamente". O agente dá atenção ao fato de que os dois sujeitos vigiados saíram separadamente, quando o mexicano abordou um carro tipo jipe que estava identificado com a legenda da Procuraduría General de Justicia del Distrito y Territorios Federales - Policía Judicial. Motivo pelo qual, claro, "presume-se que o indivíduo presta seus serviços na Polícia Judicial".

O mexicano em questão é descrito como "uma pessoa de 35 anos, de aproximadamente 1,70 de estatura, 70 quilos de peso, de porte mediano, de pele morena, olhos escuros, bigode negro e vestido de forma conservadora”. Embora a descrição possa relacionar-se a uma grande parcela dos mexicanos, o agente sugere que essa descrição deva corresponder tanto a Carlos Blanco (que realizou a ligação para a embaixada) como ao comandante Casamadrid. Da mesma forma, o agente indica que há registro de várias ligações de Casamadrid à embaixada, entre março de 1965 e novembro de 1966. "Todas essas chamadas foram para concertar reuniões entre Blanco e Luguinov" [fig. 11] ${ }^{90}$.

Não temos mais informes sobre os grampos telefônicos da embaixada soviética, que constituem uma grave violação à imunidade diplomática. Também não temos indícios de reuniões entre agentes policiais ou da DFS com funcionários soviéticos. Porém, encontramos

\footnotetext{
${ }^{89}$ Os nomes na lista são duvidosos, constatamos que vários deles estão escritos incorretamente, e muitos vêm "mexicanizados".

90 “Informe", Distrito Federal, 12-12-66, AGN, IPS, Caixa 1467 B, Exp. 10, folhas 1-2.
} 
informação, digamos, indireta, sobre as atividades soviéticas no México. Héctor Mariscal Martínez, proprietário da empresa Servicio Aerotécnico S.A. de C.V, abastecedora de material aeronáutico, deu parte à DFS sobre as petições feitas pelo Serviço Militar Soviético de Inteligência desde 1960. O agente informa que "durante todo esse tempo, ele [Mariscal Martínez] tem acatado nossa direção”. Afirma-se, também, que o presidente Díaz Ordaz tinha conhecimento prévio sobre a relação da empresa com a inteligência soviética.

O agente informa que Mariscal contactou a DFS, pois, resultava estranho que a petição soviética, nesta ocasião, se fizesse sobre o território fronteiriço entre México e EUA. Até 1966, as cartas aeronáuticas compradas pelos soviéticos tinham sido sobre o território norteamericano unicamente. Essa informação, indicou Mariscal, é de uso exclusivo dos governos mexicano e estadunidense, pelo que "respeitosamente se solicitam instruções sobre como proceder neste caso" ${ }^{91}$. Não encontramos nenhuma resposta.

De outro lado, a Agência de Notícias Nova China (Xinhua) também foi objeto de vigilância, e inclusive de infiltração. Num breve informe de 1966 "obtido pelos meios estabelecidos na Agencia Chinesa de Notícias", narra-se um assunto tratado numa reunião particular entre os correspondentes chineses. O agente, obviamente infiltrado, indica que a reunião girou em torno à esquerda mexicana. Num balanço elaborado pelos chineses "fizeram referência de que no México existem muitos grupos que mantêm posições revolucionárias, porém, são uma espécie de seita, porque não formam uma corrente social"92.

Finalmente, no terreno da cooperação em matéria de segurança e inteligência, o governo mexicano possivelmente ofereceu fazer vistas grossas à utilização do território mexicano para a realização de atividades encobertas. Novamente, o jornalista Manuel Buendía oferece um relato do que aconteceu - entre 30 de janeiro de 1976 e 20 de janeiro de 1977 - com a CIA sob o comando de George Bush. Segundo o jornalista, em julho de 1976, uma parte do Comando das Organizações Revolucionárias Unidas (CORU) ${ }^{93}$ entraram em território mexicano para sequestrar e assassinar o cônsul cubano na cidade de Mérida, Yucatán. Foi preso o estadunidense Gaspar Eugenio Jiménez Escobedo e identificado o cubano Orestes Ruiz. Na tentativa de sequestro, resultou morto um colaborador do cônsul. De

\footnotetext{
91 “Asunto: Solicitud del Servicio Soviético de Inteligencia para que se le proporcionen fotografías aéreas de la frontera entre México y Estados Unidos”, 05-01-67, AGN, IPS, Caixa 1467 B, Exp. 10, folhas 1-8. O documento contém sete anexos com fotocópias das cartas aeronáuticas solicitadas pelos soviéticos.

92 "Informe obtenido por los medios establecidos en la Agencia China de Noticias", Distrito Federal, 23-07-66, AGN, IPS, Caixa 3033 A, Exp. 12, folha 1.

${ }^{93}$ O CORU foi integrado por um grupo de asilados cubanos nos EUA. Criado por George H. W. Bush, ele foi liderado pelo médico cubano Orlando Bosch. A criação do grupo se deu numa reunião coordenada por Lawrence Seternfield (que dois anos depois assumiria a seção da CIA no México), em San José, Costa Rica. O primeiro ato público foi a explosão de um avião cubano de passageiros em que morreram 73 pessoas.
} 
forma paralela, outro comando do CORU realizou atentados com dinamite no prédio da embaixada de Cuba na Cidade do México. Escobedo conseguiu fugir em 21 de março de 1977, "quando a CIA gastou alguns dólares ao subornar dois guardas" da prisão da Cidade do México, aonde foram conduzidos (BUENDÍA, 1984, p. 45). Não encontramos documentação da DFS que proporcionasse detalhes sobre esses acontecimentos.

\subsubsection{A Dirección Federal de Seguridad por dentro}

No que diz respeito à segurança interna, a DFS foi rapidamente transformada numa polícia política com capacidade persecutória e firmemente anticomunista. Até pouco antes do movimento estudantil de 1968, a DFS se dedicava unicamente à localização da dissidência e infiltração de organizações políticas independentes ou de dentro do próprio movimento estudantil. Depois de 1968, funcionava também como um braço armado do poder Executivo "utilizando não a lei, mas sim a tortura, a delação, a extorsão, e até o assassinato" (SIERRA, 2003, p. 102).

Os agentes recrutados se constituíram numa elite, as ordens provinham diretamente do presidente, ou do secretário da SEGOB. No sistema de tipo presidencialista, como o mexicano, era preciso ter gente de confiança cuidando da segurança nacional. Sendo assim, o método de recrutamento geralmente respondia à lógica do que na cultura política mexicana se conhece como "amiguismo". Isto é, pessoas recomendadas por gente de confiança do presidente e que eram diretamente entrevistados por ele (AGUAYO, 2014a).

No vídeo intitulado Así es la Dirección Federal de Seguridad, realizado em 1981, antes do colapso da instituição, descreve-se o funcionamento do recrutamento. De fato, o vídeo gira em torno de um suposto cidadão que se dirige ao escritório da DFS no intuito de ingressar como agente. Segundo a narração que acompanha a história, a seção de recrutamento estaria dedicada a localizar os candidatos "em áreas universitárias, com estudos acima do ensino médio e, depois de investigar sua qualidade moral, são propostos ao superior, para o seu ingresso".

O procedimento se centra nas avaliações psicológicas que comprovem a capacidade intelectual do candidato, assim como a elaboração de respostas estando ciente dos perigos e responsabilidades inerentes a esse tipo de trabalho. Uma vez concluída a parte psicológica, procedia-se à elaboração de um exame físico. Se os resultados fossem a contento, poderia ser assinado um "ato secreto", que era o compromisso de entregar a vida, se necessário para o 
bem-estar nacional: "aqui começa uma etapa de conscientização e de contato com a mística da DFS".

O símbolo da instituição era o tigre:

O tigre é um animal poderoso que não foge ao perigo, ataca de frente, prefere atuar em silêncio e observa o que outros seres não conseguem enxergar; é intuitivo e inteligente, rápido e seguro, cauto e astuto; não é arrogante como o leão, nem fere por prazer como o leopardo; assim deve ser o agente da DFS $^{94}$.

Existia a fama de uma suposta proximidade desses agentes com os mais altos círculos de poder, manipulavam informações fundamentais para a segurança nacional, e, comparativamente, tinham um salário melhor do que as corporações policiais. Policiais e civis que foram integrados à DFS recebiam, além disso, um grau militar procedente do Estado Maior Presidencial, com o objetivo de engrossar o salário. Contavam, também, com a liberdade para desenvolver outro tipo de trabalho, sem especificar qual, o que deixou abertura para um sem-fim de abusos de autoridade e corrupção (AGUAYO, 2014a). Contudo, o regulamento interno funcionava a partir de duas obrigações básicas: "o dever e a disciplina, atributos que os agentes devem ter e que irão espelhar mediante a obediência e a subordinação"95.

A DFS contava com diversas áreas, como a Seção de Depósito e Armamento, e como a Seção de Veículos, onde se destacava um “caminhão acondicionado como laboratório para exames de criminalística e dois ônibus adaptados especialmente para deslocar 20 elementos em cada um". A instituição também dispunha de dois aviões para movimentos rápidos, cuja manutenção dependia do Departamento de Servicios Generales. Dentro das instalações também existia uma "loja de autoserviço para os agentes, cabelereiro e até um banco para o pessoal que requeresse algum empréstimo em efetivo" (TORRES, 2005, p. 21-22).

Com relação à informação gerada pelos agentes, o vídeo que referimos mostra o processo operativo de elaboração, processamento e arquivo dos informes. Existe, portanto, um grupo de redatores, transcritores e mecanógrafos que resumem a informação para incluí-la num documento chamado "Panorama geral da República". Este departamento de

\footnotetext{
${ }^{94}$ Así es la Dirección Federal de Seguridad, Dir.: Alfonso Cabrera Morales, 52 min. Disponível em: https://www.youtube.com/watch?v=USr-CFgmRtc [último acesso em: 30-05-16]. O filme, com características de propaganda, realizou-se para uso exclusivo do presidente José López Portillo. Dirigido por Alfonso Cabrera Morales (subdiretor operativo da DFS), os cinegrafistas foram o chefe e subchefe da Secção Audiovisual da instituição, sendo editor o agente Alberto Flores Parra, e o narrador, Pedro García Bello (Chefe do Departamento de Informação Foranea) (TORRES, 2005, p. 21).

${ }^{95}$ Así es la Dirección Federal de Seguridad, Dir.: Alfonso Cabrera Morales, 52 min.
} 
processamento de informação "tem como principal função a de corrigir os possíveis erros ou omissões dos informes que emite a DFS ${ }^{\prime 96}$.

Mas, quais eram os temas de interesse da segurança nacional? Como se produzia a informação? No documento intitulado "Instrutivo de informação" elaborado pela DFS encontramos os critérios que deviam ser considerados pelos funcionários e agentes da Direção para a recopilação de informação. Segundo o manual, a informação é uma descrição e numeração detalhada de tudo relacionado a um fenômeno ou acontecimento "fortuito ou premeditado", elaborada de maneira consciente, sistemática e estruturada. A informação devia dividir-se segundo sua periodicidade (constante, intermitente ou esporádica); por seu conteúdo (política, econômica, social, camponesa, estudantil, operária, confidencial, internacional); por sua forma (verbal, escrita, televisada); por suas fontes (jornalística, bibliográfica).

Para a realização plena desse tipo de trabalho, o instrutivo assinala que é "necessário que o informante tenha critério e sentido comum". Além disso, tem que ser objetivo nas suas apreciações e "não se deixar levar pelos sentimentos". Os informes deviam ser escritos com a linguagem "normalmente usada por pessoas de certa cultura. Evitando usar palavras grandiloquentes ou em desuso". As informações recolhidas tinham que ser detalhadas: "Dados gerais (dia, hora, lugar e quem organizou, presidiu ou encabeçou); Quem deu por iniciado o ato ou incidente; Pormenores do ato ou incidente; Aspectos interessantes do ato ou incidente; Fechamento do informe". Estes informes se dividem, por sua vez, em quatro partes:

a) Setor: Os setores que até o momento se utilizam aqui são: uma combinação de conteúdo e de fonte, a saber:

- Político

- Camponês

- Popular

- Internacional

- Laboral

- Especial

b) Localidade: É o lugar onde se gera a informação, geralmente é uma localização geográfica: México, DF; Culiacán, Sinaloa; Paris, França.

c) Assunto: É uma condensação do fenômeno, acontecimento ou incidente, assinalando alguma ou algumas características mais importantes da informação que se vai passar.

d) Corpo do informe: O conteúdo do informe terá que fazer uma descrição LÓGICA, DETALHADA E CONCRETA do sucedido. Podendo se fazer de duas formas:

- Do geral ao particular.

- Do particular ao geral.

\footnotetext{
${ }^{96}$ Así es la Dirección Federal de Seguridad, Dir.: Alfonso Cabrera Morales, 52 min.
} 
Os atos enfocados pelos agentes da DFS eram: "reuniões, comícios, passeatas, manifestações, paradas, greves, assembleias, conclaves, congressos, seminários, mesas redondas, concentrações". Por outro lado, o incidente, concebido como um "fenômeno ou acontecimento que não é previsível" e que, por seu caráter fortuito ou acidental deve ser melhor descrito, podendo ser "catástrofes, meteoritos, incêndios, roubos, assaltos, atentados, sabotagem, terrorismo, acidente".

O manual considera que grande parte dos atos ou incidentes são cometidos por organizações. Isto é, por um "agrupamento de pessoas com uma ideologia, características comuns e um ou vários objetivos gerais comuns, que possuem uma estrutura definida e um conjunto de objetivos pré-estabelecidos”. As características comuns podem ser econômicas, sociais, laborais, políticas, ou ainda, uma mescla de todas as anteriores. Os objetivos comuns poderiam ser:

1. Toma de poder.

2. Controle de: a organização, de pessoas ou grupo de pessoas de outras organizações.

3. Manutenção ou exercício do poder.

4. Conservação do poder.

5. Reunião de: fundos econômicos, dados estatísticos, dados científicos ou técnicos.

6. Exercício ou manutenção do poder legal: aplicação e administração de leis e/ou regulamentos, estatutos ou mandamentos, etc.

A partir de tais objetivos, o instrutivo sugere que os partidos, movimentos, coligações, sindicatos, uniões, frentes, comitês, células, coletivos e o próprio governo, podem ser considerados como organizações.

Ponderando sobre o anterior, o instrutivo contém um "Prontuário para a obtenção de dados elementares de informação":

1) Assembleias, Comícios, Convenções, Congressos, Mesas redondas.

1.1. Presidência. Nome e cargo de cada pessoa.

1.2. Lugar e local de realização.

1.3. Horário. Início e final, assinalando a hora em que ocorram incidentes.

1.4. Assistência. No caso de assembleia, apontar se há registro de quórum legal, com base nos seus estatutos.

1.5. Oradores. Nome, cargo e conteúdo da sua intervenção. Se o orador está presidindo, somente apontar seus dois sobrenomes.

1.6. Resolutivos.

1.7. Faixas, cartazes, seus textos.

1.8. Estar pendente se depois do ato se efetua alguma entrevista para algum jornal, ou se é efetuada alguma reunião em algum restaurante ou alguma manifestação. 
2) Comícios, Manifestações.

2.1. Hora de início.

2.2. Local de desenvolvimento ou ponto de partida.

2.3. Dirigentes do evento e seus cargos.

2.4. Composição dos contingentes, apontando o número aproximado de participantes e organização a que pertencem e no caso de participar menores de idade, apontar porcentagem.

2.5. Incidentes ou exclamações durante o evento.

2.6. Término do ato. Neste caso, onde termina a manifestação.

2.7. Presença de elementos policiais ou militares.

3) Projeção de filmes subversivos ou proibidos.

3.1. Lugar ou sala cinematográfica.

3.2. Custo do ingresso.

3.3. Assistência.

3.4. Tema e título do filme, comentando conteúdo.

3.5. Tempo de duração.

Finalmente, o instrutivo indica igualmente um "Prontuário para a obtenção de antecedentes pessoais":

1. Nome completo.

2. Ideologia.

3. Domicílio atual. Escritório, se o tem. Telefone Part. [particular]. E do escritório. Se é funcionário, seu escritório e Telefone oficial.

4. Local e data de nascimento.

5. Estado civil. Nome do(a) cônjuge. Filhos e seus nomes e idades.

6. Atividade atual e renda.

7. Estudos. Ensino básico, escola, nome e período. Ensino médio, escola (pública ou particular) nome e período. Preparatória, Normal ou Vocacional. Profissional. Data de exame profissional, e título da tese [trabalho de conclusão do curso]. Obtenção de título em tal data assinado por tal reitor.

Observações: Se durante a época de estudante foi líder estudantil e conduta observada. Algum outro curso de alguma especialização no país ou no estrangeiro. Escola, período, e se obteve diploma.

8. Nexos políticos. É amigo de tal ou qual funcionário e desde que tempo.

9. Propriedades, suas características e avalista.

10. Antecedentes penais, se os têm, data, expediente e motivo.

11. Comprovante eleitoral, número, filiação ou credencial de Partido (x) e seu Número. Cartilha do Serviço Militar Nacional, e Carteira de Habilitação.

12. Se elaborou ou escreveu algum livro, seu título e tiragem, e se colabora em alguma coluna jornalística ou revista.

13. A que partido pertence, tempo de militância e cargo desempenhado... assim como a eficácia. Cargo de eleição popular, período, e se foi positiva ou negativa sua função, e o apoio de quem ou daqueles que foi ${ }^{97}$.

\footnotetext{
97 "Instructivo de información; Prontuario para la consecución de datos elementales de información; Prontuario para la obtención de antecedentes personales", 1980, AGN, IPS, Caixa 3038 A, Exp. 2, folhas 1-11.
} 
Com base nesses tópicos, o arquivo da DFS concentrava a informação política, econômica, social, terrorista, subversiva e de atividades clandestinas, desde $1947^{98}$. Informação procedente das investigações realizadas por agentes infiltrados nas áreas sujeitas a conflitos, que em muitos casos tinham orientação para fotografar, filmar e gravar áudios (TORRES, 2005, p. 22). É assim que sabemos da existência de um departamento de informação audiovisual. Contudo, nenhum tipo de material com essas características, à exceção das fotografias, pode ser consultado atualmente.

Noutro manual localizado no AGN, intitulado "Análise do procedimento atual para o controle e processamento de informação", é indicado que, além do arquivo, a DFS está dividida em duas grandes seções que contam com seus respectivos agentes com características particulares. Uma delas, destinada à informação proveniente da área metropolitana, é conformada por quatro grupos de inspetores: os dois primeiros, "encarregam-se de realizar todas as investigações em geral (laboral, política, econômica, agrária, magisterial e religiosa)"; o terceiro grupo se dedica exclusivamente à área estudantil, isto é, à análise da "problemática vigente no DF [Distrito Federal] e em todas as entidades educativas"; por último, o quarto grupo, denominado "Vale do México", cobrindo as informações gerais desenvolvidas na área metropolitana do Estado de México. A outra seção estava destinada à investigação da área estadual. Esta mantinha informado diretamente o "subdiretor de investigações, tendo também contato [...] com o grupo de estudos especiais". Sendo que este segundo grupo se encontra "melhor preparado". Em ocasiões, "existe a necessidade de reforçar as áreas estaduais de investigação" ${ }^{99}$.

Possivelmente, esse grupo de estudos especiais, de acordo com o vídeo referido, conformaria o grupo de atividades de contrainteligência. Esse vídeo menciona como justificativa da existência de tal grupo, o fato de que,

os asilados políticos em diferentes nações [vão] utilizar o território alheio como plataforma para realizar atos de tipo militar contra os governos de seus países de origem e, em ocasiões, fica comprovado que no México realizam atividades delituosas para conseguir os fundos necessários para continuar com seus movimentos ${ }^{100}$.

A segurança nacional, sob estas características e práticas, continuou nas mãos da DFS.

\footnotetext{
${ }^{98}$ Así es la Dirección Federal de Seguridad, Dir.: Alfonso Cabrera Morales, 52 min.

99 “Análisis del procedimiento actual para el control y procesamiento de la información”, 1980, AGN, IPS, Caixa 3038 A, Exp. 2, folhas 1-6.

${ }^{100}$ Así es la Dirección Federal de Seguridad, Dir.: Alfonso Cabrera Morales, 52 min.
} 
Até que, entre 1980 e 1982, o então secretário da SEDENA, o general Félix Galván Díaz, cria um adendo. A segurança nacional deve ser entendida como a manutenção do equilíbrio social, econômico e político, o que deve ser garantido pelas forças armadas (AGUAYO, 1990, p. 116; PELLICER, 1981). Poderíamos explicar essa mudança durante o sexênio compreendido entre 1976 e 1982, especialmente a partir do descobrimento de lençóis petrolíferos no Golfo do México. A segurança era necessária para a defesa das instalações petroleiras diante dos possíveis interesses estrangeiros, considerando, também, as possibilidades de sofrer efeitos colaterais das guerras civis que assolavam a América Central.

\subsection{As Forças Armadas: profissionalização e despolitização}

Considerando que a segurança nacional recaía tanto sobre a DFS como nas Forças Armadas, voltemos um pouco no recorte temporal, no intuito de contextualizar o papel das Forças Armadas dentro do sistema político mexicano. O pacto não escrito entre o governo civil e o exército não tem sido abalado pelo passo do tempo, nem sequer no contexto do Informe Rockefeller.

Lembremos que os "cuartelazos", como foram denominados os golpes de Estado e as frequentes rebeliões militares nos primeiros anos pós-revolucionários, priorizaram a necessidade de institucionalizar a atividade política, limitando a autonomia dos caudilhos locais, diversificando e organizando as bases do poder. Daí que um dos primeiros movimentos do PNR-PRI fosse uma importante reforma militar encabeçada pelo general Joaquín Amaro, cujo eixo se deu na "profissionalização" e na "despolitização" da instituição castrense. Se neutralizada, funcionaria como garantia da transmissão pacífica do poder, subordinada ao "Chefe Máximo das Forças Armadas", o presidente. Até hoje, a reforma de Amaro continua sendo considerada como o momento fundador das Forças Armadas modernas.

A reforma abarcava dois aspectos, principalmente, a eliminação efetiva do poder dos caudilhos e a profissionalização dos elementos armados. Esta empresa foi complexa. O fato de que o exército fosse a única instituição que tinha a capacidade de disputar o poder, e, ao mesmo tempo, a única instituição capaz de respaldar um projeto político, exigia cuidados especiais:

o exército, amplamente politizado desde seu nascimento em plena luta 
revolucionária, não ia seguir ninguém mais do que o caudilho, ou, dito em outros termos, ninguém que não fosse um caudilho poderia governar $o$ exército e a República ou integrar em um novo organismo político um país esquartejado pela guerra civil (CÓRDOVA, 1980,p. 263).

Fica evidente a necessidade de negociar politicamente com os caudilhos. O aliciamento, a compra de fidelidades e as concessões especiais foram o pano de fundo da reforma (PLASENCIA, 2010). A Secretaria de Guerra "lhes deu suficientes apoios para cobrir suas necessidades militares e comerciais. Em troca, mantiveram a paz, garantiram a lealdade de seus subordinados e muitos se enriqueceram" (LOYO, 2003, p. 76) ${ }^{101}$.

Segundo a especialista na institucionalização do exército mexicano, a historiadora Martha Beatriz Loyo, Amaro se formou ideologicamente nas fileiras maderistas e, posteriormente, constitucionalistas. Situava-se entre um liberalismo moderado, progressista e reformador. Em termos de estrutura e estratégia, Amaro foi assíduo leitor e estudioso da literatura militar alemã e francesa. Herdeiro do pensamento radical do século XIX, distinguiuse por seu anticlericalismo e moralismo:

Seu discurso era revolucionário no sentido de uma mudança nas injustas condições que padecia a maioria da população, e era parte do que entendia como revolução; inclusive quando falava de socialismo nunca ficava clara sua ideia, mas acreditamos que se explica na relação com progresso, mudança, modernidade (LOYO, 2003, p. 96).

A profissionalização foi o objetivo central da reforma. Entendemos como profissionalização o processo pelo qual se pretende tecnicamente "superar características tradicionais da arte da guerra: da valentia à eficiência, da improvisação à programação: o maior número de vitórias com o menor número de perdas humanas e materiais" (PIÑEYRO, 1985 , p. 14). Consistia fundamentalmente no aperfeiçoamento da preparação técnica e cultural dos membros. A refundação da instituição castrense tenta de qualquer maneira diferenciar-se do antigo exército porfiriano. Por outro lado, procura a superação da heterodoxia militar do processo revolucionário, criando um mando centralizado, um sistema burocratizado e um espírito de casta. A instituição militar foi recriada, organizada, equipada e adestrada para a violência:

101 A Secretaria de Guerra muda de nome depois dessa reforma. A nova Secretaría de la Defensa, simbolicamente, põe fim à guerra interna, transformando a corporação militar num dos pilares da defesa das instituições. 
assim como as instituições legislativas (parlamento) ou a presidencial estão feitas e têm o reconhecimento jurídico para legislar e executar decretos e leis ou propor programas, o exército baseia suas atividades de coerção ou ameaça do uso da mesma em ambos os planos (PIÑEYRO, 1985, p. 15).

Refundaram-se as Forças Armadas com o objetivo de escorar o sistema político, e não para ser um interlocutor. Segundo a lógica sustentada por vários autores especialistas em história militar, quanto maior e mais eficiente for o processo de profissionalização de um exército, mais alto será o nível de despolitização (LIEUWEN, 1968; LOZOYA, 1977). Contudo, considerando as formas como se desenvolve a história das forças armadas, nos inclinamos pela análise elaborada por José Luis Piñeyro, o qual assevera:

A maior qualidade profissional permite uma superior ingerência política
potencial ou real (demostrada pelos casos do Brasil e da Argentina, entre
outros), quer seja para desempenhar as missões específicas da segurança
interna ou externa ou para incursionar por novos campos (assessoria e
administração de empresas públicas, da atividade diplomática, etecétera) das
funções normais do conjunto do Estado (PIÑEYRO, 1985, p. 15).

A reforma enfatizou uma campanha de "moralização" na eliminação de práticas como o jogo de azar, o roubo e o alcoolismo. Como parte importante da reforma, promulgou-se uma Lei de Disciplina Militar, que estabelecia que "o serviço das armas exige que o militar leve o cumprimento do dever até o sacrifício, e que anteponha ao interesse pessoal, a soberania da Nação, a lealdade às instituições e a honra do exército e da armada nacionais" (LOYO, 2003, p. 139). Paralelamente, foi declarada a missão histórica da renovada instituição castrense: "Defender a integridade e independência da Pátria, manter o império da Constituição e das demais Leis e preservar a ordem interna" (LOZOYA, 1977, p. 139). No terreno ideológico, sublinha-se como característica fundamental dos militares, valores como a obediência, a honradez, o sentido de justiça e o respeito mútuo.

No plano político mais amplo, o PNR-PRI também estava sendo reformulado, por isso acontecesse uma mudança na concepção de um partido de massas para um partido de setores, corporativo, "de filiação coletiva e em não poucos casos, sem nexos com os cidadãos que, pela via de suas organizações gremiais ou camponesas, passavam a ser, sem sabê-lo, membros do partido" (ALCOCER, 1993, p. 120). O governo do general Cárdenas ajudou na reorganização das estruturas de camponeses, operários e funcionários públicos. Além disso, conseguiu garantir a representatividade dos três setores no interior do Partido. Ele foi convertido num celeiro de funcionários públicos: deputados, governadores, senadores e, 
acima de tudo, espaço de destaque político para levar vantagem na carreira presidencial. Os militares estavam contemplados dentro desse pacto.

O PNR-PRI já não representava simplesmente uma facção política. Converteu-se noespaço simbólico, onde a nação mexicana estava representada. Apesar da retórica "esquerdista" de Cárdenas, da nova estrutura do partido e da política de radicalização das massas, a falta de democracia na toma de decisões deixava as massas como um simples legitimador das decisões tomadas de cima.

O aprofundamento, por outro lado, das reformas sócio-econômicas revolucionárias (reforma agrária, infraestrutura e expropriação petroleira) requeriam um aperfeiçoamento do instrumental ideológico-político para conseguir seu pleno desenvolvimento. Cárdenas dirigiu seus discursos para as massas operárias, camponesas, e, enfaticamente, para a baixa oficialidade do exército: o soldado raso, o "filho legítimo da revolução". Com as duas primeiras classes sociais estabeleceu fortes alianças. Mas também, outorgou concessões e reconheceu as conquistas legítimas dos militares (como mencionamos anteriormente), formando uma barreira de proteção em relação ao confronto organizado a partir das frações burguesas nacionais e internacionais que se opunham violentamente às reformas. Foi um momento de ruptura com os velhos militares aliados ao presidente Calles e de recomposição da hierarquia militar. Foram promovidos jovens oficiais educados no novo colégio militar e alocados em cargos políticos estratégicos.

Depois de uma disputada eleição de um candidato presidencial para o período de 1940 a 1946, o partido sofre uma nova fratura. As pressões de diversos setores sociais (principalmente empresariais) para diminuir a radicalização das reformas contribuiu para a eleição do general Manuel Ávila Camacho, o último presidente militar. Sob a bandeira da conciliação nacional e da unidade a todo custo, Ávila Camacho protagoniza fortemente a saída do setor militar do Partido.

Pouco popular entre os militares por sua nula experiência no campo de batalha e sua notória trajetória na burocracia militar, é o contraposto do halo carismático do general Cárdenas. Tirando a representatividade dos militares do PRM, excluía também qualquer tipo de oposição à política conservadora que estava defendendo. O principal argumento de sua proposta foi a necessidade de manter o corpo castrense longe de qualquer tipo de situação que possibilitasse a desunião. Não era conveniente criar inimizades políticas num contexto de Guerra Mundial. Dizia Ávila Camacho: 
devem intervir, nem direta nem indiretamente, em questões de política militante ou eleitoral, pois, autorizar que se realizem comícios dentro do quartel é provocar a divisão de seus elementos, o que, por sorte, ficou desde muito tempo, eliminado dessas funções cívicas (ÁVILA CAMACHO apud IBARROLA, 2003, p. 17).

Mesmo com a caricatura que se fez da participação mexicana na Guerra Mundial, o impacto interno que teve a entrada do México é um tema ainda pouco estudado. Entre 1944 e 1945, o presidente Ávila Camacho decretou um estado de exceção. Suspendeu as garantias individuais no intuito de preservar a segurança interna. Depositou energia na melhoria dos serviços de inteligência, o que fez com que o exército começasse a ser utilizado para funções de espionagem, delação e perseguição de opositores políticos.

Nesse contexto de alinhamento com os EUA, México aceita o primeiro empréstimo internacional depois do processo revolucionário (40 milhões de dólares). Foi para a compra de equipamento bélico, assim como para treinamento de soldados. Contudo, numa sociedade politizada e nacionalista - herança do cardenismo - começaram a aparecer controvérsias sobre a cooperação entre os países. Especialmente, ao se sugerir a possibilidade de instalação de bases navais e aéreas, além da liberação do passo de tropas norte-americanas em solo mexicano. O próprio Cárdenas, como secretário da SEDENA, rechaçou as pretensões de Ávila Camacho e do Departamento de Estado e Defesa dos EUA.

$\mathrm{O}$ projeto revolucionário dos anos quarenta debatia-se entre o nacionalismo e a influência econômica e pragmática dos EUA. No âmbito militar, ainda sob a influência de Cárdenas, forma-se a primeira geração de oficiais formados em academias estadunidenses. Seu retorno e ocupação de lugares claves dentro da SEDENA implicou num deslocamento dos quadros cardenistas.

A primeira metade da década de quarenta marca o fim de uma época de governantes militares. O general Ávila Camacho promoveu incansavelmente a importância do civismo para a consolidação plena do sistema político. Desde 1929, data na que triunfa pela primeira vez um candidato presidencial do PNR-PRI, não houve nenhuma tentativa de golpe militar. Nunca houve nenhuma declaração de discordância com as ordens presidenciais, nem na esfera operativa, nem na política. Desde 1946, o México deixou de ser governado por generais, consolidando-se, assim, a imagem internacional, aliás, no contexto da Guerra Fria, do presidencialismo civil, desmilitarizado e revolucionário do sistema político mexicano.

Porém, os militares não se restringiram à participação burocrática dentro da SEDENA. No processo de profissionalização e de negociação com os velhos quadros revolucionários, 
podemos localizar uma ampla e constante "participação militar". Este conceito desenvolvido por Samuel Huntington não se limita à descrição do militarismo presente nos regimes que convulsionaram o Cone Sul na segunda metade do século XX. Para o cientista político norteamericano existem quatro funções que podem ser desempenhadas pelos militares dentro de um sistema político, tanto de maneira simultânea como separada:

1) $\mathrm{O}$ rol institucional na medida em que controlam certos recursos sociais, entre os quais estão homens e meios financeiros; 2) o político: na medida em que realizam atividades políticas e têm cargos de governo; 3 ) o instrumental: conforme os militares participam mais que os civis na política interna e internacional nos meios diplomáticos, políticos, econômicos ou de outro tipo; e 4) o rol ideológico: conforme os militares conseguem influir sobre as classes dominantes e as classes subalternas (HUNTINGTON, 1974 apud PIÑEYRO, 1985, p. 33).

No caso mexicano, vemos como os altos comandos militares se consolidam na burocracia dos estados, ocupando cargos de eleição popular (governadores, deputados, senadores), e são os dirigentes absolutos dos corpos policiais e de inteligência. Um dos maiores exemplos de "participação militar" é do coronel Alfonso Corona del Rosal. Veterano da Revolução, formado no Heroico Colégio Militar, o coronel se desempenhou como gerente do Banco Nacional do Exército e da Armada, governador do estado de Hidalgo, e como presidente do Comitê Executivo Nacional do PRI. A proximidade com a instituição presidencial lhe garantiu sua permanência nas cúpulas do poder. Rapidamente ele resume o modo de governar priísta ao descrever uma reunião para a qual foi convocado, quando Gustavo Díaz Ordaz havia sido eleito presidente:

Sorriu e me perguntou: "O que você gostaria de fazer?" Minha resposta foi rápida: the manifestei que tinha estado longo tempo consagrado às atividades políticas e que, se tinha a intenção de oferecer-me algum cargo para continuar servindo meu país e a ele como presidente, me atraia a perspectiva de estar na frente de uma dependência que se construísse materialmente, com o objetivo de não continuar dedicando todo meu tempo à política militante (CORONA DEL ROSAL, 1995, p. 149).

Depois dessa reunião, foi entregue para ele a Secretaría de Patrimonio Nacional, na qual permaneceu por dois anos, até 1966, quando foi designado Chefe do Departamento do Distrito Federal, tornando-se uma figura chave na repressão ao movimento estudantil. 


\subsubsection{O Exército mexicano no contexto latino-americano}

A complexa relação entre a instituição presidencial e a corporação militar, bem como a permanência da participação política dos altos escalões militares (revestida de civilismo) pode-nos ajudar a entender o porquê dos militares mexicanos não terem sido considerados como sujeitos de transformação, a qual fosse favorável aos EUA, como o informe Rockefeller e a DSN propunham. Tal questão nos oferece elementos para questionar, também, o fato de que não temos notícias - ao menos não nos documentos de consulta pública - da existência de facções militares de esquerda, ou mesmo de direita. Isto é, não sabemos de nenhum tipo de oposição militar à instituição presidencial. Da mesma forma que a câmara dos deputados e o senado, as Forças Armadas representam um efetivo respaldo às ordens presidenciais. A tendência de representação da composição social dos comandos mais baixos da corporação castrense identificando sua origem popular, bem como a exaltação da lealdade, está presente nos informes presidenciais de nosso recorte temporal.

Díaz Ordaz aponta que "da entranha mesma do povo nasceu nosso Exército [...] e cumpre com honra a delicada missão que o próprio povo lhe conferiu: salvaguardar a soberania da Pátria, a integridade do território e nossas instituições" (GDO, 1966, p. 66) ${ }^{102}$. Essa missão também é apontada como uma "grave responsabilidade", pois consiste em "manter a paz, a tranquilidade e a ordem internos, sob o império da Constituição, afím de que funcionem nossas instituições, de que os mexicanos possam desfrutar da liberdade que a lei garante e o país continue seu progresso”. As Forças Armadas são reconhecidas pela presidência de Díaz Ordaz como guardiões das instituições caracterizada pela “inquebrantável lealdade, a estrita disciplina e o imaculado patriotismo de seus membros" (GDO,1969, p. 368). Reconhecimento feito um ano após o massacre dos estudantes em 1968.

Por sua vez, o presidente Echeverría aponta que "as Forças Armadas mantêm uma inquebrantável fidelidade a sua origem popular e constitucional" (LEA, 1973, p. 126). Popular, porquanto é considerado como um setor do povo organizado para a paz. Sua atividade se orienta "conforme os objetivos da comunidade" (LEA, 1972, p. 73). Está integrado "por homens surgidos da entranha popular. Por isso, respaldam uma ordem política e social ao serviço das maiorias, em que se mantém a vigilância das garantias individuais e se

\footnotetext{
${ }^{102}$ Todas as citações relativas aos informes presidenciais correspondem à edição descrita na introdução deste trabalho (Informes presidenciales. México: Dirección de Servicios de Investigación y Análisis, Subdirección de Referencia Especializada, 2006). Portanto, abreviaremos a cita colocando unicamente as letras iniciais do presidente citado (Gustavo Díaz Ordaz: GDO; Luis Echeverría Álvarez: LEA; José López Portillo: JLP), ano e número de página.
} 
ampliam os direitos sociais" (LEA, 1975, p. 254). Constitucional, considerando que a Revolução Mexicana "teve como aspiração originária o estabelecimento de um estado de direito e de um regime civilista de governo", do qual as forças armadas são um firme sustento. Neste sentido, a corporação castrense, "não alimentam no seu seio nenhuma atitude contrária à transformação do país. Contribuem, em contrapartida, para o cumprimento do programa adotado pela nação mediante o sufrágio" (LEA, 1972, p. 72-73).

Finalmente, López Portillo assevera que as forças armadas "constituem a força pública que é uma instância do direito. Quando atuam para garantir a vigência das instituições, expressam o império da nação. Não são forças de repressão que implicariam em arbitrariedade, mas sim, o sólido aval do Estado" (JLP, 1977, p. 13-14). O soldado mexicano é definido como "inseparável do tronco popular do que provém, é servidor fiel e fiável de nossas instituições, com as que lhe identifica sua honra, uniforme e compromisso". Nesse sentido, a lealdade é um dos elementos nos que mais se detém o mandatário. Aponta, por exemplo, que "o Exército e a Marinha são o povo no serviço das armas; formam com ele e dento do governo, uma unidade inquebrantável”. A lealdade às instituições, ou melhor, a "fidelidade intransigente", como é chamada por López Portillo, é a "essência de nossos militares, e é um patrimônio espiritual que em nome do Governo e do povo do México convoco a manter incólume" (JLP, 1979, p. 114-115).

As declarações públicas dos oficiais militares seguem o mesmo caminho de reafirmação da vocação histórica da corporação na defesa das instituições do sistema político mexicano. Contudo, não puderam se distanciar completamente do complexo panorama internacional e do protagonismo militar em várias partes do continente, tendo que se posicionar.

Entre os documentos consultados, encontramos uma série de matérias de jornal que continham entrevistas ou posicionamentos de importantes representantes militares feitos a repórteres dos veículos de circulação nacional entre 1976 e 1977. Os principais tópicos giram em torno dos temas pautados nos discursos presidenciais: a fidelidade ao presidente e às instituições, e, portanto, à nação; assim como a garantia do desinteresse em se constituir como uma força política que ameaçasse a ordem institucional.

Com motivo de um ato comemorativo pelo 44 aniversário da fundação da Escola de Guerra, o diretor da escola, o general Pedro Feria Rivera, afirmou no ato que "no Exército jamais haverá uma traição porque nesta Escola nos forjamos no crisol da lealdade"103. Motivo

\footnotetext{
103“El Ejército jamás traicionará a la Patria”, El Sol de México (p. 2), Distrito Federal, 16-04-76, AGN, IPS, Caixa 1747 B, Exp. 6, folha 1.
} 
suficientemente poderoso como para garantir que no México jamais poderia acontecer um golpe de Estado ${ }^{104}$.

De seu turno, o subsecretário da SEDENA, o general Héctor Camargo Figueroa, questionado sobre a possibilidade de coincidir com as "teses latino-americanas" sobre a utilização da força militar para combater o comunismo, avalia que "todos os exércitos do mundo são para garantir a paz interior e a defesa de seu próprio país. Então, de acordo com a ideologia que cada país professe, é o exército que tem". Acrescentou, ainda, que "o Exército [mexicano] é apolítico e somente exerce seus direitos cidadãos, na medida da individualidade, sem que se envolvaa instituição em partidarismos"105.

Em 1976, o general Antonio de la Fuente, então diretor de educação militar, declarou num almoço oficial (cujo objetivo não se adverte na matéria) que "o Exército jamais se separará nem um ápice da Constituição e salvaguardará as instituições”. Afirma que existe, sim, a possibilidade de que qualquer militar possa se candidatar para cargos políticos enquanto cidadão, porém, "a finalidade do Exército é salvaguardar o país em qualquer caso" 106 .

De outro lado, o secretário da SEDENA, durante o mandato de Echeverría, dirigindose ao alto oficialato da corporação militar, num balanço realizado ao finalizar os seis anos de exercício, exortou que

não esqueçam que somos militares, depositários da confiança que o Estado mexicano deixou em nossas mãos para sua segurança e proteção; que nunca trocaremos de bandeira, desconhecendo a que juramos defender, e que, por cima de todas as coisas, de todos os interesses, se encontram os mais elevados valores que constituem a integridade da pátria mexicana ${ }^{107}$.

Reiterou que "o exército garante e seguirá garantindo a lealdade, preservar a ordem interna e seguir impulsionando os serviços sociais" ${ }^{\text {"108 }}$, pois considera que estas três pautas são a base da atuação das Forças Armadas mexicanas.

Noutra matéria sobre o mesmo evento, aponta-se que, além de outros militares de

\footnotetext{
104 "Nunca habrá un Golpe de Estado en México", OCHOA CÉSPEDES, Ernesto, Novedades (p. 1,11), Distrito Federal, 16-04-76, AGN, IPS, Caixa 1747 B, Exp. 6, folha 1.

${ }^{105}$ “Nos forjamos en el crisol de la lealtad; el Ejército jamás traiciona”, GARGALLO, Carlos V., Ovaciones (p. 2), Distrito Federal, 16-04-76, AGN, IPS, Caixa 1747 B, Exp. 6, folha 1.

106 "El Ejército no se separará un ápice de la Constitución, dijo el Gral. Antonio de la Fuente", LLERGO, Pilar, Avance (p. 14), Distrito Federal, 26-11-76, AGN, IPS, Caixa 1747 B, Exp. 6, folha 1.

107 "Exhortó Cuenca Díaz a los militares a ser siempre leales a las instituciones del país”, BOLAÑOS, Demetrio, El Universal (p. 1, 10), Distrito Federal, 29-11-76, AGN, IPS, Caixa 1747 B, Exp.6, folha 1-2.

108 "El Ejército garantiza las instituciones. Cuenca Díaz hace balance de su labor en 6 años", GUZMÁN, Roberto, Novedades (p. 1, 15), Distrito Federal, 29-77-12, AGN, IPS, Caixa 1747 B, Exp. 6, folha 1-2.
} 
altapatente com suas famílias, o evento contava com a presença de delegações estrangeiras: vice-presidentes, vice-primeiros-ministros e dirigentes de organismos internacionais, como a OEA, a Comunidade Econômica Europeia, presidentes do poder legislativo de algumas nações, representes do Banco internacional, entre outros ${ }^{109}$. Ou seja, o discurso de respeito às instituições e garantia da ordem interna tinha uma interlocução internacional, sobre a qual não se comenta nada mais.

Nesse mesmo ano, os questionamentos aos secretários militares estavam em torno à situação internacional, especialmente sobre o contexto latino-americano. O chefe do Estado Maior Presidencial de Echeverría, o general Jesús Castañeda Gutiérrez, afirmou enfaticamente que "em Latino-américa os militares se sentem salvadores, no México não" $\mathrm{Na}$ sua análise, comenta que esta situação se deve à posição privilegiada das corporações militares, que tem provocado que estes cheguem a se considerar uma elite de características "tradicionalistas com mentalidade colonialista" ". Isto é, o exército de outras latitudes latinoamericanas "se sente alheio ao povo e obrigado unicamente às burguesias ou elites de poder". No México, segundo este general, isto não acontece enquanto os militares sejamos "cidadãos comuns e correntes com todos os deveres que tem qualquer cidadão do país" ${ }^{\prime 12}$.

Avalia-se que a divisão de poderes, base em que se construiu o sistema político, ajudou que "tanto a igreja como a cabeça militar [...] se distanciassem [do Estado]", constituindo-se, assim, na característica diferencial em relação ao resto dos exércitos do continente. Em outros termos, o chefe do Estado Maior considera que "a situação que prevalece nos países sul-americanos originou-se porque lhe faltou líderes como ocorreu com Juárez, Madero e Morelos, entre muitos outros que fizeram a revolução",114.

Por outro lado, em 1977, o secretário da SEDENA do sexênio de López Portillo afirmava categoricamente que "o exército mexicano não recebe nenhuma assessoria militar de parte dos Estados Unidos nem de outro país nenhum”. Declarava que a instituição mexicana contava com a capacitação necessária e suficiente "para manter a paz e a segurança do país,

\footnotetext{
109 "Reitera Cuenca Díaz la lealtad del Ejército a las instituciones", Avance (p. 1, 9), Distrito Federal, 29-11-76, Caixa 1747 B, Exp. 6, folha 1.

110 "Castañeda Gutiérrez: En Latinoamérica los militares se sienten salvadores, en México No", FLORES DE LA VEGA, Benjamín, Ovaciones (p. 1), Distrito Federal, 22-11-76, AGN, IPS, Caixa 1747 B, Exp. 6, folha 1.

111“En México 'los militares no nos sentimos salvadores de la Patria': Jesús Castañeda”, MOLINA, José, El Sol de México (p. 1, 14), Distrito Federal, 22-11-76, AGN, IPS, Caixa 1747 B, Exp. 6, folha 1.

112 "Ni privilegios ni canonjías; el Ejército, obligado a servir al pueblo: Gral. Castañeda Gutiérrez", CÁMARA, José Lizardo, Avance (p. 1, 8), Distrito Federal, 22-11-76, AGN, IPS, Caixa 1747 B, Exp. 6, folha 1.

113“Castañeda Gutiérrez: En Latinoamérica los militares se sienten salvadores, en México No", FLORES DE LA VEGA, Benjamín, Ovaciones (p. 1), Distrito Federal, 22-11-76, AGN, IPS, Caixa 1747 B, Exp. 6, folha 1.

114 “En México 'los militares no nos sentimos salvadores de la Patria’: Jesús Castañeda”, MOLINA, José, El Sol de México (p. 1, 14), Distrito Federal, 22-11-76, AGN, IPS, Caixa 1747 B, Exp. 6, folha 1.
} 
motivo pelo qual não requer, de jeito nenhum, de assessoria estrangeira". Na mesma entrevista, garantiu que "México não comprará material bélico no estrangeiro. Temos o suficiente para a defesa de nosso território e não esperamos nenhuma agressão" ${ }^{\text {"115 }}$.

Fazendo referências não só à questão das assessorias, o geral Galván aproveita a ocasião para se distanciar dos EUA no tema da cooperação, quando afirma que o país "recebe convites para assistir a reuniões continentais ou regionais de diversas agrupações militares e de vários países". Esclarece que a participação mexicana é unicamente como "observador, mas sem autorização para emitir opiniões ou afirmar qualquer declaração ou pacto, já que o nosso país, permanece na margem dessas agrupações" ${ }^{" 16}$. Esta aclaração se localiza no contexto da presença do chefe da Força Aérea Mexicana, general Héctor Bertier Aguiluz, na reunião anual de militares latino-americanos realizada em Buenos Aires, Argentina ${ }^{117}$.

A seção editorial do jornal El Nacional destaca a atitude das autoridades militares considerando o corpo castrense "uma instituição popular ao serviço do povo cuja eficácia humana e técnica não tem outro objeto que o de preservar os resultados que a nação obteve ao longo da sua história”. Destaca-se, assim, o fato de que o México deve priorizar a construção de laços culturais, "de amizade e de colaboração com as demais nações do Hemisfério, mesmo com as reservas em relação à estrutura e filosofia mesma de nossas instituições"118.

Os posicionamentos que demostram o nacionalismo militar no contexto internacional também tiveram repercussão no terreno pedagógico e material. Ou seja, existe um interesse por se distanciar das práticas tutelares dos EUA e de seu protagonismo militar nos processos políticos do Cone Sul. Contudo, encontramos uma assimilação mexicana desses princípios da política norte-americana compartilhados por colegas latino-americanos, ainda que de uma maneira discreta.

\subsubsection{Preparação da Guerra Total}

Diferentemente de grande parte dos Estados latino-americanos, o mexicano não recebeu dos Estados Unidos grandes dotações em empréstimos, doações ou venda de equipamento militar

\footnotetext{
115 “Categórica declaración de Galván López: El ejército no recibe asesorías extranjeras”, Ovaciones, Distrito Federal, 13-01-77, AGN, IPS, Caixa 1747 B, Exp. 6, folha 1.

116 “'México no comprará armas; no esperamos ninguna agresión', dice el Gral. Galván”, LOZANO, Jesús M. Excélsior (p. 4), Distrito Federal, 16-03-77, AGN, IPS, Caixa 1747 B, Exp. 8, folha 1.

117 "No está prevista la adquisición de armamento al exterior: Gral. Galván”, El Nacional (p. 1), Distrito Federal, 16-03-77, AGN, IPS, Caixa 1747 B, Exp. 8, folha 1.

118 "México prefiere los vínculos culturales", El Nacional (p. 5), Distrito Federal, 17-03-77, AGN, IPS, Caixa 1747 B, Exp. 8, folha 1.
} 
pesado ou leve, terrestre, naval ou aéreo, nem de armamento pessoal ou treinamento para soldados mexicanos (PIÑEYRO, 1985, p. 71). Isto é, comparativamente, houve um número reduzido de mexicanos em academias norte-americanas, porém, essa questão numérica ou estatística não esclarece muita coisa sobre a atuação contrainsurgente dos elementos treinados [fig. 12-13].

Por volta de 1977, mesmo ano em que se fizeram as declarações que reproduzimos no itemanterior, o Estado Maior da Defesa Nacional produziu uma lista de oito fólios, sem destinatário, com a relação de nomes de militares mexicanos no estrangeiro (seja como agregados, seja como estudantes), e vice-versa (militares estrangeiros no México). Já dos agregados mexicanos constam doze militares, nove ajudantes, três comissionados, e um secretário, somando um total de vinte e cinco militares. Desses, dez estavam em Washington.

Nas listas observamos, da mesma forma, que os militares mexicanos se encontravam estudando exclusivamente nos EUA. Especialmente no Forte Huachuca de Arizona. Um major e três capitães realizavam o curso de "Inteligência para Chefes", com uma duração de cinco meses. No Forte Benning de Georgia, havia dois tenentes no curso "Básico de transmissão e sistemas de rádio", de oito meses. Dois tenentes no curso "Básico de artilharia de campanha", com duração de quatro meses, no Forte Sill, Oklahoma. Por último, dois majores no curso de "Operações aéreas" de dois meses, na Zona do Canal de Panamá. Contabilizando um total de doze militares em $1977^{119}$.

Estes números aparentam ser mínimos, considerando os dados aportados pelo pesquisador Jorge Luis Sierra Guzmán (2003, p. 49), que aponta que, entre 1964 e 1968, o presidente Díaz Ordaz manteve 306 oficiais estudando nas academias norte-americanas. Por outro lado, em 1967 se fundaram dois espaços no México para a formação de especialistas em contraguerrilha: a Escuela de Aplicación de Infantería, Artillería, Zapadores y Servicios, e a Escuela de Aplicación de Caballería. Em ambas as instalações "os estudantes aprenderam [fazendo estágios] em Norte-América os últimos conhecimentos sobre a guerra irregular e a antisubversão" (PIÑEYRO, 1985, p. 86).

Se no terreno dos planos de ensino, as Forças Armadas também marcaram certa distância em relação à perspectiva de tutela norte-americana, não deixaram de lado a modernização teórica. O Manual de operaciones en campaña, editado pela primeira vez em 1969, tinha como objetivo pedagógico a instrução para alcançar a unidade doutrinária, sintetizando a tradição militar mexicana com a renovação teórica que se desenvolve no âmbito

\footnotetext{
119 "Relación de agregados militares extranjeros y mexicanos", Distrito Federal, 01-06-77, AGN, IPS, Caixa 1747 B, Exp. 8, folhas 1-7.
} 
internacional. Ao longo dos dois tomos, podemos encontrar breves reflexões sobre os grandes tópicos da DSN, sobretudo no que se relaciona à Guerra Total e à segurança interna.

Resulta interessante, no manual, o breve balanço que se faz sobre a Guerra Fria. Período histórico descrito pelos militares mexicanos como uma luta política internacional aonde:

produzem-se intervenções dissimuladas, fomenta-se a subversão, levam-se a cabo demonstrações de força militar, atacam-se os contendentes nos foros internacionais, provocam-se entre si transtornos econômicos e se desenvolve uma intensa propaganda contendo rumores negativos, propalando alarmes falsos ou mencionando, inclusive, verdades que não deviam ser descobertas (SEDENA, 1981a, p. 16).

Indica-se, além do mais, que no México não existe Guerra Fria. Pois, segundo o Manual, os governos mexicanos são respeitosos e cuidadosos no extremo da observância sobre o Direito Internacional, "não pode reconhecer como 'guerra' a situação na qual ela não se manifesta conforme ao direito, ou ainda menos se de fato, mas com todas as características que conformam um real e verdadeiro estado bélico" (SEDENA, 1981a, p. 16).

$\mathrm{Na}$ perspectiva militar mexicana se reconhece que os conflitos entre Estados (ou entre grupos dentro do mesmo Estado) podem ser de dois tipos: a) Divergências que consistem em simples desacordos e lutas de interesse, que geralmente podem ser resolvidos através da política ou de uma efetiva negociação diplomática; b) Diferenças profundas e irreconciliáveis, em ideologia e interesses materiais e morais que se resolvem unicamente por médio da guerra. É neste plano que a guerra se apresenta no México, pois se avalia a existência de unidade e força ideológica do sistema político mexicano.

A guerra, então, pode se classificar considerando diversos fatores. Segundo as entidades envolvidas (guerra internacional ou civil); por sua extensão nos objetivos, meios e alcances (guerra total, guerra limitada); ou pelas causas que a originam (políticas, econômicas, ideológicas). No caso de uma Guerra Total, o objetivo seria "destruir o adversário, aniquilá-lo, desorganizá-lo; enfim, prejudicá-lo desde todos os pontos de vista em grau máximo". Numa situação deste tipo, mobilizam-se necessariamente "todos os recursos humanos, materiais, econômicos, etecetera, da nação" (SEDENA, 1981a, p. 13-14).

Contudo, pode existir uma Guerra Total no caso de que a integridade nacional seja ameaçada por um agressor interno. Si o "império da Constituição" ficar numa situação de risco, as Forças Armadas têm o dever de "previr e reprimir atos antissociais ou contra o Estado, levadas a cabo por pessoas ou grupos transgressores da lei”. Nesse ínterim, se os 
transgressores usam uma forma de guerrilha ou rebelião armada, as tropas devem "atuar conforme as normas doutrinárias de fazer a guerra", considerando, paralelamente, o fato de que os procedimentos táticos podem ser restringidos ou modificados "de acordo com as diretivas que dite o Governo da República, quando este busque a solução ao problema por meio de ação social, política e econômica” (SEDENA, 1981a, p. 29-30).

Numa situação de risco, o Plan de Defensa Nacional II (DN-II) é a base para o planejamento de qualquer estratégia. Nele se desenvolvem os aspectos táticos e estratégicos das ações militares em torno a possíveis distúrbios civis e contra a subversão armada ou não armada. O DN-II parte da análise dos alcances e limitações das Forças Armadas que configuram as hipóteses de guerra.

O DN-II considera a possiblidade de que a totalidade dos efetivos militares no território nacional são reduzidos. Sendo assim, enfatiza-se a importância da eficiência do aparato de controle integral, não só o militar. Isto é, a garantia da segurança interna descansa na cooperação entre a instituição castrense, as corporações policiais (federais, estaduais, municipais, judiciais, preventivas e de caminhos), assim como em outros elementos que combatam e previnam o surgimento da subversão.

Avaliando as características impróprias, agrestes, de vastas regiões, e que possibilitam a existência e permanência de ações guerrilheiras, o DN-II considera necessária a utilização de "especialistas" que ajudassem nas tarefas de espionagem, guia, comunicação, e, em momentos extremos, também de combate (SIERRA, 2003, p. 49). Em 1964, a SEDENA publica um manual para a organização, funcionamento e emprego de corpos de defesa rurais. Considera-se prioritária a organização, fornecer equipamento e adestramento aos camponeses para colaborar diretamente com as Forças Armadas. De acordo com o documento, estes elementos não receberiam salário, mas sim, a atenção pertinente no caso de haver feridos no cumprimento do dever. No caso de morte em combate, suas famílias receberiam uma pensão. Os Cuerpos de Defensa Rural (CDR) teriam autonomia para a organização interna, porém, respondendo diretamente às ordens dos comandantes regionais do exército ${ }^{120}$. Finalmente, se diz que os CDR "não desempenharão serviços que correspondam à polícia, particularmente em funções próprias da conservação da ordem durante o desenvolvimento de feiras, festivais ou atos semelhantes" (ARANDA, 2014). Ou seja, estes corpos paramilitares seriam acionados

\footnotetext{
${ }^{120} \mathrm{O}$ território mexicano estava dividido em zonas militares, com comandos rotativos. Medida que, por um lado, combatia a possibilidade de instauração de caudilhos militares regionais. Por outro lado, o ato de designar os comandantes militares diretamente pela presidência possibilitava a vigilância sobre os governadores. Desde 1965, a divisão territorial também possibilitava manter presença armada nos locais de maior atividade da oposição (PLASENCIA, 2010, p. 77).
} 
unicamente sob vigilância militar.

Finalmente, o DN-II destaca que a magnitude populacional e geográfica impossibilita a corporação militar para atuar em mais de uma frente simultaneamente. Motivo pelo qual "se impõe uma lógica dissuasiva ou repressiva de caráter preventivo frente a qualquer fenômeno armado ou não armado com potencial expansivo no corpo da sociedade mexicana" (PIÑEYRO, 2008, p. 75). Desta maneira, pela avaliação das possibilidades militares para o controle da ordem interno, ganham um papel importante os corpos policiais e, sobretudo, paramilitares.

$$
* * *
$$

No contexto da Guerra Fria foram exportadas, então, uma série de conceitos e teorias que de alguma maneira - direta ou indireta - influíram na política continental. O centro hegemônico na América Latina definitivamente são os EUA. Assim, destacamos o anticomunismo (um método de leitura da realidade e como guia ideológico dos Estados) enquanto um dos elementos necessários para o entendimento dos processos políticos da região. Agora, a partir da análise traçada pelo percurso realizado pelo senador Rockefeller, as relações entre os EUA e a América-Latina se transformam. Primeiramente, a pouca efetividade das invasões militares em territórios considerados comunistas, ou com uma presença forte das organizações com perfil simpático aos soviéticos, fez com que se reformulasse a forma de fazer a guerra. Considerando, também, que os exércitos, por seu forte componente nacionalista, consistem na corporação com maiores possibilidades de proporcionar a segurança necessária para o desenvolvimento econômico, uma vez que essa era a condição necessária para evitar as aproximações com o comunismo, os norte-americanos desenvolvem a Doutrina de Segurança Nacional e a Doutrina Contrainsurgente disseminada a través de campi de ensino especializados em exércitos e polícias latino-americanos. Os "nativos" sob tutela dos EUA seriam os encarregados da repressão e do aniquilamento dos inimigos do desenvolvimento.

A partir da metade da década de sessenta, começam a suceder-se golpes de Estado pelo continente, que a historiografia tem denominado, justamente, como regimes de Segurança Nacional. No caso mexicano, a linguajem própria dessas teorias foi evitada. A Segurança Nacional não é um conceito apropriado pelo Estado mexicano, mas a DFS foi encarregada por manter a ordem interna. Aliás, a DFS foi fundada a partir do modelo do FBI. Apreciamos, a partir de vários relatórios, como foi construída e, principalmente, quais os temas de interesse na realidade mexicana e as maneiras de sistematizar a informação. $\mathrm{O}$ 
controle da segurança interna foi posto, então, nas mãos dos órgãos de vigilância. Apesar de divergir discursivamente em relação às imposições norte-americanas, podemos notar uma colaboração estreita entre a DFS e a CIA e que não se limitou à troca de informação relevante. Embora os presidentes mexicanos ostentassem discursos nacionalistas inflamados, pudemos averiguar a submissão da inteligência mexicana às pautas norte-americanas.

Como a segurança interna mexicana estava controlada pelos EUA, não foi necessário qualquer impulso político do exército mexicano como ocorrera noutras partes do continente. Afinal, historicamente, o exército e o poder federal (civil desde 1946) tinham um pacto. O presidencialismo mexicano, através do seu braço executor, a DFS, já estava se encarregando da manutenção do Estado de Direito. Na fundação das forças armadas mexicanas se erigiram duas palavras-chave: profissionalização e despolitização. Com tal pressuposto, o corpo militar não tinha aspirações políticas, pois sua função primaria era a defesa das instituições. Contrapondo-se às corporações latino-americanas, os militares mexicanos se esforçaram em passar uma imagem popular, criticando as aspirações elitistas dos outros. Porém, apreciamos como a hierarquia militar também controlava alguns dos postos estratégicos no sistema político, que eram indicados pelo presidente, ou, inclusive, por eleição popular.

Nessa mesma linha, o repúdio à intervenção norte-americana se vê abalado, quando vemos que, a partir de 1964, com o aparecimento dos movimentos armados no território mexicano, o exército passar por uma renovação de equipamentos e, ainda mais significativamente, por uma renovação doutrinária. Institucionalizam-se os corpos paramilitares. A linguagem militar se transforma e se adapta às novas tendências exportadas pelos norte-americanos. 


\section{POLÍTICA EXTERNA MEXICANA}

Uma das características que se destacam quando se avalia o impacto da Guerra Fria no continente americano, é a implantação de governos militares através de golpes de Estado apoiados pelos EUA e justificados pelo informe Rockefeller. Como foi analisado, não temos notícias sobre algum movimento de oposição dentro das Forças Armadas que significasse um perigo real para o sistema político mexicano. Contudo, o discurso da Guerra Fria foi expressado por outros meios. A política externa manifesta uma série de contradições entre os assuntos externos e as políticas internas. Os mandatários mexicanos dos sexênios em avaliação colocaram o México no meio da disputa internacional inclinados à esquerda como uma potência moral de oposição aos EUA. Paralelamente os conflitos internos foram lidos a partirda Doutrina de Segurança Nacional, combatendo, assim, à oposição com estratégias contrainsurgentes.

Podemos estabelecer várias peculiaridades entre os modos pelos quais agiu a política externa mexicana de cada um dos mandatários analisados. Destacamos, de maneira geral uma divisão temporal. Entre 1964 e 1970, nosso primeiro sexênio analisado, podemos observar uma postura internacional de caráter defensivo, pautada pela experiência histórica anterior à Revolução de 1910. Isto é, ela reflete o trauma ocasionado pelas constantes intervenções estrangeiras no território; o peso que implica o fato de compartilhar uma grande fronteira com os EUA; assim como a necessidade de se concentrar na construção, consolidação e fortalecimento das instituições nacionais, pois, até 1917, não existiam condições de governabilidade, a violência e a guerra civil eram uma constante desde o século XIX (CHABAT, 1986). Estes elementos estão arraigados na expressão da defesa da livre autodeterminação dos povos e a não-intervenção nos assuntos relacionados à soberania.

No entanto, entre 1970 e 1982, pode-se apreciar que ambos os mandatários apelam a esses preceitos de uma maneira muito mais ativa, e, até poderíamos considerar, militante. Observamos a busca de protagonismo internacional e de liderança regional nos últimos doze anos de nosso recorte temporal.

Gustavo Díaz Ordaz, ao longo de seus informes, se mostra extremamente cauteloso nas suas posições. Em 1968, o presidente aponta que toda nação "tem o direito de escolher o caminho que considere mais indicado, de acordo com sua idiossincrasia, para buscar a liberdade e a felicidade dos homens que integram [os países]; mas todos têm a obrigação de lutar para que a diversidade não se traduza em conflito". Nesse mesmo discurso, o mandatário manifestou que as posições mexicanas expressadas nos foros internacionais são sempre 
congruentes "com o princípio tradicional do México de respeitar o direito de cada povo a seguir o sistema social e político que considere melhor, sempre que, no exercício desse direito, respeite o dos outros países que buscam seu progresso por seus próprios caminhos". Sob tal princípio, México propôs, na reunião da OEA realizada em 1967, que os Estados membros do organismo canalizassem seus esforços para o "desenvolvimento econômico e social de nossos povos, no entendimento de que tais esforços não se deterão pelo propósito de nenhum Estado ou organização para subverter instituições de outro". Finalmente acrescenta que:

O México é um país de profunda tradição revolucionária. Sua história, carregada de tragédias, é o resultado de grandes comoções estruturais que nem sempre foram do agrado de outras nações. Sabemos bem, porque [no passado] sofremos em carne própria, o que é o isolamento na esfera internacional, a pressão externa, a crítica acerba e despiedada, a incompreensão dos esforços realizados por um povo para construir um futuro melhor. Precisamente por essa experiência dolorosa compreendemos e respeitamos as tentativas de outros povos para resolver, por via própria, seus problemas materiais e espirituais, ainda quando não coincidamos com os caminhos e os métodos elegidos (GDO, 1968, p. 253).

Como um país que se formou a partir de uma convulsão revolucionária e como vizinho dos EUA, cuja parceria econômica é fundamental, Díaz Ordaz se esforça por manter a neutralidade a favor do desenvolvimentismo. Agora, a "neutralidade" como princípio tradicional se radicaliza, principalmente, a partir do momento em que o México é colocado dentro do mapa mundial, em 1970. Tanto Echeverría como López Portillo se assumem como "terceiro-mundistas" e defendem essa posição.

Em seu primeiro informe Echeverria afirma que os princípios que tem normatizado permanentemente a conduta do México no âmbito internacional se mantêm invariáveis: “igualdade jurídica entre os Estados, não intervenção e autodeterminação dos povos, solução pacífica de controvérsias e cooperação entre os membros da comunidade de nações”. A mudança qualitativa que referimos está presente quando, na mesma frase, Echeverria declara enfaticamente que "não alentamos animadversões sistemáticos, mas tampouco ingênuas confianças" (LEA, 1971, p. 53). Considerando o anterior, Echeverría briga para que o país abandone seu lugar de espectador passivo perante os conflitos internacionais;

por deixar clara a postura do México ao lado dos países débeis, subjugados e explorados, e com isso, mantermo-nos fieis aos princípios fundamentais de nossa política internacional; por realizar atos concretos e não somente 
declarativos para a união dos países do Terceiro Mundo e lograr, assim, melhores condições em sua relação com os países mais poderosos [...] Tudo isso consolida o prestígio da nação no âmbito internacional e amplia o conteúdo de sua independência (LEA, 1975, p. 250).

Observamos como a percepção do país passou de ser um Estado que se definia autônomo e soberano perante as disputas das potências por conseguir ampliar suas influências, para ser parte do Terceiro Mundo. Assim o reafirma José López Portillo, quando assinala que "historicamente nossa doutrina foi muito além das posições defensivas, que garantem independência e afirmam soberania”. Saudava o fato de que o México estivesse participando, de maneira ativa, "no empenho de transformar o sistema internacional. Queremos um amanhã, se a insanidade não o impede, de nações corresponsáveis e não de superpotência" (JLP, 1978, p. 95). Contudo, na percepção da independência e soberania do México, assim como da militância para a transformação da realidade imposta pela Guerra Fria, o mandatário é o suficientemente cuidadoso para não enturvar as relações com os vizinhos do norte. López Portillo assevera que:

Para o México, a manutenção de boas relações com os Estados Unidos constitui uma pedra angular de sua relação com o exterior. Questão de realidades, não de gostos ou caprichos. Mas não pode haver boas relações com os Estados Unidos se não se baseiam em primeiro lugar, no respeito (JLP, 1982, p. 296).

O posicionamento mexicano na discussão sobre a pertinência e possibilidades de criação de mecanismos de integração latino-americana, "baseados nos princípios de livre associação e de reciprocidade, além do tratamento preferencial para os países de menor desenvolvimento", estiveram presentes, de uma maneira moderada, na agenda do presidente Díaz Ordaz. Ele baliza que este processo deve ser um "esforço da América Latina, circunscrito exclusivamente a ela, sem hostilidade para com os EUA e Canadá ou alguma das grandes áreas industrializadas do mundo".

Cabe lembrar que Díaz Ordaz está discursando nos tempos da Aliança para o Progresso. México era beneficiário desde $1961^{121}$. O próprio Díaz Ordaz demarca:

\footnotetext{
${ }^{121}$ Em números, Díaz Ordaz informa que pela Agência Internacional de Desenvolvimento tem-se permitido o auspício e concessão de créditos em campos tão importantes como agricultura, preparação de técnicos, moradia, obras de pequena irrigação. Além de receber da mesma agência um crédito importante para o Centro Nacional de Agricultura. Também háo empréstimo que seria destinado para financiar obras que contribuissempara o aumento da produção total e de rendimento por hectare das terras ejidales ou das pequenas propriedades agropecuárias.
} 
o programa cooperativo que se conhece como a Aliança para o Progresso, cujos princípios e metas reiteradamente expressam que concordam com os que inspiram e perseguem a Revolução Mexicana. Esta coincidência no ideário, a firme determinação do Governo do México de prosseguir com as reformas iniciadas dentro do marco de nossa Revolução - posteriormente auspiciadas pela Aliança para o Progresso - e a teoria que ela sustenta de que os recursos financeiros exteriores devem ser somente complementários dos esforços de cada um dos povos em processo de desenvolvimento, nos levaram a manifestar, uma vez mais, nossa convicção otimista de que, apesar dos obstáculos encontrados no seu caminho, a Aliança para o Progresso é um programa que deve seguir adiante (GDO, 1965, p. 11-12).

Ou seja, ele apresenta como necessária a unidade econômica latino-americana, construída desde a América Latina. Não nega a importância de se segurar os empréstimos oferecidos pela potência vizinha, pois "não se trata de ir contra ninguém, mas de somar nossos esforços a favor de nós mesmos" (GDO, 1965, p. 47). Aclara, também, que o México é "uma independência que se firma, definitiva e vigorosamente, dentro da interdependência e da solidariedade com as demais nações", acrescenta que uma "interdependência" não significa submissão ou domínio de um Estado sobre outro, e sim, um "complemento e apoio mútuo, de muitas soberanias, tantas como povos autônomos existem, para somar esforços e enfrentar os problemas que acometem o homem".

Ponderando a conceitualização anterior, Díaz Ordaz se posiciona no contexto da luta internacional entre as potências, de uma maneira solidária, pois considera "um dever, antes que nada, moral, que exclui qualquer hegemonia". Assim, esclarece que o México aspira consolidar sua independência sem deixar de lado a aspiração à solidariedade, "dentro da igualdade jurídica", querendo "contribuir à concórdia entre as nações e o entendimento entre os governos". Como outras vezes ao longo de seu sexênio, o presidente Díaz Ordaz estende a mão, "num gesto de franca e cordial amizade em direção a todos os povos e governos de nosso Continente, de modo que nunca falte, ao menos, um fio de comunicação, apesar dos problemas, dificuldades ou transformações com os quais possam confrontar-se nossos irmãos" (GDO, 1965, p. 54).

De sua parte, Luis Echeverria rompe totalmente com o discurso cordial dentro do embate da Guerra Fria. De maneira inversa, o discurso dele se apresenta agressivo com respeito às potencias, e solidário com os países que não pertencem a nenhum dos campos de influência. Segundo Echeverría, o confronto entre os blocos hegemônicos da pós-guerra, fundamentado no temor recíproco, assim como as "fechadas zonas de influência, limitaram as opções internacionais dos Estados", precipitaram o desabamento de "antigos impérios, acelerou-se o processo de descolonização e foi frequente o estouro de guerras localizadas. 
Estes fenômenos configuraram o marco em que se forjou nossa geração".

Para Echeverria, o processo de Guerra Fria mantém outras frentes que até esse momento tinham sido ignoradas, minimizadas pelas aspirações hegemônicas das duas grandes potências:

\begin{abstract}
Os povos outrora subjugados procuram novas fórmulas para consolidar sua independência e superar o atraso econômico. Nossa comunidade latinoamericana está em ebulição e urgida de mudanças nas suas estruturas internas. Esse é o cenário em que nos toca atuar.

Nunca pretendemos constituir-nos em lideranças de ninguém, exceto de nosso próprio destino. Agrupamo-nos ativamente com o Terceiro Mundo e, em especial, articulamos esforços libertadores com a América Latina. Sua luta é também a nossa e devemos coordenar ações para romper as relações de dependência e aceder ao pleno desenvolvimento. Isolados somos débeis, unidos às maiorias cresce nossa viabilidade de progresso. Este é o caminho escolhido para alcançar as nossas metas.

Praticamos uma política exterior independente e o seguiremos fazendo. A todos os foros onde nos leva o interesse da República, expomos nossas convicções com igual franqueza. Temos expressado a tese do México e escutado com atenção e respeito às de outros povos e governos. Falamos com a energia que as circunstâncias exigem, mas também com a serenidade que nos impõe a maturidade alcançada pelo país e na análise cuidadosa da realidade de nosso tempo (LEA, 1972, p. 102-103).
\end{abstract}

Echeverría reconhece a América Latina como o espaço onde o México pode - e deve ter maior influência. Igual que seu antecessor, está em pugna pela integração continental, pois “chegou o tempo de deixar de lado diferenças ideológicas e unificar nossa ação política e econômica" (LEA, 1972, p. 104). Assumindo o protagonismo, informa à população mexicana que durante a assembleia da OEA declarou que o "México nunca concebeu a unidade hemisférica como fórmula de servidão nem como instrumento ao serviço de um Estado ou grupo de Estados. O pan-americanismo, como colaboração entre iguais, não deixou de ser uma aspiração". E como forma de confrontação direta acrescenta que fez um chamado para acabar com os vestígios da Guerra Fria "que parecem se perpetuar na região, pondo fim a uma política continental que nega o direito dos Estados de erguer a estrutura que melhor convenha a seus interesses" (LEA, 1972, p. 108).

Echeverría, além do mais, mostra-se como um feroz crítico da OEA, pois a considera que a organização é "cada dia menos operante". Em 1974, inicia uma campanha internacional para promover uma reforma estrutural do organismo, porque, segundo o presidente mexicano, a OEA "rechaça a realidade do pluralismo político e persiste em se manter como um cenário 
teatral de inocultáveis manobras hegemônicas" (LEA, 1974, p. 232) ${ }^{122}$.

Aproveitando a brecha aberta pelas críticas à OEA, o presidente Echeverría defendeu a pertinência da participação na IV Conferência dos Países não Alinhados ${ }^{123}$, celebrada na Argélia em 1973. Na Conferência, informa o mandatário, elaborou-se um documento que seria apresentado à Assembleia Geral da OEA. Entre outras coisas, o documento enfatiza o fato de que "o não-alinhamento significa assumir posições e responsabilidades independentes perante os problemas da paz e do desenvolvimento autônomo de todos os países". Fazendo própria a voz dos não-alinhados, Echeverría adverte que, seja ou não sancionada a carta pela Assembleia, "estamos decididos em manter seus princípios fundamentais e se as potências não aceitas cooperar conosco, a Carta será, de todos modos, uma convicção permanente na luta pela libertação dos povos do Terceiro Mundo" (LEA, 1974, p. 233-234).

López Portillo, por sua vez, continua na mesma linha. Reconhece que

diante das tensões entre as superpotências, cai-se no vício de considerar erroneamente cada conflito local, toda luta de um povo, como um simples reflexo da oposição entre elas que em ocasiões são as que atiçam os conflitos, convertidos, assim, em "casos-prova" de seu poderio, que não necessita já de demonstração alguma (JLP, 1981, p. 271).

Para a análise das relações internacionais do último sexênio de nosso recorte temporal, apontamos que a leitura Oriente-Ocidente foi superada. Daí a necessidade de "influenciar nos acontecimentos e não somente invocatória de princípios”. Dessa maneira, uma missão do governo de López Portillo consistiu

na sua iniciativa para celebrar uma reunião internacional sobre cooperação e desenvolvimento a nível de Chefes de Estado ou de Governo, que proporcione o impulso político indispensável para tirar da estagnação e da frustração as negociações econômicas entre países desenvolvidos e países em desenvolvimento, resumida como diálogo Norte-Sul (JLP, 1981, p. 271).

\footnotetext{
${ }^{122}$ Resultaria interessante conhecer essas propostas para aprofundar mais na concepção mexicana no plano internacional, contudo, não achamos informações a respeito.

${ }^{123}$ A partir da década de cinquenta, nos territórios de Ásia e África que permaneciam sob domínio colonial, desenvolve-se um processo de guerras de descolonização. Dessa forma, novas potências, como a China, começaram a tutelar essas novas nações aproveitando o discurso de confronto bipolar da Guerra Fria. Porém, um grupo de Estados buscou construir uma política de neutralidade. Em 1961, realizam a Conferência dos países Não-Alinhados. Sukarno (Indonesia), Tito (Iugoslávia) e Castro (Cuba) foram as lideranças mais reconhecidas (VEIGA; DA CAL; DUARTE, 1998, p. 177). Ideologicamente, textos como Os condenados da Terra, de Franz Fanon, e A guerra de guerrilhas, de Che Guevara, nutriram o pensamento dos Não-Alinhados. Assim, as lutas contra o racismo e pela descolonização, a partir de um processo revolucionário inevitavelmente violento, tomaram força.
} 
Como se pode observar, o latino-americanismo esteve presente durante os três períodos abordados. Contudo, cada um dos presidentes assumiu diversas posições a respeito das convulsões políticas internacionais. Díaz Ordaz, por exemplo, anuncia que nos casos em que se apresentem "situações anómalas", não procederá por retirar os representantes diplomáticos mexicanos. Estes “permanecerão nos países onde estão acreditados, no exercício normal de suas funções, sem significar, por isto, o reconhecimento dos novos regimes". Explica, também, que o governo mexicano não pode reconhecer ou desconhecer regimes, "pois a prática do reconhecimento é alheia aos princípios que o México mantém desde 1930 e que tomaram o nome do então Secretário de Relações [Exteriores], Genaro Estrada" ${ }^{124}$.

Também, de alguma maneira, não condena diretamente os golpes à democracia que despontaram em cadeia no continente, o presidente Díaz Ordaz considera que o único método para conseguir a paz e a estabilidade necessárias para o desenvolvimento, era o "esforço constante e firme para melhorar a vida econômica, social e cultural dos povos no marco das liberdades individuais e da crescente justiça social" (GDO, 1966, p. 125). Apegando-se à definição de democracia contida no artigo terceiro da constituição mexicana, sentencia:

Deploramos quando um país irmão se separa do caminho da democracia, mas acreditamos que não o ajudamos a voltar à que cremos é a boa senda condenando-o ao isolamento. A democracia, como a justiça, como a reforma social, para ser autênticas, hão de apoiar-se na decisão espontânea dos povos. Não podem ser impostas desde o exterior, nem sequer indiretamente (GDO, 1966, p. 125).

\subsection{Asilo político}

A política de recepção dos asilados foi um instrumento utilizado pelos governos mexicanos para marcar uma posição diferenciada no que concerne às convulsões políticas que assolaram a segunda metade do século XX latino-americano. Nos informes de Díaz Ordaz, há menções ao exílio a partir de 1967. Destinam-se poucas linhas, de fato, citam-se as cifras correspondentes ao número de estrangeiros que ingressaram no país com licença provisória

\footnotetext{
${ }^{124}$ Gerardo Estrada foi jornalista e escritor, funcionário dos primeiros governos após o conflito revolucionário. Destacou-se como ministro de Relaciones Exteriores (1921). Posteriormente, em 1931, publica a doutrina batizada com seu nome. A Doutrina Estrada, fundamentalmente, opõe-se a que qualquer país estrangeiro se posicione, favoravelmente ou não, a outro governo, partindo da sistematização das experiências que os governos pós-revolucionários tenham enfrentado no plano internacional. Negava o direito de reconhecer ou desconhecer governos, sob o argumento de que cada país é independente para construir o governo e o sistema político que melhor resolva os interesses da nação.
} 
(turistas, trabalhadores, estudantes, participantes de congressos, periodistas, artistas); o número de migrantes que tiveram concessão de asilo por motivos políticos; assim como o número de estrangeiros que foram expulsos por violação à Ley General de Asentamientos Humanos. No informe se especifica que, em 1968:

Obtiveram a qualidade de imigrado 1.568 pessoas, 2.280 a de imigrantes e 1.379 a de visitantes. A 60 pessoas lhes foi dado asilo político. Foi necessário expulsar 1.010 estrangeiros por violações a nossas leis. Tanto a Procuradoria Geral da República como a de Justiça do Distrito Federal continuaram no exercício das atribuições que lhes concedem a Constituição e as leis, a tarefa de investigação de atos delitivos e o exercício da ação penal correspondente (GDO, 1968, p. 203).

Echeverría coloca o direito de asilo como "uma das maiores contribuições de nosso continente para aperfeiçoar esta humanitária instituição. Garantir a vida e a liberdade dos perseguidos políticos é fronteira ineludível entre civilização e barbárie”. Desde 1970, México se consolida como um país de braços abertos que promete "respeitar e fazer respeitar estritamente os convênios de asilo vigentes". Dito isso, o presidente propõe uma modificação à Ley General de Población, que, de fato, foi aprovada esse mesmo ano. No informe se sugere, então, que com essa reforma "ampliamos este direito a todos os perseguidos do mundo e não somente aos latino-americanos". Echeverría anuncia que "durante o presente período [1973-1974], México outorgou asilo a 729 estrangeiros, de distintas nacionalidades e tendências ideológicas, que solicitaram nossa hospitalidade" (LEA, 1974, p. 318-319).

Echeverría aprofunda no sentido dado ao asilo como pilar da política exterior mexicana. Segundo a avaliação do escritor José Agustín, em Luis Echeverría existe uma necessidade de distanciar-se do estilo conservador de seu antecessor, Díaz Ordaz. Podemos perceber a intenção de emular o radicalismo nacionalista do general Lázaro Cárdenas e a defesa da democracia através do asilo para alguns atingidos por regimes militares, o que ofereceu a oportunidade a Echeverría de aproximar sua figura à de Cárdenas ${ }^{125}$.

\footnotetext{
${ }^{125}$ Lembremos que durante a presidência do general (1934-1940), as fronteiras mexicanas foram abertas para os ibéricos que fugiam da perseguição por motivos políticos, depoisdo golpe militar do general Francisco Franco, em 1936. Eram denominados "transterrados" e tiveram uma importância fundamental na reformulação da academia mexicana, especialmente, na área das ciências humanas. Eram vários intelectuais republicanos, entre os que podemos citar os filósofos José Gaos, Wenceslao Roces, Luis Villoro e o marxista Adolfo Sánchez Vásquez. Refundaram a Faculdade de Filosofia e Letras da UNAM e também contribuíram, de maneira decisiva, na criação de El Colegio de México, entre outras atividades culturais, acadêmicas e editoriais. Também foram recebidos espanhóis que fugiam da violência e da crise econômica, concentrando-se na área comercial, fundamentalmente na abertura de lojas de móveis, eletrodomésticos e mercearias. Da mesma forma, foram recebidos os célebres "niños de Morelia" - filhos de republicanos, órfãos para os quais foram construídos albergues e escolas.
} 
O presidente Echeverría, na sua luta por erguer-se como a voz do Terceiro Mundo, procurou estreitar laços com o governo da Unidade Popular (UP) chilena. Este relacionamento foi amplamente citado nos seus discursos. Em 1973, ele menciona que "a fim de contrapor-se à estratégia isolacionista contra o Chile, acordamos a venda de petróleo e cereais". Medida cujo propósito foi de "fortalecer, na cooperação econômica, a solidariedade fraternal" (LEA, 1973, p. 129). Esta postura se anuncia no momento da viagem de Echeverría para o Chile, e de Allende para o México.

Já no contexto do golpe no Chile, podemos conhecer a preocupação norte-americana em relação à possível reação mexicana na defesa do governo da Unidade Popular e do allendismo, isso através de um dos documentos diplomáticos recentemente publicados pela organização Wikileaks. Apenas 15 dias depois do golpe, o secretário de Relações Exteriores, Emilio Rabasa, teve uma longa conversa com o embaixador norte-americano Joseph John Jova, devido à convocação feita por este último no objetivo de conhecer as intenções mexicanas no contexto do golpe militar no país sul-americano. Num telegrama se destacam vários pontos da posição do funcionário mexicano a respeito da questão chilena.

Primeiramente, expõe-se que os mexicanos consideravam Allende como um péssimo administrador sem os conhecimentos necessários sobre políticas econômicas. Porém, reconheciam no chileno um grande patriota, pois tentou de múltiplas formas terminar com a oligarquia nacional. Agora, seu assassinato foi avaliado pela autoridade mexicana como um erro, porquanto terminou-se criando um mártir "porque os elementos da esquerda na América Latina agora poderiam concluir que a revolução seria a única via para alcançar seus objetivos", desacreditando, simultaneamente, na luta eleitoral como via democrática para a tomada do poder.

Sobre a atitude intempestiva do presidente mexicano, Barrasa confessa, de maneira confidencial para o embaixador, que geralmente as decisões são tomadas unilateralmente. Isto é, Echeverría não pediu opinião de nenhum colaborador. Considerando o anterior, o secretário de Relações Exteriores propõe três situações hipotéticas que o Estado mexicano poderia ter seguido, segundo os preceitos da Doutrina Estrada: "retirar toda a missão diplomática; deixar um grupo no encargo ou trazer de volta o embaixador" ${ }^{\prime 26}$. Esta última opção seria a menos provável. Barrasa não explicita porquê.

Finalmente, em 1974 Echeverría aponta que

\footnotetext{
126“"Foreign Minister's atitudes re Cilean Problem”, Bureau of Inter-American Affairs, Distrito Federal, 26-0973, Wikileaks.Disponível em: https://www.wikileaks.org/plusd/cables/1973MEXICO07260 b.html [último acesso em: 30-05-16].
} 
a morte do ilustre estadista Salvador Allende, Presidente Constitucional do Chile e leal amigo do México, comoveu profundamente a opinião pública de nosso país. O luto oficial decretado em sua memória foi um modo de reafirmar nossa fé inquebrantável nos governos constitucionais e no destino da democracia latino-americana (LEA, 1974, p. 232).

Echeverría, sem colocar em dúvida, garante que "nosso rechaço à política da força nos levou a condenar, sem rodeios, toda violação aos direitos humanos e toda perseguição ditatorial por razões políticas". Consequentemente, anuncia o rompimento das relações diplomáticas "com o atual regime do Chile que derrocou com o apoio do exterior o Governo Constitucional do patriota Presidente Salvador Allende” (LEA, 1976, p. 424).

Informa, também, que "por razões de caráter humanitário mantivemos, transitoriamente, aberta nossa Embaixada no Chile, depois de ter sido derrocado o governo constitucional. México outorgou asilo diplomático a 197 chilenos” (LEA, 1975, p. 318-319). Da mesma forma que no caso dos asilados espanhóis três décadas antes, os contingentes de exilados chilenos foram conformados por militantes da esquerda (UP e MIR), além de acadêmicos e intelectuais vinculados ao allendismo (ROJAS MIRA, 2014): "A partir desse momento, Echeverría mais que nunca se sentiu o novo Cárdenas", assegura José Agustín (2013).

Marcado por este mesmo estilo radical em torno ao tema do asilo político, o presidente López Portillo anuncia que seu governo "se mantém e persistirá fiel à humanitária instituição do Direito de Asilo, o que não vulnerabiliza em nada nossa doutrina política, pelo contrário, a enaltece, porque nós não asilamos ideias senão homens". Especifica que o direito de asilo também é um objetivo da política exterior de seu governo, pois contribui para "localizarmonos na comunidade internacional, abertos ao diálogo amplo e construtivo, com todos os países da Terra" (JLP, 79, p. 152). Como observado até agora nos informes dos dois últimos sexênios analisados, este tema tem pesos diferentes na política mexicana. No entanto, como reflexo da crise centro-americana do fim da década dos setenta, López Portillo deixa de utilizar o termo asilo e muda para refúgio. O presidente diz:

Temos sido cautelosos em garantir aos estrangeiros que ingressam no país a ampla liberdade e direitos que consagram nossas leis e de modo especial o manter vigente o direito de asilo, exercido cada vez com maior frequência na medida em que se fecham as opções democráticas em outros países. Com as Nações Unidas estabelecemos a Comissão de Ajuda a Refugiados (JLP, 1982, p. 288-289). 
O sexênio de López Portillo teve que confrontar números altos de guatemaltecos ingressando no território mexicano fugindo da ditadura militar que assolava o pequeno vizinho do Sul. Grande parte dos centro-americanos que cruzaram a fronteira instalaram-se na região das quebradas no estado de Chiapas. Local onde confluíram com vários grupos indígenas do estado, que também estavam num processo de deslocamento perante à crescente onda de expropriações de terras para a construção de represas, além da violência exercida por caciques e militares $^{127}$.

Os refugiados guatemaltecos, majoritariamente indígenas, não receberam o tratamento preferencial, honesto e humanitário, dos asilados do sexênio anterior. Num breve relato do pesquisador Sergio Aguayo, menciona-se que durante sua estância na fronteira sul como colaborador na proteção de refugiados, em 1981, presenciou que "uma das atividades do comandante Alberto Estrella era receber gado do exército guatemalteco em troca de refugiados" (AGUAYO, 2014a).

Ao mesmo tempo, nos informes de López Portillo se aponta que perante a ausência de democracia em outras latitudes do continente, o direito de asilo e refúgio são iminentes. Diante deste panorama irrefutável conclui, aliás, que "nenhum mexicano está asilado em embaixada ou país estrangeiro". O México, proclama, mantinha uma "vocação de paz para garantir os direitos humanos dos que padecem perseguição por suas convicções políticas. Aqui não só as respeitamos. São consideradas opções institucionais para o povo de México" (JLP, 1982, p. 288-289).

\subsection{O anticomunismo mexicano}

A partir dos aspectos trazidos sobre a política exterior, entre 1964 e 1982, podemos ter um panorama da atitude mexicana no contexto da Guerra Fria. Destaquemos, agora, como a renovação dos princípios internacionais repercutiu na ordem interna em duas direções políticas extremas. À esquerda, o fato de criar um discurso francamente progressista em reprovação aos sistemas antidemocráticos instaurados, assim como a defesa da

\footnotetext{
${ }^{127}$ Entre 1974 e 1987, o estado de Chiapas, fronteira com a Guatemala, teve 982 líderes políticos assassinados, 1.084 camponeses presos sem fundamentos jurídicos legais, feridos em confrontos com o exército, por volta de 500 torturados, bem como 300 desaparecidos, além de um número importante de famílias deslocadas (GONZÁLEZ CASANOVA, 1995, p. 89). Desde a década de setenta, o território do estado de Chiapas se encontra militarizado, pois é considerado como uma fonte de recursos naturais de importância estratégica. Além disso, nele estavam as usinas que geravam três-quartos da energia consumida em todo o país. O território, então, era considerado como zona de segurança nacional.
} 
autodeterminação de Estados como o cubano, o chileno ou o nicaraguense, teve um efeito de abafar as demandas da esquerda local. Dessa forma, no âmbito internacional se reforçou a imagem de um México revolucionário e intransigentemente democrático. O historiador Enrique Condés Lara menciona que o discurso oficial ajudou "conseguir melhores condições para isolar e aplastar [a oposição civil e armada] [...] e conseguiu o que quis: todo o mundo se desentendeu do que acontecia no México, e o aniquilamento dos rebeldes foi mais fácil” (CONDÉS, 2007b, p. 10).

A repercussão do discurso radical dos mandatários mexicanos também ecoou, porém, dentro dos setores da direita, que de maneira paralela à esquerda iniciaram um processo de radicalização. Como podemos observar nos discursos presidenciais anteriormente citados, o anticomunismo é uma pauta alheia. Contudo, o anticomunismo tem uma longa tradição na história mexicana.

A militância anticomunista, num amplo espectro de organizações, teve uma importante atividade de pressão econômica e política para provocar a desestabilização dos governos mexicanos. Paralelamente a esta atividade política, os líderes da direita mantinham corpos paramilitares para o combate à esquerda. Embora o Estado mexicano se distanciou do “anticomunismo apocalíptico" da Guerra Fria, sua relação com a militância de direita é estreita e, ao mesmo tempo, contraditória. Por um lado, promoveu, protegeu e instrumentalizou a direita, já que contribuía com a imagem democrática que o próprio governo tentava construir para si. Ou seja, o governo deixou nas mãos da direita as ameaças e ataques diretos contra as manifestações da esquerda. Já as organizações anticomunistas rapidamente se tornaram uma verdadeira ameaça desestabilizadora da ordem interna. Vejamos, a seguir, estas duas expressões da relação entre o Estado mexicano e o anticomunismo a partir dos informes elaborados pelos agentes da DFS.

\subsubsection{O MURO e o Yunque}

O Movimiento Universitario de Renovadora Orientación, o MURO, é uma violenta organização de jovens católicos que aterroriza as universidades públicas. A partir do estudo de sua estrutura e modus operandi, pode-se acessar as formas de expressão do anticomunismo mexicano na sua complexidade. Esta análise, também, enriquece o panorama da disputa pela hegemonia no México, diversificando os atores em voga.

Num memorando de quatro folhas sem assinatura, intitulado "A UNAM vítima da 
agitação promovida pelo MURO”, o agente se aproxima da organização de ultradireita e lança algumas hipóteses sobre seus métodos, detendo-se, principalmente, no bosquejo de sua estrutura. Primeiramente, o agente reconhece o MURO como uma "organização secreta" de inspiração católica. Cabe mencionar que não se lhe caracteriza como "organização clandestina" ou "terrorista", tal como comumente se descreviam as organizações de esquerda. Isto pode se entender no contexto da tradição maçônica do século XIX.

O campo de ação do MURO, onde recrutavam, esta focalizado nos centros universitários da região central e ocidental do país. Dada a amplitude geográfica, o agente aponta que são vários os nomes que utilizavam: um deles era MURO, outro Liga Universitaria Nacionalista (LUN), Frente Universitario Anticomunista (FUA), entre outros que não menciona. Com pouca clareza sobre o assunto, o autor do informe não reconhece, de fato, as diferenças entre estas facções anticomunistas, nem o sentido cronológico das mesmas $^{128}$. Sobre isso, advertimos que um antecedente importante do MURO é o FUA, fundado em 1965 na cidade de Puebla. Dois anos depois, o MURO começa a aparecer nas universidades da Cidade do México. Já na década de setenta, abrangendo Puebla, Guadalajara, Michoacán e a Cidade do México, apareceram vários grupos, como o Movimiento Cristianismo Sí, a Guardia Unificadora Iberoamericana (GUIA), a Nueva Guardia, a Juventud Inconforme Positiva, entre outros de menor importância.

Apesar de ser uma organização na qual seus militantes eram majoritariamente jovens estudantes universitários, o agente chama a atenção para o fato de que a "chefia suprema" pertence ao engenheiro Ramón Plata Moreno, formado na Universidad Autónoma de Puebla $^{129}$. Aliás, Puebla se converteu durante a década de sessenta num verdadeiro campo de batalha entre o comunismo e o anticomunismo. Um ilustrativo panfleto, assinado pelo Gran Núcleo Cristiano de Puebla, demonstra isso. Descreve uma performance realizada por jovens universitários da UAP que parodiavam uma missa. Diante disso, o suposto Gran Núcleo respondeu acusando o ato de satanismo, expressando a sua indignação por estes fatos que "nos devem fazer compreender que o grupo Comunista que por nossa negligência apoderouse da Universidade está passando já à tentativa de destruição de nossa Religião, seguindo a

\footnotetext{
128 “Memorándum: La UNAM víctima de la agitación promovida por MURO”, Distrito Federal, 04-04-68, AGN, IPS, Caix 1448 B, Exp. 42, folhas 1-4.

${ }_{129}$ Plata Moreno nasceu na Cidade do México, em 1935. Estudou em colégios lasallistas na cidade de Puebla,depois ingressa no curso de engenharia na universidade pública, porém, manteve contato com os professores jesuítas e com a hierarquia católica da cidade. Na faculdade, eleintensifica a militância direitista, o que culminaria na fundação do Yunque. Foi assassinado a tiros na porta da casa de sua sogra, na Cidade do México em 1979.
} 
máxima de Lenin "A Religião é o ópio do Povo"” [fig. 14] ${ }^{130}$.

Segundo a bibliografia quase hagiográfica elaborada por Klaus Feldmann Petersen (um velho militante do FUA e do MURO) ${ }^{131}$, Plata Moreno, aconselhado pelos sacerdotes da cidade de Puebla, funda a organização de alcance nacional denominada Yunque ${ }^{132}$. A organização concebida como "um corpo de combate contra o comunismo, a maçonaria e todos os demais inimigos de Deus e de sua Igreja, centrando-se na instauração do Reino de Deus em nossos corações e no México" (GONZÁlEZ RUIZ, 2013). Para cumprir o ambicioso plano, Plata Moreno elaborou uma estrutura clandestina em forma de pirâmide invertida onde a liderança nacional se encontrava na ponta inferior.

O Yunque se distinguia por ser uma organização:

\begin{abstract}
"primordial": nada é mais importante, nem a família, que a Organização; "hierárquico-consultiva": nenhuma decisão se pode tomar sem o consentimento do chefe superior; "reservada": totalmente secreta; e "combativa formadora de quadros políticos": por isso o recrutamento de adolescentes depois de um rigoroso processo de observação e análise, para logo serem adscritos para a luta política (DELGADO, 2003).
\end{abstract}

Sob essas condições, Plata Moreno concebeu a criação de células de cooptação de jovens católicos, anticomunistas, ou passíveis ao doutrinamento que conformariam, por sua conta, as "pré-organizações". Situadas na parte superior dessa pirâmide invertida, as organizações como o MURO e o FUA tinham a função de combater corpo a corpo os elementos anticristãos, assim como impedir a detecção e possível desarticulação da organização maior, despistando e confundindo os serviços de inteligência.

Na investigação apresentada pelo agente da DFS, o MURO estava fundamentalmente integrado por estudantes dos Colégios Lassallistas pertencentes à congregação dos Irmãos das Escolas Cristãs ${ }^{133}$, sob direção do religioso Rafael Martínez Escobar, quem oferece “apoio

130 “Satanismo Antirreligioso", Puebla, 04-06-64, AGN, IPS, Caixa 1573 A, Exp. 1, folha 1.

131 O livro intitulado Ramón Plata Moreno: Un cruzado da hispanidad y mártir de Cristo Rey. Breves y auténticas notas a 25 años de su muerte era visto unicamente entre os círculos de ultradireita. As notícias que temos sobre ele correspondem às notas dos jornalistas Álvaro Delgado (2009), publicadas na revista Proceso, e de Edgar González Ruiz (2013), na Revista Contralínea.

${ }^{132}$ Em português, é a ferramenta "bigorna". O nome faz referência à solidez e firmeza que têm as bigornas nos constantes golpes para forjar o aço.

${ }^{133} \mathrm{O}$ ensino básico era obrigatoriamente laico. O Artigo 3 Constitucional suprimia a educação religiosa em escolas públicas e privadas, reservando o monopólio do ensino fundamental para o Estado. Herança das disputas entre a Igreja e o Estado no século XIX, a educação pública era constitucionalmente antirreligiosa. Isto é, a educação religiosa estava banida por ser considerada nociva para a construção da Revolução, da Nação. Contudo, desde 1940, permitiu-se que os colégios privados ministrassem aulas de religião. Paulatinamente, prestigiosos colégios e universidades religiosas se implantaram no país. Em termos do general Ávila Camacho, a educação continuou nas mãos do Estado, mas, "sua orientação é agora democrática em vez 
pessoal e ilimitado" às organizações estudantis.

Rafael Martínez é lembrado como diretor do Colegio Benavente, na capital do estado poblano. A transcendência do personagem reside, segundo o agente da DFS, em que

desde este colégio se prepararam agitações que tiveram repercussão nacional, como a concentração de católicos na catedral poblana, a que contou com o respaldo do arcebispo Octaviano Márquez y Tóriz ${ }^{134}$, ano de 1961; y os distúrbios promovidos pelo Frente Universitario Anticomunista [...] que chegaram ao extremo de obrigar o exército a patrulhar as ruas de Puebla ${ }^{135}$.

Como mencionamos anteriormente, os espaços de recrutamento são localizados dentro dos colégios e universidades privadas. Referindo-se novamente ao caso do MURO, o agente explica que no processo de seleção dos militantes se explorava "a mentalidade religiosa dos estudantes, a quem tratam de convencer da necessidade de depor as autoridades da UNAM, às que acusam de comunistas para suplantá-las por profissionais fanáticos pelo MURO". Podemos dizer, então, que se recrutam jovens de escolas religiosas para atacar nas universidades públicas.

Até aqui, o agente encontra na existência do MURO um fator ideológico, pois, como foi previsto por Plata Moreno, ao ser organizações estudantis desviava-se a atenção dos objetivos maiores. Contudo, a DFS adverte sobre os alcances do doutrinamento, que também iam no encontro do "assalto do poder público". Sem apresentar argumentos fundamentados, o informe aponta que a organização considerava os governantes mexicanos como "não católicos", para o qual sustentavam "princípios revolucionários contrários à religião".

No fundo, a análise das fontes financeiras das organizações universitárias teria contribuído para sustentar a ideia do assalto ao poder. $\mathrm{O}$ agente apresenta uma lista de indivíduos que vão além do clamor ideológico anticomunista, nacionalista ou religioso, para

de socialista" (ADAME GODDARD, 2003, p. 27). Por outro lado, os Irmãos das Escolas Cristãs chegaram no México a partir de 1905. Até 1914,haviam estabelecido colégios em Puebla, Saltillo, Monterrey, Morelia, Querétaro, Zacatecas, Cidade do México, Toluca e Torreón. Porém, os 196 franceses que integravam a congregação foram obrigados a fugir do país devido ao caráter jacobino da Revolução mexicana. Entre 1920 e 1938, retornam sigilosamente (COORDINACIÓN CENTRAL DE LA SALLE, 2014). Finalmente, no contexto da apressurada industrialização da economia mexicana, a Universidad La Salle inicia suas atividades em 1962, tornando-se, assim, a primeira universidade lasallista da América Latina. Atualmente, conta com 15 campi ao longo do território mexicano (UNIVERSIDAD LA SALLE, 2016).

${ }^{134}$ Octaviano Márquez y Toriz foi arcebispo da arquidiocese de Puebla desde 1950 até 1975, ano da sua morte. Encabeçou as manifestações contra a autonomia e o crescimento dos setores de esquerda dentro da planta docente e discente da universidade de Puebla. Tornou-se o porta-voz da oligarquia do estado contra o comunismo. Particularmente ligado ao FUA, é considerado, além de ideólogo, um dos financiadores desse grupo (DELGADO, 2003).

135 "MEMORANDUM: La UNAM víctima de la agitación promovida por MURO”, Distrito Federal, 04-04-68, AGN, IPS, Caix 1448 B, Exp. 42, folhas 1-4. 
tomar forma de grupo com interesse político. Grupos que, no contexto da solidez da instituição presidencial do sistema político mexicano, empreenderam uma "cruzada" pela hegemonia: a ordem lasallista anteriormente referida; "O grupo financeiro de Monterrey, através do engenheiro Javier Cobarrubias e do intermediário oculto do MURO, Bernardo Ardavín"136.

Não localizamos informações sobre o citado Cobarruvias. Porém, sobre Ardavín Migoni, a informação é muito mais ampla. Considerado como um dos hierarcas do Yunque, Ardavín foi vice-reitor da Universidad La Salle entre 1970 e 1974, cargo que lhe serviu para fomentar o trabalho de recrutamento para o Yunque nas diversas instalações. Chegou a ser um dos chefes nacionais da organização clandestina (DELGADO, 2003) ${ }^{137}$.

Finalmente, como outra das fontes de ingressos econômicos do MURO, menciona-se o grupo de Guillermo Guajardo Davis, "por meio de seu secretário, o refugiado cubano Carlos Lamar" ${ }^{\prime 138}$. Sobre o primeiro nome, encontramos que em 1961 Guajardo Davis foi diretor fundador do Consejo Nacional de Publicidad $(\mathrm{CNP})^{139}$. É uma organização considerada peculiar dentro da constelação de organizações empresariais, pois seu objetivo não é defender os interesses econômicos de um grupo, mas de "influenciar nos valores que, de acordo com seus dirigentes, devem prevalecer na sociedade mexicana" (RUÍZ OCAMPO, 1999, p. 12). Guajardo Davis contava com a simpatia do empresariado. Entre 1948 e 1950 foi presidente da Confederación de Cámaras Industriales de los Estados Unidos Mexicanos (CONCAMIN).

Num outro informe encontramos o nome de Luis Felipe Coello: um dos fundadores do Yunque, considerado um dos "doze iluminados" que ajudaram a Plata Moreno na estruturação da organização clandestina dentro da mitologia criada por eles mesmos (DELGADO, 2003). Personagem importante para entender a irrupção pública do Yunque na UNAM, em 1961. Ele foi quem concebeu a importância de deslocar um grupo de Puebla para a Cidade do México, sob a lógica de que a UNAM era o grande celeiro do comunismo. Presidente do MURO desde

\footnotetext{
136 “Memorándum: La UNAM víctima de la agitación promovida por MURO”, Distrito Federal, 04-04-68, AGN, IPS, Caix 1448 B, Exp. 42, folhas 1-4.

${ }^{137}$ Além desse trabalho secreto na década de setenta, Ardavín foi presidente da Confederación Patronal de la República (COPARMEX). A COPARMEX é um sindicato de empresários fundado em 1929 pelo industrial Luis G. Sada com a finalidade de se constituir num instrumento de pressão política que protegesse os patrões dos artigos constitucionais que beneficiavam os trabalhadores. Também se contrapôs às grandes centrais sindicais de operários e camponeses que funcionavam como base governista. Recentemente, Ardavín Migoni prestou seus serviços como assessor da SEGOB (2004-2005), da Secretaria del Trabajo (2003-2006), e fez parte da Comissão de Vigilância do Instituto del Fondo Nacional de Vivienda para los Trabajadores. Tudo isso durante o governo panista de Vicente Fox. No âmbito privado, é sócio e gerente de várias empresas de construção e dono da consultoria Estrategia Empresarial, que trabalha diretamente com o PAN (GONZÁLEZ RUIZ, 2012).

138 "MEMORANDUM: La UNAM víctima de la agitación promovida por MURO", Distrito Federal, 04-04-68, AGN, IPS, Caix 1448 B, Exp. 42, folhas 1-4.

${ }^{139}$ Organização ainda na ativa. Em 2001, mudou seu nome para Consejo de la Comunicación, A. C.
} 
sua fundação, a DFS o coloca como o enlace entre o MURO e o engenheiro Alfredo Medina Vidiella $^{140}$, membro distinguido do Frente Cívico Mexicano de Afirmación Revolucionaria (FCMAR).

O FCMAR surgiu como uma reação ao Movimiento de Liberación Nacional (MLN) que, encabeçado pelo general Lázaro Cárdenas, reunia um amplo espectro político que ia do centro à esquerda. Sua bandeira de luta era a defesa da Revolução Cubana ${ }^{141}$. O FCMAR, então, no seu manifesto publicado em 1961, fazia um chamado à sociedade civil para se organizar na margem de qualquer partido político para impedir a infiltração de doutrinas alheias:

que disfarçadas de um falso radicalismo pretendem precisamente suprimir as instituições democráticas, para substitui-las por um regime totalitário que acabaria com nossas liberdades e que, ao destruir a pátria, lar e família, terminaria para sempre com as formas tradicionais da vida mexicana (BRIZ, 2002, p. 105).

A Frente reunia empresários de Monterrey, Puebla e da Cidade do México. Entre os militantes de maior renome podemos citar os ex-presidentes Abelardo Rodríguez (1932-1934) e Miguel Alemán Valdés (1946-1952), ambos representantes da facção direitista do PRI, e paralelamente, empresários de sucesso após suas respectivas presidências.

Nas reuniões entre o MURO e o FCMAR descritas pela DFS se destacam duas questões. Por um lado, o FCMAR financiava a organização do MURO, por intermédio do

\footnotetext{
${ }^{140}$ Pioneiro da exploração madeireira na região da península de Yucatán. Fundador e diretor da Colonia Yucatán y De la Sierra, espaço onde se estabeleceram as empresas Maderas de Yucatán, Maderera del Trópico, Caobas Mexicanas e Lignum, todas sob a direção de Medina Vidiella.

${ }^{141}$ Depois de gestão como secretário da Defesa Nacional, entre 1940 e 1946, o general Lázaro Cárdenas volta à vida pública para a organização da Conferência pela Soberania Nacional, a Emancipação e a Paz, com o objetivo de criar uma frente anti-imperialista latino-americana. Realizada entre o dia 5 e 8 de março de 1961, a Conferência teve representantes de todos os continentes. Os eixos discutidos foram, entre outros, a premissa de que sem emancipação econômica não haveria independência política, que a luta contra o imperialismo era condição fundamental para qualquer plano de desenvolvimento dos países latino-americanos, e que a Revolução cubana mostrava o caminho para acabar com a dominação estrangeira. Nesse encontro foi decidido criar o MLN. O novo organismo representou a primeira frente ampla de caráter autônomo capaz de juntar todas as forças anti-imperialistas e partidárias, independentemente de filiação ideológica e classe social. Não era um partido, nem se propunha à luta eleitoral. O objetivo principal era defender um projeto de nação inspirado no nacionalismo da época cardenista. Sem ideologia específica, seu programa estava concentrado em quatro pontos: 1) a luta contra o imperialismo e suas guerras, 2) a defesa da soberania nacional, 3) a busca da democratização do país, e 4) a prática de uma série de reformas econômico-sociais que elevassem as condições de vida da população. O programa está baseado nos princípios constitucionais, ponderando métodos legais e pacíficos para a reforma do Estado. É uma experiência interessante, porque muitas das futuras lideranças guerrilheiras passaram pelas fileiras do MLN. O movimento, finalmente, não sobreviveu. Vários fatores determinaram a ruptura das organizações que o conformavam: não existia uma estratégia e tática definida; no interior se vivenciou uma luta pelo controle do movimento (muitos dos quadros eram lideranças do PRI, uma das questões que incomodavam a "esquerda doutrinária"); existia um desacordo sobre a questão eleitoral.
} 
jornalista Fernando Alcalá ${ }^{142}$, quem, por sua vez, recebia informação "acerca dos movimentos políticos de direita e de esquerda dentro da UNAM, [assim como sobre] os trabalhos que [o MURO] realizou para conseguir a unificação da direita”. Isto, pelo menos, desde 1962. O outro assunto em que Luis Felipe Coello e o engenheiro Medina Vidiella participavam ativamente, consistia em reuniões de caráter organizativo para a "construção de comités em Campeche e em Mérida, Yuc. [Yucatán]"143.

Agora, a relação entre o setor empresarial com o exílio cubano é uma questão pouco estudada e com poucas referências na historiografia. Nos documentos da DFS encontramos o nome de Henri Agüero Garcés, que participou de um atentado à dinamite contra as instalações do jornal, considerado de esquerda (El Día), em 1965. O MURO reclamou a autoria do atentado. Agüero Garcés ainda é apontado pelo jornalista Álvaro Delgado como integrante do Movimiento Nacionalista Cristiano, organização anticastrista com sede em Miami, Florida (DELGADO, 2003). O agente da DFS se refere à confabulação dirigida pelo MURO e à utilização da experiência contrarrevolucionária dos grupos cubanos.

O objetivo da aliança foi "planejar atentados terroristas no México com o propósito de obrigar nosso governo a mudar sua política com Castro Ruz"144. A esse respeito, no informe de 1968, o presidente Díaz Ordaz aponta, sem chegar a ser explícito, que “o tempo fará compreender a razão de quem, equivocadamente, tentam lastimar o México, porque persiste em se manter generosamente aberto para o povo cubano, sem distinção de divergências ideológicas ou políticas" (GDO, 1968, p. 248). Supomos que o receptor dessa mensagem seja diretamente o Yunque.

A DFS registra duas viagens com destino a Miami realizados por Plata Moreno e seu "segundo" no comando, Luis Felipe Coello. A finalidade das viagens era se reunir com "o agente anticastrista Aldo Rosado e com um senhor de sobrenome Dorticós, sobrinho do Presidente de Cuba (1959-1976), quem, ao que parece, se diz inimigo político de seu consanguíneo". O anticastrista Aldo Rosado Tuero fundou na década dos sessenta o jornalAcción, órgão de difusão do Movimiento Nacionalista Cristiano, anteriormente referido.

\footnotetext{
${ }^{142}$ Fernando Alcalá era originário da península de Yucatán. Trabalhou em grande parte dos jornais de circulação nacional. Era chefe de redação do Excélsior na data do informe citado (1964). Posteriormente, funda o jornal Avance, em Yucatán. Membro de uma família vinculada ao jornalismo, cujo membro mais destacado foi seu homônimo, Fernando Alcalá Pérez, um dos fundadores do sistema de notícias ECO, pertencente ao monopólio da comunicação, Televisa (PAXMAN; FERNÁNDEZ, 2013).

143 "Movimiento Universitario de Renovadora Orientación (MURO)”, Distrito Federal, 12-03-64, AGN, IPS, Caixa 2851 A, Exp. 14, folhas 1-5.

144 "Movimiento Universitario de Renovadora Orientación (MURO)", Distrito Federal, 12-03-64, AGN, IPS, Caixa 2851 A, Exp. 14, folhas 1-5.
} 
Rosado Tuero era o Chefe Nacional dessa organização ${ }^{145}$.

O agente da DFS adverte como os indivíduos Plata Moreno e Coello, "que inicialmente atuaram como católicos e anticomunistas sinceros", passam por um processo de radicalização: "se fanatizaram e agora se manifestam com verdadeira fobia contra o atual regime do Senhor Presidente Díaz Ordaz"146. Isto é, sem aprofundar na estrutura clandestina do Yunque, mas com os indícios da rede de relações e financiamentos que providenciou MURO, aponta para a transcendência da simples organização das juventudes católicas universitárias. Numa avaliação final, o agente comenta que o MURO:

dá-se à tarefa de organizar homens de negócios, industriais, comerciantes, profissionais e padres de família que lhes servem para se apoderar de associações cívicas, partidos políticos de oposição, câmaras de comércio, centros patronais, como meios para alcançar o poder ${ }^{147}$.

Os agentes que deram continuidade às atividades do MURO não chegam a elucidar a estrutura e objetivos do Yunque. No transcorrer dos relatórios encontramos um indício sobre a existência de vínculos entre Luis Felipe Coello e algum membro da hierarquia da Igreja católica ou do setor empresarial. Porém, a descrição das atividades dos jovens militantes da universidade estão apenas nos informes que adquirem um destaque especial. Uma possível explicação pode ser o fato de que o próprio Estado instrumentalizou essas organizações estudantis para não ter que intervir diretamente na confrontação com a esquerda nos espaços universitários.

As atividades do MURO resultaram benéficas para o apontamento e localização das principais lideranças de esquerda. Uma das principais atividades do MURO centrava-se na organização de protestos contra intelectuais universitários vinculados a ideias de esquerda, ou simplesmente com posturas críticas. Os métodos de protesto do MURO variam radicalmente em termos da aplicação da violência. Um primeiro nível - menos violento - pode se perceber na descrição dos protestos encabeçados por Luis Felipe Coello contra o intelectual Rubén Bonifaz Nuño ${ }^{148}$, que em 1964 foi nomeado diretor da Revista Universidad Nacional e da Gaceta Unviersitaria, "por se caracterizar com ideologia de esquerda". No ato da toma de

\footnotetext{
${ }^{145}$ Atualmente o indivíduo cubano, agora cidadão estadunidense, mantém a página web de notícias chamada Nuevo Acción. Disponível em: http://nuevoaccion.com/ [último acesso em: 30-05-16].

146 "Memorándum: La UNAM víctima de la agitación promovida por MURO", Distrito Federal, 04-04-68, AGN, IPS, Caix 1448 B, Exp. 42, folhas 1-4.

147 “Memorándum: La UNAM víctima de la agitación promovida por MURO”, Distrito Federal, 04-04-68, AGN, IPS, Caix 1448 B, Exp. 42, folhas 1-4.

${ }^{148}$ Poeta e tradutor de obras clássicas. Professor de latim na UNAM, foi membro da Academia Mexicana de la Lengua desde 1962.
} 
posse os muristas apareceram para gritar contra o intelectual.

Outra atividade frequentemente registrada nos relatórios era a realização e conferências dentro das instalações universitárias, sempre presididas por Coello. A DFS reportou a realização da palestra intitulada "O papel da juventude no mundo atual", realizada na Faculdade de Química da UNAM. Os convidados foram membros da Juventud Estudiantil Católica, da Liga Nacional de Estudiantes Mexicanos, do Frente Estudiantil "Newton”, e da Sociedad de Alumnos de la Facultad de Química ${ }^{149}$. Todas, sem mais, organizações de direita. Não temos informação sobre o acolhimento dos eventos pela comunidade universitária.

Sabe-se, também, da sistemática colocação de "periódicos murales", ou seja, cartazes em grande formato colados nos muros das instalações universitárias. Um relatório de 1974 traz a informação de um agente infiltrado na Preparatória No.9 da UNAM. O agente transcreve o texto: “os estudantes não devem aceitar ideias exóticas como o comunismo, socialismo, etc., alheias à pátria e às entidades estudantis do país que somente fomentam a desorientação e a divisão entre os estudantes. Morra o comunismo como câncer da humanidade". O agente também repara no desenho gráfico do mural, onde se plasma uma suástica nazista junto à mensagem intimidatória: "se aprecias tua integridade física, não mutiles ou destruas este mural"150.

O amedrontamento era frequentemente arma usada nas práticas dos muristas. No relatório intitulado "Antecedentes e atividades de Luis Felipe Coello Macías", aponta-se que Coello organizou um "comando" de nome "Mariano", composto por estudantes dos colégios privados Cristóbal Colón, México, Tepeyac, e da Universidad Iberoamericana (todos da rede lasallista). O objetivo do "comando Mariano" era a confrontação direta contra o grupo "Linterna" da Escuela de Economía da UNAM. Na Escola, o grupo de Coello foi expulso pelas autoridades após "queimar uma fotografia de Fidel Castro", agredir e ameaçar a estudantes considerados de esquerda. Outra das demandas do comando nessa ação era a exigência de que fosse "reduzido o horário às aulas de marxismo""151.

A prática mais comum do MURO, porém, é sua habilidade e eficiência na conformação de corpos de choque com métodos claramente paramilitares. No relatório de 23 de agosto de 1966, descreve-se o confronto com estudantes da Preparatoria No. 7 da UNAM. O conflito iniciou-se quando os estudantes proibiram a entrada do MURO, que pretendiam

\footnotetext{
149 "Movimiento Universitario de Renovadora Orientación (MURO)", Distrito Federal, 12-03-64, AGN, IPS, Caixa 2851 A, Exp. 14, folhas 1-5.

150 “Información General de los Estados”, 03-11-74, Distrito Federal, AGN, IPS, Caixa 1159 B, Exp. 4, folha 1.

151 "Movimiento Universitario de Renovadora Orientación (MURO)", Distrito Federal, 12-03-64, AGN, IPS, Caixa 2851 A, Exp. 14, folhas 1-5.
} 
vender seu órgão de difusão dentro das instalações ${ }^{152}$. Sem a adesão esperada por parte dos estudantes, somente alguns poucos adquiriram exemplares. A irritação chegou quando os muristas perceberam que os estudantes que tinham comprado o Puño iniciaram um comício denunciando as posições abertamente fascistas da organização, contidas na publicação. Nesse ato, os exemplares foram queimados. No dia seguinte:

chegaram cinquenta muristas aproximadamente, penetraram no interior das instalações ao grito de "en fila". Os que não levavam armas fizeram guarda de karatê; os demais portavam punhos de ferro, varas de metal, facas, navalhas, antebraços metálicos e paus com pregos ${ }^{153}$.

Finalmente, os estudantes conseguiram - mesmo sem a intervenção oportuna das autoridades da escola e com a chegada demorada dos corpos policiais - repelir a invasão dos muristas. Não temos notícias de feridos graves nesse confronto. Estes ataques de tipo paramilitar se tornarão recorrentes até a década dos oitenta dentro das instalações universitárias.

Noutro informe classificado como confidencial e urgente, exatamente um ano após o massacre de estudantes de 1968, ou seja, em 2 de outubro de 1969, o agente apostado no IPN informa sobre a reunião de vinte dirigentes de diversas escolas e faculdades dessa instituição. Seu intuito era organizar as atividades para lembrar a fatídica data. Além do relatório dos acordos, o agente chama à atenção sobre o "arteiro assalto" do espaço estudantil ocupado pelo Comité de Lucha da ESIME. Adverte, de igual forma, sobre a pichação deixada no lugar: "Primeiro aviso do MURO".

Apesar da longa experiência enfrentando os métodos da organização de direita, a avaliação dos estudantes, desta vez, apresenta uma divergência. Eles dizem estar

seguros de que foi o grupo de choque que têm o Governo do Distrito Federal, para repelir todo movimento revolucionário dos estudantes e operários. Disseram que o mesmo tinham feito na Preparatoria Popular, onde deixaram letreiros assinados pelo MURO.

Por volta de 1969, os estudantes tinham certeza da existência de grupos paramilitares organizados pelo governo do DF, aos que chamam "Los Halcones", "Los Vampiros" ou "Los

\footnotetext{
${ }^{152}$ A DFS guardou alguns exemplares dos jornais do MURO. No caso de Puño: Para golpear com la verdad! eBrecha Universitaria, podemos apreciar que a impressão era de dez mil exemplares para distribuição focalizada nas universidades públicas.

153 “Enfrentamiento", Distrito Federal, 23-08-66, AGN, IPS, Caixa 1611 B, Exp. 9, folha 1.
} 
Guante Blanco"154. Identificados como íntimos colaboradores do Serviço Secreto e do corpo de granaderos, bem como apoio das corporações policiais. Na desconfiança com que os estudantes avaliaram a autoria do MURO nos atentados contra as instalações universitárias, podemos perceber que existe uma linha muito tênue para diferenciar os paramilitares de direita com os do Estado.

Os relatórios da DFS poucas vezes apresentam uma análise de informação. Isto é, geralmente se resumem numa compilação de informações, baseada, sobretudo, no que os agentes escutam em reuniões, nos corredores de centros educativos, nas cafeterias. Assim, por exemplo, um agente aponta que:

Entre os diversos setores sociais desta Capital, há rumores de que os elementos do MURO e do organismo denominado "Boinas Verdes" são os autores da colocação das bombas que explodiram ontem a noite em diversos locais do Distrito Federal, com o objetivo de criar confusão e fazer crer à opinião pública que foram estudantes ressentidos por frustrar sua manifestação do sábado 10 do [mês] atual ${ }^{155}$.

Pela informação consultada, não conhecemos nenhuma organização ou corporação mexicana denominada "Boinas Verdes". Ou melhor, sabemos que esse é o nome do esquadrão de elite antisubversivo do exército dos EUA, denunciado por praticar e ensinar técnicas de "tortura, assassinatos seletivos de prisioneiros e combatentes, contribuir nas matanças de indígenas, treinar grupos paramilitares, etecétera, nos países chamados eufemisticamente "nações hóspedes"” (LÓPEZ Y RIVAS, 2012, p. 46). Ou seja, nos regimes que solicitam sua assessoria $^{156}$.

Na avaliação dos ataques perpetrados em 1972, indica-se que:

as características dos fatos têm o selo inconfundível do grupo dos "Boinas Verdes" que na América Central e do Sul propiciaram alianças entre fanáticos e técnicos devidamente treinados nesse tipo de atos e, nesse caso,

\footnotetext{
154 “Informe confidencial: Instituto Politécnico Nacional”, Distrito Federal, 02-10-69, AGN, IPS, Caixa 1494 B, Exp. 6, folhas 1-2.

155 "Se rumora entre los diversos sectores sociales (...)”, Distrito Federal, 10-06-72, AGN, ISP, Caixa 1783 D, Exp. 13, folhas 1-2.

${ }^{156}$ A partir do levante do Ejercito Zapatista de Liberación Nacional (EZLN), em 1994, temos maior clareza sobre um corpo de elite treinado pelos EUA. Conhecidos como "boinas verdes mexicanos", o Grupo Anfibio de Fuerzas Especiales (GAFES), atualmente, chama-se Cuerpo de Fuerzas Especiales de México. O grupo foi escalado pelos altos mandos militares mexicanos, e treinado com verba e tecnologia estadunidense na nova versão contrainsurgente da guerra de baixa intensidade inaugurada em El Salvador e Nicaragua, faz alguns anos. Por volta de 2007, um total de 1.378 homens de um total de 5.500desses gafes(assim conhecidos devido à sigla do grupo) desertaram do exército e iriam compor um dos grupos de assassinos mais violentos que operam atualmente no território mexicano: Los Zetas, vinculados ao narcotráfico, ao sequestro e venda de pessoas (REYES, 2009).
} 
os membros do MURO, considerando-se que as perícias sobre os restos dos explosivos demostraram que os autores são peritos na matéria ${ }^{157}$.

Finalmente, acrescenta-se, apesar da polícia ter prendido "alguns suspeitos”, os verdadeiros culpados estariam naquele momento fora do país. Não localizamos mais elementos que apontassem para essa linha de investigação. Porém, existem listas com os nomes de militantes presos e processados por atividades subversivas relativas a 1972, e em nenhuma delas há referência a militantes do MURO condenados ou julgados [fig. 15] ${ }^{158}$.

\subsubsection{Rumores}

As atividades da direita, como visto, não se restringem ao âmbito universitário. Durante o sexênio do presidente Echeverría aparece um fenômeno novo dentro das práticas políticas da oposição de direita: a implantação sistemática de rumores desestabilizadores.

Em 1973, a defesa do processo político chileno, a condenação ao golpe de Estado, mas, principalmente a recepção de exilados sul-americanos mobilizou de novo os setores anticomunistas mexicanos, e de uma forma ainda mais agressiva. Embora contemos com registros de rumores prévios a 1973, que vão até o fim do mandato de Echeverría, nota-se uma mudança no destinatário do rumor. Em 1971, por exemplo, sobre uma campanha oficial de vacinação de crianças contra a tifo em escolas públicas, dizia-se que na realidade estavam aplicando medicamentos para a esterilização de meninos e a destruição do útero das meninas (AGUSTÍN, 2013). Ainda que o rumor tivesse seguido uma rota que abrangia boa parte do país, na cobertura feita pelo jornalista Manuel Buendía, foi no estado de Guerrero que o pânico teve maior reverberação entre as classes menos favorecidas.

São várias as teorias sobre os métodos de espalhar o rumor. Para Buendía, utilizavamse "camionetes de som, que surpreendentemente percorreram alguns bairros operários para desaparecer imediatamente com igual mistério" (BUENDÍA, 1984, p. 32). Para a DFS, as falsas notícias eram propagadas por jornais locais. Aponta-se que os rumores "têm produzido psicoses entre os pais de família, e estão sendo desmentidos categoricamente por toda classe de atividades tanto municipais como estaduais e federais". No mesmo relatório, o agente

\footnotetext{
157 "Se rumora entre los diversos sectores sociales (...)", Distrito Federal, 10-06-72, AGN, ISP, Caixa 1783 D, Exp. 13, folhas 1-2.

158 "Relación de las vicitas (sic) que resibieron (sic) el día de aller (sic) los llamados presos políticos de la Cárcel Preventiva de la Cd.", Distrito Federal, 21-08-72, AGN, IPS, Caixa 953, folhas 1. / "Cárcel preventiva de la ciudad y de mujeres", Distrito Federal, 30-09-73, AGN, IPS, Caixa 1490 A, folhas 1-11.
} 
acusou o sensacionalismo de vários jornais de circulação local como El Gráfico, Prensa Libre, Crónica Gráfica e La Verdad de Guerrero ${ }^{159}$. Junto com estas manobras mediáticas soma-se o fato de que o PAN, "tomou por certa a existência daquela classe de vacina e exigiu contas publicamente ao governo" (BUENDÍA, 1984, p. 32). Ardil político que sustentava o rumor e promovia a generalização do pânico.

Segundo a DFS, o fim do pânico foi possível pela matéria aparecida noutro meio impresso, El Sol de Medio Día, intitulada "Prenderam os monges que injetavam crianças em Acapulco" [fig. 16]. A redação afirmava que foram presos um par de norte-americanos, homem e mulher, de nome Arthur P. Aerutis e Vanimpe Aprudiff. Evidentemente "perturbados mentais", ambos foram flagrados vestidos como religiosos e efetivamente injetando sustâncias químicas em crianças da entidade ${ }^{160}$.

Com estes precedentes, podemos deduzir dois possíveis centros geradores do rumor. Por um lado, considerando que o estado de Guerrero é um dos que apresentaram maior atividade guerrilheira desde a década de sessenta, difundir a presença de sujeitos estranhos e suspeitos com a finalidade de danar crianças, poderia ser uma maneira de desarticular as possíveis redes de solidariedade em torno aos guerrilheiros que permaneciam na clandestinidade. Ou melhor, além de negar ajuda a pessoas desconhecidas, também poderia ajudar para que os próprios moradores da região denunciassem qualquer movimento fora do normal.

De maneira inversa, devemos lembrar que o estado estava submerso na lógica contrainsurgente. $\mathrm{O}$ estado de Guerrero estava militarizado. $\mathrm{O}$ exército dedicava-se publicamente a atividades que teoricamente conhecemos como "ação cívica", em que o assistencialismo social nas regiões de maior força guerrilheira era uma constante ${ }^{161}$. Assim, o exército geralmente comandava as campanhas de vacinação, sendo que o rumor de que tais campanhas seriam danosas às crianças, produziria, além do repúdio, a mobilização dos moradores para exigir a expulsão dos militares da região. Infelizmente não temos mais

159 "En los diferentes sectores de la entidad, se comenta positivamente las labores que efectúa el Ejército", Chilpancingo, 14-12-71, AGN, IPS, Caixa 1783 D, Exp. 13, folhas 1-4.

160 "Atraparon a los monjes que inyectaban a niños, en Acapulco", El Sol de Medio Día (p. 4), Chilpancingo, 1512-71, AGN, IPS, Caixa 1783 D, Exp. 13, folha 1.

${ }^{161}$ Tanto a ação cívica como as operações de caráter psicológico estão localizadas dentro do que é conhecido como Guerra de Baixa Intensidade (GBI). O exército é empregado em tarefas que não são propriamente militares com o objetivo estratégico de construir um consentimento ativo e organizado em torno ao funcionamento do sistema imperante. Para chegar a um clima favorável para o desenvolvimento da GBI, utilizam-se as forças militares em dois sentidos; tanto para limpar seu historial repressivo, como para legitimar sua participação na política repressiva do Estado: "O ser humano tem seu ponto mais crítico na mente. Uma vez alcançada sua mente, foi vencido o 'animal político', sem receber necessariamente balas [...] Esta concepção da guerra de guerrilhas como guerra políticaconverte as operações Psicológicas no fator determinante dos resultados" (EZCURRA, 1988, p. 96). 
informação sobre os desdobramentos dos rumores nas regiões de intensidade guerrilheira.

Enquanto isso, entre o 18 e o 21 de novembro de 1976 - um mês antes da transmissão de poderes como prevista e que tradicionalmente ocorre no primeiro de dezembro - vários rumores com outras características tornavam-se em sérias ameaças para a segurança nacional. Os relatórios concernentes simplesmente apresentam uma compilação das versões que circularam em várias cidades do país. Porém, é notável que revelam as contradições entre as versões dos rumores e algumas das reações populares perante uma ameaça que nunca tinha sido uma possibilidade real para essa geração de mexicanos. Este novo rumor girava em torno a um golpe de Estado iminente. Como todo rumor, as confusões e versões contraditórias percorreram o território.

Primeiro, dizia-se o golpe de Estado seria realizado contra o governo de Echeverría, seja pela ação do terrorismo comunista, quer por uma suposta facção de militares ultranacionalistas. Numa segunda versão, o golpe seria dado pelo próprio mandatário no intuito de instaurar reformas socialistas. Em ambas as versões, no fundo, encontra-se a reação contra o discurso abertamente terceiro-mundista referido anteriormente.

$\mathrm{Na}$ cidade de Jalapa, Veracruz, a imprensa local foi identificada pela DFS como os propagadores dos rumores. $\mathrm{O}$ agente cita uma breve matéria do jornal $A B C$ em que se destaca que "dentro da campanha de rumores, hoje transcendeu, de última hora, que a esposa do presidente Echeverría e seu filho Pablo tinham sido vítimas de um atentado em que pereceram". O agente, além disso, recolhe o rumor ouvido nas ruas sobre a possibilidade de que as sucursais bancárias "podem ser dinamitadas" "162, neste caso, apelando aos métodos da esquerda.

Neste mesmo sentido um agente reporta que num bairro da cidade de Guadalajara, sem mencionar o local específico, encontraram-se as seguintes pichações:

Proletariado, a resposta operária à crise econômica deve ser a revolução socialista.

Proletários, nenhum apoio às oligarquias financeiras e seu governo.

Proletários, respondamos pela revolução à "política de cinturón apretado" de Portillo.

Proletários, o 20 de novembro triunfaremos.

Assina: Revolución Proletaria ${ }^{163}$.

Sobre este informe, por não ter mais dados em torno ao suposto grupo que realizou as

\footnotetext{
162“'Información de Veracruz”, Jalapa, 19-11-76, AGN, IPS, Caixa 1747 B, Exp. 6, folhas 1-2.

163 "Por medio de pintas se invita a la ciudadanía", Guadalajara, 19-11-76, AGN, IPS, Caixa 1747 B, Exp. 6, folha 1 .
} 
pichações, podemos especular duas coisas. Primeiro, que a esquerda organizada aproveitou o clima de nervosismo para tentar fazer um chamado ao operariado mexicano. Outra possibilidade é que uma ou várias pessoas que orquestraram os rumores teriam inventado algum nome que referisse à esquerda para apoiar a hipótese de que o governo de Echeverría tinha um pacto com grupos "marxistas" para dar o golpe. Ou, também, uma possibilidade é que a direita utilizara esse nome para gerar aversão contra a esquerda. O nome "Revolución Proletaria" bem poderia pertencer a algum grupo de esquerda, porém, não temos elementos para confirmar sua existência.

Sob a hipótese da possibilidade de que um grupo de esquerda desse um golpe, a DFS informa a respeito das demonstrações de preocupação expressadas nos EUA. Jack L. Richardson, subchefe da Border Patrol em Del Río, Texas, assim como Lee G. Kreeimer, chefe de migração nessa mesma cidade, comunicaram-se telefonicamente com o chefe da Oficina de Población da cidade Acuña, Francisco González Quintanilla. Eles disseram ter informação sobre a intensidade dos distúrbios na fronteira. Provinha de um suposto telegrama vindo de McAllen, Texas, afirmando "que havia terroristas nas pontes de Hidalgo, Tex. E de Progreso, Tamps. [Tamaulipas], brigando com os oficiais" "164. A informação, aponta o agente, foi negada pelos funcionários mexicanos que aproveitaram para alertar os norte-americanos sobre a diversidade de informações e a pouca clareza sobre a origem delas.

Por outro lado, no DF se reportou à circulação de um rumor no IPN. Um agente não identificado aponta que em várias escolas do Instituto estão recomendando que os alunos avisassem seus familiares para que não venham "presenciar o desfile cívico que se realizará para comemorar o aniversário da Revolução Mexicana”. Afirmavam que seria o espaço em que se deflagaria o autogolpe de Echeverría. Para os estudantes, uma facção radicalmente nacionalista próxima do mandatário seria a articuladora, pois

o Lic. Luis Echeverría é filho de pais estrangeiros, motivo pelo qual seus familiares não são conhecidos como no caso de sua Senhora e é por esta causa que tem afetado tanto à economia nacional; pois em nenhum momento lhe interessam os mexicanos, sendo que unicamente se preocupa por sua família e seus amigos estrangeiros ${ }^{165}$.

Uma série de rumores que "a cada momento se tornam mais intensos" apontam que o

\footnotetext{
164 "Autoridades fronterizas norteamericanas", Ciudad Acuña, 20-11-76, AGN, IPS, Caixa 1747 B, Exp. 6, folha 1.

165 "Circula un fuerte rumor en las escuelas del IPN", Distrito Federal, 18-11-76, AGN, IPX, Caixa 1747 B, Exp. 6 , folha 1 .
} 
presidente Echeverría tinha sido ferido por uma bala no estado de Sonora, enquanto realizava uma visita oficial. Pelo boato, o atentado seria o motivo real pelo qual suspendera sua visita ao estado de Durango, e não por causa de uma gripe, como foi informado oficialmente. O agente registra no relatório que paralelamente corria palavra de que o general Hermenegildo Cuenca Díaz, secretário da SEDENA, junto a outros militares de alta patente, foram presos, "apontados de estar preparando um golpe de Estado nos próximos dias"166.

Na cidade de Reynosa, no fronteiriço estado de Tamaulipas, comentava-se que o golpe de Estado era deflagrado pelo próprio presidente Echeverría, que "tratará se reeleger por mais dois anos". O agente ouviu essa mesma versão em alguns pontos de reunião, como restaurantes e casinos. Enfatiza que "alguns canais de televisão e rádio dos Estados Unidos tem dado como notícia” o golpe. Segundo a análise do agente, essa situação reforçou o boato, fazendo com que qualquer notícia que desmentisse o rumor fosse desconsiderada de forma geral pela população ${ }^{167}$.

Nesta mesma linha, na cidade de Zacatecas, registrou-se que "pessoas dos diferentes círculos sociais" preveem a possibilidade de que ocorram distúrbios em vários estados da república, "principalmente em Sonora com o fim de levar a cabo um golpe de Estado". Como mencionamos anteriormente, o mandatário encontrava-se em Sonora antes do 20 de novembro. Menciona-se, também, que "há um distanciamento entre o Lic. Luis Echeverría Álvarez, Presidente do México e o Lic. José López Portillo, Presidente eleito" ${ }^{168}$. Nesta cidade, pois, deixa-se ver a possibilidade de que o golpe seja realizado com a finalidade de evitar a presidência de López Portillo.

Esta informação foi providenciada por um prefeito do estado de Baja California, Fernando Marqués Arce, que afirmou ter sido informado pela Polícia Municipal sobre o possível golpe, um decreto de estado de exceção, “e que o Presidente da República se fará responsável provisionalmente pelo Poder Executivo Federal, para, posteriormente convocar novas eleições"169.

O falatório do golpe se valia igualmente do clássico método do "panelaço chileno". O congelamento das contas bancárias mobilizou a população de várias cidades como Saltillo, Colima e Mazatlán. A pavorosa teve repercussão, sobretudo, dentro das classes médias. Na cidade de Tepic, Nayarit, “começou a se espalhar o pânico entre os correntistas das distintas

\footnotetext{
166 "Han circulado intensamente los rumores de que el presidente de la república fue herido de un balazo", Durango, 18-11-76, AGN, IPS, Caixa 1747 B, Exp. 6, folhas 1-2.

167 "Hay desconcierto entre la población”, Reynosa, 18-11-76, AGN, IPS, Caixa 1747 B, Exp. 6, folhas 1-2.

168 "Información de Zacatecas", Zacatecas, 19-11-76, AGN, IPS, Caixa 1747 B, Exp. 6, folha 1.

169 "Se observa completa calma en esta ciudad", Tijuana, 19-11-76, AGN, IPS, 1747 B, Exp. 6, folha 1.
} 
sucursais do banco privado nesta cidade". O suposto golpe de Estado motivou a saída de pequenos e medianos capitais dos diversos bancos da região, alcançando entre "os cinquenta e cem cartões cancelados" $" 170$.

As reações tiveram diversas intensidades. No relatório correspondente à cidade de Tijuana, Baja California, o agente cita conversações com empregados bancários, e inclusive com o subgerente do Banco Internacional de Baja California. Os entrevistados apontam que até esse momento não se tinham registrado retiros ou trocas de divisas que fossem significativos para alarme. Por outro lado, assinalam que, apesar dos rumores e da evidente "falta de confiança por parte dos correntistas, não se registrou nada anormal e que seguem as mesmas atividades comerciais" $" 171$.

$\mathrm{O}$ agente de Reynosa registra as repercussões em quanto à possibilidade de incremento no preço dos energéticos. $\mathrm{O}$ agente é enfático acusando os próprios funcionários federais que no meio da crise de pânico "afirmam que não sucedera nenhuma medida de que não subiriam os energéticos e posteriormente o fazem" ${ }^{\prime 172}$. Por outro lado, a iminente desvalorização da moeda mexicana provocada pela crise política também provocou um movimento anormal de operações bancárias. No estado de Tlaxcala "registraram-se compras de dólares de mais de 300 mil dólares" $" 173$.

Sem pronunciamentos oficiais registrados, num relatório de 21 de novembro, da cidade de Villahermosa, Tabasco, o presidente Echeverría questionado pelos repórteres sobre a boataria, "criticou os mexicanos malnacidos que propalavam rumores [desde] o dia 19 de mês e curso"174.

Alguns agentes lançam nos seus informes algumas hipóteses sobre a origem dos rumores. Como mencionamos, não existem análises sérias, simplesmente se realizam afirmações sem fundamento, geralmente baseadas em outros rumores ou preconceitos. Num relatório do DF, de maneira categórica se assevera que:

A onda de rumores com diferentes versões entre amas de casa, empregados, trabalhadores, lideranças menores de alguns organismos políticos e chefes dos mesmos, são consequência de que agitadores como os do Partido Laboral Mexicano [...] faz vários meses tem-se dedicado a atacar

\footnotetext{
170 "Hoy se registraron varios retiros", Tepic, 19-11-76, AGN, IPS, Caixa 1747 B, Exp. 6, folha 1.

171 "Se observa completa calma en esta ciudad", Tijuana, 19-11-76, AGN, IPS, 1747 B, Exp. 6, folha 1.

172 "Hay desconcierto entre la población”, Reynosa, 18-11-76, AGN, IPS, Caixa 1747 B, Exp. 6, folhas 1-2.

173 "Hoy se rumoró que mañana se llevará a efecto un golpe de Estado", Tlaxcala, 19-11-76, AGN, IPS, Caixa 1747 B, Exp. 6, folhas 1-2.

174 "Información de Villahermosa", Villahermosa, 21-11-76, AGN, IPS, Caixa 1747 B, Exp. 6, folha 1-2.
} 
funcionários e ex-funcionários do atual regime ${ }^{175}$.

O elemento em que se fundamenta esta acusação é a presença de nomes de funcionários do governo de Echeverría apontados como fantoches do governo norteamericano de Jimmy Carter, através do órgão de difusão do Partido Laboral Mexicano. Ou seja, podiam ler-se más intenções nessas acusações.

Em outro informe, com item correspondente à situação apresentada na cidade de Tijuana, que trata da distribuição do jornal Evening Tribune dos EUA, na primeira folha se lê: “Tentativa de golpe do México é negada". O revelador do relato não é a transcrição da matéria do jornal, que, de fato, não aporta nenhum dado relevante. Mas, nas últimas três linhas, que fogem totalmente da questão do jornal norte-americano, sim há. Não são dadas explicações, simplesmente se menciona que "chegou-se a saber que estes rumores estão sendo propalados pelas secretarias dos bancos e em grupos religiosos, como os Caballeros de Colón, que se encarregam dos mesmos" ${ }^{\text {176. }}$.

A partir desta informação, podemos juntar outros dados localizados num breve informe sobre Tlaxcala, onde se menciona que o rumor apareceu, pela primeira vez, em escolas de educação superior, ou seja, universidades. Especificamente "de estudantes tlaxcaltecas que assistem na Universidad Autónoma de Puebla", como tínhamos dito, celeiro dos grupos anticomunistas estudantis antes referidos.

Finalmente, no relatório datado de 24 de novembro de 1976, destaca-se o boletim informativo da Central Nacional Campesina (CNC) distribuído nos principais jornais de circulação nacional, bem como entre os telejornais da empresa Televisa. A CNC se posiciona a respeito dos rumores de golpe e "denunciam que Andrés Marcelo Sada, manipulador do lembrete da COPARMEX, é ponta-de-lança do imperialismo e autor de atentados contra o México". A denúncia está baseada no vínculo sugerido entre a intensificação dos rumores e uma importante greve em diversos setores promovida pelo empresário Sada.

Sada é acusado, assim, pela retirada de capital do país para investi-lo em bens imóveis nos EUA. Motivo pelo qual é acusado pela central camponesa de traição à pátria:

Deixamos assentado que, com suas fobias, seus preconceitos e sua perversidade antinacionalista, compromete seriamente o setor que diz representar e que os verdadeiros industriais logo expressarão seu repúdio a quem é autor dos murmúrios contra o México e quem pretende, com a

\footnotetext{
175 "Serie de rumores que se han propalado en la Ciudad", Distrito Federal, 19-11-76, AGN, IPS, Caixa 1747 B, Exp. 6, folhas 1-4.

176 "Información de Baja California", Tijuana, 20-11-76, AGN, IPS, 1747 B, Exp. 6, folhas 1-2.
} 
caricatura grotesca de Pinochet, dar lições de direito e de moral ${ }^{177}$.

Desta maneira, o informe chama a atenção de que o boletim foi impresso na Câmara dos Deputados. Considerando que a CNC é uma organização oficialista, totalmente alinhada com o presidente, poderíamos considerar, pois, que ela é versão oficial.

Agora, considerando o anterior, assim como algumas conclusões expostas pelos agentes nos relatórios, podemos depreender três possíveis sujeitos propagadores dos boatos: os EUA, os grupos católicos de ultradireita e os empresários encabeçados por Andrés Sada. Estes dois últimos grupos, como vimos no item anterior, podem ser considerados como grupos que compartilham objetivos e métodos e ideologia. Neste sentido, localizamos uma reveladora nota editorial assinada por uma das personalidades mais controversas do jornalismo mexicano, Salvador Borrego Escalante ${ }^{178}$.

Para o escritor existem uma série de sinais que demonstram as tentativas do presidente Echeverría para diminuir o peso político - e militar - das forças armadas. Os tradicionais desfiles militares realizados anualmente em comemoração ao início da luta pela independência mexicana (16 de setembro) foram a fachada perfeita para mostrar os planos presidenciais.

Segundo Borrego, uma primeira debilidade expressa pela corporação castrense era sua "feminização":

Seus vestidos e uniformes eram dos mais variados: desde saias longas típicas, até minissaias, micro-saias e algo assim como uma aproximação de biquini. Quanto aos passos de marcha, era uma mescla de paso redoblado e paso de camino, em momentos com marcadas ondulações de cadeira ${ }^{179}$.

A participação de um total de mil quinhentos e setenta mulheres enquadradas nas Forças Armadas se justificava pelo argumento oficial de que "se a mulher desfruta dos mesmos direitos do homem, tem as mesmas obrigações”. Contudo, isso é uma mostra da debilidade da corporação. Borrego ironiza: "Quer-se igualar o que é por natureza diferente?

\footnotetext{
177 "Boletín informativo de la CNC", Distrito Federal, 24-11-76, AGN, IPS, Caixa 1747 B, Exp. 6, folhas 1-4.

${ }^{178}$ Escritor e jornalista, nascido em 1915. Autor do livro Derrota Mundial (1953) em que expõe, a partir da análise dos primeiros anos da Guerra Fria, os mecanismos da suposta infiltração judeu-maçônica-comunista. Abertamente partidário do nacional-socialismo, é o mais reconhecido defensor das teses de Hitler no México. Sua extensa obra jornalística e bibliográfica serviu de inspiração para o Yunque e outros grupos estudantis de direita, bem como para os quadros fundadores do PAN (PROCESO, 2008). Ainda hoje existem grupos de estudos da obra deste escritor, sobretudo, entre os setores neonazistas.

179 “"Plan Y' en México. Postergación del Ejército”, BORREGO, Salvador, El Norte, Monterrey, 19-09-76, AGN, IPS, Caixa 1747 B, Exp. 6, folha 1-2.
} 
Se da mulher se lhe quer fazer soldado, não se pretenderá também converter o homem em mãe?".

Para além da suposta fragilização do corpo militar pela presença sexual e pela paquera da mulher mexicana, o verdadeiro problema é a insistência oficial em que o exército tem uma função social. Versão que "deslava, distorce e mutila as funções especificamente castrenses, até converter a milícia numa sociologia de partido".

$\mathrm{Na}$ visão de Borrego, ambas as modificações são idênticas nos seus resultados às transformações "progressistas" que se pretendem introduzir na instituição mundialmente mais sólida, a Igreja Católica. Isto é, o autor observa na "desmilitarização" do Exército e no paralelo processo de "dessacralização" da igreja, um perigoso buraco por onde os movimentos revolucionários "de tipo marxista" podem ir-se acomodando. Cita alguns exemplos internacionais para, segundo ele, entender o que está acontecendo no México:

Para que o marxismo pudesse triunfar na URSS foi necessário acabar com os comandantes e a oficialidade do Exército. O comunismo foi vencido na Espanha pelas forças armadas. O movimento marxistoide de Goulart no Brasil foi desbaratado também pelo Exército. Em Cuba, o marxismo pôde consolidar-se até que esquartejasse o exército e o substituiu com milicianos e comandos soviéticos.

O autor alerta: para que o marxismo seja implantado, é necessário fragilizar as cúpulas dos exércitos nacionalistas. Por outro lado, o fortalecimento desses exércitos ajuda à destruição dessas forças contrárias à pátria. Para Borrego, México está dentro do grupo "progressista", seguindo os exemplos impostos pelo governo de Allende no Chile.

Borrego ressalta, enfim, os métodos empregado por Allende e o suposto "Plano Z". Devido à perda de apoio popular para a instauração total de um Estado socialista, o mandatário chileno tentara assassinar os chefes do exército, no intuito de substituí-los por milicianos "fanatizados no socialismo". Adverte que Echeverría está caminhando nesse mesmo sentido com o desfile do corpo feminino e a "fragilização de suas tradições militares com o plausível fim do 'serviço social', e doutrinamento de seus mandos com aulas de ‘civismo' e de 'história' que são materialismo dialético" ${ }^{\text {"180 }}$.

Sob esta mesma linha, localizamos um documento assinado por uma suposta "Unión Defensora del Ejército Mexicano" [fig. 17]. Escrito como espécie de manifesto dirigido "a todos os Chefes Oficiais e Classes de nosso Glorioso Exército Nacional”, o documento se

\footnotetext{
180 “'Plan Y' en México. Postergación del Ejército”, BORREGO, Salvador, El Norte, Monterrey, 19-09-76,
} AGN, IPS, Caixa 1747 B, Exp. 6, folha 1-2. 
intitula "O comunismo inimigo mortal dos militares". Nele se enfatiza que, em geral, os exércitos nacionalistas são os inimigos naturais das organizações comunistas, de fato, o maior obstáculo para seu triunfo. Descreve-se, também, as táticas utilizadas para debilitar a corporação castrense: infiltração, propaganda, e propagação de atos imorais que contribuam à indisciplina, que, portanto, corrompam a moral militar. Havia também assassinatos de chefes e oficiais que se opunham à dominação comunista.

A tática mais eficaz para a destruição dos exércitos, segundo o panfleto, consiste em:

desvirtuar os verdadeiros fins e objetivos do exército, fazendo que estes se dediquem a atividades alheias a suas verdadeiras funções, que são a defesa e salvaguarda da nação e suas instituições contra seus inimigos internos e externos, e se distraiam em ações de chamada "Labor Social" ou outro tipo de atividades totalmente alheias e contraditórias à verdadeira finalidade do exército mexicano, como são, por exemplo, as chamadas "Granjas Coletivas Militares" onde atualmente os comunistas infiltrados em nosso atual governo querem que se concentrem as energias de uma grande parte de nossos contingentes para distraí-los de sua missão de salvaguarda da pátria, e para que os chefes oficiais e tropa vão-se acostumando a viver sob um regime de "coletivização", que é o mesmo que um regime comunista ${ }^{181}$.

Nesta análise, o governo estaria infiltrado pela grande quantidade de exilados “comunistas chilenos, espanhóis, uruguaios, etc., que covardemente fugiram de seus países quando os governos patriotas e os exércitos desses países lhes impediram que seguissem seu nefasto trabalho".

Da mesma forma que Salvador Borrego, o panfleto cita o "Plano Z" chileno. Como mencionado acima, consistia na eliminação dos mandos militares nacionalistas. Segundo o ponto quatro do plano, citado literalmente, os guerrilheiros que funcionavam como guardacostas de Allende, ou melhor, o Grupo de Amigos Personales (GAP) constituído por militantes do Movimiento de Izquierda Revolucionaria (MIR) ${ }^{182}$, atuariam de maneira coordenada aproveitando as concentrações militares das comemorações à pátria. Este dado é importante para considerar que o rumor alcançou o grau máximo de paranoia um dia antes das comemorações da Revolução Mexicana.

O panfleto cita, além do Plano Z, o livro intitulado Peligro: Subversión en América, atribuído ao general Manuel Benítez, em que se descrevem as táticas utilizadas pelas forças

\footnotetext{
181 “Ante los planes siniestros venidos de los más altos niveles de nuestro gobierno”, Distrito Federal, 1976, AGN, IPS, Caixa 1747 B, Exp. 6, folhas 1-5.

182 O MIR foi um grupo guerrilheiro chileno fundado em 1965. Após a vitória eleitoral de Salvador Allende, em 1970, o MIR declara que haverá uma trégua nas ações armadas, abandonando, assim, a clandestinidade e iniciando um processo de formação de um partido de massas. Alguns quadros políticos e militares do MIR participariam ativamente no governo da Unidade Popular.
} 
comunistas lideradas por Sukarno, na Indochina, com o objetivo de assassinar militares. Tentativa que finalmente se viu frustrada pela ação nacionalista do exército com grande apoio popular. Cita, também, os casos em que esta tática comunista teve sucesso. As referências, especificamente, são a Revolução Russa e a formação do Exército Vermelho, assim como a mais recente e próxima experiência cubana, na qual o "tirano Castro Ruz", uma vez que tomou o poder, em 1959, "fuzilou os militares que não se subjugaram".

Um sinal de alerta se deu no tradicional desfile militar do 16 de setembro de 1976, no qual Raúl Castro participou como convidado especial da presidência, enquanto que "em Santiago de Cuba mandou metralhar 81 membros da oficialidade do exército cubano alinhados na frente de um buraco previamente aberto com um buldôzer onde depois foram sepultados". Perguntam: "Será isso o que querem implantar no México os comunistas 'Oficiais' e os comunistas infiltrados no PRI que estão reproduzindo as mesmas táticas que os comunistas usaram em tantas outras ocasiões?".

Este peculiar documento de cinco páginas está acompanhado da fotocópia de um envelope cujo remitente é o major José M. Pulido Gómez, da Escuela Militar de Ingenieros. Possivelmente, o manifesto circulava dentro da instituição. Na historiografia sobre as forças armadas mexicanas, não existe nenhuma referência à citada Unión Defensora del Ejército Nacional $^{183}$.

Embora não encontremos documentos da inteligência que tornassem explícita a relação dos rumores com algum grupo específico, destacamos o fato de que, desde 1974, Echeverría alertava: "Golpes de Estado em alguns países latino-americanos foram precedidos pelas campanhas de rumores que se originam em alguns círculos empresariais irresponsáveis ou que fomentam estes atos de terrorismo para suscitar a confusão" (LEA, 1974, p. 181). Um ano depois, o mandatário declarava que:

Grupos minoritários suscitam, todavia, anacrônicas querelas e tentam minar a autoridade das instituições. Aspiram a predominar atrelados a seu poder econômico. Supõem, ainda, que as transações na cúspide podem substituir as verdadeiras soluções e perpetuar, para eles, uma era de facilidade e de abundância. Ignoram o curso da história e pretendem, de forma estéril, detêla. Entusiasmaram-se muitos desses grupos quando ocorreu o golpe de estado na república irmã do Chile. São grupos econômicos, poucos, por sorte, cada vez menos (LEA, 1975, p. 268-269).

Echeverría se vale de uma caracterização irônica dessa elite quando sugere que "si

\footnotetext{
183 “Ante los planes siniestros venidos de los más altos niveles de nuestro gobierno", Distrito Federal, 1976, AGN, IPS, Caixa 1747 B, Exp. 6, folhas 1-5.
} 
muitas horas que se dedicam ao [jogo de] canastra uruguaia, aos desfiles de modas e a murmurar contra o próximo, se dedicassem um pouco a servir ao próximo, avançaria muito o México". Isto é, aparentemente, para o mandatário as origens dos rumores estavam claras (LEA, 1975, p. 281).

$$
* * *
$$

A política externa mexicana é, sem dúvida, o espaço discursivo onde se aprecia o nacionalismo revolucionário por excelência. $\mathrm{O}$ apelo à luta do revolucionário povo mexicano é o tema que legitima o sistema político mexicano. Aporta elementos para radicalizar a oposição aos ditados estadunidenses. $\mathrm{O}$ asilo político, por exemplo, é uma bandeira levantada para criticar Estados firmemente apoiados pelos Estados Unidos, tornando-se, desta maneira, numa voz com moral suficiente para liderar o grupo dos Países Não-Alinhados.

Este movimento estratégico do governo mexicano teve duas repercussões. Por um lado, a legitimidade internacional ajudou a tirar os olhos de outros países dos processos repressivos internos. Receber asilados foi a maior demonstração internacional de que o México era um país maduro e democrático. Por outro lado, esse mesmo discurso tentou esvaziar as pautas da esquerda. Nesse sentido, a defesa da Revolução Cubana e do processo democrático chileno acobertavam a repressão e aniquilamento da oposição interna, pois num país aberto e democrático esta não podia ser outra coisa mais que movimentos artificiais promovidos por agentes com interesse na desestabilização do sistema mexicano.

Enquanto isso, os setores conservadores entraram num processo de radicalização. Seu relacionamento com o Estado mexicano foi ambíguo. Por um lado, foi instrumentalizado. Os relatórios revisados a respeito da organização juvenil de ultradireita, o Muro, nos ajuda a entender este processo. A organização mencionada era um grupo de choque destinada a confrontar corpo a corpo as organizações de esquerda que atuavam nas universidades públicas. Dos relatórios conseguimos observar vários de seus métodos. Apesar de não estar cooptado pelo governo, o Muro ajudou no confronto aos elementos da esquerda nos momentos de maior organização estudantil antes e depois de 1968. Dessa maneira, o Estado não tinha que utilizar seus corpos repressivos. Os jovens católicos, ainda que tenham sido vigiados, nunca foram presos nem condenados.

Os mesmos relatórios sobre o Muro nos ajudam a conhecer mais sobre a ultradireita mexicana e seus vínculos com importantes nomes do setor empresarial e político. O Yunque, nesse contexto, era simplesmente a fachada de uma organização maior que, além de ter a 
questão católica como guia ideológico, tinha (e ainda tem) aspirações políticas. A radicalização da política externa mexicana foi o pretexto perfeito para começar a encaminhar planos de desestabilização. Avaliada como uma ameaça real, podemos apreciar através dos relatórios da DFS como foram se desenvolvendo uma onda de rumores que, em poucos dias, chegaram até mesmo a colocar a possibilidade de um golpe de Estado.

Se a linguagem anticomunista não foi adotada literalmente nos discursos presidenciais, as organizações católicas encabeçadas por políticos importantes, intelectuais, e, sobretudo, pelo empresariado mexicano, tiveram uma relevante participação na guerra suja, tanto contra o governo, como contra o movimento social. 


\section{INSTITUCIONALIDADE E ORDEM INTERNA}

A necessidade de demonstrar a impossibilidade de que as doutrinas estrangeiras encontrassem espaço dentro da sociedade mexicana expressou-se na insistência em demonstrar uma bagagem ideológica própria, a qual era herança da tradição revolucionária e sólida base das instituições do sistema político mexicano. A Constituição é repetidamente caracterizada como a síntese do histórico da luta do povo mexicano, e, paralelamente, síntese de suas aspirações. Para Echeverría, a "Carta Magna” é simplesmente "a organização política, as garantias individuais e os direitos sociais que consagra, são fruto de uma experiência intransferível. Assinalam o único caminho pelo qual pode transcorrer, em forma civilizada e livre, a vida dos mexicanos" (LEA, 1971, p. 5).

Entrementes, até a primeira metade do sexênio de Díaz Ordaz reconhece-se como movimento social unicamente aquele dos operários e camponeses parcialmente controlados pelas grandes centrais sindicais aliadas ao Estado. Isto é, as lutas estudantis e de outros setores profissionais, enquadrados na categoria de classe média, são, portanto, desconsideradas como uma força política real. As colocações da esquerda radical que pugnavam por uma transformação do sistema político definitivamente foram enquadradas entre o terrorismo e a delinquência organizada. Porém, esta distinção é quase sempre matizada. É assim que o presidente Echeverría aponta que tanto camponeses como operários são os criadores "de nossas instituições mais avançadas. Foram suas lutas as que nutriram o movimento revolucionário. Eles são os verdadeiros autores do Direito Social Mexicano, precursor no mundo" (LEA, 1976, p. 369).

Alguns anos antes, quanto às instituições, Díaz Ordaz concluia que elas seriam suficientemente sólidas e maduras, inclusive para que possam coexistir quaisquer tipos de ideologias por tratar-se de um regime de "pacífica convivência, alimentado no direito" (GDO, 1965, p. 57). Da mesma forma, considera que o sistema político mexicano nasceu como um crisol de opiniões e ideias contrapostas, cuja expressão foram as lutas facciosas durante o processo armado iniciado em 1910. Posteriormente, as diferenças se conciliaram na criação de um partido que priorizava os benefícios das maiorias sobre qualquer vaidade individual. A Revolução, como é denominada a gestão do PRI, que para então tinha aproximadamente cinquenta anos no poder,

nasceu da confluência de distintas ideias; obteve fórmulas de todas elas e sua eficácia radica [no fato de] [...] que atualiza seus princípios, harmoniza 
interesses para obter objetivos válidos para diversos setores e perfeiçoa as instituições essenciais da vida política e social do México (GDO, 1966, p. 134).

Após o movimento estudantil, os jovens foram os protagonistas da luta social, dessa forma, as falas dos presidentes foram direcionadas diretamente à juventude. Echeverría faz um chamamento para que "se debatam as ideologias, que se enfrentem os interesses", como um exercício indispensável para o fortalecimento da democracia. Porém, essa atividade devese desenvolver unicamente quando "o povo e o governo cumpram sinceramente os preceitos de nossa Lei Suprema" (LEA, 1971, p. 5) no intuito de colaborar no processo de continuidade da Revolução. Do mesmo jeito, garante que no México se respeitam todas as crenças e ideologias, porquanto:

Ninguém é perseguido pelo exercício de seus direitos políticos e desfrute de suas liberdades. Não pretendemos uniformizar o pensamento, senão, pelo contrário, aspiramos que a crítica reflexiva e de boa fé contribua ao progresso social. Por isso mesmo, a consciência nacional repudia os aventureiros da desordem (LEA, 1971, p. 8).

Diante da efervescência das forças sociais e do reclamo pela abertura nos processos políticos, Echeverría começa, em 1972, a acentuar a necessidade de uma reforma eleitoral que "alentará a participação das minorias" dentro do poder público. No discurso daquele ano, insinua a necessidade de "consolidar no plano legal as novas tendências da democracia mexicana" (LEA, 1972, p. 71). Desta forma:

Respeitosos da dissidência ideológica e dispostos a aperfeiçoar nossa vida democrática, queremos assegurar às minorias sua representação nos órgãos do Estado. Vemos, nos partidos, não uma ameaça à estabilidade, mas sim os melhores canais para que se expresse a vontade das distintas tendências políticas. Não aceitamos, em troca, a atividade dos grupos que mediante recursos ilegais pressionam para lograr simples interesses pessoais (LEA, 1972, p. 72).

Sob o mesmo prisma, López Portillo, no âmbito da concretização de uma reforma eleitoral $^{184}$, garantia que era necessário a existência de espaços para "todas as correntes

\footnotetext{
${ }^{184}$ A reforma política proposta por Echeverría não significava uma modificação real da estrutura do sistema político mexicano. Além de alterar a idade para ser elegível, a reforma eleitoral simplesmente reforçava a participação dos pequenos partidos existentes até esse momento. É a partir do governo de López Portillo que a reforma adquire um tom mais radical, ainda que, segundo a avaliação das lideranças guerrilheiras, também tinha interesses contrainsurgentes. Rangel Hernández (2013, p. 425-426) aponta que a construção da Ley de
} 
filosóficas e todas as projeções de pensamento; mas sem comprometê-la [a democracia] mais que com seu próprio tempo e circunstância”. Assim, o desenvolvimento da democracia, atendendo às circunstancias,

obriga o Estado a admitir a reunião das mais variadas antitéticas ideologias. Havemos de procurar a participação política de todos os grupos plurais que divirjam, mesmo que sejam minorias, contem com formas válidas para dar vazão a sua inquietude sem acreditar em brechas clandestinas, nem percorrer labirintos de impotência, as vezes heróica, que não vão a parte alguma (JLP, 1977, p. 49).

Dá-se ênfase a um distanciamento com respeito aos regimes ditatoriais. Díaz Ordaz exalta a exemplaridade da estabilidade mexicana, "que permite o exercício das liberdades fundamentais, a convivência de homens, de crenças e ideologias, não somente diferentes, em ocasiões contraditórias, de partidos políticos opostos, etecetera" (GDO, 1966, p. 131-132). A paz mexicana ou pax priísta como coloquialmente é chamada é fundamentalmente "dinâmica, democrática, oposta à paz coercitiva das ditaduras" (GDO, 1966, p. 132).

Aponta, também, que "uma ideologia que se sente infalível é puro sectarismo e a seu amparo se cometem as mais graves equivocações" (GDO, 1966, p. 135). O sectarismo é expressão da obstinação de um "reduzido setor enganado", que deliberadamente esquece que no México "existem os meios legais para promover uma demanda, manifestar descontento ou inconformidade e solicitar a satisfação ao dano sofrido" (GDO, 1969, p. 368). Acrescenta que o sectarismo é provocado pela "cegueira da paixão, a vaidade e o rancor" (GDO, 1970, p. 438). Em contrapartida, as metas da Revolução Mexicana são desenhadas, então, pelo próprio povo mexicano, sendo que qualquer tipo de extremismo fica desarmado e neutralizado: "a nosso povo, nem o contágio externo, nem a impostura ideológica, nem as simples ambiciones lograrão apartá-lo da linha de ação que está determinada pelo passado histórico que o nutre" (GDO, 1965, p. 58).

Ora, em palavras de Echeverría, o "México conduziu sua revolução à ordem jurídica" (LEA, 1975, p. 253). Com o passar do tempo, o povo mexicano "jamais toleraria outra ditadura, quaisquer que fosse seu signo ideológico", ou seja, "uma paz pública sem liberdades, um sistema político em que os líderes sociais, os intelectuais ou os cidadãos, são silenciados e perseguidos” (LEA, 1972, p. 79). Em complemento às características das ditaduras, Echeverría aponta que "perante a falsa energia de toda ditadura, cremos no poder

Organizaciones Políticas y Procesos Electorales. Foi uma maneira de "institucionalizar o conflito social" a partir da abertura do espaço legal para partidos políticos de oposição. 
da democracia, na força do consenso maioritário, e na fortaleza da razão e no vigor que gera uma comunidade de homens livres" (LEA, 1974, p. 180).

Finalmente, no entendimento de López Portillo, a Revolução Mexicana, nasceu

sem ortodoxias geométricas, nem moldes sufocantes porque se origina na entranha mesma do povo; sem planejar ditaduras, porque de combater uma, nasce [outra]; sem admitir imposições estrangeiras, porque na descolonização, explica-se [a Revolução Mexicana]; sem confabular com nenhuma potência, porque é anti-imperialista, e encontra a fórmula de fazer síntese dialética do social e do individual, e transformar a revolução em Constituição e a Constituição em instituições dinâmicas (JLP, 1978, p. 99).

\subsection{O inimigo interno}

A administração de Gustavo Díaz Ordaz, desde o início, se enfrentou à explosão de grupos clandestinos, sobretudo rurais, como explicitado na introdução. Nos seus informes, pudemos apreciar, não há menções explícitas aos sujeitos sociais dos quais está falando, não explica os fatos armados, nem menciona o nome de grupos ou líderes. Quando fala da subversão, simplesmente generaliza:

quando pequenos grupos, esquecendo-se do dever moral de salvaguardar e proteger o sistema, que, ao mesmo tempo, a eles os ampara, separam-se das normas legais, prejudicam sua própria causa e fortalecem os inimigos de nosso progresso (GDO, 1965, p. 57).

Díaz Ordaz, num primeiro momento, define o inimigo. Parte de dois conceitos que se tornaram frequentes ao longo dos informes, e que, paulatinamente, irão sendo preenchidos com adjetivos diversos, como pequenos grupos, crise moral. Díaz Ordaz sublinha uma série de valores desejáveis na juventude mexicana no propósito de construir a imagem do inimigo por contraste.

A juventude, então, é considerada como parte constitutiva do futuro da Revolução Mexicana. Dessa maneira, seria decepcionante, comenta o presidente, caso ela se manifestasse "conformista e resignada". Porém, o país não precisa de uma juventude "irresponsável que abrace com incauta paixão todas as causas, que se tome como instrumento dócil a serviço de interesses bastardos ou como caixa de ressonância de estéreis desafogos" (GDO, 1966, p. 130). Estes traços de inocência atribuídos à figura do jovem mexicano, segundo o mandatário, 
são resultado de sua idade, da adolescência. Alerta que a adolescência "não é um escape à realidade, nem outorga imunidade perante a lei, é desorientação transitória, consequência da transformação individual, mas, ao mesmo tempo, potencial criador" (GDO, 1966, p. 131). Por outro lado, a responsabilidade das ações da juventude, assim como sua desorientação, são corresponsabilidade de

nós os mais velhos, os pais, os professores, os governantes, os que temos o dever de aproximarmo-nos, [...] de ajudá-los para que suas dúvidas desapareçam ou seus problemas não os confundam, não os desorientem, [...] sem querer impor-lhes condições que, eles podem crer, são preconceitos nossos ou uma autoridade que não lhes dá o direito de se explicar nem lhes explica porque se lhes impõe ou em que se funda (GDO, 1967, p. 190).

O conhecimento da história mexicana ajudaria, também, para "que não sejam instrumentos de quem tenta utilizá-los por interesse escuso, empurrando-os a ações que os prejudicam" (GDO, 1967, p. 191). Nessa perspectiva, a rebeldia é um problema vinculado à idade, instabilidade emocional, assim como à vantagem que tiram disso pessoas ou grupos com interesses que contrariam a Revolução Mexicana e suas propostas.

A incredulidade sobre as causas materiais dos levantes juvenis expressa-se na definição que Díaz Ordaz elabora sobre a classe média mexicana: em crescimento, politicamente ativa e profundamente privilegiada, "fruto genuíno da Revolução Mexicana" (GDO, 1966, p. 136). Nesse sentido, a juventude de classe média não sofre danos. De outro modo, atende ao sentimento de "inconformidade", que é a outra característica considerada "natural" e até aceitável nos jovens. De fato, para o presidente é preciso que não se aceite passivamente a ordem social. Essa atitude seria um fator necessário para continuar no progresso. Mas a inconformidade não pode se expressar "alocadamente". Isto é, rebelando-se contra toda ordem, "sem ter consciência do que querem e do que vão edificar no lugar do que pretendem destruir". Assim, Díaz Ordaz lamenta: "Que grave dano fazem os modernos filósofos da destruição, que estão contra tudo e a favor de nada!". Então, exorta os jovens para “ter ilusões, mas não se deixar alucinar" (GDO, 1968, p. 268).

Outra característica destacada na juventude é o "aventureirismo". Definido como contrário ao exercício político é, simultaneamente, "ausência de bandeiras programáticas e pobreza ideológica". A aventura promove a "desordem, a violência, o rancor, o uso de símbolos alarmantes e a prédica de um voluntarismo aventureiro que trata de desviar nossa sociedade" (GDO, 1969, p. 367). A recusa intransigente a qualquer tipo de negociação oferecida pelo Estado é uma expressão dessa característica. O aventureirismo, então, 
"somente obedece à inadaptação ou à superestimação da própria pessoa", pois sua prática é simplesmente o "acatamento servil de pautas alheias" (GDO, 1966, p. 133).

Por outro lado, conforme avança o processo de radicalização da esquerda, o inimigo se configura como um ente que atua à margem da legalidade, conspirando pela sedição. Tem-se consciência de que o inimigo não é homogêneo: uns querem que as ações violentas "exaltassem a resistência às mudanças e se provocasse um retrocesso nacional"; outros, "de súbito obcecadospela ação, pensaram fazer realidade imediata seus anseios ideológicos, nutridos na fantasia e nas leituras mal digeridas"; por último, estão os que "atuaram por pagamento e os vulgares pescadores de río revuelto"185 (GDO, 1969, p. 367). É desse jeito que o inimigo interno representa, também, "as dissímeis forças do exterior e internas, disputando-se entre si a direção" (GDO, 1969, p. 368).

Em 1969, Díaz Ordaz deixa entrever a ideia da existência de grupos armados. Novamente, sem mencionar nenhum nome ou sigla de grupo, sustenta que:

quem queira defender suas ideias, respeitando as dos demais; exercer seus direitos, sem lesar os de outros; fazer verdadeira política e não atividade subversiva e criminosa, não precisa de nomes falsos, de trevas, de lúgubres catacumbas, para que se refugiar na clandestinidade, quando podem brigar por seus ideais em campo aberto, organizando-se politicamente e atuando no amparo da lei, que é seu melhor escudo e garantia? (GDO, 1969, p. 370$371)$.

Como as atividades subversivas estavam cada vez mais presentes no cotidiano, o presidente Díaz Ordaz, no entanto, continuava negando sua existência, bem como declarava a inexistência de presos políticos. Segundo sua própria definição, um preso por motivos políticos "é quem está privado de sua liberdade exclusivamente por suas ideias políticas, sem ter cometido delito algum". Os militantes que permaneciam recluídos nos presídios militantes de grupos clandestinos, organizações políticas, ou estudantis - eram consideradas pessoas "contra quem o Ministério Público formulou acusação, não por subjetivos motivos políticos ou pelas ideias que professem, mas sim, por atos executados que configuram delitos previstos no Código Penal" (GDO, 1968, p. 260). Díaz Ordaz se pergunta retoricamente: "Deve ou não ser delito não preparar a invasão do território nacional ou a submissão do país a um governo estrangeiro?” (GDO, 1968, p. 261).

Finalmente, enquanto a classe média "irresponsavelmente" se rebelava, Díaz Ordaz

\footnotetext{
${ }^{185}$ A expressão completa é: A río revuleto, ganancia de pescadores. Significa aproveitar situações de confusão para tirar vantagem.
} 
cria um parêntese para recolher as "comovedoras" mensagens de ânimo expressadas por um jovem operário da capital e por um jovem camponês do estado de Zacatecas. O mandatário relata a anedota do encontro com os dois jovens, exaltando o diálogo com o jovem camponês, que afirmou que a juventude campesina do país “está em plena luta e com as armas na mão; mas que sua luta é o trabalho no campo e que as armas que empunha são a enxada, a picareta e a pá, a esteva e o volante do trator" (GDO, 1968, 269).

No mesmo tom inaugurado por Díaz Ordaz, aprofunda Luis Echeverría na descrição desse novo tipo de inimigo. Detém-se com mais minúcia nas características psicológicas, sempre tendo como marco essa juventude exemplar, herdeira dos preceitos revolucionários, e sempre respeitosa das instituições, anteriormente esboçada pelo seu antecessor. Echeverría diz que "os jovens estudantes, os jovens camponeses, os jovens operários e os jovens funcionários públicos de hoje representam a melhor garantia para enlaçar e tornar irreversível o processo transformador pelo qual estamos empenhados" (LEA, 1974, p. 174). Aponta, assim, que é necessária uma renovação cívica e moral a fim de que a Revolução Mexicana responda às inquietudes e desafios colocados pelo presente. Por outro lado, "o verdadeiro revolucionário", diz Echeverría, "transforma a realidade e se transforma com ela. A cada etapa histórica deve corresponder uma nova consciência, uma nova atitude e uma nova conduta" (LEA, 1972, p. 112).

Contudo, Echeverría alerta para o crescimento da "delinquência, a proliferação de gangues, a agressividade, a apatia e todo gênero de condutas antissociais [que] são parte de um processo de degradação dos valores essenciais da convivência” (LEA, 1971, p. 13). Para o chefe de Estado, estas formas organizativas, que não são políticas, ao contrário, referem-se às características que podem se atribuir ao terrorismo. Entre os três presidentes analisados em nosso recorte temporal, Echeverría é o único em utilizar a palavra terrorismo.

$\mathrm{Na}$ avaliação de Echeverría, a violência como estratégia de luta "não tem arraigamento em nosso país" (LEA, 1973, p. 126). Primeiro, porque aqueles que utilizam a violência devem entender que para "ser autocríticos e revolucionários é necessário voltar para nossa verdade; não tratar de reproduzir fora de lógica o que passou em 1917 ou em 1918 em outros países, para aplicá-los aqui no México" (LEA, 1976, p. 436). Em segundo lugar, a tradição revolucionária mexicana e uma democracia consolidada ajudam para que "a oposição possa desenvolver-se livremente, [pois] as organizações clandestinas resultam artificiosas e estão destinadas a uma existência precária". Isto é, o terrorismo "como estratégia de luta somente pode prosperar num clima de opressão totalitária" (LEA, 1973, p. 126). No entendimento do presidente, o México não compartilha os métodos opressivos de outros regimes. 
O objetivo dos grupos terroristas seria o de "debilitar a unidade dos mexicanos diante do exterior, que o que pretendem é endurecer a posição das autoridades". Ou seja, "induzi-las a dar um salto para trás na história”. Dessa forma, para Echeverría:

O terrorismo é reacionário. Está vencido pela história. É fruto da confusão. Nasce, se desenvolve e morre isolado do povo. Revela incapacidade para convencer e para vencer no terreno da política e no terreno das ideias. $\mathrm{O}$ terrorismo é fascista. É expressão de falta de apoio popular e de medo à inteligência, por isso se refugia na clandestinidade e ameaça a existência humana (LEA, 1976, p. 348-349).

Em 1974, o presidente Echeverría expõe com profusão quem são e como se comportam os "pequenos grupos de covardes terroristas" no México:

desafortunadamente integrados por homens e por mulheres muito jovens que no México têm consideráveis semelhanças com grupos que, nestes dias em que estes atos estão na moda em quase todo o mundo, atuam de modo parecido. Surgidos de lares geralmente em processo de dissolução, criados num ambiente de irresponsabilidade familiar, vítimas da falta de coordenação entre pais e professores, maioritariamente crianças que foram de lenta aprendizagem; adolescentes com um maior grau de inadaptação genérica, com inclinação precoce pelo uso de estupefacientes em seus grupos com uma notável propensão à promiscuidade sexual e com um alto grau de homossexualidade masculina e feminina; vítimas da violência; que veem muitos programas de televisão (LEA, 1974, p. 180-181).

De tal descrição podemos obter uma radiografia do conservadorismo da sociedade mexicana. A família seria o núcleo da sociedade. Sendo assim, o divórcio, a promiscuidade e a homossexualidade são sua antítese. Novamente, na definição dos inimigos da nação, encontramos as deficiências educativas como um fator produtor da violência, seja por desatenção familiar ou por incapacidade intelectual dos indivíduos, enquanto que, nos informes presidenciais nunca se avaliam as precariedades da educação pública.

Enfim, pode-se observar que a definição de Echeverría realmente complementa as características que o manual da SOA esboça sobre a figura do "terrorista":

1. Idade. O terrorista urbano usual pelo geral tem uma idade que flutua entre os 22-25 anos.

2. Sexo. O terrorismo urbano continua predominantemente um fenômeno majoritariamente masculino. A filiação feminina constitui menos de 16 por cento (baseado em prisões/identificação do pessoal terrorista). O papel que desempenham é majoritariamente confinado à coleta de inteligência, mensageiros, enfermeiras ou pessoal médico, e na 
manutenção das casas de albergue terroristas.

3. Estado Civil. O terrorista em geral é solteiro. As exigências de movimento e flexibilidade evitam que o terrorista tenha tempo para estar preocupado com responsabilidades familiares. As estatísticas indicam que $75-80 \%$ dos terroristas capturados eram solteiros.

4. Origem urbana $x$ rural. O terrorista tem que estar intimamente ligado ao terreno em que está operando (SOA, 1989g, p. 5).

Finalmente, no contexto das pressões políticas por uma reforma eleitoral, assim como por uma Lei de Amnistia, paulatinamente o "terrorista" adquire o nome de "opositor". No último informe de Echeverría, ele retoma a ideia de que seu governo "não podia [...] prescindir da força transformadora da juventude". Avalia, então, a necessidade de criar os canais institucionais "ao idealismo deles, a seu compromisso de servir às melhores causas, a sua crítica criadora, a sua disposição para promover mudanças” (LEA, 1976, p. 347).

O processo de "readaptação" da esquerda armada é descrito por Echeverría quando declara que "inclusive aqueles jovens que irrompiam em grandes e profundas críticas dentro do foro da proteção, da impunidade dos pátios e dos jardins feitos com o esforço do povo, chegam a se adaptar". A adaptação é uma mostra de que o idealismo é um sinal de maturidade, pois "chegam a buscar emprego, inclusive, nos escritórios dos advogados mais conservadores e dos testas-de-ferro do México. Chegam, afinal, a fraquejar totalmente, a corromper-se". Para o presidente Echeverría, os universitários vivenciam "uma rebeldia juvenil passageira, porque careciam de uma verdadeira convicção revolucionária". Uma mostra de ingenuidade "impulsionada por leituras apressuradas, por conselhos superficiais" (LEA, 1976, p. 436).

Nos informes presidenciais correspondentes ao período encabeçado por López Portillo, praticamente não encontramos referências à esquerda armada. Simplesmente, como um epílogo à descrição feita por Echeverría sobre o "arrependimento" das juventudes rebeldes, assinala que a "dissidência não é sinônimo de violência, que a oposição não deve se associar ao delito" (JLP, 1977, p. 14). Ainda que o mandatário alerte sobre a falsa vinculação entre oposição e delinquência, neste sexênio foram os meios impressos de comunicação os que pautaram a criminalização dos guerrilheiros.

\subsubsection{O inimigo interno na imprensa}

A relação entre imprensa e o Estado pós-revolucionário é descrita pelo jornalista Jacinto Rodríguez Munguía a partir de quatro pontos relevantes: 
Que perante o poder e suas ações, a maioria dos jornalistas optaram pela conveniência.

[...] Que perante o medo que impunha o poder através de seus mecanismos de controle, subsídios, papel, publicidade, a maior parte dos meios optou pela conveniência.

[...] Que perante o horizonte de perder a influência que dava ter um jornal, uma revista, uma concessão de rádio e televisão, a maior parte dos meios optaram pela conveniência.

[...] Que em muitos casos não foi necessária a cooptação, a pressão, o controle do papel nem publicidade ${ }^{186}$; que em muitos casos os donos dos meios e os jornalistas mesmos, simplesmente assumiram as decisões do poder como suas, optando pela conveniência antes que pela responsabilidade ética. Nestes casos concretos houve necessidade de tomar decisões, já que o projeto ideológico do governo coincidia com o dos empresários dos meios e, em alguns casos, com o dos mesmos jornalistas (RODRÍGUEZ MUNGÍA, 2007, p. 22-23) $)^{187}$.

Os mecanismos de controle informativo são perceptíveis num relatório da DFS a respeito de uma onda de explosões produzidas na Cidade do México em 1969. O diretor da corporação, o capitão Fernando Gutiérrez Barrios informa que "A petição do C. Secretario de Gobernación, a Procuraduría General de la República, auxiliada pela do Distrito, deu fé dos fatos emitindo um boletim de imprensa em que, de forma sucinta, minimiza até onde é possível estes acontecimentos". A justificativa para minimizar os acontecimentos foi que, até então, não identificaram o grupo que cometeu os atos terroristas" ${ }^{\prime 188}$.

Nesse mesmo sentido, numa carta assinada pela DFS, em 1966, dirigida a Rómulo O'Farril, presidente do jornal Novedades, a carta aponta que“na edição correspondente ao dia de hoje [...] aparece um editorial que longe de contribuir patrioticamente à campanha nacional de "empadronamiento" 189 , parece estar intencionalmente dirigido a causar desorientação". Na carta há alegação, além do mais, de que foi elaborada respondendo à ordem do então secretário da SEGOB, Luis Echeverría, para o que recomendavam que se realizasse uma nota

\footnotetext{
186 Entre 1935 e 1936, o governo de Lázaro Cárdenas cria dois organismos que regulavam o trabalho da imprensa: o Departamento Autónomo de Prensa y Publicidad (DAPP) e a Productora e Importadora de Papel (PIPSA). O DAPP estabelecia os critérios para o relacionamento direto com o cinema, a rádio, a televisão, a imprensa e o governo, ou seja, os mecanismos para a compra de espaço dentro dos jornais para a propaganda do Estado (RUIZ OJEDA, 2013). Por outro lado, a PIPSA garantia o fornecimento de papel a preços baixos, no intuito de promover o trabalho dos editores de livros e de jornais. Como presidente desta empresa paraestatal foi nomeado o secretário da SEGOB, assim, o Estado podia exercer "um controle sutil sobre os meios de informação, sem cair na censura". (GONZÁLEZ MARÍN, 2006, p. 106).

${ }^{187}$ A esse respeito é interessante observar a reação do maior grupo de telecomunicações, Televisa, diante o massacre de estudantes em 1968. No telejornal de maior audiência, 24 Horas o célebre âncora, Jacobo Zabludovsky, iniciou o programa, poucas horas após o fim do operativo com a frase: "Hoje foi um dia ensolarado", para posteriormente noticiar um "tumulto" entre estudantes onde houve "lesionados".

188 “Información”, GUTIÉRREZ BARRIOS, Fernando, Distrito Federal, 07-09-69, AGN, IPS, Caixa 1783 D, Exp. 13, folhas 1-5.

${ }^{189}$ Consistia no registro dos indivíduos em domicílios, os maiores de idade, com a elaboração de uma carteira de identificação que, além de ter os dados pessoais, funcionava para exercer o voto.
} 
de esclarecimento com as informações reais, "apesar de que o prejuízo já tinha sido causado"190.

Embora não tenhamos proposto aqui uma análise hemerográfica, tivemos acesso a uma série de recortes de jornais arquivados pela própria DFS. Existem alguns poucos exemplares inteiros, mas, na maioria das vezes, encontramos matérias soltas, cabeçalhos ou transcrições. A partir desses elementos, conseguimos perceber que nos recortes relativos aos grupos armados há uma ênfase no desprestígio e criminalização das guerrilhas. Ou melhor, não existe nenhuma consideração sobre as causas ou motivações dos levantes; não há nenhuma referência aos programas ou projetos políticos dos grupos; não se publicam os comunicados deles. As matérias giram em torno das ações. Dessa maneira, nos meios informativos que se apresentam aos grupos e militantes, de uma maneira negativa e ideologizada "tratando de reduzir o impacto que as guerrilhas pudessem ter num plano social" (MENDOZA GARCÍA, 2008, p. 145). Assim, os meios impressos criam um ambiente propício para justificar a violência e promover a eliminação dos grupos armados.

Tendo em conta os recortes de jornais localizados no AGN, poderíamos fazer uma breve distinção temporal. Embora a criminalização dos grupos armados sempre esteve presente no nosso recorte cronológico, a imprensa normalmente não reconhecia que os grupos armados surgidos na década de sessenta tivessem programa político. Sobre os guerrilheiros de Chihuahua, na matéria intitulada "5 detidos pelo assalto ao quartel Madera", indicava-se que "os detidos são cinco, entre eles duas mulheres, todos com uma grande quantidade de codinomes, sintoma específico de que pertencem a grupos que buscam alterar a paz do país"191.

A partir dos anos setenta, os grupos armados foram sistematicamente desqualificados, reproduzindo-se depoimentos emitidos por funcionários encarregados da segurança, sejam militares ou policiais. A falta de ideologia política, assim como o "sangue frio", são os argumentos mais utilizados para a descaracterização dos guerrilheiros. Em 1976, por exemplo, escrevia-se que "Esses delinquentes, com crueldade e cinismo, igualmente atacam tanto a policiais como a crianças, anciãos e mulheres, afirmou o Regente [governador] Octavio Sentíes"192.

Em 1977 se destacava na capa do jornal Ovaciones: “Galván: que nem são

\footnotetext{
190 “Carta”, PÉREZ PEÑA, Rubén, Distrito Federal, 10-11-66, AGN, IPS, Caixa 2938, Exp. 38, folhas 1-3.

191 "5 detenidos por el asalto al cuartel Madera", Chihuahua, 28-01-67, Ovaciones (p. 34), AGN, IPS, Caixa 1448 B, Exp. 41, folha 1.

192 "Esos delincuentes, con crueldad y cinismo (...)", Distrito Federal, 12-08-76, Ovaciones (p. 1, 8), AGN, IPS, Caixa 1920 A, Exp. 1, folha 1.
} 
guerrilheiros, nem ativistas". O então secretário da SEDENA, o general Félix Galván, garantia que os guerrilheiros não existiam mais. Os indivíduos que estavam gerando o clima de violência no país eram grupos de delinquentes descontentes por medidas tomadas pelo governo federal. O secretário resume que "não há problemas subversivos"

Numa outra matéria intitulada "Há tranquilidade total no país, assegura o Gral. Galván", incluía-se a declaração do presidente López Portillo na qual sublinhava "que os índices de 'guerrilheiros' não constituem um perigo para o país, já que se estima que seu número é demasiado reduzido 'e não chega a constituir um perigo para a paz interior do país"”. Nesse rumo, um ano após essa matéria, noticiava-se que "o roubo ao banco não é uma escalada de violência" ${ }^{\prime 194}$. Na mesma matéria se alertava que não podia ser chamado de terrorista quem está assaltando bancos, pois os métodos utilizados remetem às práticas dos delinquentes comuns ${ }^{195}$.

\subsection{A conspiração comunista internacional}

Os três governos analisados fazem um balanço dos conflitos sociais internos como se fossem produzidos por uma conspiração estrangeira. Isto é, como parte da introdução de ideologias e projetos incompatíveis com o desenvolvimento histórico do país, deixando de lado a explicação do conflito nacional em termos de uma crise política e econômica.

Em Movimiento subversivo en México, o general Mario Arturo Acosta Chaparro (1999) expõe a causa fundamental da radicalização da juventude urbana e rural. Segundo sua versão e como pilar da contrainsurgência, o motivo dos levantes armados está na penetração ideológica russo-cubana através do movimento estudantil e dos militantes do Partido Comunista Mexicano.

A conspiração comunista contra um país que acolheria as olimpíadas em 1968, teria sido orquestrada desde Havana, Cuba. Na análise feita pelo general sobre a Conferência

\footnotetext{
193 "Galván: que ni son guerrilleros, ni activistas", ÁBREGO G., Alejandro, Distrito Federal, 30-03-77, Ovaciones (p. 1, 10), AGN, IPS, Caixa 1747 B, Exp. 8, folha 1.

194 "Hay tranquilidad total en el país", OCHOA CÉSPEDES, Ernesto, Distrito Federal, 16-04-77, Novedades (p. 19), AGN, IPS, Caixa 1747B, Exp. 8, folha 1.

195،El robo al banco no es una escalada de violencia, señaló Sahagún Vaca”, Distrito Federal, 26-07-78, El Sol de México, AGN, IPS, Caixa1778 A, Exp. 2, folha 1. Francisco Sahagún Vaca foi nomeado responsável da División de Investigaciones para la Prevención de la Delincuencia (DIPD), em 1975. Religioso e de pessoalidade excêntrica, Sahagún Baca desconfiava até de seus colaboradores mais próximos. Estabeleceu um controle férreo da delinquência na Cidade do México. Os quarteis policiais "viveram sua melhor época: encarceramentos, espancamentos, sequestros, torturas, assassinatos, se multiplicavam como ações disfarçadas em defesa da segurança da cidadania" (CABILDO, 1989).
} 
Tricontinental realizada na ilha, em 1966, onde, segundo o general, uma das resoluções foi a organização de atos contra os governos do Japão, França e México, “com o fim primordial de desestabilizá-los e mudar para o socialismo". A estratégia cubana foi a criação da Organização Latino-Americana de Solidariedade (OLAS) em 1967. Esse organismo, segundo Acosta Chaparro, é o "braço armado executor" na luta contra o colonialismo "na busca da reivindicação latino-americana" (ACOSTA CHAPARRO, 1999).

Efetivamente, os líderes terceiro-mundistas que participaram da conferência identificaram o renascente militarismo japonês, sob amparo do imperialismo norte-americano, como uma força "copartícipe da exploração econômica de que são objeto os povos asiáticos, em razão de seu desenvolvimento econômico". Dessa maneira, identifica-se o Japão como peça-chave de supostos pactos militares onde os norte-americanos escoram suas bases militares, que, por sua vez, afetam violentamente as populações que lutam por sistemas democráticos e independentes por meio das armas. A esse respeito, utiliza-se como exemplo as lutas no Laos, na Tailândia, Federação Malaia, Filipinas e atual Indonésia. Contudo, o caso do Vietnam é o mais representativo das lutas na região asiática. As resoluções de solidariedade com os povos asiáticos em luta giram em torno da solidariedade incondicional com "as justas lutas de libertação nacional” do continente, assim como o compromisso de denúncia e condenação dos fatos repressivos e de violação aos tratados internacionais sobre as guerras (ORGANIZACIÓN LATINOAMERICANA DE SOLIDARIDAD, 1967, p. 69-71).

Com relação à França, a nação europeia é considerada “o principal perigo e inimigo fundamental dos povos africanos". Junto à Grã-Bretanha representa o neocolonialismo, cujos mecanismos de opressão tem-se modificado e fortalecido através da independência, "formal e enganosa", das antigas colônias. A denúncia elaborada pelos participantes da Tricontinental reside em que as metrópoles sustentam regimes "fascistas de minorias brancas" que, com métodos violentos, aniquilam as lutas desses povos por independência e autodeterminação. Assim como na observação sobre os países asiáticos, a Trincontinental resolve denunciar e condenar as condições dos povos africanos e as manobras coloniais, com o "mais firme e decidido apoio e solidariedade militante a todos aqueles que hoje em África [...] lutam com as armas na mão" (ORGANIZACIÓN LATIONAMERICANA DE SOLIDARIDAD, 1967, p. 63-65).

Já quanto ao México, as únicas referências feitas durante a Conferência Tricontinental estão num sentido empático e solidário. Coloca-se a experiência mexicana para explicar os métodos norte-americanos de intervenção, sobretudo durante o século XIX. Na contramão da hipótese de Acosta Chaparro - que mencionamos colocar o México como um objetivo do 
braço armado da Tricontinental - encontram-se expressões de adesão à política internacional mexicana proferidas pelo próprio Fidel Castro, no discurso de fechamento da Primeira Conferência da OLAS, em agosto de 1967. O comandante Castro sublinhou que "a OEA não tem nem um átomo de vergonha, a OEA não tem nem um átomo de moral. E nenhum dos governos deste continente, que - com exceção do México - são cúmplices confessos dos atos de bandidagem contra nosso país" (ORGANIZACIÓN LATIONAMERICANA DE SOLIDARIDAD, 1967, p. 118).

Nesse mesmo sentido, a informação correspondente à solidariedade dos mexicanos à guerrilha liderada por Che Guevara, na Bolívia, avivou um certo interesse por parte dos agentes de inteligência que se mobilizaram nos meios intelectuais. No relatório intitulado "Informe que pode ser útil", um agente da DFS ressalta os assuntos tratados numa suposta reunião entre Gustavo Alatriste - diretor da revista de esquerda Sucesos, descrito de forma leviana como "comunista com vínculos guerrilheiros na Venezuela, Colômbia, etc." - com um sacerdote dominicano supostamente chamado "Julián Pablo". Na reunião, além de trocar impressões sobre as propostas teóricas da psicanálise, conversaram

acerca da possibilidade de que o Padre Julián Pablo convença o pintor José Luis Cuevas e os senhores Giraud e Piazza para aceitar um convite de Alatriste para protestar, publicamente, contra o Governo boliviano pela detenção do jornalista comunista francês Regis Dabray, que está preso na Bolívia por ter formado parte de uma guerrilha ${ }^{196}$.

$\mathrm{Na}$ explicação contrainsurgente construída por Acosta Chaparro, a proliferação de agrupamentos juvenis com inclinações terroristas são provas "irrefutáveis" da "infiltração soviético-cubana". Como prova para esta afirmação, o general descreve a explosão de um artefato caseiro na embaixada da Bolívia, na Cidade do México, em 1967, como uma reação ao assassinato do comandante Ernesto Che Guevara.

Entre 1967 e 1972 permaneceram na prisão os estudantes Enrique Condés Lara, Fabio Barbosa Cano, Francisco Luna Leal, Mario Rechi Montiel, Luis Enrique Gerardo del Toro y Nájera y Antonio Gersheson Tafelov. Acusados dos delitos de conspiração, associação

\footnotetext{
196 "Informe que puede ser útil”, Distrito Federal, 13-07-67, AGN, IPS, Caixa 1467 A, Exp. 1, folha 1. No fim do sexênio de Gustavo Díaz Ordaz, e, especialmente, após o massacre dos estudantes de Tlatelolco, os intelectuais mexicanos se uniram em severas críticas ao governo, o que teve, inclusive, repercussão internacional. Conhecemos, por exemplo, a renúncia de Octavio Paz como embaixador do México na Índia, em protesto. Existe um empenho por parte dos governos por vigiar, e, de fato, cooptar os intelectuais para legitimar-se. No caso de Echeverría, a ação foi bem sucedida, pois apesar de sua obvia participação nos fatos do 2 de outubro e na repressão posterior, conseguiu que intelectuais da altura de Carlos Fuentes ou Fernando Benítez, que foram críticos de Díaz Ordaz, fizessem campanha política a seu favor. "Echeverría ou o fascismo" foi a expressão que utilizaram.
} 
criminosa, tentativa de causar danos à propriedade por explosão, e o próprio dano em propriedade alheia por explosão consumada, lesões e roubo ${ }^{197}$. Familiares, professores e amigos dos prisioneiros apelaram contra a sentença utilizando o argumento das violações ao devido processo.

Numa carta enviada diretamente ao secretário da SEGOB, Mario Moya Palencia, se faz uma descrição pontual dos acontecimentos em que, além dos assinalamentos detalhados sobre as violações, pedia-se a intervenção pessoal para a libertação dos estudantes. Os signatários argumentavam, em primeiro lugar, que os estudantes foram detidos em novembro de 1967, "incomunicados durante mais de oito dias, e, finalmente, apresentados perante o Juiz Terceiro do Distrito em Matéria Penal”. As sentenças se basearam, segundo a carta, "unicamente nas declarações arrancadas mediante pressões físicas e morais durante a incomunicação a que estiveram sujeitos”. A partir da debilidade jurídica desta sentença, os signatários vão enumerar uma série de irregularidades ocorridas durante o processo contra os estudantes. Denunciam que:

Permaneceram mais de cinco anos encarcerados em Lecumberri sem que, até o momento, tenha-se concluído seu processo, porquanto a Constituição marca claramente um prazo não maior de um ano para tal. Em maio de 1969, foram sentenciados em primeira instância a penas extraordinariamente exageradas para os delitos que se lhes acusa e que vão dos 17 aos 25 anos de prisão.

$\mathrm{Na}$ carta se argumenta, contudo, que não são conhecidos casos com essas características, mesmo em países com regimes ditatoriais. Sendo apontada que a razão que motivou essas condenações é de ordem política. Finalmente, a carta cita um parágrafo com a alegação apresentada pelo Ministério Público para refusar um pedido de amparo:

\begin{abstract}
A incomunicação, em caso de ser demonstrada, é infantil crer que intimida elementos marxistas leninistas [...] A incomunicação pode causar efeitos de tipo psicológico e de pavor em pessoas que se intimidam com este fato, mas não com elementos acostumados à luta, como eles a chamam [...]. Sua declaração com respeito à incomunicação não produz nenhum efeito, e é imprópria de elementos como eles, que são de luta, segundo o manifestam em sua declaração ${ }^{198}$.
\end{abstract}

Por outro lado, nos relatórios produzidos por agentes infiltrados nas universidades, há

\footnotetext{
197 "Responsables de un acto terrorista en la embajada de Bolivia en el año de 1967", BARREDA MORENO, Luis de la, Distrito Federal, 24-03-73, AGN, IPS, Caixa 3033 A, Exp. 13, folhas 1-2.

198 "Carta a Moya Palencia”, Distrito Federal, c. 1973, AGN, IPS, Caixa 3033 A, Exp. 13, folhas 1-2.
} 
uma série de comentários relacionados com uma onda de ataques de dinamite ocorridos em 1969. As detonações de artefatos de fabricação caseira nos sanitários de diversas dependências não tiveram maiores consequências além dos danos materiais. As explosões se localizaram nos escritórios da SEGOB, da Procuraduría General de Justicia da capital, num estúdio de televisão do grupo Televisa, e no prédio do jornal El Sol de México ${ }^{199}$.

Os comentários recolhidos no IPN apontavam o estudante Enrique Aguilar Mora como um dos responsáveis. O agente afirma que Aguilar Mora tinha retornado de uma breve estância em Cuba alguns dias antes das explosões enfatizando que a chegada do estudante coincidia com "os chamamentos e mensagens da OSPAAL [Organização de Solidariedade dos Povos de África, Ásia e América Latina] aos povos da África, Ásia e América Latina que aparecem na edição de hoje na página 13 de Prensa Latina"200. Assim, a DFS relaciona a chegada de um mexicano de Cuba com a ordem de "criar um, dois, três, muitos Vietnam" (palavras de ordem do comandante Che Guevara) com as dinamitações para a geração de condições que possibilitassem um levante social.

Sem nenhum tipo de investigação e tão somente pelos comentários ouvidos nos corredores universitários, o agente informa que "ordenou-se as detenções contra vários estudantes na Vocacional No. 5 hoje por agentes da DFS". Os estudantes que foram acusados tinham contra si vários indícios que os tornavam suspeitos. Insinua-se uma possível relação entre estas explosões com as ocorridas contra a embaixada da Bolívia dois anos antes, pois existia uma suposta relação familiar "um tal Max, de quem se ignora o sobrenome e do qual se disse que era parente ou amigo de Enrique Condés Lara, detido pelo bombazo na Embaixada da Bolívia, em novembro de 1967". Além disso, o agente aponta que anteriormente um dos estudantes que estão sendo interrogados "lançou uma ameaça, em 25 de julho, no comício da Plaza del Carrillón onde manifestou que, 'a burguesia ia se arrepender',201

Agora, na linha traçada pelo general Acosta Chaparro, o presidente Díaz Ordaz esboça uma série de distúrbios surgidos, segundo ele, na linha cubana, mas sem mencionar nomes

\footnotetext{
199 "Informe de las explosiones", GUTIÉRREZ BARRIOS, Fernando, Distrito Federal, 07-09-69, AGN, IPS, Caixa 1783 D, Exp. 13, folhas 1-5.

${ }^{200}$ A Agencia Informativa Latinoamericana ou Prensa Latina, é um organismo fundado por Fidel Castro em 1959 no intuito de dar cobertura mediática aos acontecimentos do continente. Entre os nomes que deram suporte a este projetoencontramos a Jorge Ricardo Massetti e Rodolfo Walsh, ambos os jornalistas e guerrilheiros argentinos, além do escritor colombiano Gabriel García Márquez. Com sede permanente em 31 países, a Agência de notícias Prensa Latina, continua difundindo informação como mídia digital. Disponível em: http://prensa-latina.cu/ [Último acesso em: 04-11-2016].

201 "Comentarios relacionados con los recientes acontecimientos terroristas", Distrito Federal, 18-09-69, AGN, IPS, Caixa 1783 D, Exp. 13, folhas 1-3.
} 
dos países que supostamente estariam patrocinando a desestabilização dos governos democráticos. Para o mandatário, os "distúrbios juvenis" coincidem com a realização de atos de transcendência internacional. Por exemplo, em Punta del Este, Uruguai, durante a reunião da OEA, "aproveitou-se a juventude estudantil para provocar graves conflitos"; ou em Veneza, durante a Bienal de Pintura, "que foi interrompida com atos violentos"; e por último, em Paris, enquanto se celebravam uma série de conferências para negociar a paz no Vietnam, que "foram obscurecidas pela chamada revolução de maio" (GDO, 1968, p. 255).

A rebeldia juvenil que explode no paradigmático "sessenta e oito" é referida com ares de suspeita, inserida dentro da onda mundial. Para Díaz Ordaz

de algum tempo até hoje, em nossos principais centros de estudo, começouse a reiterar insistentemente a reprodução das palavras de ordem usadas em outros países, os mesmos cartazes, idênticas lendas, algumas vezes em simples tradução literal, outras em tosca paródia (GDO, 1968, p. 255).

Para Díaz Ordaz, a "ansiedade de imitação" foi o sentimento que se apoderou de centenas de jovens "de maneira servil" e irreflexiva. A este respeito, num relatório de 13 de agosto de 1968, um agente da DFS deu-se à tarefa de reproduzir as faixas, cartazes e palavras de ordem vistas e ouvidas durante uma passeata. Num momento em que o movimento estudantil estava alcançando seu ponto mais alto quanto à aceitação popular, os temas são bem diversos, para além das palavras de ordem internacionais ${ }^{202}$. Contabilizamos dezesseis laudas com as transcrições. Sublinhamos quatro grandes pautas, que expressadas na passeata, demonstram a diversidade das demandas estudantis:

1) A exigência do respeito ao estado de direito e contra a repressão: "Díaz Ordaz, não estendas a mão, toma a Constituição, respeita-a"; "Um bom governo não afoga em sangue os problemas. Os resolve"; "Liberdade aos estudantes presos".

2) Os referentes históricos: "Díaz Ordaz, onde está o Servo da Nação?"203; "Porfirio Díaz Ordaz: Mata-os en caliente"204; "Mais vale morrer de pé, que servir eternamente

\footnotetext{
202 Tomamos como referência a "marcha do silêncio" (13 de setembro) por ser registrada como a maior e melhor organizada das passeatas convocadas pelo $\mathrm{CNH}$. A partir daí, a repressão começou a intensificar-se. As instalações universitárias foram invadidas por militares, havendo um grande número de estudantes presos e desaparecidos, concluindo no fatídico 2 de outubro.

${ }^{203}$ O sacerdote José María Morelos y Pavón, apelidado o "Siervo de la Nación”, foi um dos mártires da luta pela independência do México no século XIX, autor do documento intitulado "Sentimientos de la Nación", uma espécie de pré-constituição. Trata-se de um símbolo histórico utilizado pelo governo de Díaz Ordaz.

${ }^{204}$ Mistura do nome do ditador Porfirio Díaz com o do mandatário Díaz Ordaz. A frase "mátalos en caliente" (i.e. mata-os rapidamente) é atribuída ao ditador, que supostamente a proferiu quando deu a ordem para aniquilar uma greve de trabalhadores têxtis na cidade de Cananea, em 1908.
} 
ajoelhado" "205; "Se Juárez não tivesse morrido, o teriam empurrado para os granaderos".

3) As denúncias de manipulação mediática: "Povo, não te deixes enganar pela imprensa vendida"; "Os agitadores são a ignorância, a fome e a miséria"; "Os livros não matam, as baionetas sim".

4) As referências à esquerda internacional: "O Che não morreu, vive entre nós"; "Até a vitória, sempre"; "Cuba sim, ianques não"206.

Díaz Ordaz aponta que foram localizadas três tendências principais no interior do movimento:

a de quem desejava pressionar o Governo para que se atendessem determinadas petições, a de quem tentou aproveitá-lo com fins ideológicos e políticos e a de quem se propôs a semear a desordem, a confusão e o rancor, para impedir a atenção e a solução dos problemas com a finalidade de desprestigiar o México, aproveitando a enorme difusão que haveriam de ter os encontros atléticos e esportivos, e impedir, talvez, a celebração dos jogos Olímpicos (GDO, 1968, p. 255).

O presidente aponta que a provocação e a incitação à violência, incentivando-se estudantes, tem o objetivo de criar um clima de intranquilidade social, favorável aos distúrbios de rua ou para gerar "ações de maior envergadura, das mais encontradas e inflamadas tendências políticas e ideológicas e dos mais variados interesses, em curiosa coincidência ou despreocupado contubérnio" (GDO, 1968, p. 262).

De seu turno, Luis Echeverría opina que a radicalização dos grupos de oposição unicamente configura "delitos que tentam se encobrir debaixo de um matiz político" cuja finalidade última é a "alteração do espírito de trabalho que anima a Nação". Afirma, também, que os executores e "quem desde a escuridão o patrocinam, ignoram, ou fingem ignorar, que as transformações políticas e sociais não são produto de ações isoladas, senão da participação popular consciente e majoritária" (LEA, 1974, p. 179). As políticas de seu mandato estiveram direcionadas, diz Echeverría, para "reencontrar a identidade política do país, e, com ela, a identidade nacional". Dessa forma, "quem vincula seus interesses e seu destino a centros externos de poder não acreditam no México nem confiam na potencialidade criadora de seu povo". A luta por justiça social devia estar vinculada à defesa da "nossa identidade e nossos verdadeiros interesses; é afirmar os valores em que se sustentam a independência e propor a

\footnotetext{
${ }^{205}$ Frase atribuída ao revolucionário Emiliano Zapata.

206 “Mantas y cartelones”, Distrito Federal, 13-08-68, AGN, IPS, Caixa 1458 A, Exp. 31, folhas 1-16.
} 
justiça como única via para edificá-la” (LEA, 1976, p. 440).

Observamos, portanto, que para o general Acosta Chaparro e também para os presidentes Díaz Ordaz e Echeverría, a crise social e os métodos organizativos da oposição (militar ou política) não estão vinculadas a nenhum fator da realidade mexicana. Em nenhum momento são explicitadas as tradições de luta do movimento estudantil, nem dos indígenas e camponeses mexicanos. Na versão construída por eles, a dissidência se baseou unicamente nas diretrizes cubanas [fig. 18].

\subsubsection{Terrorismo e apoio estrangeiro}

O apoio externo ao movimento armado mexicano é uma das peculiaridades dos processos políticos mexicanos no contexto da Guerra Fria. Lembremos que uma das premissas das doutrinas estadunidenses quanto à política exterior está em relação com o interesse soviético por apoiar técnica e financeiramente pequenos grupos, geralmente vinculados com os Partidos Comunistas, para a desestabilização dos regimes democráticos e a eventual instauração do socialismo. O interesse soviético em território latino-americano, segundo explicam os próprios estadunidenses, não existia durante os primeiros anos da Guerra Fria devido ao “fatalismo geográfico". Isto é, considerava-se suficiente a ação dos Partidos Comunistas locais, pois não existia a possibilidade real de mobilizar pessoal soviético. De acordo com esse pressuposto, o continente americano ganha importância para a política soviética na medida em que os EUA reformulam, da mesma maneira, sua política latino-americanista (TRUCCO, 1999, p. 46).

Num relevante artigo publicado na Military Review, o cientista político John B. McConaughy (2000) aponta que Fidel Castro traiu uma revolução cujos fins eram nacionalistas, cedendo diante do imperialismo soviético. A prova disso foi ter nomeado o "agente comunista internacional" Ernesto Guevara como ministro da economia nacional. Baseado no testemunho do ex-militar anticastrista, Pedro Luis Díaz Lanz, o autor garante que o plano de Castro era impor o modelo econômico soviético, apesar de ser um atentado contra a democracia e a liberdade (LAN, 1959 apud McCONAUGHY, 2000, p. 58) ${ }^{207}$. A partir desse

\footnotetext{
${ }^{207}$ Depoimento de Díaz Lan, antigo chefe da Fuerza Aérea Cubana, para o Subcomitê de Segurança Internado Senado dos EUA, em 14 de julho de 1959. O ex-militar garantiu que Castro disse a ele, literalmente: "Vou introduzir em Cuba um sistema como o que tem os russos, e até melhor que o sistema russo. Agora vou expropriar as terras daqueles que cooperavam ou simpatizavam com o governo anterior. Mais tarde, vou expropriar a terra de todo mundo" (McCONAUGHY, 2000, p. 58).
} 
instante, a URSS modificou sua política em relação ao continente. Segundo McConaughy, eram três os principais objetivos: 1. Destruir e paralisar a OEA; 2. Dividir os países internamente a fim de que os comunistas pudessem tomar o poder; 3. Isolar os EUA do resto do continente. Agora, para cumprir esses objetivos, os soviéticos se esforçariam por infiltrar comunistas em sindicatos, organizações populares e, na medida do possível, em governos débeis ou com certas simpatias com o socialismo. O último recurso seria o impulso da guerra de guerrilhas e do terrorismo (McCONAUGHY, 2000, p. 59).

Na definição de Richard Clutterbuck (1981, p. 9), o terrorismo "é a tática em que costumam acudir as minorias e os indivíduos frustrados por sua incapacidade para transformar a sociedade por meios considerados 'legítimos' por dita sociedade'. A este respeito, o manual contrainsurgente da Escola das Américas define que o "terrorismo é a arma dos débeis, radicais e psicopatas [...] uma etapa embrionária de uma insurgência, um ponto de partida" (SOA, 1989g, p. 1). São ações na margem das instituições cuja finalidade é exercer pressão para garantir seus fins. Agora, Clutterbuck também especifica que existe uma distinção entre as ações terroristas e as criminais ou delinquenciais. A diferença, óbvia, é que os infratores atuam com fins de lucro pessoal e os terroristas apresentam uma motivação política. Contudo, o autor ironiza dizendo que as motivações políticas "não são, em ocasiões, mais que um pretexto para obter poder ou compensações de índole pessoal” (1981, p. 14).

Apesar de que as organizações guerrilheiras ou terroristas podem ser nacionais (com aspiração à tomada do poder), transnacionais (que operam cruzando fronteiras nacionais), ou internacionais (que representam os interesses de um governo e operam cruzando fronteiras nacionais), em qualquer caso, o apoio externo é comum nesta classificação. Na teoria, o apoio estrangeiro pode provir de simpatizantes que, geralmente, "subministram fundos ou armas aos terroristas como costumam fazê-lo, por exemplo, algumas organizações de cidadãos norteamericanos de ascendência irlandesa que apoiam o IRA". Outro tipo de apoio pode vir de governos que, de maneira clandestina ou aberta, "tendem a apoiar movimentos de resistência que se enfrentam a exércitos de ocupação ou a grupos que lutam contra regimes coloniais" (CLUTTERBUCK, 1981, p. 20).

A SOA classifica o apoio externo em quatro tipos: é moral quando existe o reconhecimento da legitimidade das demandas, assim como da respeitabilidade de um movimento e de seus militantes; geralmente o apoio moral é público. $\mathrm{O}$ apoio também pode ser político, quando se abraçam as lutas de outros povos defendendo-as nos foros internacionais como a ONU ou a OEA, gerando um clima de pressão internacional para a resolução de conflitos a favor da nação apoiada. É material quando se traduz em somas de 
dinheiro, entrega de armas ou medicamentos; quando se oferece assessoria política, treinamento militar, ou apoio direto no combate. Por último, o manual denomina um tipo de apoio como santuário, que acontece quando se oferece adestramento logístico complexo dentro de bases seguras, isto é, em território estadunidense.

Uma questão interessante colocada pelo manual e que, de uma forma ou outra, justificaria a insistência dos governos mexicanos na teoria da conspiração internacional é que "naqueles casos em que o apoio externo não é um fator determinante para os objetivos dos insurgentes, isto pode significar que o governo é débil”" (SOA, 1989c, p. 17).

\subsubsection{A Revolução Cubana e a "orfandade" da guerrilha mexicana}

O grande impacto simbólico da Revolução Cubana na região latino-americana não está em questão. No caso mexicano, a defesa do governo revolucionário da ilha é uma reivindicação abraçada por grande parte da esquerda mexicana. Assim, por exemplo, desde 1960 se realizam passeatas na Cidade do México todo o 26 de julho em comemoração ao assalto ao quartel Moncada, manifestações nutridas majoritariamente por organizações universitárias. Dentro da esquerda armada, como apreciamos anteriormente, o GPG de Chihuahua assumiu como linha tática o foquismo, ou castro-guevarismo, como também é chamado. $\mathrm{O}$ expresidente Lázaro Cárdenas, desde o MLN, defendia intransigentemente o processo caribenho, inclusive, teve que ser pressionado pela SEDENA, em 1961, a ficar no México, pois se dispunha a viajar à ilha para se unir às milícias cubanas contra as tropas anticastristas que atacaram Playa Girón (REYNAGA MEJÍA, 2007). Essas manifestações de solidariedade e de vontade de imitação ecoaram pelo mundo inteiro.

Os revolucionários cubanos, de seu lado, sob a premissa de que "a solidariedade é a ternura dos povos", expressaram a vocação internacionalista na sua política externa. A postura cubana pode ser diferenciada cronologicamente: entre 1959 e 1961, abraça-se a solidariedade e as relações amistosas entre Estados, ou seja, apegados ao direito; entre 1962 e 1967, uma vez isolados após sua expulsão da OEA e das restrições impostas aos Estados para manter relações políticas e econômicas com a ilha, os cubanos começam um processo de composição de uma "diplomacia alternativa", direcionada, fundamentalmente, aos movimentos armados da região. Finalmente, a partir de 1967, após o golpe que significou o assassinato de Che Guevara na Bolívia, a solidariedade não se restringe aos grupos armados, se diversifica, alcançando, também, os movimentos nacionalistas de tipo reformista, como poderia se 
caracterizar o governo de Allende no Chile (DOMÍNGUEZ GUADARRAMA, 2014, p. 4344).

Mas lembremos que a tese do general Acosta Chaparro se apoia na perspectiva de que os grupos armados mexicanos eram diretamente promovidos e auxiliados pelo governo cubano. Porém, observando com maior detalhamento as características da diplomacia alternativa cubana, não encontramos nenhum tipo de reflexo no processo armado mexicano.

Desde 1959 Cuba cria um organismo chamado "Departamento M", dirigido por Manuel Piñeiro Losada, paralelamente diretor da Dirección General de Inteligencia. O Departamento $\mathrm{M}$ se encarregava especificamente do "apoio às guerrilhas revolucionárias da América Latina e o Caribe". Em 1961, o Departamento é absorvido pelo Ministerio del Interior, adquirindo o nome de Dirección para las Relaciones com los Movimientos Revolucionarios de América Latina y África. Ainda sob o comando de Piñeiro, iniciam-se uma série de campanhas cubanas no exterior. $O$ primeiro caso confirmado de intervenção cubana se registra em 1962, na construção do "foco de Salta" organizado por Ricardo Masetti (ex-diretor geral da Prensa Latina) no norte argentino. Contudo, como aponta o ex-chanceler mexicano Jorge G. Castañeda, não existe um registro confirmado sobre a participação cubana em todos os casos de focos guerrilheiros, nem se tem certeza de que a organização do apoio para o estrangeiro dependesse unicamente de Piñeiro.

Em resumo, desde 1959, a política cubana apoiou um número grande de grupos armados de diversas formas:

brindou treinamento a jovens de distintos países em instalações militares cubanas, os capacitou em técnicas de inteligência e em foças especiais, também formou combatentes e oficiais. Apoiou com armamento, dinheiro e oficiais cubanos, diversas tentativas de luta armada no continente. Brindou seu território como retaguarda, onde dirigentes podiam encontrar refúgio e apoio para desenvolver seus projetos revolucionários e, inclusive, reformulálos. Seu território foi local de encontro entre os distintos movimentos revolucionários no mundo (CASTAÑEDA, 1995, p. 68).

Nesse contexto, o caso mexicano é particular, pois a relação estabelecida entre o Estado cubano e o mexicano selou um pacto, mesmo sem ser de forma escrita, de nãoagressão. É conhecida a amizade estabelecida entre o chefe da DFS, Fernando Gutiérrez Barrios, com o próprio Fidel Castro, que remonta a 1956, quando o primeiro, então chefe de controle da DFS, possibilitou a saída dos cubanos no Granma para iniciar a insurreição armada. A amizade se reflete num relatório, não assinado, escrito em primeira pessoa, em que 
se descreve uma conversa com Gustavo Alatriste, diretor da revista de esquerda Sucesos. Segundo o escrito, Alastriste recentemente tinha voltado da ilha onde manteve um encontro com Fidel Casto, "o qual havia conversado sobre minha pessoa em forma elogiosa e pediu [a Alatriste] que, enquanto chegasse ao México me trouxesse uma saudação, e insistiu em que eu visitasse esse país". O relatório enfatiza a admiração que Castro expressa pelo México

e a seus Presidentes, já que considera que os políticos mexicanos sempre se caracterizaram por seu patriotismo e habilidade, ainda quando constantemente recebem fortes pressões do Imperialismo, como no caso do Presidente Díaz Ordaz, o que, apesar dessas pressões, continuou com a linha digna do México e seus princípios de Não Intervenção e Livre Autodeterminação dos Povos, o que tem sido um obstáculo para os Estados Unidos na sua política agressiva principalmente contra a República de Cuba; que sua negativa para a integração de uma força interamericana de defesa, é muito elogiada pelo povo e governo cubanos e que há de ser uma constante preocupação dos Estados Unidos a postura do México na próxima reunião que tratam de realizar, de Presidentes de Latino-América, já que nosso Governo não estará de acordo com muitas situações que tratarão os Estados Unidos de impor, o que quiçá se traduza para o México em situações difíceis [fig. 19] ${ }^{208}$.

Por esse tom amistoso, supomos que quem escreve o relatório é o próprio Gutiérrez Barrios. A morte do "capitão cavaleiro", como foi apelidado pelos cubanos do Granma, foi sentida pelo comandante Castro. No ano 2001, desde Havana, Castro se pronunciou a respeito: "Dom Fernando foi um grande homem. A intervenção deste mexicano exemplar foi chave. Sem Dom Fernando não haveria tido revolução nem existiria uma Cuba livre, certamente, não haveria Fidel" (IBARRA, 2001).

No território mexicano existia uma "base de segurança" integrada, provavelmente, por dez ou vinte agentes da DFS que mantinham contato direto com o agente da CIA para o qual entregavam informes sobre as atividades dos centros diplomáticos dos países socialistas (AGUAYO, 2014a). Descrevemos, anteriormente, a espionagem mexicana sobre a embaixada soviética, agora, no caso cubano, a partir da documentação que foi consultada, poderíamos estipular que o esquema de espionagem mexicano girava em torno ao registro de indivíduos que viajavam entre México e Havana. Em ambos os casos, o consentimento dessa grave violação à imunidade diplomática foi silenciosamente aceito por ambos os países socialistas, pois, por um lado, "Cuba garantia um canal de comunicação com a América Latina num período em que tinha sido excluída da comunidade hemisférica". Por outro lado, "a URSS desfrutava de um lugar privilegiado para realizar atividades de espionagem" (AGUAYO,

${ }^{208}$ Distrito Federal, 27-12-66, AGN, IPS, Caixa 1467 B, Exp. 10, folhas 1-2. 
2014a).

Apesar da amizade entre o líder revolucionário cubano e o dirigente da repressão no México, vemos como um dos pontos que se destacam na elaboração de antecedentes de ativistas, estudantes e militantes de organizações políticas é a relação que estes mantinham com a Revolução Cubana.

Num documento de dezesseis laudas, relatam-se os "antecedentes e atividades de elementos agitadores comunistas”. São oitenta e dois nomes de militantes majoritariamente adscritos à CCI, o MLN e o PCM, mas também de indivíduos dos quais se diz que "não é comunista, mas ataca o governo", até pessoas que em eventos políticos "incitam à revolução armada”. Entre eles, destacamos a Gilberto Rincón Gallardo, que formou parte do Comité Mexicano de Solidaridad con Cuba, espaço político de onde, supostamente, incitava à subversão através de discursos "em forma similar a como o fazia Fidel Castro Ruz". Outro estudante, Vicente Villamar Calderón, é indicado como agitador do setor universitário desde 1958. Há registro de duas viagens realizadas para Cuba em 1962 e 1964, suspeitando-se que "fez um curso sobre 'Guerra de Guerrilhas"”.

Outros dez nomes são apontados pelas viagens feitas para Cuba e, em menor medida, para Moscou. Destacamos, também, os antecedentes de Marciano Sarabia Fernández, que, supostamente, além de viajar para Cuba, dedica-se a redigir a propaganda onde "difunde as táticas e princípios da Revolução Cubana”. Por sua vez, a ativista da Unión Democrática de Mujeres Mexicanas dedica-se especificamente à organização de grupos de brigadistas mexicanos para visitar a ilha por meio do Comité Pro Defensa de Cuba. Finalmente, mencionemos o médico Juan Álvarez Márquez, que supostamente se declara "amigo de Fidel Castro Ruz, quem o convidou várias vezes a visitar Cuba"209.

Outro relatório contém duas listas em que aparecem dezoito nomes e números de passaportes dos mexicanos que viajavam com destino à Havana no voo 465 da companhia Cubana de Aviación, em 1966. Segundo a DFS, estas pessoas participariam num "Curso intensivo de Guerra de Guerrilhas em Havana, que terá uma duração de 30 dias a partir do dia 18 do pressente mês". Todos os passaportes, supostamente, foram expedidos na cidade de Puebla, "por cortesia da Embaixada de Cuba em nosso país" [fig. 20] ${ }^{210}$. Dentre as pessoas citadas, localizamos vários nomes do que seria, posteriormente, o núcleo fundador das

\footnotetext{
209 "Antecedentes y atividades de elementos agitadores comunistas", AGN, IPS, Caixa1573 A, Exp. 1, folhas 116.

210 "Personas que salieron con destino a Cuba a estudiar el curso de guerra de guerrillas", Distrito Federal, 23-0766, AGN, IPS, Caixa 826, Exp. 8, folha 1.
} 
Fuerzas de Liberación Nacional ${ }^{211}$.

Outra lista, desta vez correspondente a 1969, assinala o retorno de mexicanos desde Cuba, onde se encontravam desde 27 de dezembro. Sem o agravante dos supostos cursos de guerra de guerrilhas, alerta-se, porém, que “o conhecido agitador” Ramón Danzós Palomino permanece na ilha ${ }^{212}$.

O espectro da guerrilha cubana e de sua diplomacia alternativa teve repercussão dentro do território mexicano. Os agentes da DFS localizados no estado de Nuevo León, por exemplo, escreviam sobre a entrada de um suposto cubano com a missão de "dirigir os movimentos de agitação dentro das diversas agrupações [do norte do país] e para cujo fim tinha lançado um boletim". A pesquisa sobre o "cubano" foi promovida pela manifesta preocupação da Cámara de la Industria de la Construcción, sediada na cidade de Monterrey. O agente, então, considerando a presença cubana, sem aprofundar nos dados ou apresentar mais indícios, informa que "o Governo do estado considera que a atuação destes grupos está tomando um caráter de verdadeira gravidade" 213.

No sul do país, numa carta arquivada pela DFS, dirigida diretamente ao presidente da República, Echeverría, com cópia ao secretário da SEGOB, López Portillo (entre outros funcionários), é assinada pelo presidente do Consejo de Administración del Hotel Paso de Montejo, Manuel Cáceres Baqueiro. A carta informa sobre a chegada de um bilhete para o Hotel Mayab, que indica a ameaça de um suposto grupo de filiação guerrilheira, o "Grupo Queretano", de causar perdas e danos nas instalações da propriedade de Cáceres. Mas também contra sua família no caso de não entregar 500 mil pesos. $\mathrm{O}$ empresário enfatiza o medo de que as ações guerrilheiras atropelem a construção de uma cidade industrial que foi projetada pelo presidente Echeverría para a região, situada, além do mais, numa das regiões de maior fluxo turístico do país. Cáceres relata que "dada a gravidade que se poderia suscitar ao surgir em Yucatán um grupo guerrilheiro e a proximidade geográfica com a República de Cuba, considero necessária a imediata e enérgica intervenção das mais altas autoridades da Nação"214.

\footnotetext{
${ }^{211}$ Os nomes são Alfredo Zárate Mota e Napoleón Glockner. Segundo a historiadora Adela Cedillo (2008), a viagem foi no contexto das comemorações pelo aniversário do assalto ao quartel Moncada.

212 "Mexicanos que regresaron hoy de Cuba", Distrito Federal, 10-01-69, AGN, IPS, Caixa 3033 B, Exp. 7, folha 1. Ramón Danzós Palomino (1918-2002), militante fundador do PCM, foi um líder camponês dirigente da CCI e fundador da Frente Electoral del Pueblo (FEP), organização que o apoia como candidato independente nas eleições presidenciais de 1964. Expulso da CCI por suas posições radicais, cria a Central Independiente de Obreros Agrícolas y Campesinos (CIOAC) (FLORES LÚA; PARÉ; SARMIENTO SILVA, 1988)

213 "Estado de Nuevo León. Grupo de Agitación", Monterrey, 11-12-64, AGN, IPS, Caixa 1573 A, Exp. 1, folha 1.

${ }^{214}$ Mérida, 19-08-72, AGN, IPS, Caixa 1738 D, Exp. 13, folhas 1-3.
} 
Apesar da angústia demonstrada pelo empresariado mexicano e da teoria da conspiração estrangeira, não existem indícios materiais do apoio do governo cubano aos grupos armados mexicanos. Pelo contrário, a amizade entre ambos Estados selou um pacto em que um cuidava do outro. O responsável pelo Ejército Guerrillero de los Pobres (EPGGuatemala) no México, "Sebastián”, narra que numa entrevista realizada diretamente com o Comandante Manuel Piñeiro, em 1975, ele advertiu "que se eu estava me relacionando com os residentes, acabariam partindo-me a bunda" ("Carta de Sebastián a Casimiro y Compañeros de la Comisión Ejecutiva”, 1975 apud CAMPOS, 2014, p. 93). Ou seja, além de não receber apoio direto do Estado cubano, os guerrilheiros mexicanos se encontraram com a impossibilidade de tecer laços organizativos com grupos armados de outros países.

Os guerrilheiros mexicanos, através de dois sequestros, o primeiro em 1971, o outro em 1973, conseguiram que vários guerrilheiros que se encontravam aprisionados fossem recebidos em território cubano e que, de fato, se lhes outorgasse o status de exilado político. No primeiro caso, a Asociación Cívica Nacional Revolucionária (ACNR) de Genaro Vázquez sequestrou o concessionário da Coca-Cola e reitor da Universidad Autónoma de Guerrero, Jaime Díez Castrejón. Uma das condições para a libertação do reitor foi o pagamento de dois milhões de pesos para repartir entre as famílias das vítimas dos abusos policiais e militares no estado de Guerrero. A segunda condição consistia na libertação de militantes armados prisioneiros em vários cárceres do país. A Secretaria de Relaciones Exteriores, em contato com o governo cubano, dispôs um avião da Fuerza Aérea Mexicana para trasladar o grupo de presos (CASTELLANOS, 2008, p. 132-134).

Nesse grupo se encontrava Ismael Bracho, que garante que não existiu nenhum tipo de aproximação com as Fuerzas Armadas cubanas, nem de parte da ACNR, grupo ao que pertencia, "e nunca soube que outros grupos mexicanos os tivessem". Porém, os mexicanos tiveram a possibilidade de estudar e, de fato, integrar-se à dinâmica da Revolução: “Quando eu cheguei me incorporei aos companheiros que estavam lá. A maioria nos dedicamos a estudar. Alguns estivemos antes em hospitais, curando-nos das sequelas da luta, e depois começamos a trabalhar" (DÍAZ, 1996). No caso de Bracho, através do Instituto Cubano de Amistad con los Pueblos (ICAP), participou na construção de prédios e nas safras, continuou seus estudos, e posteriormente se dedicou à docência.

Por oturo lado, as Fuerzas Revolucionarias Armadas del Pueblo (FRAP), grupo armado da cidade de Guadalajara, como primeira ação pública planejaram o sequestro do cônsul dos EUA, Terrance Georges Leonhardy. Exigiam, em troca, a libertação e traslado para Cuba de trinta presos pertencentes a diversos grupos armados, avaliados como os 
melhores elementos de seus respetivos grupos. Segundo as FRAP, uma vez reunidos na ilha poderiam se reorganizar para retornar para o México e retomar a luta revolucionária. $\mathrm{Na}$ versão de um dos liberados, Alfredo Campaña (atualmente professor da UAG), narra-se uma experiência oposta à descrita anteriormente:

Morava num hotel na Havana Velha, o Regis. Ali moramos dez anos. O governo cubano nos deu asilo político, com um tratamento semelhante ao empregado dentro das formalidades diplomáticas: hotel, refeições e uma ajuda econômica que, todo mês, nos permitia comprar um livro. Era pouquinho. Nos davam café da manhã, comida e janta no hotel, onde não nos cobravam e nos tinham reservado um quarto para duas pessoas. Essa era nossa casa.

Campaña acrescenta que não se integrou à vida econômica e social da ilha, pois na sua qualidade de estrangeiro "não era sujeito de toda a confiança". Em relação à suposta possibilidade de reorganização guerrilheira a partir de Cuba, Campaña diz que "todo mundo vive sob a regulamentação internacional; não há margem para que cada um faça o que quiser". Afirma que o governo cubano advertia "que aqui são bem-vindos os que venham, mas nós priorizamos a relação que temos com o governo mexicano e não nos identificamos com outro tipo de movimentos" (DÍAZ, 1996).

Finalmente, num testemunho colhido por Carlos Montemayor, José Luis Alonso Vargas, outro dos presos soltos em troca do cônsul norte-americano, narra-se um encontro entre os guerrilheiros mexicanos com o comandante Manuel Piñeiro:

Em primeiro lugar, nos esclareceu que por ter uma boa e necessária relação diplomática com o México, Cuba não nos iria dar treinamento militar, como para o resto dos guerrilheiros da América Latina; que os governos do continente, da Guatemala para baixo, tinham rompido relações com eles e os tinham expulso da OEA por ordens dos Estados Unidos.

E que o México era a exceção. Por isso não iam pôr em risco essas excepcionais relações diplomáticas ajudando-nos com os treinamentos. Que podíamos solicitar tudo o que quiséssemos, menos isso; o que queiram estudar, nos disse, diga-nos, o que querem estudar? E em que nível estão? Entregue-nos seu currículo, e também por escrito expliquem-nos tudo o que queiram que saibamos de vocês. Porque se entendia que alguns de nós chegávamos com nossas lendas, usadas nas vidas clandestinas, e outros com as identidades verdadeiras [...].

Nessa ocasião, o comandante Piñeiro nos falou do tipo de vida que íamos levar [...]. Nossa sede era Havana, mas se saíssemos de Havana, deveríamos avisar os motivos - para onde íamos? por quanto tempo? - e todo o necessário para que eles cuidassem de nossa segurança. Alguns de nós não gostaram da negativa deles de treinar-nos. Não gostamos disso, porque para todos, ou quase todos, o objetivo principal era o treinamento militar e voltar 
o mais rápido possível para o México (MONTEMAYOR, 2010, p. 7).

A historiografia sobre a guerrilha somente considera a existência de um grupo guerrilheiro treinado militar e ideologicamente no estrangeiro, o Movimiento de Acción Revolucionaria (MAR) organizado por estudantes mexicanos da Universidade da Amizade entre os Povos "Patrice Lumumba" de Moscou. Eles conseguiram ser treinados na Coréia do Norte por recomendação do embaixador cubano em Moscou. Foram cinquenta e três os mexicanos treinados no país asiático, entre janeiro de 1969 e outubro de 1970 (CASTELLANOS, 2008, P. 173-178; CONDÉS, 2009b, p. 35-71).

\subsubsection{Maoísmo e a guerra popular prolongada no México}

Apostamos na existência de outro caso de treinamento de guerrilha - considerando os resultados desta investigação. Trata-se da experiência formativa do Partido Revolucionário del Proletariado Mexicano (PRPM). De orientação maoísta, o grupo teria conseguido treinamento ideológico e militar no maior país comunista asiático, aliás, durante a Revolução Cultural. Dada essa polêmica, queremos aqui aprofundar nos dados que os documentos da DFS nos aportam para o estudo desse grupo.

Nos primeiros anos da década de quarenta começou a formação de grupos, sobretudo trotskistas, a partir de dissidências do PCM. A expulsão do escritor e militante José Revueltas do PCM precipitaria a conformação da Liga Leninista Espartaco (LLE). A base teórica estava explícita nas propostas de Revueltas no texto Ensayo sobre un proletariado sin cabeza onde expressou que o PCM não estava presente na consciência organizada da classe operária, que, então, encontrava-se sem liderança. A construção do verdadeiro partido revolucionário, segundo Revueltas, era um imperativo nesse momento em que o PCM estava obsoleto (REVUELTAS, 1962). Em 1966 a LLE se fusiona com outras organizações pequenas de orientação maoísta, para, finalmente assumir o nome de Liga Comunista Espartaco (LCE) ${ }^{215}$.

\footnotetext{
${ }^{215}$ Não é muito clara a influência do pensamento de Rosa Luxemburgo nos espartaquistas mexicanos. Segundo Octávio Rodríguez Araujo, é possível que o apelo ao espartaquismo deva-se à concepção mais flexível e democrática do partido elaborada por Rosa Luxemburgo, que dizia que "a liberdade é sempre unicamente a do que pensa de outra maneira". Enquanto que, em referência à ditadura do operariado, ela colocava que o objetivo devia ser a expansão e não a supressão da democracia. Mas não da democracia burguesa (que não é democrática). Ou seja, uma ditadura da classe operária e não de uma minoria dirigente "que atue em nome da classe" (LUXEMBURG, 1977, p. 585, 591). A partir dessa questão, Rodríguez Araujo cogita a possibilidade de que nessas concepções se localizem as motivações teóricas da ruptura com o PCM. O reflexo de Luxemburgo nos espartaquistas mexicanos se faz presente quando "não diziam que suas organizações fossem
} 
A LCE reivindicava as teses fundamentais do maoísmo, considerava que a tomada do poder tinha que estar vinculada irremediavelmente à luta guerrilheira implantada no campo e avançando para as cidades. Reconheciam, então, o pensamento de Mao Zedong como o guia científico mais elaborado para a transformação da realidade mexicana (FERNÁNDEZ CHRISTLIEB, 1978, p. 145). Esta organização aglutinou grande parte dos grupos próchineses surgidos após o conhecimento das resoluções do XX Congresso do Partido Comunista da União Soviética ${ }^{216}$.

Nesse momento de rupturas e definições no comunismo mexicano, podemos situar dois grupos que não formariam parte da LCE, mas que teriam um trabalho muito mais orgânico e direto com os chineses: O Movimiento Marxista Leninista de México (MM-LM) e o Partido Revolucionario del Proletariado Mexicano (PRPM). Um personagem fundamental para a reconstrução da história dessa vertente do maoísmo é o engenheiro Javier Fuentes "Pancho" ou "Popoca" que teria participado de ambas as organizações.

Javier Fuentes nasceu em 22 de julho de 1925, no Distrito Federal [fig. 21]. Em 1951 se forma como engenheiro petroleiro ${ }^{217}$, provavelmente do IPN. Militou nas organizações de esquerda independente mencionadas anteriormente, o MLN e a CCI em $1963^{218}$. Radicado no estado de Morelos, foi nomeado para vários cargos de direção política, tanto na CCI, como na Frente Electoral del Pueblo (FEP) ${ }^{219}$. Aliás, foi postulado como candidato a deputado federal pela FEP para representar o Segundo Distrito do estado de Guerrero ${ }^{220}$.

Expulso da CCI pelo extremismo de seus posicionamentos, contacta o MM-LM, cujos militantes eram melhor conhecidos como "mamelucos",221. Segundo Emery Ulloa, Javier

o partido da classe operária, e sim, um núcleo que trabalharia para formá-lo" (RODRÍGUEZ ARAUJO, 2014, p. 20).

${ }^{216}$ Para o historiador Barry Carr, a discussão URSS-China não teve muita ressonância dentro do comunismo mexicano. A influência maoísta ("ir para o povo, aprender do povo") esteve mais presente dentro do nascente movimento urbano popular e em menor medida na guerrilha (CARR, 2000, p. 237). Porém, observamos que por volta de 1960, ano de realização do XIII Congresso Nacional do PCM, iniciou-se um processo de redefinição de políticas e táticas próximas ao eurocomunismo reformista da metade da década dos sessenta. Em 1961, foram expulsos os militantes comunistas pró-chineses encabeçados por Camilo Chávez e Edelmiro Maldonado, até então, membros da Comissão Política do PCM, entre outros jovens que nutriram a LCE.

217 “Ingeniero Javier Fuentes Gutiérrez”, Distrito Federal, AGN, IPS, Caixa 3033 A, Exp. 12, folha 1.

218 "Partido Revolucionario del Proletariado Mexicano", Distrito Federal, 03-08-72, AGN, IPS, Caixa 2538, Exp 1 , folhas $1-2$.

219 "Ing. Javier Fuentes Gutiérrez", Distrito Federal, 26-06-64, AGN, IPS, 3033 A, Exp. 12, folha 1. O FEP foi um partido de esquerda não governista fundado pelo guerrilheiro camponês, Rubén Jaramillo, em 1963, que lançou candidaturas independentes para vários cargos de eleição popular. Aliás, o FEP era ilegal, pois não cumpria com os requerimentos para ser um partido, devido às limitações impostas pela lei eleitoral.

220 "Partido Revolucionario del Proletariado Mexicano", Distrito Federal, 03-08-72, AGN, IPS, Caixa 2538, Exp 1, folhas 1-2.

${ }^{221}$ Foi a organização conformada por militantes expulsos do PCM, majoritariamente intelectuais e estudantes universitários, em 1966. Era dirigida por Francisco Emery Ulloa (LAGUNES CASTILLO, 2010, p. 138; CONDÉS, 2009c, p. 108). 
Fuentes nunca formou parte orgânica dos mamelucos, ele teria sido chamado com o objetivo de criar e dirigir outra organização que se dedicasse, como o MM-LM, à difusão da literatura maoísta com apoio direto dos chineses. A difusão das teorias chinesas, nesse primeiro momento, estava inscrita no âmbito político, porém a DFS aponta que Javier Fuentes esteve, desde 1963, vinculado (como dirigente) a diversos grupos armados.

O primeiro relatório em que aparecem descritas as atividades de Fuentes relacionadas com os chineses data de 26 de julho de 1966. Aí, o capitão Gutierres Barrios, diretor da DFS, faz a descrição pormenorizada de uma reunião entre Fuentes e Pieng Cheng, chefe da Agência Chinesa de Notícias, ocorrida em 4 de julho do mesmo ano. Na suposta reunião, Fuentes agradece o convite para viajar para a China. Além disso, informa sobre a necessidade de que seu passaporte esteja em nome de "Xavier Popoca Gutiérrez". Isto é, os chineses estavam elaborando um documento falso para o mexicano. Em outro tema, menciona-se que o engenheiro será o responsável pela Distribuidora Interamericana de Publicaciones, que venderia livros por meio da "El Primer Paso", livraria localizada no centro da capital.

$\mathrm{Na}$ descrição do esquema de cooperação se informa que a "Agência Noticiosa 'Sin Jua' (sic) lhe envia seiscentas libras esterlinas mensalmente, assim como também por mediação das distribuidoras “Gouzi Sudian' (sic) e “Waiwen Shudian' (sic) com sede em Pequim. Recebiam diferente literatura gratuita e propaganda" com o objetivo de que os lucros fossem utilizados para cobrir os gastos gerados pelo treinamento e manutenção de uma organização armada $^{222}$. A propaganda chinesa chegava no México para quatro endereços. À Distriuidora Interamericana de Publicaciones e à livraria "El Primer Paso", ambas no nome do engenheiro Fuentes; à livraria "Lina" de Jaime Villa Sole; ao endereço particular de Juan Larios Tolentino, talvez advogado, membro da Sociedad Mexicana de Amistad con China Popular; e à doutora Esther Chapa Tijerina, da Sociedad de Amigos de China Popular ${ }^{223}$.

Pelo tom do relatório que contém a entrevista entre Fuentes e Pieng Cheng, ao que parece, provém de algum infiltrado. Também, em termos pragmáticos, é detalhada a maneira de realizar entrevistas com os trabalhadores da Distribuidora no objetivo de que o chinês selecionasse os indivíduos com maior aptidão para viajar para a China e receber o treinamento teórico e militar ${ }^{224}$. A partir desse fato, tudo indica que existia um consentimento chinês para a formação de guerrilhas em território mexicano.

\footnotetext{
222 "Boletín entregado a los periodistas por la PGJR", Distrito Federal, 19-07-67, AGN, IPS, Caixa 3033 A, Exp. 10 , folha $1-2$.

223 "Nombres y cargos que ocupan las personas a quienes estaba dirigida la propaganda China que fue decomisada", Distrito Federal, AGN, IPS, Caixa 3033 B, Exp. 6, folha 1-3.

224 "Informe sobre: Javier Fuentes Gutiérrez", Distrito Federal, 29-07-66, AGN, IPS, Caixa 3033 A, Exp. 12, folhas 1-2.
} 
No dia 17 de julho de 1967, informa-se que foram apresentados à PGR quatorze pessoas de um grupo armado cujo nome nunca é mencionado, mas supostamente encabeçado por Javier Fuentes:

relacionados com a participação em atos subversivos que tendiam a derrocar o Governo e instaurar um de tipo "popular socialista", para isto planejavam integrar guerrilhas rurais e urbanas para o que efetuariam um treinamento prévio e, depois, em forma simultânea, iniciar em diferentes entidades da República, "focos insurrecionais" que coincidiriam com atos de sabotagem e terrorismo na Cidade do México, principalmente contra negócios com capital norte-americano e instalações de serviço público; também orquestravam o assalto a uma agência do Banco de Industria y Comercio com a finalidade de prover-se de condições para a aquisição de armas e incrementar seu movimento 225 .

Entre os detentos encontrava-se Adán Nieto Castillo ${ }^{226}$, apontado como autor intelectual da organização, ex-militante do PCM e "agora com ribetes trotskistas". Segundo o relatório, Nieto Castillo tentava formar uma organização operário-estudantil tendo oferecido

instrução a vários jovens que haviam integrado já este grupo subversivo, para que cometessem atos de terrorismo em diversas instalações da Capital da República, como início de seu movimento, prometendo-lhes, além do mais, proporciona-lhes instrutores para o manuseio de explosivos com tal $\mathrm{fim}^{227}$.

Cabe mencionar que - até onde se sabe - Nieto Castillo não tinha nenhum tipo de relação orgânica com o engenheiro Fuentes, pois pertenciam a ambientes diferentes cujos campos de ação pouco se relacionavam. No caso dos outros prisioneiros, também é difícil considerar que eles estivessem todos juntos num pretenso grupo armado, pois, segundo as mesmas informações proporcionadas nos relatórios, somente alguns tinham vínculo direto com os maoístas de Fuentes.

José Luis Calva Téllez, estudante da UNAM, é apontado como chefe do grupo e autor intelectual de um assalto ao Banco de Industria y Comercio que não chegou a concretizar-se. Ele também seria o encarregado pelo recrutamento. Pablo Alvarado Barrera é apontado como

\footnotetext{
225 “Investigación sobre actividades subversivas", Distrito Federal, 18-07-67, AGN, IPS, Caixa 3033 A, Exp. 10, folha 1.

${ }^{226}$ Secretáriogeral do Sindicato Nacional de Mineros y Metalúrgicos de la República Mexican, entre 1946 e 1950. Advogado dos operários da mineradora de Nueva Rosita, Palau y Cloete, Coahuila, em 1950. Trabalhou, também, como assessor do Sindicato de Choferes de la Línea de Transporte Local Peralvillo-Cozumel. (GARCÍA SÁNCHEZ, 2008, p. 87, 90).

227 "Boletín entregado a los periodistas por la PGJR", Distrito Federal, 19-07-67, AGN, IPS, Caixa 3033 A, Exp. 10 , folhas 1-4.
} 
“o segundo" na hierarquia do grupo ${ }^{228}$. Roberto Iriarte Jiménez "David Rojo", o suposto coordenador geral do movimento e instrutor de guerrilha urbana. Silvestre Enrique Marenco Martínez, por sua vez, teria ensinado o grupo na tática de guerra de guerrilhas ${ }^{229}$. Raúl Contreras Alcántara, estudante da UNAM, também teria trabalhado na Distribuidora Interamericana e "membro proeminente" do grupo. Eduardo Fuentes y de la Fuente seria apenas trabalhador da livraria e estudante da UNAM. César Catalán Sánchez, estudante, encarregado da compra de armamento. Enrique Escudero Mastache, como estudante do IPN. Manuel Méndez Prado, estudante especialista na elaboração de explosivos. Daniel Camejo Guanche, que teria a função de dar ao grupo ajuda econômica, medicinas e propaganda para o movimento $^{230}$. Marina Concepción Hernández de Calva, como estudante e esposa de José Luis Calva ${ }^{231}$.

Dentro desse mesmo grupo de prisioneiros presentou-se a Miguel Ángel Flores Bernal e a Adrián Campos Díaz, ambos camponeses do estado de Guerrero, acusados de envolvimento num atentado contra um veículo militar.

Como podemos observar, a maioria dos presos eram estudantes ${ }^{232}$. No jornal $L a$ Prensa de 19 de julho de 1967, denuncia-se o desaparecimento de sete membros do conselho estudantil de uma escola da UNAM. Insinua-se, ainda, a possibilidade de que eles tivessem sido sequestrados, posto que não tinham notícias deles nem em hospitais e nem em centros de detenção policial ${ }^{233}$. Entre os nomes citados na breve matéria do jornal encontram-se os estudantes apresentados como membros do grupo de Fuentes, acima mencionados, e Marco Antonio Rivas Guzmán, Maximino Ortega e Ángel Benhumea, que não tinham nenhuma relação com o grupo maoísta. Pelas datas que temos, o grupo dos quatorze presos foi entregue em 17 de julho, mas o jornal em que aparece a matéria corresponde ao dia 19 do mesmo mês.

\footnotetext{
${ }^{228}$ Professor normalista pertencente ao Grupo Popular Guerrilero de Arturo Gámiz. Após o fatídico assalto ao quartel de Madera, juntou-se ao Movimiento 23 de Septiembre. Em 24 de setembro de 1971, ele foi sequestrado pela DFS junto com Florentino Jaimes, colaborador do grupo guerrilheiro de Genaro Vázquez Rojas, dentro das próprias instalações da Cárcere de Lecumberri, onde ambos eram prisioneiros. Não se teve notícia deles até o dia 4 de dezembro do mesmo ano, quando Alvarado apareceu assassinado na cozinha do presídio. A versão oficial apontou que Alvarado tentou fugir junto com outros três presos comuns. Sua morte nunca foi esclarecida (URIARTE BONILLA, 2009).

${ }^{229}$ Guerrilheiro salvadorenho com uma suposta experiência em vários países centro-americanos, desde 1959 (mas não se indica em quais). Trabalhava com o engenheiro Fuentes na livraria ("Investigación sobre actividades subversivas", Distrito Federal, 18-07-67, AGN, IPS, Caixa 3033 A, Exp. 10, folha 1).

${ }^{230}$ Venezuelano residente no México, de suposta orientação trotskista ("Informe”, Distrito Federal, 18-07-67, AGN, IPS, Caixa 3033 A, Exp. 10, folhas 1-2).

231 "Boletín entregado a los periodistas por la PGJR", Distrito Federal, 19-07-67, AGN, IPS, Caixa 3033 A, Exp. 10 , folhas $1-4$.

232 "Situación escolar de los que se mencionan", Distrito Federal, 19-07-67, AGN, IPS, Caixa 3033 A, Exp. 10, folhas 1-2.

233 "Desaparecieron siete líderes de estudiantes", La Prensa, Distrito Federal, 19-07-67, Caixa 3033 A, Exp. 10, folha 1 .
} 
Não temos a data em que apareceram. Ou seja, os três estudantes não relacionados permaneceram pelo menos outros dois dias em detenção.

Afinal, a detenção dos supostos maoístas teve repercussões internacionais. Um telegrama arquivado pela DFS proveniente de São Francisco, Califórnia, dirigido a Díaz Ordaz aponta que:

PROFUNDAMENTE PERTURBADOS PELA
TORTURA REPORTAGEM DE
ANTICONSTITUCIONAIS NA PRISÃO DE DANIEL CAMEJO E MAIS
DOZE PESSOAS COMO SUPOSTOS MAOISTAS ponto URGE A
COMPLETA RESTAURAÇÃO DA LIBERDADE CIVIL ponto OS
OLHOS DE TODOS OS AMERICANOS POSTOS NA CIDADE DO
MÉXICO ponto RESPEITOSAMENTE
DIANE ADLER Y SYDNEY SCHIFFER

A contundente e irônica resposta da presidência através da SEGOB saiu no mesmo dia. O texto sublinha o tom da política repressiva:

Senhores Diane Adler e Sydney Schiffer,

São Francisco, Cal.

SEU TELEGRAMA TRINTA JULHO DIRIGIDO SENHOR PRESIDENTE REPÚBLICA FOI ENVIADO PARA ESTE ESCRITÓRIO ponto CARECEM VOCÊS TOTALMENTE CAPACIDADE LEGAL E MORAL PARA DIRIGIR SOLICITAÇÃO FORMULAM ponto SUA INFORMAÇÃO É FALSA vírgula POIS TODO PRESO NO MÉXICO GOZA AMPLAS GARANTIAS CONSTITUCIONAIS ponto PESSOA REFEREM-SE SE ACHA SUJEITA A PROCESSO LEGAL POR DIVERSOS DELITOS VEIO A COMETER NO MÉXICO ponto SERIA CONVENIENTE QUE OS OLHOS DE VOCÊS vírgula QUE FORMAM PARTE DOS "OLHOS DE TODOS OS AMERICANOS POSTOS NA CIDADE DO MÉXICO” coma COMO VOCÊS DIZEM vírgula SE DIRIGISSEM PARA ASSUNTOS DE SUA INCUMBÊNCIA ponto ATENTAMENTE ponto

O SUBCHEFE DO DEPTO. DE MIGRAÇÃO

DA SECRETARIA DE GOBERNACIÓN

LIC. J. CARLOS OSORIO ${ }^{235}$.

Paralelamente às detenções foi investigada a casa de Javier Fuentes, local que funcionava como depósito da livraria. Sobre isso, encontramos um pacote de dezesseis fotografias com diversos aspectos da propaganda recolhida tanto na casa, como nos armazéns da Dirección de Correos, antes de ser despachados para os destinatários que anteriormente

\footnotetext{
${ }^{234}$ Caixa alta no original.

235 “Telegrama”, Distrito Federal, 30-07-67, AGN, IPS, Caixa 3033 B, Exp. 6, folhas 1-2. Caixa alta no original.
} 
apontamos [fig. 22]. Ainda que a introdução ao país de livros, folhetos ou publicações periódicas não constituía um delito, segundo o Artigo 22 do Código Aduanero, o poder Executivo tinha a faculdade de "proibir ou restringir a importação, exportação ou transito das mercadorias que se considerem nocivas à salubridade pública, que afetem a moral, o decoro nacional, a economia do país ou que constituam um perigo para a tranquilidade ou segurança do mesmo". Nesse aspecto, o item IV do Artigo 441 da Ley de Vías Generales de Comunicação proíbe a circulação no correio de correspondência que "presumivelmente possa ser utilizada no cometimento de um delito, mas é claro que a circulação desta classe de correspondência não constitui por si mesma um delito, mas sim que é, em todo caso, um instrumento para o cometimento de delitos futuros". Finalmente, o Artigo 29 da Ley de Imprenta estabelece "responsabilidade criminal para aqueles que importem, reproduzam ou exponham escritos, livros impressos e demais objetos em que há ataques à vida privada, à moral ou à paz pública” ${ }^{, 236}$. Estes elementos jurídicos foram considerados para expedir o mandado de prisão contra Javier Fuentes Gutiérrez.

Até esse momento, as investigações sobre a participação política do engenheiro Fuentes o apontavam como dirigente de um grupo armado, além das acusações de violação de várias disposições legais pela distribuição de propaganda subversiva. Mas ainda estava livre.

Segundo outra série de relatórios com datas anteriores à detenção dos quatorze indivíduos, em 1967, Fuentes fora expulso da CCI pelo radicalismo de suas posições. Teria-se dedicado a formar círculos de estudo sobre maoísmo no estado de Morelos voltados a jovens estudantes e camponeses da região previamente identificados e escolhidos durante sua permanência na CCI. Entre os que teriam comparecido a reuniões encontramos Antonio e Israel González, Rafael Equihua, Aquileo, Primo, Pedro y Florencio Medrano; Abundio e "el Tlacuache", dois ex-guerrilheiros da década dos anos cinquenta; Justo, um indígena de Xoxocotla; e Carmelo Cortés, que depois faria parte do PDLP-BCA junto a Lucio Cabañas ${ }^{237}$.

O objetivo principal dessas reuniões era convencer os assistentes de que o estudo da teoria maoísta seria fundamental para iniciar a luta revolucionária, para o qual era oportuno começar a incrementar a organização para depor o governo e instaurar um de tipo socialista. A partir dessas reuniões se decide pela criação do PRPM.

\footnotetext{
236 "Memorándum relativo a las disposiciones legales aplicables a las publicaciones impresas con propaganda subversiva", Distrito Federal, AGN, IPS, Caixa 3033 A, Exp. 10, folha 1.

${ }^{237}$ Personagens importantes para o movimento urbano popular do estado de Morelos na década de setenta. Constituíram-se nas lideranças das organizações que recuperariam terras para a fundação de colônias populares. (MIER MERELO, 2003, p. 340).
} 


\subsubsection{O PRPM e o treinamento militar}

De forma paralela a sua atividade com os camponeses morelenses, Fuentes mantinha relação com um grupo de jovens estudantes e profissionais da Cidade do México. Entre eles estavam Jesús Gómez Ibarra, a esposa dele, “Teresa"238, Raúl Ernesto Murguía Rosete, Rosalba Robles Vessi e a advogada Judith Leal Duque. Com eles, reunia-se para estudar a história do México e, particularmente, para fazer leituras da sociedade mexicana a partir da doutrina marxista-leninista-maoísta ${ }^{239}$. Estes jovens tinham a seu favor não carregar sobre suas costas as lutas ideológicas da esquerda dos cinquenta e sessenta, "eles não tinham vivenciado a disputa sino-soviética, nenhum havia militado no PCM, nem provinha dos antigos núcleos maoístas do MM-LM, tampouco das células maoístas do espartaquismo" (CHAO BARONA, 2001, p. 101). O negócio da livraria, portanto, era um centro de recrutamento.

Durante o movimento estudantil de 1968, o engenheiro inicia um processo de seleção de estudantes nas universidades públicas. Além dos jovens citados acima, encontrava-se Antonio García de León, da Escuela Nacional de Antropología e Historia (ENA). Após a repressão do movimento e o massacre de 2 de outubro, o engenheiro junto aos estudantes elabora um programa de luta para o PRP, cujo objetivo era

expandir o Partido com a ideia de fazê-lo nacional, devendo-se buscar o aglutinamento de todos os grupos revolucionários que operavam na República para fazer e fomentar a luta armada a nível nacional e com força avassaladora, toda vez que se fizessem em forma simultânea e desde diferentes frentes, insistindo em que a linha mais conveniente para o novo sistema a estabelecer-se no país era e é a "maoísta" 240.

Por volta de maio de 1969, o engenheiro Fuentes consegue que alguns militantes do PRPM - entre estudantes e camponeses - viajassem para Pequim em dois grupos. No primeiro, viajam Raúl Munguia, Rosalba Robles, Israel González, Rafael Equihua, Judith Leal Duque e Florencio Medrano. No segundo, Antonio García de León e Aquileo Medrano, que fariam escala em Helsinki e em Paris, onde encontrariam "Teresa", encarregada dos contatos com a embaixada chinesa para garantir a entrega das passagens e diárias. Uma vez reunidos em Pequim, foram conduzidos para Nanquim.

\footnotetext{
${ }^{238}$ Desconhecemos o nome real.

${ }^{239}$ ROBLES VESSI, Rosalba: depoimento [01-04-2010], México. Entrevista concedida a Azucena Citlalli Jaso Galván. Robles menciona que este grupo da capital somente conheceu o engenheiro pouco antes do ocorrido no movimento estudantil, em outubro de 1968.

240 "Partido Revolucionario del Proletariado Mexicano", Distrito Federal, 03-08-72, AGN, IPS, Caixa 2538, Exp.

1 , folhas 1-6.
} 
A intenção de que fossem para uma escola de quadros internacionais dependente do Partido Comunista da China era para a preparação ideológica intensiva, mas também, para o treinamento militar. O grupo esteve presente para ver as ações dos jovens universitários pertencentes à Guarda Vermelha da Revolução Cultural Proletária. Diz García de León:

Tínhamos que nos levantar às cinco da manhã, correr. Depois eram operações militares, assaltos a "casa mata", e outras coisas. E aprendemos a armar e desarmar com os olhos fechados um fúsil chinês. Supostamente eram os fuzis que nos íam enviar para fazer a revolução no México. Então, eu podia já, com os olhos fechados, desarmá-lo e logo voltá-lo [armá-lo]. E, bom, nos ensinaram muitas técnicas, a fazer bombas e um monte de coisas mais $^{241}$.

Já Rafael Equihua se alonga na descrição dos treinos, na declaração que provém do interrogatório de 3 de agosto de 1972, quando foi detido pela DFS na cidade de Cuernavaca, Morelos:

Às 6.00 horas faziam exercícios de ginástica e caminhadas; às 6.30 horas asseio e imediatamente depois um café da manhã leve; das 8.00 às 11.30 horas aulas teóricas; às 12.00 horas almoço, e na continuação um cochilo; das 14.30 às 18.30 horas novas aulas e logo o tempo para jantar e depois discussão ou comentários sobre o estudado e às 21.00 horas dormir; que as aulas consistiam em política, estratégia e tática militar, explosivos e manuseio de armas de fogo e práticas de tiro, lembrando que destas últimas só tiveram duas ou três práticas, não quanto aos explosivos, que foram mais amplas, ensinando-lhes o manuseio de explosivos, dinamite, minas, e como fabricar e conectar detonadores; que também realizaram simulacros práticos de ataques e emboscadas nos quais participavam todos os membros do grupo mexicano já mencionados e como inimigos atuavam soldados chineses usando fuzis sem cartuchos e em ocasiões lhes davam balas de salva, usando camuflagem e os chineses sempre diziam que no simulacro lutavam contra japoneses $^{242}$.

Há de se notar o detalhamento feito pelo interrogado para a descrição dos treinos, sobretudo porque o depoimento foi dado depois de cinco anos da viagem, certamente sobtortura e intimidações psicológicas.

O grupo treinado volta para o México no fim do mês de dezembro de 1969 com a finalidade de fazer trabalho político no campo. Para cobrir as despesas econômicas da compra de armamento, o PRPM mantinha um local de aluguel e reparação de bicicletas em

${ }^{241}$ GARCÍA DE LEÓN, Antonio: depoimento [22-04-2009], México. Entrevista concedida a Azucena Citlalli Jaso Galván.

242 "Partido Revolucionario del Proletariado Mexicano", Distrito Federal, 03-08-72, AGN, IPS, Caixa 2538, Exp.

1 , folhas 1-6. 
Cuernavaca, onde trabalhava Florencio e Aquileo Medrano. Da mesma forma, tinham uma serralharia num bairro popular da capital, onde trabalhava Rafael Equihua ${ }^{243}$ - além da livraria "El Primer Paso".

Antes de iniciar qualquer atividade guerrilheira, a DFS começou a perseguição aos militantes, pois foram identificados desde sua chegada da China. Um fato que ocorreu em ferreiro de 1970 precipitou a desarticulação do grupo. Numa oficina de reparação de aparelhos eletrodomésticos que funcionava como arsenal de um grupo guerrilheiro denominado Comité de Lucha Revolucionaria (CLR) foram detonadas duas bombas que estavam sendo armadas no local. Na avaliação de García de León, é provável que as pessoas que aí trabalhavam, vendo-se rodeadas pela polícia, decidiram se suicidar, explodindo as bombas com a cortina de ferro fechada ${ }^{244}$. O CLR foi catalogado pelas autoridades como organização terrorista, porque nesse momento foram vinculados com as detonações de bombas colocadas nos prédios dos jornais El Sol de México, El Heraldo, num estúdio de Televisa, assim como na SEGOB ${ }^{245}$.

Segundo as conclusões lançadas pelas investigações da DFS, o CLR - culpável de conspiração, incitação à rebelião, associação criminosa, fabricação de bombas, dano em propriedade alheia e lesões - mantinha relações com outros grupos armados que operavam em Chiapas, Tabasco, Mérida e Guerrero, especificamente com o grupo de Genaro Vázquez, e no Distrito Federal e Morelos, com o PRPM. Para as autoridades, de fato, o CLR e o PRPM eram um só, e Fuentes Gutiérrez o artífice da coordenação entre ambos os grupos extremistas ${ }^{246}$. Agora, para Rosalba Robles, a suposta aliança entre o CLR e o PRPM nunca se realizou, isso devido à detenção precipitada dos militantes do CLR ${ }^{247}$.

Por volta de fevereiro de 1970, a célula do PRPM da Cidade do México começa a apresentar dificuldades com um simpatizante do grupo encarregado da distribuição da propaganda do grupo no bairro de Tlatelolco. Não apresentava as contas do que era vendido, estava segurando o material e, no geral, mostrava um comportamento bem suspeito. Para tentar melhorar o relacionamento com os integrantes do movimento, Javier Fuentes reúne

\footnotetext{
243 "Partido Revolucionario del Proletariado Mexicano", Distrito Federal, 03-08-72, AGN, IPS, Caixa 2538, Exp. 1, folhas 1-6.

${ }^{244}$ GARCÍA DE LEÓN, Antonio: depoimento [22-04-2009], México. Entrevista concedida a Azucena Citlalli Jaso Galván.

245 "Captura y consignación de un grupo terrorista”, El Día, Distrito Federal, 15-02-70, AGN, IPS, Caixa 3033 A, Exp. 10, folha 1.

246 "Texto de la consignación de Raúl Ernesto Murguía Rosete, Rosalba Robles de Murguía y Judith Leal Duque", El Día, Distrito Federal, 07-03-70, AGN, IPS, Caixa 3033 A, Exp. 10, folha 1.

${ }^{247}$ ROBLES VESSI, Rosalba: depoimento [01-04-2010], México. Entrevista concedida a Azucena Citlalli Jaso Galván.
} 
Raúl Munguía, Rosalba Robles e Judith Leal Duque no intuito de se apresentar no apartamento do simpatizante para conversar e reforçar as medidas de segurança.

Chegando no local, em vez do simpatizante estavam postados aproximadamente sessenta homens comandados por Miguel Nazar Haro, então subdiretor da DFS. Rosalba Robles aponta que, evidentemente, houve uma delação ${ }^{248}$, e García de León coincide. Num encontro posterior, questionado por García de León sobre os motivos da delação, o simpatizante argumentou que a polícia tinha sequestrado sua esposa, que estava grávida. Ameaçando-o com o estupro e a tortura dela, o homem aceitou fazer a denúncia sobre o encontro $^{249}$.

A partir daí foram sequestrados o engenheiro Javier Fuentes, Murguía Rosete, Robles Vessi e Leal Duque. Após vários dias de permanência num local desconhecido provavelmente o Campo Militar No. 1 ou algum outro escritório policial ocupado como cárcere clandestino $^{250}$ - foram apresentados às autoridades e acusados de conspiração, incitação à rebelião, associação criminosa e encobrimento dos delitos de dano em propriedade alheia por explosão e lesões ${ }^{251}$.

Com o núcleo do PRPM na prisão, o restante do grupo se dispersa. Os detentos permanecem em Lecumberri e no presídio de mulheres de Santa Martha Acatitla por volta de quatro anos. São libertados possivelmente como mostra de amizade do governo mexicano após a viagem realizada pelo presidente Echeverría à República Popular Chinesa, em abril de $1973^{252}$.

Apesar da captura, o treinamento militar e ideológico alavancado pelo engenheiro abriu espaço para outro tipo de experiências revolucionárias. Por exemplo, vários dos camponeses que viajaram para a China fundaram em 1971 a Asociación Nacional Obrero Campesino Estudiantil (ANOCE), organização que pode ser enquadrada como movimento urbano popular. Formada por camponeses empobrecidos, majoritariamente migrantes provenientes do estado de Guerrero, no dia 31 de março de 1973, a organização ocupa a propriedade do filho do governador do estado de Morelos no intuito de construir uma colônia

\footnotetext{
${ }^{248}$ ROBLES VESSI, Rosalba: depoimento [01-04-2010], México. Entrevista concedida a Azucena Citlalli Jaso Galván.

${ }^{249}$ GARCÍA DE LEÓN, Antonio: depoimento [22-04-2009], México. Entrevista concedida a Azucena Citlalli Jaso Galván.

${ }^{250 ،}$ “Nessas circunstâncias alguém era introduzido e conduzido com os olhos vendados. Podes descrever o lugar por dentro, mas não sabes o que é" (ROBLES VESSI, Rosalba: depoimento [01-04-2010], México. Entrevista concedida a Azucena Citlalli Jaso Galván.).

251 "Texto de la consignación de Raúl Ernesto Murguía Rosete, Rosalba Robles de Murguía y Judith Leal Duque", El Día, Distrito Federal, 07-03-70, AGN, IPS, Caixa 3033 A, Exp. 10, folha 1.

${ }^{252}$ ROBLES VESSI, Rosalba: depoimento [01-04-2010], México. Entrevista concedida a Azucena Citlalli Jaso Galván.
} 
popular (PONIATOWSKA, 1980; JASO GALVÁN, 2010).

Sob a ideologia maoísta do dirigente Florencio Medrano, a Colonia Proletaria Rubén Jaramillo foi concebida como o primeiro passo na guerra popular prolongada. Isto é, a construção da base de apoio que possibilitaria, mais adiante, a ação de um grupo armado. Contudo, após seis meses de uma experiência radical de construção de cooperativas e de constante pressão às autoridades pela legalização do território, precipitados pela invasão do exército, o núcleo político - e militar - da ANOCE decide entrar na clandestinidade guerrilheira e conformar o Partido Proletario Unido de América (PPUA). O projeto imaginado pelo engenheiro Javier Fuentes Gutiérrez viu-se parcialmente concretizado no PPUA, prolongando-se até 1978, ano em que Florencio Medrano é abatido.

$$
* * *
$$

Neste capítulo observamos a descrição que os informes dos presidentes analisados produzem em torno da institucionalidade mexicana. A ênfase colocada na descrição da Revolução Mexicana como processo de luta que culmina na junção de várias ideologias. Isso possibilita aos mandatários argumentar que no país existe liberdade e espaço para qualquer teoria e ideologia. A perspectiva revolucionária - criação nacional - não pretende exportar seus métodos revolucionários, mas também não deixa que se imponham modelos de fora. É a partir da criação dessa imagem de maturidade democrática e institucional que se constrói o inimigo interno.

O "PRI-governo" se institui como a encarnação do espírito nacional. Dessa forma, os mandatários constroem a figura dos jovens desorientados promovidos por forças que nunca são nomeadas, mas que estão no exterior e que são contrárias aos princípios revolucionários da nação. Conforme os grupos armados aprofundam suas atividades, também são descritos de uma forma mais contundente, onde os desvios de todo tipo são uma regra. Porém, é através da imprensa que os guerrilheiros são criminalizados, numa descrição das atividades guerrilheiras fora de contexto. Sem ser apresentadas como um método de luta com reivindicações políticas, as ações armadas aparecem na seção policial, enquanto que há um espaço privilegiado para a voz das autoridades, as quais confirmam que os guerrilheiros são, na verdade, delinquentes comuns sem ideologia.

A conspiração internacional como fonte dos grupos armados é o conceito-chave para entender a contrainsurgência mexicana. A pesar de que pública e internacionalmente o México se posicionava a favor da autodeterminação dos povos, os agentes da repressão 
partiam do fato de que existia uma conspiração comunista trabalhando na desestabilização do Estado mexicano. Contudo, apreciamos a difícil relação dos revolucionários cubanoscom os grupos armados mexicanos, apesar daqueles viverem um momento de forte solidariedade com os povos em luta na Ásia, África e América Latina, viram-se impossibilitados em apoiar os revolucionários mexicanos. A guerrilha no México, então, apresenta um vazio em termos de apoio das forças da esquerda mundial, ela é órfã. No entanto, conhecemos a existência vastamente documentada de um grupo armado treinado pela Coréia do Norte, o Movimiento de Acción Revolucionaria. A partir dos relatórios da DFS avaliados, pode-se apreciar um pouco da trajetória do Partido Revolucionario del Proletariado Mexicano, organização guerrilheira de recorte maoísta que conseguiu doutrinamento ideológico e militar proporcionado pela China. Contudo, a solidariedade dos países comunistas não teve continuidade, quando os guerrilheiros retornam para o território mexicano. 


\section{CONTRAINSURGÊNCIA NO MÉXICO}

De maneira geral, pode-se caracterizar o terrorismo de Estado a partir da sistematização de três fatores que se apresentam de forma recorrente como método para aniquilar os grupos que são avaliados como ameaça à Segurança Nacional: a tortura, a execução sumária, e o desaparecimento forçado (FAZIO, 2011). O terror de Estado, aplicado na guerra suja mexicana, comporta esses três fatores e possuiu, entre outras, seis características bem definidas:

- A estratégia do Estado com relação aos grupos armados foi exclusivamente de "contenção e aniquilamento".

- Partindo da análise de que as ações armadas e a propaganda elaborada pelos grupos guerrilheiros, na verdade, não conseguiram reverberar na população, as forças contrainsurgentes não tiveram a necessidade de empreender uma luta ideológica para combatê-los.

- Devido ao fato de que não existiam grupos organizados de defesa dos direitos humanos, por um tempo a contrainsurgência operou sem pressão ou denúncias de peso sobre os excessos governamentais. Formalmente, o Comité Pro-Defensa de Presos Perseguidos, Desaparecidos y Exiliados Políticos de México foi fundado em 1977 por Rosario Ibarra de Piedra, mãe de um guerrilheiro da Liga Comunista 23 de Septiembre desaparecido em 1974 (ÁVILA CARRILLO, 1998).

- O exército foi utilizado para o aniquilamento das guerrilhas rurais, enquanto que o extermínio da guerrilha urbana ficou em mãos das corporações policiais.

- O Estado mexicano paramilitarizou os grupos de contrainsurgência urbana e os deixou atuar com total impunidade.

- Devido às características internas dos grupos armados urbanos - isolados das massas, dispersos pela ação da repressão, e divididos internamente - o Estado se especializou na infiltração dos grupos com a finalidade de atacar a estrutura, ou melhor, destruir a direção política e militar das organizações (SIERRA, 2008, p. 362).

\subsection{O exército no campo mexicano}

Até antes de 1965, a corporação castrense permanecia concentrada nas cidades, confrontando 
diretamente os movimentos sociais que radicalizaram na década de cinquenta ${ }^{253}$. Depois do frustrado assalto ao quartel de Madera, Chihuahua, o presidente Díaz Ordaz ordenou as chamadas "Maniobras Conjuntas del Ejército y la Marina" em 1966, assim como os "Ejercicios Regionales del Ejército" (ETR). Ambas ações militares consistiram na mobilização de milhares de soldados pelo treinamento para as ações antiguerrilheiras e antisubversivas (PIÑEYRO, 1985, p. 85). Postados na totalidade do território mexicano de acordo com uma melhor divisão territorial recentemente estabelecida, mantinham um controle quase absoluto de possíveis insuflações de cunho armado. Entre 1965 e 1966 foram mobilizados por volta de vinte e dois mil soldados, setecentos e trinta veículos, três mil armas automáticas, vinte aviões e nove furgões (SIERRA, 2003, p. 48).

O objetivo - além da clara demonstração da máquina bélica do Estado - era a possibilidade de conter, com maior eficiência e velocidade, os distúrbios civis, fossem estudantis, operários, sindicais ou agrários, mas, especificamente, a subversão armada. Pela primeira vez na era pós-revolucionária introduzia-se na linguagem militar as palavras "subversão", "guerra revolucionária", "guerra de guerrilhas", entre outras que estavam em voga no Cone Sul. A Revista del Ejército, em 1971, elabora uma definição própria do conceito "contraguerrilha":

Compreende uma variedade de operações militares e providências de diverso gênero encaminhadas, umas e outras, não unicamente para vencer e minar a resistência armada dos guerrilheiros ou elementos combatentes, mas também toda oposição da população civil; para tanto, tais operações abarcam e mesclam a atividade bélica e as medidas de ordem sócio-econômica, política e psicológica destinada a desalentar toda resistência ativa ou passiva de dita população e, ainda, lograr o apoio, a simpatia ou, pelo menos, a neutralidade popular, considerando que é invencível quando está bem conduzida, suficientemente estendida, e apoiada pelo povo (PIÑEYRO, 1985, p. 90).

Ou seja, o exército mexicano assume a definição elaborada pelos EUA sobre a contrainsurgência e, sobretudo, quanto à Guerra de Baixa Intensidade (GBI). O manual norteamericano Small Wars, de 1940, elaborado após a sistematização das experiências da Guardia Nacional nicaraguense contra as guerrilhas lideradas por Augusto César Sandino, aponta que o uso brutal da força não é de forma alguma apropriado, ou melhor, não é benéfico politicamente pensando num contexto mais amplo em que a vitória tem que ser também no

\footnotetext{
${ }^{253}$ Durante o sexênio de Adolfo López Mateos (1958-1964), o exército teve um papel chave para sufocar as greves de maquinistas de trem (1959-1959), dos funcionários da Compañía Mexicana de Aviación, do sindicato de telegrafistas e de funcionários dos correios (1960); contra o movimento estudantil na capital, em Guerrero e em São Luis Potosí (PIÑEYRO, 1985, p. 83).
} 
terreno político: "Nas guerras de pequena escala, tolerância, simpatia e bondade deveriam ser os aspectos cruciais em nossas relações com a maior parte da população" (CASSIDY, 2005, p. 26). Esta reflexão sobre como devia atuar o exército contra as guerrilhas populares ganha corpo após a guerra no Vietnam. Nesse aperfeiçoamento da estratégia se misturam coordenadamente a ajuda econômica, as operações psicológicas e as medidas preventivas de segurança.

No caso mexicano, a estratégia militar operou em torno da "ação cívica" (AC). Echeverría alavancou projetos em que a burocracia militar "participou no campo, não só num sentido estritamente militar, mas também como intermediário, tratando de preencher o vazio deixado pelas estruturas civis de mediação com as atividades de trabalho social" (PIÑEYRO, 1985).

O programa de AC mexicana elaborado em 1971 tinha objetivos específicos que beneficiariam a imagem da instituição militar no interior do país, inclusive internacionalmente. Para tal efeito, a meta geral foi a pacificação do território e zerar as possíveis causas que geram os brotes armados. A contribuição direta do exército é avaliada pelo governo como a garantia dos avanços do progresso nacional, pois a AC aplicada de maneira sistemática reduziria as possibilidades de que uma força guerrilheira ganhasse a simpatia da população. O coronel José Pánico Rodríguez apontou que sob essa estratégia “injeta-se variedade ao adestramento das tropas, elevando-se sua moral”. Assim, os soldados que participassem nesse tipo de estratégia teriam condições de aprender um ofício (alvenaria, marcenaria, alfabetização, entre outros). Dessa forma, seria mais simples o processo de reintegração dos soldados à vida civil. Finalmente, a corporação ganharia prestígio nacional melhorando proporcionalmente a qualidade e as condições de vida do pessoal da carreira militar.

Uma imagem nítida do funcionamento da AC pode ser acompanhada num relatório da cidade de Matamoros, Tamaulipas. O comandante da $18^{\text {a }}$ Zona Militar, general Gómez Cuevas, envia informes à DFS advertindo dos resultados da vigilância sobre dois militantes da CCI. No mesmo espaço informativo, o militar aproveita para fazer um balanço sobre a distribuição de víveres para as pessoas prejudicadas pela queda do teto de um refúgio devido à passagem de um ciclone pela região. Na mesma operação, informa o general, os cidadãos foram trasladados para uma escola, enquanto os militares reconstruíam o refúgio ${ }^{254}$.

Diante dessa imagem idealizada do exército ajudando o povo em desgraça, em 1976,

254 “Informe", Matamoros, AGN, IPS, Caixa 1467 A, Exp. 1, folha 1. 
segundo o jornal Últimas Noticias, no estado de Guerrero, que concentrava o maior número de soldados na totalidade do território nacional, não existia estado de sítio. Em entrevista, o comandante da $27^{\mathrm{a}}$ Zona Militar (com sede no porto de Acapulco) negou que a tropa estabelecida em Guerrero fosse a mais repressiva do país. O general diz:

\begin{abstract}
"Os camponeses vivem tranquilos porque o exército os protege. Todos os povoados do Estado quiseram que ao menos dois soldados estivessem com eles". Expressou o militar que "os soldados são camponeses. Daí sai o exército, igualmente, dos operários" $" 255$.
\end{abstract}

\title{
5.2. Contrainteligência e infilttração
}

Teoricamente a inteligência - considerada um dos componentes-chaves da contrainsurgência - é sistematizada pelo tenente coronel estadunidense David Kilcullen (2006, p. 26) em cinco pontos fundamentais: 1) a contrainsurgência é uma guerra de inteligência; 2) a inteligência trata com o próprio povo; 3) as operações e a inteligência se retroalimentam; 4) qualquer operação tem um componente de inteligência; 5) todos os níveis de comando devem envolverse na inteligência.

Em amplo sentido, o objetivo da inteligência é facilitar certo entendimento a respeito da "nação anfitriã, do ambiente operacional e dos próprios insurgentes para que os comandantes possam abordar os assuntos que impulsionam a insurgência", proporcionando elementos para determinar a maneira de atacá-los e liquidá-los. O agente de inteligência deve ter a preparação adequada para "identificar e avaliar as redes para determinar quem são os insurgentes e como operam”. Também deve ter a capacidade de tomar fragmentos de dados para combiná-los em informes que possibilitem a análise com base nas supostas capacidades e intenções dos insurgentes (TEAMEY; SWEET, 2007, p. 20).

Aliás, lembremos que em julho de 1963 é estabelecida a Escola das Américas (SOA, na sigla em inglês) em Fort Gulick, na zona do canal de Panamá, sede do Comando Sul das Forças Armadas dos EUA. A Escola contava com sete manuais de operação de treinamento em guerra antisubversiva. Segundo a antropóloga Leslie Gill, foram escritos pelo Pentágono e CIA. Na década de sessenta, foram distribuídos através do Programa do Exército para a Assistência de Inteligência ao Estrangeiro, sob o nome segredo de "Project X" pelo "Curso 0-

\footnotetext{
255 “La situación militar en Guerrero", PÉREZ, Raúl, Últimas Noticias (p. 1, 3), Distrito Federal, 05-01-76, AGN, IPS, Caixa 1747 B, Exp. 6, folha 1.
} 
47” dedicado especificamente a atividades antiterroristas (ROBIN, 2004, p. 353).

Para esse curso, especificamente, criou-se o Manual de estudio. Emitido pela Escola das Américas, estava dividido em sete partes: a) Guia para as análises da insurgência; b) Contrainteligência; c) Guerra revolucionária e ideologia comunista; d) Inteligência de combate; e) Interrogação; f) Manejo de fontes; g) Terrorismo e guerrilha urbana. Os manuais, escritos em espanhol, foram abertos para consulta pública em setembro de 1966 pelo Pentágono, após receber pressão de grupos religiosos e movimentos de base nos EUA. Os manuais aparentemente foram utilizados entre 1966 e 1991 (HAUGAARD, 1997).

Em 1965, o diretor da DFS, o capitão Fernando Gutiérrez Barrios, criou um grupo especializado em movimentos subversivos. Miguel Nazar Haro foi o encarregado de normatizá-lo e dirigi-lo. Recém-graduado pela Academia Internacional de Polícia e pela SOA, Nazar era especialista em grupos subversivos e contrainsurgência, com ênfase na penetração do comunismo na América Central (RODRÍGUEZ CASTAÑEDA, 2012). Esse grupo, denominado C-047, tinha um caráter secreto e estava por cima do controle dos agentes da DFS: "Deram-me a ordem de formar um grupo para investigações especiais; tinha dez elementos trabalhando espionagem e contraespionagem" (TORRES, 2008, p. 26). O C-047 estava formado por cinco mulheres e cinco homens, majoritariamente pertencentes à DFS. O nome faz referência clara ao programa de treinamento contraisurgente da SOA.

O grupo de contrainteligência baseava sua atividade na compilação de informação proveniente de uma grande rede de informantes que se especializaram na infiltração em grupos "inimigos" do regime. Nazar é explícito na estratégia: "Parti de como obter dados e informação para estabelecer um princípio de investigação. Assinalei para eles que a base fundamental eram as relações públicas; fazer amigos nos diferentes setores da população para obter informação" (TORRES, 2008, p. 27).

O percurso que identificamos na institucionalização da inteligência, a partir do corpo documental consultado, pode ser descrito da seguinte forma: conhecimento de uma informação a partir da rede de informantes previamente estabelecida; detenção e interrogação de indivíduos envolvidos; busca de evidências incriminatórias (propaganda ou armas); avaliação da informação na sua totalidade e, finalmente, sugestão de procedimento.

Mas enfim, como eram tecidas as redes de informação? Um relatório sem assinatura proporciona os antecedentes de "Luis Ramírez Freyre", recrutado como agente investigador, comissionado para assuntos político-civis no estado de Chihuhua. O indivíduo foi introduzido na UGOCEM e no PPS, pois tinha conhecimento e experiência militante dentro de ambas as organizações. Antes havia participado como secretário particular de Dionisio Sánchez, 
dirigente do PPS nesse estado. Além disso, ficou avaliado como significativa a participação dele em algumas recuperações de terras organizadas pela UGOCM. Como mencionado, a ocupação de terras era o método mais radical das organizações camponesas de esquerda independente na luta contra os latifundiários no norte do México. Partindo, então, dessa experiência, acredita-se que Ramirez Freyre teria sido um canal útil para obter acesso à informação que se encontrava nas cúpulas da esquerda na região.

No relatório se destaca sua capacidade para o trabalho de infiltração, pois o indivíduo:

estudou para Investigador Privado por correspondência da Cidade do México, no Instituto de Ciências Policiais. Rafael Barraza Coronado [supomos ser o nome verdadeiro de Ramírez Freyre] esteve como membro da Unión de Detectives nesta cidade, com o Delegado nesta, Porfirio Montreal, no ano de 1958. Esteve como investigador a serviço do senhor José Urbina, comerciante de curiosidades nesta cidade.

Sublinha-se a fidelidade previamente demonstrada, uma vez que o candidato para investigador repassa informação importante ainda sem pertencer propriamente à DFS. O relatório afirma que vários planos de recuperação de terras privadas foram informados com bastante antecedência. Além do que, o aspirante aportou nomes e detalhes sobre os integrantes e líderes da $\mathrm{UGOCM}^{256}$.

Em outro relatório, desta vez sobre a Liga Comunista 23 de Septiembre, o agente aponta que os dados foram trazidos por um estudante "que colabora com informações desse tipo". Acrescenta que o jovem, "de confiança", foi convidado para uma reunião nas proximidades da cidade de Culiacán, Sinaloa, num suposto espaço que funcionava como local de impressão de propaganda. O estudante informou que "não sabe o endereço, mas assim que consiga saber, repassará os dados" ${ }^{257}$. Seja por convicção própria ou obrigados a tornar-se infiltrados por coação física e psicológica, os relatórios sobre os grupos armados provenientes de infiltrados são os mais frequentes.

Afinal, num relatório de 1968 encontramos uma avaliação sobre "elementos subversivos detidos". Dessa vez, o próprio Nazar Haro descreve que o Servicio Secreto de la Jefatura de Policía do Distrito Federal "através de um contato que trabalha para esta corporação, confidencialmente de nome Silvano Camacho Castillo", recebeu informação, e que elementos radicais iniciavam treinamento na técnica da guerra de guerrilhas. $\mathrm{O}$ intuito era

\footnotetext{
256 "Se rinde informe", Chihuahua, 13-12-66, AGN, IPS, Caixa1467 B, Exp. 10, folhas 1-2.

257 "Integrantes de la Liga Comunista 23 de Septiembre”, Culiacán, 03-03-77, AGN, IPS, Caixa 1920 B, Exp. 3, folhas 1-2.
} 
de cometer um atentado contra o presidente de El Salvador, que chegaria em território mexicano para uma visita oficial.

Após receber essa informação, vários indivíduos foram presos e interrogados. Felipe Villanueva Vélez, cujos dados pessoais constam no relatório, apontou que em 1966 conheceu um estudante (Martín Sánchez Gómez) num ato político do MLN. A partir de então, esses dois "trocaram impressões sobre as ideologias de esquerda na atualidade no âmbito internacional". Começaram a se reunir frequentemente com outras três pessoas - Arturo Torres Cruz, Juan Ramírez Rodríguez e Luis Martínez García - chegando à conclusão de que "o único caminho de instaurar no México um governo socialista seria mediante uma luta armada, e não com o sistema que as diferentes ideologias agrupadas em vários grupos panejavam mediante a transição pacífica”.

Estabelecido o acordo sobre essa tese, segundo o interrogado, sem contar com um programa político formal, decidiram "efetuar, primeiramente, treinamento físico e de tiro em Ajusco [...] onde todos e cada um deles colaboraram com uma pequena quantia de dinheiro". Devido aos conhecimentos de Villanueva Vélez na área de química, ele dedicou-se a proporcionar fórmulas para a elaboração de explosivos caseiros. O objetivo, por fim, era manter uma sólida preparação bélica para que "o dia em que no México algum partido ou grupo político formasse um exército nacional para a luta armada de libertação nacional, estes [recrutas], dada sua preparação, teriam a facilidade de se unir a tal luta". No relatório se indica que essa versão foi confirmada no interrogatório dos outros quatro detentos.

A partir de tais declarações, um grupo de agentes da DFS se apresentou nos domicílios dos prisioneiros. Aí, encontraram "diferentes panfletos, livros e revistas das que se obsequiam às diversas organizações aficionadas à linha cubana, soviética e chinesa”. Seguindo esses indícios, o relatório aponta que o grupo responde às características foquistas. De maneira organizada, Nazar elabora três conclusões:

1/a. - Em nenhum momento, nenhum dos elementos desse grupo teve a ideia, o valor ou o desejo de cometer atentado algum.

2/a. - Efetivamente, não têm ideologia política definida, pelo contrário, encontram-se influenciados pela propaganda que têm lido relativa à guerra de guerrilhas e desejaram se destacar neste plano, preparando-se para isso, sem ter programa, objetivo ou planos de ação, afetados pela miséria em que vivem.

3/a. - Não representam, em nenhum momento, periculosidade política de ação de massas, já que atuam em forma anárquica, porém, sim, celularmente, 
num momento dado, poderiam cometer um ato aventureiro ${ }^{258}$.

Avaliando em conjunto o corpo documental consultado no AGN, estimamos que este é o relatório melhor elaborado a partir de um interrogatório, considerando que grande parte dos documentos contêm, na maioria, informação breve e descritiva. Ou seja, não apresentam nenhum tipo de avaliação e análise da informação, portanto, são parciais, não são conclusivos [fig. 23].

\subsubsection{O Movimiento Revolucionario del Pueblo}

O manual denominado "Manejo de fuentes" elaborado pela SOA propõe que um dos objetivos da inteligência é "lograr uma vitória de caráter permanente". Idealmente, as operações contrainsurgentes devem estar precedidas por ataques diretos às organizações armadas desde o processo de gestação. A infiltração nos grupos clandestinos na sua etapa de constituição tem um papel decisivo, pois é o momento em que estes mantêm medidas de segurança amplas (SOA, 1989f).

Segundo este manual da SOA, para iniciar-se uma missão de infiltração dentro de uma organização armada, devem ser seguidos quatro passos:

1) Analisar os requerimentos de informação. Ou seja, o agente encarregado da missão

deve estudar a diretiva para garantir que a entende inteiramente. Logo, deve reduzir a ordem à forma mais simples e escolher alvos específicos que hão de ser investigados. Deve também realizar uma investigação exaustiva para conseguir toda a informação pertinente e experiência adquirida previamente sobre a matéria. Dessa maneira, adquirirá conhecimentos gerais que the permitirão elaborar um plano sólido, lógico e conciso (SOA, 1989f, p. 11).

2) Analisar o alvo. Isto é, "a investigação minuciosa do alvo e a zona do mesmo para achar qualquer condição que poderia impedir ou facilitar a missão do governo". Igualmente, pode-se descrever como "o processo de coletar, cotejar e avaliar informação a respeito de um alvo a fim de poder elaborar planos para determinada missão".

3) Elaboração de planos de operação. Uma vez que se dispõe das informações descritas

\footnotetext{
258 "Se informa sobre elementos subversivos detendidos en la Jefatura de Policía", HARO, Nazar. Distrito
} Federal, 24-01-68, AGN, IPS, Caixa 3033 A, Exp. 15, folhas 1-2. 
nos dois pontos anteriores, o agente encarregado da missão está na possibilidade de elaborar o perfil do infiltrado ideal para assumir a operação: "se precisa ou não buscar uma pessoa de determinadas aptidões, como e quando lhe designará tarefas específicas ao empregado, a identidade que tal empregado terá de adotar, a natureza do apoio que lhe haverá de brindar, etc.".

4) Execução do plano. Este item depende da

experiência do agente de contrainsurgência, a habilidade dos indivíduos que participam na operação, a disponibilidade dos artigos de apoio essenciais para a feliz realização do plano - e sobretudo - o tempo disponível determinarão como e quando haverá de colocar-se em execução o plano (SOA, 1989f, p. 12).

Para identificar esses quatro pontos, utilizaremos como exemplo o caso do Movimento Revolucionario del Pueblo (MRP), pois avaliamos que os relatórios localizados sobre o grupo oferecem uma perspectiva detalhada do processo de infiltração nos grupos armados mexicanos.

Em 12 de agosto de 1966 ocorreu uma batida em duas "casas-escolas" - uma chamada "Hidalgo", a outra "Morelos" - pertencentes ao MRP, localizadas na Cidade do México. Nelas se ministrava cursos de economia política e nacional, filosofia geral e teoria e tática revolucionária (CASTELLANOS, 2008, p. 84). Eram formadoras de quadros para a guerrilha. Uma das lideranças do "grupo de agitadores de extrema esquerda" era Víctor Rico Galán, jornalista republicano espanhol naturalizado mexicano, colaborador das revistas Siempre! ePolítica.

Nos relatórios, quanto a seus antecedentes políticos, ficou como um daqueles jornalistas dos “mais venenosos. É comunista ao extremo [...]. É um elemento desmiolado e de uma mentalidade enferma. Apesar de que somente recebeu favores do regime, insiste, por inércia, em atacá-lo”. Finalmente, o perfil político de Rico Galán aponta que o indivíduo é um “comunistóide sem ética nem estética" (AGUAYO, 2014a). Em outro documento, um memorando "confidencial” se apresenta a Rico Galán como

somente um obcecado e louco político e que se deixou levar pelos do Grupo Secreto Revolucionario para fazer ridículo, pois só estão fazendo teatro para demonstrar que estão trabalhando pela Libertação Nacional e justificar deste modo os fortes gastos que tem feito desde sua chegada de Havana, pois de outra maneira seria perigoso para eles que o camarada Fidel Castro se inteirasse de que não tem cumprido com os compromissos da Conferência Tricontinental e os mande tronar a todos, porque se tem dedicado a passeios 
e a dar-se boa vida ${ }^{259}$.

Já os informes de vigilância externa do MRP, ou melhor, os relatórios sobre as atividades e movimentos dos indivíduos próximos a Rico Galán, são muito breves. A maior parte contém os horários de entrada e saída das pessoas previamente conhecidas pelo agente de vigilância. Também oferece a descrição física, no caso de que seja a primeira vez que aparece. Ainda, dados sobre a marca do carro que dirige, placa, inclusive o destino posterior dos visitantes. Um dos pontos de referência era a casa de Ana María Rico Galán, irmã de Víctor. Um dia de vigilância é descrito assim:

DIA 23. - Às $10.00 \mathrm{hrs}$. chegou quem dirige o carro placa 796MS do D.F. que já esteve em outras ocasiões anteriores, unicamente que nesta ocasião chegou acompanhado de dois indivíduos, ao que parece norte-americanos, ambos como de 30 anos de idade e com as caraterísticas de sua raça, retirando-se às $12.00 \mathrm{hrs}$. Às $14.00 \mathrm{hrs}$. chegou Víctor Rico Galán, retirandose às $15.00 \mathrm{hrs}$; às $17.30 \mathrm{hrs}$. chegou Carlos Aguilera, retirando-se às $19.15 \mathrm{hrs}$. Às $20.15 \mathrm{hrs}$. chegou "El Chino"; às $20.15 \mathrm{hrs}$. voltou o esposo da vigiada; às $21.15 \mathrm{hrs}$. saíram "El Chino" e os vigiados; às $21.45 \mathrm{hrs}$. chegou Fernando Rico Galán e sua esposa e, em virtude de não encontrar os vigiados, retiraram-se imediatamente. Às $0.30 \mathrm{hrs}$. regressaram os vigiados apagando as luzes sem haver nenhum movimento posterior ${ }^{260}$.

A partir dessas observações sobre a casa onde se reuniam os suspeitos, contando com a elaboração dos perfis e antecedentes políticos das pessoas localizadas na vigilância, o agente da DFS emite três considerações para elaborar os planos para uma operação para desarticular a organização:

1. Rico Galán “aproveita a casa de sua irmã Ana María Rico Galán de Mendizábal para formar um 'núcleo principal' que possa ser o eixo, com o tempo, da organização de uma 'guerra de guerrilhas"'.

2. A atmosfera ideológica das reuniões "se pode considerar integrada com os seguintes elementos: Marxismo-Leninismo-Trotskismo, linha dura de Pequim; agudização nos países socialistas da ideia que se cristalizou na Conferência Tricontinental de Havana”. Devido a essa apreciação, pode-se supor que existia um infiltrado.

3. Os atores principais dentro da organização, e possivelmente o núcleo político, são:

\footnotetext{
259 “Información confidencial”, Distrito Federal, 29-08-66, AGN, IPS, Caixa 2938, Exp. 29, folhas 1-3.Não temos referências sobre o citado "Grupo Secreto Revolucionario". A expressão "tronar a todos" significa "matar todos".

260 "Informe", Distrito Federal, AGN, IPS, Caixa 2938, Exp. 27, folha 1.
} 
Víctor Rico Galán, seu amigo o Eng. Gumersindo Gómez Cuevas, apelido "El Chino" (que é amante da irmã de Rico Galán), a própria irmã que empresta a casa e atende os convidados; seu esposo, Guillermo Mendizábal, que dá a impressão de ser fraco diante das iniciativas de sua esposa e de seu cunhado (e que se mostra bem amigo do amante de sua esposa); três ou quatro assíduos frequentadores de clara filiação comunista (Eng. Raúl Álvarez, Lic. Saúl Ugalde, Fernando Rico Galán - outro irmão); outros "ativistas" conhecidos, que têm ido em ocasiões, como Álvaro Ríos, exdirigente de invasões de terras em Durango e Chihuahua; Judith Reyes, companheira do anterior e agitadora em Chihuahua; Dr. Gilberto Balam Pereira, do MLN; Mario Menéndez, diretor da revista "Sucesos", etc. ${ }^{261}$.

Na teoria, isto é, no manual da SOA sobre inteligência e infiltração, enfatiza-se a necessidade de analisar a informação prévia sobre um alvo específico. É assim que se pode planejar o jeito mais apropriado de explorar o trabalho de um infiltrado para conseguir informações valiosas. Procura-se, também, identificar alvos secundários para determinar a importância e potencialidade do alvo principal (SOA, 1989d). No caso exposto acima, o agente da DFS avalia que dentro do núcleo já identificado não existem elementos competentes para organizar uma guerrilha. Desprende-se dos dados que se trata de um grupo de intelectuais de esquerda, sem um trabalho concreto com as massas. Porém, o perigo está no fato de que se sabia que estavam juntando armas e "aprendendo técnicas de construção de bombas caseiras".

Partindo dessas informações, o agente propõe como primeira ação:

somente esperar já uma próxima reunião, na qual compareça um bom número dos que se estão reunindo; uma reunião na qual, como em ocasiões o têm feito, levem suas pistolas e outras armas, a fim de detê-los e, num campo adequado, desentranhar toda a realidade e poder castigar, proporcionalmente, todos os participantes.

Quer dizer: frustrar, desde já, qualquer propósito de signo negativo, qualquer que seja sua gravidade.

E, concretamente, a respeito de Víctor Rico Galán, aproveitar a oportunidade para que se promova perante a Secretaría de Relaciones Exteriores o cancelamento de sua carta de nacionalidade mexicana que há 25 anos obteve com tanta facilidade ${ }^{262}$.

Pela análise desse informe, sabemos que o agente infiltrado é autorizado para continuar participando das reuniões. Voltemos aos manuais da SOA, quando apontam brevemente que o sujeito infiltrado é "aquela pessoa que presta seus serviços em troca de remuneração ou recompensa" (SOA, 1989f, p. 1). O "coletor de informação", como também é

\footnotetext{
261 "Informe", Distrito Federal, AGN, IPS, Caixa 2938, Exp. 39, folha 1.

262“"Informe", Distrito Federal, AGN, IPS, Caixa 2938, Exp. 39, folha 1-3.
} 
chamado, deve sempre "apresentar-se como um indivíduo inconformado, que se encaixaria bem na organização insurgente" (SOA, 1989f, p. 3). De forma ideal, as caraterísticas que deve reunir o empregado infiltrado giram em torno a duas qualidades principais: estar dentro ou próximo da região do alvo; e ter acesso a informações valiosas, ou, no caso, habilidades para conseguí-las. As qualidades pessoais que considerar são:

o valor, as debilidades, a personalidade, a ideologia, as crenças religiosas, a situação econômica, as filiações políticas, os círculos familiares, a educação, o adestramento profissional e os antecedentes militares do empregado potencial. [...] A investigação deve contribuir por determinar a motivação do empregado potencial para estabelecer se seria compatível em sua condição de empregado do governo (SOA, 1989f, p. 15).

Para cumprir com sua missão, o possível infiltrado tem que estar motivado: "esse impulso interior que determina sua maneira de pensar, sentir e atuar, e que revela a forma em que o agente de inteligência pode exercer influência sobre o empregado" (SOA, 1989f, p. 27). Essa questão é de importância capital, pois "de acordo com os sentimentos que o motive, um empregado pode ser leal a seu governo ou se tornar traidor" (SOA, 1989f, p. 16).

Por isso é preciso investigar os antecedentes do possível infiltrado antes de solicitar seus serviços. Essa investigação é similar às que se aplicam sobre os alvos de espionagem. Além disso, a avaliação sobre os empregados deve ser permanente, para garantir que não existam desvios durante seu trabalho de infiltração ou qualquer indício de instabilidade emocional (SOA, 1989f, p. 15).

Uma vez selecionado o infiltrado, os órgãos de inteligência deverão criar uma identidade para ele. Da mesma forma, deve ser treinado para desenvolver as ferramentas necessárias para não cometer erros e trair sua nova identidade. Para evitar problemas, a identidade criada deve estar estreitamente ligada a seus antecedentes reais, pois deve servir para justificar as razões pelas quais trabalha ou mora em determinados locais, ou ainda, para justificar ações ou posições enquanto se dedica a obter informações. $\mathrm{O}$ infiltrado deve estudar essa nova identidade. As suas reações devem ser imediatas, críveis e corretas em qualquer circunstância.

Finalmente, o manual aponta que depois de realizados os balanços sobre as fortalezas e debilidades da organização armada, o empregado pode proceder como infiltrado. O trabalho de infiltração pode ser realizado de diversas maneiras. A mais comum é fingir ser um elemento descontente com a situação política e econômica do país para chamar a atenção do recrutador da guerrilha, identificado previamente. Assim que estiver dentro do grupo, o 
personagem teria de causar incidentes que viessem demonstrar, para as lideranças guerrilheiras, sua capacidade de comando, provocando, paralelamente, o fortalecimento da confiança. O objetivo, então, seria galgar postos na cadeia de comando para obter informações mais precisas e efetivas.

No caso mexicano, para a meta de desarticulação do MRP, sabemos que um infiltrado emitiu, sistematicamente,relatórios sobre as reuniões de um núcleo político do MRP, ainda que não fosse o principal. Esses informes foram assinados com o código "Agente $Z$ ". $\mathrm{O}$ escolhido foi "Filiberto Vázquez Mora", mas não sabemos se era o nome verdadeiro ou imputado (TORRES, 2008, p. 29) [fig. 24]. Deduzimos, também, o nome do agente que seria elo entre a DFS e o infiltrado: Luis Ramírez López, pois assinou os primeiros relatórios pelos quais se descreve a missão de "Z”. No informe de 15 de março de 1966, Ramírez López narra a forma em que o infiltrado foi convidado por Ana María Rico Galán para ingressar no domicílio dela "segundo se pôde posteriormente constatar, de tratar de convencê-lo para que passe a ser militante ativo do Círculo de Estudos que se levam a cabo em sua casa"263.

A narração das conversas e os temas tratados nas reuniões apresentam-nos vários detalhes relevantes. Imediatamente após o convite para o círculo de estudo, a senhora Rico Galán informou para "Z" que a organização estava formada por "um grupo de elementos mexicanos inconformados com o atual governo e a injustiça que prevalece no país". Segundo Ana María, o objetivo real das reuniões, para além do estudo, era "tratar de transformar [o governo] e lograr, em forma definitiva, que se implante um sistema de Governo Socialista, mas, afim à idiossincrasia do Povo Mexicano, sem depender em forma ideológica, nem de Cuba, Rússia ou China Comunista"264.

Ou seja, para efetivar a infiltração - como mencionado anteriormente - o indivíduo empregado deve explorar as debilidades da guerrilha. Uma das mais recorrentes é a falta de segurança no recrutamento de seus militantes. Por exemplo, nesta primeira fala de recrutamento, a militante supostamente fez uma descrição pontual da tática e estratégia da organização. Detalhou que o grupo estava sendo doutrinado no círculo de estudo, mas, paralelamente, tinham treinamento físico para preparar-se para a guerrilha. Logo neste primeiro informe do infiltrado, afirma-se que os militantes fundadores já sabiam utilizar o tipo de armamento de uso exclusivo do exército. Segundo "Z", o exército proporcionaria o armamento com o qual "se prosseguirá a luta, já que, uma vez que se tome determinado

\footnotetext{
263 "Informe", Distrito Federal, AGN, IPS, Caixa 2938, Exp. 27, folha 1.

264 “Informe”, Distrito Federal, AGN, IPS, Caixa 2938, Exp. 27, folha 1.
} 
quartel, o armamento recolhido servirá para outros guerrilheiros"265.

O primeiro objetivo da infiltração, então, é "inteirar-se da estrutura da mesma, preparar uma lista dos membros, determinar suas esferas de influência e explodir seu sistema de comunicações" (SOA, 1989f, p. 14). Segundo "Z”, o indivíduo então apontado como liderança do núcleo em que foi inserido era Raúl Ugalde. Ele era o suposto encarregado da preparação de um "instrutivo baseado em exercícios utilizados pelo Exército Canadense, para manter em ótimas condições físicas todos os que participam na Guerra de Guerrilhas"266. A célula de "Z" estava efetivamente conformada pelo citado Raúl Ugalde, o engenheiro Gómez Cuevas, Guillermo Mendizábal e sua esposa, Ana María Rico Galán, Carlos Aguilera e Serafín, cujo pseudônimo era "Bonny”, liderança sindical da zona metropolitana do Estado de México $^{267}$. Menciona-se, também, a existência de militantes intelectuais com experiência no controle das massas. Estes seriam, num primeiro momento, os encarregados de falar para o povo. Os assinalados assim foram José Revueltas (cuja vinculação com o grupo não foi comprovada) e o jornalista Víctor Rico Galán.

Aceitando filiar-se, o infiltrado começou a emitir relatórios frequentes. Conhecemos aqueles correspondentes às reuniões ocorridas no lapso de 12 de abril e 8 de maio de 1966. Com isso, além dos temas discutidos para a consolidação do núcleo de "Z”, é possível aproximar-se das oscilações na estabilização do grupo guerrilheiro, bem como das dúvidas dos militantes e de seus conflitos internos.

Um dos trabalhos da célula do infiltrado consistia na politização e recrutamento de operários de Loma Linda ${ }^{268}$. O citado Serafín era o contato. A tentativa encontrou vários obstáculos. O primeiro deles foi a eleição dos militantes que teriam de falar com os operários, "pois se tem medo de algumas pessoas"269. A célula tinha conhecimento de que um membro de outra célula do MRP, um suposto militar de nome "Pancho", além de outras sete pessoas, estavam sendo vigiadas ${ }^{270}$. A desconfiança entre militantes foi um elemento para que as reuniões previstas em Loma Linda fossem suspensas por dois fins-de-semana consecutivos. Situação que causou um forte mal-estar entre os militantes, pois na visão de alguns, não existia um efetivo trabalho de base.

\footnotetext{
265 “Informe”, Distrito Federal, AGN, IPS, Caixa 2938, Exp. 27, folha 1.

266 "Informe", Distrito Federal, AGN, IPS, Caixa 2938, Exp. 27, folha 1-3.

267 "Reunión efectuada el martes 12 de abril de 1966", Distrito Federal, 12-04-66, AGN, IPS, Caixa 2938, Exp. 27, folha 1

${ }^{268}$ Bairro localizado no Estado de México, no municipio de Naucalpan.

${ }^{269}$ “Reunión efectuada el martes 12 de abril de 1966”, Distrito Federal, 12-04-66, AGN, IPS, Caixa 2938, Exp. 27 , folha 1 .

270 "Reunión efectuada el viernes 15 de abril de 1966", Distrito Federal, 15-04-66, AGN, IPS, Caixa 2938, Exp.

27 , folha 1 .
} 
Nenhum militante, excetuando-se Serafín, tinha experiência em reuniões políticas com operários, o que motivou Ugalde a dar instruções sobre a forma de interação com os trabalhadores. Havia aspectos para aprofundar e outros que deviam ser evitados: "se insistirá na questão econômica do país; na forma inoperante da solução que o governo está dando aos problemas nacionais, etc." ${ }^{, 71}$.

A reunião em Loma Linda agendada para primeiro de maio foi novamente cancelada. Porém, realizou-se outra em Tlanepantla, outro município do Estado de México. A participação foi de aproximadamente de dezenove dirigentes operários, camponeses e maquinistas de trem, incluindo representantes de outros estados ${ }^{272}$. A primeira impressão de “Z”, depois da reunião, foi que os operários, em geral, demostravam "muita agressividade". Supostamente eles falavam que somente estavam terminando de organizar uma rede de sabotagem para começar a atuar contra o Estado ${ }^{273}$. Os operários expuseram para o núcleo que "é necessário atuar para implantar o regime socialista, porque o povo já não suporta tantas injustiças" ${ }^{\text {274 }}$. Diante dessas demonstrações de radicalismo, o núcleo do MRP decidiu não expor abertamente seus princípios organizacionais, sobretudo, "por medo às indiscrições". No entanto, a célula do MRP de "Z" colocou na reunião a necessidade de continuar com o intercâmbio de experiências para, paulatinamente, socializar informações de importância, que ajudassem a prevenir a repressão. Agendou-se outra reunião que iria ocorrer em sete dias.

Na semana seguinte, Serafín, Ana María, Carlos Aguilera e "Z" partiram para Loma Linda no intuito de se reunir com três dirigentes operários. Um deles, segundo o infiltrado, resultou ser um militar, aquele de nome "Pancho", que antes - como apontamos - tinha sido considerado suspeito. "Pancho" é descrito como alguém com uma "horrível cicatriz na bochecha direita, como de dez centímetros de comprimento; vive em Loma Linda e na porta de sua casa tem um escudo do PRI, segundo diz, para que não o incomodem" [fig. 25] ${ }^{275}$. "Pancho", registra " $Z$ ", dizia ter sido sargento do exército e que ainda mantinha reuniões com alguns soldados e oficiais, os quais tenta atrair para formar um pequeno grupo de esquerda dentro da instituição militar. "Pancho" era o encarregado de conseguir armas para o MRP a

\footnotetext{
271 "Reunión efectuada el martes 26 de abril de 1966", Distrito Federal, 26-04-66, AGN, IPS, Caixa 2938, Exp. 27 , folha 1 .

272 "Reunión efectuada el domingo $1^{\circ}$ de mayo de 1966", Distrito Federal, 01-05-66, AGN, IPS, Caixa 2938, Exp. 27, folha 1-3.

273 "Reunión efectuada el martes 3 de mayo de 1966", Distrito Federal, 03-05-66, AGN, IPS, Caixa 2938, Exp. 27, folhas 1-2.

274 "Reunión efectuada el domingo $1^{\circ}$ de mayo de 1966", Distrito Federal, 01-05-66, AGN, IPS, Caixa 2938, Exp. 27, folhas 1-3.

275“"Reunión efectuada el domingo 8 de mayo de 1966”, Distrito Federal, 08-05-66, AGN, IPS, Caixa 2938, Exp. 27 , folha 1 .
} 
partir de seus supostos contatos nos quartéis. Porém, nessa reunião informou que a situação foi ficando cada vez mais "difícil e delicada, porque há muito controle sobre o armamento",276.

Após esse encontro, o núcleo trasladou-se para Tlanepantla, onde tiveram um encontro com quatro pessoas: dois indivíduos, irmãos de sobrenome Garay, "El Zacatecano", e outro sujeito de nome ou apelido não identificado. Segundo o informe, se falou que o mais novo dos irmãos Garay tinha uma experiência de três anos no exército, e o outro, por volta de seis. Assim, eles mesmos se colocavam como os mais aptos, dentro do MRP, para a manipulação de armas. Da mesma forma, os quatro indivíduos mencionados falaram sobre a capacidade de mobilização que eles poderiam gerar. Supostamente, tinham o controle de mil e oitocentos operários, dos quais mil e quatrocentos "estão dispostos a tudo, como atuar de acordo com as ordens da direção nacional" ${ }^{277}$. Esta foi a última informação relativa às reuniões em Loma Linda e Tlanepantla.

Outra das questões relativas ao núcleo de "Z" era a busca de uma casa para dar conta da principal necessidade do grupo: "a instalação de uma escola-tipo; assim como para alojar os membros de fora quando venham à cidade e para ocultar os que corram risco"278. A casa, localizada na rua Monterrey $187 \mathrm{Bis,} \mathrm{reunia} \mathrm{todos} \mathrm{os} \mathrm{requisitos} \mathrm{estabelecidos} \mathrm{pela}$ organização. Ugalde foi o encarregado de fechar e coordenar o contrato de aluguel com os representantes da dona da casa.

Nos relatórios relativos à busca de casas percebemos o aumento das responsabilidades de "Z" dentro de sua célula. Ele, junto a Ana María, foi o encarregado "de apresentar-se dizendo que somos esposos com o fim de que os donos [da casa] não suspeitem" ${ }^{\text {"279 }}$. A história, inventada no intuito de convencer os encarregados por alugar a casa, era que ambos estavam fazendo os trâmites "para um tio nosso que vem para radicar-se na [Cidade do] México, pois atualmente mora em Guadalajara (lhe dei um nome falso)", aponta "Z"280. A ordem que ambos os militantes tinham que cumprir era, assim que fechou o contrato de aluguel, tinham que conformar uma sociedade de tipo cultural, justificando dessa forma a

\footnotetext{
276،"Reunión efectuada el domingo $1^{\circ}$ de mayo de 1966”, Distrito Federal, 01-05-66, AGN, IPS, Caixa 2938, Exp. 27, folhas 1-3.

277 “Reunión efectuada el domingo 8 de mayo de 1966”, Distrito Federal, 08-05-66, AGN, IPS, Caixa 2938, Exp. 27 , folha 1 .

278،"Reunión efectuada el sábado 23 de abril de 1966”, Distrito Federal, 23-04-66, AGN, IPS, Caixa 2938, Exp. 27 , folha 1

279“"Reunión efectuada el domingo 24 de abril de 1966”, Distrito Federal, 24-04-66, AGN, IPS, Caixa 2938, Exp. 27, folha 1 .

280 "Reunión efectuada el lunes 25 de abril de 1966", Distrito Federal, 25-04-66, AGN, IPS, Caixa 2938, Exp. 27 , folha 1.
} 
presença constante de pessoas diversas ${ }^{281}$.

Apesar de ter-se estabelecido o contato, o núcleo de "Z" não foi orientado para abordar o tema financeiro. Sendo assim, o dinheiro necessário para fazer o depósito do aluguel "o proporcionou uma pessoa cujo nome desconheço e que mora na [rua] Playa Revolcadero, n. 413" 282. "Z" nunca descobriu o nome da pessoa, pois Ugalde foi o único que entrou na residência para pegar o dinheiro, enquanto ele e Ana María esperavam no automóvel. Contudo, "Z" informa que não conseguiram fechar o contrato, pois resultou que a casa era propriedade de María Conesa, uma famosa atriz. Questão que foi avaliada como perigosa, por se tratar da propriedade de uma figura pública ${ }^{283}$.

Um tema que chamou nossa atenção foram as menções à participação de elementos militares dentro do MRP. "Z" informa que vários militantes questionavam a possibilidade de um golpe de Estado encabeçado pela suposta facção do Exército que estava apoiando o grupo. Raúl Ugalde comentou na reunião que "efetivamente havia militares dentro da organização, mencionou a um tal 'Pancho' que eu [“Z”] não conheço e acho que é o pseudônimo; disse que, inclusive, há militares e guardas presidenciais que estão dentro do movimento"284.

Dezessete dias se passaram daquela reunião em que o infiltrado ouviu falar sobre "Pancho". Na seguinte, Ugalde informou que existia um comando no MRP que pretendia eliminar um capitão do exército “de nome ou sobrenome 'Cárdenas' que está infiltrado em diversos grupos como espião do governo" ${ }^{\text {285 }}$. O comando estaria conformado por Serafín e os irmãos Garay. A decisão de assassinar o militar fora tomada numa reunião à que "Z" não tinha sido convidado. Isto é, do grupo político dirigente: Víctor Rico, o próprio Raúl Ugalde, o médico Gilberto Balám e o engenheiro Raúl Martínez, além de alguns membros do "núcleo de Madera"286. Possivelmente estes sejam os nomes da direção nacional do MRP $^{287}$. De tais informes não temos mais elementos para saber o que aconteceu com esse comando, com

281 "Reunión efectuada el martes 26 de abril de 1966", Distrito Federal, 26-04-66, AGN, IPS, Caixa 2938, Exp. 27 , folha 1 .

282“"Reunión efectuada el sábado 23 de abril de 1966”, Distrito Federal, 23-04-66, AGN, IPS, Caixa 2938, Exp. 27 , folha 1 .

283 "Reunión efectuada el martes 3 de mayo de 1966", Distrito Federal, 03-05-66, AGN, IPS, Caixa 2938, Exp. 27 , folha 1 .

284“"Reunión efectuada el viernes 15 de abril de 1966”, Distrito Federal, 15-04-66, AGN, IPS, Caixa 2938, Exp. 27, folha 1 .

${ }^{285}$ Para conhecer mais sobre o capitão Lorenzo Cárdenas Barajas e a relação de seu grupo armado com vários outros (CASTELLANOS, 2008, p. 79, 84, 88-89).

${ }^{286} \mathrm{O}$ núcleo de Madera vinculado ao MRP estava integrado por Judith Reyes, cantora de músicas de protesto e jornalista, próxima à guerrilha do norte do México e, posteriormente, no estado de Guerrero no sul; Álvaro Ríos, advogado e companheiro sentimental da artista; além de Salvador Gaytán, um dos três sobreviventes do assalto ao quartel de Madera, Chihuahua de 1965.

287 "Reunión efectuada el martes 3 de mayo de 1966", Distrito Federal, 03-05-66, AGN, IPS, Caixa 2938, Exp. 27, folha 1-4. 
"Pancho" ou o capitão Cárdenas.

Nesta série de relatórios descritos acima pudemos notar alguns conteúdos sublinhados a mão e marcados com um número vermelho. Esses mesmos números foram encontrados num grupo de fichas localizado em outro expediente. Continha perguntas ou instruções breves que adquirem sentido unicamente relacionadas com a série de informes elaborados por " $Z$ ". Dentro do grupo de fichas, achamos algumas com perguntas que não conseguimos relacionar com nenhum informe, porém, tratam das preocupações dos agentes da DFS, ou seja, sobre suas linhas de investigação em torno ao MRP.

Por exemplo, a ficha marcada com o número dois ordena: "Tratar de comprovar se existe alguma relação entre este assunto e os informes proporcionados pelo General García Barragán”, secretário da SEDENA no sexênio de Díaz Ordaz ${ }^{288}$. No relatório de 12 de abril, "Z" informa a presença de militares e guardas presidenciais dentro da organização, que eram encabeçados por "Pancho" 289 . Essa informação específica está sublinhada em cor vermelho e marcada com o número dois. Os supostos informes elaborados por García Barragán não foram localizados, porém, a menção é um indício de que existiu uma investigação dentro da corporação militar sobre possíveis elementos de esquerda.

Outra informação, marcada com o número sete, está relacionada com a casa onde Raúl Ugalde recolheu o dinheiro necessário para fechar o contrato da casa que "Z" e Ana María estavam tentando alugar ${ }^{290}$. A ficha sete sugere: "Tratar de averiguar de quem se trata",291. Existem dois informes do dia 20 de maio em que se menciona Dionisio Acevedo Martínez, morador da casa localizada na rua Playa Revolcadero n. 423, no bairro Militar Urbana. Além do tipo de carro e do número da placa, comenta-se que o indivíduo não trabalha e manifesta “ser locatário" na sua declaração de impostos ${ }^{292}$. Nesse endereço também mora a proprietária da casa, de nome María Palacios Piza, enfermeira com estudos na Escuela Militar de Enfermería, que tinha o grau de capitã ${ }^{293}$. Possivelmente, essas duas pessoas sejam parte da organização.

Por último, sobre o radicalismo dos operários de Tlanepantla e Loma Linda, descrita

\footnotetext{
${ }^{288}$ c. 1966, AGN, IPS, Caja 2938, Exp. 29, fixa 2.

289 "Reunión efectuada el martes 12 de abril de 1966", Distrito Federal, 12-04-66, AGN, IPS, Caixa 2938, Exp. 27 , folha 1 .

290 "Reunión efectuada el domingo 24 de abril de 1966", Distrito Federal, 24-04-66, AGN, IPS, Caixa 2938, Exp. 27, folha 1.

${ }^{291}$ c. 1966, AGN, IPS, Caixa 2938, Exp. 29, ficha 7.

292 “Antecedentes de Dionisio Acevedo Martínez”, Distrito Federal, 20-05-66, AGN, IPS, Caixa 2938, Exp. 27, folha 1.

293 “Casa marcada con el No. 413 de Playa Revolcadero”, Distrito Federal, 20-05-66, AGN, IPS, Caixa 2938, Exp. 27, folha 1.
} 
em 3 de maio ${ }^{294}$, a ficha relacionada recomenda: "Olho vivo com este aspecto da questão",295. Nos relatórios correspondentes é feito um estudo muito breve da situação nas duas cidades. Por isso, sabemos que nem o suposto ex-militar "Pancho", nem os irmãos Garay - apontados por "Z" como importantes dirigentes operários - são conhecidos nessa área. Também não foram reconhecidos como militantes das organizações políticas às quais disseram pertencer. Aliás, a DFS não encontrou antecedentes políticos e organizacionais em nenhum âmbito, seja social, sindical ou governamental [fig. 26] ${ }^{296}$.

Um dia antes da operação para irromper nas escolas de quadros do MRP, “Z” emite seu último e breve informe. O agente da DFS que era o canal de " $Z$ " narra a dificuldade do encontro habitual com o infiltrado pelo agravamento do clima dentro da organização: "Ontem a noite, para fazer contato com ele, encontro marcado, ponto e hora, transcorreram duas horas para nos ver, passou em duas ocasiões pelo lugar, mas confirmei que o seguiam"297. Insistiuse no encontro por tratar-se do último contato antes da intervenção nas duas casas de segurança.

"Z" tinha alertado que alguns militantes do movimento já suspeitavam que ele fosse "orejadel gobierno", ou seja, infiltrado, considerando que os temas mais frequentes nas conversas era a vigilância e a espionagem que o grupo estava sofrendo. Num contexto de nervosismo, "Z" relata que foi acusado de trair a organização, aliás, responsabilizaram-no por qualquer possibilidade enfrentamento com os corpos repressivos. Segundo "Z", ele era o principal suspeito, pois era o único que saía da casa metodicamente. Perante essas acusações, os responsáveis da casa lhe retiraram a pistola, ameaçando-o, dizendo que conheciam o endereço da sua casa, o local de trabalho da sua esposa, assim como o nome da escola onde estudavam seus filhos. Em situação temerária, "Z” pediu para o agente da DFS que caso houvesse uma intervenção, ele não utilizasse o código do toque da campainha da casa, pois ele era o único militante, além da direção, que a conhecia. Seria uma espécie de delação, ele seria revelado. Considerou, também, que nesse momento todos os membros carregavam pequenas armas.

Finalmente chama a atenção de que os militantes das casas-escola começariam a se espalhar para outros estados do país no intuito de recrutar mais militantes para formar novas células guerrilheiras. Por esse motivo estavam preparando uma espécie de reunião de

\footnotetext{
294 “Reunión efectuada el martes 3 de mayo de 1966". Distrito Federal, 03-05-66, AGN, IPS, Caixa 2938, Exp. 27, folhas 1-2.

${ }^{295}$ c. 1966, AGN, IPS, Caixa 2938, Exp. 29, ficha 12.

296 "Loma Bonita, Estado de México" e "Investigación de los Hermanos Garay en Tlalnepantla, Estado de México", Distrito Federal, 20-05-66, AGN, IPS, Caixa 2938, Exp. 27, folhas 1-2.

297“"Situación de Z”, 1966, Distrito Federal, AGN, IPS, Caixa 2938, Exp. 39, folha 1.
} 
despedida. Seria um momento excepcional para encontrar a maioria dos militantes juntos.

Esse foi o último informe de "Z". Preocupado - não sabemos se pela situação emocional de "Z" ou pelo risco que ele poderia sofrer na operação - o agente da DFS fez o seguinte balanço:

“Z” está muito nervoso, não somente eles o notam; se adivinha seu temor e não o pode reprimir.

Disseram-lhe que não ficasse preocupado, que se daria toda proteção para ele e sua família.

Disseram-lhe que, durante os próximos nove dias, use gravata preta e diga que um familiar de sua senhora, muito querido dele, teria morrido na província.

Não lhe disseram que haverá atuação, mas se lhe disse que com a gravata se lhe protegerá nas ruas [fig. 27$]^{298}$.

Esta foi a última informação que localizamos antes da batida nas casas de segurança do MRP, quando aproximadamente quarenta e seis pessoas foram encarceradas. As penas foram constituídas a partir dos delitos de incitação à rebelião, armazenamento de armas e conspiração. A história desse grupo e de seus militantes não termina aí. Vários deles foram presos políticos por muito tempo, outros se uniriam posteriormente a outras agremiações armadas.

\subsection{Grupos paramilitares}

\subsubsection{Los Halcones}

Depois da passeata estudantil de 10 de junho de 1971, que foi a primeira vez que saíram pelas ruas da cidade desde o massacre de 1968, a violência de Estado novamente foi sentida pelos estudantes. Dessa vez, no contexto da volta do exílio de vários líderes do movimento, a manifestação era em apoio ao movimento dos estudantes da Universidad Autónoma de Monterrey, que lutavam contra a imposição de uma nova lei orgânica. Nessa data aparece nitidamente a força de um novo grupo paramilitar: Los Halcones. O grupo de choque é comparado com os grupos terroristas de repressão

comoLa Mano em Guatemala; o Esquadrão da Morte no Brasil; ou os

\footnotetext{
298 “Situación de Z”, 1966, Distrito Federal, AGN, IPS, Caixa 2938, Exp. 39, folha 1.
} 
Camisas Pardas de Hitler. Grupos de recorte fascista e dos quais se aproveitam os governos, que, pretendendo fazer crer que no país impera um clima de liberdade e democracia, vem-se impedidos de utilizar exército e granaderos para reprimir manifestações de descontentamento e de crítica ${ }^{299}$.

Um mês depois daquele 10 de junho, uma comissão de onze estudantes universitários sob o comando do engenheiro Heberto Castillo ${ }^{300}$, dirigiu-se à PGR no intuito de entrevistarse com o procurador, Pedro Ojeda Paullada. O objetivo era exigir da entidade um esclarecimento sobre os fatos do 10 de junho, além de exigir o desaparecimento dos corpos paramilitares e a libertação dos presos políticos de 1968, que naquele então somavam vinte e um.

Para contribuir na investigação, os estudantes sistematizaram uma série de testemunhas relacionadas com a passeata de 10 de junho num documento intitulado "Conclusões das Comissões Estudantis de Investigação e Informação". Os depoimentos correspondem a pessoas que assistiram ao ato, mas também de vizinhos da região onde aconteceu a repressão, assim como de indivíduos que se dirigiam à passeata, mas que não conseguiram chegar devido ao forte dispositivo de segurança. Outros dados relevantes foram reportados por jornalistas que também foram agredidos.

Destaquemos algumas das conclusões do documento. Enfatiza-se o fato de que os manifestantes não estavam armados, pois a manifestação era pacífica, não havendo, portanto, "fundamentos de nenhuma classe para converter as vítimas em algozes". O documento adverte que existem pelo menos trinta e oito mortos e sessenta e dois desaparecidos. Em contraposição, destaca o documento, as autoridades envolvidas violaram, basicamente, o direito cidadão de livre manifestação, permitindo e facilitando a utilização de um grupo de choque. Dessa maneira, o documento evidencia um "claro conluio entre o corpo de granaderos, a polícia judicial, a de trânsito e Los Halcones para reprimir o ato" ${ }^{301}$. Aliás, segundo os depoimentos, Los Halcones utilizaram armas de uso exclusivo do Exército.

\footnotetext{
299 "Entrevista de comisión estudiantil encabezada por Heberto Castillo", BARREDA MORENO, Luis de la, Distrito Federal, 30-08-71, AGN, DFS, H-230, L-143, Exp. 11-4-71, folhas 1-8.

${ }^{300}$ Heberto Castillo (1928-1997) foi uma destacada figura da esquerda mexicana. Professor do curso de engenharia na UNAM e no IPN. Foi secretário particular de Lázaro Cárdenas (1956) e coordenador do MLN (1959). Representante do México na Conferência Tricontinental, bem como na Organização Latino-americana de Solidariedade (OLAS), em Havana. Fez parte da Coalición de Maestros Pro-Libertades Democráticas durante o movimento estudantil de 1968. Entre 1969 e 1971, com José Revueltas, esteve preso, culpado de ser autor intelectual do movimento dos estudantes. Além das suas atividades como jornalista, fundou o Partido Mexicano de los Trabajadores (1985), sendo candidato à presidência em 1988. Após a fraude eleitoral, contribui na fundação do Partido de la Revolución Democrática junto a Cuauhtémoc Cárdenas (FUNDACIÓN HEBERTO CASTILLO, 2008).

301 "Entrevista de comisión estudiantil encabezada por Heberto Castillo", BARREDA MORENO, Luis de la, Distrito Federal, 30-08-71, AGN, DFS, H-230, L-143, Exp. 11-4-71, folhas 1-8.
} 
De acordo com os estudantes, o grupo de choque existe desde 1968, e a motivação para sua criação foi o movimento estudantil. De seu turno, o pesquisador José Luis Sierra acrescenta que o grupo seria utilizado publicamente na proteção de instalações de esgotos, bombas d'água, assim como de instalações elétricas do Distrito Federal, considerando a presença cada vez maior de grupos terroristas. Avalia que esses espaços eram alvos desses grupos - tendo em vista, sobretudo, a proximidade dos Jogos Olímpicos, que se realizariam naquele mesmo ano na Cidade do México (SIERRA, 2003, p. 82). Em outro relatório, este sem data e sem assinatura, são explicitados os métodos utilizados para controlar o movimento estudantil:

\begin{abstract}
No curso deste ano e durante a próxima campanha eleitoral, há que dispor de um grupo de choque que se forme ou fazer uso do chamado "Los Halcones", para sufocar qualquer ato de força que os escassos jovens estudantes ou não estudantes do Politécnico [IPN] queiram causar provocando problemas por esse meio $^{302}$.
\end{abstract}

Pela referência que se faz à campanha eleitoral, é provável que o breve texto, mais que um relatório, seja de instruções e que correspondam a 1969. Este foi o ano de início da campanha eleitoral de Luis Echeverría após o massacre dos estudantes. Podemos afirmar, então, que efetivamente já existiam Los Halcones e que a possibilidade de criar mais grupos paramilitares como mecanismo de repressão foi considerado pertinente.

Seguindo com a história da organização paramilitar apresentada pela comissão de estudantes, estes afirmam que foi formada pelo general Alfonso Corona del Rosal, regente do Distrito Federal durante o governo de Díaz Ordaz. O general nomeou como encarregado para essa missão o coronel Manuel Díaz Escobar Figueroa, que foi colocado como subdiretor de Servicios Generales do DF, dependência que se encarrega de coordenar a limpeza da cidade, assim como a conservação de jardins e parques públicos. De fato, Díaz Escobar recrutou os Halcones entre os garis da cidade, entre indivíduos que trabalhavam como carregadores em mercados, ou ainda, membros de gangues do DF. As pessoas que conformaram o grupo de choque pertenciam, enfim, de um estrato social baixo.

Esta versão se ratifica na declaração de um suposto Halcón que foi preso em 1971. Ele destaca que seus companheiros Halcones eram majoritariamente"elementos de muito baixa classe social, como ex-soldados, ex-choferes de transportes de lixo, ex-boxeadores, etc.", que recebiam salários como funcionários do Departamento do Distrito Federal. Segundo o

${ }^{302}$ c. 1969, AGN, IPS, Caixa 1491 B, Exp. 6, folha 1. 
historiador Rubén Ortíz, grande parte dos militares que ingressaram nos Halcones pertenciam à Brigada de Fuzileiros Paraquedistas, por meio da recomendação de um superior. Os militares eram divididos em pequenas células e sem usar o nome verdadeiro, para que ninguém os reconhecesse como militares (ORTíZ, 2014, p. 42).

Aliás, Gabriel Millán Arellano, aquele Halcón que, comentávamos, havia sido preso, relata que era chofer de ônibus de uma linha que fez greve em 1970. Num ato político, ele foi agredido pelos próprios Halcones. Por isso começou a investigar mais dados sobre o grupo de choque. Fazendo perguntas, conseguiu saber de um dos locais de treinamento, que procurou uma conversa com o encarregado "El Famoso", para quem pediu o ingresso no grupo. O único requisito obrigatório foi sua baixa do exército, coisa que o fez. Depois de um exame físico, ele foi admitido e submetido a um treinamento por dois meses ${ }^{303}$. O grupo de choque, naquele tempo, não era utilizado, enfim, somente contra o movimento estudantil.

$\mathrm{O}$ treinamento do grupo foi proporcionado pelo próprio exército. $\mathrm{O}$ documento dos estudantes aponta que "entre capitães e tenentes figura um senhor Terrones, outro Roel, Javier Castellanos, Moisés Cuauhtémoc, José Lamberto Ponce Lara, Francisco Villaseñor e Pérez Morales". Estes militares receberiam treinamento militar nos EUA, Japão e França ${ }^{304}$. Não se tem mais informação sobre esse treinamento, mas, por outro lado, trata-se de um dado também reproduzido por Sierra Guzmán (2003).

Em números, os Halcones eram cerca de setecentos membros em 1968, chegando a mil em 1971. Organicamente, estiveram divididos em quatro seções especializadas: 1) Los Charros, que pela sua experiência no exército ou em alguma gangue, tiveram permissão de portar armas. 2) Los Halcones, que basicamente eram os linchadores. 3) Los Acuario, "cabeludos" infiltrados nos movimentos. 4) Los Pancho Villa, um grupo de choque exclusivamente para o movimento estudantil. Ainda que o documento elaborado pela comissão de estudantes indicasse que existiam quatro campos de treinamento espalhados pelo Distrito Federal, temos como afirmar, considerando os depoimentos, aquele localizado no bairro de San Juan de Aragón. As práticas consistiam principalmente em aulas de ginástica, caratê, kendo e manipulação de armas ${ }^{305}$. A esse respeito, o ex-Halcón de nome Gabriel Millán Arellano, acima citado, acrescenta em interrogatório que contavam com a instrução de "Dientes Hernández" e "Carta Brava”, lutadores profissionais ativos desde a década de

\footnotetext{
303 “Declaración de Gabriel Millán Arellano", Distrito Federal, 26-06-71, AGN, DFS, H-1, L-1, Exp. 21-438-71. 304 "Entrevista de comisión estudiantil encabezada por Heberto Castillo", BARREDA MORENO, Luis de la, Distrito Federal, 30-08-71, AGN, DFS, H-230, L-143, Exp. 11-4-71, folhas 1-8.

${ }^{305}$ Exp. 11-4-71, H-230 L-143 30-08-71, F. 1-8
} 
$\operatorname{trinta}^{306}$

Em 1977, Manuel Mondragón y Kalb - médico de profissão e militante ativo durante a greve de médicos ocorrida em 1964 - aparece registrado como presidente da Federación Mexicana de Karate. A revista Contralínea aponta a existência, dentro do acervo documental da DFS, de uma carta dirigida pelo médico para o diretor da DFS, Fernando Garcia Paniagua. A missiva brevemente indica:

O propósito desta comunicação é reiterar à Dirección Federal de Seguridad nosso vivo desejo de continuar outorgando-lhe a colaboração e assessoria técnica em matéria de karatê, tae-kwon-do, kung-fu e artes marciais semelhantes e afins e, em consequência, receber o apoio desse prestigiado organismo para o melhor cumprimento dos estatutos, normas e regulamentos de nossa Federação (PADGETT, 2013).

A assessoria para o treinamento dos Halcones foi feita, então, por especialistas em artes marciais. Aliás, o médico cardiologista Mondragón y Kalb, em 1980, ocupou a chefia da Comissão do Esporte no DF com a missão de tornar o México uma potência esportiva a nível mundial $^{307}$.

Todas as necessidades orçamentárias para manter o grupo (transporte, oficinas, combustível, espaços para treinamento) foram proporcionadas diretamente pelo governo do Distrito Federal. Indica-se, também, que os salários partiam de sessenta até cento e cinquenta pesos por dia, mas "o salário depende da temeridade e selvagismo demonstrado nas ações repressivas". Dessa forma, a comissão de investigação dos estudantes aponta que é perceptível o aumento na verba destinada à Dirección de Servicios Generales, entre 1968 e $1971^{308}$.

Em 10 de junho de 1971, um grande número de Halcones se apresentaram na retaguarda da manifestação pacífica, armados com varas, cadeias e outros objetos para infringir golpes, como pode ser observado nas gravações compiladas no documentário Halcones: Terrorismo de Estado ${ }^{309}$. Aí também podemos apreciar como os jovens paramilitares foram transportados em caminhões pertencentes a Servicios Generales. A

\footnotetext{
306 "Declaración de Gabriel Millán Arellano”, Distrito Federal, 26-06-71, AGN, DFS, H-1, L-1, Exp. 21-438-71.

${ }^{307}$ Em 1984, Mondragón foi designado coordenador social da PGR, num dos momentos de maior violência no início da guerra contra o narcotráfico. Em 2012, finalmente, foi nomeado chefe da Secretaria de Seguridad Publica no governo do priísta Enrique Peña Nieto, destacando-se pela "mão dura" contra qualquer manifestação de oposição.

308 "Entrevista de comisión estudiantil encabezada por Heberto Castillo", BARREDA MORENO, Luis de la, Distrito Federal, 30-08-71, AGN, DFS, H-230, L-143, Exp. 11-4-71, folhas 1-8.

${ }^{309}$ Halcones: Terrorismo de Estado, Dir.: Carlos Mendoza, 71 min, 2009. Disponível em: https://www.youtube.com/watch?v=2sr 38brmxc [último acesso em: 03-05-16].
} 
quantidade de mortos, como mencionamos, não é conhecida, pois, como aponta Ortiz (2014), desapareceram com os corpos ou alguns foram subtraídos dos hospitais.

$\mathrm{Na}$ análise de diversos interrogatórios e declarações feitas por ex-Halcones, podemos avaliar o grande problema que trouxe para a segurança pública o treinamento de elementos das classes baixas. Após o 10 de junho, vários quadros saíram do grupo. Na declaração de um assaltante ferido, Sergio San Martín Arrieta, ele se declarou ex-Halcón. Logo em seguida, ingressou numa empresa de segurança e depois tornou-se policial de banco. Mas, aproveitando sua formação, decidiu formar um grupo de assaltantes. Conhecendo a esquerda armada e seus métodos, San Martín confessa que, durante os assaltos, ele e seus cupinchas gritavam "Viva Genaro Vázquez", a fim de confundir a polícia e fazer passar o assalto por uma expropriação guerrilheira ${ }^{310}$. Da mesma forma, Rafael Delgado Reyes incorporou-se à vida civil como operário, porém, conservando as relações com outros ex-Halcones, foi convidado a formar parte de outro grupo de assaltantes ${ }^{311}$.

Um caso especial, quanto a isso, está relacionado com outro ex-Halcón já citado, Millán Arellano. Ele confessou que saiu do grupo depois de conhecer as arbitrariedades cometidas no 10 de junho, a partir daí, começou a trabalhar como motorista de taxi. Finalmente, declara que "depois de beber com amigos" teve a ideia de denunciar o grupo paramilitar. Dessa forma, Millán contatou algum repórter da revista Por qué?: "Em troca de dinheiro entregaria documentos que guardou, por exemplo, credenciais de estudantes por meio das quais poderiam investigar se estão ou não desaparecidos". No dia em que o exparamilitar se dirigia para entrevistar-se com o jornalista, foi preso pela DFS. Na casa dele, os agentes encontraram efetivamente um número considerável de credenciais [fig. 28].

\subsubsection{Brigada Especial}

Um dos grupos contraguerrilheiros mais reconhecidos foi a Brigada Especial, melhor conhecida como Brigada Blanca. Nazar Haro, artífice e responsável por esse grupo clandestino forjado pelo Estado, afirma que:

A Brigada nasce porque quando cometiam um delito esses grupos [guerrilheiros], no local chegavam diversos grupos policiais e se

\footnotetext{
310 "Sergio San Martín Arrieta atendido em hospital por lesiones de arma de fuego", Distrito Federal, 07-01-72, AGN, DFS, H-1, L-1, Exp. 35-24-72.

311 “Interrogatorio de Rafael Delgado Reyes", Distrito Federal, 08-01-72, AGN, DFS, H-12, L-1, Exp. 35-24-72.
} 
enfrentavam a si mesmos, crendo que eram os delinquentes. Daí que, ao ver esse panorama, me surgiu a ideia de formar uma bri-ga-da-es-pe-cial (sic), composta por diferentes corporações e que se dedicasse exclusivamente a ações que cometeram esses supostos guerrilheiros (CASTILLO GARCÍA, 2003).

A ata de fundação está contida no documento denominado "Plano de Operações No. Uno "Rastreio"'. Nele se detalham as questões organizativas do grupo especial, especificandose, por outro lado, os objetivos específicos, bem como os nomes e cargos dos envolvidos.

O Plano parte de uma análise da situação dos grupos armados. Destaca-se que durante o primeiro semestre de 1976 a Liga Comunista 23 de Setembro (LC23S) tem desenvolvido com maior frequência uma série de ações armadas que estão alterando a ordem pública e, portanto, questiona-se a eficiência do sistema de segurança como um todo, enfraquecendo, assim, a imagem do governo.

Lembremos que a LC23S foi fundada como uma coordenação de grupos armados sobreviventes da repressão de Estado. A Liga tinha presença nacional e assim começaram a trabalhar de maneira conjunta e coordenada. Na avaliação do subdiretor da DFS, Nazar Haro, referindo-se à LC23S, até 1973

Não havia a delinquência que há agora, até que surgiram estes senhores treinados na Coréia do Norte que, inspirados por aventuras guerrilheiras de outros países, buscaram o poder. Acreditaram que o México era também um país onde se podia conseguir que as massas os seguissem. Puseram bombas, perpetraram sequestros, assaltaram bancos, mataram policiais com aleivosia e vantagem. Tudo com uma bandeira de guerrilheiros (CASTILLO GARCÍA, 2003).

Pelo caráter clandestino dos grupos armados, a Liga funcionou de maneira compartimentalizada. Isto é, divididos em células independentes entre si para, dessa forma, evitar a localização de dirigentes e garantir a clandestinidade da organização, distinguindo-se pela eficiência dessa característica. Os recursos vinham, principalmente, de expropriações bancárias. Um dos objetivos para a coleta de dinheiro era a impressão do jornal Madera, órgão de difusão da Liga. Para a distribuição do mesmo, recorria-se a atos de "propaganda armada" ou "repartizas" em comícios relâmpagos dentro de assembleias de operários e trabalhadores.

Agora, na avaliação do "Plano de Operações No. 1", os objetivos reais da Liga eram 
diretos, assim como assaltos e sequestros pelos quais pedem como resgate vários milhões de pesos, com os que dia a dia se fortalecem, tendo meios para comprar armas, alugar casas e para manter-se na clandestinidade ${ }^{312}$.

Considerando o anterior, a missão da BB é investigar e localizar o maior número de elementos dos comandos da LC23S para evitar mais ações armadas. O documento coloca que a Brigada "fará o rastreamento permanente a partir do 7 de junho de 1976 nas zonas críticas" ou seja, nos bairros onde o grupo armado mantinha casas de segurança. Foram identificadas oito regiões, ou "áreas críticas" distribuídas entre as periferias da área metropolitana da Cidade do México e alguns bairros populares e operários do Distrito Federal ${ }^{313}$.

Até 1976 a contraguerrilha estava organizada a partir da coordenação dos corpos policiais com a DFS no comando. A Brigada Especial esteve conformada por"membros do Exército Mexicano, Dirección Federal de Seguridad, Procuraduría General de la República, Procuraduría del Distrito Federal, Procuraduría General del Estado de México”. Isto é, existia uma efetiva relação entre a repressão e os órgãos de justiça.

A Brigada Especial é constituída por uma Comissão de Segurança, integrada pelos chefes dos diversos corpos policiais (DFS Polícia Judicial Federal, Polícia Judicial do DF, Dirección General de Policía y Tránsito, e Polícia Militar). Como responsável pela comissão foi designado Miguel Nazar Haro, então subdiretor da DFS. Contava, também, com um assessor jurídico, Alfonso Cabrera Morales, que era chefe do departamento jurídico da DFS. O coordenador geral da comissão foi o coronel Francisco Quiroz Hermosillo, comandante da Polícia Militar, que seria o responsável direto pelas ações [fig. 29].

O sociólogo José Luis Sierra sugere, num esquema completo, que a BB estava encabeçada por dois coronéis, Luis Montiel López e Guillermo Álvarez Nahara e por um chefe administrativo, neste caso, Manuel Cavazos Juárez. Nenhum dos três estão registrados em qualquer dos documentos que mencionam a criação da BB.

Num segundo nível, encontrava-se o chamado "Estado Maior”, que juntava os chefes dos diversos grupos de especialistas. Na proposta de Sierra Guzmán, indica-se que o Estado Maior da BB estaria coordenada por Nazar Haro no cargo de chefe de operações. Depois dele, estaria um representante de cada uma das corporações que aportariam elementos para a

\footnotetext{
312 "Brigada Especial. Plan de Operaciones No. 1 'Rastreo"', Distrito Federal, 1976, AGN, DFS, H-50, L-38, Exp. 11-235-76, folhas 1-8.

${ }^{313}$ Norte: Cuauhtitlán, Zumpango y Tlalnepantla; Noreste: La Venta, Ciudad Azteca, Ecatepec, Campestre Guadalupana, Santa Clara y Xalostoc; Nordeste: Naucalpan, San Mateo y Atizapán; Este, Cuchilla del Tesoro, Agrícola Oriental y Romero Rubio; Oeste: Santa Fe y Olivar del Conde; Suleste: Iztapalapa, Tláhuac y Churubusco; Suloeste: Álvaro Obregón y Magdalena Contreras; Sur, Coapa, Xochimilco y Tlalpan.
} 
constituição do grupo paramilitar: o coronel Francisco Quirós Hermosillo (chefe da Policía Militar); Florentino Ventura (diretor da Policía Judicial Federal); Jesús Miyazawa Álvarez (chefe da Policía Judicial del Distrito Federal); Arturo Durazo Moreno (chefe de Policía y Tránsito del Distrito Federal); e finalmente Rafael Rocha Cordero e Francisco Sahagún Baca (ambos chefes da División de Investigaciones para la Prevensión de la Delincuencia) (SIERRA, 2003, p. 104).

O Plano indica que a BB se dividia em três grandes setores: 1) Grupos de Operação: não se especificam no documento quantos grupos existiam, porém, se assinala que cada um deles estava composto por dois veículos para oito integrantes, e uma motocicleta para dois mais $^{314}$. 2) Grupos Especiais: três grupos de localização e neutralização de artefatos explosivos (cinco homens em cada um, mais um veículo); um grupo de ação, integrado por dez integrantes com armamento especializado; e um grupo de interrogadores composto por quatro especialistas. 3) Grupo Aéreo: utilizava dois helicópteros pertencentes à Dirección General de Policía y Tránsito.

Os policiais e militares escolhidos para configurar a BB tiveram que cursar um programa de treinamento específico:
A. Informação e análise sobre a integração, desenvolvimento e atividades da chamada "Liga Comunista 23 de Septiembre".
B. Conhecimentos sobre armamento e práticas de tiro.
C. Técnicas de Segurança.
D. Treinamento físico e combate sem armas.
E. Comunicação e codificação.
F. Condução de veículos em patrulha.
G. Conservação do equipamento de trabalho.

Além de entrar nesse programa de estudo, os membros da BB tinham que passar por treinamento para a fabricação de explosivos, bem como de neutralização e busca. Finalmente, o Plano especifica que os "brigadistas" teriam que saber como se comportar durante as operações de apreensão dos guerrilheiros. Para tal, os agentes da BB tinham de ter consciência "das táticas, agressividade e fanatismo" dos insurgentes. Igualmente, tinham que adquirir técnicas para o registro das instalações guerrilheiras, para interrogar e também para locomover os prisioneiros.

Segundo um quadro de necessidades para a atuação plena da BB, exigia-se um total de 240 especialistas; cinquenta e cinco veículos; "compensações individuais" para os agentes (além do salário como policiais ou militares), assim como a cobertura dos gastos que se

\footnotetext{
${ }^{314}$ Rubén Ortiz propõe que foram oito grupos, considerando que eram nove as “áreas críticas” (2014, p 74).
} 
gerassem durante as diligências; pede-se, ainda, setenta litros de óleo por dia, assim como 3.300 litros de gasolina por dia. Sobre esse último requerimento, o Plano enfatiza que "seria conveniente que a PEMEX [Petróleos Mexicanos] satisfizesse deste combustível o posto de gasolina do Campo Militar No. 1, para que, daí, se distribua às unidades”. Quanto aos veículos, é apontada a necessidade de que a manutenção fosse facilitada pelas oficinas mecânicas do Departamento do Distrito Federal.

No documento fundacional da BB se explicita a necessidade de manter um espaço físico (escritório, mobília e material) para oitenta pessoas dentro das instalações do Campo Militar No. 1. De acordo com o Plano, um grupo de oitenta pessoas trabalharia por 24 horas, enquanto outro grupo, com o mesmo número de agentes, descansaria até chegar o seu turno, substituindo os outros no dia seguinte. O pessoal restante estaria distribuído nas áreas mencionadas ou cobrindo as operações [fig. 30] ${ }^{315}$.

Desde 1976, a contrainsurgência alcançou o nível mais sofisticado, exercida por um corpo clandestino especializado. De fato, a BB surge com a avaliação de que a guerrilha estava debochando da efetividade da segurança pública. Por se tratar de um grupo clandestino, a BB foi sistematicamente ocultada pelo Estado. De outro lado, a própria existência da guerrilha seria negada pelos meios de comunicação. Mencionávamos que o secretário da SEDENA, general Felix Galván López, por volta de 1979, pronunciou que “os supostos guerrilheiros não são mais do que delinquentes comuns" e que suas ações não representavam uma ameaça real para a nação (LÓPEZ AZUARA, 1979, p. 26). Abria-se, dessa forma, a possibilidade de que a $\mathrm{BB}$ atuara no projeto de aniquilamento da guerrilha em total impunidade.

Escondido da mirada da imprensa, o Campo Militar No. 1 foi convertido em uma prisão clandestina, como o demonstram diversos informes onde se sublinha o fato de que os prisioneiros suspeitos de pertencer a algum grupo guerrilheiro foram trasladados à instalação militar. Mas também, grande parte dos suspeitos feridos em confrontos com a BB foram levados ao próprio hospital do "Campo Marte”, como também é conhecido. Num relatório da DFS de 1976 consta que numa operação liderada pelo "Comando Libra" da Brigada Blanca, os agentes tentaram prender um indivíduo para pedir sua identificação. O suposto guerrilheiro agrediu os agentes com disparos. A BB reagiu e o suspeito foi ferido e "trasladado para o Hospital Central Militar", onde faleceu ${ }^{316}$.

\footnotetext{
315 "Brigada Especial. Plan de Operaciones No. 1 'Rastreo"', Distrito Federal, 1976, AGN, DFS, H-50, L-38, Exp. 11-235-76, folhas 1-8.

${ }^{316}$ Distrito Federal, 11-08-76, AGN, DFS, H-23, L-39, Exp. 11-235-76.
} 
Manteve-se a existência da BB em completo sigilo, inclusive perante os próprios policias. Contudo, estes viam eles atuar, mas não tinham como lhes pedir ajuda num possível confronto com guerrilheiros. Numa entrevista com um ex-oficial de polícia, ele confirma que:

Sabíamos que existia... sabíamos mais ou menos que alguns companheiros tinham sido enviados para lá, porém, nos tinham proibido de perguntar ou dizer uma palavra. Quando algo passava na rua e sabíamos que havia sido a Liga ou outro grupo, a informação era transferida imediatamente e nós tínhamos que sair dali (ORTÍZ, 2014, p. 78).

Por volta de 1977, um jornalista chega a questionar se as instalações militares não seriam utilizadas para a tortura e execução de guerrilheiros. Mas isso, provavelmente, numa tentativa para abafar as informações sobre a repressão. O repórter Jesús M. Lozano elaborou uma extensa matéria intitulada: “Aqui não há presos políticos”. Narra com minúcias uma visita realizada no Campo Militar No. 1, a convite do secretário da SEDENA, general Felix Galván. O repórter foi praticamente intimado a comparecer:

Neste momento convido o senhor para que percorra todo o Campo, o presídio, a instalação que deseje, e que revise até embaixo das camas, para ver se há algum detento de caráter político; os reclusos que há [que] aí se encontram são militares ou marinheiros; tem o senhor toda a liberdade para fazê-lo e não haverá nenhum obstáculo para sua missão informativa.

O general Galván, questionado sobre a possibilidade de que guerrilheiros assassinados durante os interrogatórios fossem incinerados num forno crematório, localizado na instalação militar, responde ironicamente. Para Galván, um forno tinha serventia para a instituição militar: "provavelmente faça gestões, eu, para a compra de um, pois é necessário para incinerar o lixo". O jornalista, acompanhado de um oficial, visita as instalações. Foi autorizado, como pronunciou o general, a conversar com os soldados presos. Teria comprovado, assim, que a maioria dos presos estava ali por quebra de disciplina ou insubordinação. Dirige-se, ainda, aos refeitórios e dormitórios, interrogando aproximadamente oitenta presos. Segundo o jornalista, todos os militares sabiam perfeitamente qual era a pena que estavam pagando, assim como a situação nos respectivos processos. Depois de mais de uma hora dentro do Campo Militar, Lozano conclui:

Percorremos todas as instalações e também observamos embaixo das camas, como o tinha recomendado o secretário da Defesa. Não encontramos ninguém vestido de civil [...] 
Abrem-se de novo as grandes grades do presídio para permitir-nos sair e fica somente a interrogação: Onde estão os presos políticos? $?^{317}$

Contudo, temos registro de que em setembro de 1961 fora reservado um espaço dentro do Campo Militar No. 1 com a finalidade de prender ilegalmente indivíduos com uma militância política de oposição ao regime. Num acordo entre Díaz Ordaz, que então era secretário da SEGOB, com o titular da SEDENA, procede-se à organização de uma Cárcel Preventiva para Reos de Orden Federal (CONDÉS, 2007a, p. 140). Observa-se a possibilidade de que houvesse um grande número de réus que exigiriam rígidas condições de segurança, e que, devido a seus delitos, deveriam ficar em isolamento. Díaz Ordaz escreve:

considerando que no Campo Militar número 1 da Primeira Zona Militar [...] existem as condições necessárias para um estabelecimento como o mencionado, rogo ao senhor, atenciosamente, que, se para isso não há inconveniente, sirva-se dispor se proporcionem ao Departamento de Prevención Social desta Secretaria [SEGOB] as facilidades que requeira a fim de que se instale o citado Cárcere nos sítios mais idôneos do próprio Campo Militar número $1^{318}$.

\subsubsection{Interrogatórios}

Para o exército francês, devido à experiência argelina, os métodos tradicionais de coleta de dados de inteligência tornaram-se obsoletos por diversos motivos. Em circunstâncias "convencionais", a interrogação de "inimigos uniformizados" se apresenta sob as leis de guerra terrestre e no marco de tratados internacionais. Mas as insurgências de tipo guerrilheiro implicam um desafio. Os guerrilheiros de novo tipo são "terroristas e criminosos" que, por não se tratar de um exército formal, são de difícil identificação, pois "em roupas civis se misturam com a população".

Além disso, "a condição jurídica dos terroristas amparados pela lei é distinta daquela a que se refere aos combatentes legítimos (inclusive as forças não uniformizadas que portam armas abertamente e não estão mergulhadas em práticas proibidas)" (FRANÇOIS, 2009, p. 70). Essa ambiguidade jurídica, de alguma maneira, protege ou justifica a utilização de métodos ilegais.

\footnotetext{
317 “Aquí no hay presos políticos. Fue lo primero que comprobé”, LOZANO, Jesús, Excélsior (p. 1, 23), Distrito Federal, 08-02-77, AGN, IPS, Caixa 1747 B, Exp. 8, folha 1.

${ }^{318}$ Distrito Federal, 11-09-61, AGN, IPS, Caixa 2860, Exp. 10, folha 1.
} 
O interrogatório é, sem dúvida, um dos métodos mais recorrentes para a obtenção de dados de inteligência. Nos próprios balanços franceses sobre a guerra da Argélia, aponta-se que o exército estava capacitado para aplicar "a tortura se necessitava informação rapidamente, e a interrogação estândar, se este não era o caso". As imagens apresentadas por Gillo Pontecorvo, no seu filme "A Batalha de Argel"319, bem como os depoimentos de sobreviventes, podem-nos oferecer uma imagem do catálogo de possibilidades que os militares utilizaram para a coleta de dados (ROBIN, 2004).

A tortura foi amplamente respaldada pelas autoridades políticas francesas, pois

torturar as pessoas produzia bons resultados a curto prazo. Depois das sessões de tortura e mediante uma análise cuidadosa e impecável, descobriase cada uma das células das organizações do FLN/ELN, as quais, por sua vez, eram sistematicamente eliminadas (FRANÇOIS, 2009, p. 70).

A experiência francesa foi amplamente difundida por meio da SOA norte-americana, como colocado no livro e documentário elaborados pela jornalista argentina Marie MoniqueRobin (2004). Por outro lado, o manual de estudos da SOA, intitulado "Interrogação", já adverte no prólogo que os princípios e técnicas que o manual apresenta "devem ser usados dentro das limitações estabelecidas pelo Direito Internacional Humanitário".

Na sua definição, a SOA define "interrogação" como "a arte de questionar e examinar a uma fonte com o fim de obter a máxima quantidade de informação utilizável no menor tempo possível". A informação pode ser obtida de maneira direta (quando o indivíduo possui conhecimento sobre o tema de interesse); ou indireta (quando a informação é "surrupiada" sem que o indivíduo perceba). Também se classificam os tipos de interrogatório, que podem ser: "a entrevista, a pós-orientação e o surrupiamento (sic)".

O inquiridor deve definir claramente o foco "mantendo este propósito firmemente na mente para obter a quantidade máxima de informação útil”. O manual sugere que a fonte, ou melhor, o interrogado, deve estar informado do objetivo. É necessário, então, que o interrogador adote uma atitude ofensiva. Isto é, assumindo "uma posição de autoridade sobre o informante. O informante se dá conta deste fato e, em alguns casos, crê que seu futuro pode muito bem depender de sua associação como ele".

Com esta "vantagem inicial" o interrogador deve "tirar vantagem das debilidades do

\footnotetext{
${ }^{319}$ The Battle of Algiers, Dir.: Gillo Pontecorvo, 117 min., 1965. Aliás, segundo um militar argentino que teve treinamento na Escola das Américas antes do golpe de estado de 1976, numa entrevista feita pela jornalista Marie Monique-Robin, aponta que os militares franceses, convidados especiais da Escola das Américas, utilizavam o filme de Pontecorvo para treinar os alunos latino-americanos.
} 
informante (prisioneiro) segundo se fazem aparentes e exibindo continuamente uma atitude de confiança e segurança de si mesmo". Enquanto isso, o fato de que o interrogado passou por uma experiência traumática recente, como a detenção, coloca-o numa situação de medo e vulnerabilidade, e assim, a tal "ansiedade geralmente se acrescenta a falta de conhecimento e compreensão de parte do informante do que está por ocorrer ou pelo temor infundado de que será torturado ou executado".

Já para o interrogador requer-se uma preparação prévia, ou seja, deve estar adequadamente informado tanto sobre os contextos nacionais e internacionais, como sobre os antecedentes políticos e as "circunstâncias de captura e sobre a atitude, conduta e tratamento do prisioneiro durante a custódia”. O manual alerta que, uma vez iniciado o interrogatório, é indesejável fazer pausas não previstas. Dessa forma, como parte da preparação, sugere-se que o especialista conte com os "apoios ou instrumentos de interrogatório" próximos a ele. Esta equipe, diz o manual, "inclui cartas, lápis, cadernos, esquadros e câmera". O tipo de informação que se espera, segundo a SOA, é variada, podendo "refletir sentimentos pessoais, estados de ânimo ou assuntos familiares". Assim, é preciso verificar constantemente a veracidade da informação, ou seja, repetir constantemente os interrogatórios até que não existam informações contraditórias (SOA, 1989e).

No caso mexicano, dentro dos relatórios da DFS encontramos várias referências aos interrogatórios, sobretudo, aos aplicados a supostos militantes da Liga Comunista 23 de Septiembre (LC23S). Em tais documentos, observamos um padrão nos procedimentos: detenção; interrogatório; busca de informação (documentos, armas ou pessoas) nas casas de segurança cujo endereço é proporcionado pelo interrogado; reconhecimento de outros militantes através de fotos; e, finalmente - ainda que não em todos os casos - apresentação do interrogado no Ministério Público para iniciar um processo de julgamento.

Num relatório correspondente ao primeiro de maio de 1975, informa-se sobre um assalto bancário no bairro de Villa Coapa (DF) no 25 de abril. Na expropriação organizada pela Brigada Roja, ou melhor, a célula guerrilheira da LC23S que operava no DF, houve "dois policiais bancários e um funcionário assassinado" 320 . Em outras versões, este acontecimento é lembrado como um dos mais sanguentos, registrando-se onze pessoas mortas, das quais oito eram policiais bancários, dois eram civis e um deles era funcionário do banco, enquanto não houve nenhum guerrilheiro caído (RANGEL, 2013, p. 355). De fato, a expropriação de Villa Coapa foi somente um dos três bancos que foram assaltados em

\footnotetext{
320 "Liga Comunista 23 de Septiembre 'Brigada Roja", Distrito Federal, 01-05-75, AGN, IPS, Caixa 1491 B, folhas 1-9.
} 
espetacular operação guerrilheira. Entretanto, nessas versões se assinala que um militante foi ferido e capturado enquanto cobria a fuga dos demais militantes.

É indicado no relatório que este militante capturado "ao ser interrogado durante vários dias afirmou chamar-se José Hernández Morales e ser oriundo de Caborca, Son. [Sonora]”. Pela datação supomos que se passaram seis dias entre a detenção e a apresentação do relatório. Isto é, seis dias de interrogatório. Esta informação foi rapidamente desmentida, pois "a instâncias do interrogatório" confessou chamar-se Lisenco Antonio Licea Verdugo ${ }^{321}$, oriundo de Mexicali, Baja California. Estudante de engenharia no IPN, começou a militar na organização guerrilheira e por isso, em 1973, abandona os estudos.

Tanto o interrogado como sua esposa, Consuelo Idalia Baños Mora "Hilda", formam parte do comando "José Alfonso Rojas Díaz" da LC23S. Ambos "realizam as ações subversivas com fortes medidas de segurança e clandestinidade, já que, de forma alguma, conhecem as casas de 'segurança' que a mencionada brigada tem". Segundo o interrogado, a Liga opera da seguinte forma: "quando tem reuniões, o encarregado de haver alugado o imóvel os traslada ao local encapuzados para que ninguém, em nenhum nível, conheça o endereço".

É relevante a descrição da "Brigada Roja", que, segundo o interrogado, estava composta por vários comandos batizados com o nome de algum guerrilheiro morto em combate: "José Alfonso Rojas Díaz" homenageia um companheiro dele assassinado num confronto com policiais; ou "Diego Lucero", militante morto numa expropriação bancária no estado de Chihuahua. Finalmente, aponta que o responsável de todos os comandos é David Jiménez Sarmiento "Chano", que foi reconhecido por Licea numa fotografia.

Quanto aos objetivos da organização guerrilheira, o interrogado declarou que, naquele momento, consistia no assassinato "durante os assaltos, ou fora deles, de quantos policiais que encontrem e causar igualmente atos terroristas, não importando que percam a vida”. Nesse ínterim, também confessa sua participação em duas expropriações realizadas em dezembro de 1974, uma contra o Banco Nacional e outra no Banco de Comercio, ambos na Cidade do México. Além do mais, confirmou que existia um trabalho de distribuição de propaganda em diversos bairros operários da capital.

O relatório novamente sublinha e justifica:

Apesar do estrecho interrogatório ao qual tem sido submetido, o antes manifestado são os únicos dados que se conseguiu obter deste indivíduo que

\footnotetext{
${ }^{321}$ O nome correto é Antonio Lisenco Licea Verdugo.
} 
metralhou o helicóptero da Polícia que sobrevoava a área do assalto, não lhe importando as consequências que teriam ocorrido se esse aparato fosse alcançado pelo fogo, pois, se escusa dizendo que, passasse o que passasse, era uma luta armada 322 .

No mesmo relatório descreve-se a detenção de um indivíduo suspeito que disparou contra um agente da DFS enquanto este tentava abordá-lo. No interrogatório, o indivíduo afirmou chamar-se "José Hernández", o mesmo nome falso que Licea Verdugo tinha confessado. Contudo, “depois de estrechos interrogatórios” manifestou chamar-se Abel Ignacio Chávez Velázquez. Confessou pertencer, junto com seu irmão, à brigada "Diego Lucero" da LC23S. Da mesma forma, reconheceu ter executado três policiais com a finalidade de obter armas, isso no dia oito de outubro de 1974.

Finalmente, a partir das duas detenções, afirma-se que:

apesar de existir relação ideológica e militância dentro da mesma organização subversiva, não se conhecem entre si Abel Ignacio Chávez Velázquez e Lisenco Antonio Licea Verduto, o qual nos sugere o grau da clandestinidade e segurança que esta organização está realizando.

O relatório assinado pelo próprio diretor da DFS, capitão Luis de la Barreda Moreno, está acompanhado por cinco fotografias. Três delas pertencem aos membros que foram identificados nos interrogatórios: Consuelo Idalia Baños Mora "Hilda", esposa de Licea Verdugo; Olivia Ledezma Flores de Hernández, participante de uma das expropriações; e David Jiménez Sarmiento "Chano”, então, dirigente nacional da LC23S. Três dessas fotos são de identificação, ou seja, extraídas do passado dos guerrilheiros, como as escolares e familiares. As fotos seguintes foram tiradas nos interrogatórios. Na primeira aparece unicamente o rosto de Licea Verdugo, que está bem machucado e aparece deitado numa cama, com um tubo no nariz. O segundo fotografado, Chávez Velázquez, aparece igualmente espancado e com um cacetete sustentando sua cabeça [fig. 31] ${ }^{323}$.

O intenso interrogatório, combinado com dias de tortura em Licea Verdugo, foi fundamental para conhecer dados específicos sobre a organização interna da Brigada Roja. Também foi possível conhecer os endereços de várias casas de segurança, com o que se intensificou a detenção e assassinato de militantes na Cidade do México - chamada pela DFS

\footnotetext{
322 "Liga Comunista 23 de Septiembre "Brigada Roja”, Distrito Federal, 01-05-75, AGN, IPS, Caixa 1491 B, folhas 1-9.

323 "Liga Comunista 23 de Septiembre 'Brigada Roja", Distrito Federal, 01-05-75, AGN, IPS, Caixa 1491 B, Exp. 8, folhas 1-9.
} 
como “Operación 23 de Septiembre” (TAMARIZ, 2007).

Um mês após os relatos desses interrogatórios acima, encontramos um relatório sobre outro interrogatório, dessa vez de Camerino Zamora Galindo "Bernardo" ou "Ramón López", ou "El Venado", outro membro da Brigada Roja da LC23S. O indivíduo foi capturado enquanto se dirigia a um encontro marcado com Alfredo Tecla Parra, "Rafael". Apontamos, então, que se a DFS sabia da existência dessa reunião, é porque Tecla Parra já tinha sido detido e interrogado.

Além dos dados precisos sobre sua família e seus estudos, o interrogado, natural de Oaxaca, narra como, em 1970, foi recrutado pela guerrilha. Reconhecido por um estudante do tempo em que estudavam no IPN, Camerino Zamora Galindo foi convidado "para que formasse parte de uma guerrilha com o fim de derrocar o governo e instalar um de tipo socialista e levar ao poder o proletariado". O recruta, Leopoldo Ângulo Luque "Matus" deu instruções para que fosse transferido para uma casa de segurança onde permaneceu por um mês estudando marxismo-leninismo, tendo também treinamento militar.

Zamora Galindo recebeu a ordem de ajudar na construção de um braço camponês dentro da estrutura da Liga, a "Brigada Emiliano Zapata". O interrogado é muito detalhista ao indicar a relação de pessoas que conheceu e sobre as ações realizadas pela organização. Por exemplo, falando da Brigada, indicou queela se divide em duas comissões, uma formada por ele mesmo e por e 'Antonio', “os quais sobem a Serra para politizar os camponeses e reconhecer a zona", enquanto que a outra comissão, "integrada pelos restantes fica em Jamiltepec".

Descendo da serra e em contato com a outra comissão, Zamora toma conhecimento do sequestro de Raymundo Soberanes Otero, um rico pecuarista da região. É encarregado para a vigilância do sequestrado. Uma vez que o resgate pedido foi negado, o próprio Zamora Galindo ordenou a execução de Soberanes Otero, realizada por um indivíduo de apelido "La Pinta", "quem o degolou com um machado sem que houvesse desprendimento de cabeça, havendo-o enterrado no lugar onde o tinham sequestrado".

Segundo o interrogatório, a organização avaliou que o trabalho em Oaxaca tinha falhas e o exército já estava perseguindo os membros da Brigada. Em fuga, Zamora se dirige à Cidade do México, onde é apresentado a membros da Brigada Roja. Iniciou o trabalho fazendo propaganda em várias fábricas têxtis. Posteriormente, ele é selecionado para participar na expropriação de um banco projetada para o dia 5 de dezembro de 1974. Depois, narra o assassinato de um policial que tentou deter o grupo enquanto visitava as fábricas e obras, bem como o homicídio de dois pedreiros que se opuseram à presença dos guerrilheiros 
no local de trabalho.

O relatório assinado pelo diretor da DFS, De la Barreda Moreno, está igualmente acompanhado pela foto do interrogado, que apresenta severas mostras de tortura. A cabeça vem apoiada por um braço, o rosto muito inchado, inclusive, há sangue no nariz e na boca. As roupas dele, além de estar ensanguentadas, parecem molhadas ${ }^{324}$. Cabe mencionar que, segundo o pesquisador Gilberto López Limón, Camerino Zamora foi sequestrado no dia 3 de junho de 1975 por agentes da DFS. O relatório com o interrogatório está datado 5 de junho. É no dia em que o corpo do interrogado apareceu morto nas ruas da cidade e apresentado como morto num enfrentamento com agentes policiais. Ou seja, foi abatido extrajudicialmente (LÓPEZ LIMÓN, 2006).

Como havíamos mencionado, Alfredo Tecla Parra foi detido justamente um dia antes que Camerino Zamora, ou seja, em 2 de junho de 1975. Até dia 7 de junho foi apresentado diante do Ministério Público para ser julgado e processado ${ }^{325}$. Foram 5 dias de interrogatório em que se identificou através de fotografias a grande parte dos militantes da Brigada Roja, entre eles Araceli Ramos Watanave "Magdalena", e Leonardo Jiménez Alvarado "Juan", de quem se anexam fotografias. Porém, o relatório do 9 de junho indica que vários nomes foram identificados por Alfredo ${ }^{326}$.

Em outros relatórios de menor extensão, podemos encontrar breves referências aos interrogatórios e seu método brutal, considerando, aliás, o procedimento de insistir na extração de informações. Em dezembro de 1975, em Culiacán, Sinaloa, um estudante de economia em interrogatório confessou pertencer à LC23S. Contudo, “continuará sendo interrogado, pois, se sabe que foi líder durante os movimentos estudantis. Pode aportar informação para encontrar outros extremistas",327.

Em quinze de janeiro de 1976, a Policía Municipal de Culiacán, Sinaloa, registrou dois domicílios em que, supostamente, moravam integrantes da LC23S. Em um dos endereços

\footnotetext{
324 "Liga Comunista 23 de Septiembre 'Brigada Roja", BARREDA MORENO, Luis de la, Distrito Federal, 0506-75, AGN, IPS, Caixa 1491 B, Exp. 10, folhas 1-6.

325 "Liga Comunista 23 de Septiembre 'Brigada Roja", Distrito Federal, 07-06-75, AGN, IPS, Caixa 1491 B, Exp. 10, folhas 1-7.

326 "Liga Comunista 23 de Septiembre", Distrito Federal, 09-06-75, AGN, IPS, Caixa 1491 B, Exp. 11, folha 1. Os nomes identificados foram: José Antonio Amaya López "El Piojo"; Roberto Antonio Gallangos Cuz "Simón"; Blanca Estela Cervantes Tavera "Luisa"; José Bonfilio Cervantes Tavera "David" ou "Davis"; Luis Miguel Corral García "El Güero"; Ángel Delgado Sarmiento "Héctor"; Mario Domínquez Ávila "Benito"; Eduardo Esquivel Revilla "León"; Rosalvina Garavito Elia "Gertrudis"; Rodolfo Gómez García "El Viejo"; David Jiménez Sarmiento "Chano"; Olivia Ledezma Flores "Mariana" ou "La Güera"; Octavio Márquez Vázquez "Delmar"; Delia Morales López "Rita"; Rosenda Ramos Watanave "Ana"; Lázaro Torralva Álvarez "Carlos"; Ana Lilia Tecla Parra "Renata"; José Ángel García Martínez "El Gordo"; "Andrea".

327“"Declaraciones de Benjamín García Paez, presunto miembro de la Liga Comunista 23 De Septiembre”, Distrito Federal, 02-12-75, AGN, IPS, Caixa1920 B, Exp. 3, folhas 1-2.
} 
conseguiram prender sete estudantes. Eles "foram trasladados para um domicílio particular localizado na colônia Libertad, no Sul deste povoado onde estão sendo interrogados". As inquirições, portanto, não só se realizavam em instalações policiais ou militares. Finalmente, os estudantes foram soltos, porque, além de um deles resultar ser sobrinho de um senador, não encontraram nem armas nem propaganda na suposta casa de segurança vasculhada. $\mathrm{O}$ agente adverte: "ao que parece, não têm nada que ver com a Liga Comunista",328.

Naquele mesmo ano, em Ciudad Juárez, Chihuahua, num relatório brevíssimo indicase que "Jesús Villegas Corral" foi preso após matar um policial e ferir outro. Esse foi o nome dado pelo interrogado, porém, o agente desconfia que se trata de Armando Escalante Morales "El Loco", integrante da LC23S. Contudo, ainda não podem ser definidos os traços fisionômicos, "porque se encontra golpeado e desfigurado do rosto" ${ }^{329}$. Escalante Morales foi um dos militantes mais visíveis da LC23S por ter participado da fuga do presídio de Oblatos, na cidade de Guadalajara. É registrado como desaparecido desde 1978.

Torna-se cada vez melhor a perícia dos inquiridores, isto é evidente para o final da década de setenta. Destaca-se o relatório de abril de 1977 em que se narra a detenção de três elementos da LC23S: Antonio Orozco Michel "Manuel” ou "René"; José Luis Esparza Flores "Roberto", "Carlos" ou "El Padrino"; e Aurora Castillo Mata "Socabel” ou "Belém”. Foram inquiridos por agentes da Dirección General de Policía y Tránsito, na Cidade do México.

Assinado pelo diretor da DFS, o licenciado Javier García Paniagua, tal relatório alerta que:

se sabe que devido ao fanatismo e à capacidade de Antonio Orozco Michel, tem utilizado sistemas militares para evadir as respostas (sic) a seus interrogadores, consistentes em medidas de segurança encaminhadas a proporcionar dados equivocados e não sujeitos a comprovação.

Percebendo, então, que um dos prisioneiros "se conduz com falsidade", o diretor da DFS sugere incluir no interrogatório cinco pontos específicos que García Paniagua avalia como questões fundamentais para a segurança interna. $\mathrm{O}$ relatório provavelmente estava dirigido diretamente para os agentes interrogadores. O questionário indicado por García Paniagua, transcrito no relatório, é bem minucioso e evidencia o perfeito conhecimento sobre os comitês e células nas quais se organizava a Liga, assim como os métodos em que agia:

\footnotetext{
328 "Esta madrugada, elementos de la Policía Municipal y la DFS catearon dos domicílios", Culiacán, 24-01-76, AGN, IPS, Caixa 1920 B, Exp. 3, folhas 1-2.

329 “Jesús Villegas Corral”, Ciudad Juárez, 09-08-76, AGN, IPS, Caixa 1920 A, Exp. 1, folha 1.
} 
1. Organização

a) Integrantes da Direção Nacional.

b) Integrantes do Comitê Militar.

c) Integrantes do Comitê de Imprensa.

d) Número de Comandos com posição no DF.

e) Número de brigadas no interior da república com a denominação e participantes.

f) Forma de composição do Comité de Imprensa, assim como Seções deste Comitê no interior da República para a elaboração e distribuição do periódico clandestino denominado Madera.

g) Sistema de encontros clandestinos.

h) Sistema de aquisição e troca das chamadas casas de segurança.

2. Atividades delituosas realizadas

a) Detalhes.

b) Exigir dados sujeitos a comprovação: quem planejou o feito, quem elaborou comunicado, quem proporcionou dados sobre nomes, qual foi o destino do resgate, etc.

3. Planificação de atos futuros

a) Nomes de possíveis sequestrados

b) Localização de sucursais bancárias.

c) Localização de futuros homicídios de policiais.

d) Filiação e dados sobre membros da Liga possivelmente envolvidos em atos futuros.

4. Atitudes ideológicas e

a) Assinalar de forma geral a ideologia.

b) Variações ideológicas (tendo como base o marxismo-leninismo).

c) Grau de aceitação no setor operário e estudantil.

5. Situação econômica

a) Quem administra.

b) Forma de distribuição.

c) Quanto [dinheiro]necessitam para se manter.

Para concluir o documento, o diretor da DFS adverte que "de acordo com as respostas que o detido proporcione, será necessário reperguntar para alcançar o objetivo que se persegue". Ou seja, além de dar a linha de como proceder o interrogatório, ele indica a necessidade de continuar no interrogatório até ter respostas críveis e condizentes com o resto da informação que se tem sobre a Liga ${ }^{330}$.

A partir de maio de 1977 começaram formalmente as denúncias feitas por familiares de militantes armados por detenção ilegal, sequestro, tortura e assassinato contra o Estado mexicano. Nesse mesmo ano, o governo de López Portillo permitiu a realização de uma investigação liderada pela Federación Internacional de Derechos del Hombre, o Movimiento Internacional de Juristas Católicos e a Liga Internacional por los Derechos del Hombre. Da investigação depreende-se uma lista com 301 desaparecidos. Os autores do relatório

\footnotetext{
330 "Liga Comunista 23 de Setpitembre", GARCÍA PANIAGUA, Javier, Distrito Federal, 13-04-77, folhas 1-5. In: "Dirección General de Policía y Tránsito del Distrito Federal (DGPyT-DF)", Versión Pública, Distrito Federal, Período 02/01/75-28/06/79, AGN, DFS, L-2/2, folhas 1-374.
} 
enfatizam: "acreditamos que a existência da Brigada Blanca é um fato razoavelmente provado" (MARÍN, 1980, p. 7). Apesar da denúncia, os funcionários do governo negaram tanto a existência da $\mathrm{BB}$, como dos métodos que vários sobreviventes tinham denunciado. Segundo o jornalista Carlos Marín, o relatório dos juristas conclui que"sob as atuais normas regionais e internacionais no campo dos direitos humanos, o governo mexicano é responsável por cometer estes atos ilegais, levada a cabo por seus agentes" (MARIN, 1980, p. 9).

Naquele mesmo ano, o México recebeu dois representantes da organização Anistia Internacional, cuja missão era investigar as queixas existentes sobre a violação de direitos humanos: prisão e detenção arbitrária por motivos políticos, desparecimento de pessoas, tortura, e demoras inconstitucionais nos processos de presos políticos. Violações que eram relacionadas a corpos inconstitucionais especializados nesses métodos, dependentes diretamente do Estado (PROCESO, 1979, p.16).

$$
* * *
$$

As peculiaridades do Estado mexicano, assim como do movimento armado, configuraram as características da contrainsurgência mexicana: implementação do aniquilamento dos grupos armados; não houve necessidade de gerar campanhas de luta ideológica contrainsurgentesdevido ao isolamento dos grupos armados; os aparatos de repressão operaram livremente até o fim da década de setenta, pois não existiam grupos de defesa de direitos humanos que fizeram denúncias dos desaparecimentos e assassinatos de militantes armados; o exército se especializou no aniquilamento das guerrilhas rurais enquanto os corpos policiais, das guerrilhas urbanas; o Estado paramilitariza os grupos de contrainsurgência e, dada sua condição secreta, os dota de impunidade; finalmente, como reação às condições internas dos grupos armados, o Estado se especializa na infiltração das organizações armadas.

Considerando, então, que a infliltração era uma especialidade da contrainsurgência, aprofundamos no caso dessa ação no Movimiento Revolucionario del Pueblo, tendo em vista a vasta informação contida no arquivo da DFS. Este caso específico nos ajuda a conhecer os modos em que operava a inteligência e a informação proporcionada por um indivíduo infiltrado para a elaboração dos planos contrainsurgentes.

Finalmente, avaliamos alguns documentos que nos permitem conhecer os elementos que constituíram dois grandes grupos paramilitares, sua formação e sua constituição. Os Halcones e a Brigada Especial, o primeiro grupo especializado em romper greves e em enfrentar o movimento estudantil, e o segundo, criado no intuito de aniquilar a Liga 
Comunista 23 de Septiembre. A Brigada Especial, também chamada Brigada Blanca, foi bem conhecida por seus métodos de violação aos direitos humanos. Nos relatórios elaborados pela DFS encontramos que o processo era o seguinte: detenção extrajudicial; traslado a centros de detenção clandestina; sessões de interrogatórios (tortura) em que se procurava saber endereços das casas de segurança, bem como, pela apresentação de fotografias, o reconhecimento de mais militantes armados. Depois disso, alguns eram transferidos para o Ministério Público para iniciar um processo de julgamento. Outros simplesmente foram desaparecidos. 


\section{CONSIDERAÇÕES FINAIS}

Entre 1964 e 1982, percebemos uma série de modificações nos mecanismos de controle da oposição. Especificamente, o "controle" se tornou "aniquilamento". O salto qualitativo pode ser definido como a transformação de um Estado de características autoritárias para um contrainsurgente. Isto é, no México, exerceu-se o terrorismo de Estado com características semelhantes ao aplicado nos regimes com estados de exceção. Ao longo desta pesquisa, conseguimos identificar elementos da Doutrina de Segurança Nacional e da Doutrina Contrainsurgente que foram assimilados pelo governo, no processo da desarticulação dos movimentos sociais mexicanos. Também, a aparição do movimento armado socialista no país aprofunda, de maneira ainda mais evidente, a sujeição do México às propostas doutrinárias estadunidenses e seu métodos.

Sustentamos que, dentro do recorte temporal, houve uma guerra suja deveras semelhante às que ocorrem nos regimes governados por militares característicos do Cone Sul, ainda que guardadas as devidas proporções (quantitativas). Porém, o Estado mexicano manteve um papel peculiar dentro do contexto latino-americano: distanciado publicamente do sobre-dimensionamento da ameaça comunista; aplicando, também, uma política externa agressiva com respeito às ações norte-americanas. As condições ideológicas e políticas do México - resultado da institucionalização de um processo revolucionário em que as massas tiveram um papel importante - foram ferramentas de ambos os pólos hegemônicos do conflito mundial.

Em contexto, o fim da Segunda Guerra Mundial e a identificação do comunismo como inimigo do "mundo livre" supuseram a paulatina construção de medos e preconceitos provocados pelas campanhas de desinformação. A realidade se partiu em dois e a bipolaridade se apoderou do senso comum. O reflexo que essa leitura dicotômica teve nas doutrinas relativas à política externa são aqui enfatizadas, destacando-se a hegemonia norte-americana na política latino-americana.

As concepções anticomunistas se projetaram na política externa determinando a maneira pela qual se estabeleceram as relações com outras nações. Em paralelo, o anticomunismo também modifica as doutrinas militares, num contexto de competição científica, armamentista e nuclear. O avanço das lutas de liberação nacional na Ásia e África, que derrotam as antigas potências coloniais, também modifica as formas de fazer a guerra. 
Lutas periféricas que foram beneficiadas ou prejudicadas desde os grandes centros ideológicos e políticos. O anticomunismo, então, determina a estratégia total dos EUA, significando, pois, que a política interna, econômica, externa, militar, enfim, qualquer medida construída pelo Estado, conteria uma forte carga de anticomunismo. Construía-se e girava em torno dele.

Foram revisadas as experiências de fracasso dos exércitos pertencentes a potências mundiais para combater os novos tipos de guerra desenvolvidas na periferia mundial. $\mathrm{O}$ foco da redefinição da doutrina militar se deu na avaliação de que existia uma "nova fronteira" no avanço do comunismo: o Terceiro Mundo. Os inimigos tinham-se diversificado. China se consolidava como potência comunista e seus métodos de internacionalização da revolução chocavam com aquelas dos soviéticos. Na América Latina, por outro lado, aparecem governos que desenvolvem algumas medidas de benefício social, que sob os olhos anticomunistas norte-americanos, significavam avanços do comunismo no continente. Finalmente, a vitória da Revolução Cubana acendia os focos vermelhos. O inimigo estava em casa.

Considerando esses elementos, os EUA propõem uma forma específica para utilizar os recursos militares, a Doutrina Contrainsurgente. Paradoxalmente, esta nova fórmula militar enfatizava a importância da aplicação de medidas econômicas que favorecessem politicamente os governos que enfrentavam algum tipo de resistência qualificada como comunista. A legitimação popular dos regimes se sustentava a partir de medidas que iam do controle dos meios de comunicação até a implementação de programas de assessoria militar e policial, assim como outros tipos de auxílio de caráter econômico, como a Aliança para o Progresso.

A análise do informe Rockefeller nos ajuda a entender a política estadunidense em relação à situação econômica e política latino-americana nos anos setenta, numa tentativa para não perder a influência no continente. O informe, elaborado pelo senador Rockefeller, baseouse num itinerário de reconhecimento do território, o que serviu para analisar os sujeitos políticos latino-americanos. Desta avaliação se deduz que os militares são os sujeitos melhor preparados para impulsionar, de maneira efetiva, os programas de desenvolvimento econômico. Quanto mais efetiva a segurança, melhor será o desenvolvimento econômico. A proposta elaborada pelo senador remete à necessidade de colaborar estreitamente na preservação da segurança interna dos Estados. Enfatizando que a estratégia de intervenção de tropas estadunidenses tem fracassado, a proposta concreta foi elevar os apoios em forma de treinamento, capacitação e equipamento dos corpos repressivos das nações amigas. Mas, também, na aparência de programas de ajuda econômica para a estabilização do 
desenvolvimento, e, desta maneira, eliminar as condições de fundo que permitem o surgimento do comunismo.

Atendendo a esta nova fórmula econômica e militar se criaram centros de capacitação dirigidas pelos EUA. Grande parte dos exércitos latino-americanos assistiram aos cursos. A partir daí, difundiu-se um corpo doutrinário que recolhia os pontos principais da política externa estadunidense. A novidade foi que o conceito de segurança significou o eixo da nova proposta da organização social na sua totalidade. Em 1964, começam os chamados regimes de Segurança Nacional, localizados, particularmente, no sul do continente americano.

A Doutrina de Segurança Nacional, como foi chamada, destaca-se pela teorização de conceitos como "nação" ou "geopolítica", quando a "guerra total" atravessa esses conceitos. Resumidamente, a proposta consistia em que o Estado-Nação (cujas fronteiras desaparecem) representa as aspirações da população em seu conjunto. Assim, qualquer tentativa por se opor ao modelo de governo, seja através de movimentos, partidos, frentes, significava uma ameaça para a unidade nacional. A guerra total, então, era necessária para eliminar as falsas contradições introduzidas a partir do exterior, e desta forma, conservar a segurança interna. A esquerda era resultado de conspirações internacionais, nunca das condições sociais e econômicas internas. Diante de governos que flertavam com o comunismo, ou melhor, diante da proliferação de movimentos opositores e grupos armados, o exército - instituição nacionalista por excelência - era o corpo mais preparado para a restituição da normalidade democrática. A DSN promoveu a instauração de estados de exceção.

Conhecemos, assim, vários exemplos de regimes latino-americanos que foram governados utilizando essas teses. Dentro desse complexo panorama no continente, questionamos a posição mexicana nesse conjunto. Nesta pesquisa, concentramos a análise na adaptação e assimilação destas novas tendências doutrinais (segurança nacional e contrainsurgência) à realidade mexicana, considerando a proximidade com o centro hegemônico continental. Sustentamos que a intervenção norte-americana, se foi discreta, não obstante, ela aconteceu. No entanto, a assimilação aconteceu atendendo às peculiaridades da história mexicana e respeitando-as.

Historicamente, a segurança nacional não foi um conceito que tivesse sido pensado no sistema político mexicano. De fato, intuitivamente, era considerada como a forma coercitiva de controle da oposição. Não é até 1973 que se regulamenta, entregando a responsabilidade para a Dirección Federal de Seguridad. Esta instituição, fundada em 1947, é reformulada na década de cinquenta, utilizando-se como modelo o FBI. Mas não somente o modelo, pois os agentes receberam treinamento teórico e prático dos agentes norte-americanos. 
Dessa maneira, a DFS esteve encarregada de produzir, estudar a informação relativa aos movimentos sociais, partidos, ou indivíduos que fossem considerados como potenciais ameaças à segurança interna. Utilizando métodos como a espionagem e a infiltração de organizações, a partir de 1964, a DFS se tornou um braço executor de ações ilegais como a detenção ilegal e o desaparecimento de suspeitos. Em termos organizacionais, a agência de inteligência mexicana se construiu como um espaço privilegiado por várias razões. Primeiro, dependia diretamente da Secretaría de Gobernación, ou seja, do segundo homem forte do governo, cargo que praticamente implicava a candidatura à sucessão presidencial. Os agentes contratados, em sua maioria, eram escolhidos a partir das relações amistosas ou de apadrinhamento. Dentre as corporações policiais, os agentes da DFS eram aqueles mais bem pagos, pois, além de serem funcionários da SEGOB, estavam matriculados no exército, duplicando-se o salário. Como os responsáveis pela segurança interna, os benefícios eram patentes.

Um dos pontos que destacar é a maneira como se estabeleceu uma estreita relação entre os órgãos de inteligência mexicano e estadunidense. Atualmente, temos elementos que documentam a troca de informação relativas à segurança entre os dois Estados. Esta cooperação se estabeleceu a partir de uma rede de espionagem batizada com o nome de Proyecto Litempo, organizada e mantida por Winston Scott, chefe da sede da CIA no território mexicano. Em documentos recentemente abertos para consulta pública, podem-se encontrar os nomes dos mexicanos que colaboraram diretamente com Litempo. Incluindo os nomes dos presidentes Gustavo Díaz Ordaz e Luis Echeverría, encontramos também a referência ao diretor da DFS, Fernando Gutiérrez Barrios, entre outros. O nacionalismo exacerbado dos funcionários mexicanos é questionado, pois, basicamente, reagiam às pautas que a inteligência norte-americana apontava.

A cooperação não esteve restrita ao terreno da informação, pois, através da DFS, os estadunidenses mantiveram um forte controle sobre os estrangeiros exilados no México. Um caso a partir dos relatórios da DFS está relacionado aos guatemaltecos refugiados no México - lembremos que o golpe militar na Guatemala foi projetado e promovido pelos EUA. Por outro lado, o território mexicano foi utilizado como refúgio de várias figuras vinculadas com o crime organizado norte-americano, o qual, em algum momento, teve sujeitos contratados ou que cooperavam com as autoridades dos EUA. Destacamos o caso de Sam Giancana, da máfia de Chicago, implicado na invasão de Bahia dos Porcos e nas tentativas de assassinado de Fidel Castro. Inclusive, o território mexicano funcionou secretamente para que o Comando de Organizaciones Revolucionarias Unidas, comandado pela CIA, aprimorasse as operações 
contrarrevolucionárias dos exilados anticastristas. Finalmente, observamos desde os relatórios da DFS, a vigilância que se aplicou sobre embaixadas dos países pertencentes ao bloco comunista, informação que era repassada aos norte-americanos. A informação revisada indica, também, a existência de intervenção telefônica em embaixadas e consulados, uma grave violação ao secreto diplomático. Da mesma forma foram infiltradas as agências de informação chinesa, bem como uma rede de espionagem sobre os funcionários da embaixada cubana.

A segurança nacional mexicana, a princípios da década de oitenta, muda de guardião. No contexto do descobrimento de poços petrolíferos no Golfo do México e atendendo aos altos níveis de insegurança, pela onda de revoluções e guerrilhas que ocorrem na América Central. É o início do declínio da DFS e a Secretaría de la Defensa Nacional assume essa responsabilidade.

A relação entre o exército e o Estado presidencialista mexicano tem-se mostrado bastante estável desde a reforma de 1924. A avaliação feita no informe Rockefeller sobre a pertinência da presença militar como elementos restauradores da ordem democrática não teve nenhum tipo de efeito no contexto mexicano. A reforma militar pós-revolucionária, além de disciplinar e unificar ideologicamente a instituição, funcionou para estabelecer uma série de normas - não escritas - de cooperação, mas, antes de tudo, de respaldo incondicional às políticas presidenciais. Ou seja, constrói-se a imagem de uma corporação despolitizada e de uma presidência de vocação civilista. Porém, em contrapartida, os altos comandantes militares participaram organicamente do Estado, ocupando cargos estratégicos por indicação presidencial, assim como chegaram a postos de eleição popular.

Esse respaldo fica ainda mais explícito na análise das declarações de alguns dos generais mais importantes da década de setenta. No contexto da onda de golpes de Estado liderados por militares em várias partes do continente, a hierarquia militar fez um esforço significativo - considerando que geralmente se mostraram discretos nas suas declarações públicas - para enfatizar as diferenças entre os militares mexicanos e os latino-americanos. Segundo estas declarações, a maior disparidade era que o exército mexicano foi essencialmente popular e despolitizado, enquanto os outros eram partidaristas e elitistas. Isso é, os militares mexicanos não tinham aspirações políticas, para além da defesa intransigente das instituições. Estas, nos discursos presidenciais, são descritas como a síntese das lutas históricas do povo mexicano. Os militares deram destaque ao fato de que não existe uma ambição por constituir-se como uma elite salvadora, pois, como legítimos "filhos do povo", seu lugar era no mesmo nível daquele dos operários e camponeses, não estavam por cima deles. 
Contudo, o exército mexicano, a partir de 1964, iniciou um processo de renovação de seu equipamento. Mas também, de um modo mais significativo, quiçá, para nossa investigação, foi a renovação doutrinária. Assim, a partir da participação de militares mexicanos em escolas militares e policiais dos EUA, reelabora-se a estratégia militar contra os inimigos do sistema. Pela primeira vez se utiliza o método de elaboração de manuais de estudo focados na caracterização da guerra de guerrilhas, guerra total, conflito interno, guerra revolucionária e outros conceitos elaborados tanto pela DSN como pela contrainsurgência.

Naquele mesmo ano, a aparição de grupos armados de características socialistas promoveu um reacômodo dentro do aparato repressivo. Um exemplo do que foi observado é a especialização do exército para o combate de guerrilheiros nas áreas rurais, enquanto que a polícia combatia guerrilheiros urbanos nas cidades, como bem ensinavam os manuais da Escola das Américas. De outro lado, também se institucionalizam os Cuerpos de Defensa Rural, ou grupos paramilitares que ajudavam na luta contra a subversão rural. Estes movimentos chamaram nossa atenção, pois, historicamente, o exército foi utilizado para combater qualquer movimento social e, a partir da década de cinquenta, a corporação castrense esteve concentrada nas cidades.

Aos poucos, a repressão foi-se acomodando a partir dos modelos norte-americanos. De maneira paralela, a política externa expressada nos informes presidenciais posicionou ao país internacionalmente como um dedicado defensor da democracia, contudo, não como aliado incondicional dos EUA. Na análise desse tópico, observamos dois momentos. Durante o sexênio de Díaz Ordaz, ele se mostrou bastante cuidadoso a respeito da política norteamericana. Lembrando da importância dos empréstimos e outros programas de apoio econômico dos quais o México era beneficiário, Díaz Ordaz manteve uma postura defensiva. Historicamente, a política externa mexicana se definiu pela defesa da autodeterminação dos Estados através da Doctrina Estrada. Tendo fundamento na experiência mexicana após o processo revolucionário de 1910, concebe o direito dos Estados de não se deslegitimar internacionalmente, dando acento ao respeito pelos processos políticos de cada povo na eleição das formas de governo que melhor convenha. Desta maneira, Díaz Ordaz não fez nenhum tipo de condenação contra qualquer outro regime. Muito pelo contrário, pois, manteve-se firme na defesa do Estado revolucionário cubano, condenou a invasão da República Dominicana por tropas norte-americanas e se mostrou empenhado no tema do desarmamento nuclear e pela paz no Vietnam.

De toda forma, a política externa como expressa por Echeverría e por López Portillo transforma-se radicalmente. Adquire um tom militante. Os dois presidentes se posicionam 
dentro do conflito mundial e não de maneira neutra, mas sim, como parte do Terceiro Mundo. Ambos reprovam as potências hegemônicas com suas políticas de dependência que pretendiam impor a outros Estados. Echeverría foi quem se mostrou mais radical. Reestabelece relações diplomáticas e comercias com a China, viaja para Cuba e se declara defensor do regime democrático chileno encabeçado por Salvador Allende.

Pela análise dos discursos presidenciais, observamos como o anticomunismo tão característico da Guerra Fria não é incorporado na linguagem política oficial. A Revolução Mexicana de 1910 é o maior referente histórico para os mandatários. Uma questão que aparece com frequência é a exaltação daquele momento inaugural, apontando-se para o fato de que o sistema político que resultou da Revolução foi construído a partir da somatória de diversas ideologias. O pacto social mexicano se confirma nesse princípio. A constituição, então, é o documento síntese de todas as posições políticas. Os mandatários são repetitivos ao declarar que no México não existem motivos para proibir ou impedir o desenvolvimento de uma ideologia e não outra. Os níveis de maturidade da democracia mexicana, além de permitir o diálogo respeitoso com qualquer regime, possibilitam que internamente qualquer assunto possa ser discutido sob a perspectiva ideológica que se considere preferível. Partindo destas condições, o asilo político foi uma bandeira de luta de Echeverría e de López Portillo. Como consequência do golpe militar no Chile, o México recebeu um número significativo de allendistas e militantes perseguidos por Pinochet. Estes foram recebidos e privilegiados com uma série de medidas que possibilitaram e facilitaram sua permanência em território mexicano. Isto em contexto de grande repressão contra os movimentos sociais mexicanos.

Como mencionado, o anticomunismo estava totalmente fora da linguagem política. Porém, observamos as maneiras pelas quais o Estado mexicano protegeu e, inclusive, instrumentalizou os grupos de direita, estes, sim, com uma linguagem anticomunista radical. Observamos, inclusive, as tensões existentes entre estes grupos e o Estado mexicano. Esta tensa relação foi documentada através de relatórios da DFS correspondentes à investigação sobre a organização juvenil de direita chamada Movimento Universitario de Renovadora Orientación. Por outro lado, estes jovens combatiam diretamente o comunismo dentro das universidades, favorecendo uma conjuntura em que o governo mexicano não precisasse entrar nos espaços estudantis de circulação de ideias críticas, integrados aos movimentos sociais de esquerda. O governo, assim, evita confrontá-los diretamente.

De seu turno, os métodos utilizados pelos jovens católicos radicais tinham características paramilitares. Consideramos que o governo os protegeu, pois nas listas de presos localizadas nos documentos da DFS não existe nenhuma menção a este grupo 
perfeitamente identificado e sobre o qual recaiam várias denúncias públicas. O MURO, especificamente, era uma das organizações de choque que se relacionava a uma estrutura bem ampla, vinculada à hierarquia católica, ao empresariado mexicano e ao PAN, denominada Yunque. Ainda que esta organização secreta tenha escapado da mira da DFS, algumas informações encontradas nos relatórios de inteligência nos ajudam a revelar os projetos e intenções deste grupo. Sua vinculação, por exemplo, com cubanos anti-castristas e alguns atentados à dinamite em embaixadas e consulados cubanos nos apresentam indícios para considerar que o Yunque considerava os governos mexicanos como inimigos, ou seja, aliados do comunismo e anticatólicos.

A defesa do governo democrático chileno contra o golpe militar, assim como o recebimento dos exilados chilenos, acendeu o alerta dessa organização anticomunista. Vimos como a direita mexicana implementou uma estratégia para desestabilizar o sistema político mexicano, muito semelhante à utilizada pela burguesia chilena antes do golpe. Uma onda de rumores foi implantada de forma sistemática. Destaca-se uma campanha de vacinação que tinha como objetivo a esterilização de crianças de classes baixas. Explora-se a falta de alimentos, a precariedade no abastecimento de energia. Aponta-se para a desvalorização da moeda e até aparecem rumores sobre um golpe de Estado. A documentação nos ajuda a vislumbrar aqueles dias de pânico e incerteza que colocaram em risco a segurança do sistema político, aventando uma possibilidade inédita na história pós-revolucionaria: um golpe de Estado.

O discurso radical da política externa, mesmo que tenha representado um problema grave para a burguesia mexicana, por outro lado, também foi utilizado para deslegitimar as pautas da esquerda. No discurso de que o México era um país democrático com espaço para a participação política sem importar as ideologias, também se descreve o país como solidário com os governos de esquerda no continente. O Estado mexicano, dessa forma, propiciou a descontextualização da luta de oposição internamente. Nessa discussão, observamos com nitidez a contradição entre o discurso oficial e a prática da DSN no contexto mexicano.

A leitura da realidade social mexicana inscrita nos discursos presidenciais não contemplava a possibilidade de que as políticas sociais fossem insuficientes. Os motivos da proliferação de movimentos sociais, e, sobretudo, de grupos armados, são localizados como influência externa. Uma conspiração internacional. Tal como agentes patógenos, pretendia-se enfermar a sadia e madura democracia mexicana. Os discursos presidenciais, sem menção específica a qualquer personagem, grupo ou movimento concreto, aos poucos vão estabelecendo a imagem dos inimigos da nação. Vimos como se constrói essa imagem 
imediatamente depois da explosão dos movimentos estudantis e do protagonismo político que os jovens adquirem na segunda metade da década de sessenta.

Distinguimos várias características dos inimigos internos. Entre os mais referidos estavam pequenos grupos de jovens desorientados. Em suma, a inocência juvenil é aproveitada por grupos estrangeiros interessados em desestabilizar o sistema mexicano. Isto poderia ser corroborado tendo em conta as pautas das manifestações, que, sem nenhuma vinculação com a realidade nacional, seriam simplesmente uma imitação tosca das reivindicações dos jovens de outros países. Díaz Ordaz enfatiza, por exemplo, que, em última instância, os responsáveis pelo movimento eram os adultos que não conseguem entender e encaminhar a rebeldia juvenil. Assim, no momento em que avança o processo de radicalização do movimento armado, Echeverría se posiciona severamente. Para ele, os jovens que aderem ao terrorismo como método de luta configuram a síntese das desviações psicológicas e sociais mais aberrantes - homossexuais, viciados, gente com problemas de atenção, filhos de famílias desestruturadas, tudo o que seria inaceitável pela parcela conservadora da sociedade mexicana.

Para reforçar essa imagem, a imprensa, aliada ao Estado, teve um papel fundamental. Os movimentos armados sempre teriam um espaço reservado nas seções sobre a delinquência e ação policial. As notícias sobre "assaltos bancários", "sequestros" e "assassinatos de policiais" eram registrados como ações que não apresentavam referências às características organizacionais, às demandas sociais, aos programas políticos dos grupos armados. Outrossim, as autoridades militares e policiais tinham um espaço privilegiado para fazer declarações sobre essas "gangues" e os métodos efetivos que estavam aplicando para combatê-las.

López Portillo, por sua vez, suaviza o tom dessas caracterizações como feitas até então. Isto em contexto da discussão de uma reforma política e eleitoral, a qual pretendia, fundamentalmente, "legalizar" qualquer tipo de oposição. Apoiou-se, além do mais, numa proposta de lei de anistia dos presos e perseguidos pertencentes aos grupos armados. Paradoxalmente, como foi apontado, durante o seu mandato aperfeiçoaram-se os métodos de combate contrainsurgente. É um dos períodos mais repressivos da guerra suja.

Há de se destacar que os manuais contrainsurgentes mexicanos utilizavam, então, a versão da conspiração comunista internacional como forma para explicar o movimento armado no país. A tese que sustenta a contrainsurgência no México é que, a partir de 1968, a ideologia cubana se infiltra na esquerda mexicana. Trata-se de uma consequência das propostas advindas da Conferência Tricontinental de Havana. Sob esse prisma se combateu a 
guerrilha. A máxima foi reproduzida até a exaustão por toda a maquinaria repressiva (militares, policiais, juízes e meios de comunicação). Alguns dos relatórios da DFS são ilustrativos. $\mathrm{O}$ fato de se declarar comunista já era um elemento de culpabilidade.

Agora, a análise que a inteligência mexicana realizou sobre o movimento armado apresenta uma contradição. Os relatórios da DFS se esforçam por culpar o governo cubano pelo incremento da violência revolucionária, enquanto que, paralelamente, reconheciam a simpatia e a lealdade professada pelos comandantes cubanos aos governos priístas. Esta situação foi uma consequência da experiência dos guerrilheiros cubanos no México antes do início da Revolução, e pelo posicionamento do governo mexicano em sua negativa de romper relações diplomáticas e econômicas com a ilha. Como deferência e mostra de respeito pelo governo mexicano, os cubanos fizeram o possível para não se meter com os movimentos revolucionários mexicanos. Apesar da espionagem a que eram sometidos, os funcionários diplomáticos cubanos, como observamos, nunca manifestaram indignação. Da mesma forma que os soviéticos, permaneceram no território mexicano, pois este representava um lugar privilegiado, uma ponte para a América Latina. Para os cubanos, serviu perfeitamente para coordenar os movimentos revolucionários da América Central. Por exemplo, enquanto os cubanos organizavam o apoio aos guerrilheiros guatemaltecos refugiados no México, estes eram advertidos para não se intrometer na política mexicana. Sendo assim, a guerrilha mexicana, apesar de ter procurado essa ajuda, não obteve qualquer apoio efetivo nem da URSS e nem de Cuba.

Os grupos armados mexicanos foram abandonados pelos centros revolucionários internacionais. Por outro lado, a historiografia sobre a guerrilha reconhece a ajuda internacional brindada a um grupo específico. Esta versão está bastante documentada: a Coréia do Norte capacitou militarmente o Movimiento de Acción Revolucionaria. Este seria o único grupo que teria recebido ajuda externa. Não obstante, considerando alguns documentos analisados aqui, observamos certas relações entre a República Popular da China e um grupo guerrilheiro mexicano. Portanto, sustentamos que houve dois grupos treinados no exterior. Contudo, os dois grupos, depois de treinados fora, voltaram ao país sem receber nenhum tipo de apoio material ou de outro tipo.

$\mathrm{O}$ processo contrainsurgente manteve seu foco no aniquilamento da guerrilha. Avaliamos que os grupos guerrilheiros não conseguiram, de fato, construir uma base de apoio significativa entre a população, e isto, por dois motivos. Primeiro, porque a repressão dizimava os quadros, questão que impossibilitava a construção de núcleos fortes. Logo, porque foram ignorados e, em alguns casos, até mesmo criminalizados. Por isso, a estratégia 
contrainsurgente não precisou empreender uma luta ideológica. Por outro lado, até o fim da década de setenta, começaram a organizar-se grupos de direitos humanos em defesa de presos políticos e pela busca de desaparecidos. Ou seja, por um longo período, as forças repressivas atuaram sem nenhum tipo de pressão social que se opusesse de uma forma mais contundente.

No princípio contrainsurgente de que o exército tinha que focar suas atividades no trabalho assistencialista no propósito de diminuir a possibilidade de crescimento de bases de apoio das guerrilhas, a área indígena e camponesa de norte e sul do país foi maciçamente militarizada. Talvez por tratar-se de zonas em que a guerrilha teve uma presença mais forte entre a população, se fez necessário que os soldados dividissem seu trabalho entre o aniquilamento de guerrilheiros e a ação cívica, como na alfabetização, assistência em casos de desastres naturais, construção de moradias, entre outras práticas.

A repressão nas cidades, por sua vez, favoreceu o enfraquecimento dos grupos armados. Se os grupos armados procuravam recrutar quadros para alargar o movimento, as medidas de segurança que a clandestinidade exigia se viam relaxadas. Enquanto isso, a contrainsurgência mexicana se especializou na infiltração de grupos. Um excelente exemplo foi extraído da documentação relativa ao Movimiento Revolucionario del Pueblo. Podemos apreciar todo o processo de infiltração, desde a eleição de um sujeito ideal para realizar esse trabalho, até o instante que antecede a desarticulação das escolas de quadros do grupo. Temos, pois, uma descrição minuciosa do trabalho de inteligência e infiltração do Estado.

Finalmente, encontramos informação sobre os corpos paramilitares utilizados nas cidades, criados e financiados pelo Estado. Um deles, Los Halcones, dependentes do governo do Distrito Federal, reunia pessoas de classes sociais "baixas" (trabalhadores de mercados, lixeiros, ex-deliquentes, ex-presidiários). Formado com a finalidade de enfrentar no corpo a corpo o movimento estudantil, encontramos informação sobre sua utilização, também, contra vários movimentos sociais e sindicais. Sua criação, ordenada desde a SEGOB, contou com o apoio de militares e organismos especializados na promoção esportiva. Além disso, sua adscrição à Secretaría de Servicios Generales implica a intenção de ocultar sua existência, pois, contrariamente ao processo de regulamentação dos Cuadros de Defensa Rural, os Halcones não estavam institucionalizados. Ainda assim, a documentação da DFS nos proporciona elementos para conhecer alguns detalhes sobre a formação e treinamento dos Halcones, bem como os problemas que internamente enfrentavam. Referimo-nos especificamente à saída de vários indivíduos que, aproveitando seu treinamento, oficializaram sua baixa do grupo paramilitar para iniciar - ou retomar - atividades de delinquência.

Em 1976, no fim do governo de Echeverría e no meio da discussão sobre a reforma 
política, e com o discurso da abertura democrática como pano de fundo, cria-se o grupo paramilitar mais sofisticado quanto a seus métodos e com um perfil totalmente secreto. A Brigada Especial, ou Brigada Blanca, como era comumente conhecida, foi integrada por policiais especialistas em contrainsurgência com estudos nos EUA. Sua existência foi totalmente ocultada. Até finais dos anos oitenta, a BB era uma lenda. As referências a seus métodos foram apontadas por guerrilheiros sobreviventes e denunciadas pelos comitês de mães. Porém, o Estado negou rotundamente sua existência. A partir da informação recentemente aberta para consulta, localizamos uma série de documentos que confirmam a sua existência e plano de ação. Inclusive, podemos conhecer sua localização física, um organograma e as seções que a conformavam.

Contraditoriamente, como mencionado, a partir daquele ano, manejou-se a ideia da inexistência de grupos armados com motivações políticas e ideológicas, ou seja, que as ações armadas eram resultado da proliferação de gangues. Entretanto, na ata de fundação do grupo paramilitar expõe-se como objetivo principal o extermínio da Liga Comunista 23 de Septiembre. A elevação dos níveis de violência do grupo armado questionava a efetividade dos programas de segurança pública. Utilizando a documentação da DFS, pudemos parcialmente reconstruir as formas em que era obtida a informação para a análise de inteligência: os interrogatórios, ou "estreitos interrogatórios", como eram chamados nos relatórios. A tortura não é um elemento que aparece de forma explícita na documentação. Porém, com o apoio de fotografias e comparando os procedimentos narrados nos relatórios com os manuais norte-americanos, foi possível fazer uma avaliação geral do método mais utilizado. A BB é lembrada como organização especialista em proceder interrogatórios.

Indagar sobre as contradições entre o discurso público dos governos, entre 1964 e 1982, e as medidas empreendidas para o aniquilamento da esquerda armada, permite problematizar a história oficial correspondente aos anos de maior atividade armada. A partir desse panorama - que construímos a partir de pequenas histórias contidas no arquivo da polícia política, a qual, aliás, se encontra nas condições menos propícias para seu estudo observamos os mecanismos abertos e clandestinos que se conjugaram para o aniquilamento das ameaças ao establishment.

Entrementes, a aspiração mexicana à independência ideológica expressa nos discursos presidenciais, especialmente no que diz respeito à DSN, contradiz a base ideológica que sustenta os programas contrainsurgentes operacionalizados pelo Estado. É devido a essa discrepância que a (história da) guerra suja tem sido sistematicamente negada. Consideramos, então, que no recorte temporal proposto consolidam-se formas de repressão que, embora 
tenham permanecido ocultas para uma parcela importante da população, para alguns mexicanos que lutam, que se posicionam como de esquerda, essa repressão com base na DSN, sem dúvida, existiu. Ou melhor, não se trata simplesmente de uma lembrança, pois há reflexos, até hoje, de uma ameaça constante. 


\section{REFERÊNCIAS}

\section{Fontes:}

Archivo General de la Nación (México). Fondo: Secretaría de Gobernación, Sección: Investigaciones Políticas y Sociales.

Archivo General de la Nación (México). Fondo: Secretaría de Gobernación, Sección: Dirección Federal de Seguridad.

DÍAZ ORDAZ, Gustavo (GDO). Informes presidenciales. México, Dirección de Servicios de Investigación y Análisis, Subdirección de Referencia Especializada, 2006. Disponível em: http://www.diputados.gob.mx/sedia/sia/re/RE-ISS-09-06-13.pdf [último acesso em: 04-04-2015].

ECHEVERRÍA ÁLVAREZ, Luis (LEA). Informes presidenciales. México, Dirección de Servicios de Investigación y Análisis, Subdirección de Referencia Especializada, 2006. Disponível em: http://www.diputados.gob.mx/sedia/sia/re/RE-ISS-09-06-14.pdf [último acesso em: 04-04-2015].

LÓPEZ PORTILLO, José (JLP). Informes presidenciales. México, Dirección de Servicios de Investigación y Análisis, Subdirección de Referencia Especializada, 2006. Disponível em: http://www.diputados.gob.mx/sedia/sia/re/RE-ISS-09-06-15.pdf [último acesso em: 04-04-2015].

\section{Referências:}

ACOSTA CHAPARRO, Mario Arturo. Movimiento subversivo en México. México, edición del autor, enero 1990.

ADAME GODDARD, Jorge. El derecho a la educación religiosa en México; Diez años de vigencia de la Ley de Asociaciones Religiosas y Culto Público en México (1992-2002). México, Instituto de Investigaciones Jurídicas/Universidad Nacional Autónoma de México, 2003.

AGEE, Philip. Diario de la CIA. Barcelona, Editorial Laia, 1978.

AGUAYO, Sergio. De Tlatelolco a Ayotzinapa; Las violencias del Estado. México, Editorial Ink, 2015 [E-book].

La Charola; Una historia de los Servicios de Inteligencia en México. México, Editorial Ink, 2014a [E-book].

El panteón de los mitos; Estados Unidos y el nacionalismo mexicano. México, Editorial Ink, 2014b [E-book].

Los usos, abusos y retos de la Seguridad Nacional mexicana, 1946-1990. In: AGUAYO, S.; BAGLEY, B. M. En busca de la seguridad perdida; Aproximaciones a la Seguridad Nacional. México, Siglo XXI, 1990, p. 107-145.

AGUILAR CAMÍN, Héctor; MEYER, Lorenzo. À sombra da Revolução Mexicana; História mexicana Contemporânea, 1910-1989. São Paulo, EDUSP, 2000.

AGUSTín, José. Tragicomedia mexicana: La vida en México de 1970 a 1982 (vol. 2). México, 
Debolsillo, 2013 [E-Book].

ALCOCER, Jorge. La tercera refundación del PRI. Revista Mexicana de Sociología, v. 55, n. 2, p. 119-131, México, abril-junio 1993.

ÁLVAREZ GARÍN, Raúl. La estela de Tlatelolco; Una reconstrucción histórica del Movimiento estudiantil del 68. México, Editorial Ítaca, 2002.

ARANDA, Jesús. El instructivo rural data de 1964. La Jornada, México, 28-01-2014.

ARCHIVO GENERAL DE LA NACIÓN (AGN). Objetivos estratégicos. México, 2014. Disponível em: http://www.agn.gob.mx/menuprincipal/quienesomos/objetivose.html [último acesso em: 21-042015].

ARISTEGUI. Carmen. 25 mil desaparecidos. Reforma. México, 14-12-2012.

ASÍ es la Dirección Federal de Seguridad, Dir.: Alfonso Cabrera Morales, 52 min. Disponível em: https://www.youtube.com/watch?v=USr-CFgmRtc [último acesso em: 30-05-16].

ÁVILA CARRILlO, Enrique. Veinte años del Comité Eureka. Revista Memoria, n. 109, México, marzo 1998.

BARTRA, Armando. Los herederos de Zapata; Movimientos campesinos posrevolucionarios en México, 1920-1980. México, ERA, 1985.

BASÁÑEZ, Miguel. La lucha por la hegemonía en México, 1968-1980. México, Siglo XXI, 1988.

BERSTEIN, Serge. Os partidos. In: RÉMOND, René (org.). Por uma história política. Rio de Janeiro, FGV Editora, 2003, p. 57-98.

BOURDIEU, Pierre. Los ritos como actos de institución. In: PITT-RIVERS, J.; PERISTIANY, J. G. (coords.). Honor y gracia. Madrid, Alianza Universidad, 1993, p. 111-123.

BRIZ GARIZURIETA, Marcela. El Consejo Mexicano de Hombres de Negocios: surgimiento y consolidación. México, Dirección General de Estudios de Posgrado/Facultad de Ciencias Políticas y Sociales-UNAM, 2002.

BUENDÍA, Manuel. La CIA en México. México, Océano, 1984.

CABILDO, Miguel. SAHAGÚN Baca: Narcotraficante, enfermo y excéntrico encumbrado por favor del presidente a Durazo. Proceso. México, 22-07-1989.

CALLONI, Stela. Operación Cóndor: Pacto Criminal. La Habana, Editorial de Ciencias Sociales, 2005.

CAMACHO, Zózimo. Bajo escrutinio del Cisen la "Galería 1" del AGN. Revista Contralínea. México, diciembre 2007.

CÁMARA DE DIPUTADOS. Ley federal de transparencia y acceso a la información pública gubernamental. Diario Oficial de la Federación. México, 2014. Disponível em: http://www.diputados.gob.mx/LeyesBiblio/pdf/244 140714.pdf [último acesso em: 24-04-2015].

CÁMARA DE DIPUTADOS. Ley Federal de Archivos. Diario Oficial de la Federación. México, 2012. Disponível em: http://www.diputados.gob.mx/LeyesBiblio/pdf/LFA.pdf [último acesso em: 24/04/2015].

CAMPOS HERNÁNDEZ, Fabián. La revolución latino-americana y la Liga Comunista 23 de Septiembre. In: GAMIÑO, R. et. al. (coords.). La Liga Comunista 23 de Septiembre; Cuatro décadas a debate: historia, memoria, testimonio y literatura. México, Programa de Posgrado en Estudios Latinoamericanos-UNAM/ Facultad de Ciencias para el Desarrollo Humano-Universidad Autónoma de Tlaxcala/, 2014, p. 73-104. 
CARPIZO, Jorge. El presidencialismo mexicano. México, Siglo XXI, 1985.

CARR, Barry. La izquierda mexicana a través del siglo XX. México, ERA, 2000.

CARRASCO ARAIZAGA, Jorge. La CIA, "mal informada". Proceso. México, octubre 2008, p. 1923.

CASSIDY, Robert M. Ganando la Guerra de la Pulga: Lecciones de la guerra de guerrillas. Military Review, v. LXXXV, n. 1, p. 24-30, Fort Leavenworth, enero-febrero 2005.

CASTAÑEDA, Jorge G. La utopía desarmada. México, Joaquín Mortiz, 1995.

CASTELLANOS, Laura. México armado; 1943-1981. México, ERA, 2008.

CASTILLO GARCÍA, Gustavo. Los guerrilleros, aventureros que querían el poder. La Jornada. México, 05-02-2003.

CASTRO, Fidel. Segunda Declaración de La Habana. Habana, 1962. Disponível em: http://www.pcc.cu/pdf/documentos/otros doc/segunda declaracion habana.pdf [último acesso em: 10-06-2016].

CEDILLO CEDILLO, Adela. El fuego y el silencio: Historia de las Fuerzas de Liberación mexicanas (1969-1974). México, 2008. Monografía (Licenciatura en Historia). Facultad de Filosofía y Letras, Universidad Nacional Autónoma de México.

CENTRO DE DERECHOS HUMANOS MIGUEL ÁNGEL AGUSTÍN PRO JUÁREZ. Tlatlaya a un año. México, Creative Commons, 2015.

CHABAT, Jorge. Condicionantes del activismo de la política exterior mexicana (1960-1985). In: GARZA ELIZONDO, H. (comp.). Fundamentos y prioridades de la política exterior de México. México, El Colegio de México, 1986, p. 89-113.

CHAO BARONA, Alejandro (coord.). Las Hojas de la Comunidad; 2000. Cuernavaca, UNICEDESUAEM, 2001.

CHAUÍ, Marielena. O que é ideología. São Paulo, Brasiliense, 2009.

CHEVALIER, François. América Latina. México, Fondo de Cultura Económica, 1993.

CLUTTERBUCK, Richard. Guerrilleros y terroristas. México, Fondo de Cultura Económica, 1981.

COMBLIN, Joseph. A ideologia da Segurança Nacional; O poder militar na América Latina. Rio de Janeiro: Civilização Brasileira, 1978.

COMISIÓN PARA EL ESCLARECIMIENTO HISTÓRICO. Guatemala, memória del silencio; Conclusiones y recomendaciones. Guatemala, UNOPS, 1999.

CONDÉS LARA, Enrique. Represión y rebelión en México, 1959-1985. Tomo 1. La Guerra fría en México. El discurso de la represión. México, Benemérita Universidad Autónoma de Puebla/Dirección de comunicación y Relaciones Públicas: Miguel Ángel Porrúa, 2007a.

Represión y rebelión en México, 1959-1985. Tomo 2. Los años dorados del priato y los pilares ocultos del poder. 1968 y el fin de una etapa. Los acólitos del diablo. México, Benemérita Universidad Autónoma de Puebla/Dirección de comunicación y Relaciones Públicas: Miguel Ángel Porrúa, 2007b.

Represión y rebelión en México, 1959-1985. Tomo 3. Corea del Norte y México. El maoísmo en México. La revolución Cubana y México. La cara desconocida del Partido Comunista Mexicano. México, Benemérita Universidad Autónoma de Puebla-Dirección de comunicación y Relaciones Públicas: Miguel Ángel Porrúa, 2007c. 
COMITÉ INTERNACIONAL DE LA CRUZ ROJA. Los Convenios de Ginebra del 12 de agosto de 1949. Ginebra, Comité Internacional de la Cruz Roja, 2012.

CONSTITUCIÓN POLÍTICA DE LOS ESTADOS UNIDOS MEXICANOS. Diario Oficial de la

Federación. México, 05-02-1917. Disponível em:

http://www.diputados.gob.mx/LeyesBiblio/htm/1.htm [último acesso em: 09-06-2015].

COORDINACIÓN CENTRAL DE LA SALLE, Identidad. México, 2014. Disponível em: http://lasalle.edu.mx/identidad/distrito-mexico-norte/ [último acesso em: 14-06-2016].

CÓRDOVA, Arnaldo. La revolución y el Estado en México. México, ERA, 1989.

ERA, 1980.

La ideología de la revolución mexicana; La formación del nuevo régimen.México:

CORLAZZOLI, Pablo. Los regímenes militares en América Latina; Estructuración ideológica. Montevideo, Ediciones del Nuevo Mundo, 1987.

CORONA DEL ROSAL, Alfonso. Mis memorias políticas. México, Gijalbo, 1995.

COSÍO VILLEGAS, Daniel. El sistema político mexicano; Las posibilidades de cambio. México, Joaquín Mortiz, 1976.

DÁVALOS, Renato; CARRIZALES, David. Amigos y priístas rendirán homenaje a Martínez Domínguez en Monterrey. La Jornada. México, 07-11-2002.

DEUTSCHER, Isaac. Mitos da Guerra Fria. In: HOROWITZ, D. (org.). Revolução e Repressão. Rio de Janeiro, Zahar Editores, 1969, p. 15-28.

DELGADO, Álvaro. El Yunque; La ultraderecha en el poder. México, Plaza y Valdés, 2003.

DÍAZ, Gloria Leticia. Dos exguerrilleros, exiliados en Cuba durante casi una década, nunca supieron de entrenamiento a mexicanos. Proceso. México, 04-05-1996.

DOMÍNGUEZ GUADARRAMA, Ricardo. Cuba; Revolución, diplomacia (y guerrilla) en América Latina y el Caribe. In: GAMIÑO, R. et. al. (coords.). La Liga Comunista 23 de Septiembre; Cuatro décadas a debate: historia, memoria, testimonio y literatura. México, Programa de Posgrado en Estudios Latinoamericanos-UNAM/ Facultad de Ciencias para el Desarrollo Humano-Universidad Autónoma de Tlaxcala, 2014, p. 43-71.

DOYLE, Kate. 2 de Octubre de 1968 - Verdad bajo resguardo. National Security Archive. Washington, 2008. Disponível em: http://nsarchive.gwu.edu/NSAEBB/NSAEBB258/ [último acesso em: 23/4/2015].

DOYLE, Kate. Una verdad en construcción. Proceso. México, 12-06-2006.

EGUIARTE, Óscar. Diario de Campaña, 1968. In: MARCOS, M. Nada es gratuito en la Hitoria; Madera 1965, la primera lucha armada por el socialismo en México. México, Ediciones Rebeldía, 2007, p. 37-64.

EJÉRCITO POPULAR REVOLUCIONARIO (EPR), Torturan a normalistas en cuarteles de la Policía, el Ejército y la Marina. Revolución Tres Punto Cero. México, 27-04-2016. Disponível em: http://revoluciontrespuntocero.com/torturan-a-normalistas-en-cuarteles-de-la-policia-el-ejercito-y-lamarina-no-hubo-delincuencia-organizada-epr/ [último acesso em: 7/04/2016].

El imperio Rockefeller. Punto Final. Santiago, 17-09-1969.

ESCAMILLA SANTIAGO, Yllich. Tlatelolco, San Cosme y la guerrilla urbana. In: GAMIÑO, R. et. al. (coords.). La Liga Comunista 23 de Septiembre; Cuatro décadas a debate: historia, memoria, testimonio y literatura. México, Programa de Posgrado en Estudios Latinoamericanos-UNAM/ Facultad de Ciencias para el Desarrollo Humano-Universidad Autónoma de Tlaxcala, 2014, p. 109- 
139.

ESCUELA DE LAS AMÉRICAS (SOA). Manual de Estudio; Análisis. 1989a.

Manual de Estudio; Contrainteligencia. 1989b.

Manual de Estudio; Guerra revolucionaria e ideología comunista. 1989c.

Manual de Estudio; Ingeligencia de combate. 1989d.

Manual de Estudio; Interrogación. 1989e.

Manual de Estudio; Manejo de Fuentes. 1989f.

Manual de Estudio; Terrorismo y guerrilla urbana. 1989g.

ESTRADA, Ulises y SUÁREZ, Luis (ed.). Rebelión Tricontinental. La Habana, Ed. Ciencias Sociales, 2007.

EXPEDIENTE. Notas para el estudio de la coyuntura mexicana. Punto Crítico. México, n. 19, p. 3335, agosto 1973.

EZCURRA, Ana María. Intervención en América Latina; Los Conflictos de Baja Intensidad. Buenos Aires, Instituto de Estudios y Acción Social, 1988.

FAZIO, Carlos. Neocolonialismo y desaparición forzada. La Jornada. México, 19-03-2012. Terrorismo estatal e impunidad. La Jornada. México, 17-10-2011.

FERRI TÓRTOLA, Pablo. Veintiuno de los "delincuentes" abatidos en Tlatlaya fueron "fusilados" por el Ejército. Proceso. México, 17-09-2014.

FERNÁNDEZ CHRISTLIEB, Paulina. El espartaquismo en México. México: El Caballito, 1978.

FIGUEROA IBARRA, Carlos. Partido, poder, masas y revolución: la izquierda en Guatemala, 19541996. In: MARTÍN, A. (coord.). La izquierda revolucionaria latinoamericana. Colima, Universidad de Colima, 2010, p. 13-49.

FISCALÍA ESPECIAL PARA MOVIMIENTOS SOCIALES Y POLÍTICOS DEL PASADO (FEMOSPP). Informe histórico a la sociedad mexicana 2006. México, 17-11-2006. Disponível em: http://nsarchive.gwu.edu/NSAEBB/NSAEBB180/index2.htm [último acesso em: 08-06-2016].

FLORES, Lúa; PARÉ, Luisa; SARMIENTO, Sergio. Las voces del campo movimiento campesino y política agraria, 1976-1984. México, Siglo XXI, 1998.

FRANÇOIS, Philippe. Contrainsurgencia en Argelia: un punto de vista francés. Military Review, v. LXXXIX, n. 1, p. 60-73, Fort Leavenworth, enero-febrero 2009.

FUNDACIÓN HEBERTO CASTILlO. 1968, 1988, 2008; Pasado y presente de una lucha: Heberto Castillo. México, Fundación Heberto Castillo, 2008.

GAMIÑO MUÑOZ, Rodolfo. Análisis del movimiento armado en México en la década de 1970 a través de la prensa: el caso de la Liga Comunista 23 de Septiembre (1973-1979). México, 2008. Dissertação (Maestría en Sociología Política). Instituto de Investigaciones Dr. José María Luis Mora.

GARCÍA DE LEÓN, Antonio: depoimento [22-04-2009], México. Entrevista concedida a Azucena Citlalli Jaso Galván.

GARCÍA SÁNCHEZ, Liliana. Judith Reyes: Una mujer de canto revolucionario; México 19241988. México, Ediciones Clandestino, 2008.

GONZÁLEZ CASANOVA, Pablo. La democracia en América Latina; Actualidad y perspectivas. México, La Jornada/CIICH, 1995. 
Los militares y la política en América Latina. México, Océano, 1988.

La democracia en México. México, ERA, 1967.

GONZÁLEZ GÓMEZ, Roberto. Estados Unidos: doctrinas de la guerra fría, 1947-1991. La Habana, Centro de Estudios Martianos, 2003.

GONZÁLEZ MARÍN, Silvia. Prensa y poder político; La elección presidencial de 1940 en la prensa mexicana. México, Siglo XXI/UNAM, 2006.

GONZÁLEZ REYES, Max. El Informe Presidencial: de la opulencia al ocaso del presidencialismo. Estudios Políticos, n. 24, p. 55-76, México, septiembre-diciembre, 2011.

GONZÁLEZ RUIZ, Edgar. El Yunque: un libro sobre Ramón Plata. Revista Contralínea. México, 29-09-13.

GONZÁLEZ RUIZ, Edgar. Los Ardavín. Revista Contralínea. México, 01-01-2012.

GONZÁLEZ TORRES, Jonathan Agustín. ¿Qué es la Iniciativa Mérida? Cuadernos del Colectivo por una política integral hacia las drogas, n. 4, p. 5-15, México, 2012.

GORDTS, Eline. 11 cifras para entender la violencia que sacude México. Huffington Post. Madrid, 03-11-2014. Disponível em: http://www.huffingtonpost.es/2014/11/03/cifras-violenciamexico_n_6092856.html [último aceso em: 08-06-16].

GRAMMONT, Carton de. Jaramillo y las luchas campesinas en Morelos. In: MOGUEL et. al. Hitoria de la Cuestión Agraria Mexicana (tomo 8). México, CEHAM/Siglo XXI, 1989, p. 261-276.

GRAMSCI, Antonio. Risorgimento italiano. In: Cuardernos de la Cárcel (tomo 5). México, ERABUAP, 1975, p. 345-443.

GRAMSCI, Antonio. Notas sobre Maquiavelo, sobre la política y sobre el Estado moderno. Buenos Aires, Ediciones Nueva Visión, 1972.

GRIFFITHS SPIELMAN, John. Teoría de la seguridad y defensa en el continente americano; Análisis de los casos de EE.UU. de América, Perú y Chile. Santiago, Ril Editores, 2011.

GRUPO INTERDISCIPLINARIO DE EXPERTOS INDEPENDIENTES (GIEGI). Informe Ayotzinapa. México, Creative Commons, 2015.

GRUPO POPULAR GUERRILLERO. Resolutivos del Segundo Encuentro de la Sierra Heraclio Bernal. Chihuahua, 1965. Disponível em: http://movimientosarmados.colmex.mx/files/docs/G121.pdf [último acesso em: 08-06-2016].

HALCONES: Terrorismo de Estado, Dir.: Carlos Mendoza, 71 min, 2009. Disponível em: https://www.youtube.com/watch?v=2sr_38brmxc [último acesso em: 03-05-16].

HAUGAARD, Lisa. Manuales militares USA: la prueba. Envío, n. 186, Managua, setembro 1997. Disponível em: http://www.envio.org.ni/articulo/321 [Último acesso em: 26/4/2015].

HERNÁNDEZ, María Aidé. La democracia mexicana, presa de una cultura política autoritaria. Revista Mexicana de Sociología, v. 70, n. 2, p. 361-303, México, abril-junio 2008.

HOBSBAWM, Eric. Era dos Extremos; O breve século XX, 1914-1991. São Paulo, Companhia das Letras, 1995.

HUNTINGTON, Samuel. The soldier and the State: the theory and politics of civil-military relations. New York, Vintage Books, 1974.

IBARRA, Rosario. ¡Pobre Revolución! El Universal. México, 6-11-2001.

IBARROLA, Javier. El ejército y el poder: impacto e influencia política en el México moderno. 
México, Océano, 2003.

INFORME sobre "La Guerra Sucia”. Reforma. México, 12-03-2006.

JASO GALVÁN, Azucena Citlalli. La Colonia Proletaria Rubén Jaramillo; La lucha por la tenencia de la tierra y la guerra popular prolongada (31 de marzo de 1973 - enero de 1974). México, 2011. Monografía (Licenciatura en Historia). Facultad de Filosofía y Letras, Universidad Nacional Autónoma de México.

JURISPRUDENCIA que convalida la tortura en México. Proceso. México, 06-01-1979, p. 10-14.

KATZ, Friedrich. La guerra fría en América Latina y el Caribe. In: SPENSER, D. (coord.). Espejos de la guerra fría; México, América Central y el Caribe. México, Miguel Ángel Porrúa, 2004, p. 1119.

KILCULLEN, David. "28 artículos": fundamentos de la contrainsurgencia a nivel de compañía. Military Review, v. LXXXVI, n. 5, p. 66-77. Fort Leavenworth, septiembre-octubre 2006.

KLARE, Michael T; STEIN, Nancy.Armas y poder en América Latina. México, Era, 1976.

KNIGHT, Alan. Caudillos y campesinos en el México Revolucionario, 1910-1917. In: BRADING, D. A. (Comp.) Caudillos y campesinos en la Revolución Mexicana. México, Fondo de Cultura Económica, 1985, p. 32-85.

LA cobardía de El Yunque. Proceso. México, 29-12-2009.

LAGUNES CASTILLO, Gabriel L. (ed.). Breve diccionario de organizaciones y movimientos políticos de México; 1920-2005. México: Núkleo Canal de Análisis e Ideas, 2010.

LEONHARD, Wolfgang. La triple escisión del marxismo. Madrid, Guadiana, 1971.

LIEWEN, Edwin. Mexican militarism, 1910-1940; the political rise and fall of the revolutionary army. Albuquerque, The University of New Mexico Press, 1968.

LÓPEZ AZUARA, Miguel. Elenco Político, Proceso, México, 5 de septiembre de 1979, p. 26.

LÓPEZ LARA, Álvaro. "Juntos valemos más que vos...” El ritual del informe presidencial y el nuevo balance de poderes en México”. Relaciones, vol. XXVII, n. 107, p. 43-86. México, 2006.

LÓPEZ Y RIVAS, Gilberto. Estudiando la contrainsurgencia de los Estados Unidos: manuales, mentalidades y uso de la antropología. México, Semilla Rubí, 2012.

LOYO CAMACHO, Martha Beatriz. Joaquín amaro y el proceso de institucionalización del ejército mexicano, 1917-1931. México, UNAM/FCE/Fideicomiso Archivos Plutarco Elías Calles y Fernando Torreblanca/INEHRM, 2003.

LOZOYA, Jorge A. El ejército mexicano. México, El Colegio de México, 1977.

LUGO, Florencio. Pensé que moriría, pero es más fuere la convicción de actuar en pro de los más necesitados. La Jornada del Campo. Chihuahua, 19-11-2015.

LUXEMBURG, Rosa. Escritos políticos, España, Grijalbo, 1977.

MAECHLING, C. Contrainsurgencia: la primera prueba de fuego. In: KORNBLUH, P.; KLARE, M. Contrainsurgencia, proinsurgencia y antiterrorismo en los 80: el arte de la guerra de baja intensidad. México, Grijalba/Conaculta, 1990, p. 33-64.

MAPA de Operativos Conjuntos en el país. El Universal. México, 06-10-2011.

Marín, Carlos, La Brigada Blanca existe y vive en el Campo Militar No. 1. Proceso, México, 07-011980.

MARTÍNEZ, Gerardo. Límites en AGN obstaculizan investigaciones. El Universal. México, 24-03- 
2015.

MARTÍNEZ, Sanjuana. Si hay crematorios en las instalaciones del Ejército, afirma el general Gallardo. La Jornada. México, 11-01-2015.

McCONAUGHY, John B. Latinoamérica - Objetivo soviético. Military Review, v. LXXIX, n. 1, p. 52-61, Fort Leavenworth, enero-febrero 2000.

MENDOZA GARCÍA, Jorge. Los medios de información y el trato a la guerrilla. Una mirada psicopolítica. In: OKIÓN SOLANO, V; UGARTE GARCÍA, M. E. (coords.) Movimientos armados en México, siglo XX (tomo I). Morelia, El Colegio de Michoacán/CIESAS, 2008, p. 145-178.

Discursos y silencios en torno a la guerra sucia en México. In: AGUILUZ IBARGÜEN, M.; WALDMAN M., G. (coords.). Memorias (in)cógnitas; Contiendas en la historia. México, UNAM-CEIICH, 2007, p. 311-353.

MELGAR BAO, Ricardo. La memoria sumergida; Martirologio y sacralización de la violencia en las guerrillas latinoamericanas. In: OKIÓN SOLANO, V; UGARTE GARCÍA, M. E. (coords.) Movimientos armados en México, siglo XX (tomo I). Morelia, El Colegio de Michoacán/CIESAS, 2008, p. 29-68.

MEYER, Lorenzo. La tragedia persistente: La democracia autoritaria en México. México, Debate, 2013 [E-book].

de 2012.

Los caciques: Ayer, hoy iy mañana? Letras Libres. México, n. 821,p. 36-40, dezembro El informe: una brevísima historia. Reforma. México, 01-09-2005.

MILZA, Pierre. Política interna e política externa. In: RÉMOND, René (org.). Por uma história política. Rio de Janeiro, FGV Editora, 2003, p. 365-399.

MONTEMAYOR, Carlos. La violencia de Estado en México. México, Debate, 2010.

Las armas del Alba. México, Debolsillo, 2009.

$\overline{1999 .}$

La guerrilla recurrente. Ciudad Juárez, Universidad Autónoma de Ciudad Juárez,

MORALES OYARVIDE, César. Estado y Narcotráfico en México: la historia de un arreglo centenario. NuevaTribuna.es. Madrid, 11-11-2010. Disponível em: http://www.nuevatribuna.es/opinion/cesar-morales-oyarvide/estado-y-narcotrfico-en-mxico-lahistoria-de-un-arreglo-centenario/20101111064821041904.html [último acesso em: 10-06-2016].

MORENO BORBOLLA, José Luis. Una visión retrospectiva de los movimientos armados en México. Movimiento Armado Socialista (1956-1980). In: POZZI, P.; PÉREZ, C. (ed.). Por el camino del Che; Las guerrillas latinoamericanas, 1959-1990. Buenos Aires, Imago Mundi, 2011, p. 53-96.

MORENO BORBOLLA, José Luis: depoimento [06-12-2004], México. Entrevista concedida a Fiona de la Rosa González.

MOORE, Barrington. La injusticia; Bases sociales de la obediencia y la rebelión. México, Instituto de Investigaciones Sociales/UNAM, 1989.

Notas sobre o proceso de adquisição do poder. In: Poder político e teoría social; Sete estudos. São Paulo, Editora Cultrix, 1972, p. 11-32.

MORLEY, Jefferson. Nuestro Hombre en México: Winston Scott y la historia oculta de la CIA. México, Taurus, 2011.

MORLEY, Jefferson. Litempo: Los ojos de la CIA en Tlatelolco. National Security Archive. Washington, 18-10-2006. Disponível em: 
http://nsarchive.gwu.edu/NSAEBB/NSAEBB204/index2.htm [último acesso em: 10-06-2016].

NINA, Andrés. La Doctrina de la Seguridad Nacional y la Integración Latinoamericana. Nueva Sociedad, n. 27, p. 33-50, Caracas, noviembre-diciembre 1979.

OCEJA, Sandra. La novela de la guerrilla en México y el poder de los espacios legibles.México, 2013. Dissertação (Maestría en Estudios Políticos y Sociales). Facultad de Ciencias Políticas y Administración, Universidad Nacional Autónoma de México.

OFICINA DE PROGRAMAS DE INFORMACIÓN INTERNACIONAL. Alianza para la Seguridad y la Prosperidad de América del Norte. Texas, 24-03-2005. Disponível em: http://iipdigital.usembassy.gov/st/spanish/article/2005/03/20050324181819aeneerg0.8495752.html\#ax zz46yRshy00 [último acesso em 27-04-2016].

ORGANIZACIÓN DE LAS NACIONES UNIDAS. Informe del Grupo de Trabajo sobre las Desapariciones Forzadas o Involuntarias. 20-12-2011. Disponível em: http://www.ohchr.org/Documents/HRBodies/HRCouncil/RegularSession/Session19/A-HRC-19-58-

Add2 sp.pdf\#sthash.MJvqlSW4.dpuf[último acesso em: 27-04-2016].

ORGANIZACIÓN LATINOAMERICANA DE SOLIDARIDAD. Primera Conferencia de la Organización Latinoamericana de Solidaridad. La Habana, OLAS, 1967.

ORTÍZ ROSAS, Rubén. La Brigada Especial. Un instrumento de la constrainsurgencia urbana en el Valle de México (1976-1981). México, 2014. Monografía (Licenciatura en Historia). Facultad de Filosofía y Letras, Universidad Nacional Autónoma de México.

PADGETT, Humberto. Mondragón, don camaleón: de médico "rebelde" a entrenador de la policía política de LEA; de la izquierda al PRI. SinEmbargo. México, 14-01-2013. Disponível em: http://www.sinembargo.mx/14-01-2013/488229 [último acesso em: 15-06-2016].

PARTIDO ACCIÓN NACIONAL. Historia. México, 2016. Disponível em: https://www.pan.org.mx/el-cen/historia/ [último acesso em: 08-06-2016].

PAXMAN, Andrew; FERNÁNDEZ, Claudia. El tigre; Emilio Azcárraga y su imperio Televisa. México, Grijalbo, 2013 [E-Book].

PELLICER, Olga; MANCILLA, Esteban. El entendimiento con los Estados Unidos y la gestación del desarrollo estabilizador.México, El Colegio de México, 1978.

PESCHARD, Jacqueline. La cultura política democrática. México, Instituto Federal Electoral, 2001.

PIETRICH, Blanche. Segunda necropsia a restos del normalista Julio César Mondragón. La Jornada. México, 03-11-2015.

PIÑEYRO, José Luis. Ejército y sociedad en México; Pasado y Presente. México, BUAP/UAMAzcapotzalco, 1985.

PIÑEYRO, José Luis. Las Fuerzas Armadas y la guerrilla rural en México. Pasado y presente. In: OKIÓN SOLANO, V; UGARTE GARCÍA, M. E. (coords.) Movimientos armados en México, siglo XX (tomo I). Morelia, El Colegio de Michoacán/CIESAS, 2008, p. 69-89.

PLASENCIA DE LA PARRA, Enrique. Historia y organización de las Fuerzas Armadas en México, 1917-1937. México, UNAM, 2010.

PONIATOWSKA, Elena. Fuerte es el silencio. México: ERA, 1980.

¿QUÉ pasó ahí?... El legendario Palacio de Lecumberri. Excélsior. México, 08-11-2013.

RANGEL HERNÁNDEZ, Lucio. El vírus rojo de la revolución; La guerrilla en México: El caso de la Liga Comunista 23 de Septiembre, 1973-1981. Morelia: Colegio Primitivo y Nacional de San 
Nicolás de Hidalgo - Sindicato de los Profesora de la Universidad Michoacana, 2013.

REVUELTAS, José. Ensayo sobre un proletariado sin cabeza. México, ERA, 1962.

REYES, José. El manual secreto de los GAFES. La Jornada. México, 14-06-2009.

REYNAGA MEJÍA, Juan Rafael. La Revolución cubana en México a través de la revista Política: construcción imaginaria de un discurso para América Latina. Toluca, Universidad Autónoma del Estado de México/Universidad Nacional Autónoma de México/ CCyDEL, 2007.

RHI SAUSI, José Luis. La parábola de la guerrilla en México. Coyoacán, n. 3, p. 65-78, México, abril-junio 1977.

ROBIN, Marie-Monique. Escuadrones de la muerte. Buenos Aires, Editorial Sudamericana, 2004.

ROBLES VESSI, Rosalba: depoimento [01-04-2010], México. Entrevista concedida a Azucena Citlalli Jaso Galván.

ROCHÍN DEL RINCÓN, Jaime. Justicia, no sin memoria. Animal Político. México, 26-03-2015.

ROCKEFELLER, Nelson A. Informe Rockefeller (1969). Foro Internacional, v. 10, n. 3, p. 286-344, México, enero-marzo 1970.

ROCKWELL, Richard; MOSS, Richard. La reconceptualización de la Seguridad: Un comentario sobre la investigación. In: AGUAYO, S; BAGLEY, B. M. (comp.). En busca de la seguridad perdida; Aproximaciones a la seguridad nacional. México, Siglo XXI, 1990, p. 43-68.

RODRÍGUEZ ARAUJO, Octavio. 100 años de Revueltas, José. Estudios Políticos, n. 22, p. 11-26, México, septiembre-diciembre 2014.

RODRÍGUEZ CASTAÑEDA, Rafael. Estampas del represor. Proceso. México, 31-01-2012.

RODRÍGUEZ MUNGUÍA, Jacinto. La otra guerra secreta: Los archivos prohibidos de la prensa y el poder. México, Debate, 2007.

ROJAS MIRA, Claudia. Exilios sudamericanos en México: los casos argentino y chileno. Pacarina del Sur, a. 5, n. 19. México, abril-junio 2014.

RUBIO, Blanca. Resistencia campesina y explotación rural en México. México, ERA, 1987.

RUIZ OCAMPO, Alejandro. El Consejo Nacional de la Publicidad: origen, estructura y trayectoria. México, Plaza y Valdés, 1999.

RUIZ OJEDA, Tania Celina. El Departamento Autónomo de Prensa y Publicidad (DAPP) y "Los Niños de Morelia": La versión oficial del exilio español en México durante el cardenismo. In: HINOJOSA, L.; DE LA VEGA, E.; RUIZ, T. El cine en las regiones de México. Monterrey, Universidad Autónoma de Nuevo León, p. 429-452.

SALVADOR Borrego: vigencia de “La derrota mundial”. Proceso. México, 29-12-2008.

SÁNCHEZ CÁRDENAS, Carlos. Disolución social y Seguridad Nacional. México, Ediciones Linterna, 1970.

SCHMITH, Samuel. El deterioro del presidencialismo mexicano; Los años de Luis Echeverría. México: Editores Asociados Mexicanos, 1986.

SECRETARÍA DE GOBERNACIÓN (SEGOB). Reglamento interior de la Secretaría de Gobernación. Diario Oficial de la Federación. México, 2008. Disponível em: http://www.asf.gob.mx/trans/informes/IR2008i/compila/compila/Reglamentosi/35RISEGOB08.pdf

[último acesso em: 21-04-15]

Acta administrativa de entrega-recepción del acervo documental transferido al Archivo General de la Nación, por virtud del acuerdo presidencial del 27 de noviembre de 2001. Diario Oficial 
de la Federación. México, 2001. Disponível em:

http://nsarchive.gwu.edu/NSAEBB/NSAEBB258/02-SEGOB-Cisen.pdf [Último acesso em: 22-042015].

SECRETARÍA DE LA DEFENSA NACIONAL (SEDENA). Manual de operaciones en campaña, tomo 1. México, SEDENA/Ejército y Fuerza Aérea Mexicanos/Estado Mayor, 1981a.

Manual de operaciones en campaña, tomo 2. México, SEDENA/Ejército y Fuerza Aérea Mexicanos/Estado Mayor, 1981b.

SELSER, Gregorio. Cronología de las intervenciones extranjeras en América Latina. México, UACM/UNAM, 2010.

El Guatemalazo; La primera Guerra Sucia. Buenos Aires, Ediciones Iguazú, 1961.

$\overline{1955 .}$. Sandino, general de hombres libres. Buenos Aires, Ediciones Pueblos de América,

SERRA PADRÓS, Enrique. Como el Uruguay no hay... Terror de Estado e Segurança Nacional, Uruguai. 1968-1985. Porto Alegre, 2005. Tese (Doutorado em História). Instituto de Filosofia e Ciências Humanas, Universidade Federal do Rio Grande do Sul.

SMITH, Peter H. Talons of the Eagle: Dynamics of U.S.-Latin American Relations. Oxford, Oxford University Press, 1996 [E-book].

SEMO, Enrique. El ocaso de los mitos. In: SEMO, I.; GROMAN, D.; ROMERO, M. E. (Coords.). México, un Pueblo en la historia (vol. 6). México, Alianza, 1989.

SIERRA GUZMÁN, Jorge Luis. Fuerzas armadas y contrainsurgencia (1965-1982). In: OKIÓN SOLANO, V; UGARTE GARCÍA, M. E. (coords.) Movimientos armados en México, siglo XX (tomo II). Morelia, El Colegio de Michoacán/CIESAS, 2008, p. 361-404.

El enemigo interno: contrainsurgencia y fuerzas armadas en México. México, Centro de Estudios Estratégicos de América del Norte-Universidad Iberoamericana-Plaza y Valdés Editores, 2003.

SMITH, Peter. El imperio del PRI. In: TIMOTHY, A. et. al. Historia de México. Barcelona, Crítica, 2001, p. 330-331.

SPENSER, Daniela. Guerra fría y guerrilla en México: guía de acceso al archivo de la Dirección de Investigaciones Políticas y Sociales, AGN. México, CIESAS, 2003 [CD-ROM].

STAVENHAGEN, Rodolfo et. al. Neolatifundismo y explotación. México, Editorial Nuestro Tiempo, 1985.

STOPPINO, Mario. Autoritarismo. In: BOBBIO, N.; MATTEUCCI, N.; PASQUINO, G. (coords.). Dicionário de política. Brasília, Editoria UNB, 1998, p. 94-103.

TEAMEY, Kyle; SWEET, Jonathan. Organizar la Inteligencia para a Contrainsurgencia. Military Review, v. LXXXVII, n. 2, p. 20-27, Fort Leavenworth, marzo-abril 2007.

THE Battle of Algiers. Dir.: Gillo Pontecorvo, 117 min., 1965.

THOMPSON, E. P. Costumbres en común. Barcelona, Crítica, 1995.

La sociedad inglesa del siglo XVIII: ¿Lucha de clases sin clases? In: Tradición, revuelta y consciencia de clase. Barcelona, Crítica, 1979, p. 13-61.

TORRES, Jorge. DFS: la misión aniquilar. Proceso. México, 27-02-2005, p. 20-23.

TORRES, Jorge. Nazar, la historia secreta: el hombre detrás de la guerra sucia. México, Debate, 2008. 
TRUCCO, Fernando. Estados Unidos, la Unión Soviética y los movimientos revolucionarios de América Latina en la Guerra Fría. Military Review, v. LXXIX, n. 4, p. 44-49, Fort Leavenworth, julio-agosto 1999.

UNIVERSIDAD LA SALLE, Historia. México, 2016. Disponível em: http://www.lasalle.mx/somosla-salle/historia/ [último acesso em: 14-06-2016].

URIARTE BONILLA, Hugo David. El Asesinato de Pablo Alvarado Barrera. La historia no prescribe. Disponível em: http://laconvencionsinaloa.blogspot.com/2009/08/el-asesinato-de-pablo-alvaradobarrera.html [último acesso em: 15-06-2016].

VEIGA, Francisco; DA CAL, Enrique; DUARTE, Ángel. La Paz Simulada; Una historia de la Guerra Fría, 1941-1991. Madrid, Alianza Editorial, 1998.

WOLDEMBER, José; HUACUJA, Mario. Estado y lucha política en el México actual. México, Ediciones El Caballito, 1991.

ZIMBRES, Danilo. As fontes da conduta soviética [trad.]. Revista Política Externa, v. 14, n. 1, Rio de Janeiro, Editorial Paz e Terra, junho 2005. 
ANEXO 


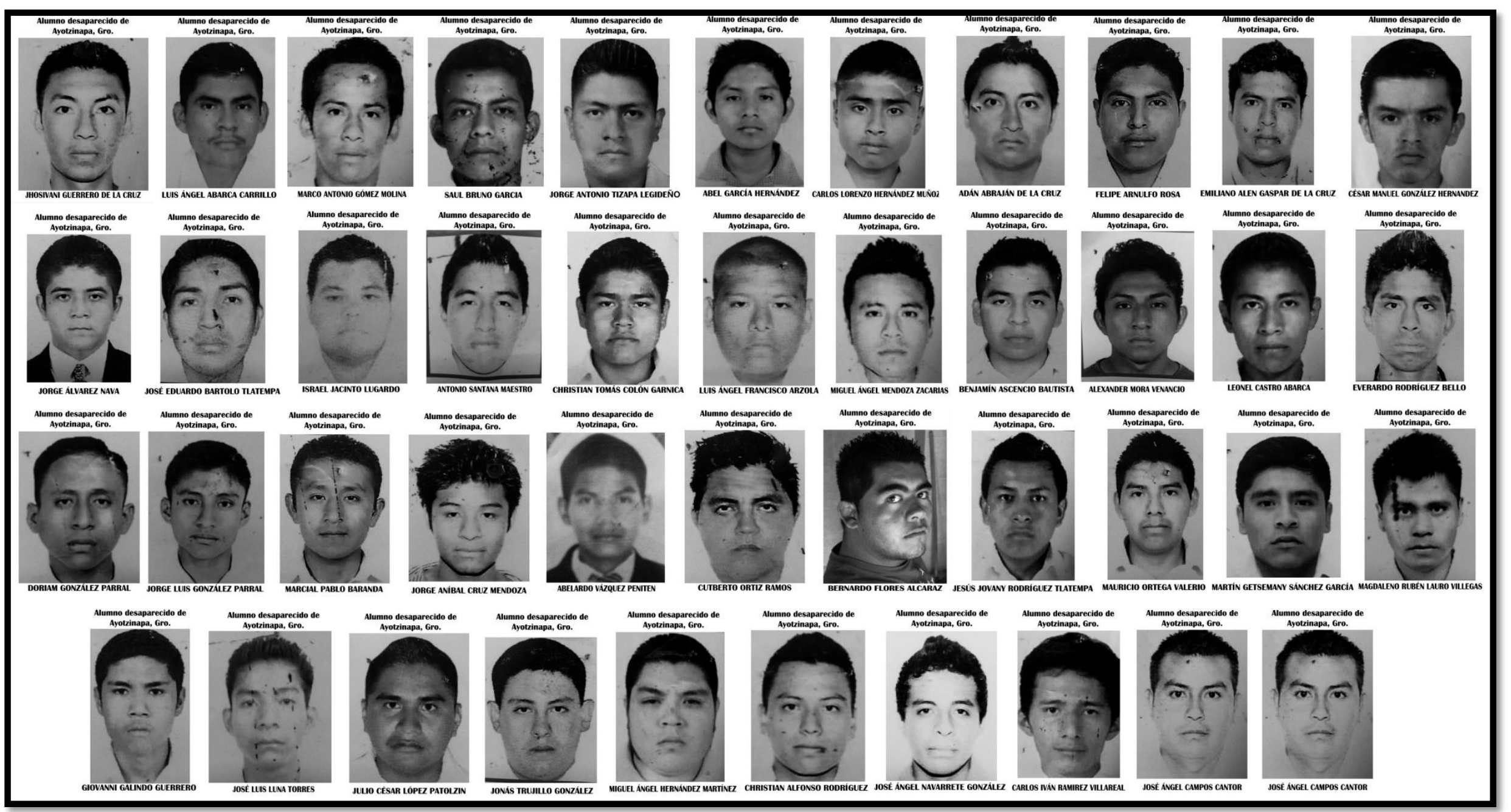

Fig. 1. Estudantes da Escuela Normal Rural "Raúl Isidro Burgos” desaparecidos no 26 de setembro de 2014 em Iguala, Guerrero. 


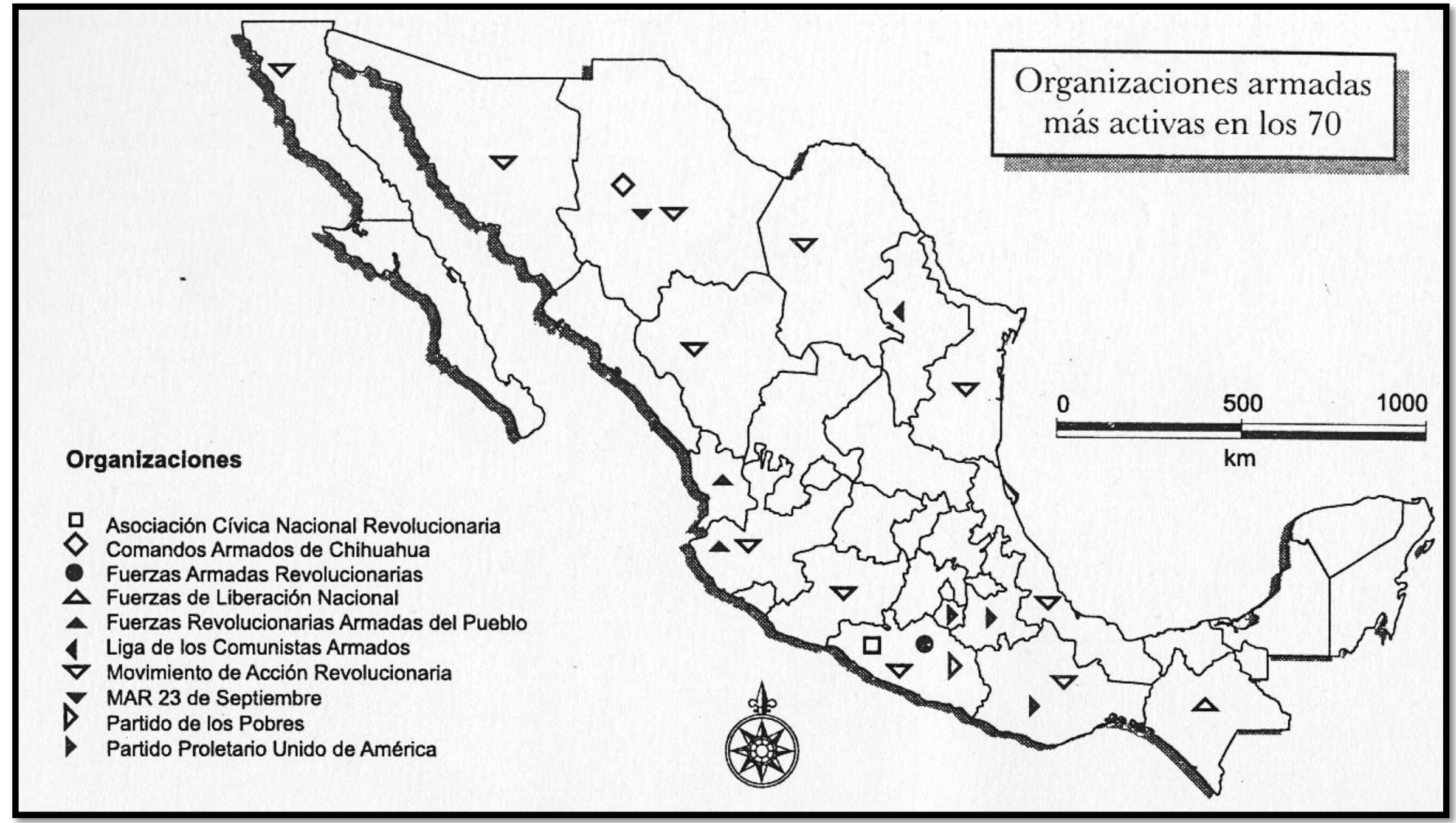

Fig. 2. Focos armados. Fonte: "Material gráfico de los movimientos armados en México (1964-1996), Centro de Investigaciones Históricas sobre Movimientos Armados (CIHMA) (CASTELLANOS, 2008, p. 358). 
DATOS CONTIDENCIALES.

1.- Bl Dootor Psblo Obmes, onbeoilia intelaotual on el morimionto de

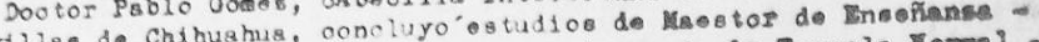

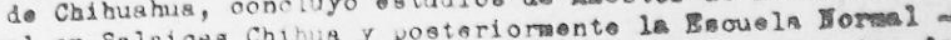
Normal Rural on SaIsionso Urbans de Cbihushus,

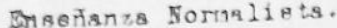

11 movimianto naoíonal juven1l reproment Uvenas Nexjornos y en 1959, eo ap1116 al

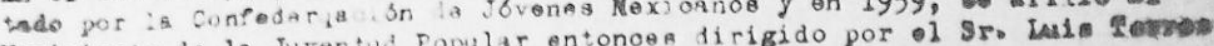
Movileien Ondoffen.

Al llegar a la oiudad do México, Nuéseimilado al Cont tó Jaolonnl de la ruventud Popular y prosiguib estudion on la Horas Guperior prisero $y$ despues on la Carrera de Nédioo C1 mijano y Partero.

on 1955 trmelado a ls oiudad de Chihuahus on dondo intois aus trabajos como rédido Cirujano y elgurs oomo dirigento del Partido Populsr.

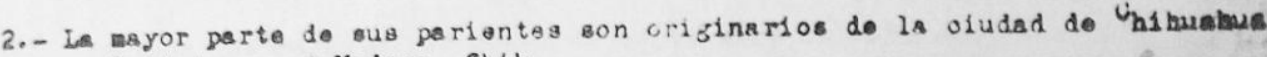
on Doliolss $y$ ar Keders, Chib.

$3^{\circ}$ - Su influenole pereonsl le permitibg estabiacer oontacto on amplloe seotor do estudientes norralistas tsnto de cielelees Chib. oomo de la cluded do

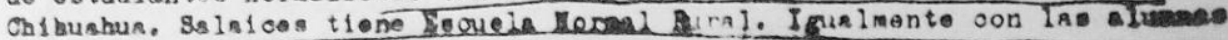
ar Fore magon donde hay Sacuela Normel Rural.

4.-Logróestableoer relaciones on grufie lel Tecnologioo de Chibuabua y des Instituto de Cienolss de is misma Ciudad, estableolendo de beoho un núloleo polftico de primera leportanola comandado por el Dr. Pablo Gónes oono anbro del Partido Populards de Chibuabus.

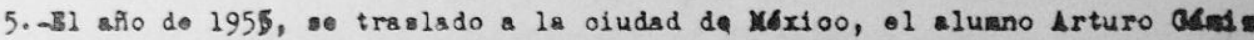
Oarole, quion ingremo a la Provucacional dol IPI y durento el movielento enosbesado por Nioandro Mendoss en/856, figuro coeso dirlgente de las Eeoulss Prevoosolomale del miano Polltbonico.

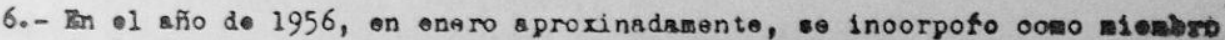
de la Juventud Popular en la oluded de M6́xioo, J por indiosolono 6o 110 jandro Qascón Merosdo, entoncos Prosidente del Comit $\rightarrow$ Faal onal de

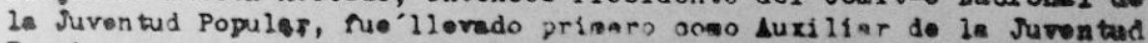

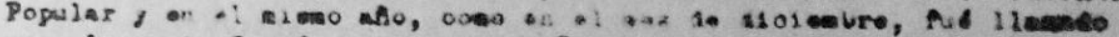
por el propio Gacón y por el Jr. Rafael Batrads Villa, para que se In corporara al Cont té Naolonsl de la Juventud Popular.

7.- In 1 affo de 1957, fue designado Seoretario General de la Juventud Popu ler, bejo ol mando del Dr. Rafael Betrada villa que figurb cono Prest dento.

8.- A fines de 1957, por rasones fanillarea, el ottado Arturo Odnis be wis

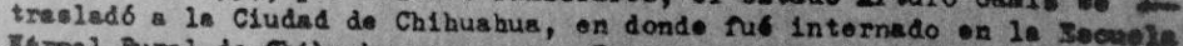

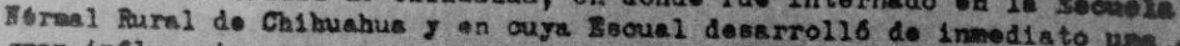
gran in?luencie.

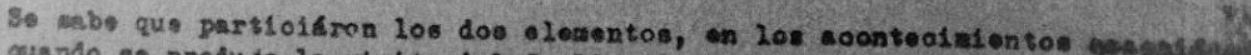

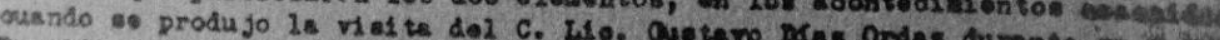
Proeldenoial.

Fig. 3. "Datos confidenciales", Chihuahua, 09-1965, AGN, IPS, Caixa 1448 B, Exp. 41, folha 1 de 2 . 


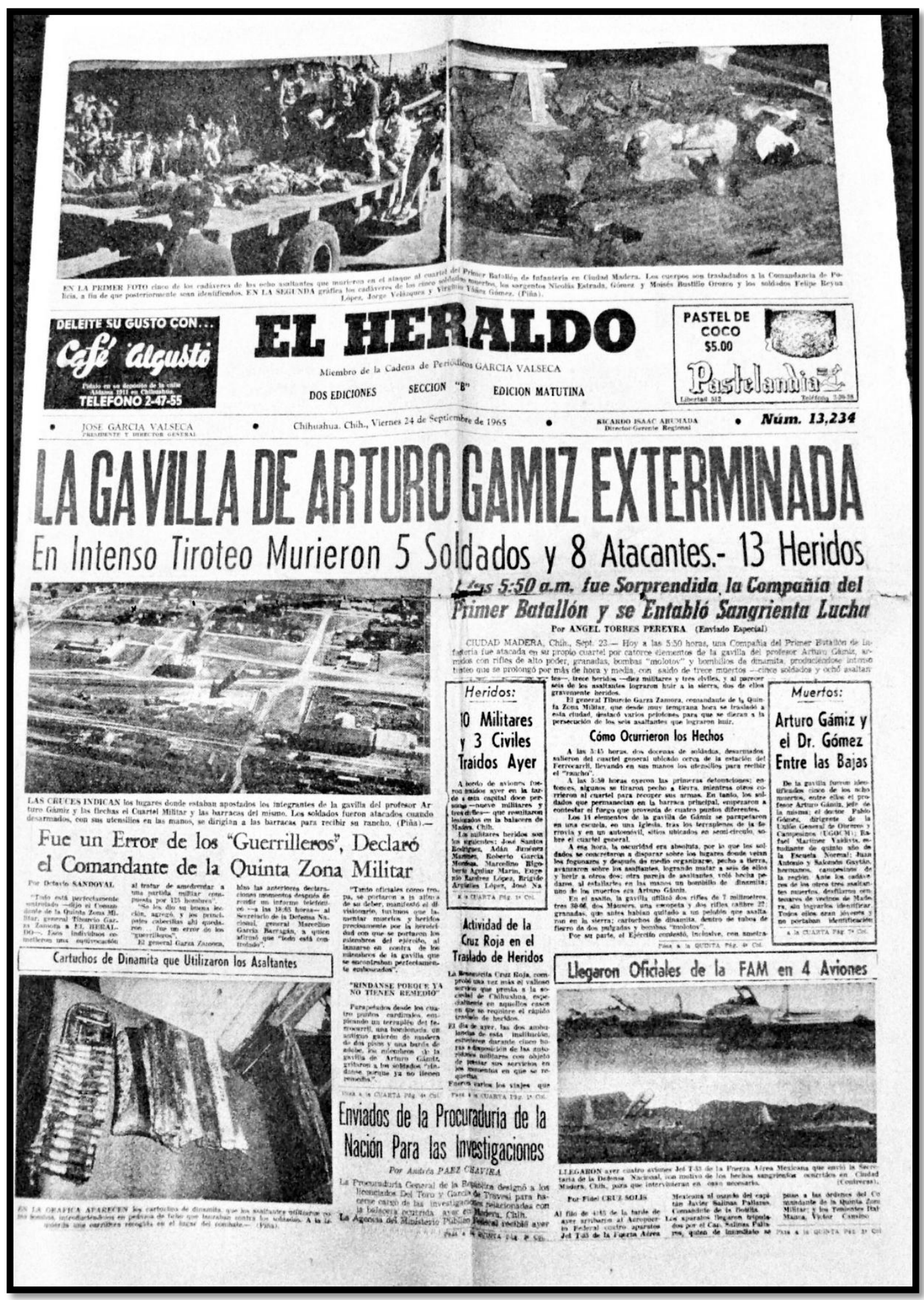

Fig. 4. El Heraldo, Chihuahua, 24-09-1965, AGN, IPX, Caixa 1455 A, Exp. 25. 


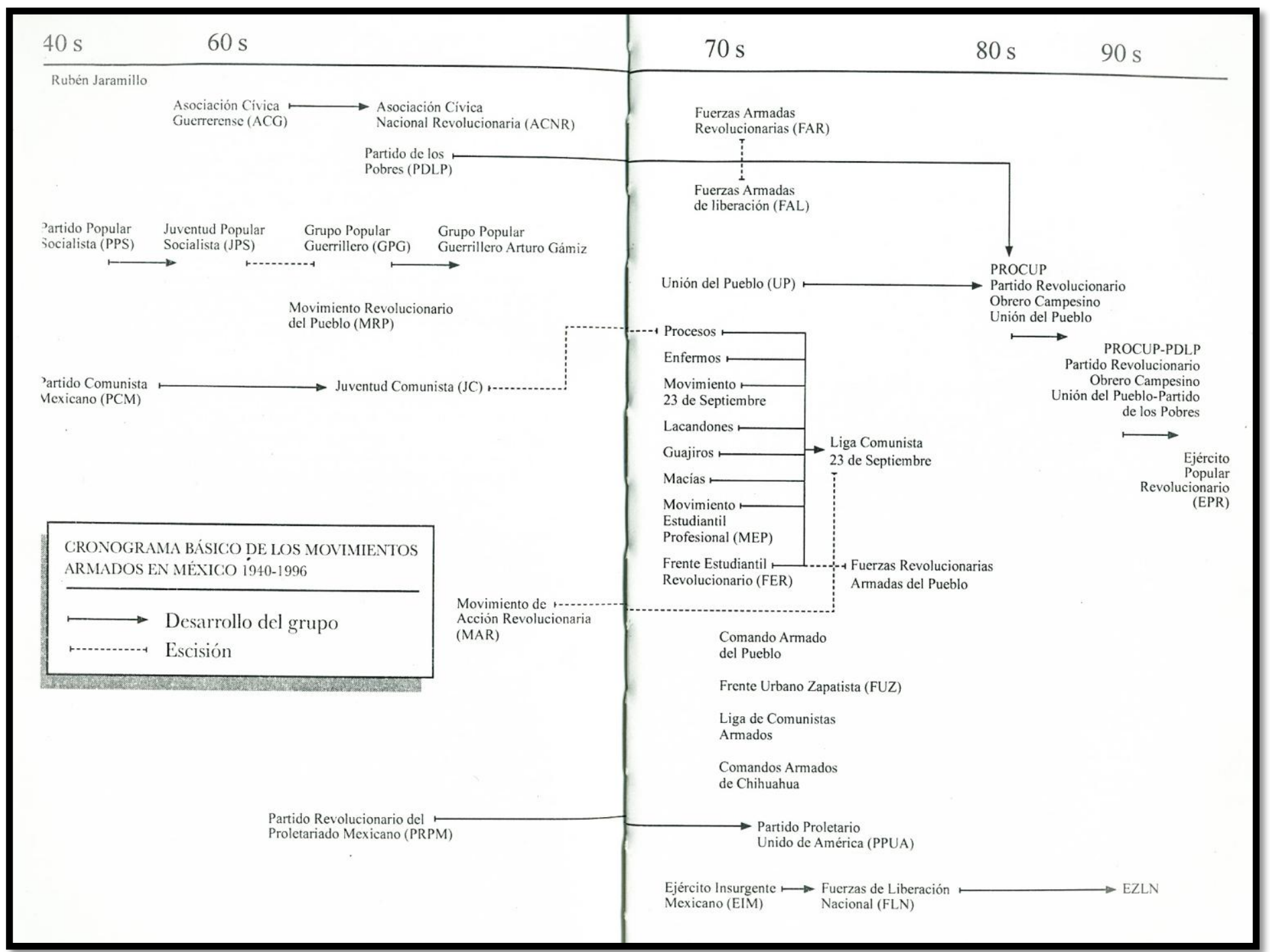

Fig. 5. Cronograma básico dos movimentos armados no México 940-1996 (CASTELLANOS, 2008, p. 354-355). 


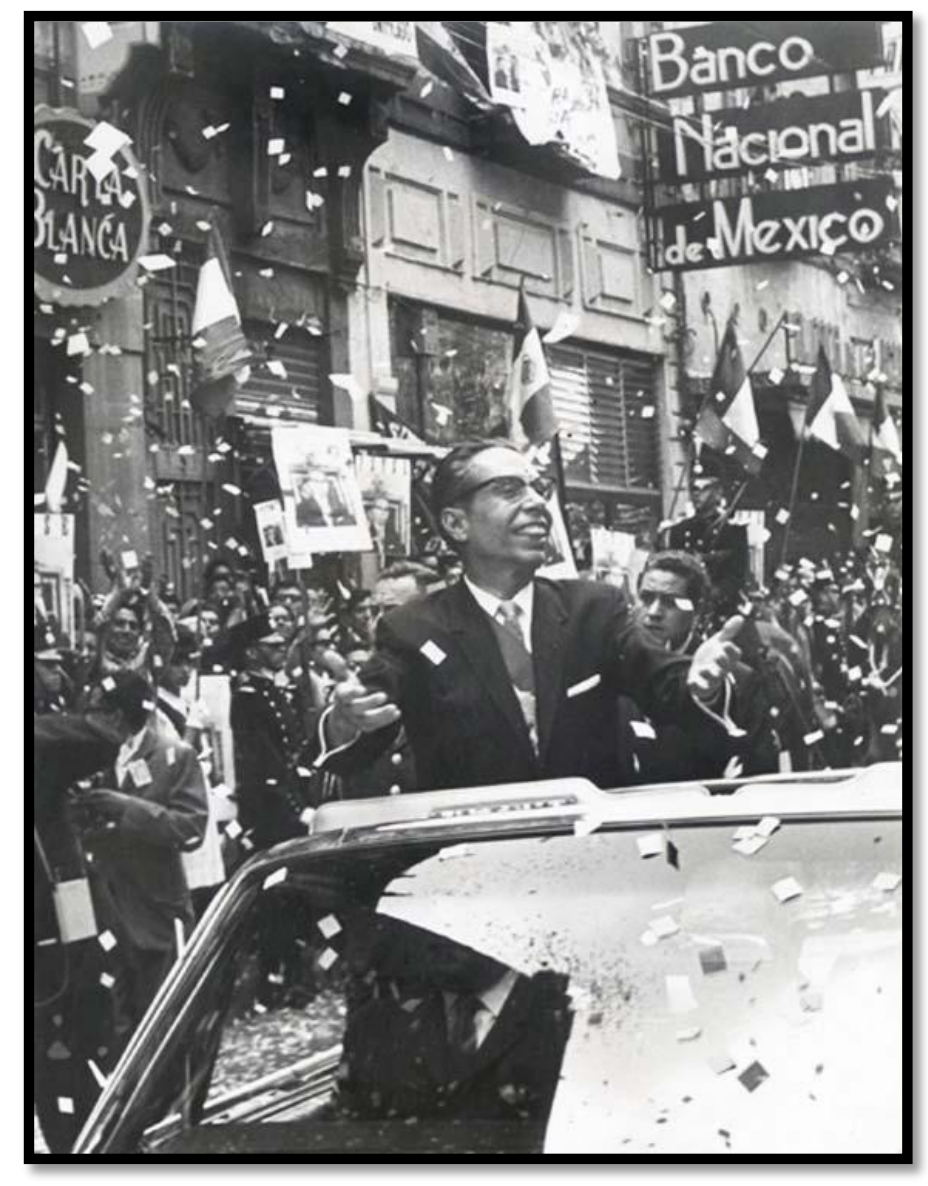

Fig. 6. Lic. Gustavo Díaz Ordaz (1968-1970) (Y con el "nuevo PRI”, ¿volverán las matracas, el confeti, el besamanos y los cantos y bailes regionales? Sinembargo, México, 17-06-2016. Disponível em: http://www.sinembargo.mx/05-09-2012/355769 [último acesso em: 17-06-2016]).

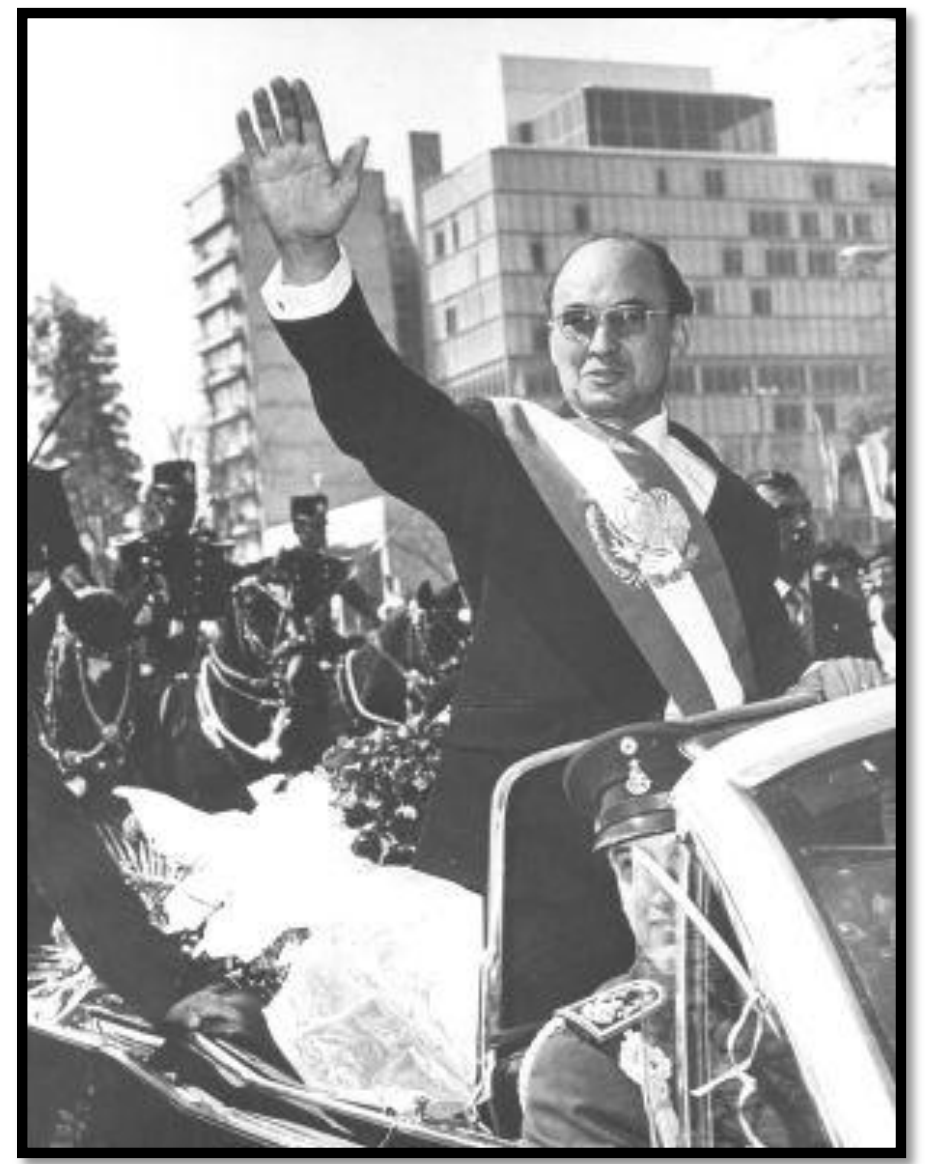

Fig. 7. Lic. Luis Echeverría Álvarez (1970-1976) (CORONA, Sonia. Wikileaks revela el lado más turbio de la presidencia de Echeverría en México. El País, México, 10-04-2013. Disponível em: /internacional.elpais.com/internacional/2013/04/10/actualidad/13655 53441_432875.html [último acesso em: 17-06-2016]. 


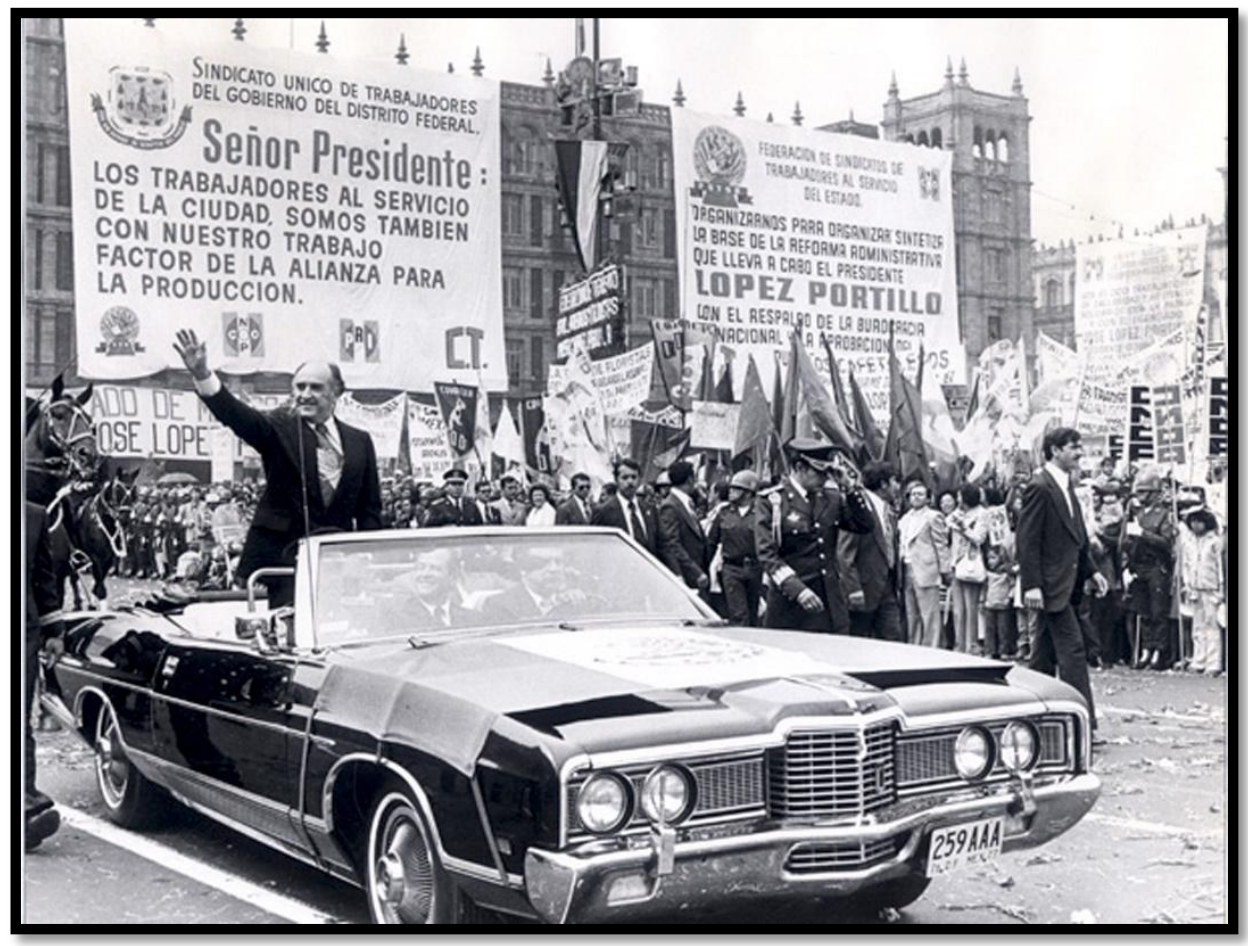

Fig. 8. José López Portillo (1976-1982) (CARMONA DÁVILA, Doralicia.Memoria Política. México, 2016. Disponível em: memoriapoliticademexico.org/Biografias/LPP20.html [último acesso em: 17-06-2016].

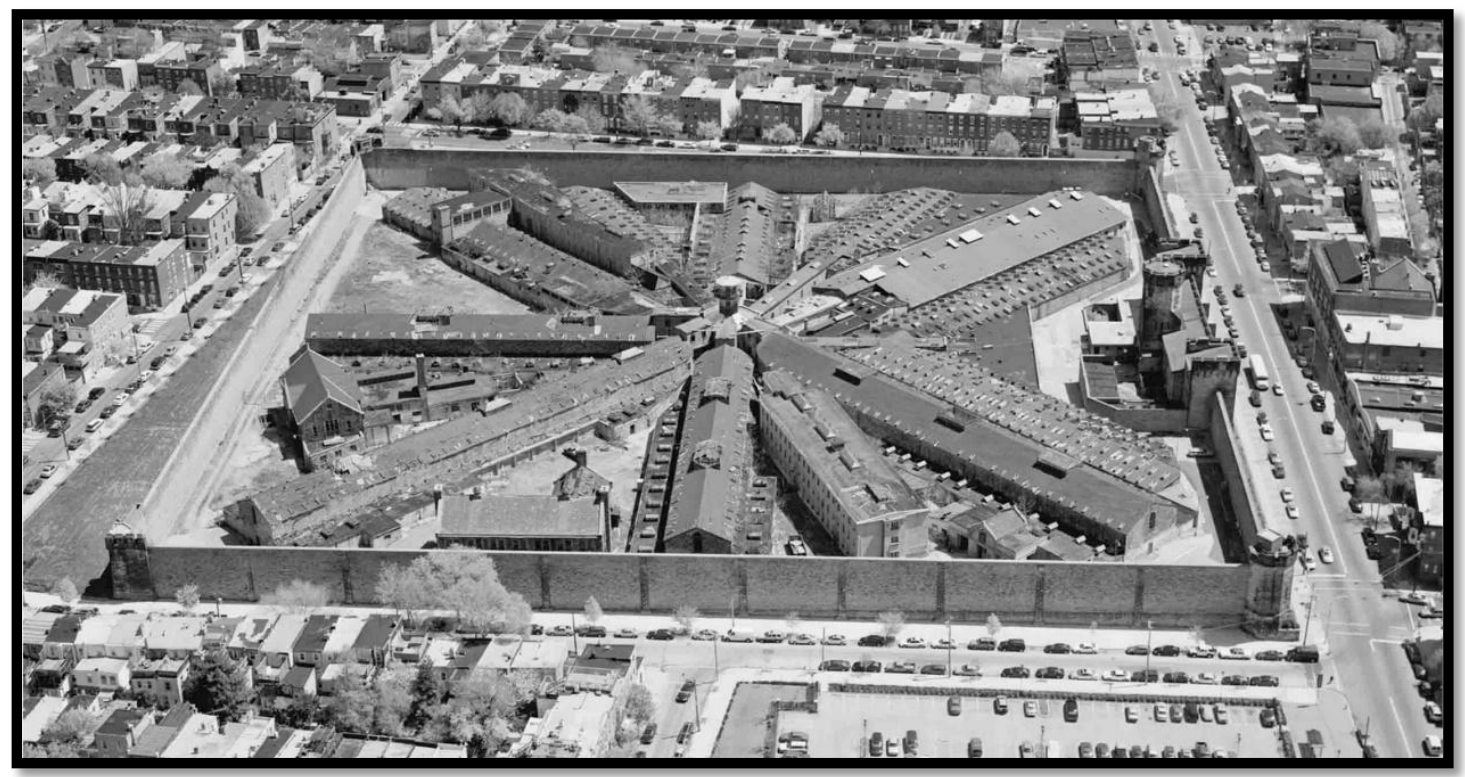

Fig. 9. Antigo Palacio de Lecumberri, hoje alberga o Archivo General de la Nación (AGN) (ARROYO TAFOLLA, Natalia. Microhistorias: el Palacio de Lecumberri. Sinembargo. México, 02-03-2013. Disponível em: http://www.sinembargo.mx/02-03-2013/542029 [último acesso em: 17-06-2016]). 


\section{DE PARTE SR. SCOTT}

10. de Agosto de 1967.

$M B M O F A N D U M$.

ASUNTO: MOISES RVAE IOTO OF OZCO LPAL.

I.- Esta persona nació en la ciucac ce Guatemala el 4 ce mayo de $19 \overline{3} \overline{0}$, Centro mérica. Su actual domicilio se encuentra en la calle de Tenis No. 88 int. 5 , México 21, D.F. Se conocen actividaces de esta persona con anteriorice al año, ie 1963 , cabienroce que ha estado en Mexico dentro y fuera dol pais en varioe años, y que tiene resicencia legal en México.

?. - F1 23 de Enero de 1963, esta persona viajó en la Iinea Cubana de Aviación de la ciudad de México a Ia ciucar de Ia Jabanacuba, exhibiendo el pasajorte guatemalteco No. 18776. Fegresó a -.México procerente e La Habana Cuba el 11 je marzo de 1963 en Ia -Linea Cubana de Aviación, diciendo que había vicitado Cuba unica--mente como turicta, pero se sabe de fuentes dignas de crédito que estuvo en la Habana cumplienco una mición del Partico Guatemaltecodel Trabajo (P.G.T.- Partico Comunista Guatemalteco), del cual él es miembro.

3.- In Febroro de 1964, solicitó asilo político en la Fm-bajada lexicgna on Guatemala, en donde so lo extentió un salvo-conincto para lexico el mes ce marzo de 1964. Durante este tiempo de-sempeñaba ol cargo de Secretario General del Partido Unidad evolucionaria (P.U.F.-Facción Inzouerista del Particio Polfitico Cuate-malteco).

4.- F1 14 de mayo de 1965 , esta persona asictió a un reunión de ririgentes comunistas guatomaltocos ie guerrilla en Néxico, con el propósito de iiscutir el plan para iniciar una revuelta en el Area re Peten de Guatemala. Fntre los presentes ce encontraba --

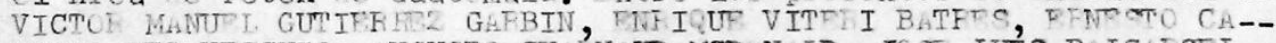

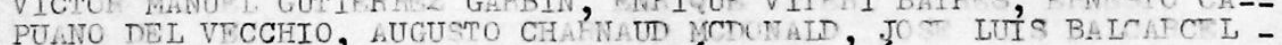
OLDONTZ y SOSA COLINDRTS. Esta reunión se IIsvo a cabo on Ja caca de culNTIPS, ubicara en la Calzaca de Tlalpan No. 1683, México, -D.F. RI plan consistió en el reclutamiento y entrenamiento de hom-bres en lexico para el grupo de guerrilleros en el area de Peten -del lacio mexicano de la frontera.

5.- En abril de 1966 esty persona viajó en Lineas Cubanas hereas de ia ciucad de México hacía Cuba desconociendose las razo-nes, usando pasaporte quatemalteco No. 16?106, extendido en quate.mala el 24 de marzo de 1965. Fegreso a la ciúad de México vía Li-neas Cubanas sereas el 7 de nnero ie 1967. Inmediatamente a su re-greso, estableció contacto con los, exilados comunistac suatemalte-cos en México, diciendoles que había estado en contacto con los gr pos guerrilleros en Cuba. Asímismo les iijo aue continuaba sienco miembro del Partido Guatemalteco iel Trabajo, pero cue estaba coopé rando extrechamente con las fuerzas armaras rebeldes (F.A.R.-Movi-miento de Guerriljas Guatemaltecas encabezanas por CTSA WOMTS). Esta persona trato de reclutar elementos guatemaltecos en el exilo_ para regresar a Guatemala a pelear en contra del Gobierno. Asimismo estuvo trabajando buscando, la posibilidad de mandar armas y muni-.. ciones a Guatemala cesce México.

Fig. 10. "Memorandum. Asunto: Moisés Evaristo Orozco Leal”, Distrito Federal, 01-08-67, AGN, IPS, Caixa 1467 A, Exp. 1, folha 1 de 2. 


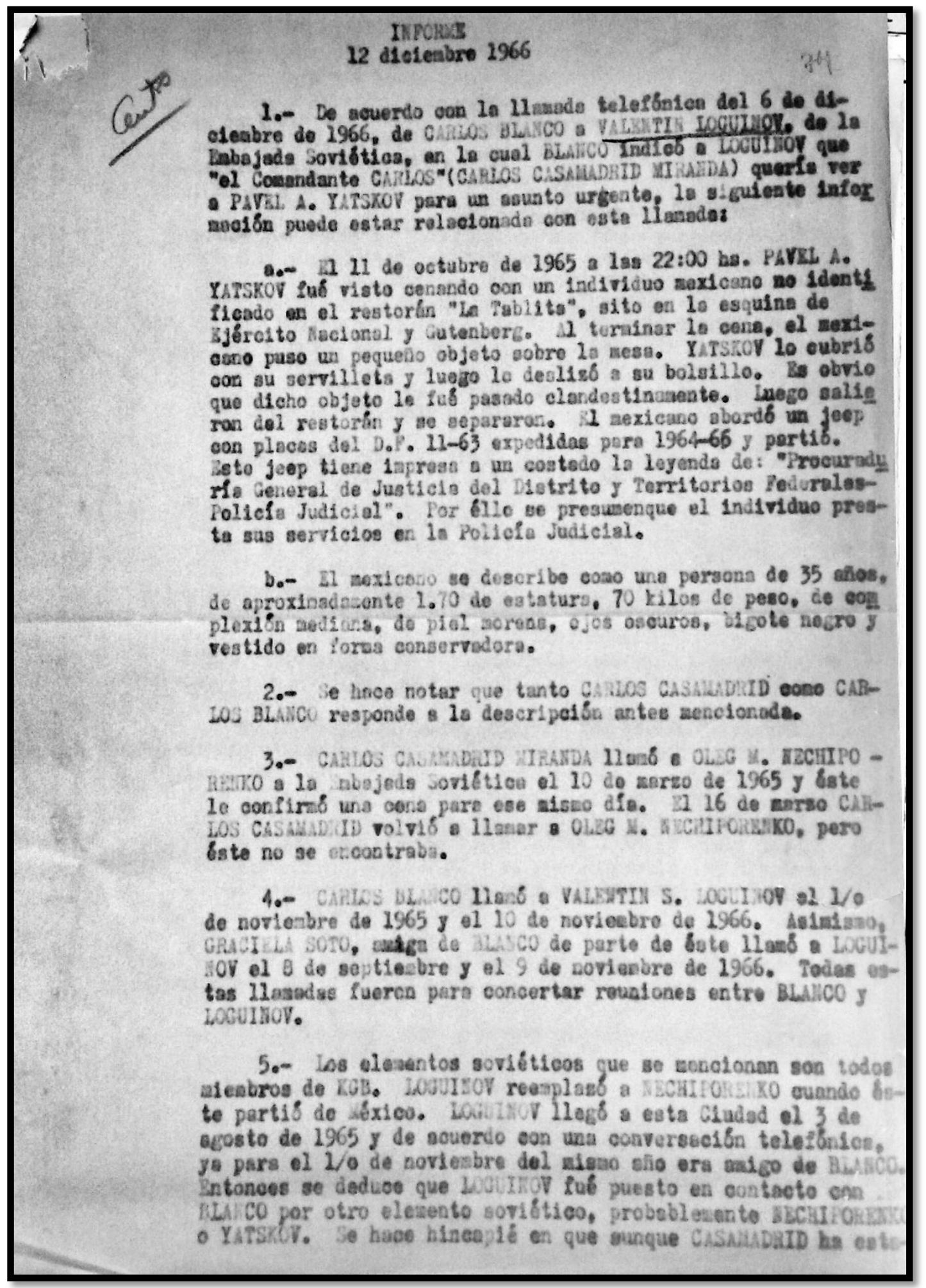

Fig. 11. "Informe", Distrito Federal, 12-12-66, AGN, IPS, Caixa 1467 B, Exp. 10, folha 1 de 2. 


\begin{tabular}{|c|c|c|c|}
\hline \multicolumn{4}{|c|}{$\begin{array}{c}\text { Cuadro 1. Militares de América Latina entrenados por } \\
\text { Estados Unidos }{ }^{1}: 1950-1968\end{array}$} \\
\hline & $\begin{array}{l}\text { ENTRENADOS, } \\
\text { AF } 1950-63\end{array}$ & $\begin{array}{l}\text { ENTRENADOS, } \\
\text { AF } 1964-68\end{array}$ & $\begin{array}{r}\text { TOTAL DE } \\
\text { ENTRENADOS }\end{array}$ \\
\hline A.rgentina & 1190 & 1216 & 2496 \\
\hline Bolivia & 764 & 1432 & $2 \mathrm{i} 96$ \\
\hline Brasil & 3416 & 2255 & 5671 \\
\hline Chile & 2219 & 1448 & 3667 \\
\hline Colom bia & 2516 & 1378 & 3894 \\
\hline Costa Rica & 208 & 321 & 529 \\
\hline Cuba & 521 & - & 521 \\
\hline Ecuador & 2246 & 1549 & 3795 \\
\hline El Salvador & 304 & 528 & 832 \\
\hline Guatemala & 903 & 1117 & 2020 \\
\hline Haití & 504 & - & 504 \\
\hline Honduras & 746 & 602 & 1348 \\
\hline MEXICO & 240 & 306 & 546 \\
\hline Nicaragua & 2366 & 1204 & 3570 \\
\hline Panamá & 768 & 2106 & 2874 \\
\hline Paraguay & 204 & 564 & 768 \\
\hline Perú & 2820 & 1624 & 4444 \\
\hline Rerública Dominicana & 955 & 1419 & 2374 \\
\hline Uruguay & 807 & 607 & 1414 \\
\hline Venzuela & 724 & 2382 & 3106 \\
\hline Total, América Latina & a 24421 & 22058 & 46479 \\
\hline
\end{tabular}

Fig. 12. Fonte: United States Congress, House of Representatives. Reprt of the Committe of Foreign Affairs together with additional and supplemental views, 96th Congress, 1st Session, Report nums. 96-97, March, 1979. United States Government Printing Office. Washington, D.C. 1979 apud PIÑEYRO, 1985, p. 161.

\begin{tabular}{|c|c|c|c|c|c|c|c|c|c|}
\hline \multicolumn{10}{|c|}{$\begin{array}{l}\text { Cuadro 2. Militares eitrenados poi el progrnma internacional de } \\
\text { educación militar de Estados Unidos: } 1975-1977 \\
\text { (Años fiscales) }\end{array}$} \\
\hline \multicolumn{4}{|c|}{1975} & \multicolumn{3}{|c|}{1976} & \multicolumn{3}{|c|}{1977} \\
\hline País & $\begin{array}{c}\text { En } \\
\text { Estados } \\
\text { Unidos }\end{array}$ & $\begin{array}{l}\text { En } \\
\text { Ultra- } \\
\text { mar }\end{array}$ & Total & $\begin{array}{c}\text { En } \\
\text { Estados } \\
\text { Unidos }\end{array}$ & $\begin{array}{c}\text { En } \\
\text { Ulitra- } \\
\text { mar }\end{array}$ & Total & $\begin{array}{c}\text { En } \\
\text { Estados } \\
\text { Unidos }\end{array}$ & $\begin{array}{l}\text { En } \\
\text { Ultra- } \\
\text { mar }\end{array}$ & Totai \\
\hline Argentina & 8 & 11 & 19 & 129 & 63 & 192 & 118 & 125 & 243 \\
\hline Bolivia & 8 & 326 & 334 & 67 & 116 & 183 & 20 & 198 & 218 \\
\hline Brasil & 282 & 19 & 301 & 422 & 18 & 440 & 455 & 34 & 479. \\
\hline Chile & 32 & 536 & 568 & - & - & - & - & - & - \\
\hline Colombia & 46 & 277 & 323 & 47 & 302 & 349 & 74 & 217 & 291 \\
\hline Ecuador & 40 & 116 & 156 & 128 & 118 & 246 & 121 & 44 & 165 \\
\hline E1 Salvador & 17 & 141 & 158 & 39 & 148 & 187 & 24 & 185 & 209 \\
\hline Guatemala & 21 & 118 & 139 & 40 & 101 & 141 & 61 & 104 & 165 \\
\hline Haití & 5 & - & 5 & 29 & - & 29 & 55 & - & 55 \\
\hline Honduras & 60 & 196 & 256 & 47 & 176 & 223 & 49 & 127 & 176 \\
\hline MEXICO* & 31 & 28 & 59 & 18 & 14 & 32 & 80 & 2 & 82 \\
\hline Nicaragua & 46 & 207 & 253 & 58 & 153 & 211 & 102 & 245 & 347 \\
\hline Panamá & 4 & 352 & 356 & 5 & 195 & 200 & 9 & 193 & 202 \\
\hline Paraguay & 50 & 51 & 102 & 51 & 61 & 112 & 59 & 104 & 163 \\
\hline $\begin{array}{l}\text { Perú } \\
\text { República }\end{array}$ & 123 & 121 & 244 & 99 & 202 & 301 & 176 & 94. & 270 \\
\hline $\begin{array}{l}\text { República } \\
\text { Dominicana }\end{array}$ & 43 & 162 & 205 & 50 & .145 & 195 & 83 & 164 & 247 \\
\hline Uruguay & 25 & 112 & 137. & 31 & 144 & 175 & 40 & 189 & 229 \\
\hline Venezuèla & 57 & 87 & 144 & 92 & 48 & 140 & 82 & 163 & 245 \\
\hline Total & & & & & & & & & \\
\hline Regionat & 899 & 2861 & 3760 & 1352 & 2004 & 3356 & 1608 & 1188 & 3.796 \\
\hline
\end{tabular}

Fig. 12. Fonte: United States, House of Representatives, Hearings before a Subcommittee of the Committee on Appropriations, 94th Congress, 2nd Sessions: "Foreign Assistance and Related Agencies, Appropriations for 1977 apud PIÑEYRO, 1985, p. 162. 


\begin{tabular}{|c|c|c|c|c|c|}
\hline \multicolumn{6}{|c|}{$\begin{array}{c}\text { ASISTENCIA MILITAR Y VENTAS MILITARES } \\
\text { DE ESTADOS UNIDOS A PAISES } \\
\text { DE AMERICA IIATINA } \\
\text { 1953-1965 } \\
\text { (Millones de dólares) }\end{array}$} \\
\hline País & $\begin{array}{l}\text { PAM * } \\
\text { (dona- } \\
\text { ciones) }\end{array}$ & $\begin{array}{l}\mathrm{Na}- \\
\text { val }\end{array}$ & $\begin{array}{c}\text { Reza- } \\
\text { gos }\end{array}$ & $\begin{array}{l}\text { Ven- } \\
\text { tas }\end{array}$ & $\begin{array}{l}\text { Total } \\
\text { por } \\
\text { país }\end{array}$ \\
\hline 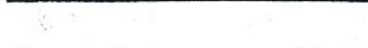 & 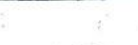 & & & 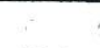 & $\sqrt{3+h y}$ \\
\hline Argentina & 36.3 & 37.0 & 1.6 & 18.9 & t) 93.8 \\
\hline Bolivia & 15.0 & - & 2.6 & - & 17.6 \\
\hline Brasil & 205.6 & 57.1 & 75.7 & 35.9 & 374.3 \\
\hline Chile & 87.8 & 29.9 & 23.3 & 3.2 & 1442 \\
\hline Colombia & 74.9 & 14.5 & 12.9 & - & 102,3 \\
\hline Costa Rica & - & 1.9 & 0.1 & - & 20 \\
\hline Ecuador & 34.8 & 10.0 & 8.1 & - & 52.2 \\
\hline El Salvador & 4.8 & - & 0.5 & - & 5.3 \\
\hline Guatemala & 11.0 & - & 2.3 & 0.1 & 13.4 \\
\hline Honduras & 5.3 & - & C. 8 & - & 6.1 \\
\hline MEXICO & 1.6 & 4.4 & 0.1 & 5.4 & 11.5 \\
\hline Nicaragua & 8.8 & - & 0.6 & - & 9.4 \\
\hline Panamá & 2.3 & 一 & - & - & 2.3 \\
\hline Paraguay & 5.8 & 1.4 & 0.9 & 0.2 & 8.3 \\
\hline Perú & 82.5 & 32.8 & 17.4 & 20.1 & 152.8 \\
\hline República Dominicana & 16.1 & 1.0 & 2.5 & - & 19.8 \\
\hline Uruguay & 37.3 & 0.1 & 7.1 & - & 44.5 \\
\hline Venezuela & 5.8 & 11.3 & 0.3 & 86.8 & 104.2 \\
\hline
\end{tabular}

Fig. 13. Fonte: VENERONI, Horacio. Estados Unidos y las fuerzas armadas de América Latina. Buenos Aires, Editorial Periferia, 1972, p. 186 apud BOILS, 1975, p. 156.
AYUDA MILTTAR DE LOS ESTADOS UNIDOS

A PAISES DE AMERICA LATINA, 1972

(En dólares)

\begin{tabular}{|cr|}
\hline País & \multicolumn{1}{c|}{ Ayuda } \\
\hline Argentina & $15.897,000$ \\
Bolivia & 666,000 \\
Brasil & $24.692,000$ \\
Chile & $5.000,000$ \\
'Ecuador & 645,000 \\
- MExico & 107,000 \\
Panamá & 173,000 \\
Perŕ & 792,080 \\
República Dominicana & 539,000 \\
Urúruay & $2.400,000$ \\
- Venezuela & $15.734,000$ \\
\hline
\end{tabular}

Fig. 13. Fonte: Los ejérictos latinoamericanos. Revista de Revistas. México, 1974, p. 9 apud BOILS, 1975, p. 156. 


\section{SATANISM0 ANTIRRELIGIOSO}

El viernes 4 de Junio un grupo de estudiantes universitarios dirigidos por los Líderes Comunistas que todos conocemos consumaron el acto mas infame de su larga cadena en contra del sentir y del progreso de la Ciudad y de la Patria.

Disfrazados de Sacerdotes recorrieron las calles de la Ciudad haciendo burla de nuestros Prelados ya que desde un coche impartian "Bendición" en forma similar a nuestros Dignatarios Eclesiásticos y lanzando gritos soeces contra la Religión y sus Ministros.

Posteriormente y con un satanísmo que hacia muchos años México no veia y dentro del recinto Universitario repitieron los insultos soeces a los Sacerdotes y Religiosos, e hicieron una Parodia similar al Santo Sacrificio de la Misa, cambiando las Sagradas formas por una jarra de vidrio en forma de miembro masculino con la cual estos infelices comunistas a quien Dios perdone impartian "Bendición".

Culminaron sus actos en este día vergonsozo para la historia de nuestra Ciudad intentando introducirse a un Templo para imitar burlonamente el acto de ofrecer flores a nuestra Madre Santísima, e in. troduciéndose por la fuerza a un Colegio de Señoritas a las cuales insultaron deshonestamente, a sí como a sus maestros y se mofaron en esta ocasión y delante de ellos del Sacramento del Bautismo en forma similar a lo antes descrito.

Estos actos sin precedente en nuestra Ciudad nos llenan de justa indignaeión a todos los Cristianos y nos deben hacer comprender que el grupo Comunista que por nuestra negligencia se ha apoderado de la Universidad está pasando ya al intento de destrucción de nuestra Religión siguiendo la Máxima de Eenín "La Religión es el opio del Pueblo".

\section{CatOLICO POBLANO:}

Preguntate a tí miłmo $i$ Que va a seguir después?

Si no hemos reaccionado ante el apoderamiento de la Universidad por los Comu. nistas, debemos al menos reaccionar en defensa de nuestra Religión.

No olvidemos que la única fuerza de este pequeño grupo Comunista es la indiferencia o cobardia del GRAN NUCLEO CRISTIANO.

Fig. 14. "Satanismo Antirreligioso", Puebla, 04-06-64, AGN, IPS, Caixa 1573 A, Exp. 1, folha 1 . 


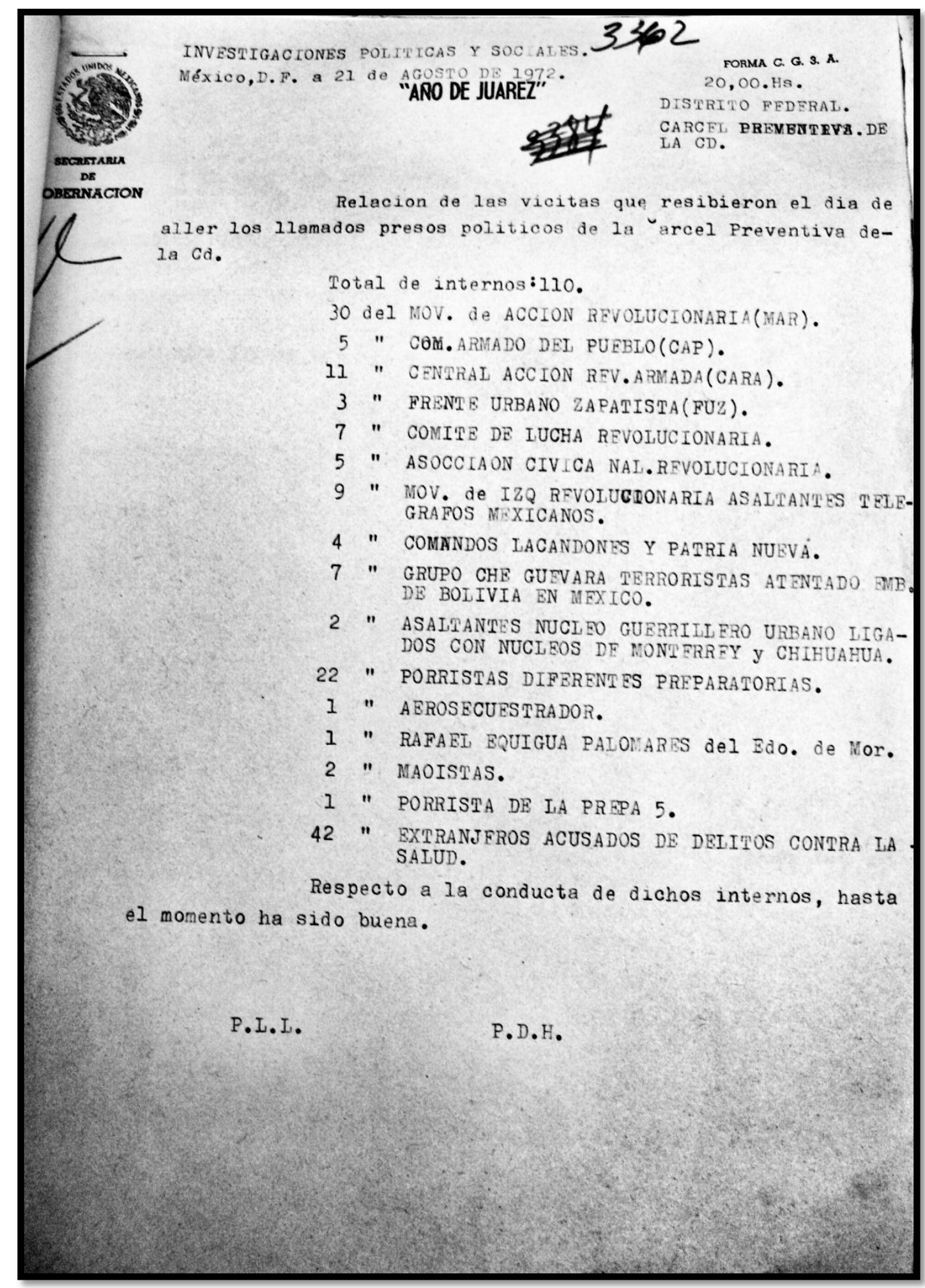

Fig. 15. "Relación de las vicitas (sic) que resibieron (sic) el día de aller (sic) los llamados presos políticos de la Cárcel Preventiva de la Cd.”, Distrito Federal, 21-08-72, AGN, IPS, Caixa 953, folha 1. 


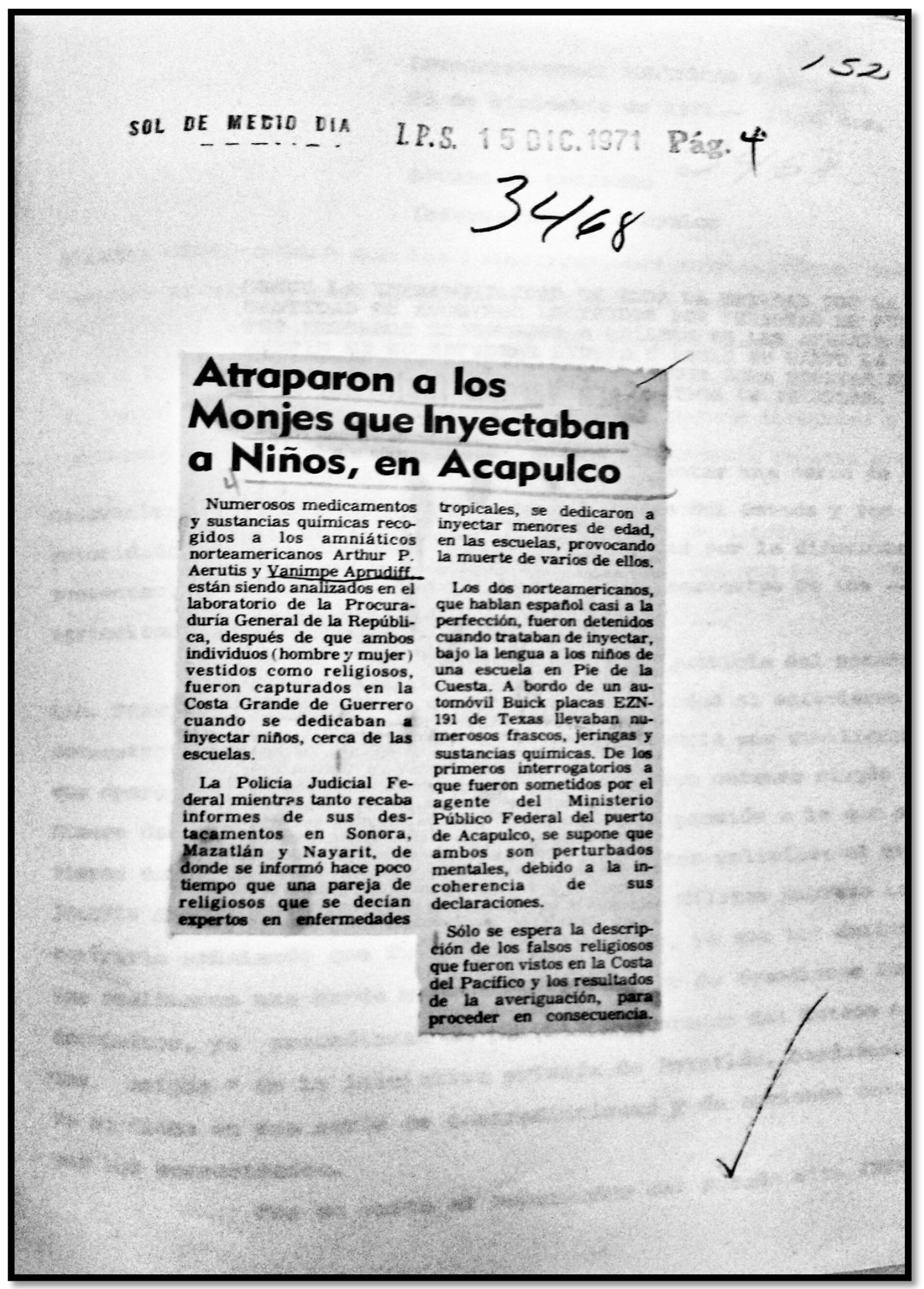

Fig. 16. "Atraparon a los monjes que inyectaban a niños, en Acapulco", El Sol de Medio Día (p. 4), Chilpancingo, 15-12-71, AGN, IPS, Caixa 1783 D, Exp. 13, folha 1. 


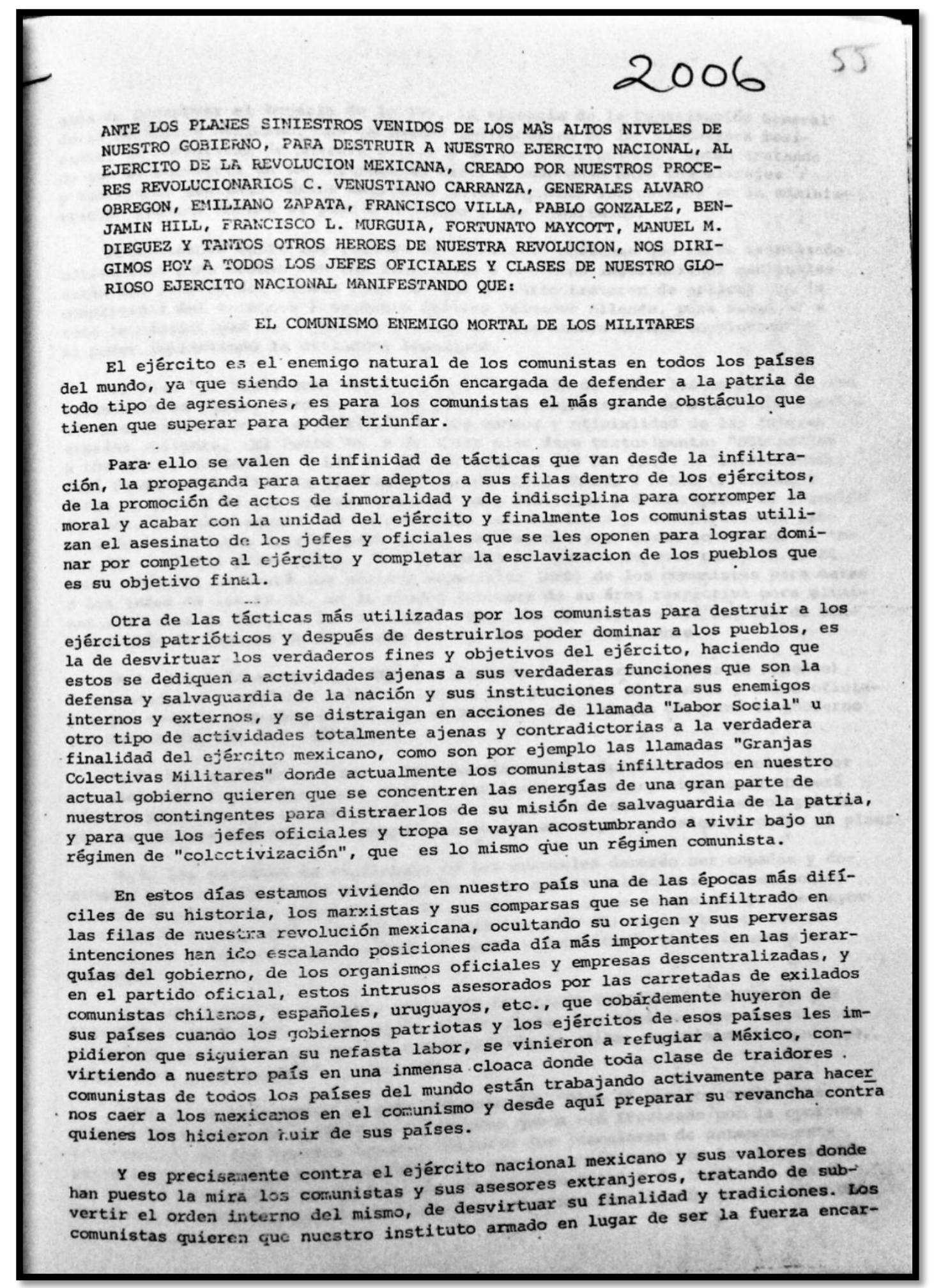

Fig. 17. "Ante los planes siniestros venidos de los más altos niveles de nuestro gobierno", Distrito Federal, 1976, AGN, IPS, Caixa 1747 B, Exp. 6, folhas 1-5. 
gada de preservar el imperio de la ley, la vigencia de la Constitución General de la República Mexicana, las garantias individuales de los ciudadanos mexicanos, la integridad de nuestra patria y de sus instituciones, están tratando de que se convierta en un instrumento dócil e indefenso ante los ultrajes " y traiciones que estos malos mexicanos están hagiendo incrustados en la administración pública contra el pueblo de México y sus libertades.

precisamente entre los cientos de "asesores" chilenos que están trabajando activamente para acabar con las libertades y nuestras instituciones nacionales están los autores del famoso Plan " $\mathrm{"} \mathrm{que} \mathrm{en} \mathrm{Chile} \mathrm{trataron} \mathrm{de} \mathrm{aplicar} \mathrm{con} \mathrm{la}$ complicidad del entonces Presidente Chileno Salvador Allende, para asesinar a tocia la oficialidad del ejército y poder de esta manera asumir completanente el poder implantando la dictadura comunista.

$$
\therefore \leqslant \frac{8}{8}
$$

El Plan "Z" tenía como objetivo la eliminación de todos los enemigós de los comunistas en Chile, pero uno de los puntos más importantes de dicho plan consistía precisamente en la eliminación de los mandos y oficialidad de las fuerzas armadas chilenas. El Punto 40. A de dicho plan dice textualmente: "DESCABEZAR A LOS MANDOS SUPERIORES $Y$ LOS DE LAS UNIDADES DE LAS FF, AA."... "Introducción: Será fundamental ELIMINAR FISICAMENTE A LOS ALTOS MANDOS Y A. LOS OFICIALES Y JEFES DE UNIDAD de las fuerzas enemigas para debilitar y desmoralizar la reacción desleal. En consecuencia, se aprovecharán las reuniones y concentraciones propias de las Fiestas Patrias para actuar masivamente y en forma coordinada en todas las ciudades principales..." ...y añaden los puntos de, este plan: "A.I, E1 mando regional empleará los núoleos especiales (MPE) de los comunistas para matar a los jefes de las FF.AA. en la ciudad cabecera de su área respectiva para eliminar con armas de fuego a los oficiales con mando de tropa en.los lugares de concentración de fuerzas de la parada militar del 19 de septiembre.

"A.2. Simultáneamente los GAP de la Moneda (los guardaespaldás de Allende) è Intendencias procederán a dar de baja a los generales Almirantes y otros oficiales que estarán reunidos asistiendo al almuerzo oficial que ofrecerá el gobierno con motivo del día del ejército.".

"A. 3, Las unidades militares descabezadas serán rápidamente controladas por los elementos leales que hemos logrado infiltrar en sus organizaciones. Deberá los elementos leales que hemos logrado Marina no tiene elementos nuestros por lo tenerse presente que la infantería de Marina no tiene elementos nuestros por lo que sus fuerzas deberán ser controladas cuanto antes por unidadę plegadas

"A, 4. Las guardias de vigilancia en los cuarteles deberán ser, copadas y doA.4. Las lucha con la colaboración dé elementos adictos e infiltrados previamente. En aquellos cuarteles en que se aprecie mayor resistencia se emplearán los Grupos especiales (NPE-3Z) En los buqques los infiltrados y colaboradores impedirán su zarpe y facilitarán posteriormente su captura:

44.B. RETENCION DE UNIDADES MILITARES DESLEALES Y GUARPIAS BLLANCAS EN SUS

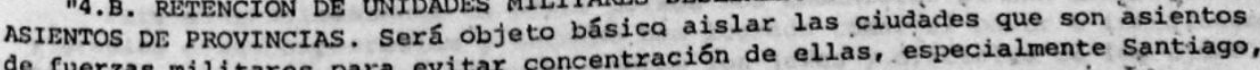
de fuerzas militares para evitar conce
Valparaíso, y Concepción"... etc. etc.

Como se ve claramente en este extracto del "Plan z" que los comùnistas estuvieron a punto de aplicar en chile pero que a ví frustrado por ia oportuna intervención de las Fuerzas Armadas Chilenas que conocieron de antemano ește perverso plan e impidieron resueltamente con su acción oportuna la aniquilación de toda la oficialidad de Chile y su comunización total y de todos los que se oponian a la implantación de la dictadura comunista por Allende y sus

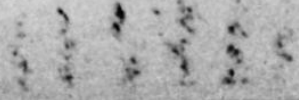


asesores cubanos, españoles, argentinos, yugoslavos, rusos, etc., que serían los encargados de ejecutar este malévolo plan.

Estos fallidos complotistas son los mismos que actualmente se encuentran trabajando en nuestra patria para destruir nuestra integridad nacional, y uncirnos al yugo socialista manejado por Moscú, son los mismos que aliados con los traidores a la revolución mexicana que se han infiltrado y controlan a los politicos corrompidos que integran el gobierno y que pretenden infiltrarse en las de nuestro glorioso ejército nacional, para repetir en México lo que intentaron en Chile, y por el valor y el coraje de sus fuerzas armadas no pudieron aplicar.

Es evidente que el primer paso será en nuestro país desintegrar el ejército nacional, dedicándolo a trabajos agrícolas en las granjas colectivas comunistas que el gobierno, imitando al fracaso ruso y al fracaso cubano, quiere propagar en el país. El segundo paso será desvirtuada la verdadera labor del Ejército Nacional de defensor de la patria y del pueblo, desprestigair sistemáticamente a jefes $y$ oficiales y proceder en el momento decisivo al asesinato en masa de los jefes y oficiales.

Queça pues claramente demostrado que la matanza de oficiales del ejército es el paso previo que los comunistas tienen que dar para tomar el poder total, y para reafirmar esto basta recordar lo que los comunistas hicieron en Indonesia cuando con la complicidad del Presidente Sukarno estuvieron a punto de tomar el. poder al final de la década de los 60. En el libro "Peligro Subversión en América", el General Manuel Benítez nos narra los siguientes hechos que acontecieron en Indonesia en aquel tiempo;.... "los comunistas buscaron en sus domicilios a los generales más importantes que formaban el alto mando militar y a seis de ellos los eliminaron en una forma feroz... Ál General Yani le volaron la cabeza con dinamita. Al General Harjono lo acribillaron a balazos en su casa. Pero ellos fueron los más afortunados. Otros Generales y un coronel, los entregaron a un grupo delirante de cien mujeres comunistas, las cuales se lanzaron sobre los generales que se encontraban inermes, se mofaron de ellos, les pegaron y con afiladas navajas y cuchillos fueron cortándoles poco a poco el cuerpo. A algunos les sacaron los ojos, luego los metieron en una fosa que cubrieron con basura..."

En este caso como en Chile, los comunistas fracasaron por la rápida y enérgica actitud de los Generales Suharto y Nasution, quienes en un par de días pusieron en pie de guerra al ejército indonesio, derrocaron al traidor presidente de la República sukarno, responsable del plan de destrucción del ejército y de la liquidación de los jefes y oficiales, cerraron los locales comunistas, clausuraron los perídicos comunistas y al enterarse el pueblo de la matanza de jefes $y$ oficiales del ejércita se desató una réplica popular que terminó con treinta mil comunistas indonesios que al.enfrentarse con el pueblo enardecido por los cobardes asesinatos de los jefes militares, y al conocer los planes de esclavización de su patria que tenịan los rojos para Indonesia, el pueblo acabó con ellos.

Pero desgraciadamente en otros países los comunistas sí han tenido éxito y gracias a sus hipocresías y engaños han logrado tomar el poder e inmediatamente han desatado terribles matanzas contra los jefes y oficiales de los ejércitos. como en Rusia, donde todo se hizo con la complicidad del jefe del Estado Alejandro Kerensky, ya que saben que son su principal obstáculo para la dominación total de los pueblos, en Rusia después de que los bolcheviques trabajaron arduamente paras pueblos, en Rusia dército, provocar desórdenes y descontento en las filas, provocar la moral des permitió provocaron la sublevación contra los después dedicarse a la brutal campaña de exterminio de los jefes del ejército, asesinando en un año a más de cINCUENTA MIL POLICIAS. 


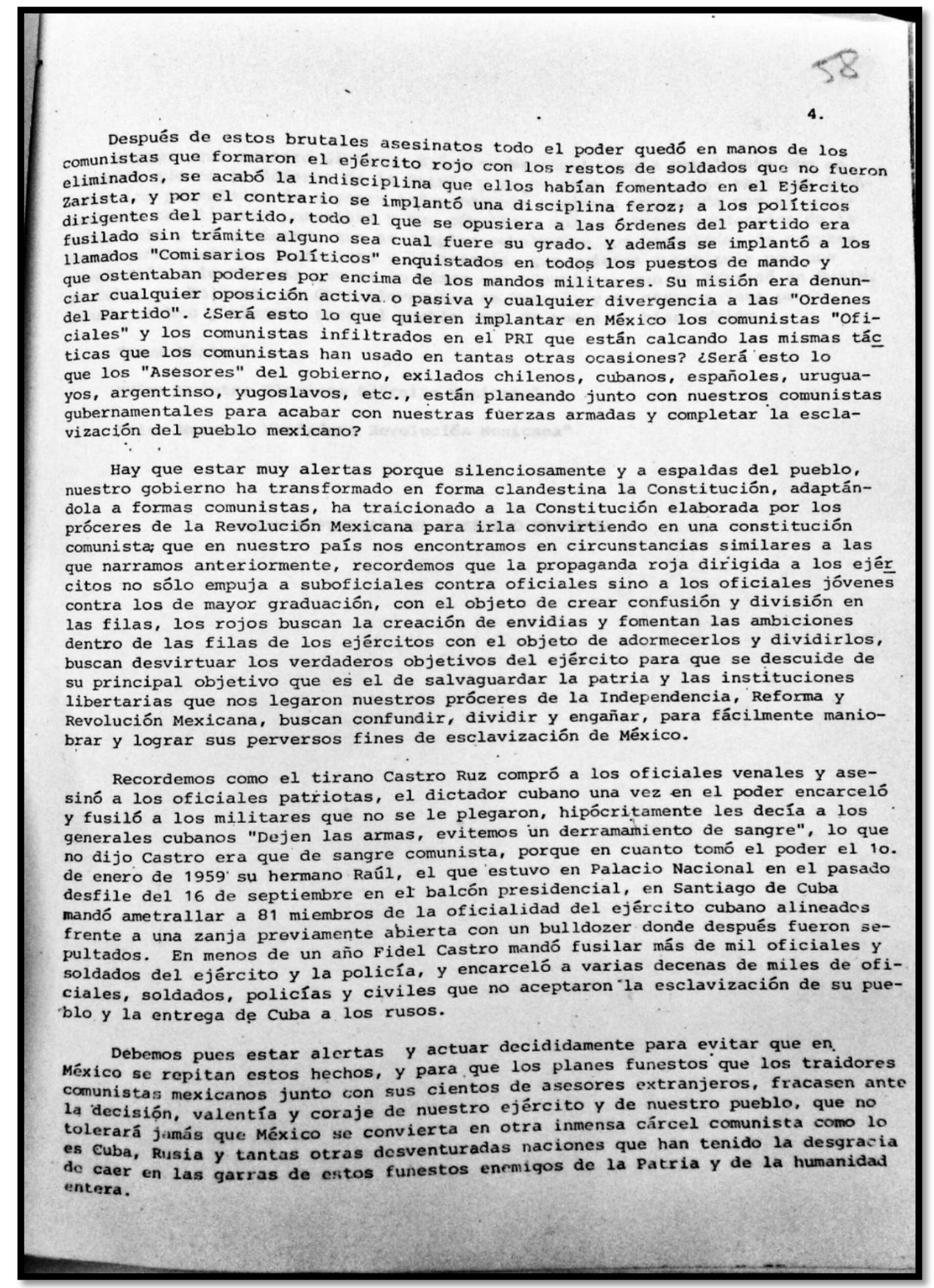


5.

. Hagamos que nuestro Glorioso Ejército Nacional cumpla cabalmente con su cometido que es la defensa de la Patria y de nuestro pueblo, que mantenga incólumes los postulados de nuestra independencia nacional amenazada por el imperialismo totalitario comunista y sus cómplices colectivistas apoderados de la burocracia y el gobierno, que se cumplan cabalmente los postulados de nuestra Revolución Mexicana justiciera y libertaria, que quieren substituir por una Revolución colectivista que es lo mismo que comunista; que ya fracasó en Rusia, en Cuba, en Polonia, en Checoslovaquia, en Hungría.y en otros países produciendo hambre y miseria para el pueblo como de todos es bien sabido.

"Viva México"

"Viva Nuestro Glorioso Ejército Mexicano"

"Viva Nuestra Verdadera Revolución Mexicana"

UNION DEFENSORA DEL EJERCITO NACIONAL 


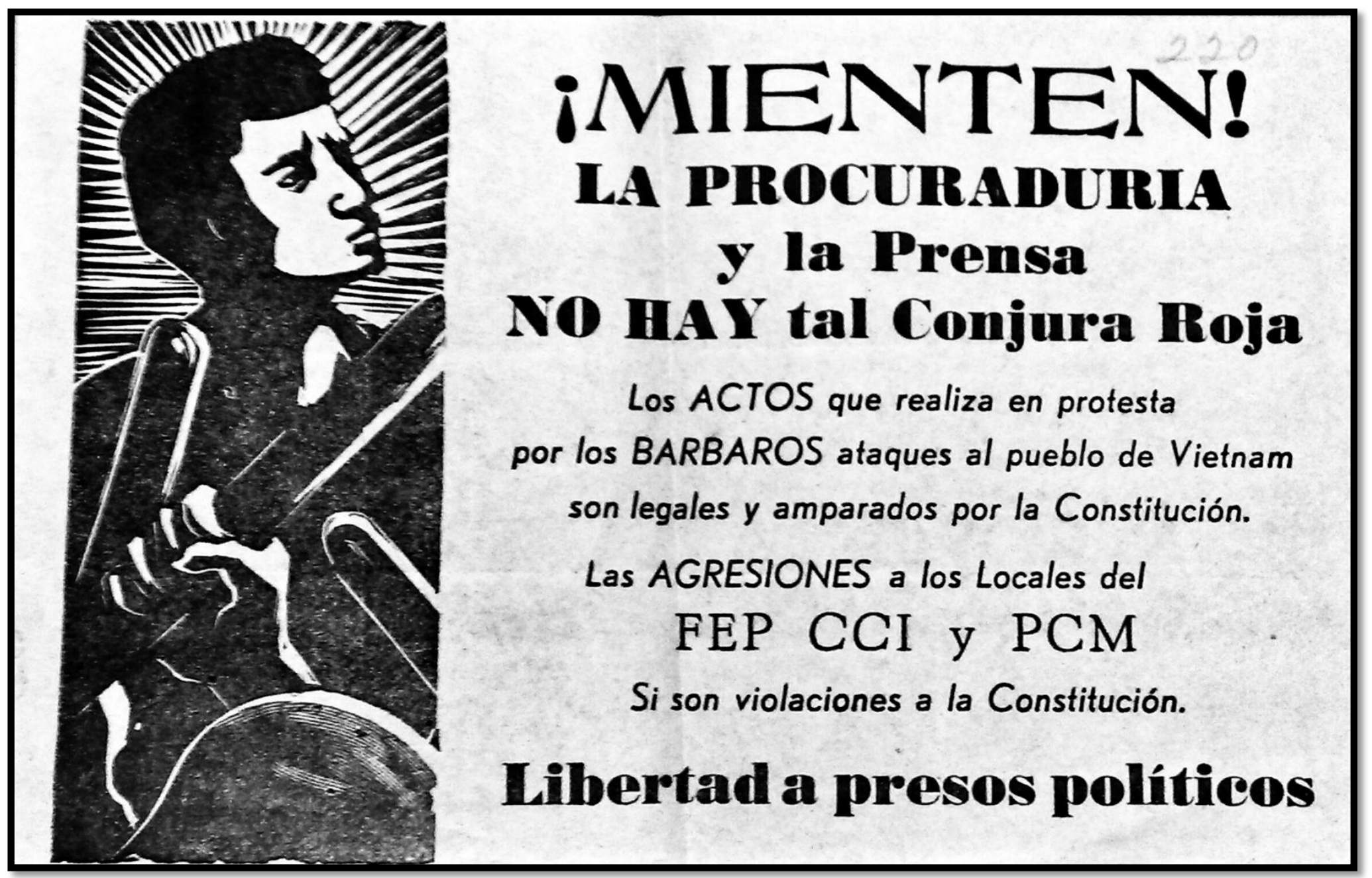

Fig. 18. "!Mienten!" Puebla, 04-06-64, AGN, IPS, Caixa 1573 A, Exp. 1, folha 1. 
27-XII-66.

Ayer por la noche ful visitado por el Sr. GUSTAVO ALA TKISTE, Director General de la Revista "Sucesos", el cual me manifestó que te nía deseos de conocerme, ya que en su úl timo viaje que efectuó a La Habana, Cuba, del 2 al 12 del presente mes, habla tenido una amplia conversación con el Dr. FIDEL CASTRO KUZ, Primer Ministro de ese --.país, el cual le había platicado sobre mi persona en forma elogiosa y le pidió que en cuento llegara a México me trajera un saludo e in-sistió en que yo visitara ese país.

GUSTAVO ALATRISTE se encuentra impresionado del desarrollo de la República de Cuba con el nuevo Régimen Kevolucionario de FIDEL CASTRO y expresa que sus viajes a ese pals obedecen a que va a realizar una pelfcula relativa a FILEL CASTRo como revolucionario, como hombre y como polftico, la cual comenzará a filmar el próximo dia 2 de enero, motivo por el cual el viernes 30 del actual saldrá nuevamen te a La Habana por espacio de 10 a 12 dias y posteriormente regresará para permanecer allá de 3 a 4 meses. Considera que será un éxito - esta pelĺcula, dado el tema que se toca y la forma en que la va a rea lizar con una nueva técnica cinematográfíca.

Hablo de su revista y de la nueva proyección que se le ha -dado, señalando que es una revista revolucionaria y libre, lo que sepuede comprobar en el último número en donde el Partido Comunista Mexicano ataca a la propia revista en forma severa, por sus articulos -

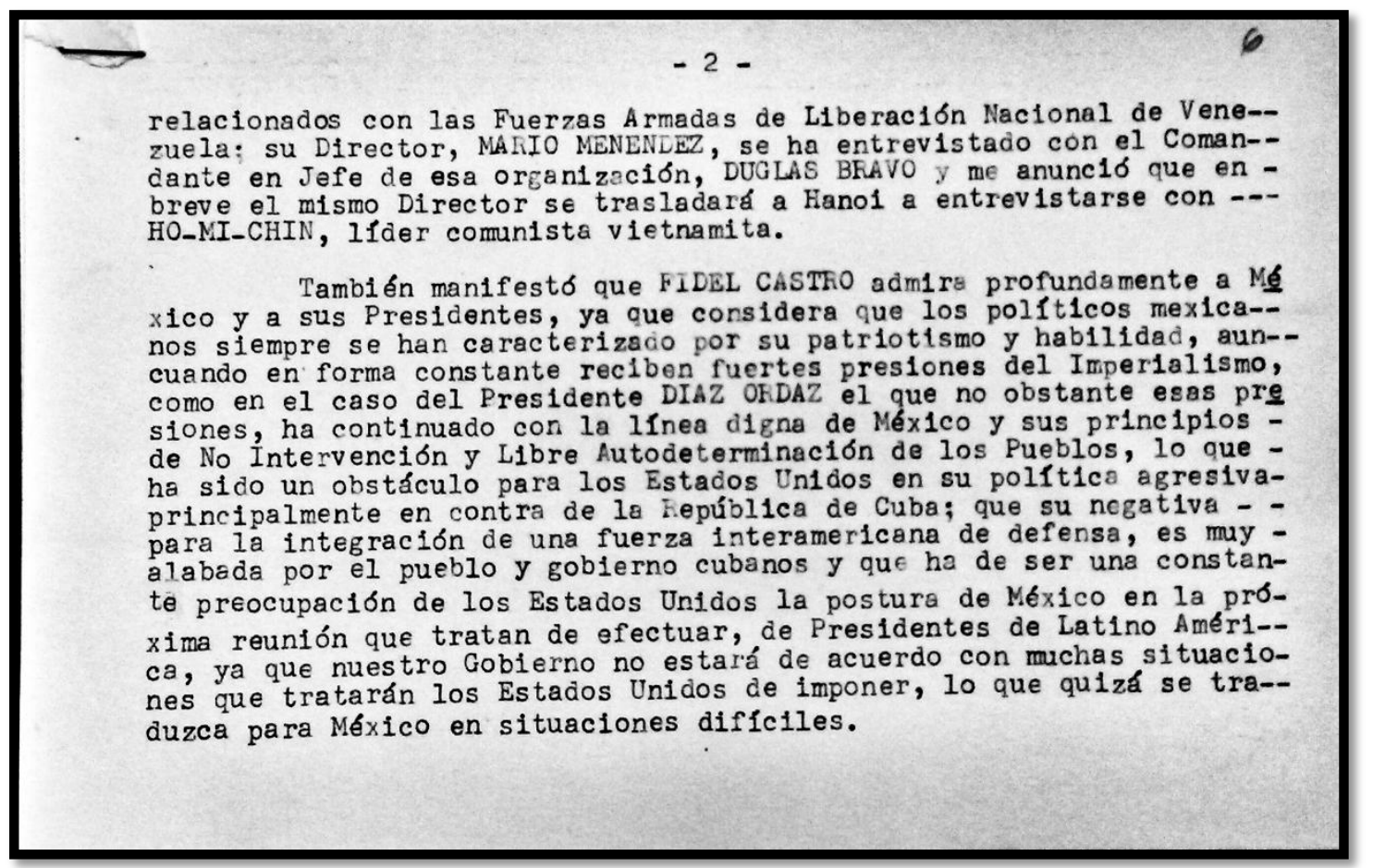

Fig. 19. Distrito Federal, 27-12-66, AGN, IPS, Caixa 1467 B, Exp. 10, folhas 1-2. 


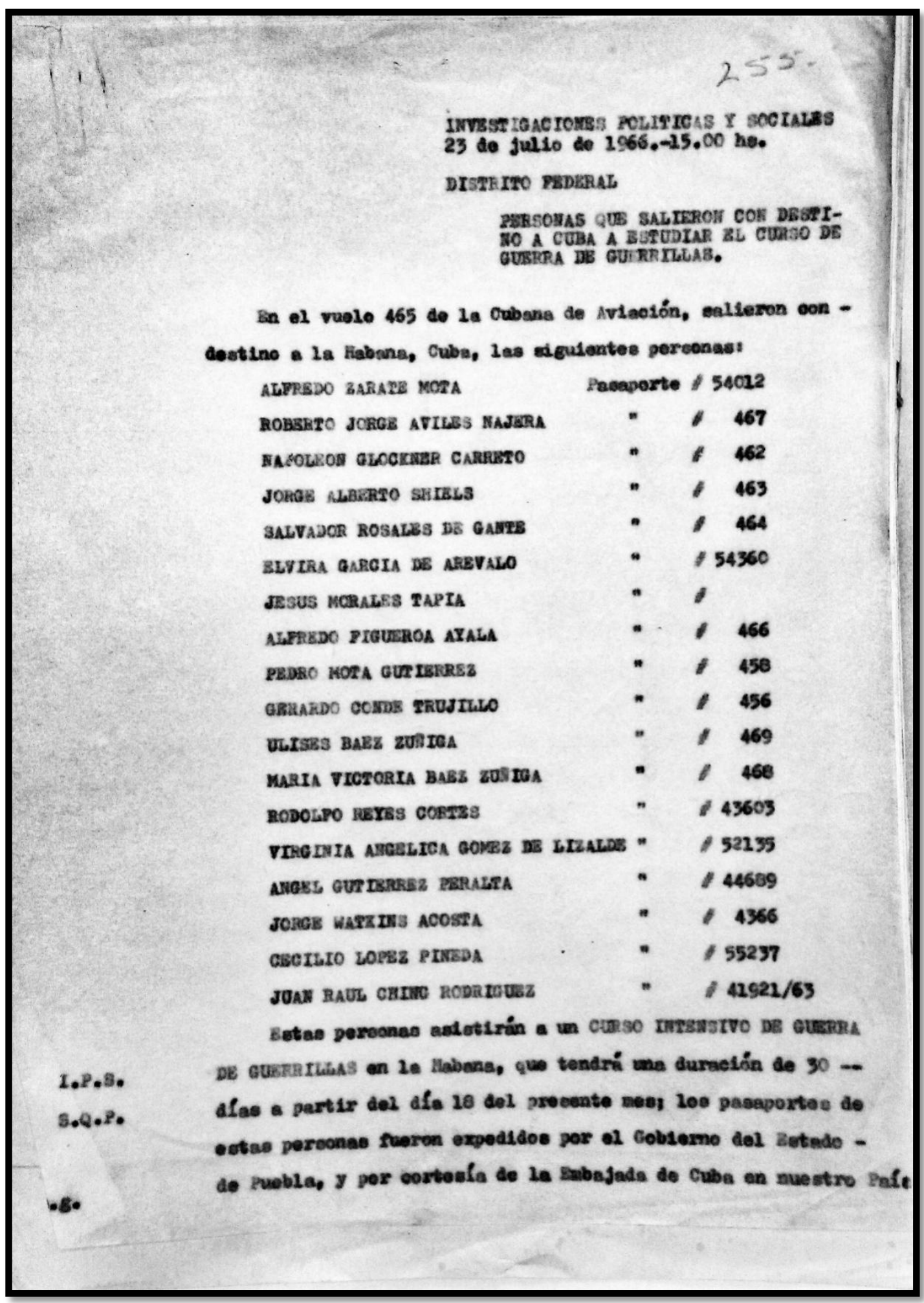

Fig. 20. "Personas que salieron con destino a Cuba a estudiar el curso de guerra de guerrillas", Distrito Federal, 23-07-66, AGN, IPS, Caixa 826, Exp. 8, folha 1. 


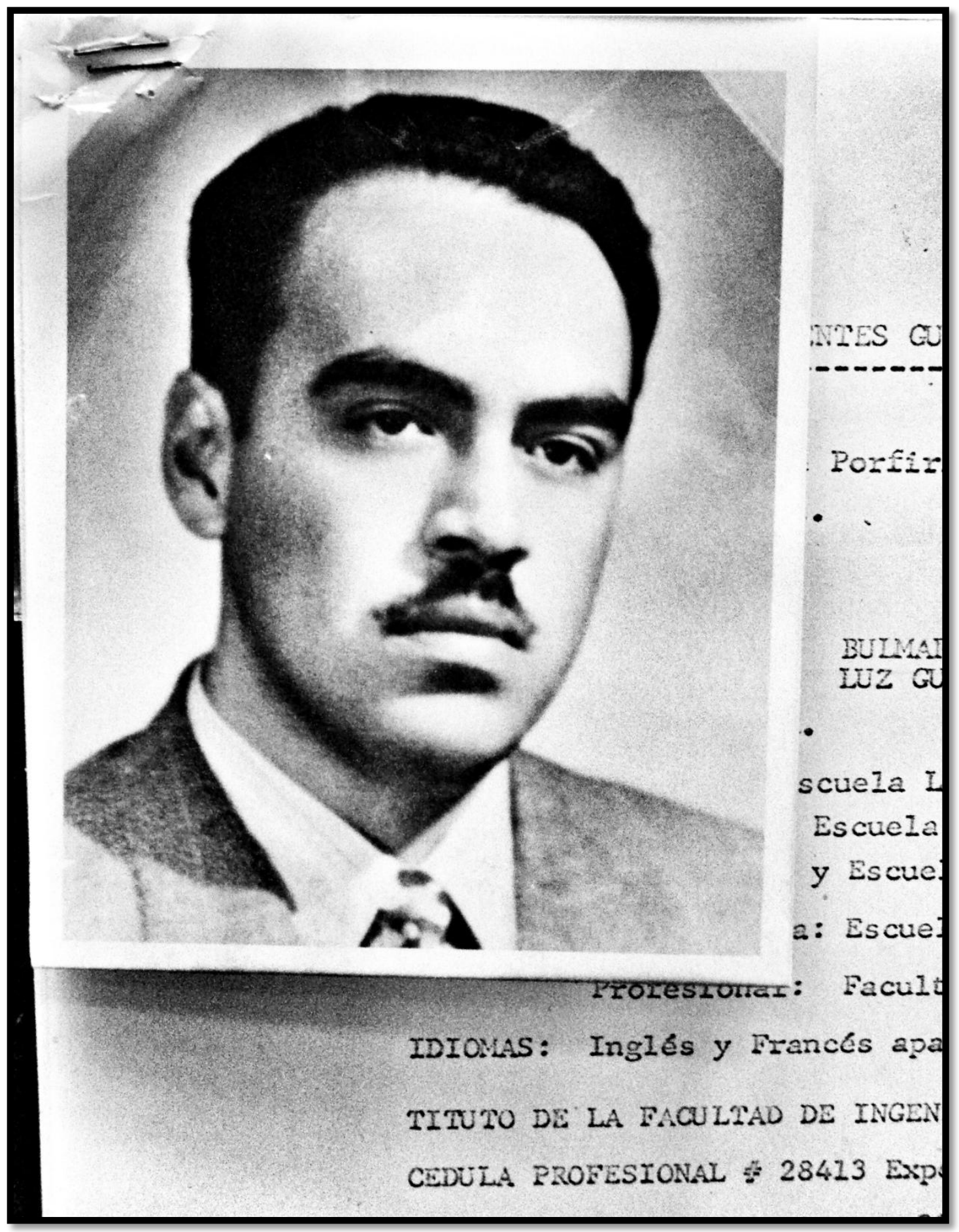

Fig. 21. "Ingeniero Javier Fuentes Gutiérrez", Distrito Federal, AGN, IPS, Caixa 3033 A, Exp. 12, foto. 

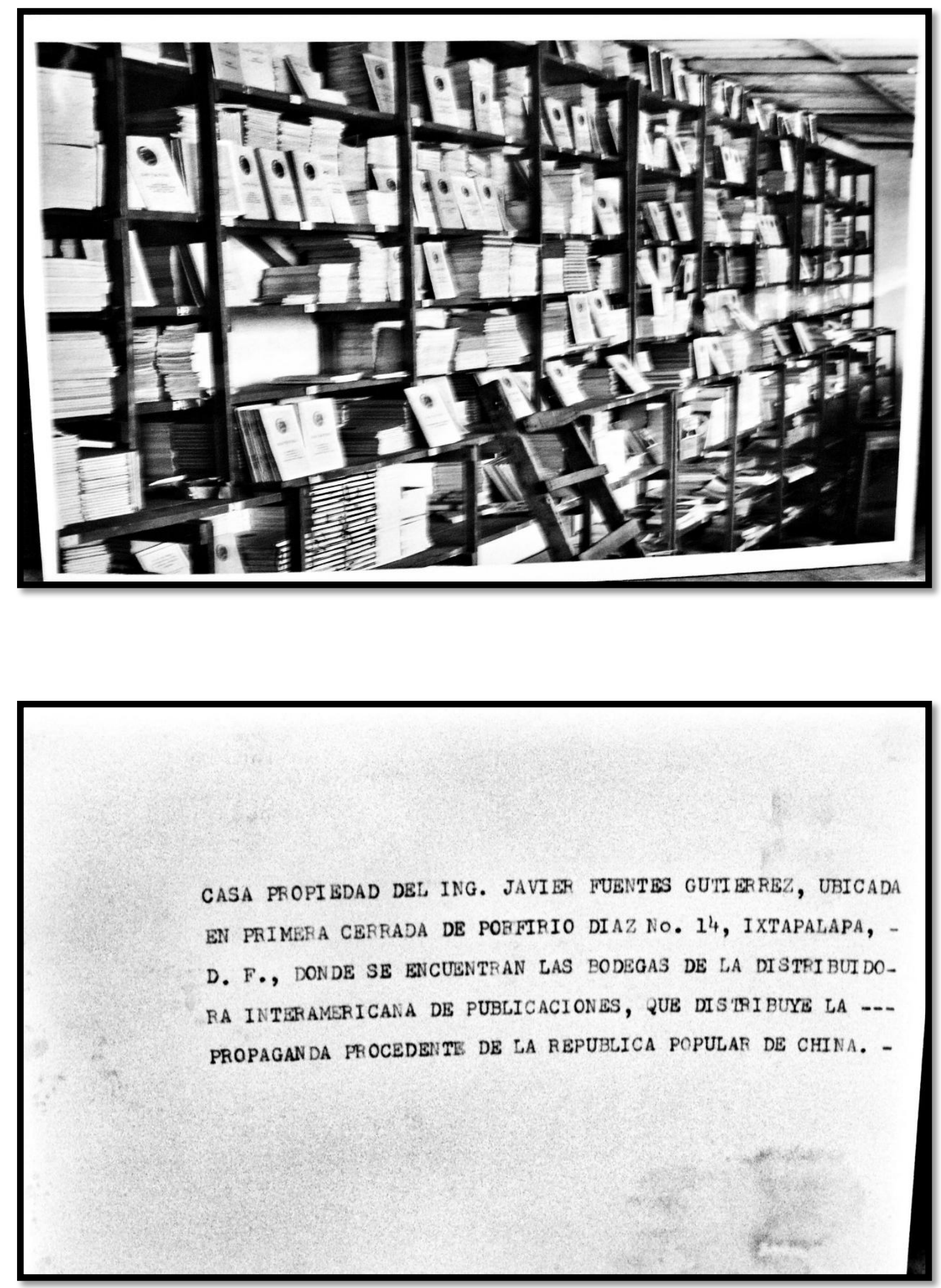

Fig. 22. Distrito Federal, 19-07-67, AGN, IPX, Caixa 3033 B, Exp. 6, fotos 3 de 17 (frente e verso). 

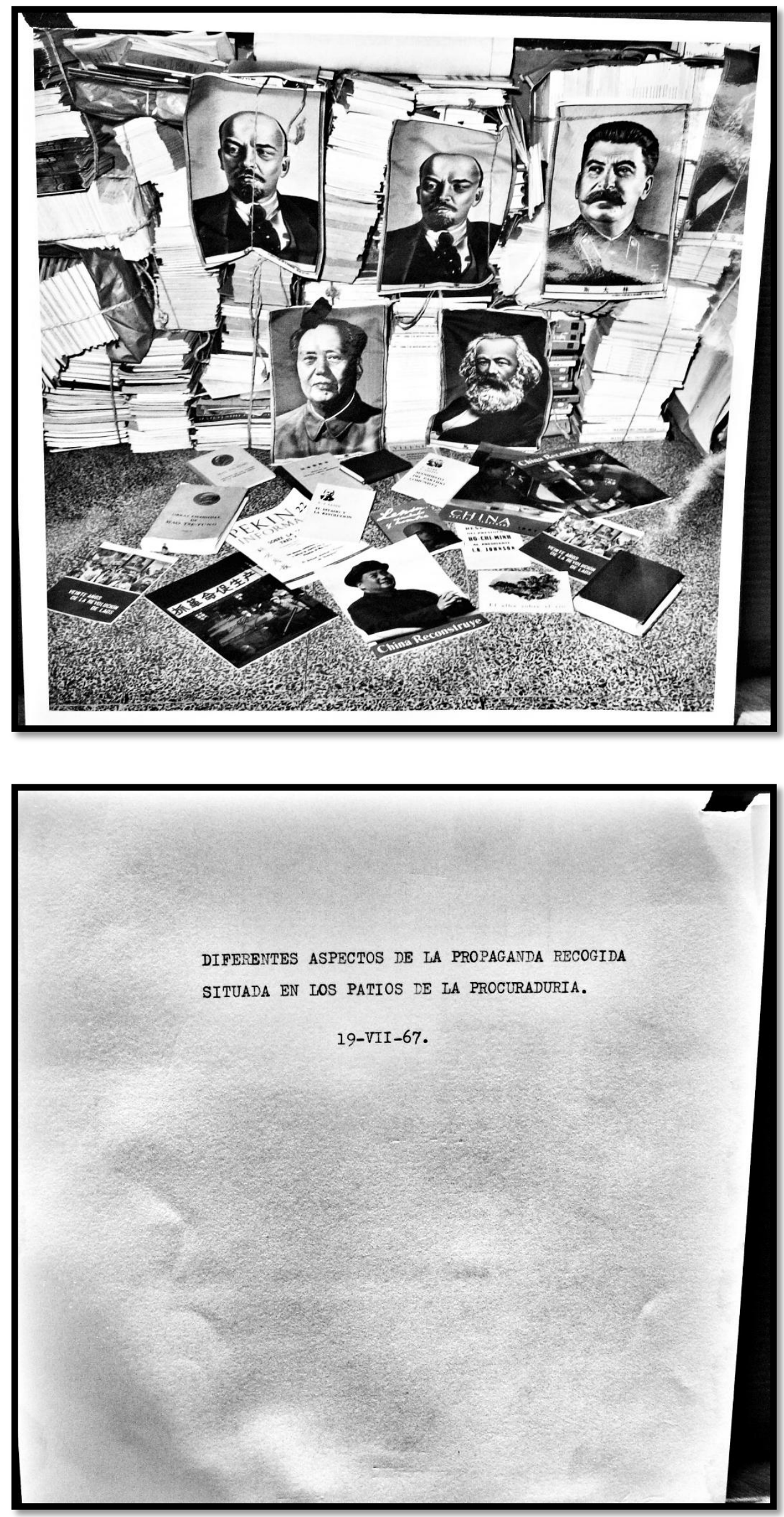

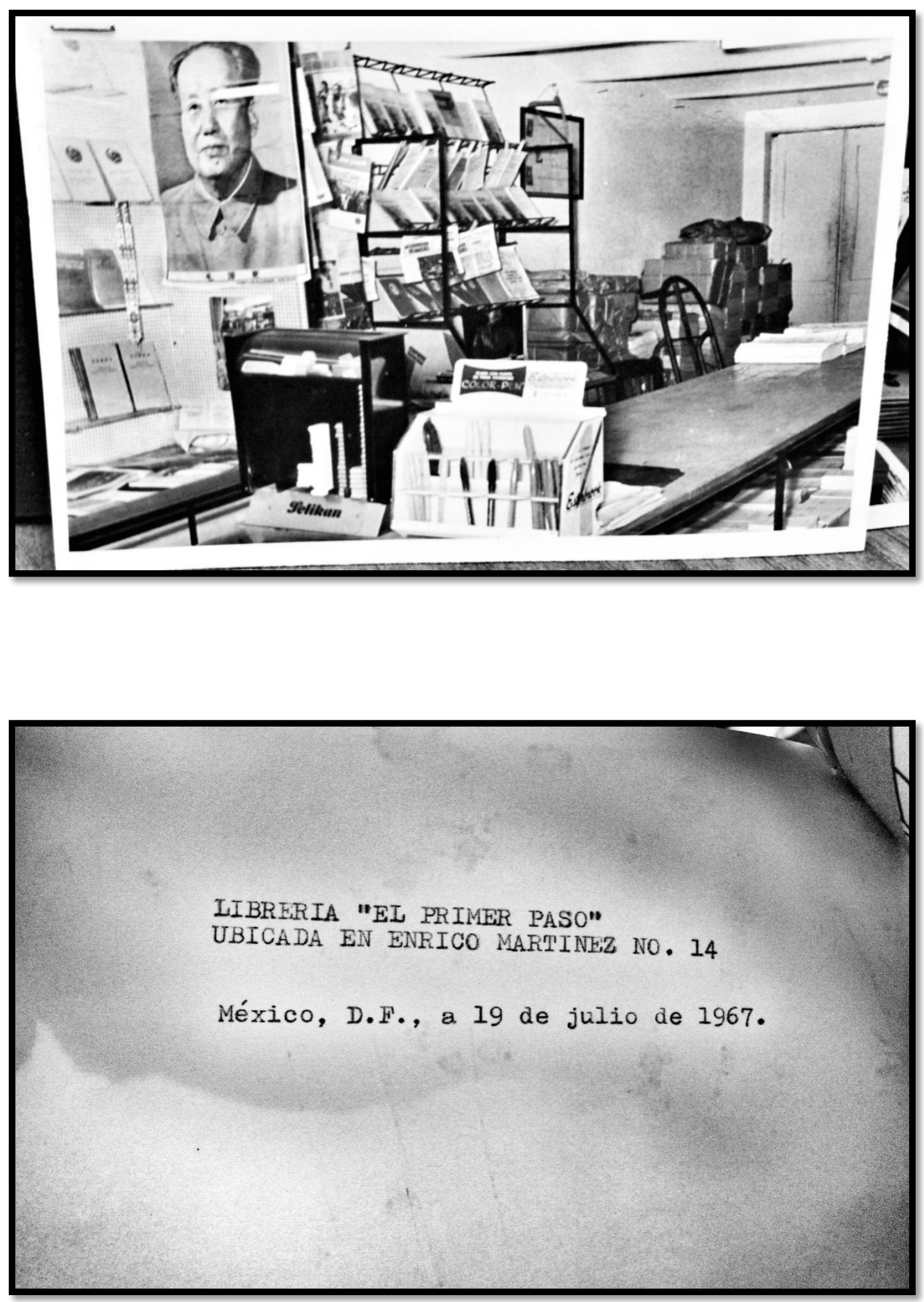


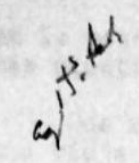

C. DIRECTOR FEDERAL DE SEGURIDAD

Presente.
ASUNTO: Se informa sobre elementos subversivos detenidos en la Jefatura de Policia.-

México, D.F., a 24 de enero de 1968.

\section{A NTECEDENTES :}

El Servicio Secreto de la Jefatura de Policla del D.F., a través de un contacto que trabaja para esta corporación confidencialmente de nombre SILVANO CANACHO CASTILLO, don domícilio en Calzada de Tlalpan \# 898 Departamento 8 Colonia Villa de Cortés, recibio información en el sentido de que elementos radicales de izquierda, que se entrenaban en la guerra de guerrillas intentaban cometer un acto de atentado fisico con motivo de la visita del Presidente de la República de El Salvador y por tal motivo procedieron, el pasaclo día 22 del actual a detener a estas personas, siendo interrogadas $\mathrm{y}$ dando como resultado lo siguiente:

\section{E $\underline{\mathrm{C}} \underline{\mathrm{L}} \underline{\mathrm{A}} \underline{\mathrm{R}} \underline{\mathrm{A}} \underline{\mathrm{C}} \underline{\mathrm{I}} \underline{\mathrm{O}} \underline{\mathrm{E}} \underline{\mathrm{E}} \underline{\mathrm{S}}:$}

FELIPE VILLANUEVA VELEZ, con domicilio en Toribio Medina -número 116 Col Algarin, fue estudiante de Ciencias Químicas habiendo estudiado hasta el tercer año, abandonando sus estudíos por -causas economicas y en la actualidad explota una pequeña tienda de abarrotes propiedad de su Padre que se encuentra enfermo. En 1966 conoci6, durante una conferencia en el Movimiento de Liberación Nacional al estudiante MARTIN SANCHEZ GOMEZ con el cual cambió impresiones sobre las ideologlas de izquierda en la actualidad en el ámbito internacional, conociendo al mismo tiempo, en ese mismo sitio a ARTURO TORRES CLLZ, JUAN RAMIREZ RODRIGUEZ, y WIS MARTINEZ GARCIA acordando todos ellos, que el único camino de instaurar en México un gobiemo socialista, serf́a mediante una lucha armada y nó con el sistema que las diferentes ideologfas agrupadas en varios grupos planeaban mediante la transición pacfifica. Por lo que acordaron sin previa elaboración de programa polltico efectuar primeramente entrenamiento físico y de tiro en el Ajusco, por lo que tuvieron varias reuniones en el Jardín de $\mathrm{S}_{\mathrm{a}} \mathrm{n}$ Fernando donde todos y cada uno de ellos colaboraron con una pequeña cantidad de dinero comprando en este un rifle calibre 22 y empezaron a realizar las llamadas -excursiones en el cerro del Ajusco en donde practicaron tiro e -hicieron ejercicios físicos. El declarante al tener conocimiento de química les proporciono varias fórmulas para elaborar explosivos que se utilizarlan el dí que en México algún partido o grupo polftico formara un ejército nacional para la lucha armada de liberación nacional. Estos, dada su preparación tendrfan la facilidad de unirse a dicha lucha. Que realizaron prácticas sobre lanzamiento de bombas molotov en el Pedregal, sitio que escogieron ya que no era peligroso porque el fuego no se extendfa y que ahí probaron que incluyendose

Fig. 23. "Se informa sobre elementos subversivos detendidos en la Jefatura de Policía", HARO, Nazar. Distrito Federal, 24-01-68, AGN, IPS, Caixa 3033 A, Exp. 15, folhas 1- 


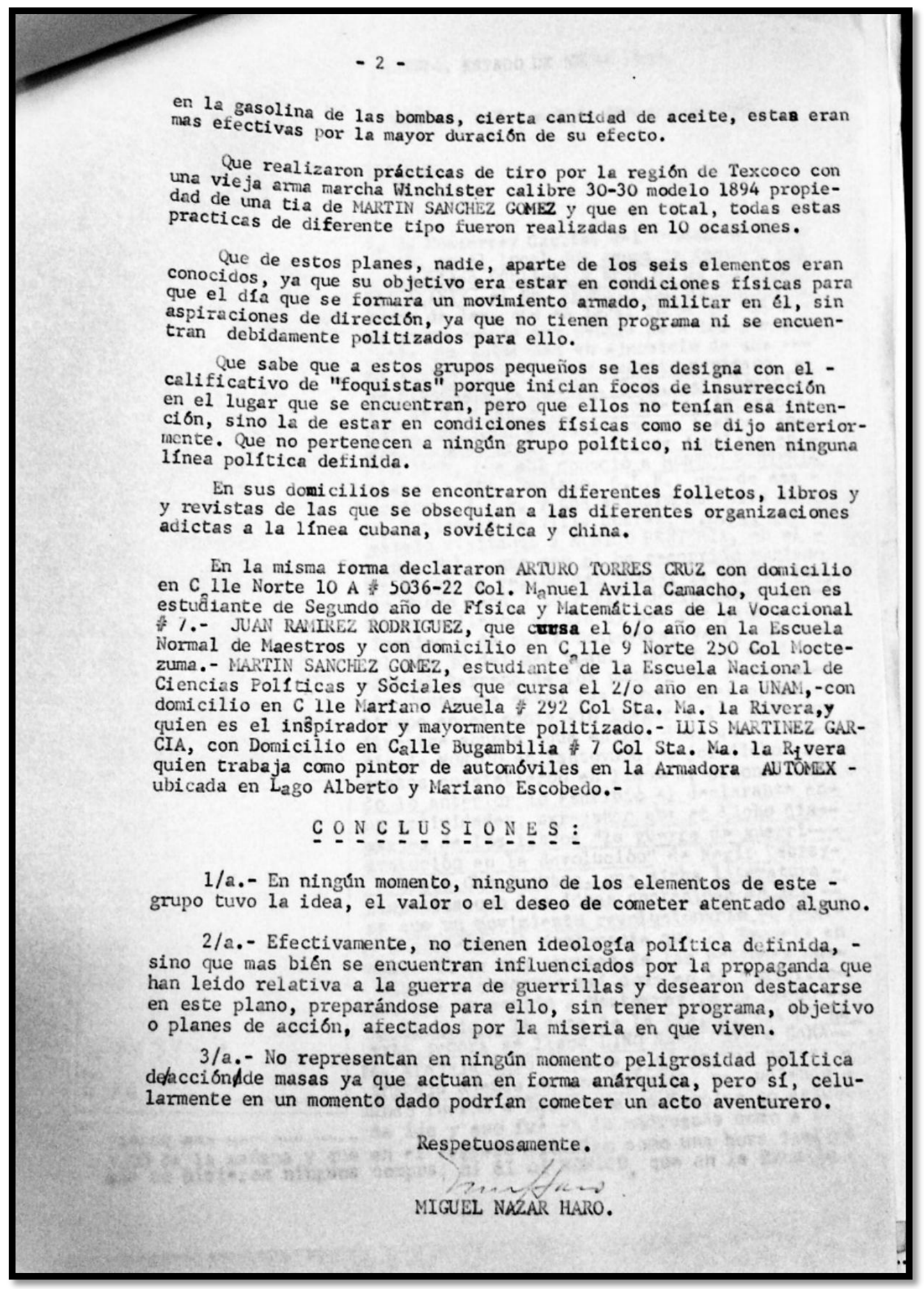




$$
8
$$


REUNION EFECTUADA EL DOMINGO 8 DE MAYO DE 1966.

A LAS 10 DE LA MAÑANA NOS TRASLADAMOS A LOMA LINDA, EDO. DE MEXICO; LA SRA. ANA MARIA, EL SR. SERAFIN "BONNY", CARLOS AGUILERA Y YO.

NOS REUNIMOS CON TRES DIRIGENTES RESULTANDO SER UNO DE ELLOS "PANCHO" A QUIEN YA HE MENCIONADO.

"PANCHO" PERTENECIO AL EJERCITO, FUE SARGENTO 10. Y EN SU PLATICA DIJO QUE CON CIERTA FRECUENCIA SE REUNE CON SOLDADOS A LOS QUE HA IDO ATRAYENDO PARA FORMAR UN PEQUEÑO GRUPO, A ESTE GRUPO TAMBIEN ASISTEN ALGUNOS OFICIALES DEL EJERCITO. "PANCHO" CONSIDERA- is QUE LLEGADO EL CASO SERAN DE MUCHA UTILIDAD TANTO PARA ENSEÑAR EL MA NEJO DE LAS ARMAS COMO PARA MANEJARLAS Y PARA SABOTEAR LAS UNIDADES DONDE SE ENCUENTRAN, PERO SEGUN PARECE NO SE LES HA DICHO NADA DEL MOVIMIENTO

"PANCHO" ES EL ENCARGADO DE CONSEGUIR LAS ARMAS EN LOS CUARTELES Y PLATICO QUE HACE ALGUNOS AÑOS LLEGO A REUNIR HASTA 200 ARMAS, PERO QUE AHORA LA SITUACION ES DIFICII. Y DELICADA PORQUE HAY MUCHOCONTROL SOBRE EL ARMAMENTO.

ESTE INDIVIDUO TIENE UNA HORRIBLE CICATRIZ EN LA MEJLLLA DERECHA COMO DE 10 CENTIMETROS DE LARGA; VIVE EN LOMA LINDA Y EN LA PUERTA DE SU CASA TIENE UN ESCUDO DEL P.R.I., SEGUN DICE, PARA QUE NO LO MOLESTEN,

DURANTE TODA LA MANANA TUVIMOS CONVERSACIONES CON ESTAS TRES PERSONAS EXPONIENDOLES UN PROGRAMA MINIMO CON EL FIN DE QUE COTROLEN A LAS GENTES QUE YA TIENEN A SU FAVOR X ADEMAS OBTENGAN NUEVOS INGRESOS.

Fig. 25. "Reunión efectuada el domingo 8 de mayo de 1966", Distrito Federal, 08-05-66, AGN, IPS, Caixa 2938, Exp. 27, folha 1. 


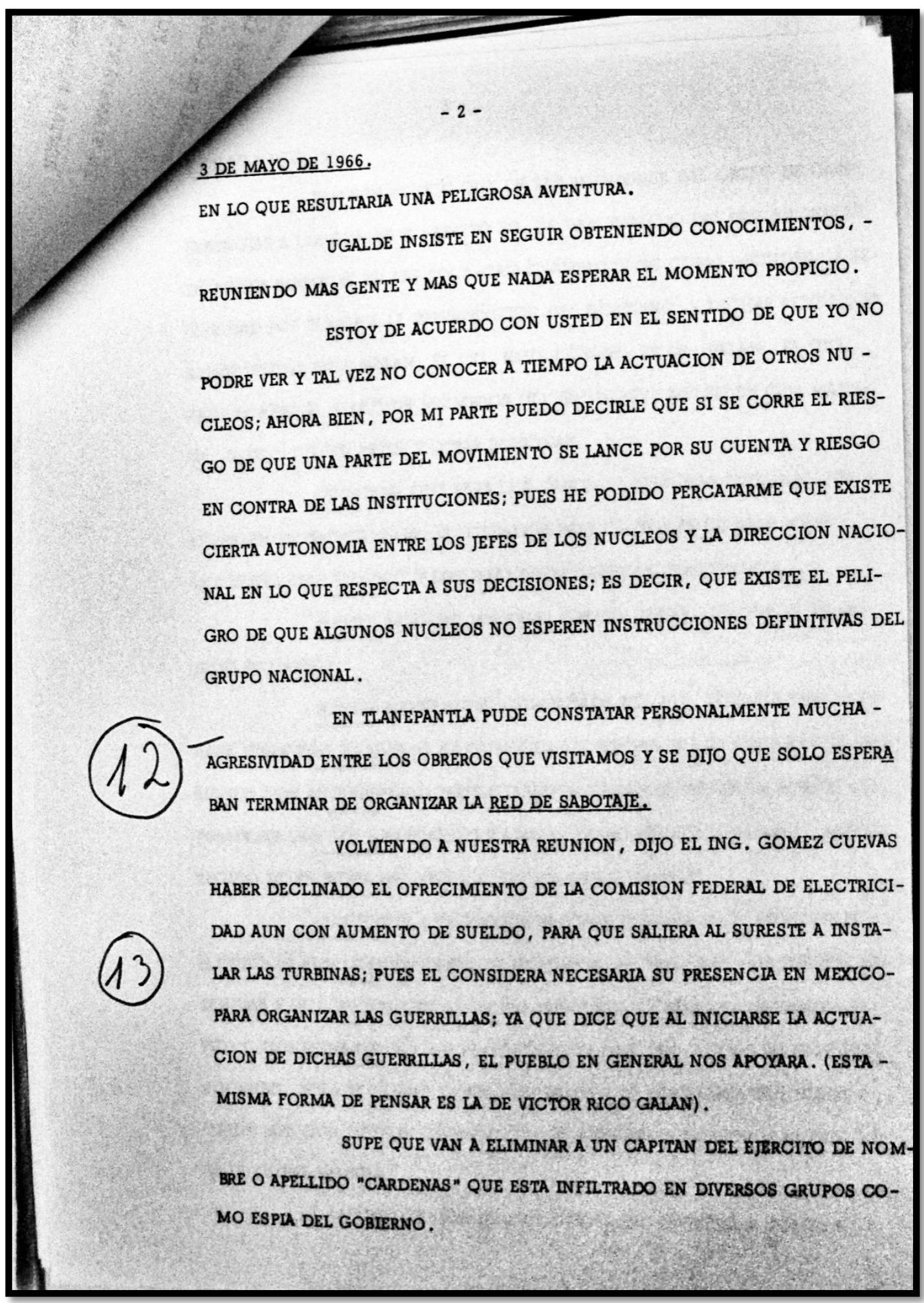

Fig. 26. "Reunión efectuada el martes 3 de mayo de 1966". Distrito Federal, 03-05-66, AGN, IPS, Caixa 2938, Exp. 27, folhas 1-2. 


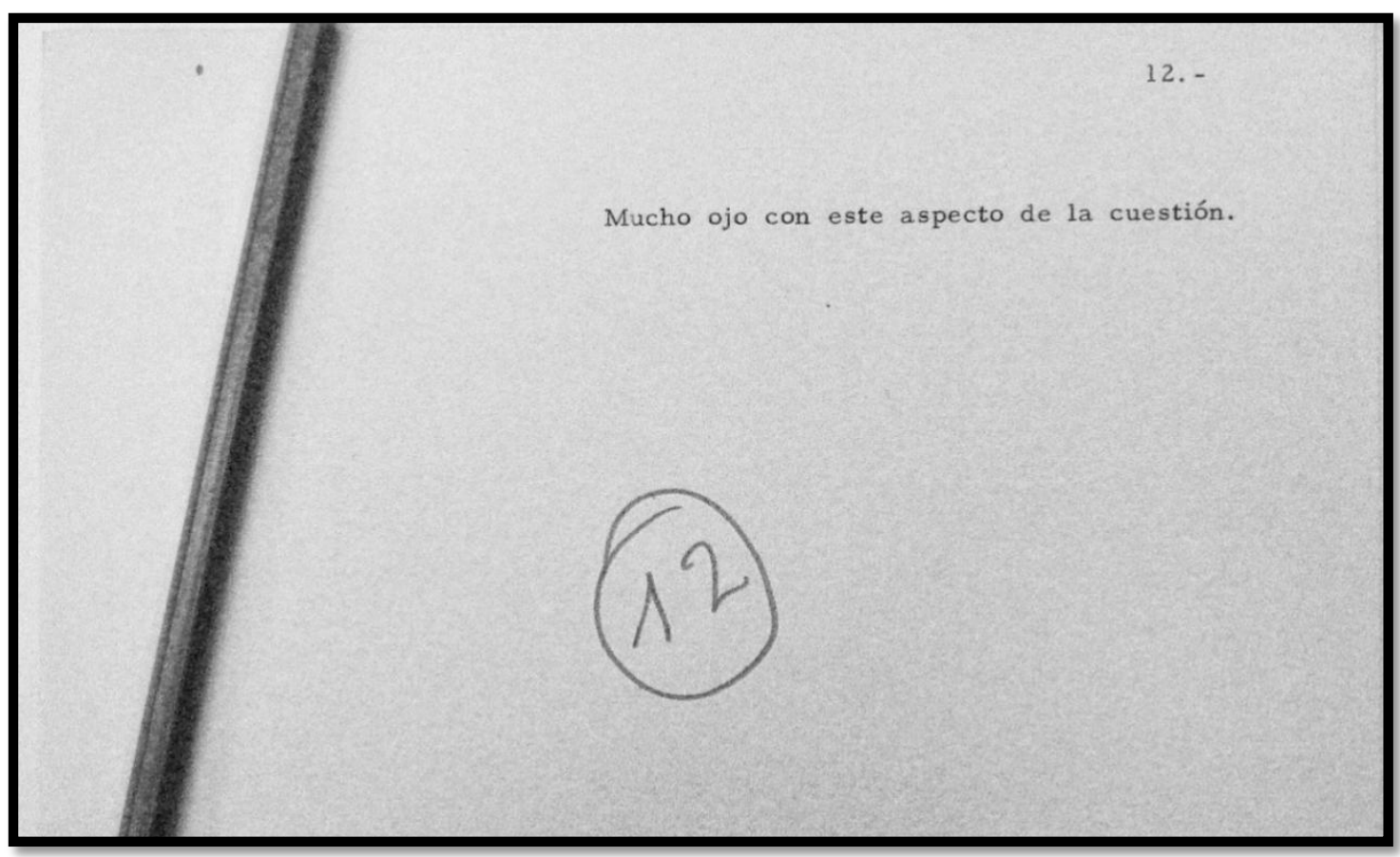

Fig. 26. c. 1966, AGN, IPS, Caixa 2938, Exp. 29, ficha 12.

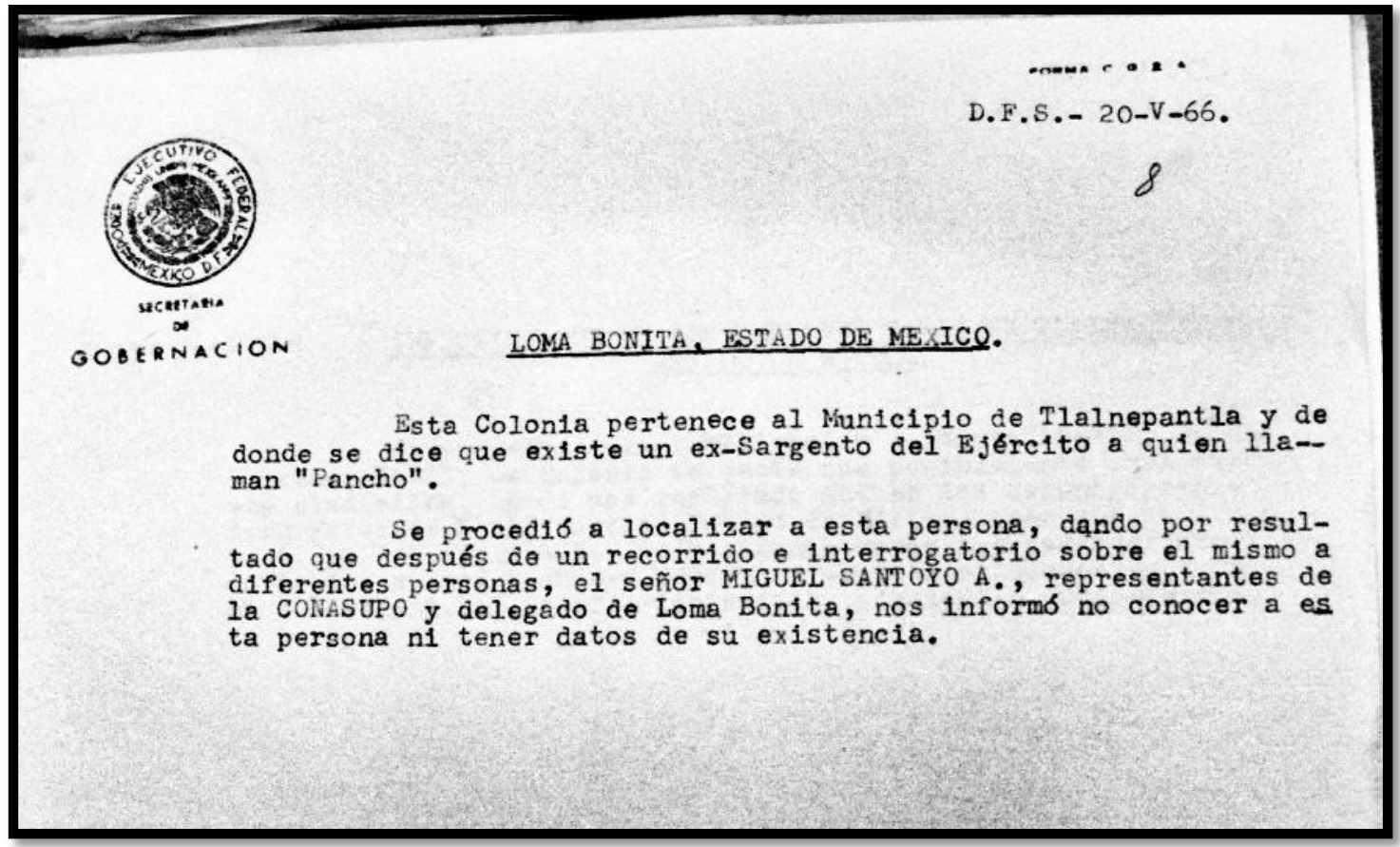

Fig. 26. "Loma Bonita, Estado de México", Distrito Federal, 20-05-66, AGN, IPS, Cixja 2938, Exp. 27, folhas 1-2 


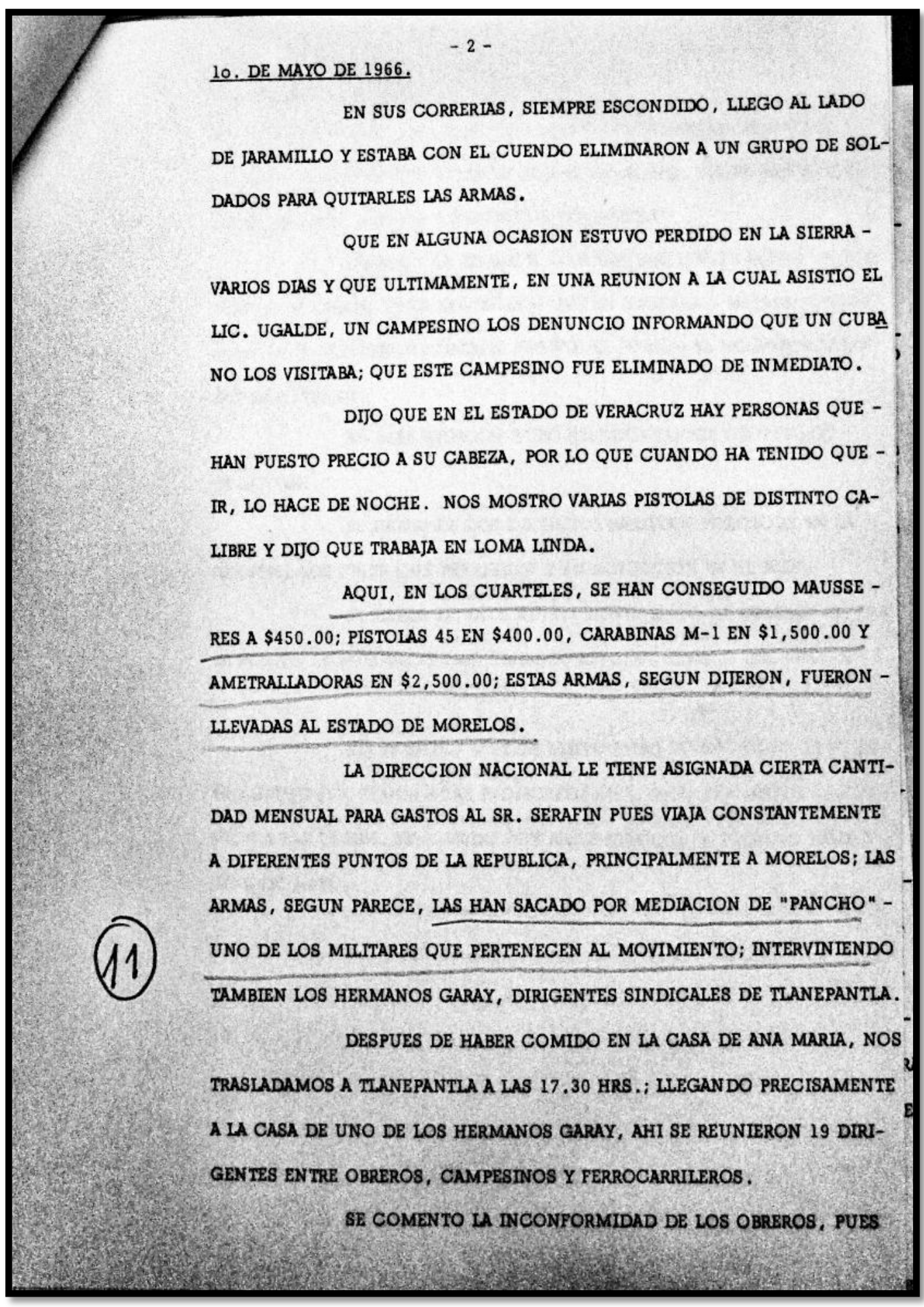

Fig. 26. Reunión efectuada el $1^{\circ}$. de mayo de 1966". Distrito Federal, 01-05-66, AGN, IPS, Caixa 2938, Exp. 27, folhas 1-2. 


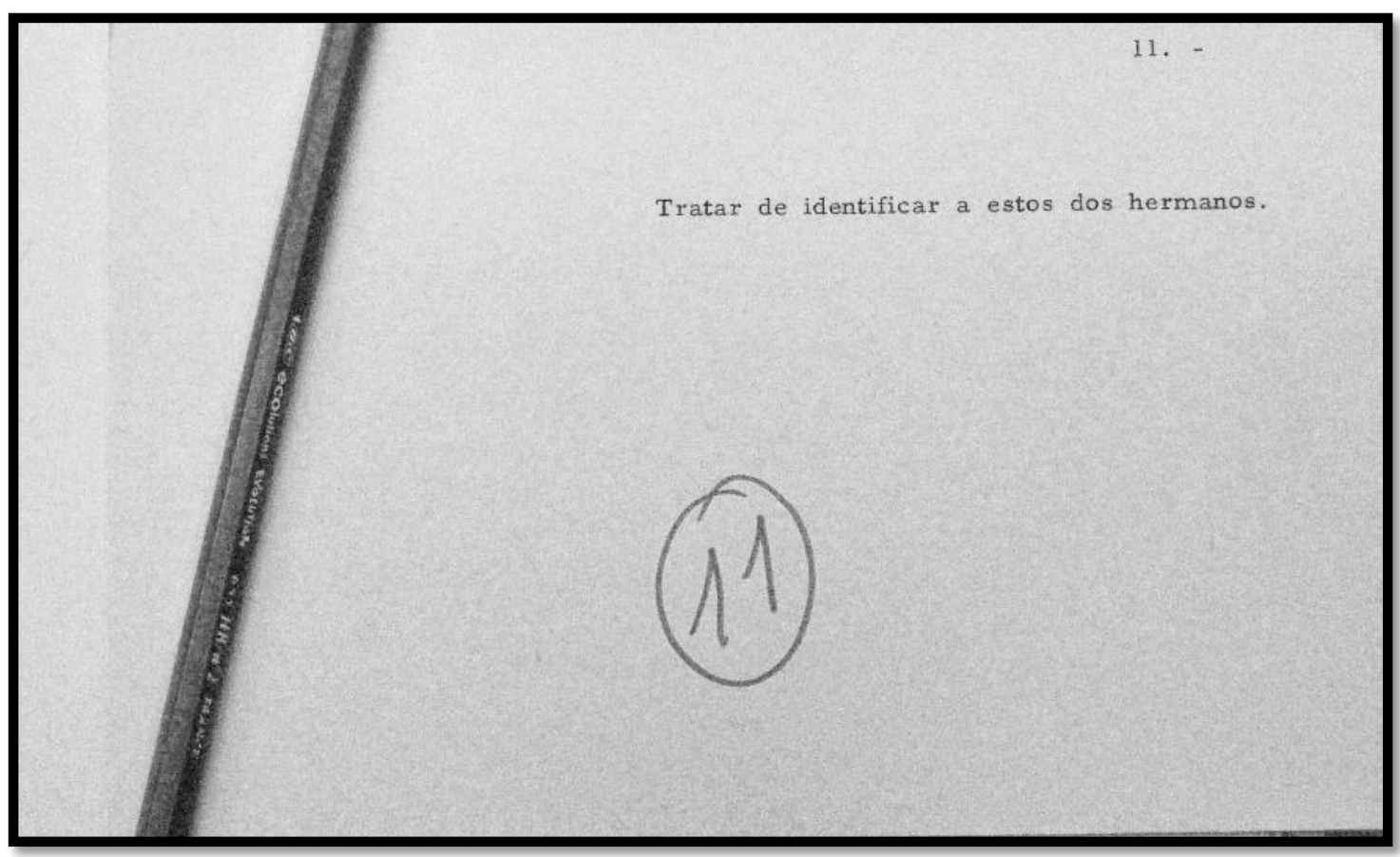

Fig. 26. c. 1966, AGN, IPS, Caixa 2938, Exp. 29, ficha 12.

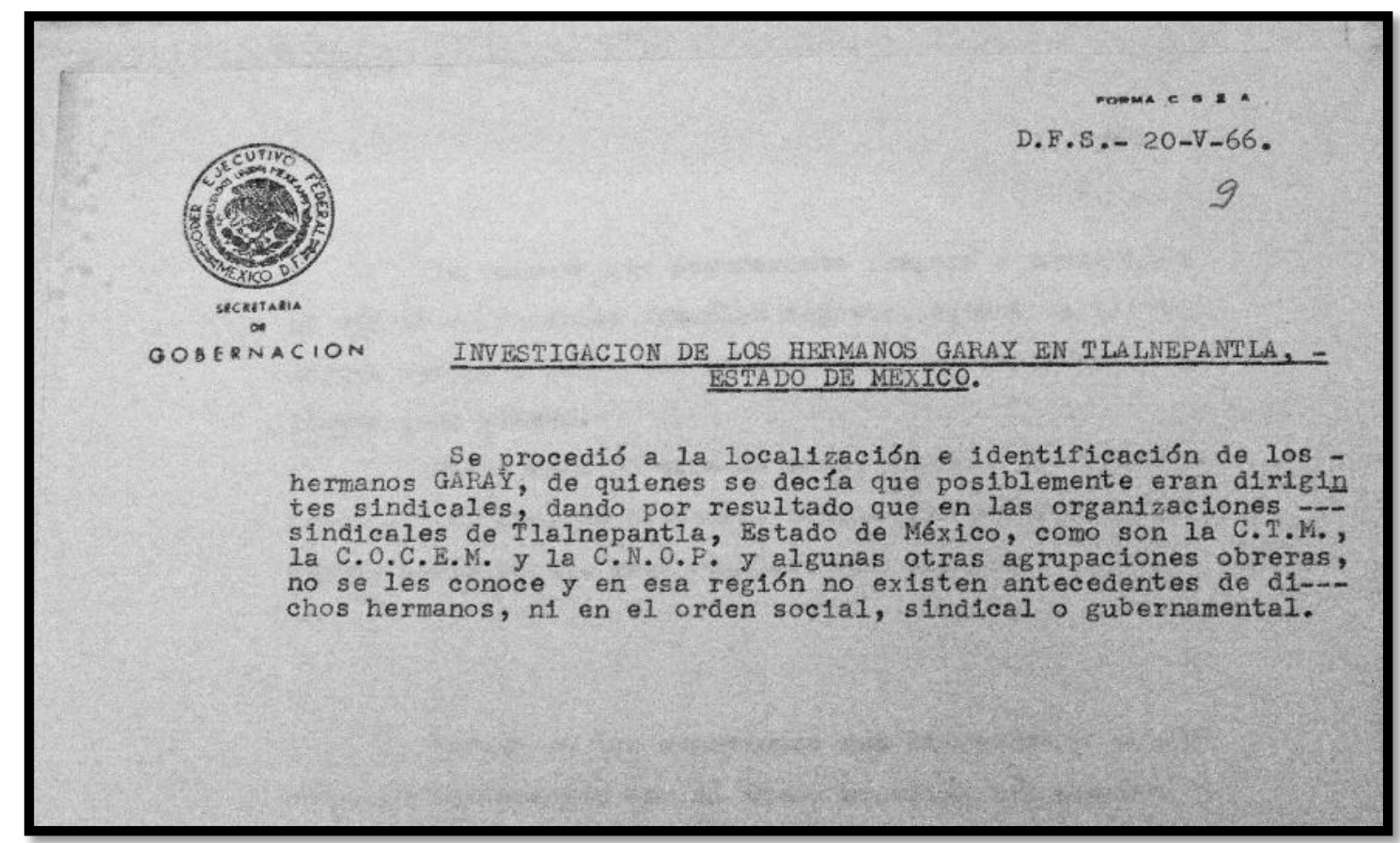

Fig. 26. "Investigación de los Hermanos Garay en Tlalnepantla, Estado de México", Distrito Federal, 20-05-66, AGN, IPS, Cixja 2938, Exp. 27, folhas 1-2. 
SIIUACION DE "Z".

ANOCHE, PARA HACER CONTACTO CON EL;PREVIA CITA, PUNTO Y HORA;TRANSCURRIERON DOS OCASIONES POR EL LUGAR PERO CONFIRME QUE DOS HORAS PARP
LO SEGUIAN.

SE INSITIO EN HACER CONTACTO POR SER LA ULTIMA VEZ Y DE ABSOLUTA NECESIDAD ASI PUDE SABE QUE:

LOS MIEMBROS DEL MOVIMIENTO SIENTEN LA VIGILANCIA, LO COMENTAN Y SOSPECHAN YA DIRECTAMENTE DE "Z".

UNO DE LOS MIEMBROS LE DIJO CLARAMENTE QUE SI ALGO PASA,EL SERA RESPONSABLE PORQUE SOLO EL SALE DE LA ESCUELA.

HACE VARIOS, CON PRETEXTOS, LE RECOGIERON LA PISTOLA. HAN VISITADO SU CASA

"Z"QUE EN CASO DE IR A DETENERLOS, NO SE USE LA CLAVE DEL TBMBRE DE ENTRADA PORQUE SOLO EL LO SABE FUERA DE LA ESCUELA Y SE. DENUNCIARIA.

OUE TODOS IOS MIEMBROS O CASI TODOS TIENEN ARMAS INDIVIDUALES.

QUE EL DOMINGO VAN A RECIBIR INSTRUCCIONES ANTES DE SALIR A SUS LUGARES DE

ORIGEN Y QUE ALGUNOS SE QUEDARAN EN MEXICO AUNQUE SEAN FORANEOS.

SERA LA DEEPEDIDA EL DOMINGO EN LA HIDALGO.

"2" ESTA MUY NERVIOSO, NO SOLO ELLOS LO NOTAN;SE ADIVINA SU TEMOR $Y$ NO PUEDE REPRIMIRLO.

SE LE DIJO QUE NO TUVIERA CUIDADO QUE SE. LE DARIA TODA PROTECCION A EL Y A SU FAMILIA.

SE LE DIJO QUE DURANTE LOS PROXIMOS NUEVE DIAS, USE CORBATA NEGRA $Y$ DIGA QUE UN FAMILIAR DE SU SEÑORA, MUY QUERIDO DE EL, HABIA MUER TO EN LA PROVINCIA.

NO SE LE DIJO QUE HABRA ACTUACION, PERO SE LE DIJO QUE CON LA COR BATA SE LE PROTEGERA EN LA CALLE.

Fig. 27. “Situación de Z”, 1966, Distrito Federal, AGN, IPS, Caixa 2938, Exp. 39, folha 1. 


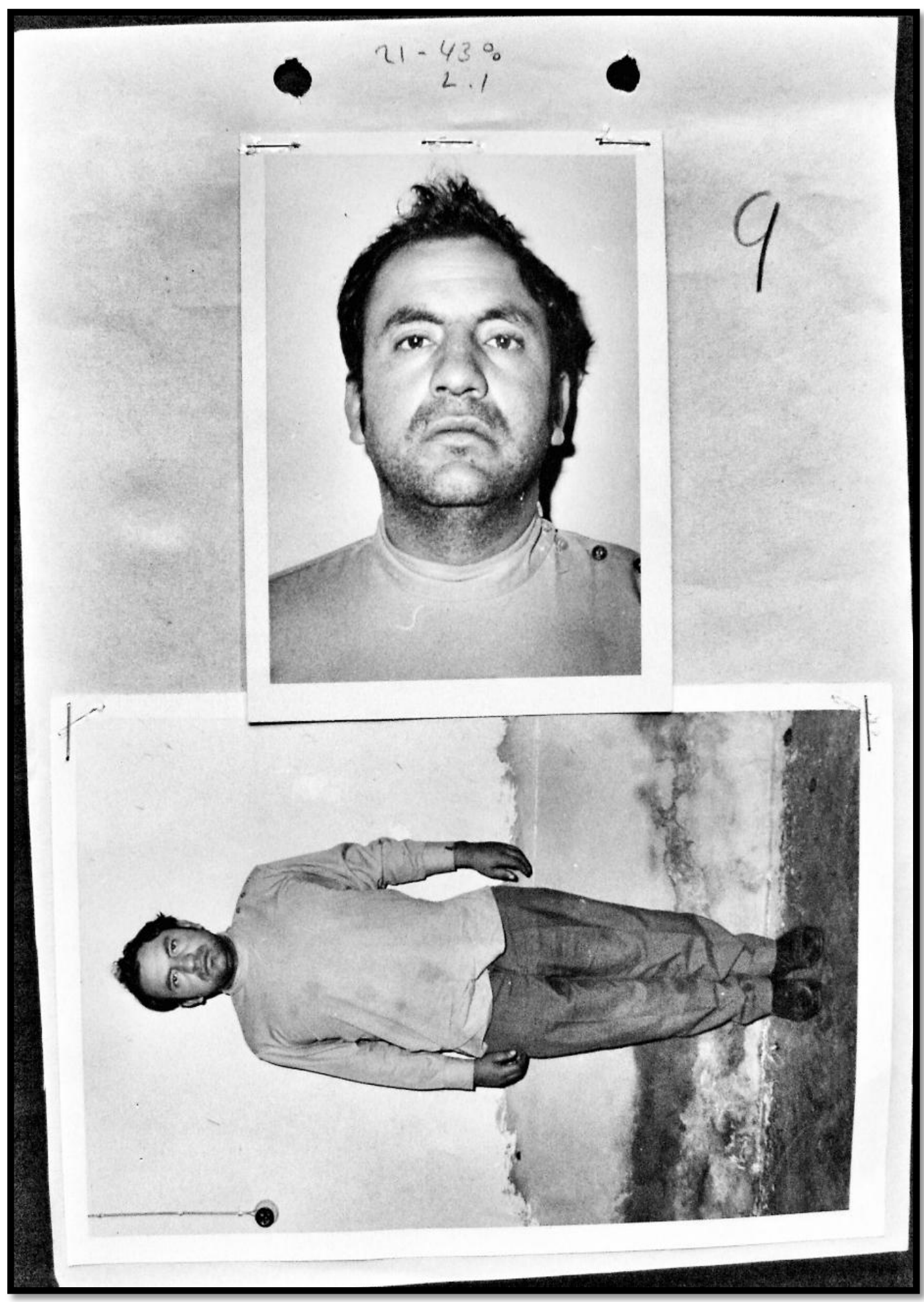

Fig 28. "Declaración de Gabriel Millán Arellano", Distrito Federal, 26-06-71, AGN, DFS, H1, L-1, Exp. 21-438-71. [Foto proporcionada por Rubén Ortíz] 


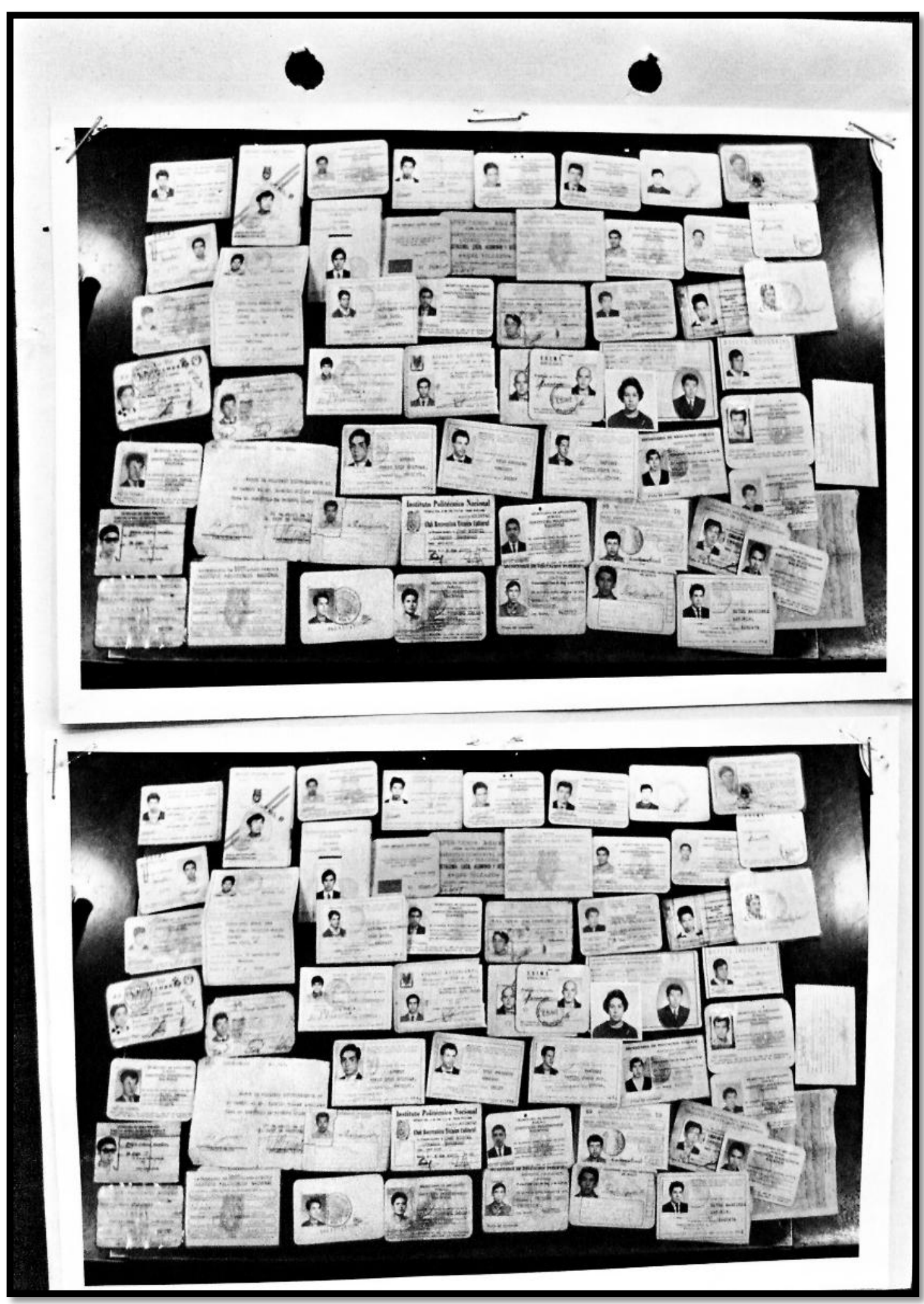




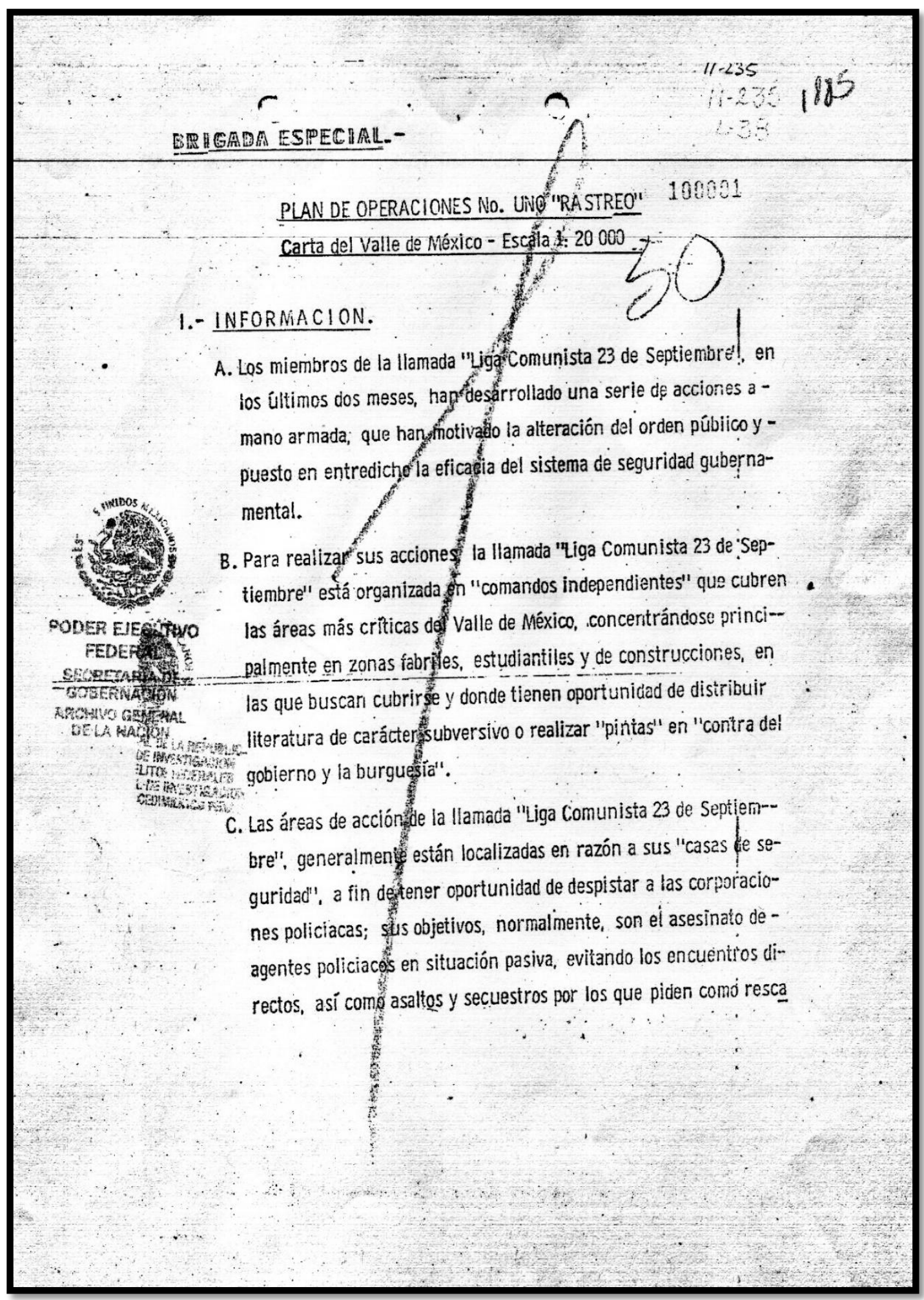

Fig. 29. "Brigada Especial. Plan de Operaciones No. 1 'Rastreo"”, Distrito Federal, 1976, AGN, DFS, H-50, L-38, Exp. 11-235-76, folhas 1, 2, 3, 8 de 8. 


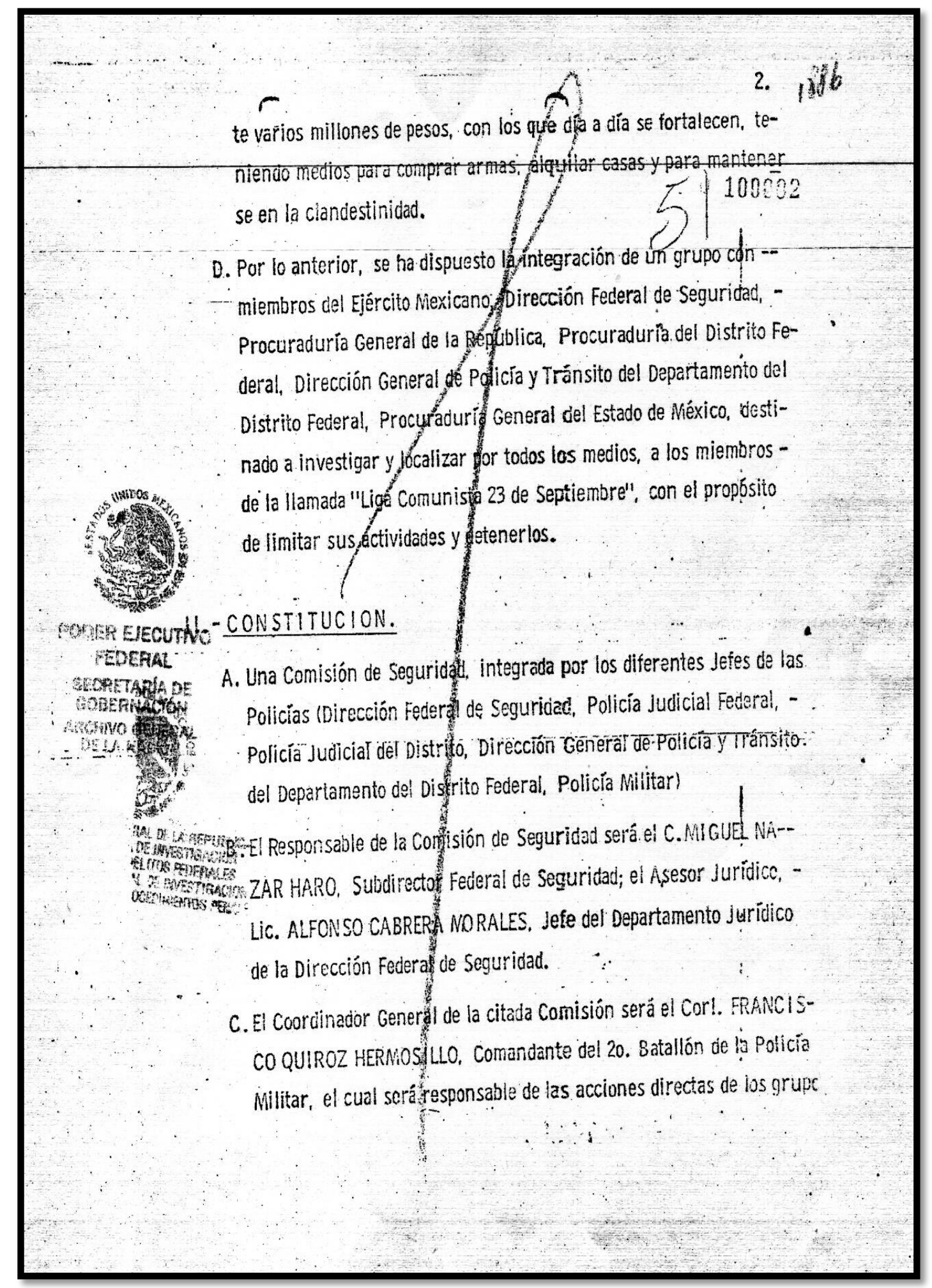




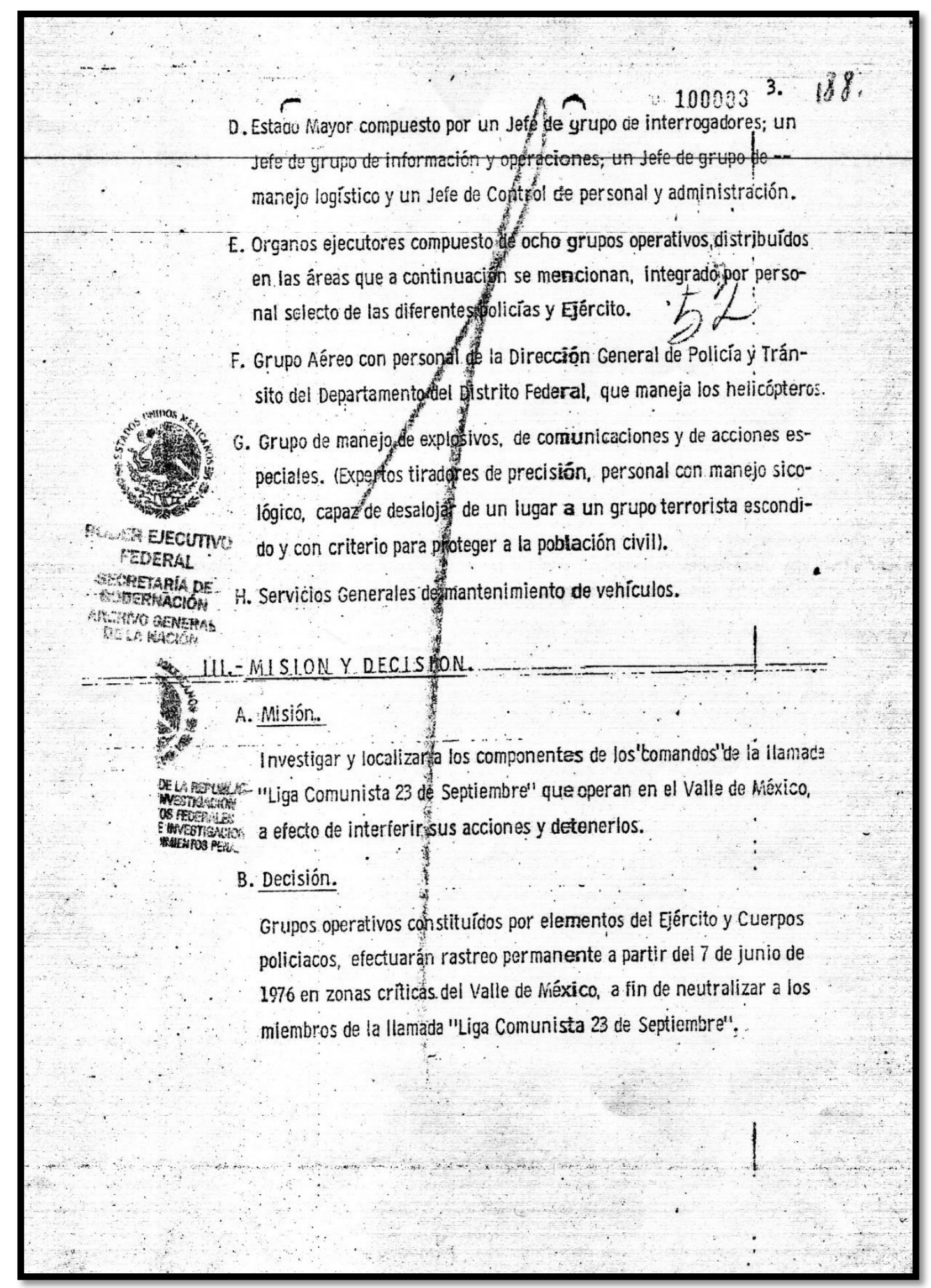




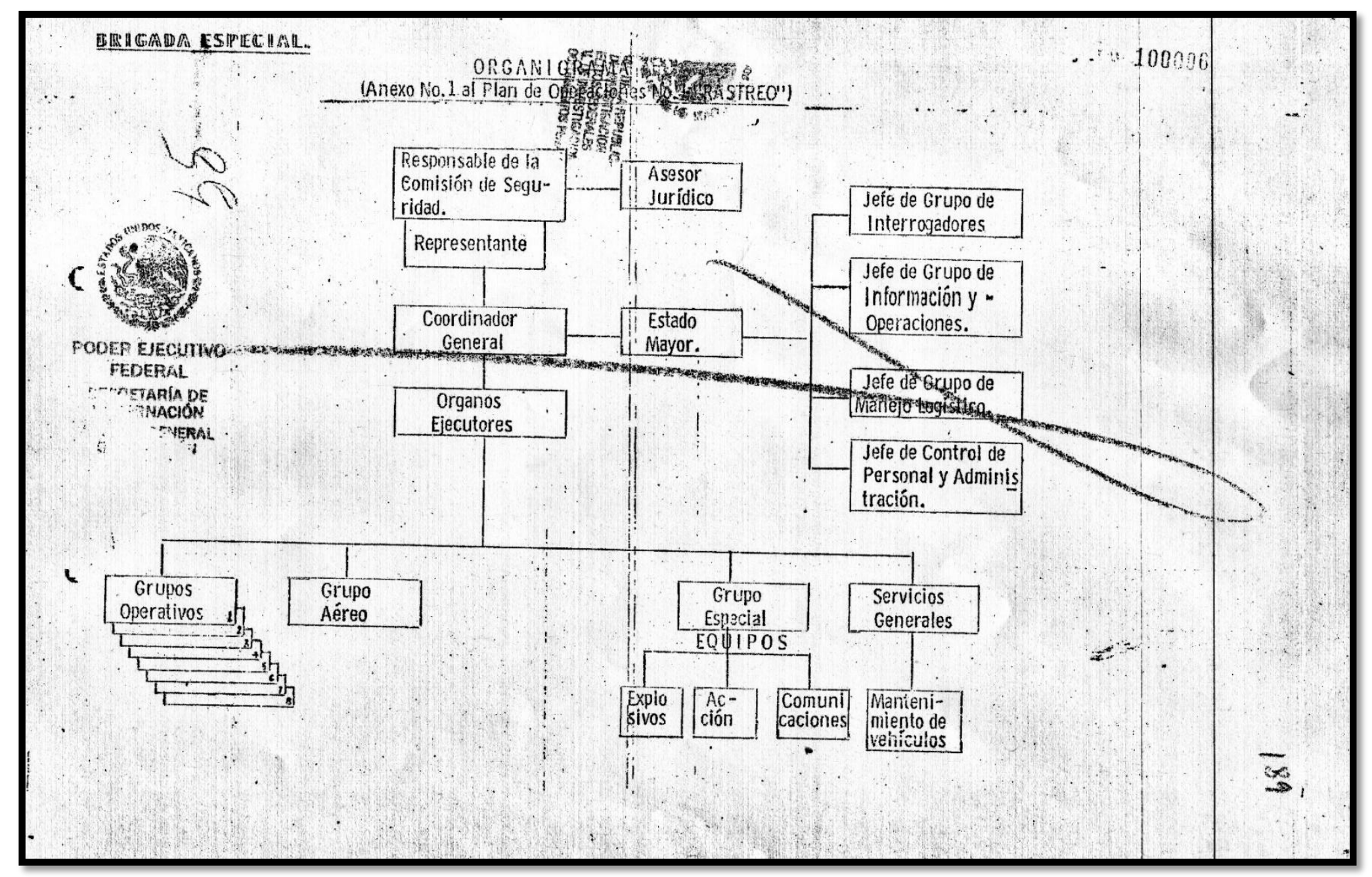




\section{BRIGADA ESPECIAL DE LA DIRECCION}

IEDERAL DE SEGURIDAL

\section{Exp.- 11-235-76 \\ H-50 L-38}

DOMICLLIO: Circular de Morelia No.8 Colonia Roma, D.F.

TELEFONOS: $557-29-14$ y $557-56-63$

REPONSABLE: MIGUEL NAZAR HARO SUb. Direc. de la D.F.S.

ASESOR JURIDICO: L.i. ALFONSO C:ABRERA MORALES

Esta integrada por 240 elementos de la I).F.S., JUDICIAL FEDERAL, JUDICIAL DEL

DISTRITO, D.G.P.T. y POLICIA MILITAR

Combate contra actividades de la llan ada LIGA COMUNISTA 23 DE SEPTIEMBRE.

PLAN DE OPERACIONES No. UNO "RASTREO"

Exp.- $11-235-76 \mathrm{H}-50 !-38$

ORGANIGRAMA: Exp.- $11-235-76 \mathrm{H} \cdot 55 \mathrm{~L}-38$

Fig. 30. "Brigada Especial de la Dirección Federal de Seguridad” Distrito Federal, c. 1976, AGN, DFS, H-50, L-38, Exp. 11-235-76, 1 folha. 


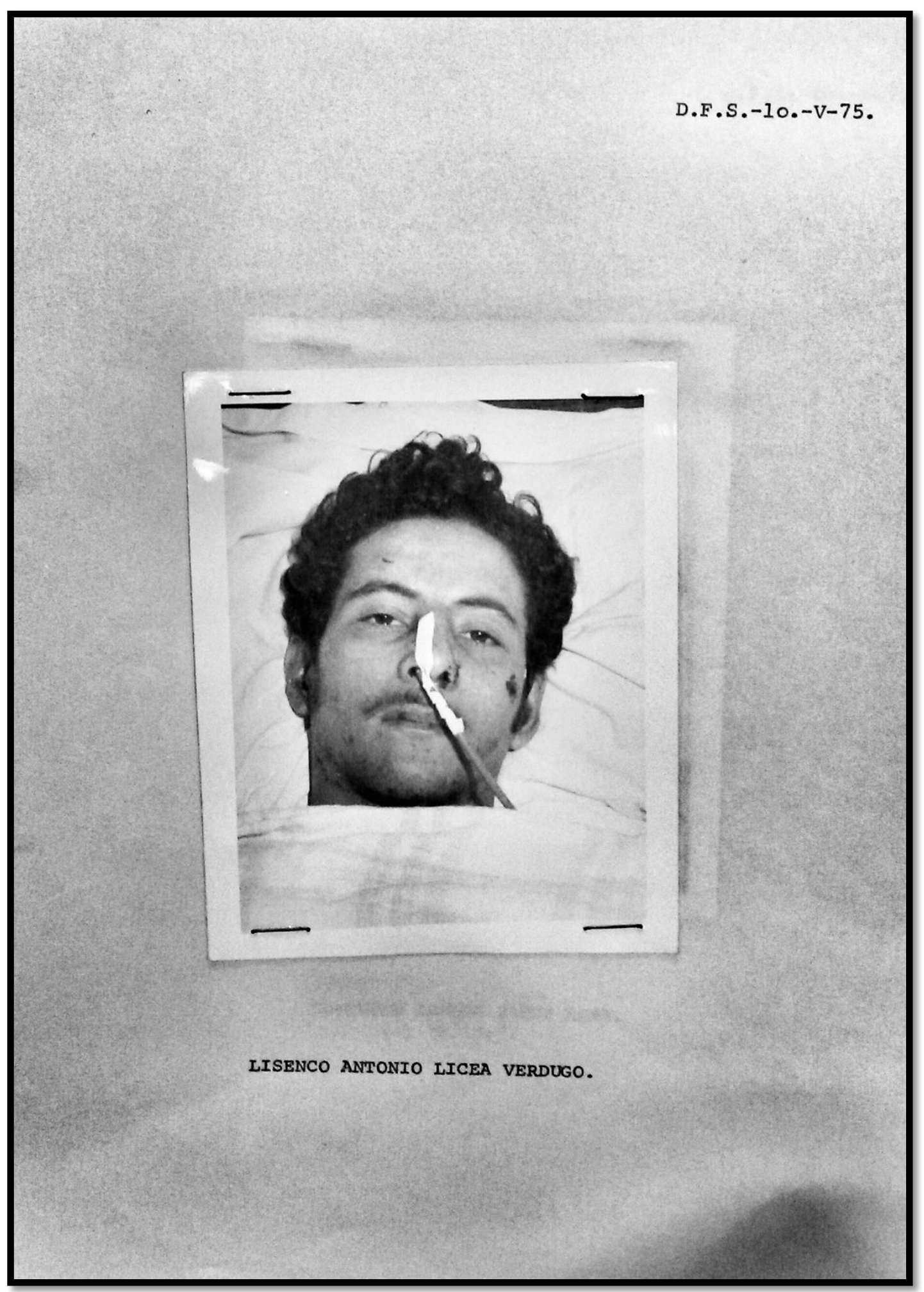

Fig. 28 "Liga Comunista 23 de Septiembre 'Brigada Roja”", Distrito Federal, 01-05-75, AGN, IPS, Caixa 1491 B, Exp. 8, folhas 5 de 9. 


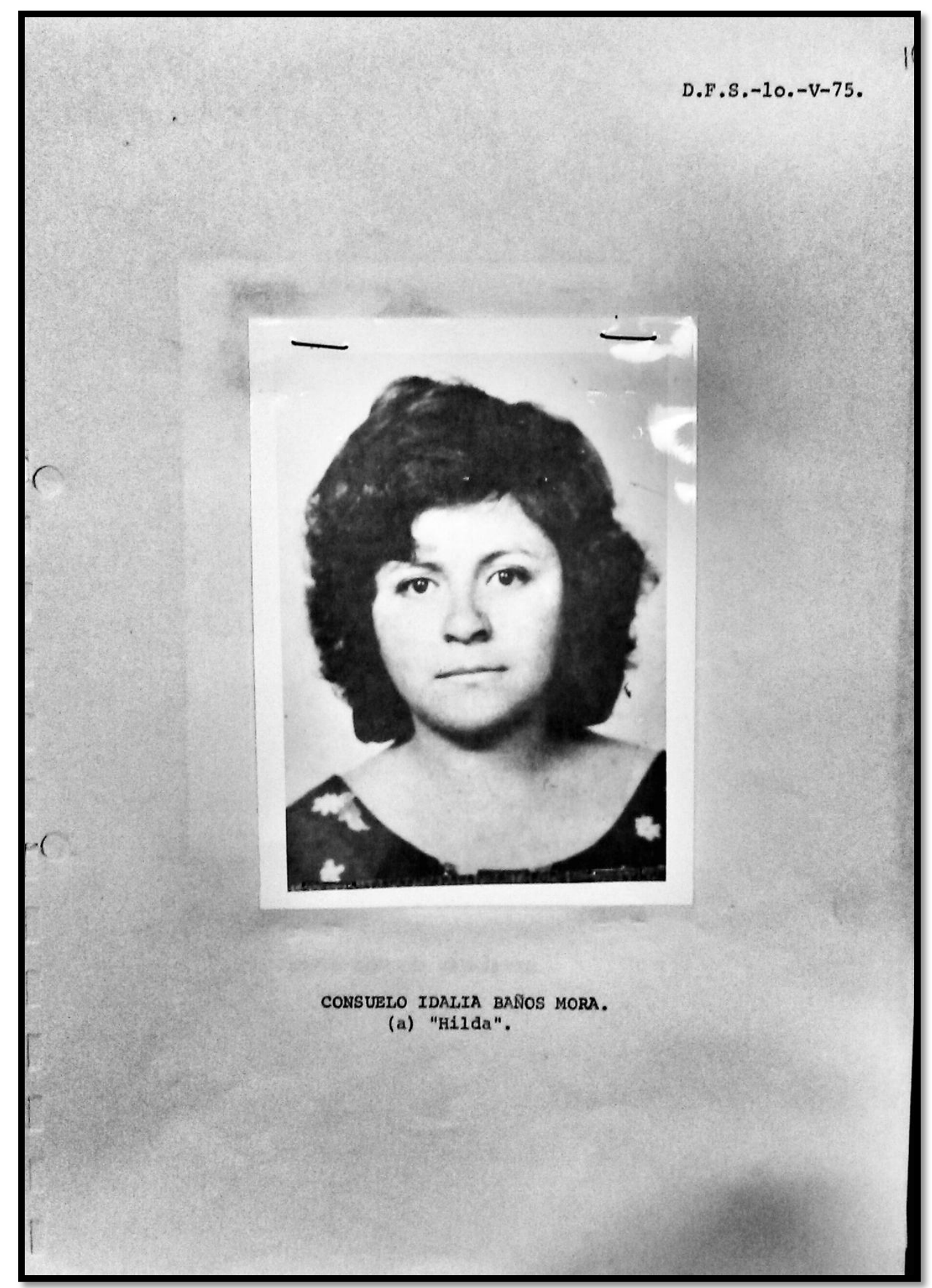




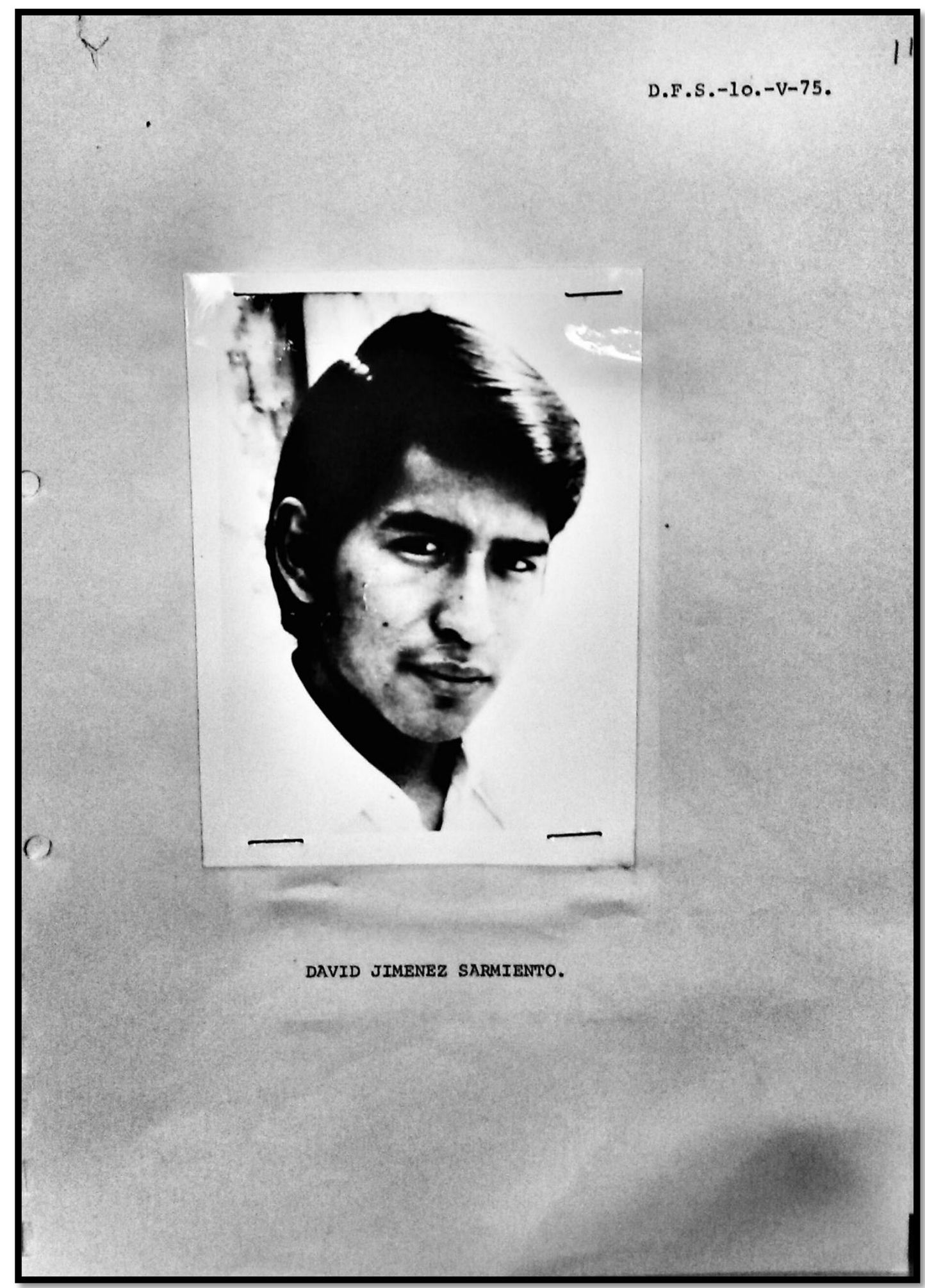




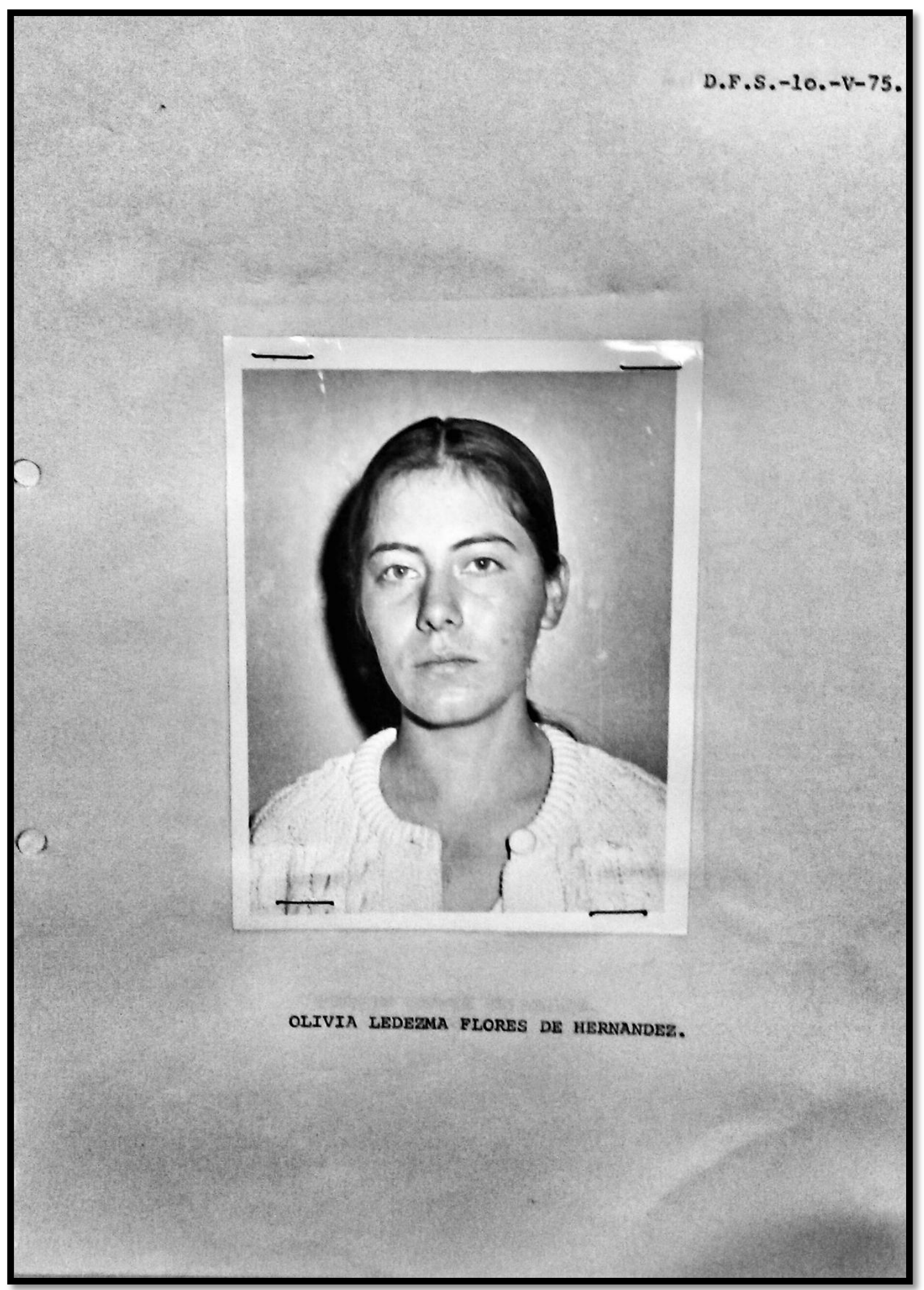




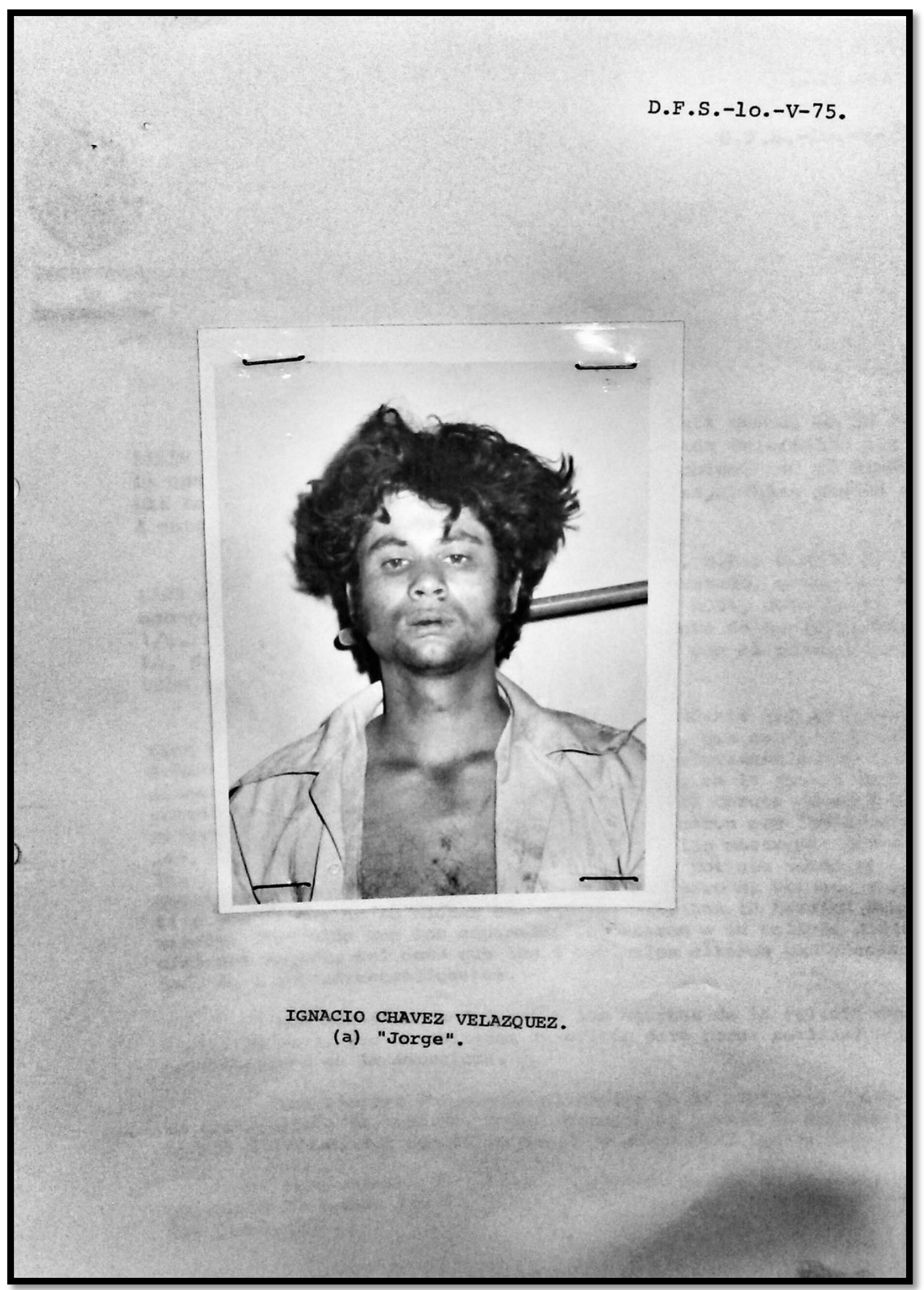

